\title{
KLANGKÖRPERBAU \\ RESONANCIAS NARRATIVAS DE LO EFÍMERO EN PETER ZUMTHOR
}

Tesis Doctoral

Universidad Politécnica de Madrid. UPM

Escuela Técnica Superior de Madrid. ETSAM

Departamento de Proyectos Arquitectónicos. DPA

Franca Alexandra Sonntag

María José Aranguren López

Alberto Martínez Castillo

2020 



\section{KLANGKÖRPERBAU \\ RESONANCIAS NARRATIVAS DE LO EFÍMERO EN PETER ZUMTHOR}

Tesis Doctoral

Universidad Politécnica de Madrid. UPM

Escuela Técnica Superior de Madrid. ETSAM

Departamento de Proyectos Arquitectónicos. DPA

Autora: Franca Alexandra Sonntag

Directora: María José Aranguren López

Codirector: Alberto Martínez Castillo

Año: 2020 

Tribunal nombrado por el Mgico. Y Excmo. Sr. Rector de la Universidad Politécnica de Madrid, el dia

Presidente $\mathrm{D}$.

Vocal D.

Vocal D.

Vocal D.

Secretario D.

Realizado el acto de defensa y lectura de Tesis el dia en la Escuela Técnica Superior de Arquitectura de Madrid

Calificación:

EL PRESIDENTE

LDS VOCALES

EL SECRETARIO 

a Ricardo, Theo y Jürgen 


\section{[Agradecimientos]}

A María José Aranguren y Alberto Martínez Castillo, mis directores;

a Susanne Hauser,

Emilia Hernández Pezzi,

Antonio Juárez Chicote,

Miguel Wenceslao Kreisler Moreno,

Inés Martín Robles,

Nicolás Maruri González de Mendoza,

Luis Guillermo Pancorbo Crespo,

Rafael Pina Lupiáñez,

Sebastian Schlagheck,

Anne Schmidt,

Javier Seguí de la Riva,

Enrique Sobejano García,

Marike van der Ben,

Ingrid Wähler,

Torsten Zwerenz;

Juan Herreros Guerra,

Rodrigo Pemjean Muñoz,

Enrique de Teresa Trilla;

Blanca García de la Fuente;

Exposeeum e.V. ,

Nüssli Group;

Ricardo Montoro Coso... sobre todo a Ricardo por estar a mi lado en este viaje. Sin su ayuda, sin su paciencia, sin su apoyo, sin su sinceridad, esta tesis no habría sido así. 


\section{[Resumen]}

Sin haber estado nunca allí, he recorrido en numerosas ocasiones el Klangkörper durante los últimos años. Su condición efímera, obsolescencia programada, no ha impedido que haya permanecido en la memoria de la arquitectura, evitando su olvido. Fue instante, y a la vez se ha convertido en un recuerdo permanente.

El ideal de representación fragmentada del mundo surgió en un contexto histórico especifico; vinculado a la hegemonía tecnológica. A finales de los años 80 dos Alemanias, bipolares ideológicamente, se enfrentaron al reto de acoger la primera Exposición Universal en suelo teutón. Una ciudad anónima debía ser la anfitriona; Hannover fue la elegida. El lema propuesto para el cambio de milenio fue HombreNaturaleza-Técnica; origen de un nuevo mundo.

La propuesta ganadora para el pabellón helvético, Batterie, paradójicamente no fue un contenedor en el cual se desarrollaba una exposición, sino que la arquitectura misma era la exposición. No era un soporte de contenidos replicado numerosas veces en este tipo de muestras. El proyecto brotó de las obsesiones de Zumthor. Un paradigmático silencio introvertido, antítesis del pabellón holandés. Un déjà vu arquitectónico con acordes reconocibles en sí mismo; y de otras melodías afines como el Pabellón Sonsbeek de Aldo van Eyck.

A través de un proceso evolutivo, la célula madre se transformó en un sistema, el Klangkörperbau. Un tapiz cuya forma se asemeja a un laberinto; supuestamente caótico, extremadamente exhaustivo. Una arquitectura aparentemente reconocible, pero enormemente desconocida. Célebre como secadero de madera, apilamiento como sistema formal y constructivo; inédito como abstracción concreta del bosque. La re-construcción capa por capa como mecanismo para el descubrimiento de sus secretos; de sus meticulosos detalles.

El Klangkörper fue un condensador dinámico, tanto a nivel espacial como sensorial. Una polifonía de y para los sentidos, que seduce al usuario mediante cualidades táctiles, sonoras, gustativas olfativas y visuales. Mediante claro-oscuros, recurrente en la obra de Zumthor, convierte el espacio del pabellón en una escenografía espacial. De la oscuridad a la luz, de la luz a la penumbra; filtrándose entre las pilas, desdibujando los contornos, modificando las geometrías, acentuando tonalidades, creando un espacio en movimiento constante. Junto al ritmo poético de las percepciones errantes. Un paisaje sonoro, un instrumento musical transitable, una caja de resonancia.

Una y otra vez transito el laberíntico como un lugar de inspiración, descubrimiento e investigación. Una aventura donde perderse, donde no hay principio, ni final. 


\section{[Zusammenfassung]}

Ohne die Gelegenheit gehabt zu haben, den Klangkörper persönlich zu besuchen, bin ich in den letzten Jahren viele Male durch inn gegangen. Sein ephemerer Zustand, seine programmierte Veralterung, haben nicht verhindert, dass der Schweizer Pavillon in der architektonischen Erinnerung verblieben oder gar in Vergessenheit geraten ist. Nur für einen Augenblick existent, ist er dennoch zu einer dauerhaften Erinnerung geworden.

Das Ideal einer fragmentierten Darstellung der Welt entstand in einem spezifischen historischen Kontext, verbunden mit technologischer Hegemonie. Ende der 1980er Jahre standen zwei ideologisch bipolare deutsche Länder vor der Herausforderung, die erste Weltausstellung auf deutschem Boden zu veranstalten. Als Gastgeber wurde eine mittelgroße westdeutsche Stadt, ausgewählt: Hannover. Das für den Jahrtausendwechsel vorgeschlagene Motto lautete: Mensch-Natur-Technik; Eine neue Welt entsteht.

Der siegreiche Entwurf für den Schweizer Pavillon, Batterie, war paradoxerweise keine Hülle, in welcher eine Ausstellung stattfinden sollte, sondern die Architektur selbst wurde zur Ausstellung. Es handelte sich nicht um ein Medium, vielfach wiederholt in dieser Art von Ausstellungen. Das Projekt entsprang Zumthors Obsessionen. Ein paradigmatisches introvertiertes Schweigen; Gegenpol zum niederländischen Pavillon. Ein architektonisches Déjà-vu mit erkennbaren Akkorden an sich; und von anderen ähnlichen Melodien wie Aldo van Eycks Sonsbeek-Pavillon.

Durch einen evolutionären Prozess wurde die Stammzelle in ein System verwandelt, den Klangkörperbau. Eine Art Gewebe, dessen Form einem Labyrinth ähnelt; scheinbar chaotisch, flächendeckend. Eine vermeindlich bekannte, jedoch weitgehend unbekannte Architektur. Berühmt als Trockenlager für Holz, aufgrund des formalen und konstruktiven Systems; unbekannt als konkrete Abstraktion des Waldes. Die Methode der Rekonstruktion, Schicht für Schicht, dient als Mechanismus zur Entdeckung der Geheimnisse ihrer akribischen Details.

Der Klangkörperwar ein dynamischer Kondensator, sowohl räumlich als auch sensorisch. Sowohl eine Polyphonie der Sinne als auch für die Sinne, die den Benutzer durch taktile, klangliche, olfaktorische und visuelle Qualitäten verführt. Durch einen HellDunkel-Kontrast, ein wiederkehrendes Thema in Zumthors Werk, wird der Raum des Pavillons in eine räumliche Szenografie verwandelt. Von der Dunkelheit zum Licht, vom Licht zum Halbschatten. Licht, welches sich durch die Stapel filtert, Konturen verwischt, Geometrien modifiziert, Tonalitäten akzentuiert. So entsteht ein Raum in ständiger Bewegung, verbunden mit dem poetischen Rhythmus wandernder Wahrnehmungen. Eine Klanglandschaft, ein begehbares Musikinstrument, ein Klangkörper.

Immer wieder durchquere ich dieses Labyrinth als einen Raum der Inspiration, der Entdeckung und der Forschung - wie eine Einladung zu einem Abenteuer, in dem man sich verliert; bei dem es keinen Anfang und kein Ende gibt. 


\section{[Abstract]}

Without having had the chance to visit in person, I have been guided through the Klangkörper many times over the past few years. Its ephemeral condition, its programmed obsolescence, has not prevented the Swiss pavilion from remaining in the memory of architecture and, avoiding its fall into oblivion. Only existent for instant in the year 2000, it still has become permanent memory.

The idea of a fragmented representation of the world emerged during a specific historical context linked to technological hegemony. At the end of the 1980s, two ideologically bipolar Germanies faced the challenge of hosting the first Universal Exhibition on Teutonic soil. A nonfamous midsize city, in then West Germany, was chosen to be its host: Hanover. The motto proposed for the edition of the millennium change was: Mankind - Nature - Technology - Origin of a New World.

The winning proposal for the Swiss pavilion, Batterie, was paradoxically not a container in which to hold an exhibition, but the architecture itself became the exhibition. It was not a supporting structure for content as found at many other iterations of this type of exposition. The project sprang from Zumthor's obsessions. The space emanates a sense of paradigmatic introverted silence, an antithesis of the Dutch pavilion. An architectural déjà vu with recognizable chords in itself; and of other similar melodies such as Aldo van Eyck's Sonsbeek Pavilion.

Through an evolutionary process, the stem cell was transformed into a system, the Klangkörperbau. A tapestry whose shape resembles that of a labyrinth; supposedly chaotic, extremely comprehensive. A seemingly recognizable, but hugely unknown architecture. Familiar as a stack of drying wood, which may have inspired the formal and constructive system; unprecedented as an abstract forest translated into built form. The re-construction method, layer by layer, is used as a mechanism for the discovery of its secrets of its meticulous details.

The Klangkörper was a dynamic condenser, both spatially and sensorially. A polyphony of and for the senses, which seduces the user by means of tactile, sound, olfactory and visual qualities. By means of a light-dark contrast, a recurrent theme in Zumthor's work, the space of the pavilion is turned into a spatial scenography. From darkness to light, from light to penumbra, light filtering through the stacks, blurring contours, modifying geometries, accentuating tonalities - a space in constant movement is being created, together with the poetic rhythm of wandering perceptions. A soundscape, a passable musical instrument, a sounding box emerges.

Again and again I traverse this labyrinth as a space of inspiration, discovery and research - like an invitation to an adventure, in which to get lost, which has no beginning, no end. 


\section{ÍNDICE GENERAL}

9 AGRADECIMIENTO / DANKSAGUNNG

11 RESUMEN / ZUSAMMENFASSUNG

25 INTRODUCCIÓN. INCERTIDUMBRE CERTERA/ EINFÜHRUNG. BESTIMMTE UNBESTIMMTHEIT

43 FETICHE / FETISCH

75 CÉLULA MADRE / STAMMZELLE

101 ВIOTOPO / ВІОТОР

143 ORGANISMO / ORGANISMUS

259 STORYBOARD / STORYBOARD

267 ANATOMÍA / ANATOMIE

369 ABSTRACCIÓN CONCRETA / KONKRETE ABSTRAKTION

391 GESAMTKUNSTWERK / GESAMTKUNSTWERK

431 CAPTURAS DE VERDAD / WAHRNEHMUNGEN

507 CONCLUSIÓN / FAZIT

525 DES-APARICIÓN / VERSCHWINDEN

529 IMÁGENES / BILDNACHWEIS

569 BIBLIOGRAFÍA / BIBLIOGRAPHIE

593 ANEXOS / ANHÅNGE 


\section{ÍNDICE DESGLOSADO}

AGRADECIMIENTO / DANIKSAGUNNG

\section{RESUMEN / ZUSAMMENFASSUNG}

INTRODUCCIÓN. INCERTIDUMBRE CERTERA / EINFÜHRUNG. BESTIMMTE UNBESTIMMTHEIT [Germen]

[Pasajes]

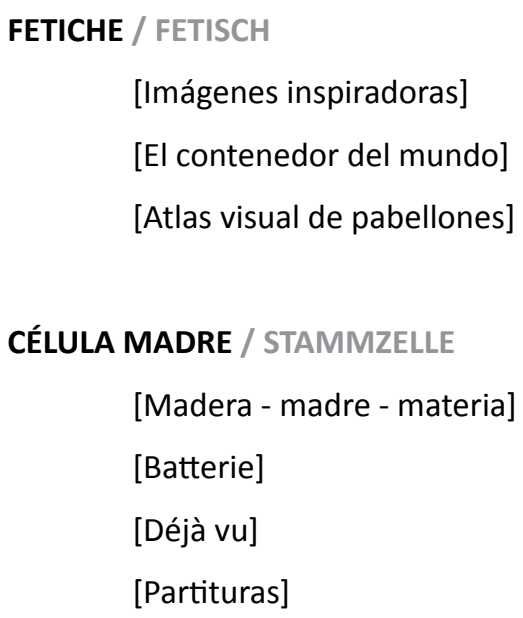




$\begin{array}{ll}143 & \text { ORGANISMO / ORGANISMUS } \\ 145 & \text { [La idea trazada] } \\ 151 & \text { [Puzzles] } \\ 157 & \text { [Mat-building] } \\ 161 & \text { [Swastika] } \\ 169 & \text { [Claros en el bosque] } \\ 173 & \text { [12 Stapel] } \\ 176 & \text { [Mitosis] } \\ 181 & \text { [Cuatro esquinas] } \\ 201 & \text { [Espacios sonoros] } \\ 233 & \text { [Espacios gastronómicos] } \\ 253 & \text { [Intrusos] } \\ 256 & \text { [Anotaciones] }\end{array}$

259 STORYBOARD / STORYBOARD

$\begin{array}{ll}267 & \text { ANATOMÍA / ANATOMIE } \\ 269 & \text { [Materia prima] } \\ 275 & \text { [Holzlager] } \\ 279 & \text { [Sohle] } \\ 291 & \text { [Fragmentos fugaces] } \\ 293 & \text { [El arte del ensamblaje] } \\ 309 & \text { [Separadores] } \\ 315 & \text { [Fragmentos de cubierta] } \\ 321 & \text { [Postensado] } \\ 328 & \text { [Manual de instrucciones en 34 pasos] } \\ 347 & \text { [La construcción en imágenes] } \\ 357 & \text { [Versorgungseinheit] }\end{array}$


ABSTRACCIÓN CONCRETA / KONKRETE ABSTRAKTION

[Natural y artificial]

[Abstraktion und Einfühlung]

[Meta-morfosis]

[Arquitectura concreta]

\section{GESAMTKUNSTWERK / GESAMTKUNSTWERK}

[Síntesis creativa]

[Idea wagneriana]

[Tentáculos]

[Polifonía de los sentidos]

[Arquitectura comestible]

[Patrón de corte]

[La luz escrita]

[Ocaso]

\section{CAPTURAS DE VERDAD / WAHRNEHMUNGEN}

[Chiaroscuro]

[Elogio de la penumbra]

[Amanecer]

[El limite de la transparencia]

[Selva ofativa]

[Le nez]

[La fragancia conformada]

[Lazos invisibles]

[El hilo de Ariadna]

[In-die-Irre-Gehen]

[La fierecilla domada]

[Stedelijk]

[Metáforas inspiradoras]

[Cavidad interior] 
507 CONCLUSIÓN / FAZIT

525 DES-APARICIÓN / VERSCHWINDEN

527 [Metempsícosis]

529 IMÁGENES / BILDNACHWEIS

569 BIBLIOGRAFÍA / BIBLIOGRAPHIE

593 ANEXOS / ANHÄNGE

595 [Entre-vista a Miguel Wenceslao Kreisler Moreno]

604 [Planimetría original] 

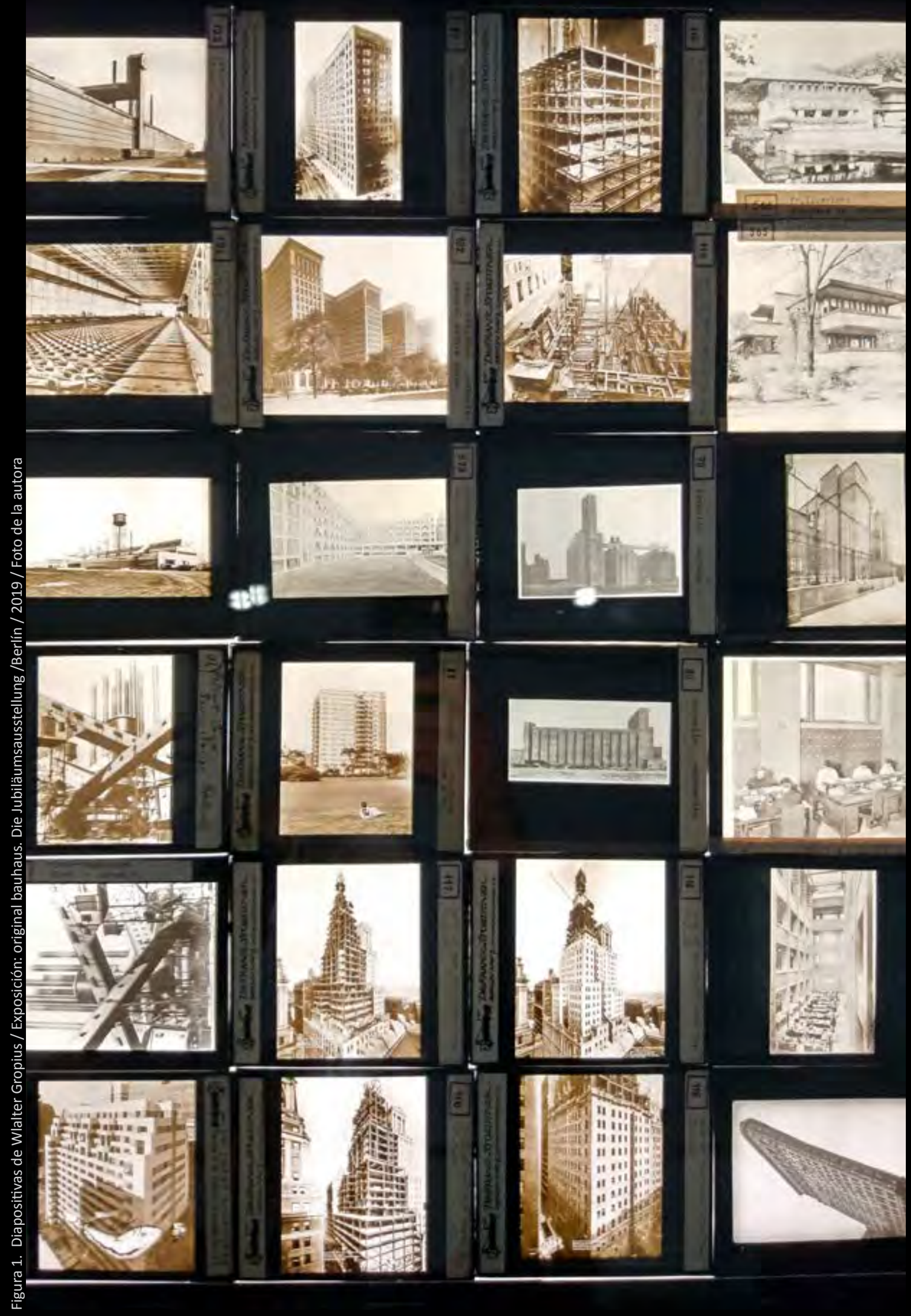
INTRODUCCIÓN. INCERTIDUMBRE CERTERA

EINFÜHRUNG. BESTIMMTE UNBESTIMMTHEIT

"(...) cosas que tenían que ser necesariamente así y no de otra manera, por razones que, para decir verdad, desconozco"1

Peter Zumthor 


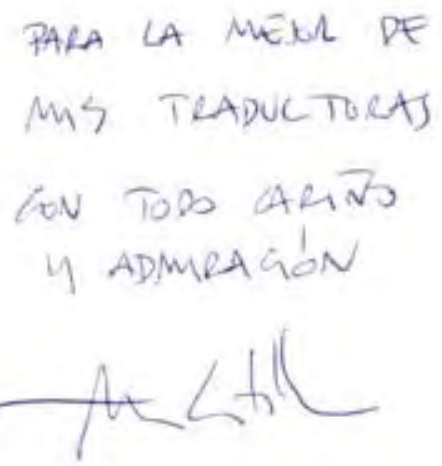

Figura 2.

Dedicatoria en mi Klangkörperbuch

Foto de la autora 


\section{[Germen]}

"el resultado de una obra de arte nunca puede ser poseído por su descripción. Las descripciones y los análisis son, en el mejor de los casos, pioneros cerebrales y pueden dar valor al intento de conquistarlo en su validez temporal y biológica a través de su propio debate."2 Lazlo Moholy-Nagy

En 2010, me regalaron un libro titulado Klangkörperbuch ${ }^{3}$. Un diccionario que versa sobre el pabellón helvético de la Exposición Universal del 2000 en Hannover. Un atlas documental que además de revelar conceptos arquitectónicos, insistía en términos o personas relacionados tangencialmente a la historia de esta construcción efímera. Una enumeración de diversos senderos en los que transitar: arquitectura, materialidad, música, escenificación, gastronomía, percepción, poesía, lugar, organización o construcción. Todo ello englobado en el concepto del Gesamtkunstwerk. Una boîte en valise ${ }^{4}$ de acciones simultáneas, y aparentemente aisladas, con una estructura narrativa a modo de collage de pedazos de textos autónomos.

La estructura del libro Klangkörperbuch es análoga a la composición arquitectónica del pabellón. No hay una única forma de leerlo. No existe un camino predeterminado; sino todo lo contrario, "Caminante, no hay camino, se hace camino al andar"s.

2 MOHOLY-NAGY, Lazlo. vom material zur architektur. Florian Kupfenberg Verlag. Mainz. 1968. Pág.7. Traducción de la autora: "das ergebnis eines kunstwerks kann niemals durch schilderung zum besitz werden. beschreibungen und analysen sind bestenfalls zerebrale wegbereiter und sie können den mut zu dem versuch geben, es durch eigene auseinandersetzung in seiner zeitlichen und biologischen gültigkeit zu erobern"

3 Nota: Alberto Martínez Castillo me regaló la publicación cuando colaboraba en su estudio; AAVV. Klangkörperbuch. Birkhäuser. Basel. 2000. ISBN: 3-7643-6324-X.

$4 \quad$ Nota: Obra de arte en forma de maleta de Marcel Duchamp.

5 MACHADO. Antonio. Antonio Machado hoy. 1939-1989: coloquio internacional. Casa de Velázquez. Madrid. 1994. Pág. 126. 


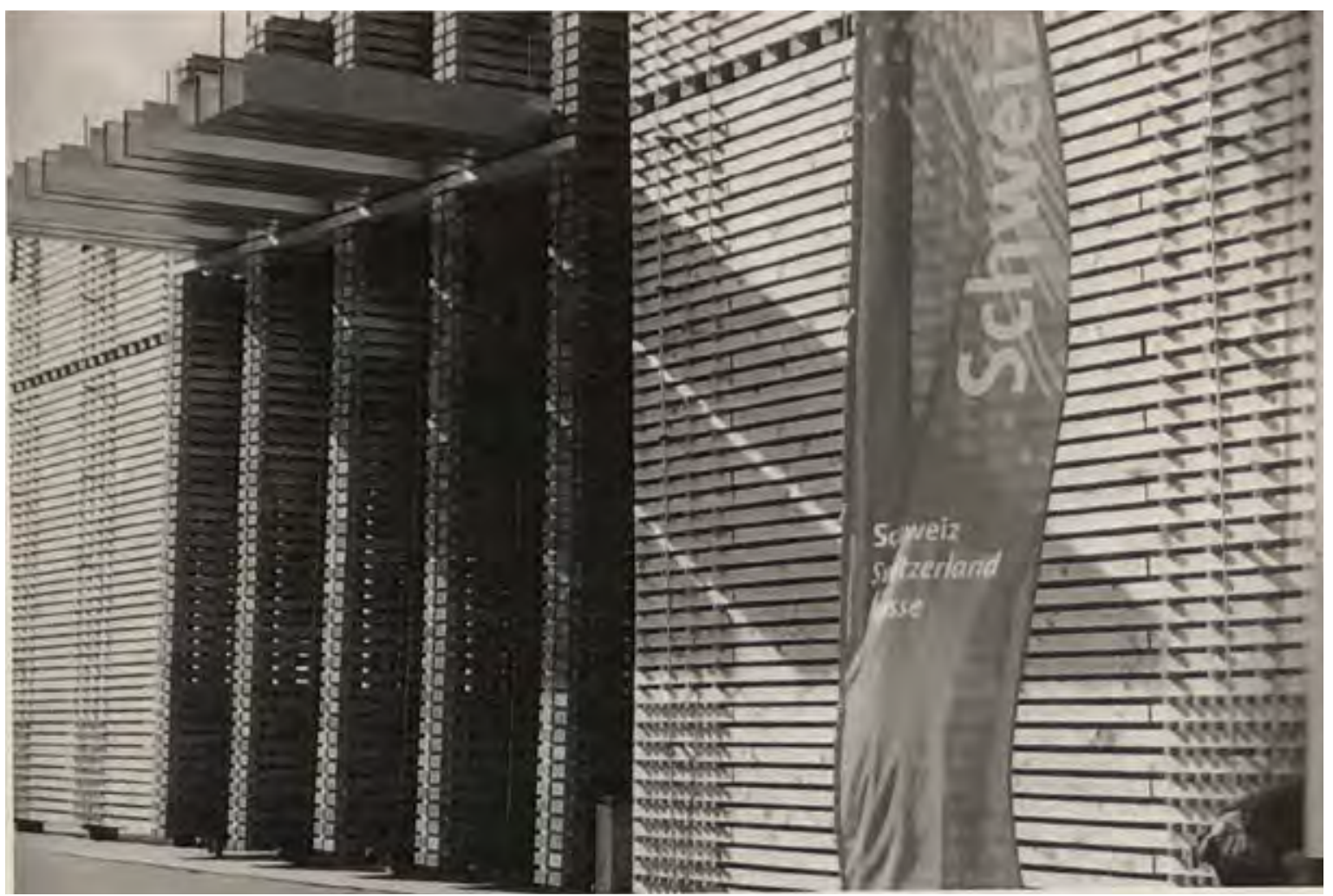

Figura 3.

Pabellón helvético / 2000 / Peter Zumthor 


\section{[Pasajes]}

"La estructura del texto es muy arquitectónica... Cada componente es extremadamente autónomo, sin embargo, hay complementariedades. Su estructura escrita es análoga al urbanismo que describe. En cuanto a su trazado, su fragmentación, es también muy arquitectónico. Cada minicapítulo tiene un título, y una de las principales razones es que, de lo contrario, habría que gastar cantidades desmesuradas de palabras, tiempo y cualquier otra cosa para crear interesantes "puentes", que corresponden a la forma, para mí, completamente imposible, de crear "conexiones" arquitectónicas en un edificio. Es un libro sin un solo "sin embargo", y eso para mí es muy arquitectónico. Tiene la misma lógica que una ciudad. De todos modos, un elemento crucial de la obra - ya sea escritura o arquitectura - es el montaje. En última instancia, sigo escribiendo guiones, que es lo que hacía cuando tenía 22 años." ${ }^{\prime 6}$ Rem Koolhaas

El pabellón helvético de Peter Zumthor es el Leitmotiv. El eje vertebral de la tesis. Una constante inspiración. El hilo rojo de Ariadna alrededor del cual gira todo. Un laberinto, que consta de diferentes itinerarios, que se descifran y componen mediante la interpretación, conformando un cuerpo teórico construido por estratos, capa a capa; como el apilamiento de listones de madera del pabellón. La disgregación en diferentes células, frente a un volumen único.

Lejos de plantear una estructura lineal y descriptiva con un posicionamiento puramente historicista, cronológico, arqueológico, simbólico, lingüístico o mitológico, se ha optado por establecer un nuevo horizonte de conocimiento espacial, constructivo, funcional, experiencial, estructural, compositivo y material. Una yuxtaposición de

6 ENTREVISTA a Rem Koolhaas de Cynthia Davidson. Why I wrote Delirious New York and Other Textual Strategies. En: https://www.burg-halle.de/home/155_noell/koolhaas-any-klein.pdf. Traducción de la autora: "The structure of the text is very architectural. I talk about blocks in analogy to New York itself; each block is subdivided in episodes that have a very architectural relationship to each other: i.e., they mostly coexist. Each component is extremely autonomous, nevertheless there are complementarities. Its written structure is analogous to the urbanism it describes. In terms of its layout, its fragmentation, it is also very architectural. Each minichapter has a title, and one of the main reasons is that otherwise you would have to spend inordinate amounts of words and time and whatever to create interesting "bridges," which correspond to the now, for me, completely impossible way of creating architectural "connections" in a building. It is a book without a single "however," and that to me is very architectural. It has the same logic as a city. Anyway, a crucial element of the work - whether writing or architecture - is montage. Ultimately, I'm still writing scripts, which is what I did when I was 22." 


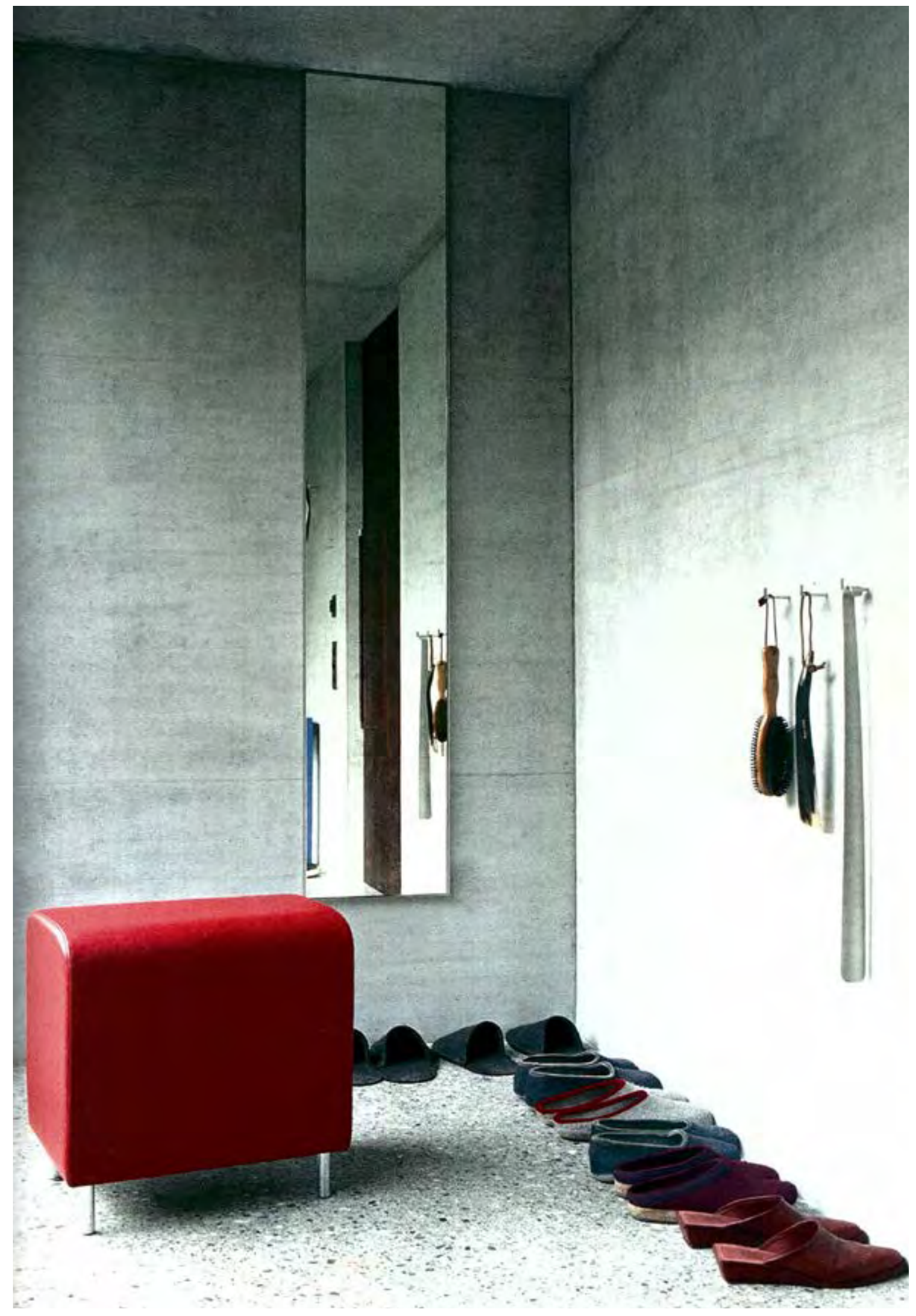

Figura 4.

Zumthor House / Haldenstein / Graubünden / Peter Zumthor. 
diversas conexiones y posicionamientos. De múltiples entradas con distintos matices que constituyen una constelación de relaciones interdisciplinares.

El marco de esta investigación interdisciplinar sirve para despertar los sentidos, la curiosidad; es decir, se construye cómo un proyecto a partir de una interpretación, estableciendo relaciones entre lo visible y lo desconocido, una hipótesis planteada. Sin embargo, la realidad es susceptible de tener distintas, y ambiguas, interpretaciones según el punto de vista. El análisis y la interpretación - como mecanismos de codificación de la información, como procesamiento, como evaluación y como verbalización - se consideran enfoques relevantes, pero también la proyección personal es inevitable. Así es por lo tanto que mis inquietudes, mis obsesiones, mis experiencias personales y mi propia subjetividad son instrumentos plausibles para descubrir, analizar, interpretar, profundizar y explicar esta investigación.

"la experiencia de un sujeto, por ejemplo, sobre una obra de arte - no es de ninguna manera idéntica a la de otro, e incluso un tema idéntico difiere de un análisis a otro"7 Pierangelo Maset

Proyectar a través de este escrito pensamientos fractales para ser recorridos. Lugares semi-laberínticos. El lector se moverá como el flaneur en el pabellón helvético. Deambular, explorar, experimentar, observar una gran variedad de lecturas permitiendo "un pensamiento asociativo, salvaje, libre, ordenado y sistemático en imágenes, imágenes arquitectónicas, espaciales, en color y sensoriales"8.

Similar al Libro de los Pasajes ${ }^{9}$, que emana de los recuerdos de la infancia de Walter Benjamin, de las experiencias del flaneur. Esta obra inacabada ${ }^{10}$ incluye notas, citas, fragmentos de texto, extractos y pensamientos escritos en francés y en alemán. El flaneur transitó la capital francesa; sus calles, sus plazas, sus arquitecturas, sus consumos, sus pasajes, sus grandes almacenes, sus modas, sus carteles, la publicidad, la prostitución.... Una colección de textos de diferentes temas, sin un sistema de clasificación realmente reconocible. Con comentarios y preguntas destinadas a

7 MASET, Pierangelo. Zwischen Vermittlungskunst und Maschinengefüge: Ästhetische Bildund der Differenz. En: Internationale Gesellschaft der Bildenden Künste (Hrsg). Kunst lehren? Künstlerische Kompetenz und kunstpädagogische Prozesse - Neue subjektorientierte Ansätz in der Kunst und Kunstpädagogik in Deutschland und Europa. Stuttgart. 1998. Pág 197. Traducción de la autora: "die Erfahrung des einen Subjekts - z.B. von einem Kunstwerk - ist keinesfalls mit der eines anderen identisch, und selbst ein identisches Subjekt differiert von Betrachtung zu Betrachtung"

8 ZUMTHOR, Peter. Pensar la arquitectura. Editorial Gustavo Gili. S.L. Barcelona. 2014. ISBN: 978-84252-2730-1. Pág. 69.

9 BENJAMIN, Walter. Libro de los Pasajes. Akal. Madrid. 2005. ISBN: 978-84-460-1901-5

10 Nota: Benjamin trabajó entre 1927 hasta su muerte en 1940. 


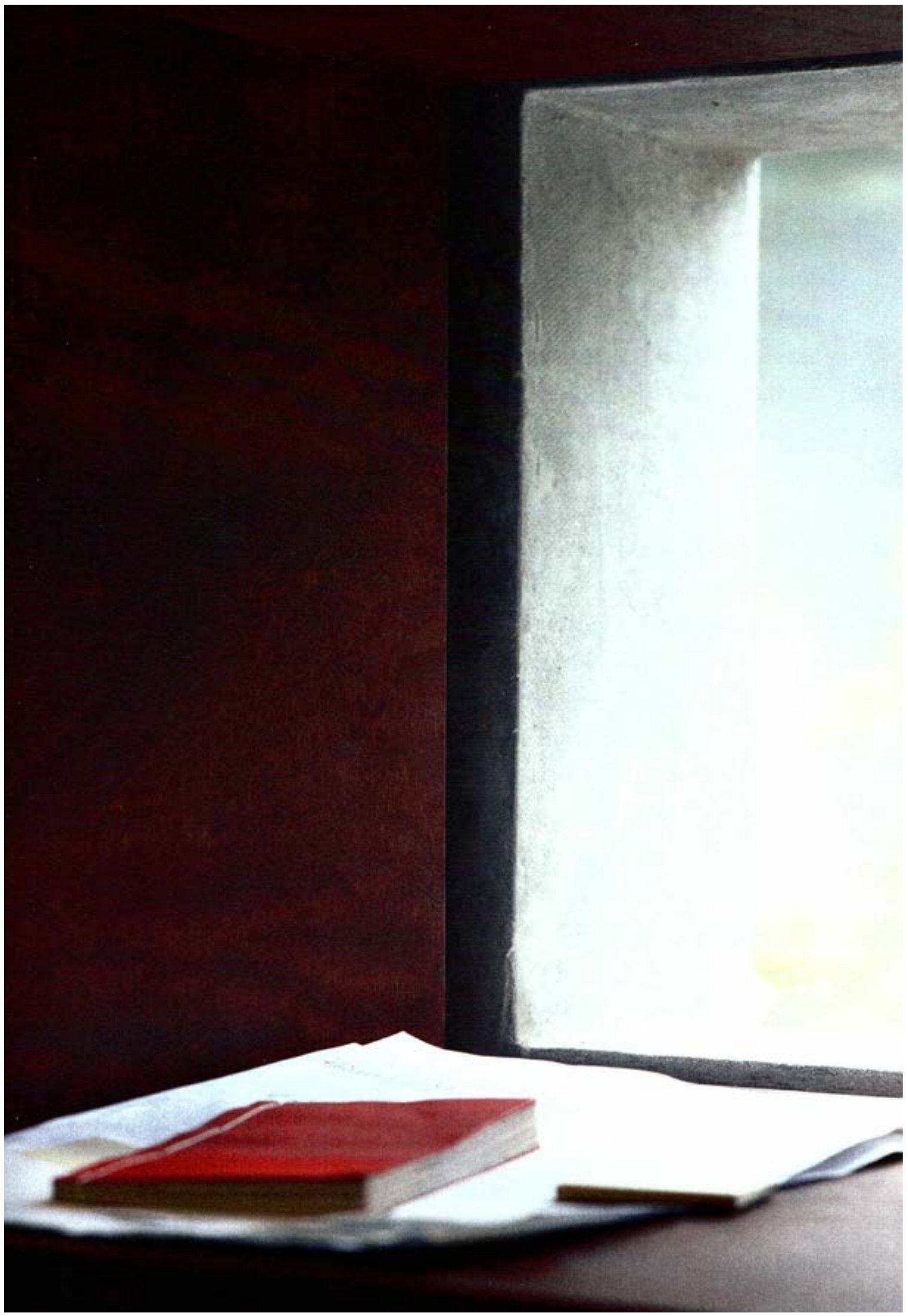

Figura 5.

Zumthor House / Haldenstein / Graubünden / Peter Zumthor. 
alentar al lector a pensar. Mediante el flaneur, Benjamin describe determinados puntos de vista, ciertos conceptos. El paseo por los pensamientos de Benjamín nos descubre su París con sus obsesiones; pasear por los de Zumthor, las proyecciones de sí mismo.

A modo de espejo de Benjamín, y del propio Zumthor; esta investigación debe entenderse como un pasaje, una transición. Nuestro París; será el pabellón helvético como caja de resonancia. Un proceso de descubrimiento. Una deriva por diferentes intereses. Un atlas de inquietudes personales alrededor del pabellón helvético. Una colección de textos relacionados con este momento construido. Un diccionario, un glosario de conceptos. Una especie de secuencia de pensamientos concisos, influencias, reflexiones, comparaciones. Un entre-tenimiento de experiencias secuenciales permitiendo una lectura diferente de los conceptos aplicados y desarrollados. Un montaje cinematográfico, y sobre todo arquitectónico. Un guión, un Delirious ${ }^{11}$. Un cofre del tesoro, un inventario con diferentes exploraciones. La arquitectura como arte mediador ${ }^{12}$. Esta tesis de proyectos sobre un proyecto, se presenta como una invitación a reflexionar en diversas direcciones. Desde la teoría práctica hasta la metodología; desde la praxis arquitectónica hasta otros ámbitos artísticos, musicales o filosóficos. Su objetivo es ofrecer un viaje alejado de la nostalgia, una travesía por su arquitectura para establecer vínculos y resonancias entre el pabellón helvético y Zumthor. Un espacio interpretativo explorando y cartografiando sus significados. Resonancias narrativas de los efímero. Ecos de la construcción del Klangkörper; es decir, el Klangkörperbau.

Parafraseando a Rafael Moneo, se podría afirmar que Escribir es pensar lo inesperado ${ }^{13}$.

¡Así que, partamos! Hay un ignoto camino por delante.

11 Nota: Delirious New York de 1978 escrito por Rem Koolhaas sobre el desarrollo urbano de Manhattan en la primera mitad del siglo XX, como versión contemporánea del Libro de los pasajes de Benjamin.

12 PALLASMAA, Juhani. Los ojos de la piel. Editorial Gustavo Gili, SL. Barcelona. 2010. ISBN: 978-84-2522135-4.

13 MONEO, Rafael. Dibujar es pensar lo inesperado. En: El Mundo.Madrid. 1 de abril /2017. https:// www.elmundo.es/cultura/2017/04/01/58deab61268e3e94088b45fd.html 


\title{
EINFÜHRUNG. BESTIMMTE UNBESTIMMTHEIT
}

\author{
"(...) Dinge, die so und nicht anders sein konnten, aus Gründen, die \\ ich eigentlich nicht kenne. ${ }^{11}$ Peter Zumthor
}

\section{[Ursprung]}

"das ergebnis eines kunstwerks kann niemals durch schilderung zum besitz werden. beschreibungen und analysen sind bestenfalls zerebrale wegbereiter und sie können den mut zu dem versuch geben, es durch eigene auseinandersetzung in seiner zeitlichen und biologischen gültigkeit zu erobern"2 Lazlo Moholy-Nagy

Im Jahr 2010 wurde mir ein Buch mit dem Titel Klangkörperbuch ${ }^{3}$ geschenkt. Ein Lexikon über den Schweizer Pavillon auf der Weltausstellung 2000 in Hannover. Ein dokumentarischer Atlas, in dem nicht nur architektonische Konzepte offenbart werden, sondern in dem auch Begriffen oder Personen aufgeführt sind, die tangential mit der Geschichte dieser ephemeren Konstruktion in Verbindung standen. Eine Aufzählung der verschiedenen Wege, die es zu beschreiten gilt: Architektur, Materialität, Musik, Inszenierung, Gastronomie, Wahrnehmung, Poesie, Ort, Organisation und Konstruktion. Eine Art Gesamtkunstwerk. Ein boîte en valise ${ }^{4}$ simultaner und scheinbar isolierter Aktionen mit einer narrativen Struktur. Eine Collage bestehend aus autonomen Texte.

Die Struktur des Klangkörperbuchs ähnelt der architektonischen Komposition des Pavillons. Es gibt nicht nur eine Möglichkeit ihn zu lesen, keinen vorbestimmten Weg, ganz im Gegenteil: "Wanderer, es gibt keinen Weg, der Weg entsteht dort, wo du gehst"15.

ZUMTHOR, Peter. Architektur Denken. Birkhäuser. Basel. 2010. ISBN: 978-3-0346-0555-7. S. 39

MOHOLY-NAGY, Lazlo. vom material zur architektur. Florian Kupfenberg Verlag. Mainz. 1968. S.7.

3 Anmerkung: Alberto Martínez Castillo schenkte mir diese Publikation, als ich in seinem Architekturbüro arbeitete; AAVV. Klangkörperbuch. Birkhäuser. Basel. 2000. ISBN: 3-7643-6324-X.

4 Nota: Das Kunstwerk von Marcel Duchamp in Form eines Koffers.

5 MACHADO. Antonio. Antonio Machado hoy. 1939-1989: coloquio internacional. Casa de Velázquez. Madrid. 1994. Pág. 126. Übersetzung der Autorin: "Caminante, no hay camino, se hace camino al andar" 


\title{
INTRODUCTION. CERTAIN INDEFINITENESS
}

\author{
"(...) things that had to be just right, for reasons which I do not \\ really understand. ${ }^{\text {11 }}$ Peter Zumthor
}

\section{[Origen]}

"the result of a work of art can never be possessed by its description. Descriptions and analyses are, at best, cerebral pioneers and can give value to the attempt to conquer it in its temporal and biological validity through its own debate."2 Lazlo Moholy-Nagy

In 2010, I was given a book entitled Klangkörperbuch ${ }^{3}$. Part dictionary about the Swiss pavilion at the World Expo 2000 in Hanover. Part documentary atlas through which not only architectural concepts are being revealed, but also is being insisted on terms or people tangentially related to the history of this ephemeral construction. An enumeration of diverse paths to follow: architecture, materiality, music, staging, gastronomy, perception, poetry, place, organization and construction. All this is included in the concept of the Gesamtkunstwerk. A boitte en valise $e^{4}$ of simultaneous actions, and apparently isolated, with a narrative structure as a collage of pieces of autonomous texts.

The structure of the Klangkörperbuch resembles the architectural composition of the pavilion. There is no single way to read it. There is no predetermined path; quite the contrary, "Walker, there is no road, the road is made by walking".

1 ZUMTHOR, Peter. Thinking Architecture. Birkhäuser - Publishers for Architecture. Basel, Boston, Berlin. 2006. ISBN: 978-3764374976. Pag. 39

2 MOHOLY-NAGY, Lazlo. vom material zur architektur. Florian Kupfenberg Verlag. Mainz. 1968. Pág.7. Translation by the author: "das ergebnis eines kunstwerks kann niemals durch schilderung zum besitz werden. beschreibungen und analysen sind bestenfalls zerebrale wegbereiter und sie können den mut zu dem versuch geben, es durch eigene auseinandersetzung in seiner zeitlichen und biologischen gültigkeit zu erobern"

3 Note: Alberto Martínez Castillo gave me the publication as a gift when I was working in his studio; AAVV. Klangkörperbuch. Birkhäuser. Basel. 2000. ISBN: 3-7643-6324-X.

4 Note: Artwork in the form of a suitcase by Marcel Duchamp

5 MACHADO. Antonio. Antonio Machado hoy. 1939-1989: coloquio internacional. Casa de Velázquez. Madrid. 1994. Pág. 126. Translation by the author: "Caminante, no hay camino, se hace camino al andar" 


\section{[Passage]}

"Die Struktur des Textes ist sehr architektonisch... Jede Komponente ist äußerst autonom, jedoch gibt es Komplementaritäten. Seine schriftliche Struktur ist analog zu dem darin beschriebenen Urbanismus. Jedes Minikapitel hat einen Titel, und einer der Hauptgründe dafür ist, dass man sonst übermäßig viel Worte und Zeit und was auch immer aufwenden müsste, um interessante "Brücken" zu schaffen, eine für mich völlig unmöglichen Art und Weise, um architektonische "Verbindungen" in einem Gebäude herzustellen. Es ist ein Buch ohne ein einziges "aber", und das ist für mich sehr architektonisch. Es hat die gleiche Logik wie eine Stadt. Jedenfalls ist ein wesentliches Element des Werkes - sei es das Schreiben oder die Architektur - die Montage. Letzten Endes schreibe ich immer noch Drehbücher, was ich tat, als ich 22 war". Rem Koolhaas

Der Schweizer Pavillon von Peter Zumthor verkörpert das Leitmotiv. Er bildet das Rückgrat dieser Forschungsarbeit; eine ständige Inspiration. Er ist der Ariadnefaden, um den sich alles dreht. Ein Labyrinth, bestehend aus verschiedenen Wegen, die durch Interpretation entziffert werden und einen theoretischen Körper bilden. Schicht für Schicht aufgebaut; wie die gestapelten Holzlatten im Inneren des Pavillons.

Weit davon entfernt, eine lineare und beschreibende Struktur mit einer rein historistischen, chronologischen, archäologischen, symbolischen, sprachlichen oder mythologischen Positionierung vorzuschlagen, wurde die Entscheidung getroffen, einen neuen Horizont räumlicher, konstruktiver, funktionaler, erfahrungsbezogener, struktureller, kompositorischerund materieller Kenntnisse zu schaffen. Ein Nebeneinander verschiedener Zusammenhänge und Betrachtungsweisen, mit unterschiedlichen Feinheiten, welche eine Konstellation interdisziplinärer Beziehungen bilden.

6 ENTREVISTA a Rem Koolhaas de Cynthia Davidson. Why I wrote Delirious New York and Other Textual Strategies. En: https://www.burg-halle.de/home/155_noell/koolhaas-any-klein.pdf. Übersetzung der Autorin: "The structure of the text is very architectural. I talk about blocks in analogy to New York itself; each block is subdivided in episodes that have a very architectural relationship to each other: i.e., they mostly coexist. Each component is extremely autonomous, nevertheless there are complementarities. Its written structure is analogous to the urbanism it describes. In terms of its layout, its fragmentation, it is also very architectural. Each minichapter has a title, and one of the main reasons is that otherwise you would have to spend inordinate amounts of words and time and whatever to create interesting "bridges," which correspond to the now, for me, completely impossible way of creating architectural "connections" in a building. It is a book without a single "however," and that to me is very architectural. It has the same logic as a city. Anyway, a crucial element of the work - whether writing or architecture - is montage. Ultimately, I'm still writing scripts, which is what I did when I was 22." 


\section{[Passage]}

"The structure of the text is very architectural. I talk about blocks in analogy to New York itself; each block is subdivided in episodes that have a very architectural relationship to each other: i.e., they mostly coexist. Each component is extremely autonomous, nevertheless there are complementarities. Its written structure is analogous to the urbanism it describes. In terms of its layout, its fragmentation, it is also very architectural. Each minichapter has a title, and one of the main reasons is that otherwise you would have to spend inordinate amounts of words and time and whatever to create interesting "bridges," which correspond to the now, for me, completely impossible way of creating architectural "connections" in a building. It is a book without a single "however," and that to me is very architectural. It has the same logic as a city. Anyway, a crucial element of the work - whether writing or architecture - is montage. Ultimately, I'm still writing scripts, which is what I did when I was 22."6 Rem Koolhaas

Peter Zumthor's Swiss Pavilion embodies the Leitmotiv. It provides a backbone for its thesis, a constant inspiration, Ariadne's thread around which everything revolves. It is a maze labyrinth consisting of different paths which are deciphered and composed through interpretation, forming a theoretical body built by stratum, layer by layer; like the stack of wooden slats inside the pavilion. It disintegrates into different cells, as opposed to merging its program into a single volume.

Far from proposing a linear and descriptive structure with a purely historicist, chronological, archaeological, symbolic, linguistic or mythological positioning the pavilion has been conceived as a precursor of spatial, constructive, functional, experiential, structural, compositional and material knowledge. It offers a juxtaposition of diverse connections and positions of multiple entries with different nuances that constitute a constellation of interdisciplinary relationships.

The framework of the underlying interdisciplinary research aims at awakening senses and curiosity. The project is constructed from an interpretation, while 
Ziel dieser interdisziplinären Forschungsarbeit ist es die Neugierde zu wecken; Beziehungen zwischen dem Sichtbaren und dem Unbekannten herzustellen; eine Hypothese aufzustellen. Jedoch ist die Analyse - als Mechanismen zur Kodierung von Information, zur Verarbeitung, zur Auswertung und zur Verbalisierung - immer anfällig für unterschiedliche und mehrdeutige Interpretationen. Auch eine persönliche Projektion ist unvermeidlich. Daher sind meine Anliegen, meine Obsessionen, meine persönlichen Erfahrungen und meine eigene Subjektivität plausible Instrumente, um zu entdecken, zu analysieren, zu interpretieren, zu vertiefen und zu erklären.

\section{“(...) die Erfahrung des einen Subjekts - z.B. von einem Kunstwerk \\ - ist keinesfalls mit der eines anderen identisch, und selbst ein identisches Subjekt differiert von Betrachtung zu Betrachtung"7 Pierangelo Maset}

Diese Arbeit gibt fraktale Gedankengänge wieder; halblabyrinthische Orte. Der Leser wird sich wie ein Flaneur im Schweizer Pavillon bewegen. Er wird wandern, erforschen, experimentieren, eine Vielzahl von Lesarten entdecken, die ein "assoziatives, wildes, freies, geordnetes und systematisches Denken in Bildern, in architektonischen, räumlichen, farbigen und sinnlichen Bilder"18 ermöglichen.

Die Lektüre dieser Forschungsarbeit ist vergleichbar mit dem Passagen-Werk ${ }^{9}$, welches den Kindheitserinnerungen Walter Benjamins entspricht. Dieses unvollendete Werk ${ }^{10}$ über die Erlebnisse des Flaneurs enthält Notizen, Zitate, Textfragmente, Auszüge und Gedanken in französischer und deutscher Sprache. Der Flaneur durchquerte die französische Hauptstadt mit ihren Straßen, ihren Plätzen, ihrer Architektur, ihrem Konsum, ihren Passagen, ihren Kaufhäusern, ihrer Mode, ihren Plakaten, ihrer Werbung, ihrer Prostitution... Das Ergebnis ist eine Sammlung von Texten zu verschiedenen Themen, denen ein klar erkennbares Ordnungssystem fehlt. Kommentare und Fragen sollen den Leser zum Nachdenken anregen. Mit den Augen des Flaneurs beschreibt Benjamin bestimmte Standpunkte, bestimmte Konzepte. Ein Spaziergang durch Benjamins Gedanken offenbart sein Paris mit seinen Obsessionen; ein Spaziergang durch Zumthors Gedanken offenbart die Projektionen seiner selbst.

7 MASET, Pierangelo. Zwischen Vermittlungskunst und Maschinengefüge: Ästhetische Bildund der Differenz. En: Internationale Gesellschaft der Bildenden Künste (Hrsg). Kunst lehren? Künstlerische Kompetenz und kunstpädagogische Prozesse - Neue subjektorientierte Ansätz in der Kunst und Kunstpädagogik in Deutschland und Europa. Stuttgart. 1998. S. 197.

8 ZUMTHOR, Peter. Architektur Denken. Birkhäuser. Basel. 2010. ISBN: 978-3-0346-0555-7. S. 69.

9 BENJAMIN, Walter. Libro de los Pasajes. Akal. Madrid. 2005. ISBN: 978-84-460-1901-5.

10 Nota: Benjamin arbeitete zwischen 1927 bis zu seinem Tod 1940 an diesem Werk. 
forming relations between the visible and the unknown and raising a hypothesis. However, reality is susceptible to different and ambiguous interpretations depending on the point of view. Analysis and interpretation - as mechanisms for encoding information, as processing, as evaluation and as verbalization - are considered relevant approaches, but also personal projection is inevitable. Thus, my concerns, my obsessions, my personal experiences and my own subjectivity are plausible instruments to discover, analyze, interpret, deepen and explain this research.

\section{"(...) the experience of one subject - e.g. of a work of art - is by no means identical to that of another, and even an identical subject differs from observation to observation." Pierangelo Maset}

Fractal thoughts will emerge while reading this dissertation which may lead the reader to semi-labyrinthine places. The reader will move like the flâneur inside the Swiss pavilion. It will wander, explore, experiment, and observe a wide variety of readings allowing "associative, wild, free, ordered, and systematic thinking in images, architectural, spatial, colorful, and sensuous pictures"s.

An experiential reading, comparable to that of the Passagenwerk ${ }^{9}$ which emanates from Walter Benjamin's childhood memories, of the experiences as a flâneur, his unfinished work ${ }^{10}$ including notes, quotations, text fragments, extracts and thoughts written in French and German. The flâneur passed through the French capital with its streets, its squares, its architecture, its consumption, its passages, its department stores, its fashions, its posters, advertising, prostitution... It results in a collection of texts on different subjects, lacking a clearly recognizable classification system. Comments and questions are designed to encourage the reader to think. Through the eyes of the flâneur, Benjamin describes certain points of view, certain concepts. A walk through Benjamin's thoughts reveals his Paris with its obsessions; a walk through Zumthor's, thoughts reveals the projections of himself.

7 MASET, Pierangelo. Zwischen Vermittlungskunst und Maschinengefüge: Ästhetische Bildund der Differenz. En: Internationale Gesellschaft der Bildenden Künste (Hrsg). Kunst lehren? Künstlerische Kompetenz und kunstpädagogische Prozesse - Neue subjektorientierte Ansätz in der Kunst und Kunstpädagogik in Deutschland und Europa. Stuttgart. 1998. S. 197. Translation by the author:"die Erfahrung des einen Subjekts - z.B. von einem Kunstwerk - ist keinesfalls mit der eines anderen identisch, und selbst ein identisches Subjekt differiert von Betrachtung zu Betrachtung"

8 ZUMTHOR, Peter. Thinking Architecture. Birkhäuser - Publishers for Architecture. Basel, Boston, Berlin. 2006. ISBN: 978-3764374976. Pag. 67-69.

9 BENJAMIN, Walter. Libro de los Pasajes. Akal. Madrid. 2005. ISBN: 978-84-460-1901-5

10 Note: Benjamin worked on this book from 1927 until his death in 1940 
Als Spiegel Benjamins bzw. Zumthors kann diese Forschungarbeit als eine Passage, ein Übergang verstanden werden. Unser Paris wird der Schweizer Pavillon sein. Ein Resonanzkörper. Ein Entdeckungsprozess. Ein Umherschweifen durch verschiedene Interessen. Wie ein persönlicher Atlas rund um den Schweizer Pavillon. Eine Sammlung von Texten, die sich auf diesen konstruierten Moment beziehen. Ein Lexikon, ein Glossar von Begriffen. Eine Art Sequenz von prägnanten Gedanken, Einflüssen, Reflexionen, Vergleichen. Eine Art Unterhaltung von aufeinanderfolgenden Erfahrungen, welche eine etwas andere Lesart der angewandten und entwickelten Konzepte ermöglicht. Eine kinematographische und vor allem architektonische Montage. Ein Drehbuch, ein Delirious ${ }^{11}$. Eine Schatzkiste. Architektur als vermittelnde Kunst ${ }^{12}$. Diese Arbeit über ein gebautes Projekt wird als Einladung zum Nachdenken über verschiedene Konzepte vorgestellt: von der praktischen Theorie bis zur Methodik; von der architektonischen Praxis bis zu anderen künstlerischen, musikalischen oder philosophischen Bereichen. Ihr Ziel ist es, eine Reise ohne Nostalgie, eine Reise durch Architektur des Klangköprers anzubieten sowie Verbindungen und Resonanzen zwischen dem Schweizer Pavillon und Zumthor herzustellen. Ein Interpretationsraum, der die Bedeutungen des Pavillons erforscht und kartographiert. Erzählerische Resonanzen des Ephemeren. Echos an die Konstruktion des Klangkörpers, d. h. Klangkörperbau.

Wenn man Rafael Moneo paraphrasiert, könnte man sagen, Schreiben ist das Denken an das Unerwartete ${ }^{13}$.

Also, los geht's! Vor uns liegt ein unbekannter Weg.

11 Anmerkung: Delirious New York 1978 von Rem Koolhaas über die Stadtentwicklung von Manhattan in der ersten Hälfte des 20. Jahrhunderts, als zeitgenössische Version von Benjamins Buch der Passagen 2135-4.

13 MONEO, Rafael. Dibujar es pensar lo inesperado. En: El Mundo.Madrid. 1 de abril /2017. https:// www.elmundo.es/cultura/2017/04/01/58deab61268e3e94088b45fd.html. Übersetzung der Autorin: „Zeichnen ist das Denken an das Unerwartete“ 
As a mirror of Benjamin, and of Zumthor himself; respectively, this research must be understood as a passage, a transition. Our Paris - the Swiss pavilion as a sounding box, explored through a process of discovery, a drifting through different interests. It resembles an atlas of personal concerns around the Swiss Pavilion, a collection of texts related to this constructed moment, a dictionary, a glossary of concepts. A kind of sequence of concise thoughts, influences, reflections, comparisons and an entertainment of sequential experiences allow for a different reading of the concepts applied and developed: as a cinematographic and, above all, architectural montage, a script, a Delirious ${ }^{11}$, a treasure chest, an inventory with different explorations. Architecture as a mediating art ${ }^{12}$. This thesis on a build project, is presented as an invitation to reflect oin different concepts, from practical theory to methodology, from architectural practice to other artistic, musical or philosophical fields. Its aim is to offer a journey away from nostalgia, a journey through its architecture and to establish links and resonances between the Swiss pavilion and Zumthor. It attempts drawing an interpretative space exploring and mapping underlying meanings, narrative resonance of the ephemeral echoes of the construction of the Klangkörper; that amount to the Klangkörperbau.

Paraphrasing Rafael Moneo, it could be affirmed that: Writing is thinking the unexpected ${ }^{13}$.

So, let's go! There's an unknown path ahead.

11 Note: Delirious New York 1978 written by Rem Koolhaas on the urban development of Manhattan in the first half of the 20th century, as a contemporary version of Benjamin's Book of Passages

12 PALLASMAA, Juhani. Los ojos de la piel. Editorial Gustavo Gili, SL. Barcelona. 2010. ISBN: 978-84-2522135-4.

13 MONEO, Rafael. Dibujar es pensar lo inesperado. En: El Mundo.Madrid. 1 de abril /2017. https:// www.elmundo.es/cultura/2017/04/01/58deab61268e3e94088b45fd.html. Translation by the author: "Drawing is thinking the unexpected" 


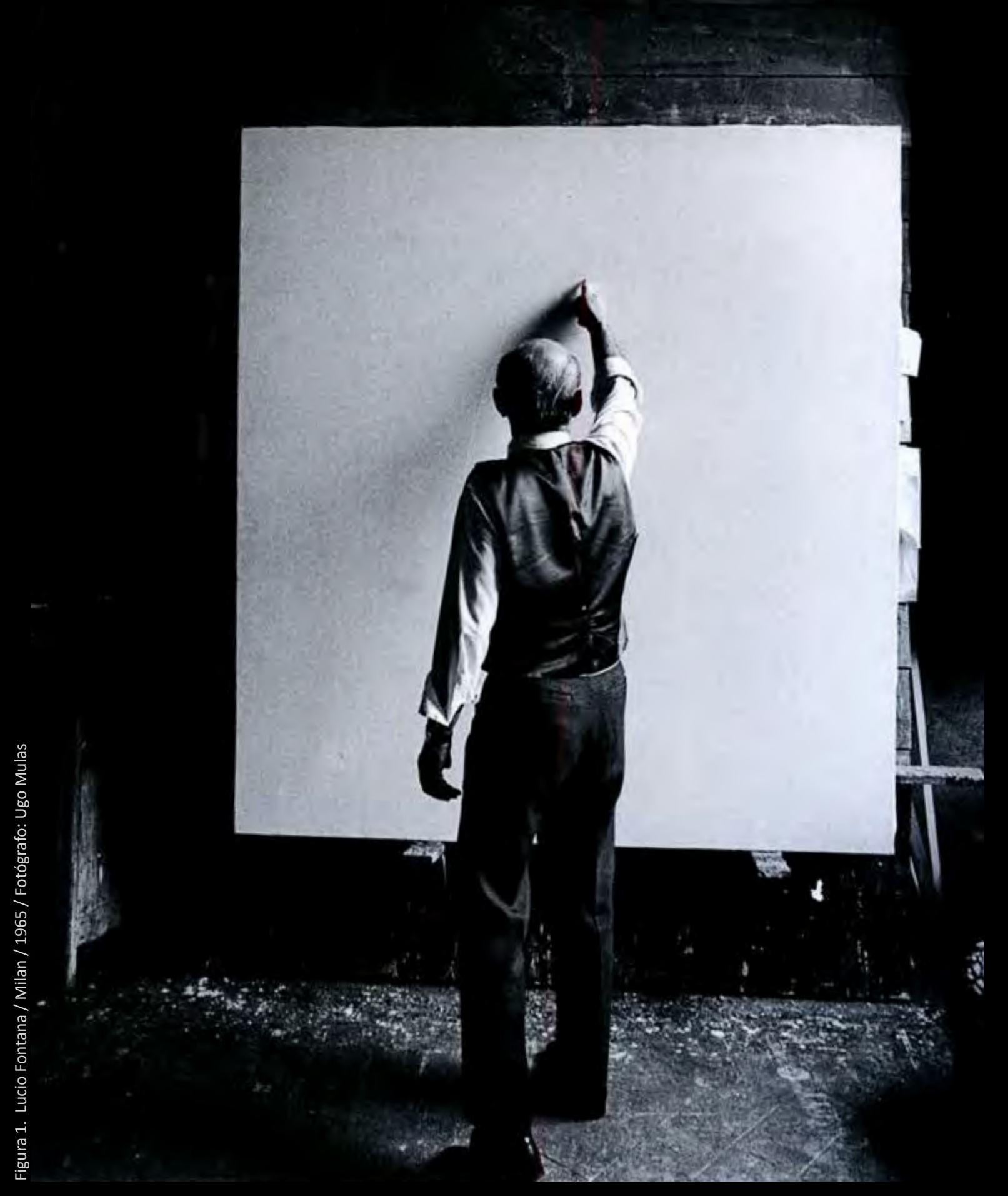




\section{FETICHE}

FETISCH

"Las exposiciones universales son los lugares de peregrinación hacia el fetiche llamado mercancía. ... Surge ésta del deseo de "entretener a las clases trabajadores, y se convierte para ellas en una fiesta de emancipación." ${ }^{\prime \prime}$

Walter Benjamin 


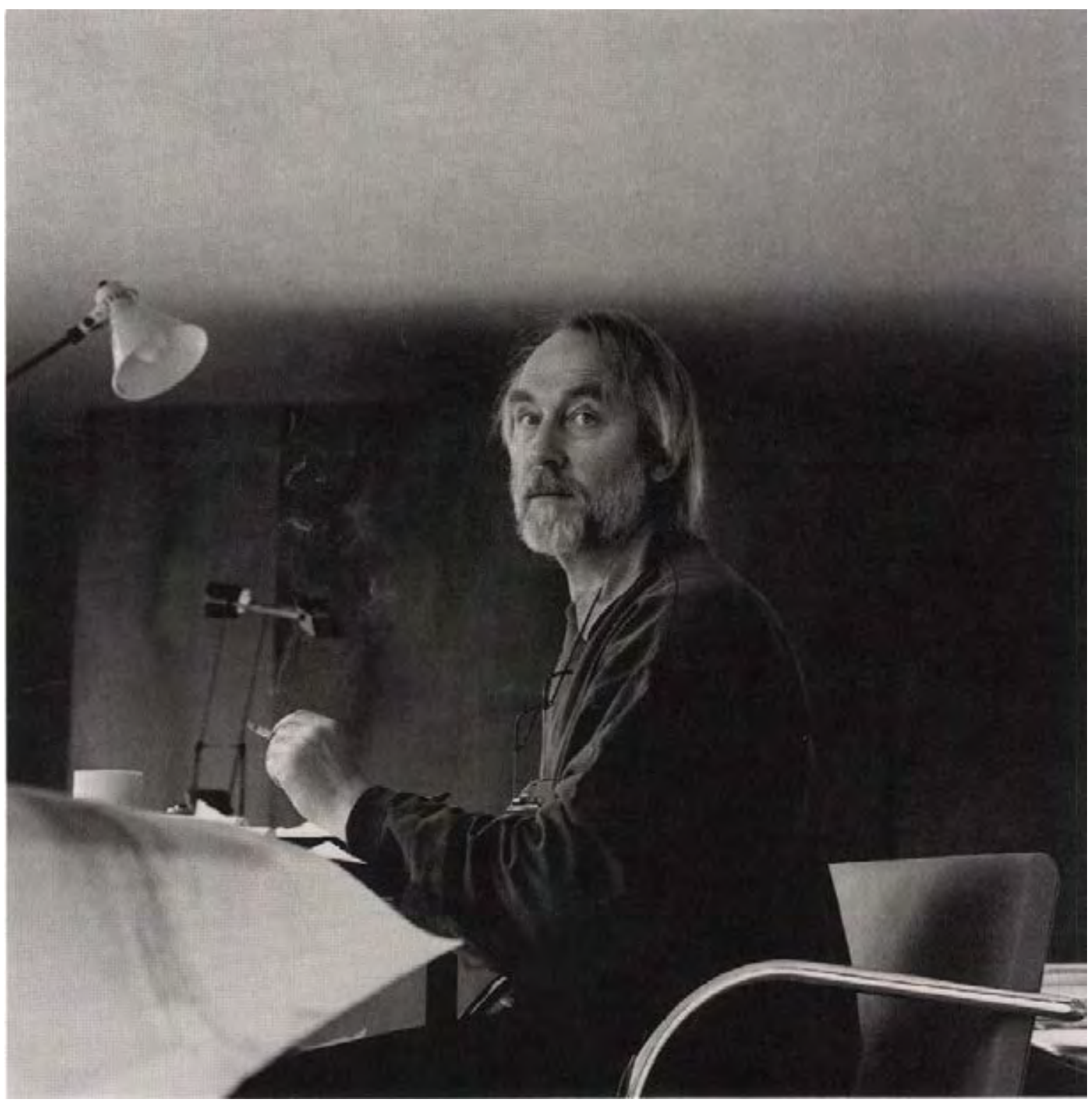

Figura 2.

Peter Zumthor / Fotógrafo: Hans-Peter Siffert 


\section{[Imágenes inspiradoras]}

"Es jueves santo de 2003. Aquí estoy, sentado en una plaza al sol, un gran soportal, largo, alto, hermoso bajo el sol. La plaza frente de casas, iglesia, monumentos - como un panorama ante mis ojos. A mi espalda la pared del café. La justa densidad de gente. Un mercado de flores. Sol. Las once. La cara de enfrente de la plaza en sombra, de un apacible color azulado. Ruidos maravillosos: conversaciones cercanas, pasos en la plaza, en la piedra, pájaros, ligero murmullo de la multitud, sin coches, sin estrépito de motores, de vez en cuando ruidos lejanos de una obra. Me figuro que el comienzo de las vacaciones ya ha ralentizado los pasos de la gente. Dos monjas - esto es de nuevo real, no me lo estoy inventando - dos monjas cruzan la plaza gesticulando, con un andar rápido, sus tocas ondean ligeramente, cada una de ellas lleva una bolsa de plástico. La temperatura: agradablemente fresca, y cálida. Estoy sentado bajo el soportal, en un sofá tapizado en un verde pálido, en la plaza, la estatua de bronce sobre su alto pedestal frente a mí me da la espalda, contemplando, como yo, la iglesia con sus dos torres. Las dos torres de la iglesia tienen un remate diferente; empiezan siendo iguales abajo y, al subir se van diferenciando. Una de ellas es más alta y tiene una corona de oro alrededor del extremo de la cúpula. Pronto vendrá hacia mi B., cruzando en diagonal la plaza desde la derecha."2 Peter Zumthor

Para Zumthor, la arquitectura es mucho más que un espacio construido. Su pensamiento va más allá de la forma y la construcción. En el origen, algunas imágenes seleccionadas. Estas en un estado embrionario aparecen borrosas a modo de sentimiento; hasta que su desarrollo permite revelar su concreción ${ }^{3}$. Imágenes atmosféricas de su entorno o de la trivialidad de la vida cotidiana. Sentimientos, instintos, sensualidad, intuiciones, experiencias, impresiones visuales, imaginaciones sobre el uso, conocimientos adquiridos, situaciones espaciales, estados de ánimo,

2 ZUMTHOR, Peter. Atmósferas: entornos arquitectónicos - las cosas a mi alrededor. Gustavo Gilli. Barcelona. 2006. ISBN: 9788425221170. Pág. 15-17.

3 Entrevista a Peter Zumthor de Astrid Rappel. "Der Kern meiner Arbeit ist eine ganzheitliche Betrachtungsweise". En: Bauwelt 9. 2012. https://www.bauwelt.de/themen/betrifft/Der-Kernmeiner-Arbeit-ist-eine-ganzheitliche-Betrachtungsweise-Interview-Peter-Zumthor-2085076.html 


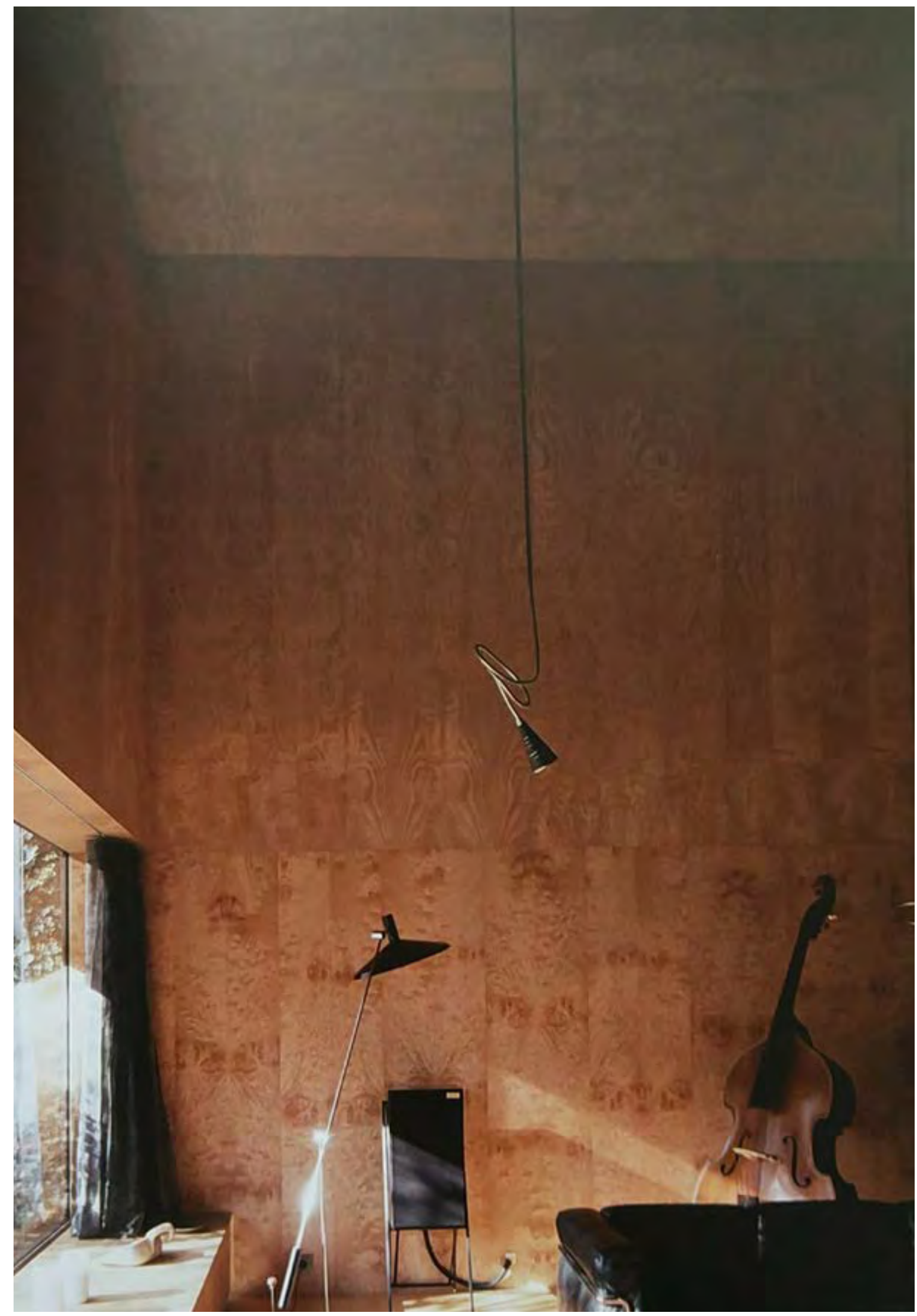

Figura 3.

Zumthor House / Haldenstein / Graubünden / Peter Zumthor 
observaciones, consideraciones filosóficas y poéticas, olores, paisajes, recuerdos de infancia como el picaporte de la puerta del jardín de la tía, el ruido de los guijarros bajo sus pies, el olor a pintura de aceite ${ }^{4}$. Un tránsito por diferentes disciplinas como la arquitectura, las bellas artes, la fotografía, la literatura, la poesía, la música o el cine. Reflexiones que dan a conocer las secretas pasiones que le animan realmente en su trabajo ${ }^{5}$. Una radiografía cognitiva de matices, un juego discursivo de sentimientos y razones, de experiencias y recuerdos. Zumthor gira todas sus constelaciones alrededor de la arquitectura, en gran medida la excusa perfecta para hacerlo sobre sí mismo.

\footnotetext{
“¿Qué diablos me conmueve a mi...? ¿Como puedo proyectar algo asi?"”

"Es un gran todo, todo está conectado. Hay muchas influencias. El arte es el humus de mi vida. La experiencia del arte, de la inteligencia, de la tristeza, de la melancolía, de la ironía: todas estas cosas son importantes para mí porque van más allá de la vida pragmática."7 Peter Zumthor
}

Siendo profesor $^{8}$ en la Accademia di Architettura dell'Università della Svizzera Italiana en Mendrisio, Suiza, propuso a sus alumnos operar con la memoria experiencial; suscitado por materiales in-materiales, por referencias invisibles, subjetivos, fugaces, emergentes. Los recuerdos personales, recuerdos almacenados, recuerdos que se adhieren a objetos, lugares, personas, tiempos y sensaciones específicas. Todo este magma sirve para encontrar claves interpretativas para los procesos constructivos. "Las ideas llegan, y no sé de dónde vienen. Ese es un gran regalo. En realidad, toda la vida es inspiración (...)"

4 ZUMTHOR, Peter. Pensar la arquitectura. Editorial Gustavo Gili. S.L. Barcelona. 2014. ISBN: 978-84252-2730-1. Pág. 7.

5 Idem. Pag. 21.

6 ZUMTHOR, Peter. Atmósferas: entornos arquitectónicos - las cosas a mi alrededor. Gustavo Gilli. Barcelona. 2006. ISBN: 9788425221170. Pág. 11.

7 ENTREVISTA a Peter Zumthor. Mich kann man nicht einfach kaufen. En: Tagesanzeiger. 17. Diciembre. 2017. https://www.tagesanzeiger.ch/kultur/kunst/mich-kann-man-nicht-einfach-kaufen/ story/27212992.Traducción de la autora: "Es ist ein grosses Ganzes, es hängt alles zusammen. Es gibt viele Einflüsse. Die Kunst ist der Humus meines Lebens. Das Erlebnis von Kunst, von Intelligenz, von Trauer, von Melancholie, von Ironie: Alle diese Dinge sind mir wichtig, denn sie gehen über das pragmatische Leben hinaus."

8 Nota: Zumthor ha enseñado en el Southern California Institute of Architecture SCl-ARC en Los Ángeles, la Technische Universität Munich y la Graduate School of Design GSD de la Harvard University. Durante doce años, desde 1996, año de fundación, hasta 2008, también fue profesor en la Accademia di architettura di Mendrisio.

9 ENTREVISTA a Peter Zumthor de Wojciech Czaja. Gänsehaut . . . das ist mein Honorar. En: Der Standart. 23. Mayo 2009. https://www.nextroom.at/actor.php?id=3965\&inc=artikel\&sid=31033. Traducción de la autora: "Die Ideen kommen einfach, und ich weiß nicht woher. Das ist ein großes Geschenk. Eigentlich ist das ganze Leben Inspiration..." 


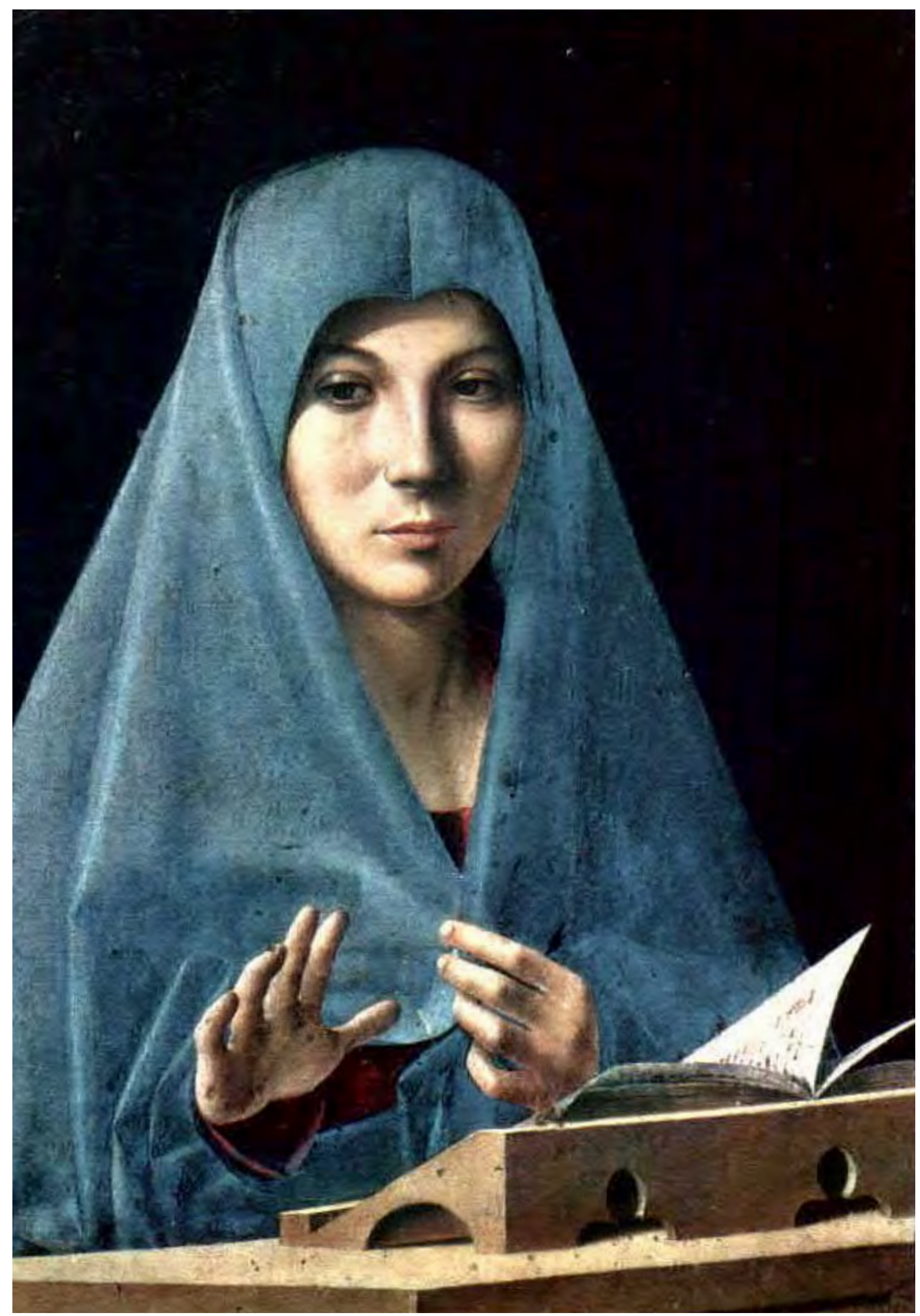

Figura 4.

Annunziata / Antonello da Messina / 1475-1476 
A través de sus escritos, Zumthor cartografía sus motivaciones, sin describir recurrente y explícitamente su propia arquitectura. En la exposición en la que fue comisario en 2017 para conmemorar el vigésimo aniversario ${ }^{10}$ del Kunsthaus en Bregenz no mostró sus obras arquitectónicas. En su lugar expuso el contexto inspirador de su práctica arquitectónica. Un programa de conciertos, lecturas de libros, proyecciones de películas, charlas, fotografías, paseos por un jardín injertado en su interior. Una interacción de diferentes ámbitos que le interesan a él ${ }^{11}$. Una "gran fiesta de las artes al que todos están invitados"12 donde poder abrir y mostrar su maleta Duchampesca ${ }^{13}$. Un muestrario fragmentado de su imaginario del que se rodea en su estudio en Haldenstein. Un cofre escondido que atesora sus recuerdos, imágenes, pensamientos e inspiraciones.

¿Sería posible reconstruir esa Boîte-en-valise con el Klangkörperbau?

10 Nota: Exposición. Dear to Me. 16. September 2017 - 7. Januar 2018. Bregenz

11 ENTREVISTA a Peter Zumthor de Jeanette Kunsmann y Stephan Burkoff. Was mir lieb ist. Peter Zumthor feiert in Bregenz. Illustrierte für Design und Architektur nํ․ 2017. Pág. 116. Traducción de la autora: "Also ich will nichts von mir zeigen, sondern Dinge, die mir lieb sind. Ich habe ja auch ein bisschen den Hang zum Gesamtkunstwerk. Bücher habe ich gerne, Gärten habe ich gerne und Musik habe ich gerne. Da entstand es, und ich skizziere. Es geht hin und zurück, bis alles stimmt."

12 ZUMTHOR, Peter. Dear to Me-ein Fest der Künste. Ausstellungskatalog Dear to Me. En: https://www. kunsthaus-bregenz.at/fileadmin/user_upload/KUB/Presse/Aktuelle_Ausstellung/Peter_Zumthor/ Programm_Peter_Zumthor_Dear_to_Me.pdf. Pág. 12.

13 Nota: Boîte-en-valise es una maleta como - a modo de museo de viajes - que contiene una colección de obras de Duchamp, en forma de reproducciones en color. 

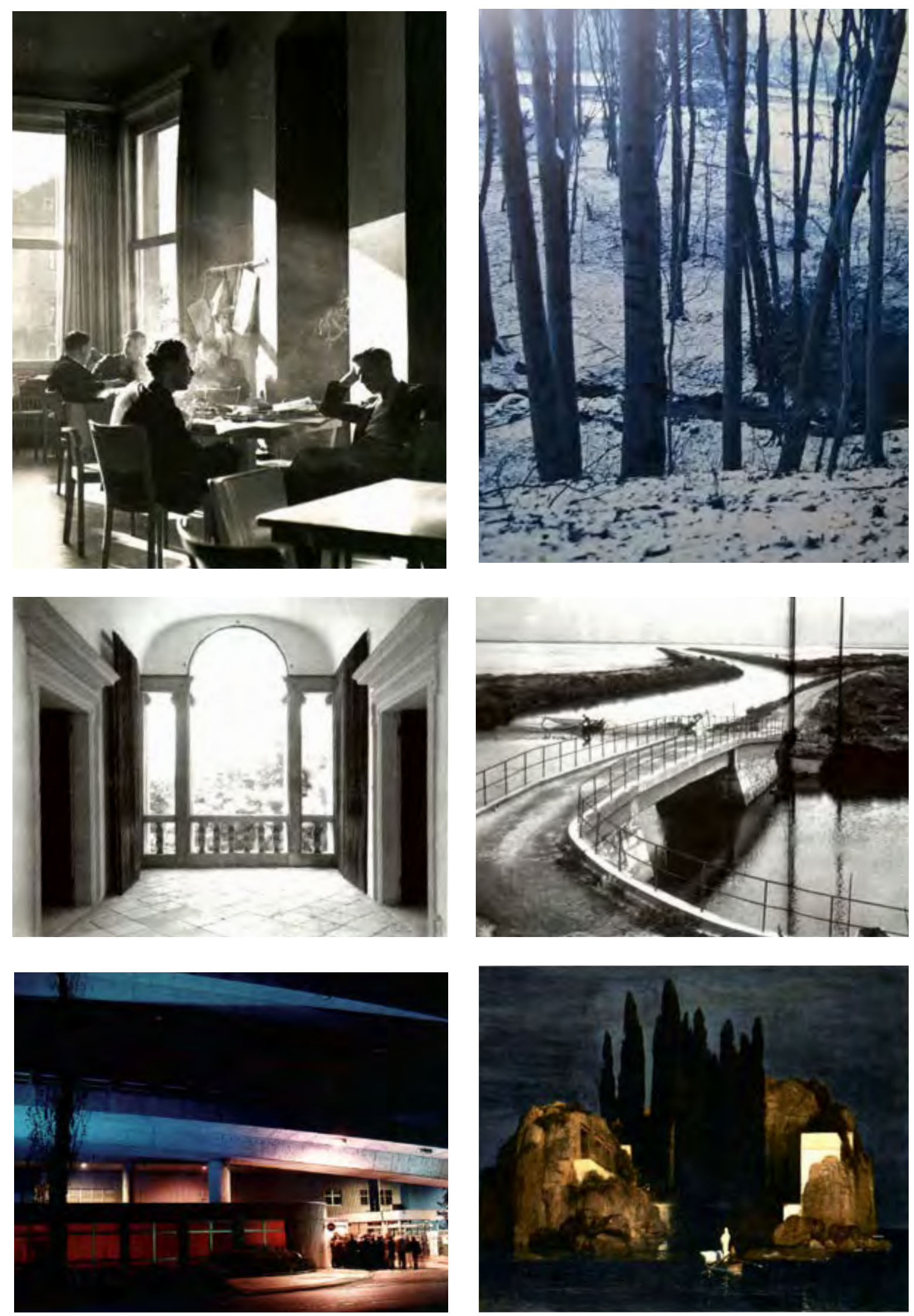

Figura 5 - 10.

Imágenes inspiradoras para Peter Zumthor 

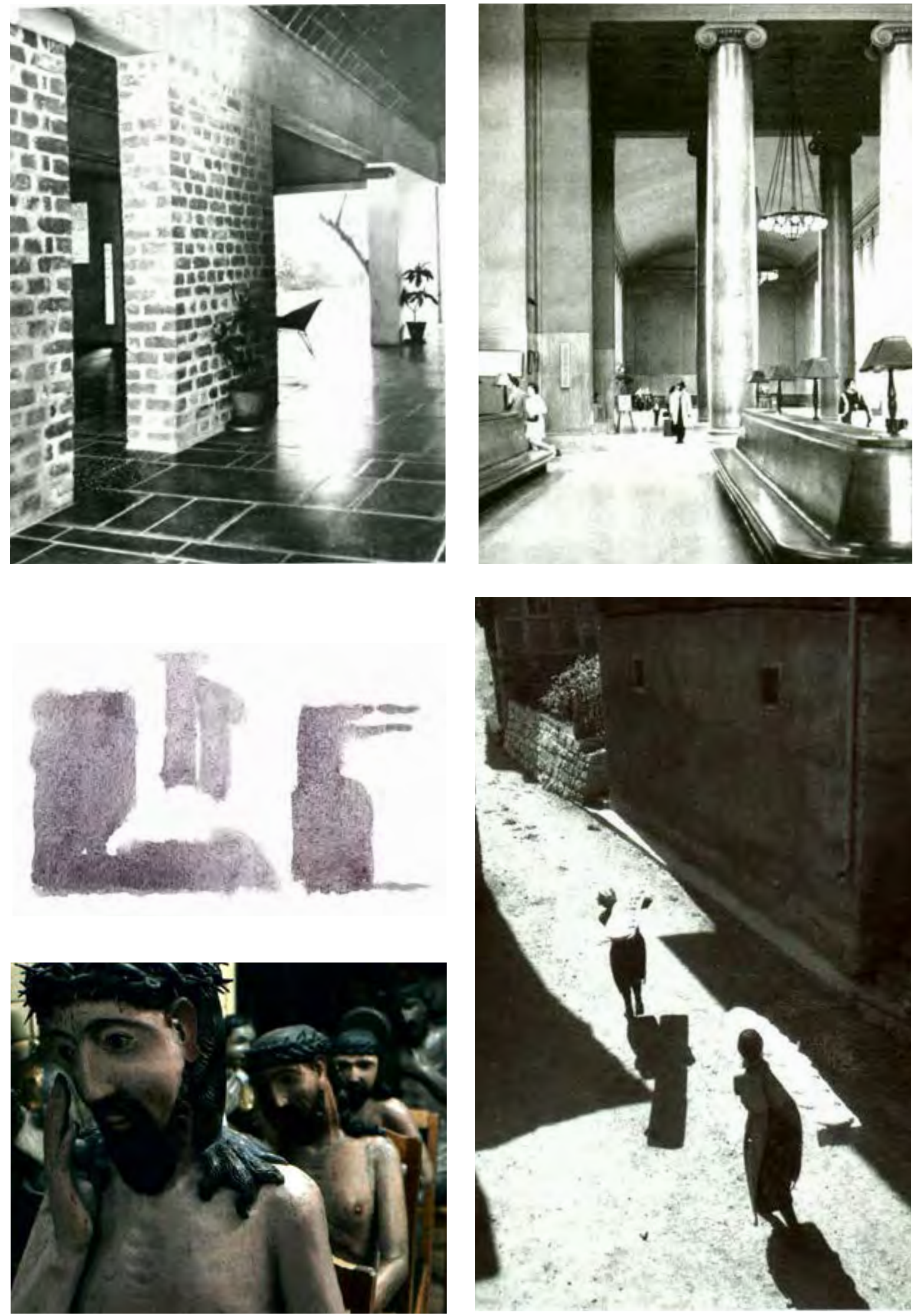

Figura 11 - 15

Imágenes inspiradoras para Peter Zumthor 

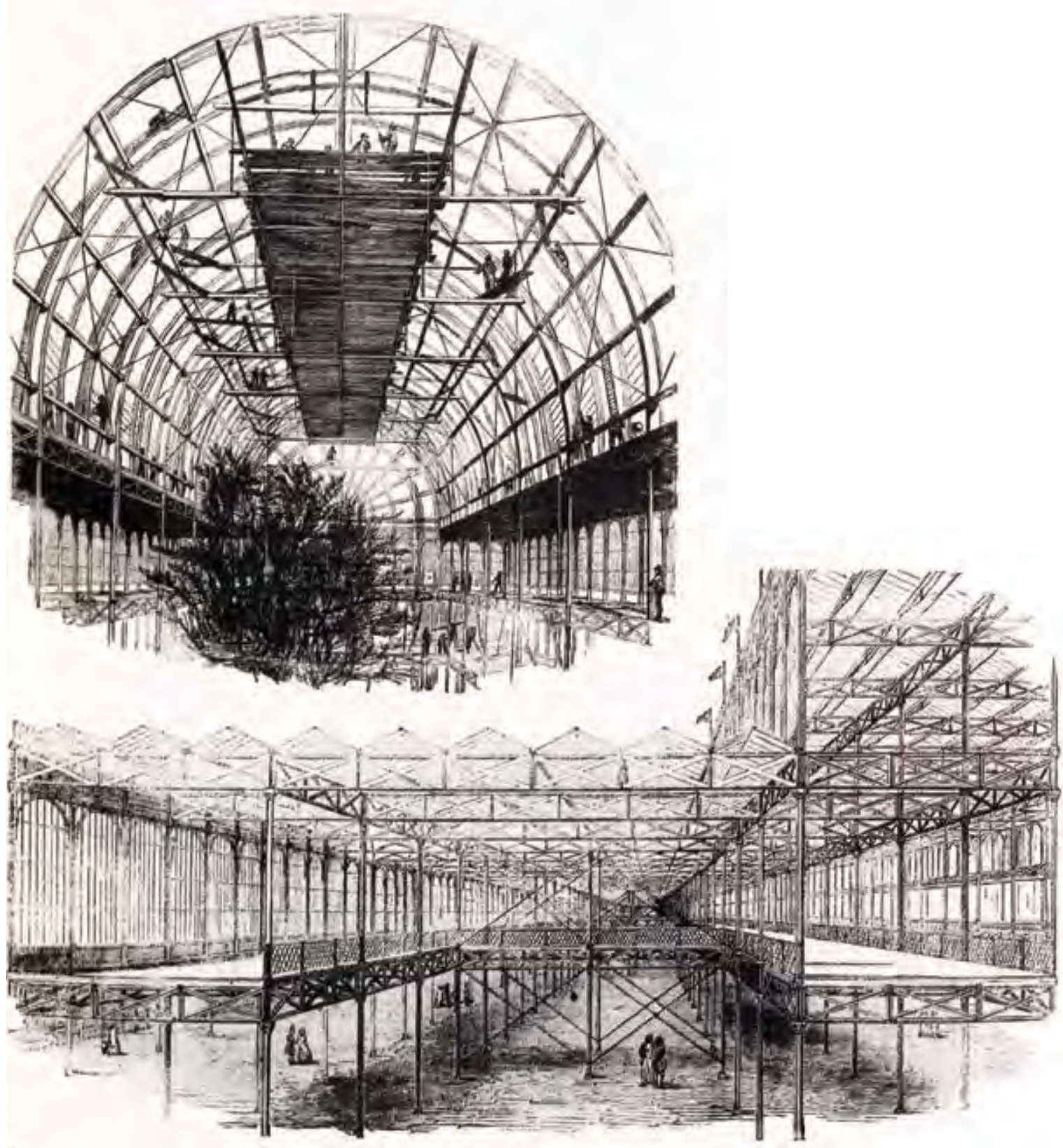

Figura 16.

Crystal Palace / Joseph Paxton / Londres / 1851 


\title{
[El contenedor del mundo]
}

\author{
"Era arcaico, primitivo, pero tan grande que parecía \\ contener en su interior la infinitud, el espacio se extendía \\ ininterrumpidamente hasta donde la vista pudiera alcanzar, \\ encuadrado por el modulo regular de la estructura hasta \\ deshacerse paulatinamente en una neblina óptica formada por \\ la distancia y la luz"14 Reyner Banham
}

En el siglo XIX se inició una contienda mediática por la hegemonía tecnológica; sobre todo entre Inglaterra y Francia, entre Londres y París. El objetivo era mostrar y de-mostrar supremacía económica, científica e industrial a toda la sociedad, tanto a expertos como a profanos. Fruto de esta rivalidad surgió la idea de organizar un acontecimiento pionero propio de la era de la industrialización; una Exposición Universal.

Las exposiciones a nivel nacional; es decir circunscritas a una única potencia, ya existían en algunos países europeos. Entre ellas destacó la primera Exposition nationale des produits de l'industrie inaugurada el 19 septiembre de $1798^{15}$ en el Campo de Marte de París; impulsada por el ministro del interior Nicolas François de Neufchâteau. Gracias al intercambio entre los diferentes oficios y manufacturas; se podía tener una visión panorámica de los productos fabricados por la Industria francesa. Las Exposiciones industriales parisinas se sucedieron en varias ediciones, pero no con periodos constantes ${ }^{16}$ siendo el crecimiento de las mismas exponencial en visitantes y expositores. La décima edición de Exposition nationale des produits de l'industrie celebrada entre el 1 de mayo y el 29 de junio de 1844 en Les ChampsÉlysées se concentró en una gran infraestructura temporal en Grand Carré des Jeux de Les Champs Elysées. Tras su gran éxito de convocatoria donde congregó casi 4.000 expositores; el siguiente paso expansivo fue intentar abrirlo a otras naciones.

14 BANHAM, Reyner. Guia de la arquitectura moderna. Editorial Blume. Barcelona. 1979. ISBN: 84-7031104-2. Pág. 56.

15 GIEDEON, Sigfried. Espacio, tiempo y arquitectura. Editorial Reverté. Barcelona. 2009. ISBN: 978-84291-2091-2. Pág. 260.

16 Nota: Primera edición en 1798; con una duración de 3 días con 110 expositores. Segunda edición en 1801; seis días con 229 expositores. Tercera edición en 1802; 7 días con 540 expositores. Cuarta edición en 1806 con 24 días y 1.422 expositores. Quinta edición tras la Primera Guerra Mundial en 1819 con 35 días y 1.662 expositores. Sexta edición en 1823 con 50 días y 1642 expositores. Séptima edición en 1827, 62 días con 1.695 expositores. Octava edición en 1834, 60 días con 2.447 expositores. Octava edición en 1839; 60 días con 3.281 expositores. Décima edición, 60 días con 3.960 expositores. Undécima edición en 1849, 60 días con 5494 expositores. 


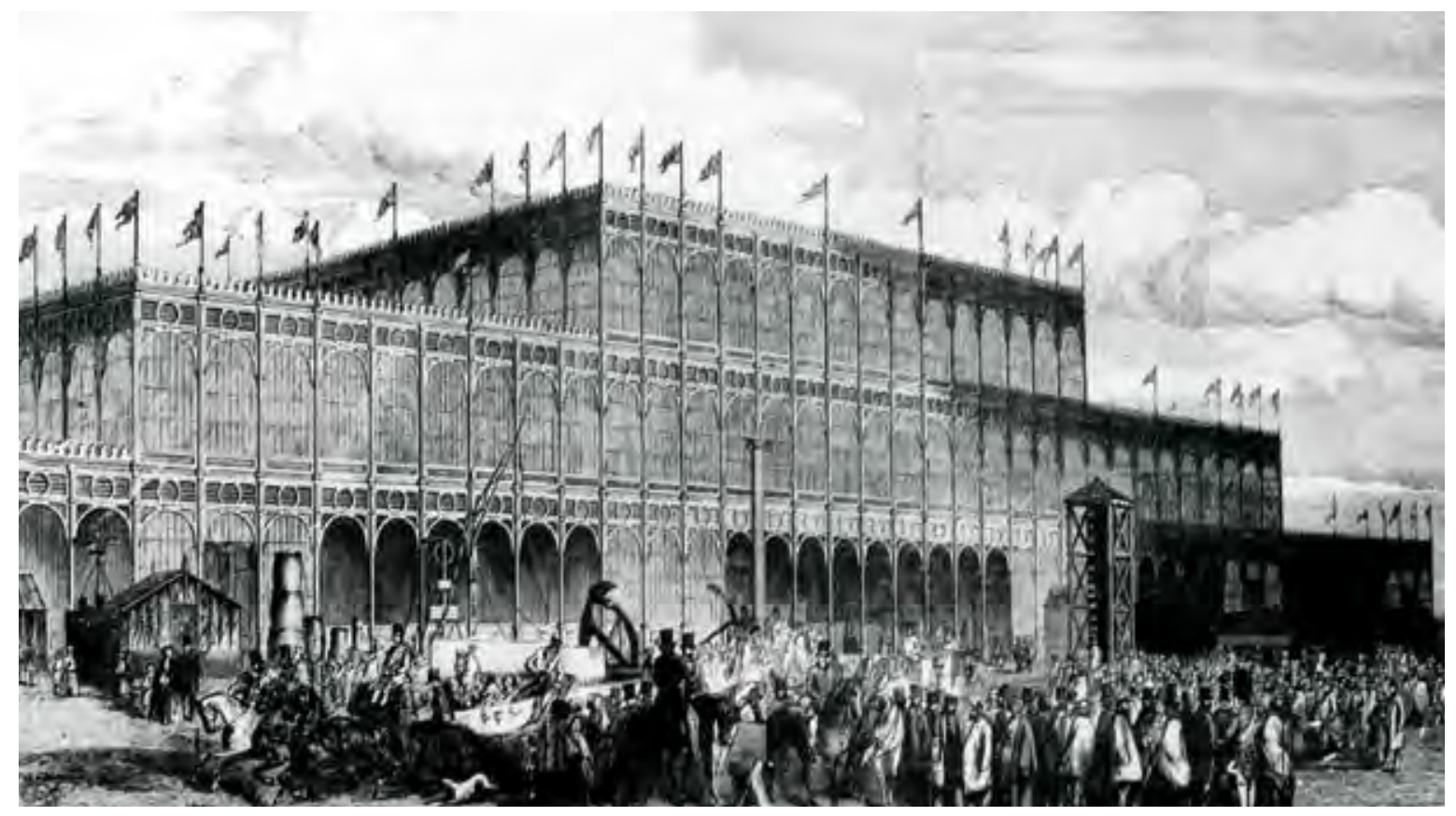

Figura 17.

Entrada oeste / Crystal Palace / Joseph Paxton / Londres / 1851

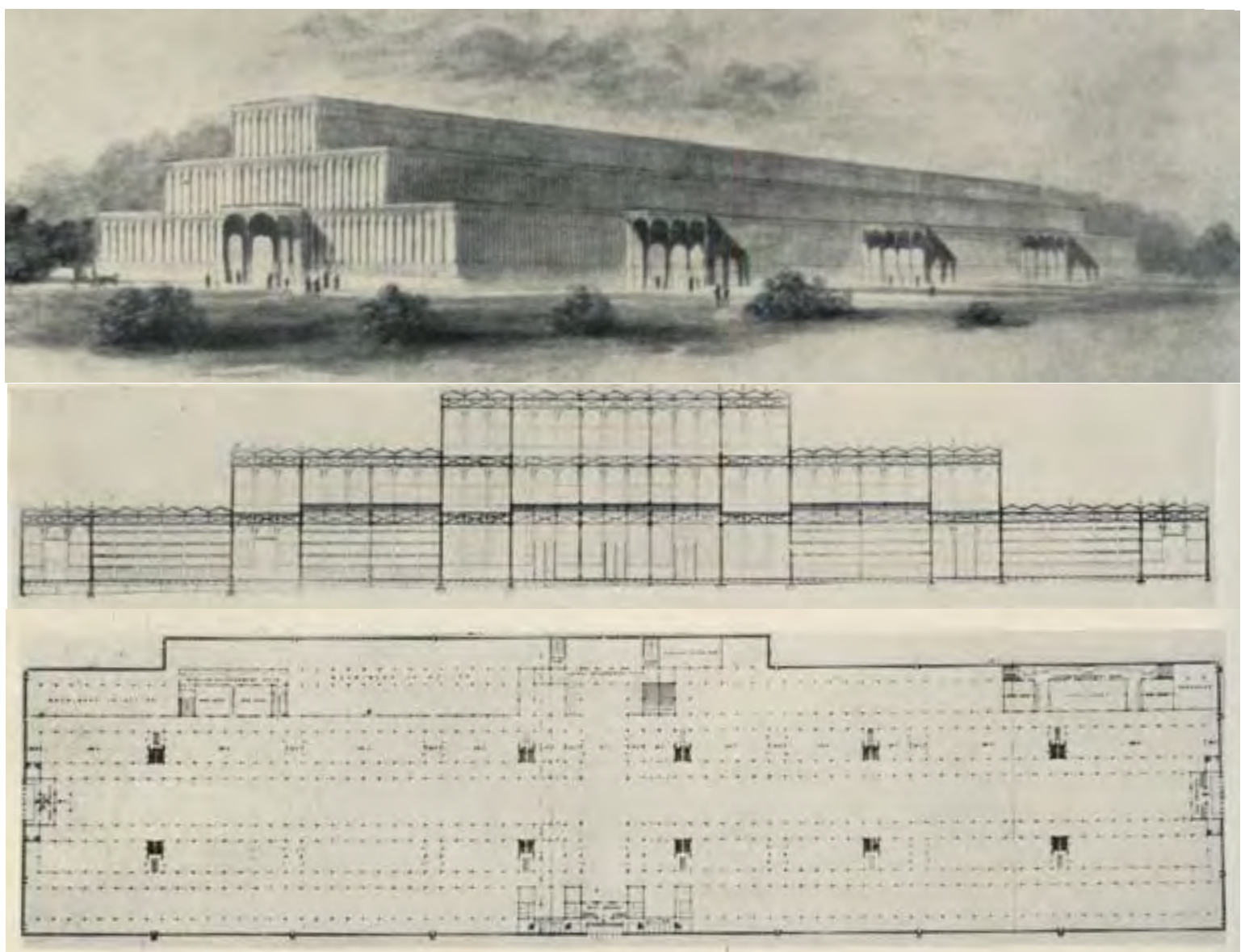

Figura 18.

Propuesta de Joseph Paxton para el Crystal Palace con sección y planta 
Francia e Inglaterra rivalizaron por ser las pioneras en llevar a cabo una muestra universal. En ese momento ambas serán las dos únicas potencias hegemónicas con las infraestructuras necesarias para poder llevar a cabo esta compleja empresa. Una muestra donde poder descubrir las innovaciones industriales de varias naciones; así como potenciar las relaciones comerciales internacionales en respuesta a la incipiente expansión industrial.

Mientras que Francia fracasó en su voluntad de internacionalizar la undécima edición de su exposición industrial en $1849^{17}$ debido a dificultades políticas internas; Inglaterra tendrá su estandarte indiscutido en el Príncipe Albert, esposo de la reina Victoria. En 1845 Friedrich Engels describió la situación de la siguiente manera:

"Esta es en resumen la historia de la industria inglesa en los últimos sesenta años, una historia que no ha tenido su par en los anales de la humanidad. Hace sesenta y ocho años un país como todos los demás, con ciudades pequeñas, poca industria, y una población agrícola invariable pero relativamente grande; y ahora un país como ningún otro, con una capital de tres millones y medio de habitantes, con fábricas colosales, con una industria que abastece a todo el mundo. Y casi todo con una población diligente, inteligente, densamente poblada, de la cual dos tercios están ocupados por la industria y que consiste en clases completamente diferentes, sí, que forma una nación completamente diferente con costumbres y necesidades diferentes a las de esa época. La revolución industrial tiene el mismo significado para Inglaterra que la revolución política en Francia y la revolución filosófica para Alemania." ${ }^{18}$ Friedrich Engels authentischen Quellen. Leipzig. 1845. en: Marx/Engels. Gesammelte Werke. Band 2. Berlin. 1980. Traducción de la autora: "Das ist in kurzen die Geschichte der englischen Industrie in den letzten sechzig Jahren, eine Geschichte, die ihres Gleichen nicht hat in den Annalen der Menschheit. Vor sechzig/achtzig Jahren ein Land wie alle anderen, mit kleinen Städten, wenig und einfacher Industrie und einer dünnen, aber verhältnismässig grossen Ackerbaubevölkerung; und jetzt ein Land wie kein anderes, mit einer Hauptstadt von drittelhalb Millionen Einwohnern, mit kolossalen Fabrikstädten, mit einer Industrie die die ganze Welt versorgt und die fast alles mit einer fleissigen, intelligenten, dichtgesäten Bevölkerung, von der zwei Drittel durch die Industrie in Anspruch genommen werden und die aus ganz anderen Klassen besteht, ja, die eine ganz anderen Nation mit anderen Sitten und anderen Bedürfnissen bildet als damals. Die industrielle Revolution." 


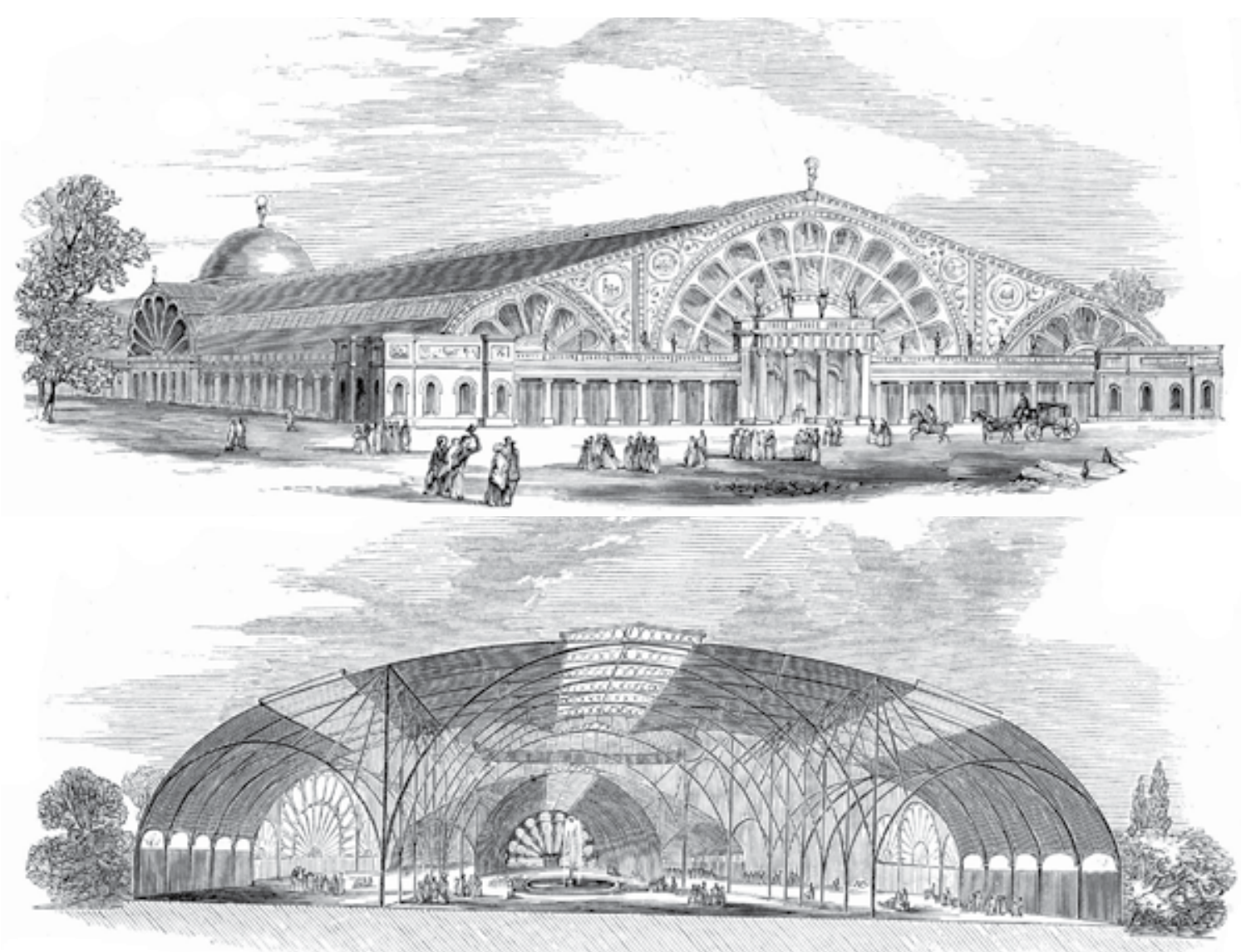

Figura 19.

Propuesta de Messrs. $R$ and T. Turner para el concurso de ideas / 1850
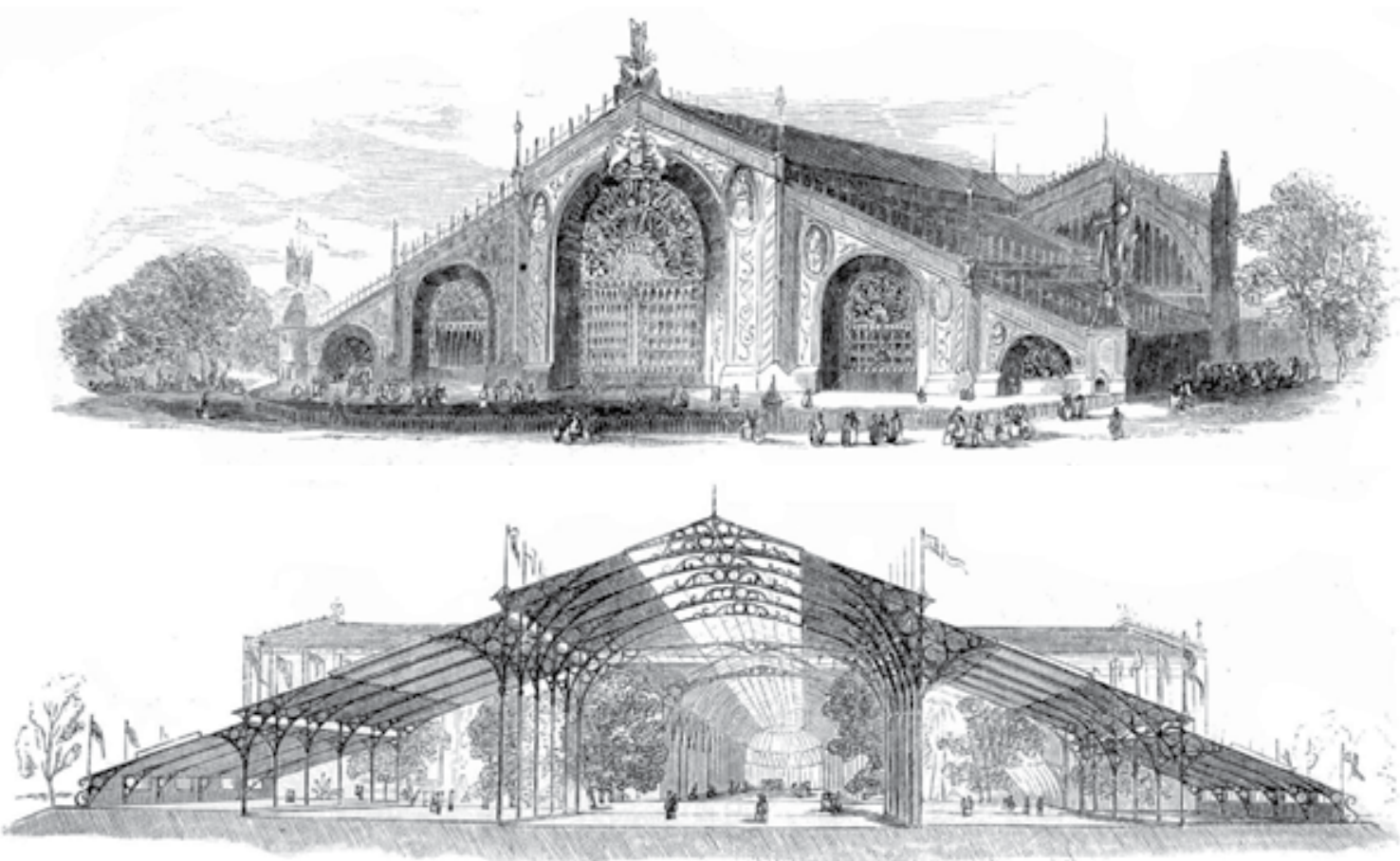

Figura 20.

Propuesta de M. Hector Horeau para el concurso de ideas / 1850 
Inspiradas en las muestras francesas, las exposiciones industriales nacionales en Inglaterra, predecesoras a la Gran Muestra; se emprendieron en gran medida gracias al impulso de Henry Cole, miembro recién nombrado del comité de la Society for the Encouragement of Arts, Manufactures and Commerce. Cole fue un activo defensor de la simbiosis entre lo industrial y el arte como motor de un nuevo estilo. A principios de 1849 funda la revista sobre diseño manufacturado Journal of Design and Manufacturers, distanciándose de las criticas hacia la industrialización. En este clima de optimismo manufacturero se puso en marcha dos años antes la primera de una serie de modestas exposiciones anuales consecutivas en la cuales se mostraban la producción del Art Manufacture inglés. El Príncipe Albert conoció personalmente a Henry Cole durante una visita a la Exposición parisina de industria en $1849^{19}$; y decidió dar el impulso político necesario para transformar la cuarta Exhibition of Art Manufactures en la primera Exposición internacional en tierras británicas.

A principios de 1850, se creó la Royal Commission para la organización de este enorme acontecimiento con el respaldo de la Reina Victoria. Uno de los comités constituidos tuvo la responsabilidad de velar por el diseño y la construcción de la muestra. El Building Committee estuvo compuesto por políticos, arquitectos e ingenieros ${ }^{20}$, mostrando los tres ámbitos sobre los cuales se asentaron las pertinentes decisiones. Políticamente se solicitó que el innovador contenedor se convirtiera en un tótem simbólico de la supremacía industrial inglesa; mientras arquitectos e ingenieros exigieron que fuese un reflejo de las nuevas posibilidades constructivas de su tiempo. Se inició así la convocatoria de un concurso internacional para la elección de la mejor infraestructura; adecuada a los cánones victorianos, además de ser realizable y sobre todo viable.

El concurso internacional tuvo un gran éxito de convocatoria; presentándose al mismo 245 propuestas $^{21}$. Entre todas ellas 65 obtuvieron una mención; siendo dos de ellas mención especial: el arquitecto francés $M$. Hector Horeau y la oficina irlandesa Messrs. R. And T. Turner. Ambos proyectos propusieron una sección a modo de granero de grandes dimensiones. Mientras que la propuesta "francesa" planteó un esquema a dos aguas; los pórticos "irlandeses" se conformaban a través de arcos. Ambos contenedores contenían dos tratamientos distintos, e incluso inconexos.

19 Nota: El príncipe Alberto de Sajonia-Coburgo-Gotha ya era conocedor de las muestras francesas anteriormente. En 1844 visitó la décima edición de la Exposition nationale des produits de l'industrie a la edad de 24 años; cinco años después de llegar al trono como regente.

20 Nota: A principios de Enero se conformó el Building Committe presidido por el Duque de Buccleuch. También serán parte del mismo el Conde de Ellesmere; los arquitectos C. R. Cockerell, Charles Barry y Thomas L. Donaldson; así como los ingenieros Robert Stephenson y I. K. BruneL, y William Cubitt.

21 BENEVOLO, Leonardo. Historia de la arquitectura moderna. (1974). Editorial Gustavo Gili. S.A. Barcelona. 2005. ISBN: 84- 252-1793-8. Pág. 129. 


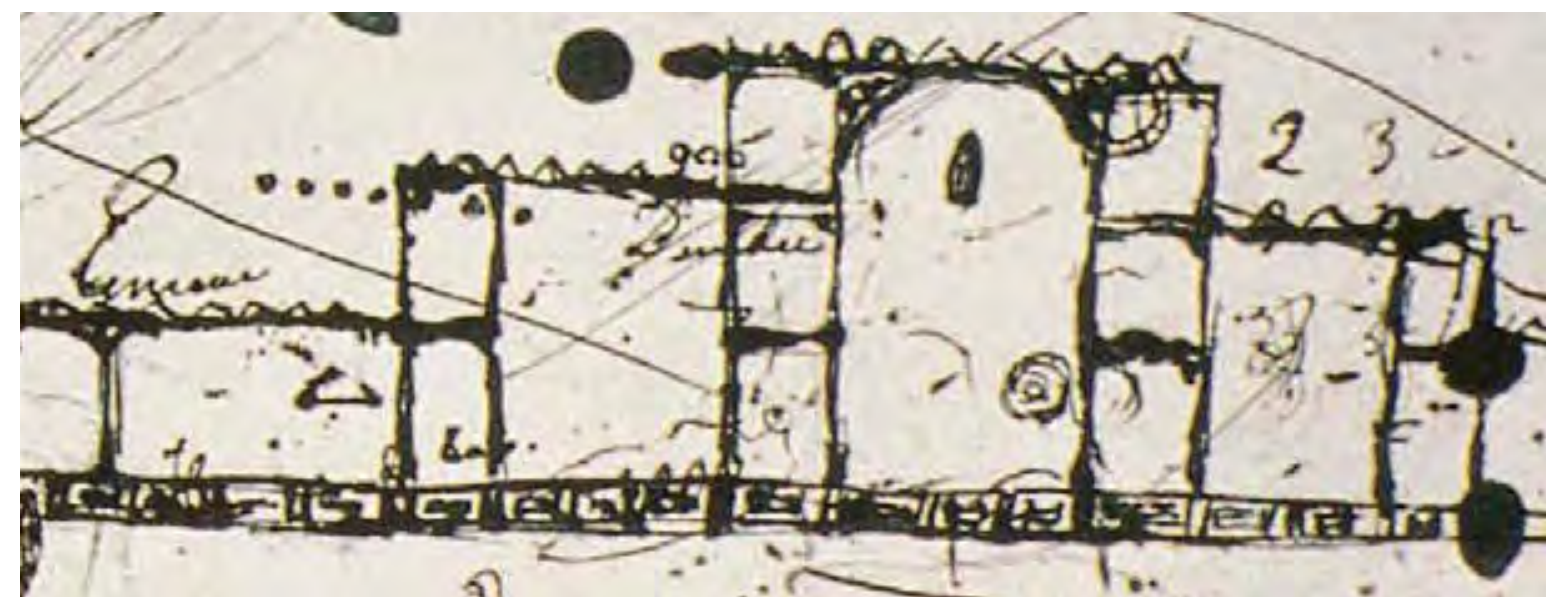

Figura 21.

Crystal Palace / Joseph Paxton / Croquis

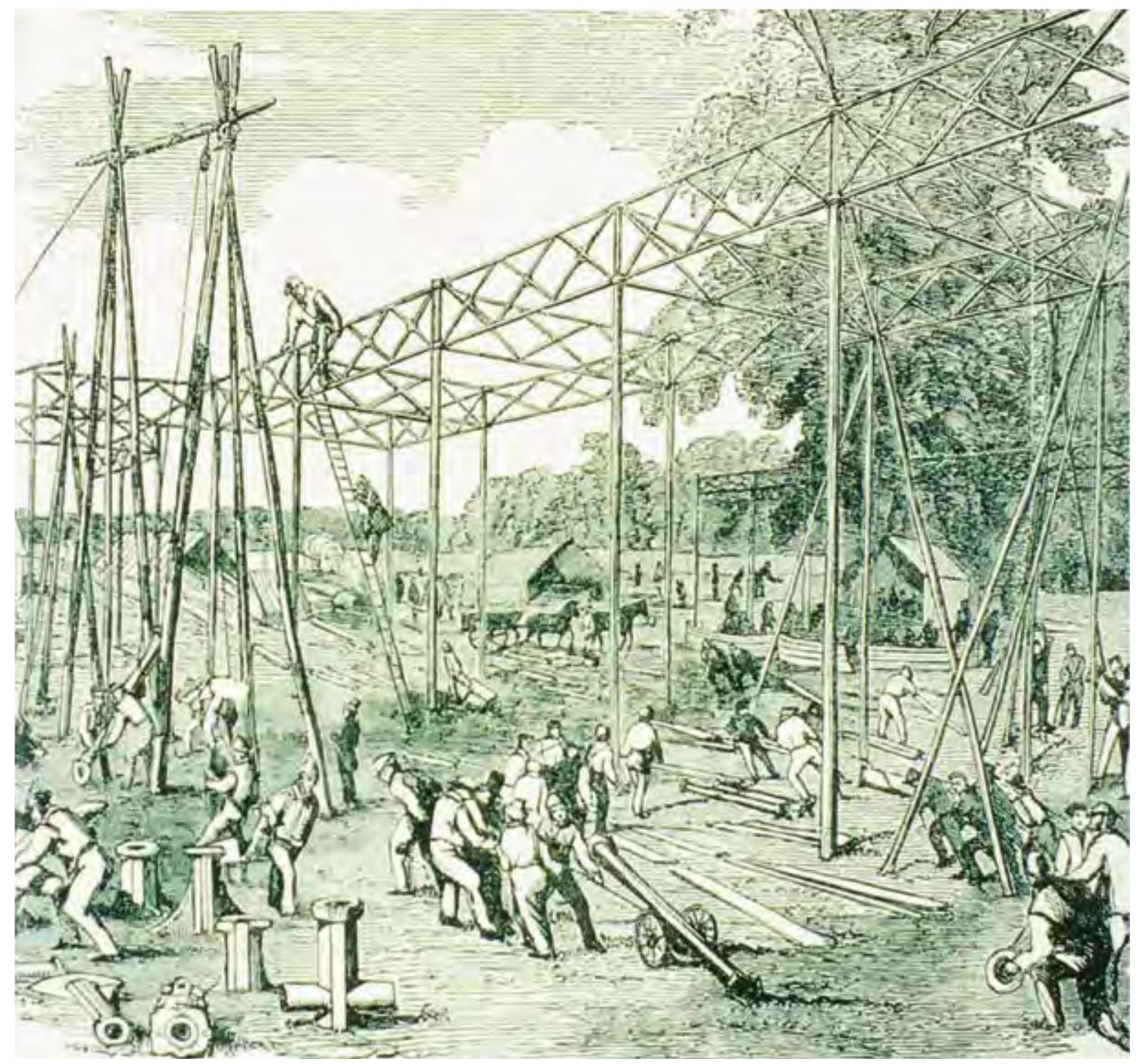

Figura 22

Los primeros días de la obra / Crystal Palace / Joseph Paxton 
Mientras que el interior fluía como un espacio continuo de grandes luces cubierto por un esqueleto industrial innovador; sin embargo los cerramientos de fachada se materializaban mediante un lenguaje historicista. Ambas propuestas, analizadas en profundidad por el Building Committe; fueros consideradas irrealizables y económicamente inviables, por lo que se decidió declarar desierto el concurso.

Tras la experiencia fallida, el Building Committee cambió el proceso de adjudicación de la "catedral de la tecnología". No exento de polémica y con la oposición de varios sectores sociales, el Comité desarrolló un proyecto base sobre el cual se convocó un nuevo concurso; pero esta vez de licitación. El proyecto, a modo de plantilla, fue una especie de recopilatorio de las propuestas premiadas en el concurso de ideas; un collage entre la catedral St Paul y una estación de ferrocarril ${ }^{22}$. El nuevo proceso de licitación, al cual fueron invitadas varias empresas, tuvo unas bases donde se valoró especialmente que las propuestas aportasen sistemas de construcción que redujeran costes y agilizaran los procesos de su puesta en marcha. Finalmente, el 22 de junio de 1950 se publicó el proyecto oficial en The Illustrated London News; así como en un folleto específico para los licitadores.

Una vez iniciado el nuevo proceso; el Building Committe fue desafiado, en forma y fondo, por un afamado y reputado constructor de invernaderos. Apenas dos semanas después de la publicación del proyecto base ${ }^{23}$; Joseph Paxton publicó en el mismo tabloide una propuesta alternativa. Gracias a la gran acogida de la opinión pública y especialmente a la pertinencia y solvencia de este diseño industrial, finalmente Paxton hizo que su proyecto fuese el elegido. Solamente 20 días antes del inicio de las obras; el 10 de Julio de 1850, el Building Committe llegó a un acuerdo económico con un consorcio compuesto por la empresa de ingeniería Fox and Henderson, el fabricante de vidrio Chance Brothes of Birmingham, y el propio Joseph Paxton.

\footnotetext{
"El proyecto de Palacio de cristal procede de Joseph Paxton, jardinero mayor del duque de Devonshire, para quien había construido en Chatsworth un conservatory (invernadero), de cristal y hierro. Su proyecto resultaba recomendable por ser seguro contra el fuego, por su diafanidad, por la rapidez de su realización y por su bajo coste, triunfando sobre el del comité."24 Walter Benjamin
} 1851-1936: A Portrait of Victorian Enterprise. London, Hugh Evelyn, 1970. 

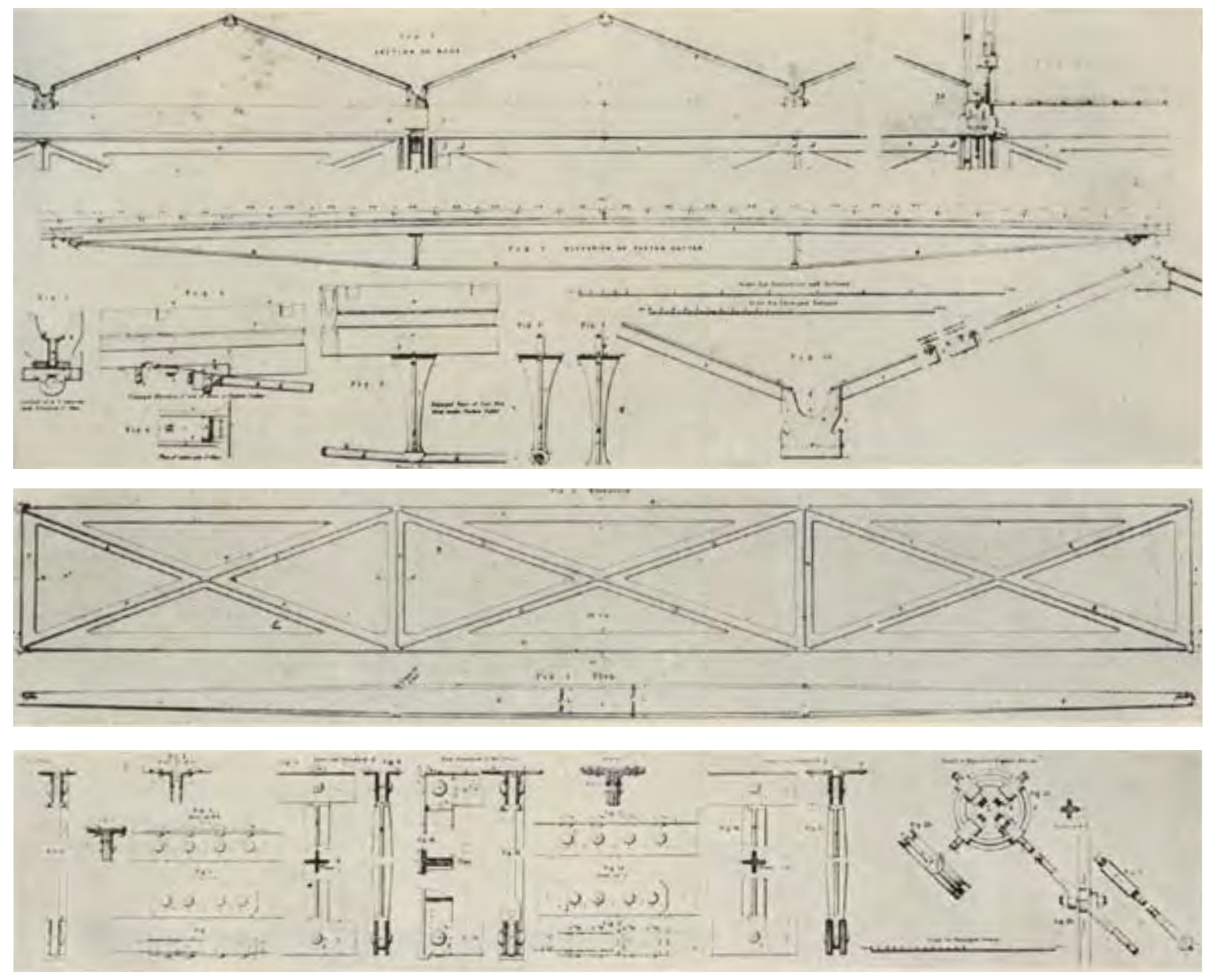

Figura 23.

Detalles / Crystal Palace

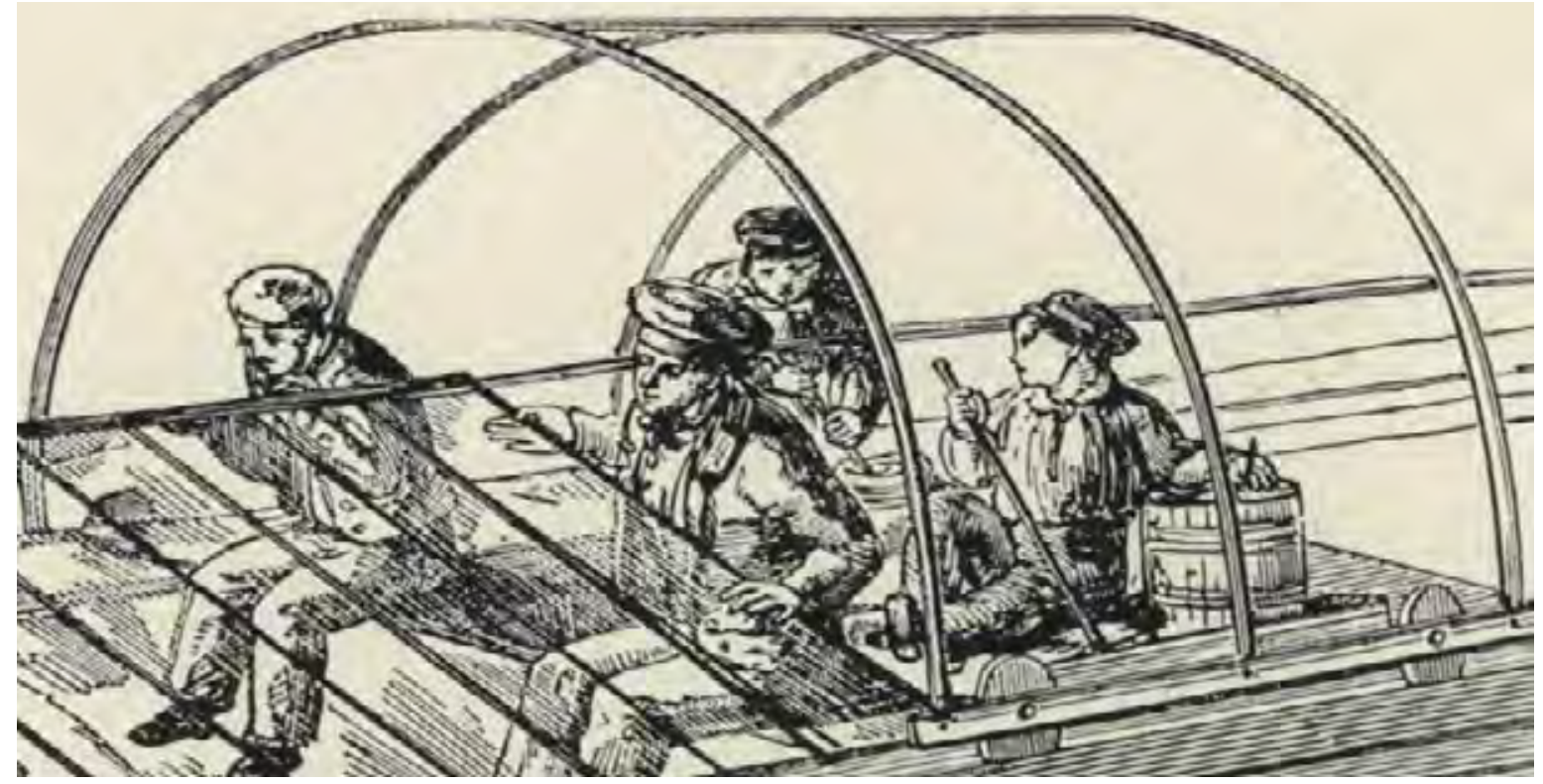

Figura 24.

Montaje / Crystal Palace 


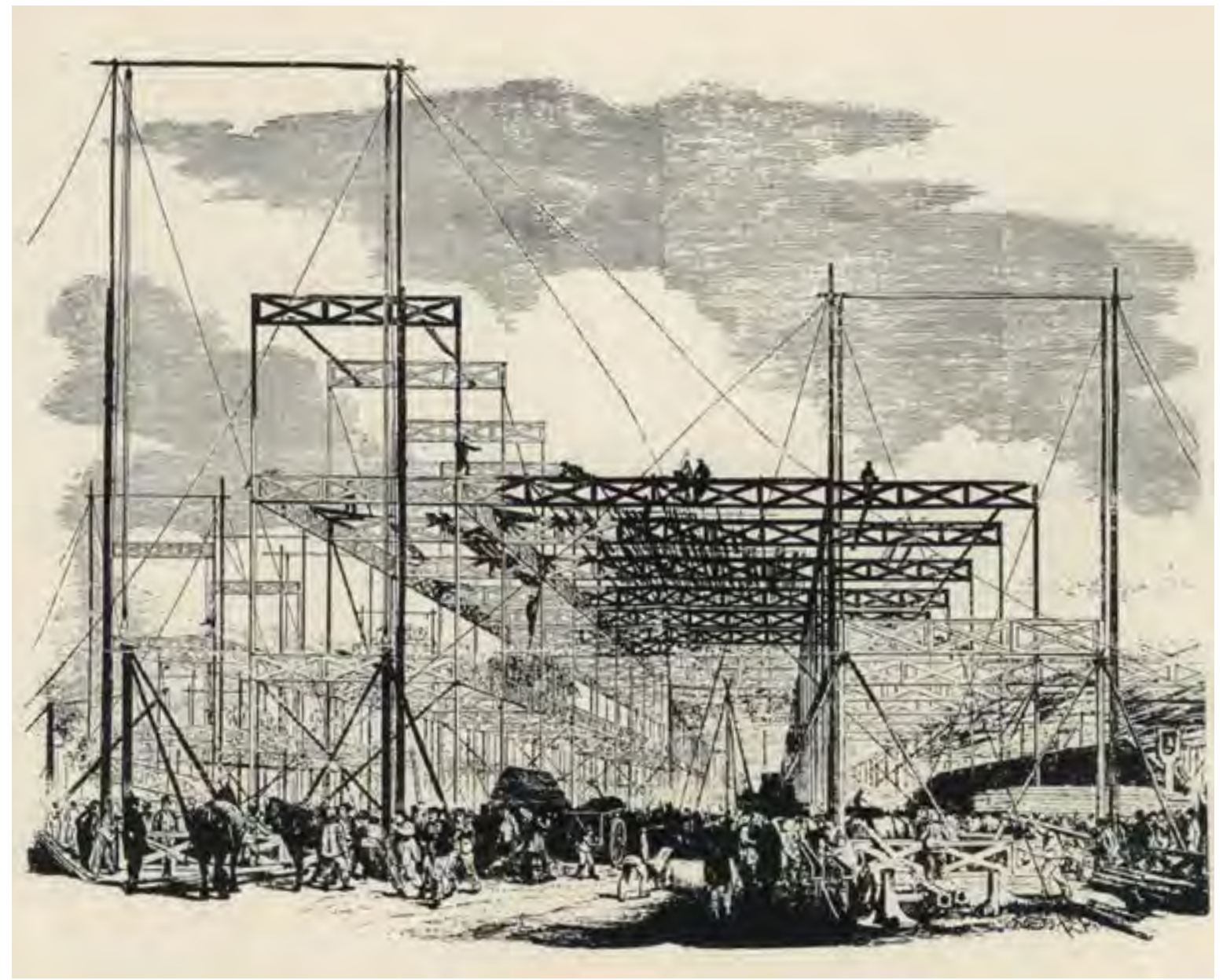

Figura 25.

Proceso de construcción / Método de prefabricación y montaje del esqueleto / Crystal Palace / 1850

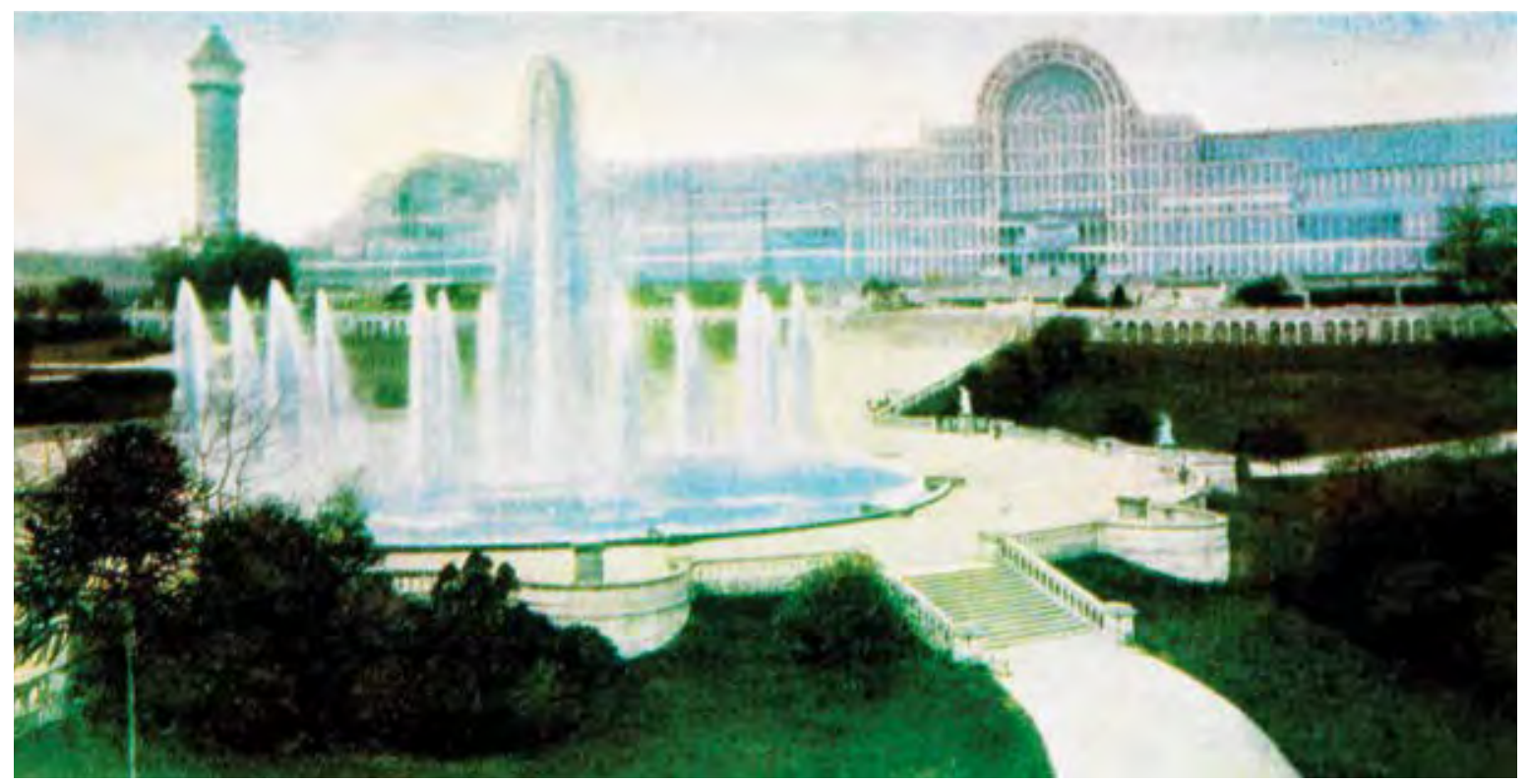

Figura 26.

Crystal Palace / Joseph Paxton / Sydenham 


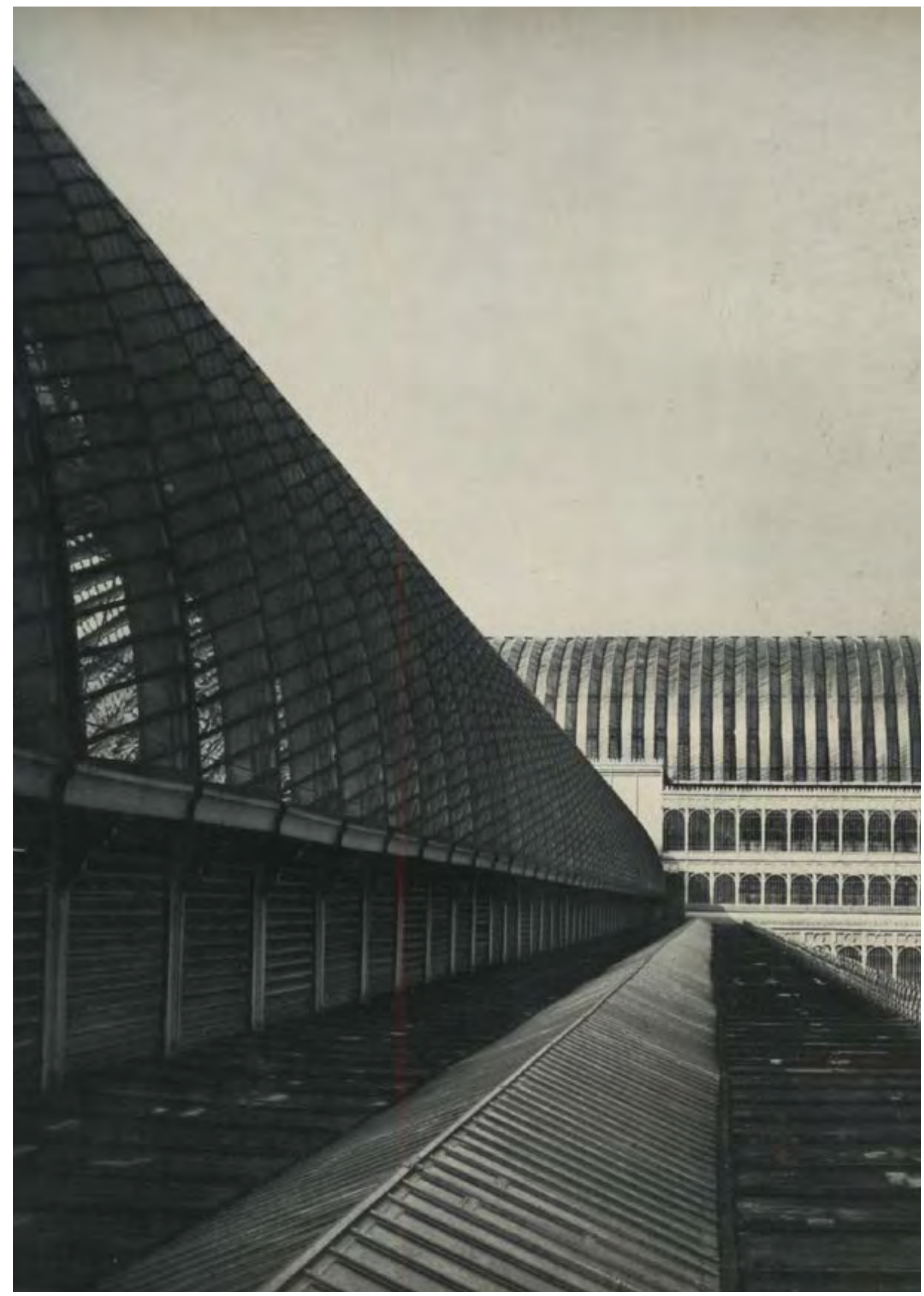

Figura 27.

Crystal Palace 
El Glass House pasó a ser el Crystal Palace, ocupando unas explanadas al sur de Hyde Park entre Totten Row y Kensington Gate. Este palacio industrial fue erigido como un nuevo desafío tecnológico del momento. Una gran basílica simétrica en vidrio de cinco naves adinteladas a diferentes niveles sobre un eje central. El proyecto publicado por Paxton no contemplaba el espacio central abovedado más alto. Esta mutación fue posterior; con el objetivo de incorporar en el espacio interior una serie de árboles existentes en el lugar. La planta en cruz simétrica contenía un eje longitudinal de más de medio kilómetro y otro trasversal de más de un centenar de metros.

"El edificio tenía una longitud de 564 metros, lo que corresponde a 1851 pies ingleses. Este número alude al año de la exposición. La anchura era de 124 metros. La nave central tenía una altura de 20,31 metros. Las dos naves interiores tenían 12,80 metros de altura, los dos exteriores 6,71 metros. La nave insertada tenía una anchura de 22 metros y una altura de 33 metros. El área cubierta era de unos 74.000 metros cuadrados. El área de exposición se amplió con una planta de galería de unos 20.000 metros cuadrados, a la que se accedió mediante 10 escaleras de dos brazos en el interior del edificio. Para desarrollar las dimensiones espaciales aproximadas, el edificio era cuatro veces más grande que la Catedral de San Pedro en Roma.... 3.500 toneladas de hierro fundido para 3.230 columnas y 2.141 vigas, 550 toneladas de hierro forjado, 83.238 metros cuadrados de vidrio, 46 kilómetros de canalones y 307 kilómetros de escalones de ventanas fueron utilizados como material de construcción."25

Esta colosal filigrana tectónica, compuesta de piezas en hierro fundido, vidrio y madera; será un complejo puzzle prefabricado y estandarizado. Su mecanización industrial permitió reducir los tiempos y costes de construcción significativamente.

FRIEBE, Wolfgang. Architektur der Weltausstellung. 1851-1970. Edition Leipzig. Stuttgart, Berlin, Köln, Mainz. 1983. ISBN: 3-17-007722-8. Pág. 18-19. Traducción de la autora: "Der Baukörper besass eine Länge von 564 Metern, das entspricht 1851 englische Fuss. Diese Zahl spielt auf das Jahr der Ausstellung an. Die Breite betrug 124 Meter. Das Mittelschiff hatte eine Höhe von 20,31 Metern. Die beiden inneren Seitenschiffe waren 12,80 Meter, die beiden äusseren 6,71 Meter hoch. Das eingeschobene Querschiff hatte eine Breite von 22 Metern und 33 Meter Höhe. Die überdachte Grundfläche betrug etwa 74000 Quadratmeter. Erweitert wurde die Ausstellungsfläche durch ein Galeriegeschoss von etwa 20000 Quadratmetern, das durch 10 zweiarmige Treppen im Inneren des Gebäudes erschlossen wurde. Um ungefähre räumliche Grössenvorstellungen zu entwickeln, sei gesagt, dass das Gebäude viermal so gross war wie der St.-Peters Dom in Rom... Als Baumaterial wurden 3500 Tonnen Gusseisen für 3230 Säulen und 2141 Träger, 550 Tonnen Schmiedeeisen, 83 238 Quadratmeter Glas, 46 Kilometer Dachrinnen und 307 Kilometer Fenstersprossen verbraucht." 


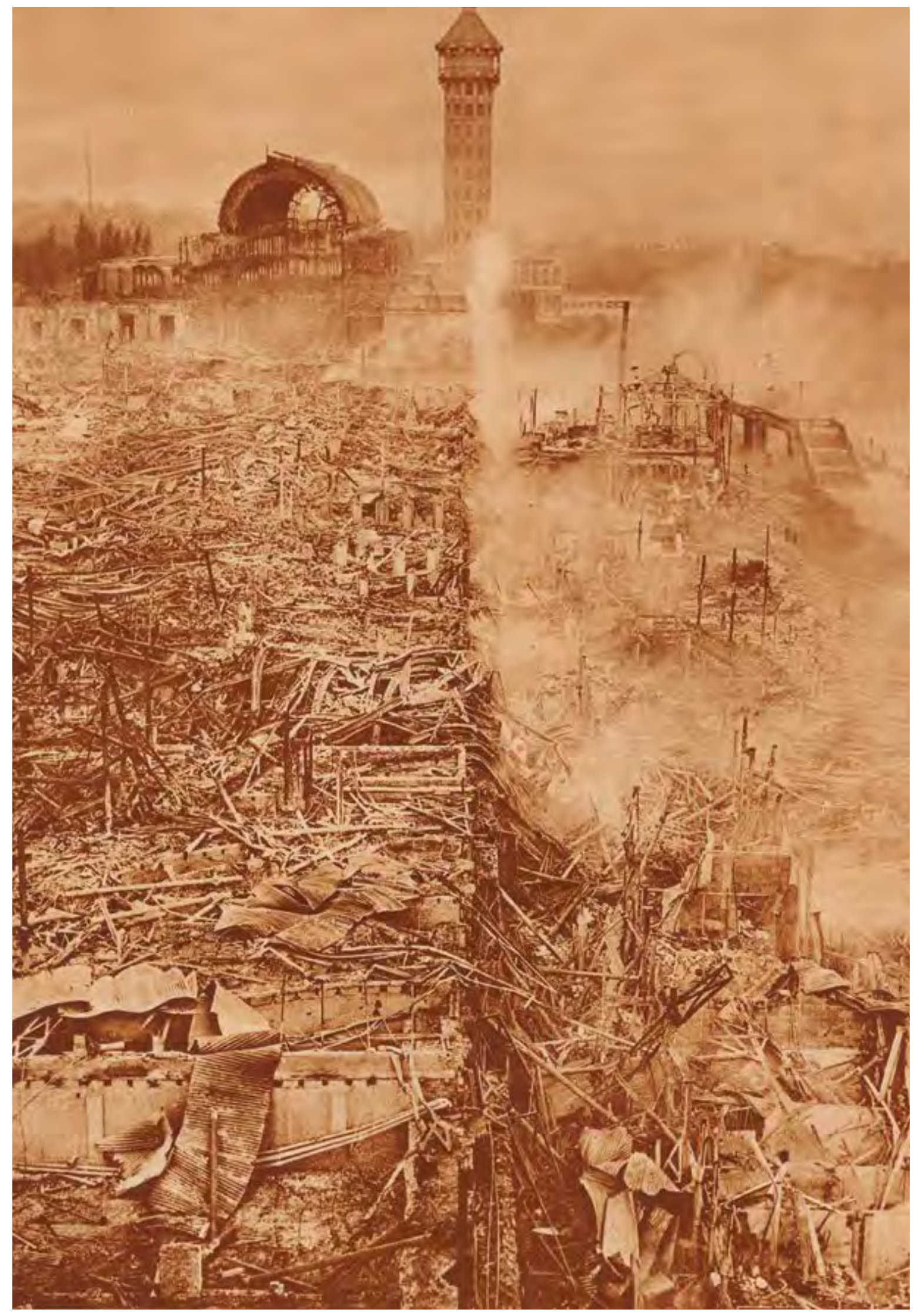

Figura 28.

Vista de la escena del incendio / Crystal Palace / Joseph Paxton / Sydenham 
Así mismo supondrá "la materialización de un nuevo concepto de edificio, un concepto para el que no había precedentes ${ }^{226}$. Las piezas serán manufacturadas en taller y montadas en obra. Su planteamiento estructural es clásico, a base de pórticos en ambas direcciones con un orden modular de 7,30 $\mathrm{m}^{27}$. Este entramado bidireccional de cerchas trianguladas se sustentaba en un bosque de columnas en retícula. Este enorme mecano contenía un sofisticado sistema de drenaje. La propia estructura -montantes, arriostramientos horizontales, y una cámara bajo la planta baja- contenía la red de desagüe. La envolvente de vidrio transparente era en todas sus fachadas continua y fina. Sin embargo; la cubierta se montó en forma de sierra evitando las condensaciones gracias a la ventilación natural. La precisa prefabricación de los elementos, el ágil sistema de montaje y una minuciosa logística de obra, permitieron que el Crystal Palace pudiera ser construido en tan sólo cinco meses ${ }^{28}$.

El 1 de mayo de $1951^{29}$, se inauguró la Great Exhibition of the Works of Industry of All Nations donde participaron alrededor de 14.000 expositores de los cuales aproximadamente la mitad eran ingleses. Toda la exposición universal estará contenida en este coloso invernadero, heredero del Chatsworth House; ya no como manifestación de la mecanización de la naturaleza, sino como expresión tecnológica de las nuevas posibilidades de la era de la industrialización. Un símbolo de la supremacía de la mecanización de la producción industrial inglesa. Como estaba previsto, el Crystal Palace fue desmontado tras la finalización de la muestra y trasladado de Hyde Park a Sydenham con alteraciones formales pero con el mismo sistema de montaje. En su nueva ubicación siguió acogiendo acontecimientos de carácter expositivo de forma regular, hasta que en $1937^{30}$ un incendio lo destruyó definitivamente.

La Primera Exposición Universal fue un éxito rotundo de público en los cinco meses y medio que permaneció abierta, con más de seis millones de visitantes, unos 35.000 cada día. Tras este nuevo paradigma, Londres y París se alternaron la organización de las cuatro ediciones siguientes ${ }^{31}$. En esta euforia técnica de las 291-2091-2. Pág. 266-267.

27 Nota: 24 pies ingleses.

28 Nota: El Crystal Palace se concluyó el último día de 1950. Quedaban sin embargo pendientes todos los trabajos de acondicionamiento interior de los espositores.

29 NORBERG-SCHULZ, Christian. Los principios de la arquitectura moderna. Editorial Reverté. Barcelona. 2005. ISBN: 9788429121070. Pág. 132.

30 GIEDEON, Sigfried. Espacio, tiempo y arquitectura. Editorial Reverté. Barcelona. 2009. ISBN: 978-84291-2091-2. Pág. 264.

31 Nota: Londres 1851, París 1855, Londres 1862, París 1867. 


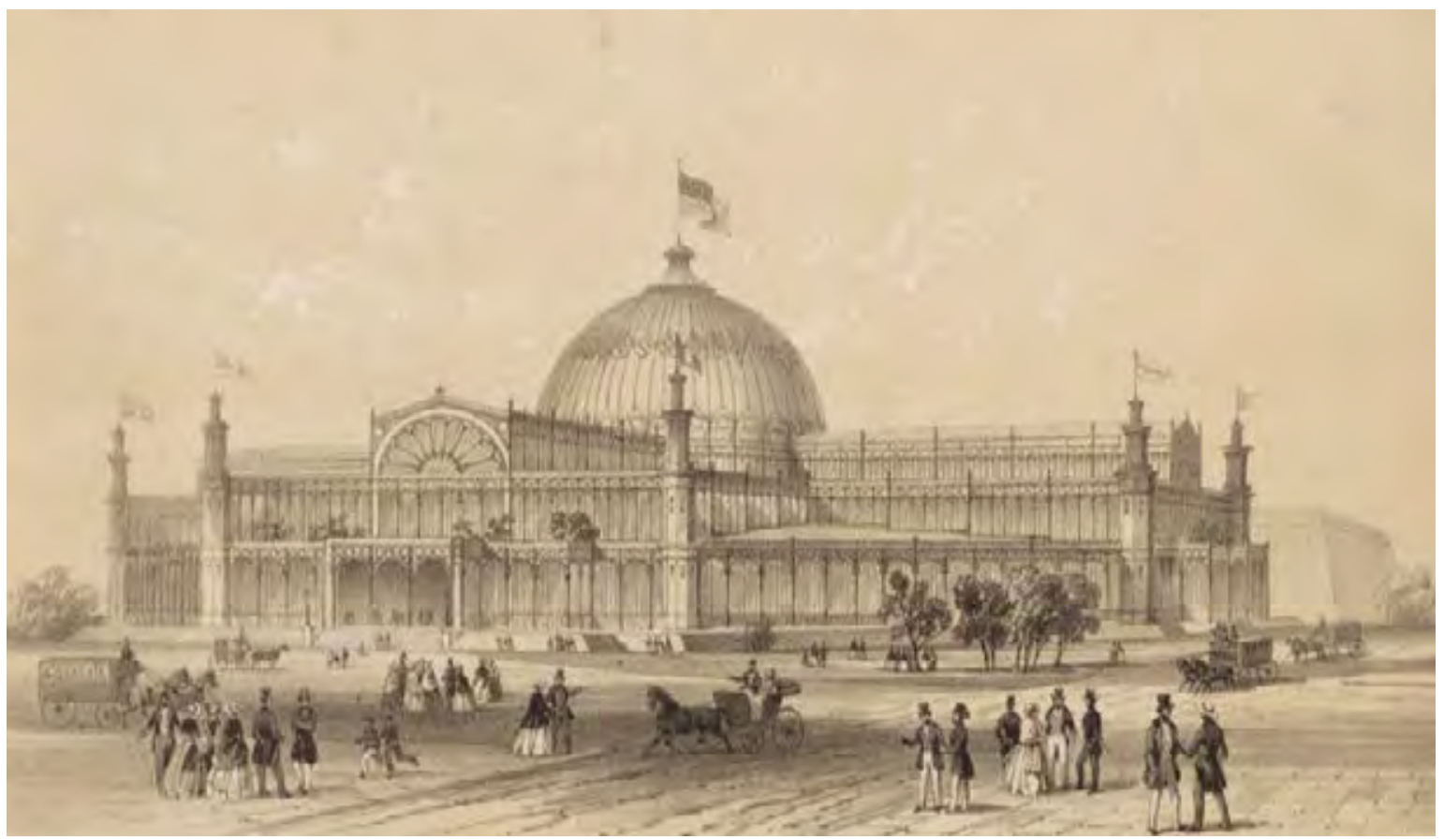

Figura 29.

Crystal Palace / New York / 1853-54

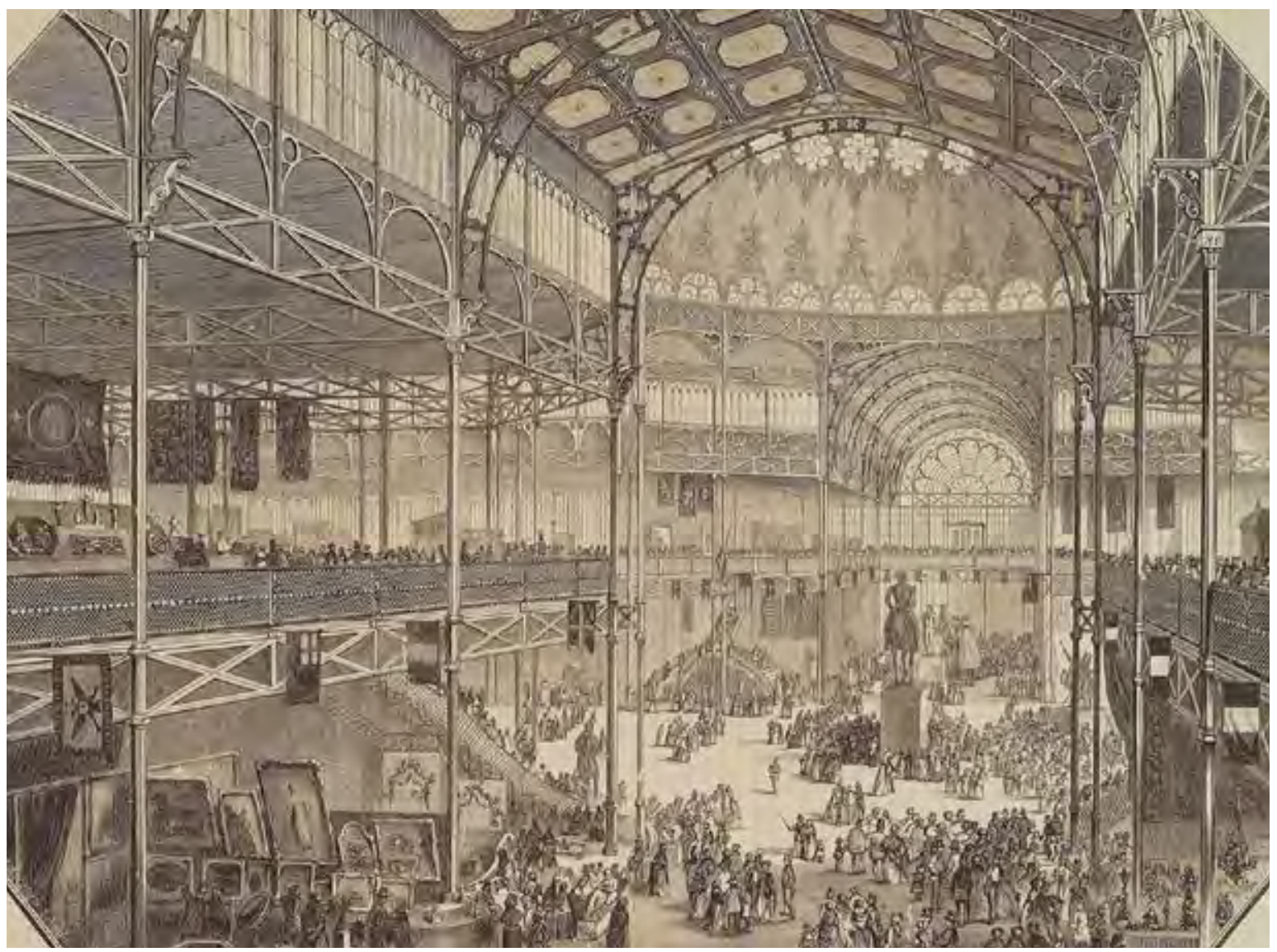

Figura 30.

Interior / Crystal Palace / New York / 1853-54 
potencias industriales como Inglaterra o Francia, pronto se sumará a la pugna Estados Unidos. La filigrana estructural del Crystal Palace será recurrente en años sucesivos como reflejo construido de la innovación tecnológica e industrial. Esta gran "burbuja del conocimiento" se convertirá en un modelo para las sucesivas exposiciones posteriores. Así surgirán ejemplos paradigmáticos de grandes sistemas estructurales desarrollando al máximo las nuevas capacidades portantes y espaciales como el Crystal Palace en la Exposición de Nueva York en 1853, la Torre Eiffel de Gustave Eiffel y la Galería de las Máquinas en la Expo de Paris 1889, la Rueda Ferris en la Expo de Chicago en 1893, la cúpula Biosfera de Montreal de Buckminster Fuller o el Pabellón Alemán de Frei Otto en Montreal 1967, entre otros.

\section{"(...) es una caja de Pandora llena de nuevas y revolucionarias técnicas e invenciones..."32 Rem Koolhaas}

Al igual que el Crystal Palace en Londres, la replica neoyorquina de 1853 constituyó una reinterpretación de la estructura flexible y modular hecha de hierro y vidrio. Una diferencia sustancial entre el Crystal Palace de New York y su original, fue la referencia a la arquitectura eclesiástica. El danés Georg Carstensen y el arquitecto alemán Karl Gildemeister optaron por una planta basada en forma de cruz griega; coronada por una enorme cúpula de 100 pies de diámetro. Esta "catedral de la tecnología", uno de los primeros edificios metálicos de la ciudad, se convirtió en un símbolo del rápido y enorme crecimiento del comercio y la industria, siendo un referente decisivo de la conquista hacia la verticalidad.

"El inspirador ejemplo de la Gran Exposición de Londres, celebrada en 1851 en el Crystal Palace, desata la ambición de Manhattan, que dos años después ya ha organizado su propia feria (...) La (...) construcción, complementaria, es una torre (...) 'Si exceptuamos la Torre de Babel, tal vez podría decirse que éste es el primer rascacielos del mundo' (...) Tales inspecciones desde lo alto se convierten en un tema recurrente (...)"133 Rem Koolhaas 


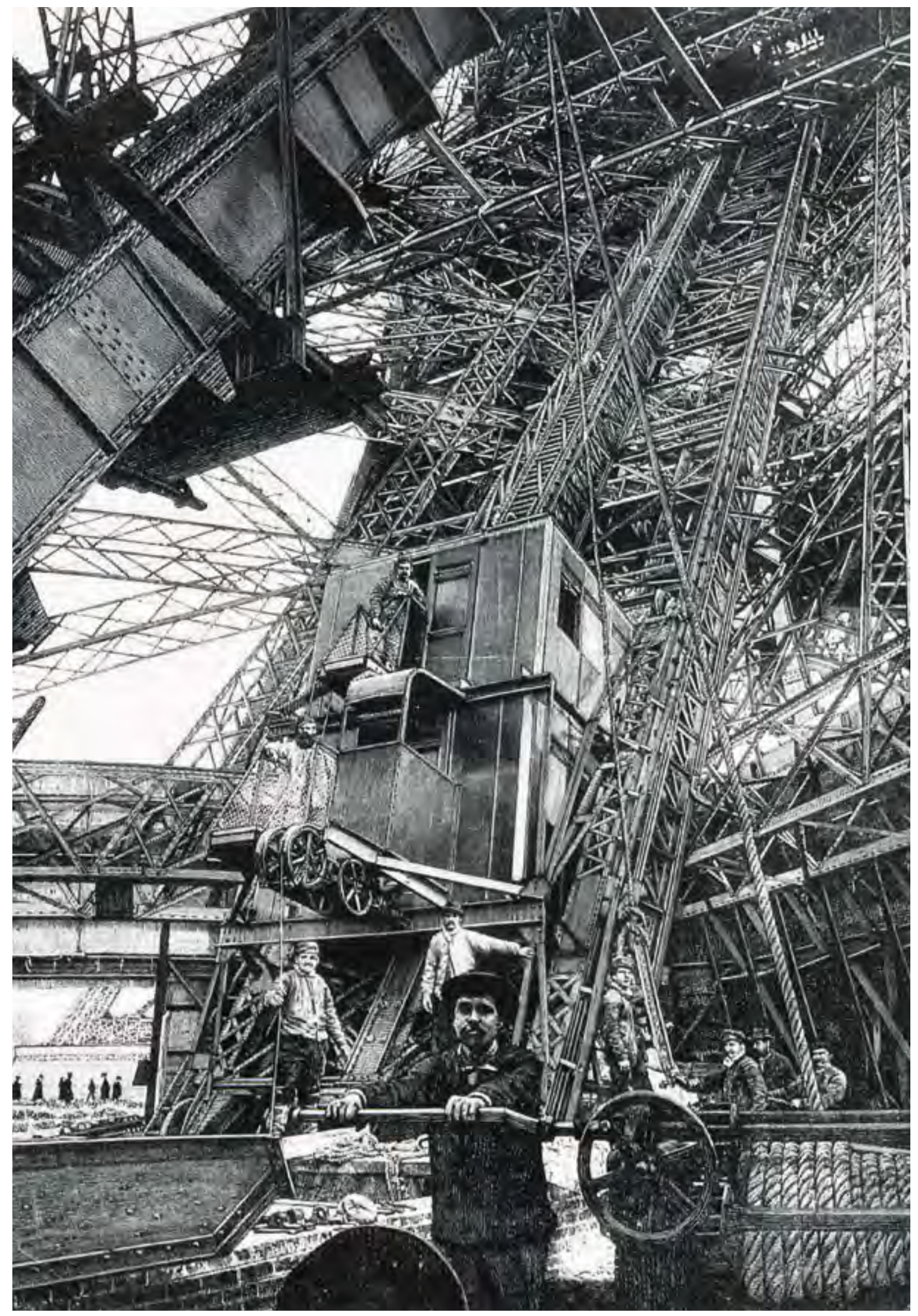


Pero no sólo Estados Unidos tuvo su fetiche arquitectónico. Tras el impacto que tuvo el Crystal Palace, Francia quiso "recuperar el liderazgo en el progreso industrial"34 con la cuarta Exposición Universal francesa. Esta muestra tuvo lugar en el Campo de Marte durante la conmemoración del centenario del inicio de la Revolución Francesa. A modo de Torre de Babel como expansión de un paisaje vertical construido, se eleva la Torre Eiffel. Una construcción de hierro que desafió la gravedad y las acciones del viento mediante riostras. Un esqueleto expansivo en vertical de hierro con una altura de $312 \mathrm{~m}$. Una infraestructura sin límites claros entre interior y exterior. Un sistema abierto en constante intercambio con su entorno. Junto a la Galeria de las Maquinas del arquitecto Ferdinand Dutert y el ingeniero Victor Contamin, re-utilizada para la Expo de 1900; estos lugares heroicos permanecerán inalterables, frente a constantes cambios en su interior. Semejante a las estaciones de tren, donde los vagones expositivos entran y salen dispuestos sobre las vías mostrando sus respectivos contenidos. Espacios escenográficos donde poder mostrar diversas escenografías efímeras sobre el mundo.

Nuevos métodos de procesamiento así como las novedosas posibilidades de los nuevos materiales requirieron nuevas construcciones y procesos de producción ${ }^{35}$. Estos experimentos utópicos manufacturados, alternativos a la artesanal construcción tradicional, representaron en si mismos e hicieron visible un decidido punto de inflexión en la construcción-Wendepunkt de Bauens ${ }^{36}$.

34 ANTIGÜEDAD DEL CASTILLO-OLIVARES, M.a Dolores, NIETO ALCAIDE, Víctor, Martínez Pino. Joaquín. El siglo XIX: la Mirada al pasado y la modernidad. Editorial Universitaria Ramón Areces. Madrid. 2015. ISBN: 978-84-9961-195-2. Pág. 173

35 WEBER, Helmut. Industrielle Herstellungsverfahren unter besonderer Berücksichtigung des Stahlbaus. En: Bauen + Wohnen = Construction + habitation = Building + home: Internationale Zeitschrift. Heft 11. Einfamilienhäuser = Maisons familiales = One-familiy houses. Band 22. 1968. Pág. XI4. Traducción de la autora: "neue Bearbeitungsverfahren und neue Arbeitsweisen mit Hilfe von neuen Materialien bedingen neue Konstruktionen und einen neuen Herstellungsvorgang" 
[Atlas visual de pabellones]

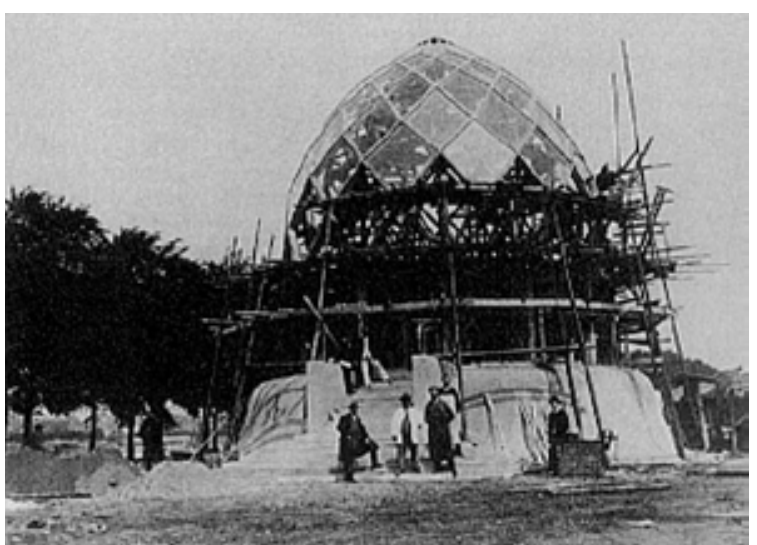

Pabellón de Cristal / Colonia / 1914 / Bruno Taut

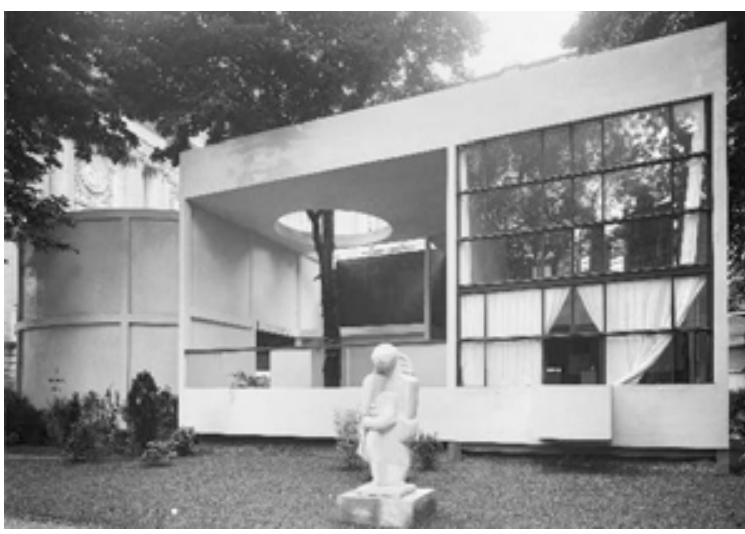

Pabellón L’Esprit Nouveau / Paris / 1925 / Le Corbusier

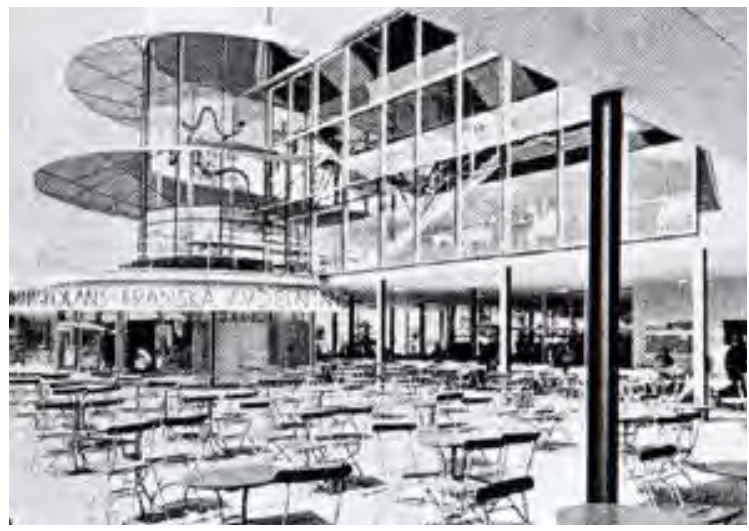

Café Paraíso / Estocolmo / 1930 / E.G. Asplund

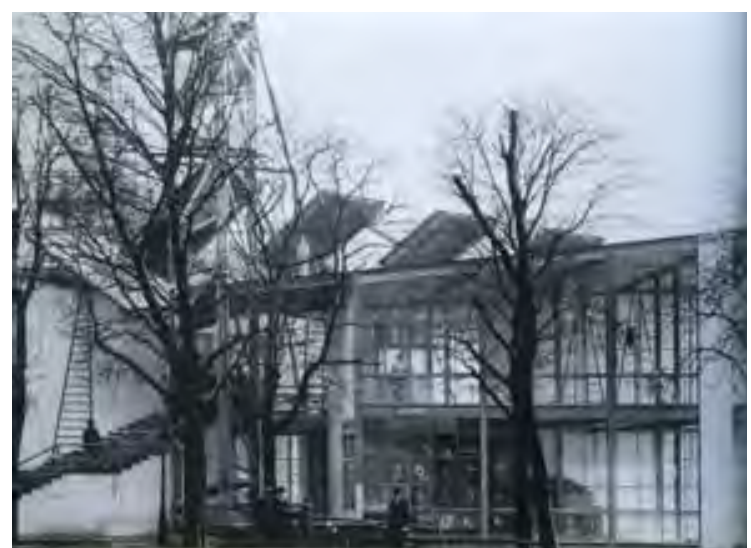

Pabellón URSS / Paris / 1925 / Konstantin Melnikov

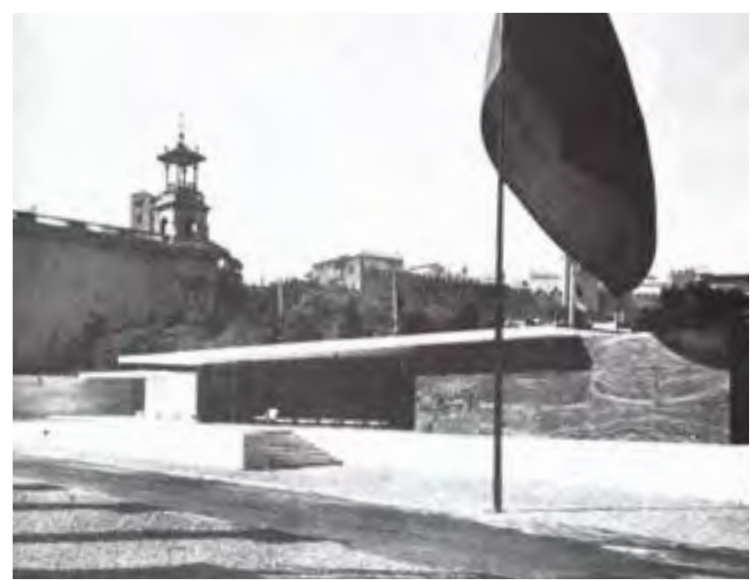

Pabellón Alemania / Barcelona / 1929 / Mies van der Rohe

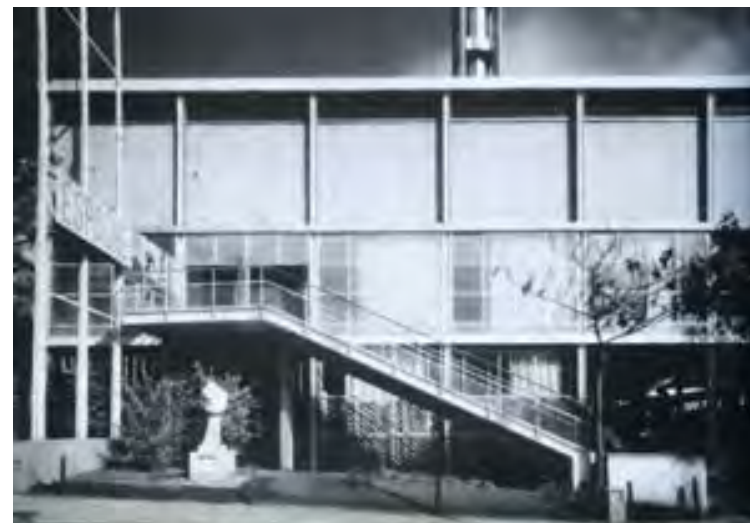

Pabellón España / Paris / 1937 / Josep Sert y Luis Lacas 


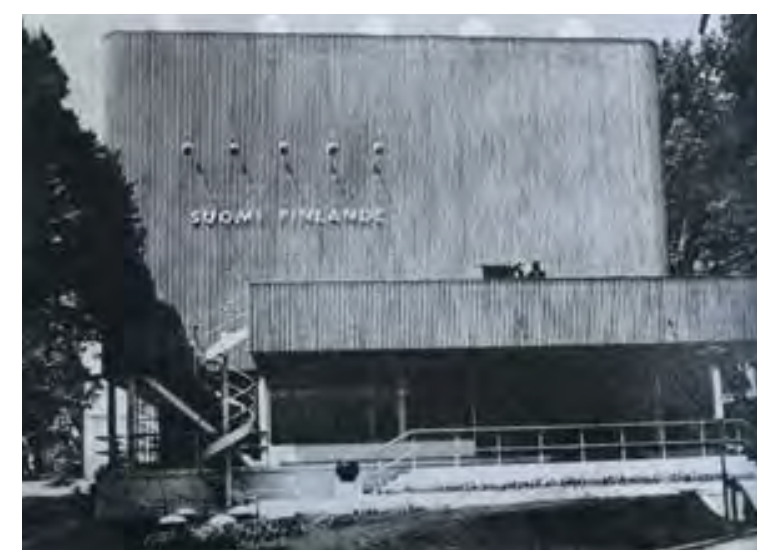

Pabellón Finlandia /Paris / 1937 / Alvar Aalto

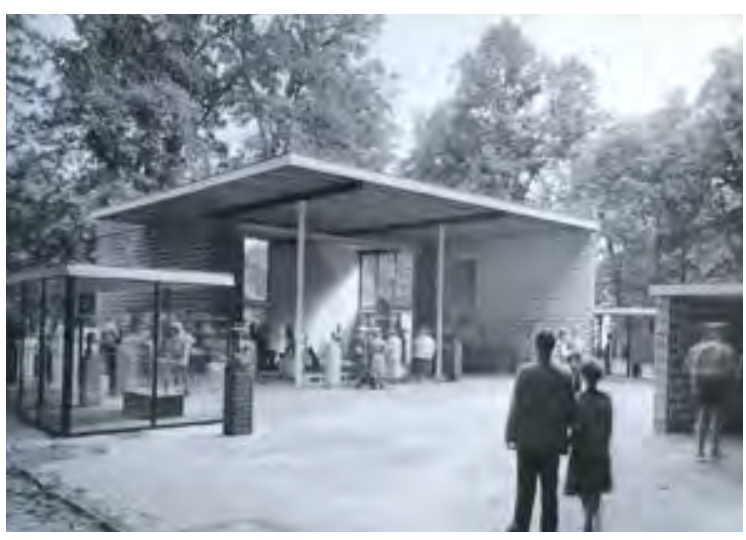

Pabellón Sonsbeek / Arnhem / 1955 / Gerrit Rietveld

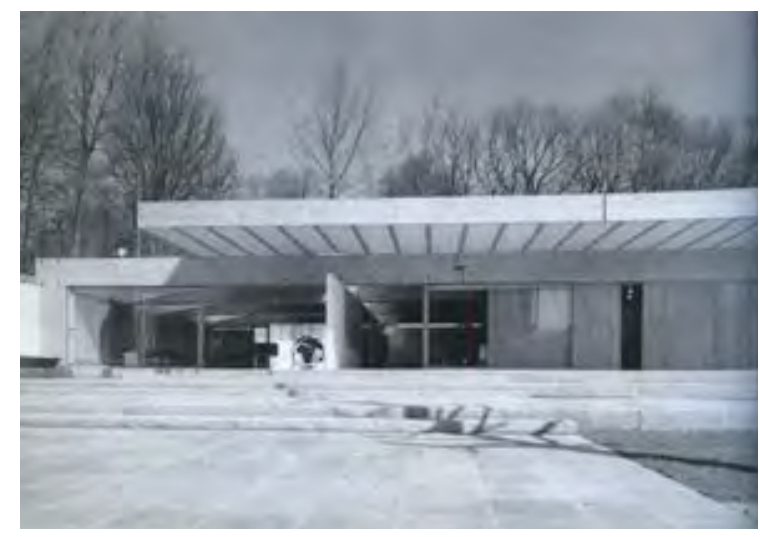

Pabellón Noruega / Bruselas / 1958 / Sverre Fehn

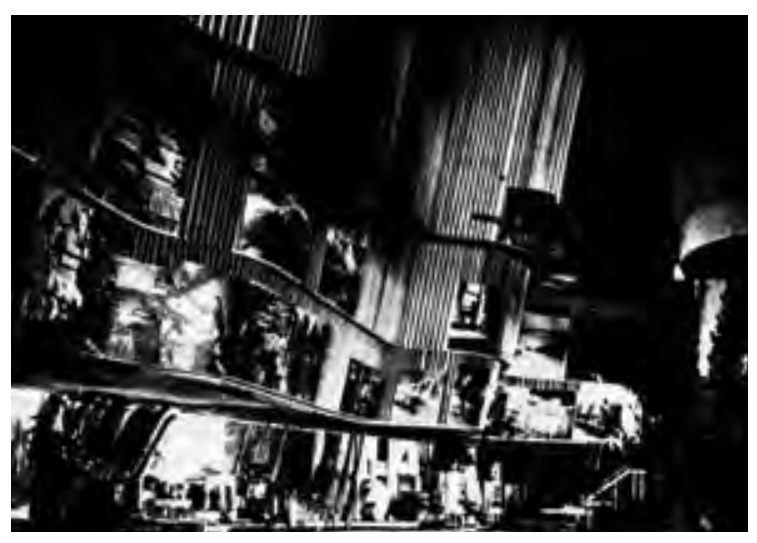

Pabellón Finlandia / Nueva York / 1939 / Alvar Aalto

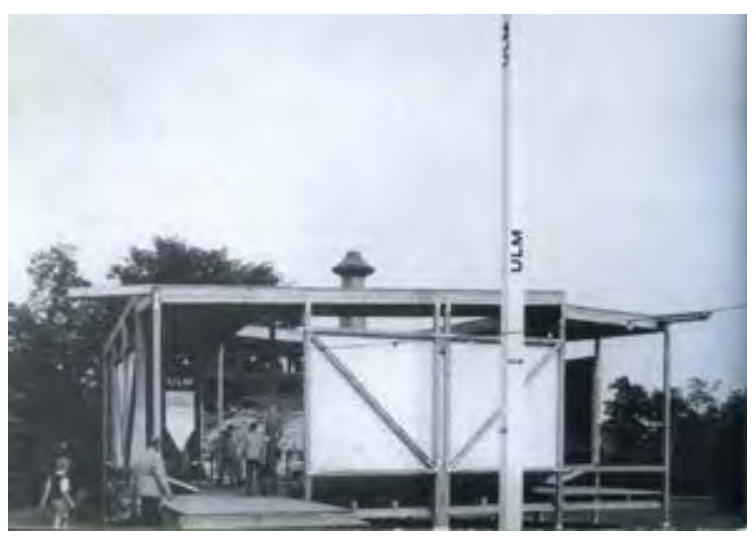

Pabellón Ulm / Ulm / 1955 / Max Bill

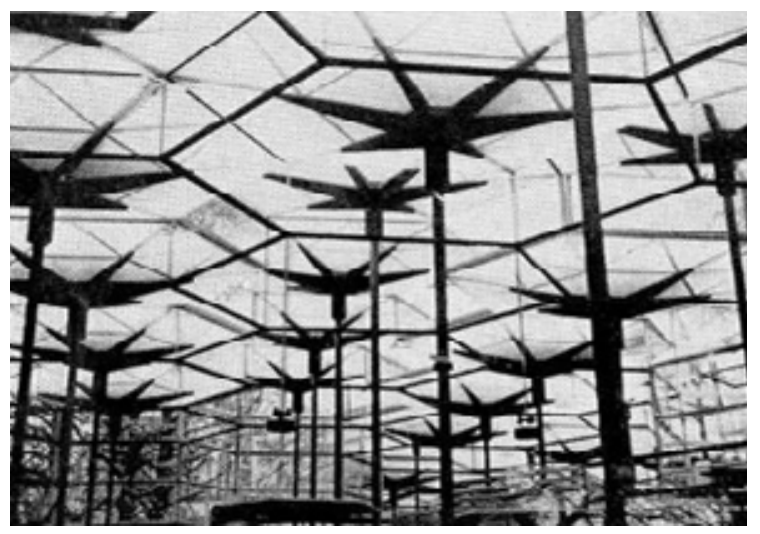

Pabellón España / Bruselas / 1958 / Corrales y Molezún 


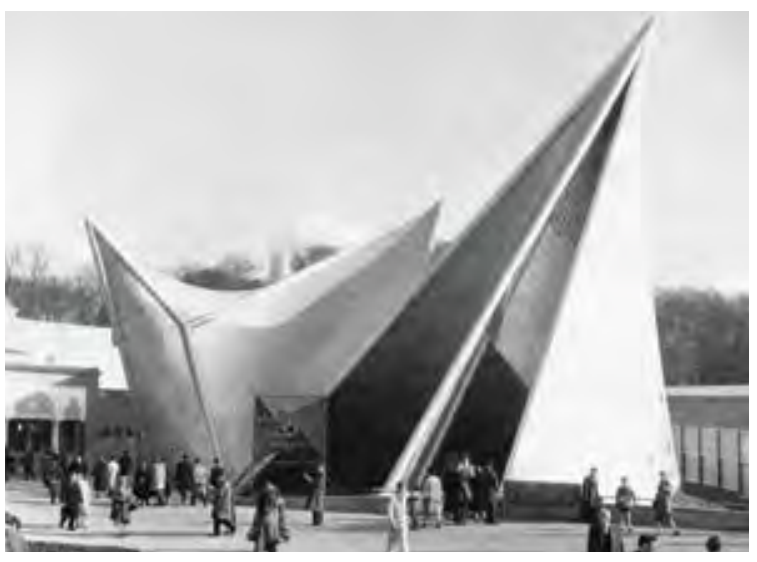

Philips Pavilion / Bruselas / 1958 / Le Corbusier

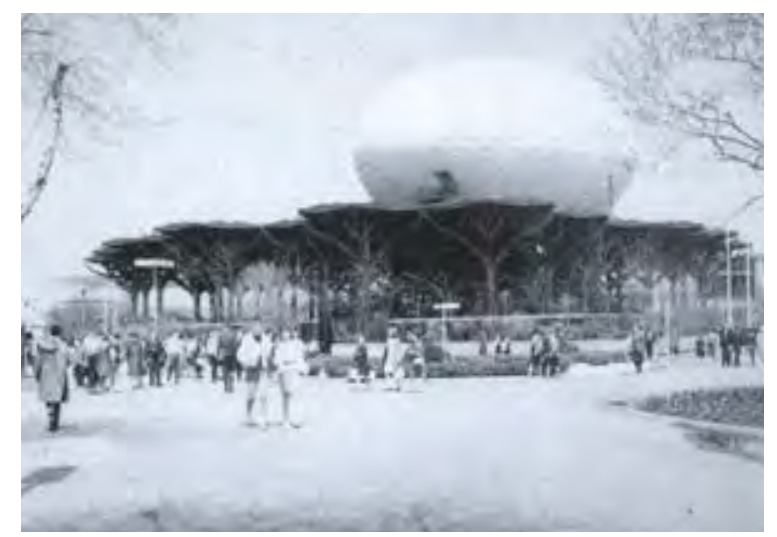

Pabellón IBM / Nueva York / 1964 / Charles y Ray Eames

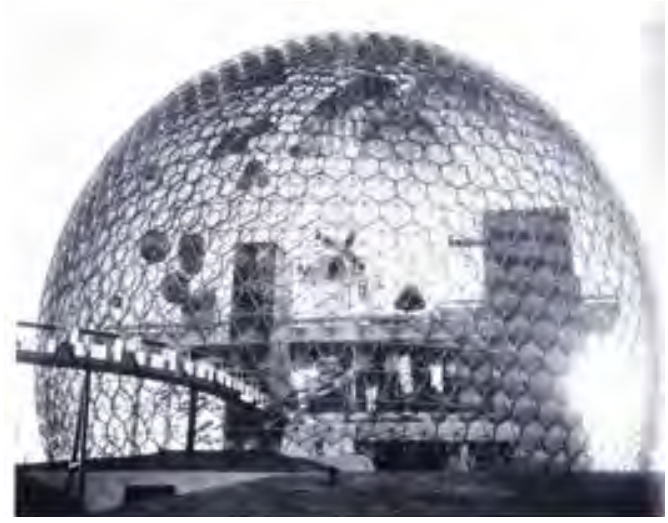

Pabellón EEUU / Montreal / 1967 / Richard Buckminster Fuller

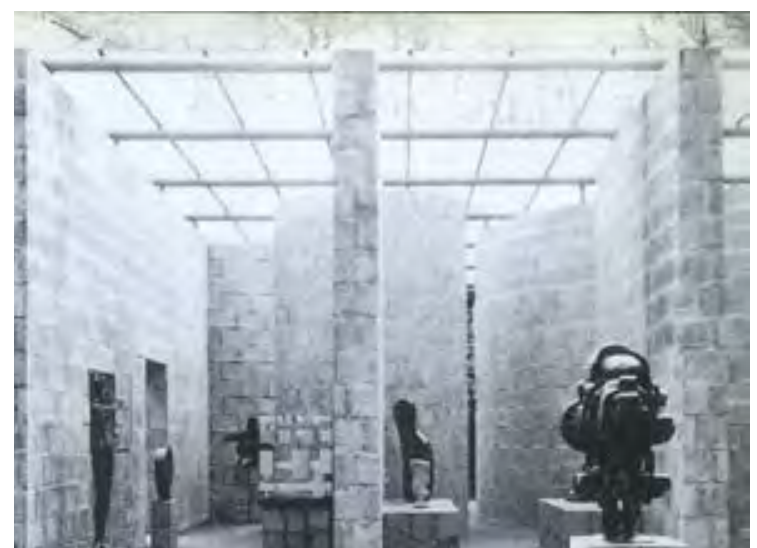

Pabellón Sonsbeek / Arnhem / 1965-66 / Aldo van Eyck

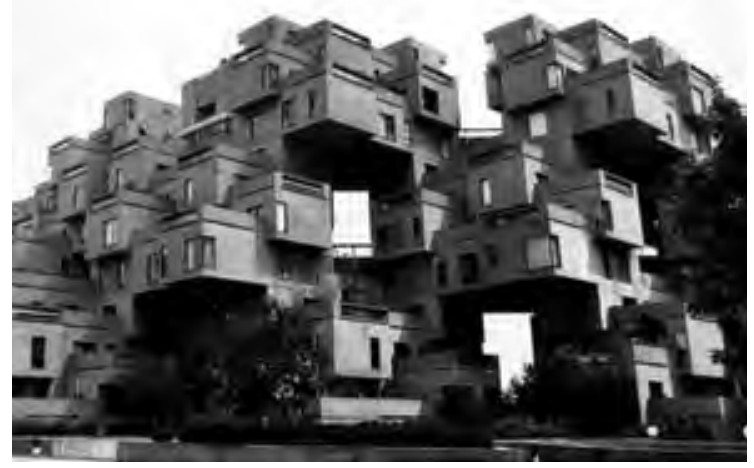

Habitat 67 /Montreal / 1967 / Moshe Safdie

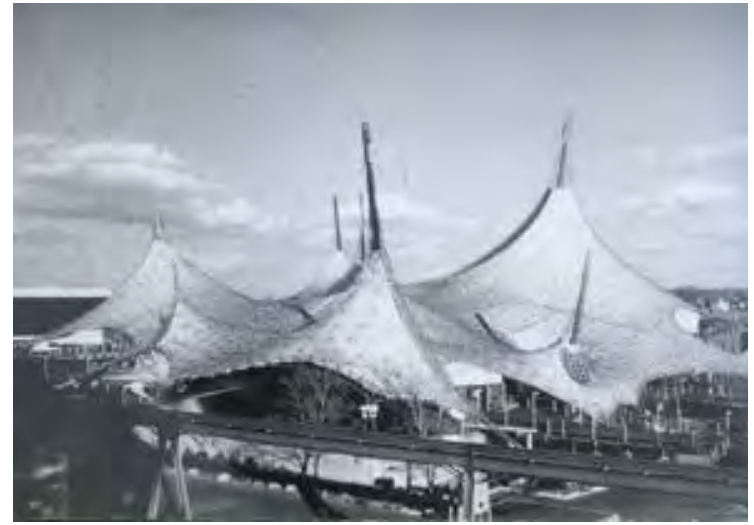

Pabellón Alemania / Montreal / 1967 / Frei Otto 


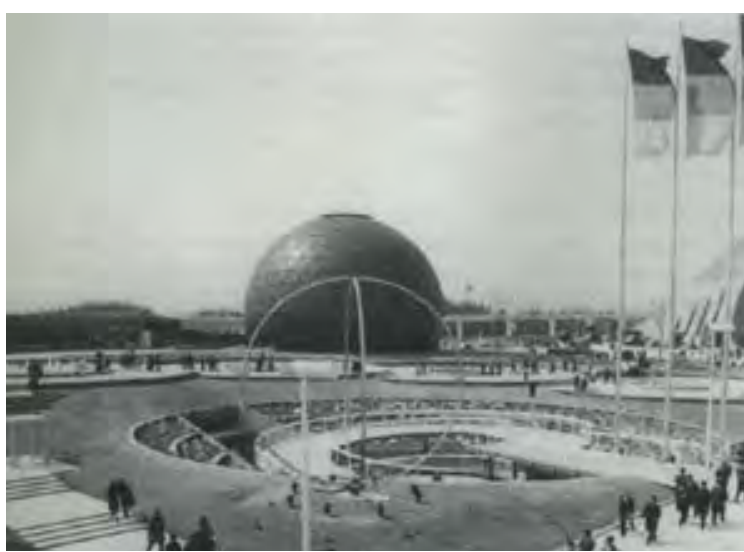

Pabellón Alemania / Osaka / 1970 / Bornemann y Stockhausen

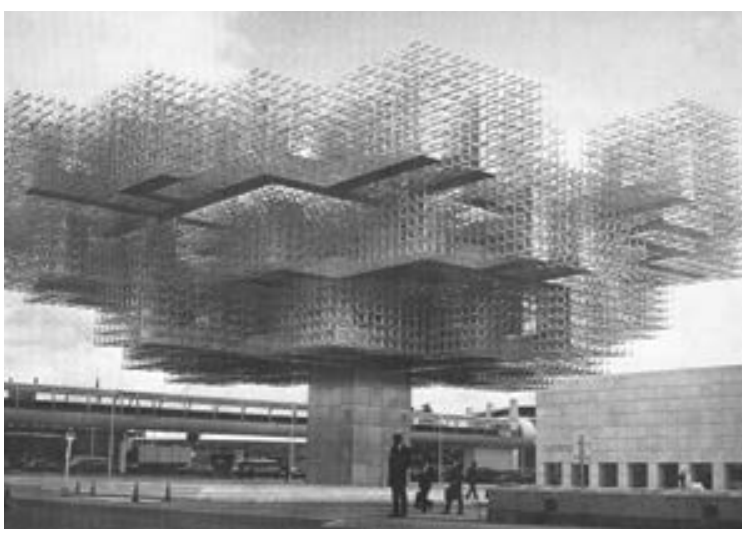

Pabellón Suiza / Osaka / 1970 / Willi Walter, Charlotte Schmid , Paul Leber

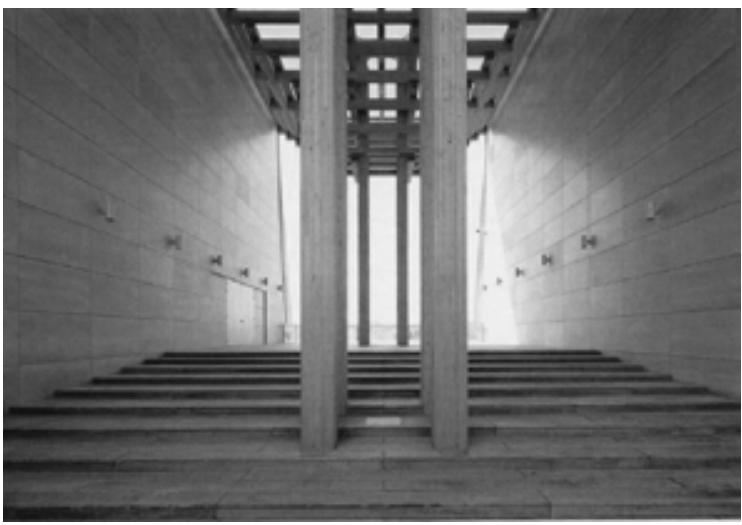

Pabellón Japón / Sevilla / 1992 / Tadao Ando

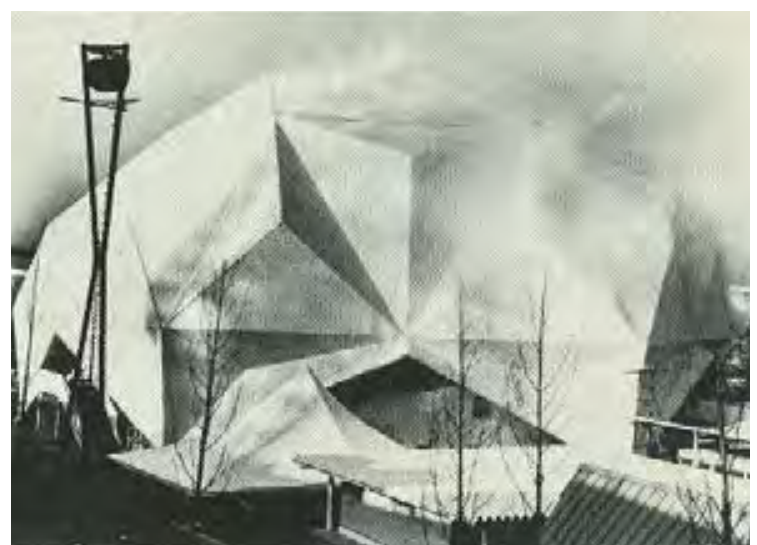

Pabellón Pepsi Cola / Osaka / 1970 / Billy Klüver y E.A.T.

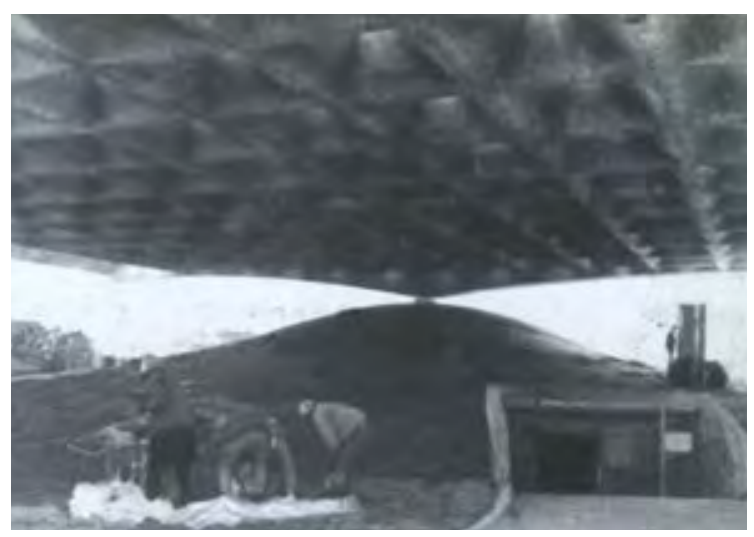

Pabellón Brasil / Osaka / 1970 / Paolo Mendes Da Rocha

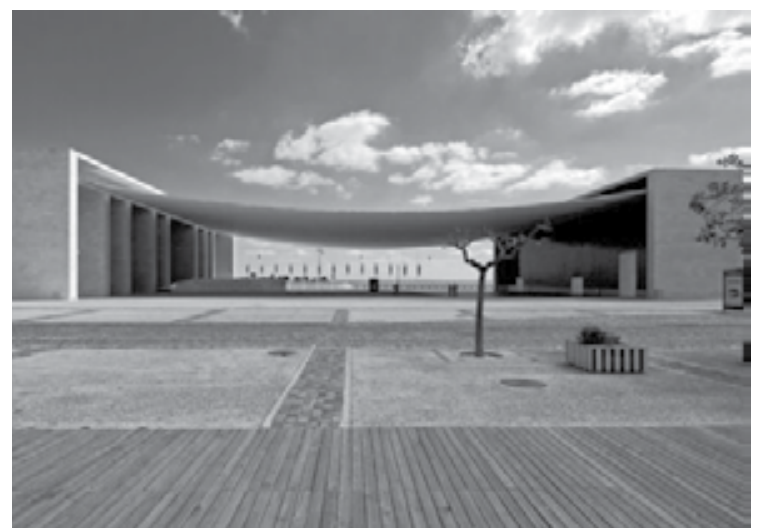

Pabellón Portugal / Lisboa / 1998 / Álvaro Siza y Eduardo Souto de Moura 


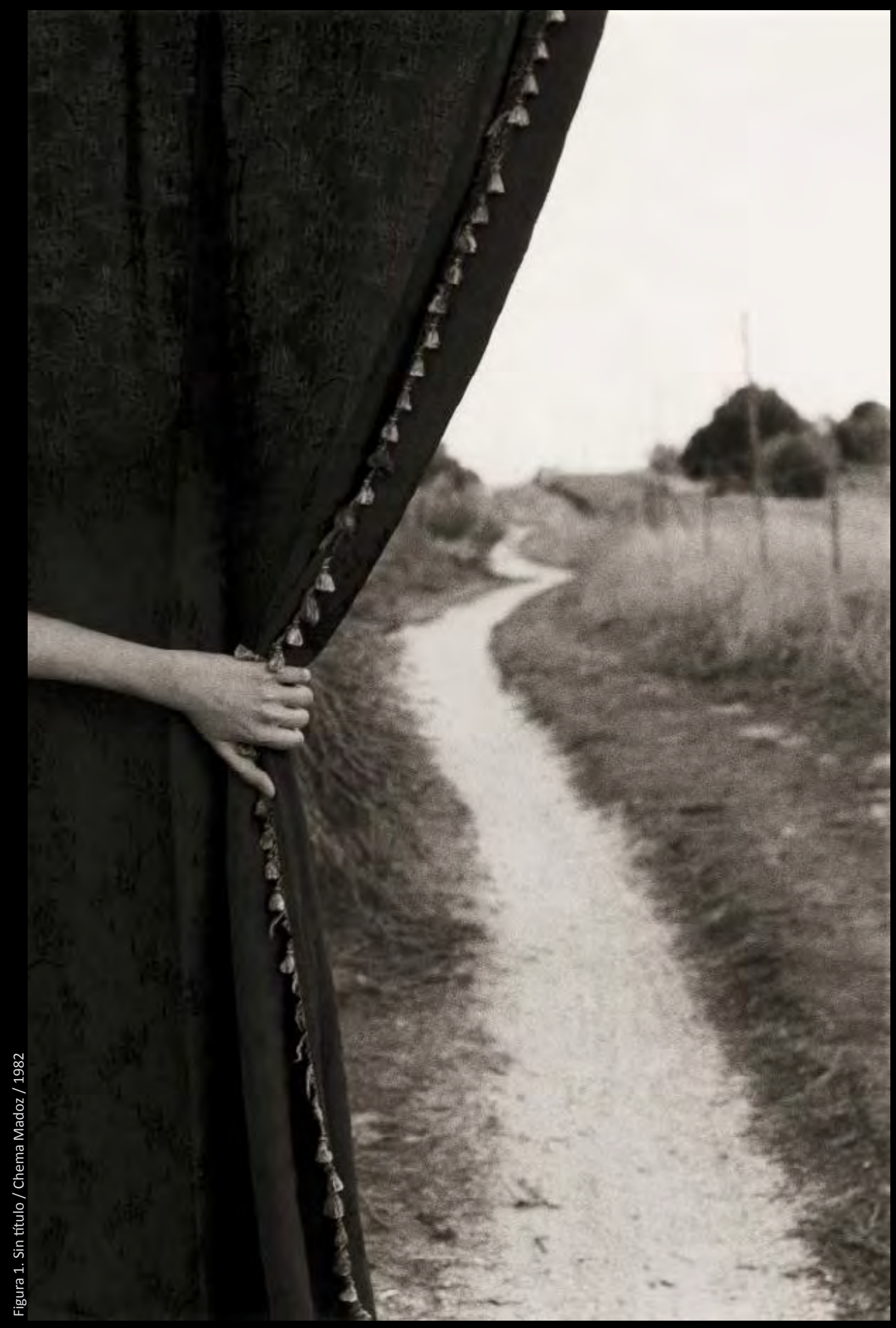




\section{CÉLULA MADRE}

STAMMZELLE

"En realidad, consecuente habría sido no participar en la Exposición universal. Una Expo es un poco absurda ya que el concepto de naciones que se presentan es del siglo XIX. Las Exposiciones universales estaban en una crisis existencial, y mientras esto fuese así no teníamos voluntad de participar. Esta podría haber sido su (Zumthor) posición. El movimiento del visitante, el espacio, el terreno trazado; todo ello tratando de re-definir el concepto de Exposición Universal donde cada país se presenta con sus obras de arte. Para todo ello hacía falta una dosis de coraje..."

Plinio Bachmann. Responsable literario del Pabellón suizo

BACHMANN Plinio. MOLL, Bruno Klangkörper = Corps sonoré = Corpo sonoro. T\&C Film. 2000. Traducción de la autora del sonido original: "Konsequent wäre eigentlich gewesen, wir machen nicht mit an einer Expo, weil eine Expo ist ein bisschen doof und das Konzept von Nationen die sich präsentieren, gehört ins 19. Jahrhundert. Weltausstellungen sind eigentlich in einer totalen Sinnkrise und solange das so ist, ist uns das zu unsicher und wir machen nicht mit. Das hätte auch seine (Zumhtors) Haltung sein könne. Die Bewegung, dass man dahingeht, diesen Raum, diese Parzelle bespielt und dann versucht Weltaustellung neu zu definieren, als ein Ort, wo sich Länder mit Kunstwerken präsentieren, dafür braucht es auch eine Portion Mut, mitmischen zu wollen". 


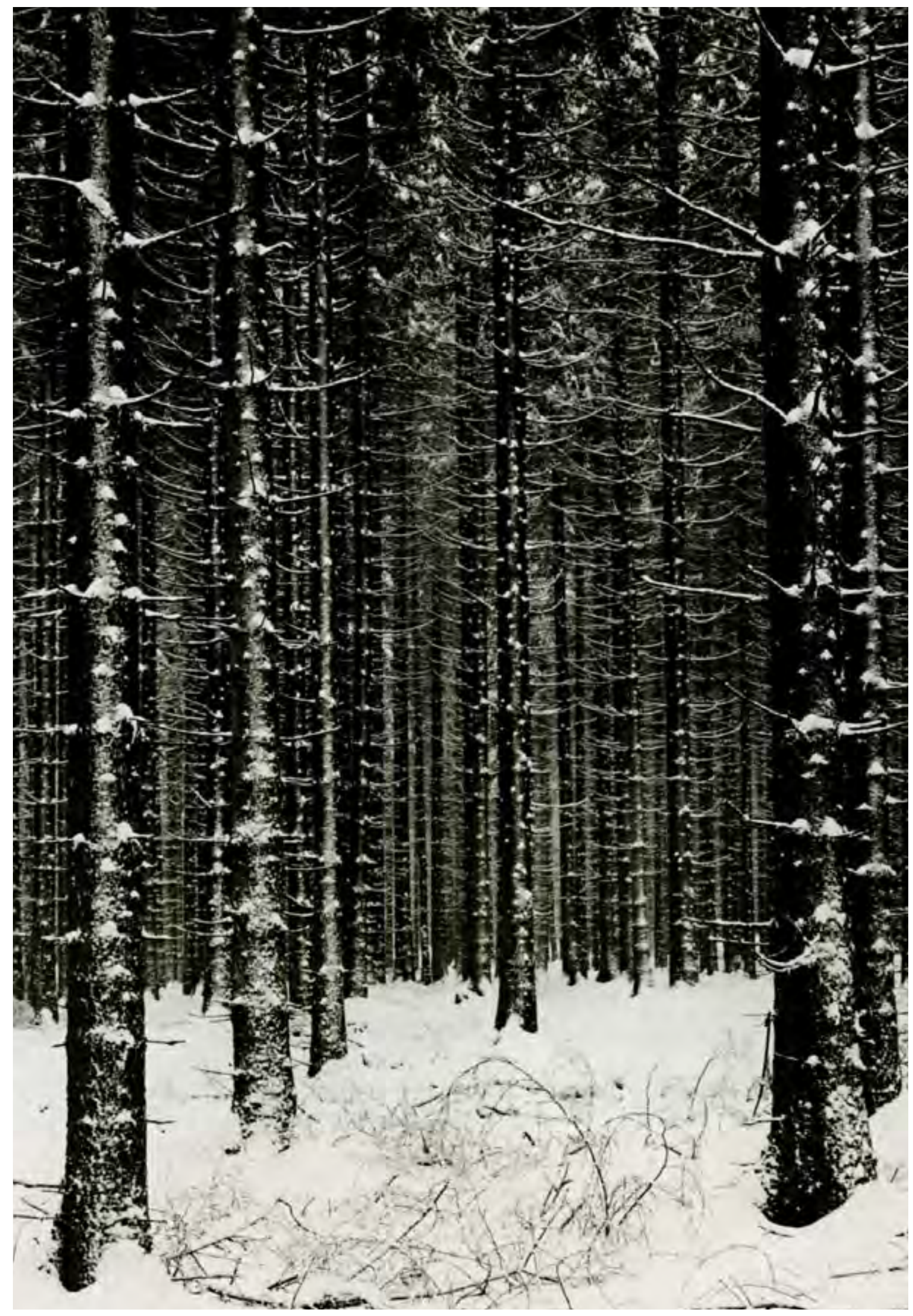




\section{[Madera - madre - materia]}

"Después de haber trabajado durante años en construcciones de piedra y hormigón, acero y vidrio, ¿Cómo querrías construir hoy una casa de madera?", me pregunta mi joven colega. Me viene enseguida en mente la imagen de dónde puedo sacar mi respuesta: un bloque macizo de madera, grande como una casa, un volumen compacto a base de la masa biológica de la madera y estratificado horizontalmente, se ahueca practicando en él ranuras con la altura de las habitaciones y cavidades bien precisas, transformándolo en un edificio..." Y el hecho de que el volumen de la casa así construida varíe su extensión al hincharse o contraerse la madera, el hecho de que al principio se mueva y pierda una altura considerable habría de ser entendido como una calidad suya, tematizada en el proyecto", le digo yo. "En mi lengua materna, el español, se da un parentesco entre los términos 'madera', 'madre' y 'materia', contesta mi joven colega. Y así iniciamos una conversación sobre las propiedades sensoriales y el significado cultural de las materias primas madera y piedra, y cómo podríamos conseguir que se expresen en nuestros edificios." ${ }^{\prime 2}$ Peter Zumthor 


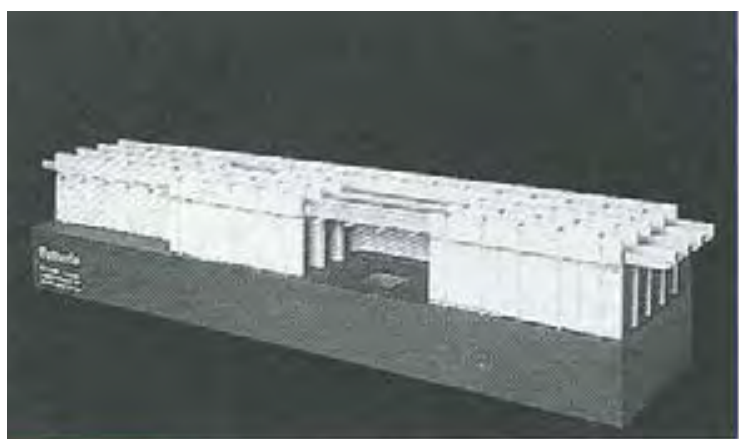

1. Premio

(Fr. 30.000.-)

Peter Zumthor

Haldenstein

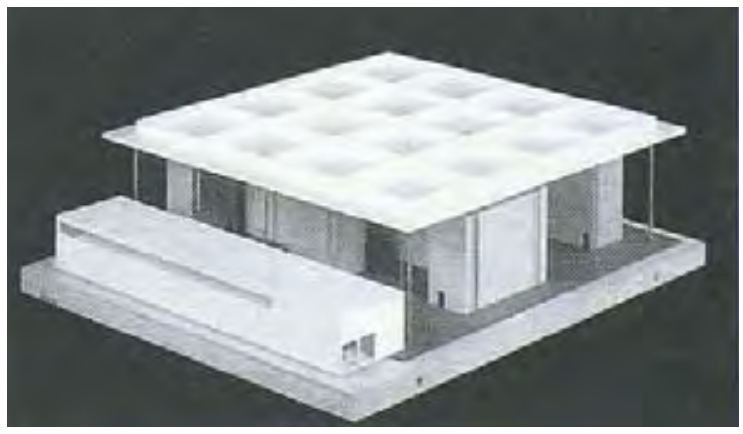

3. Premio

(Fr. 21.000.-)

Werner Egli \& Hans Rohr

Baden-Dättwill

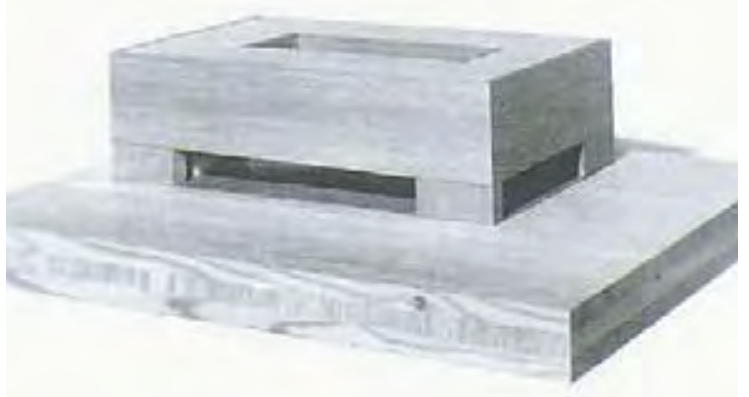

5. Premio

(Fr. 13.000.-)

Margit Althammer \& René Hochuli

Zürich

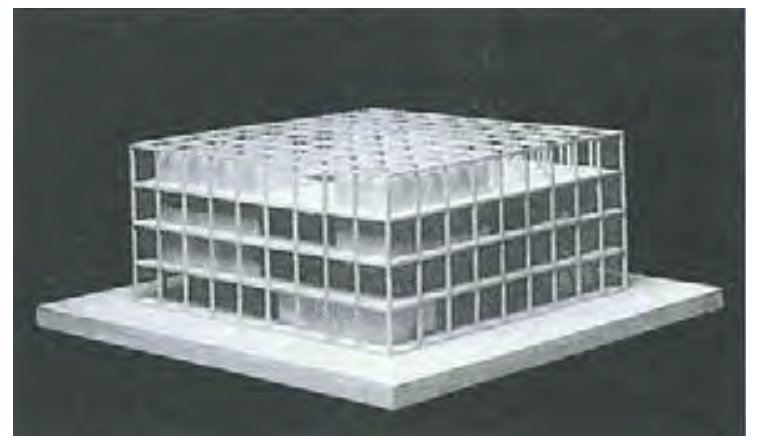

2. Premio

(Fr. 25.000.-)

Max Dudler

Zürich

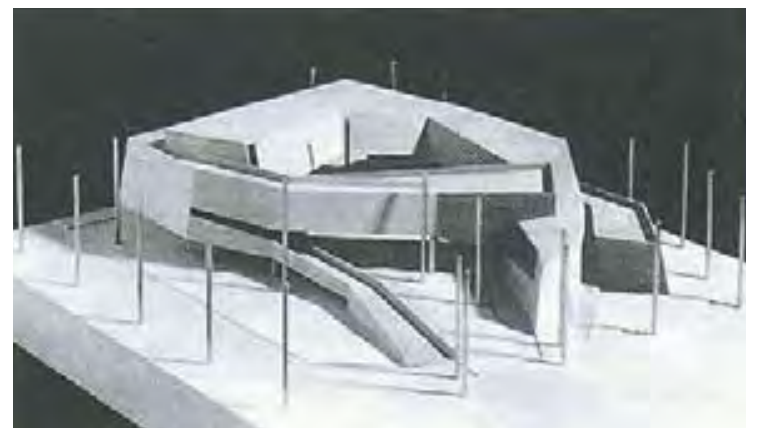

4. Premio

(Fr. 20.000.-)

Jauslin Vehover Wimmer

Zürich

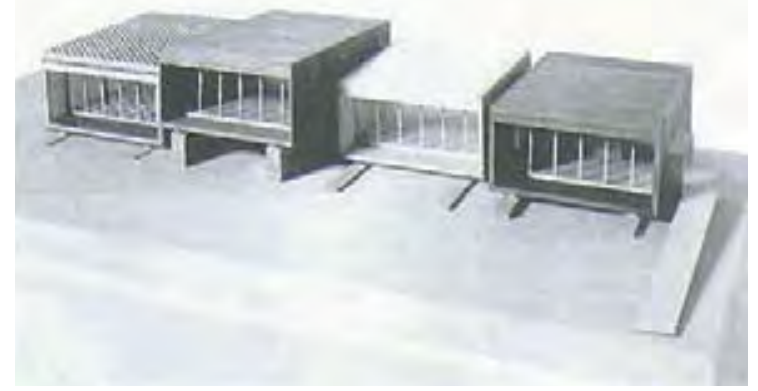

6. Premio

(Fr. 11.000.-)

Wagner Graser AG

Zürich 


\section{[Batterie]}

Cinco años antes de la inauguración de la Weltausstellung ${ }^{3}$ del nuevo milenio en Hannover bajo el título Hombre-Naturaleza-Técnica; origen de un nuevo mundo; Suiza fue invitada por vía diplomática a participar en la Exposición universal. Frente a la posibilidad de ser parte de un contenedor con varios países, o incluso de no participar como la delegación norteamericana; los responsables helvéticos optaron por la construcción de un pabellón propio para su re-presentación. Para ello se destinó una partida presupuestaria de nueve millones de francos suizos para su construcción; más una cantidad similar adicional para las actividades a desarrollarse en su interior ${ }^{4}$. En 1996 la "Comisión de Coordinación de la Presencia de Suiza en el Extranjero", en estrecha colaboración con la "Oficina de Edificios Federales" ${ }^{\prime 6}$ decidieron convocar un concurso para la selección de la mejor propuesta arquitectónica de conformidad con las disposiciones suizas ${ }^{7}$.

El concurso de ideas con intervención de jurado se desarrolló mediante procedimiento abierto, anónimo y en dos fases. Fue publicado el 10 de octubre de $1996^{8}$ en el "Boletín Oficial de Comercio de Suiza" . Las bases establecían una serie de condicionantes previos de obligado cumplimiento; entre otros, el uso de la madera en el pabellón o la sostenibilidad de todo el proceso de construcción. Así en enero del siguiente año, el jurado ${ }^{10}$ presidido por Arthur Hänsenberger seleccionó Universal en Alemania bajo el lema Mensch-Natur-Technik; eine neue Welt entsteht.

4 AAVV. Botschaft über die Teilnahme der Schweiz an der Weltausstellung "Expo 2000 Hannover". Bundesblatt. Band 5. Heft 39. Geschäftsnummer 98.040. 22. Junio. Pág. 4674. Nota: La partida presupuestaria estaba garantizada por el gobierno suizo exclusivamente, siendo fruto de un estudio de anteriores participaciones. Se destinó inicialmente una cantidad de 9.090 .000 francos suizos para la construcción, más el equipamiento; y 8.910 .000 francos suizos para los gastos de funcionamiento de las actividades del pabellón.

5 Nota: Koordinationskommission für die Präsenz der Schweiz im Ausland KOKO. Traducción de la autora:

6 Nota: Amt für Bundesbauten. Traducción de la autora:

7 Ley Federal Suiza y el Reglamento de Adquisiciones, respectivamente. Traducción de los autores del texto original: "Bundesgesetz y Verordnung über Beschaffungswesen ". AAVV. Botschaft über die Teilnahme der Schweiz an der Weltausstellung "Expo 2000 Hannover". Bundesblatt. Band 5. Heft 39. Geschäftsnummer 98.040. 22. Junio. Pág. 4669.

8 AAVV. Botschaft über die Teilnahme der Schweiz an der Weltausstellung "Expo 2000 Hannover". Bundesblatt. Band 5. Heft 39. Geschäftsnummer 98.040. 22. Junio. Pág. 4670.

9 Nota: Schweizerischen Handelsamtsblatt. Traducción de la autora:

10 GENERALKOMMISSARIAT. Schlussbericht des Generalkommissariates. Weltausstellung Expo 2000 Hannover 1.6.-31.10.2000. Die schweizerische Beteiligung mit "Klangkörper Schweiz ". Bundesamt für Kultur. Bern. 2001. Pág.101. Nota: Presidente: Arthur Hänsenberger, Oberdiessbach; Vocales expertos: Michele Arnaboldi, Locarno / Christoph Eggenberger, Zürich / Walter Tschopp, Neuenburg / Claudine Lorenz, Sitten / Claude Ritschard, Genf / Werner Sutter, Zürich / Marc Syfrig, Luzern; Otros vocales: Norber Bargmann, Hannover / Eva Brechtbühl, Zürich / Jean-Jacques Cevey, Montreux / Klaus Jacobi, Bern / Wilhelm Jaggi, Bern 


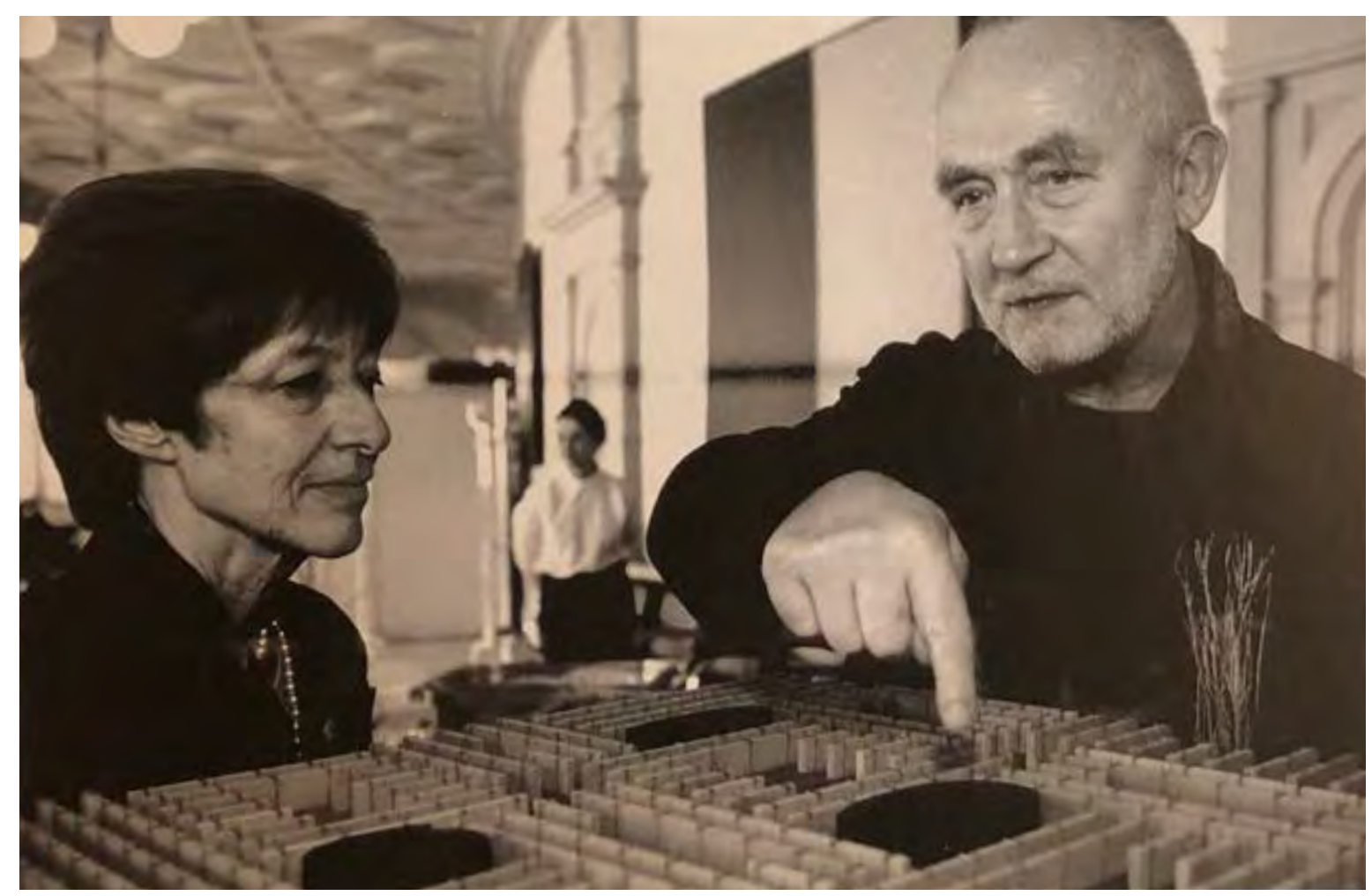

Figura 9.

Peter Zumthor con la Generalkommissärin Ruth Grossenbacher 
dieciocho $^{11}$ de entre las 129 propuestas presentadas, incluyendo algunas de fuera de Suiza. En una segunda fase las propuestas seleccionadas pudieron desarrollarse con un mayor nivel de definición. El Concurso fue fallado el 1 de septiembre de 1997; siendo seis proyectos ${ }^{12}$ premiados finalmente.

Se concederán seis premios ordinales. El tercer premio fue para el proyecto de Werner Egli y Hans Rohr, que planteó una gran cubierta perforada bajo la que se agrupaban nueve espacios de exhibición diferentes. El segundo premio fue para Max Dudler, con una estructura reticular clara, estricta y geométrica en volumen.

La propuesta bajo el lema Batterie ${ }^{13}$ fue la ganadora para construir el pabellón de la Expo del 2000. El Acta del fallo del concurso describió las cualidades del proyecto ganador, incidiendo especialmente en su condición fenomenológica, de la siguiente manera:

"Desde la perspectiva del jurado, el concepto del Pabellón Suizo sorprende por su originalidad. Es diferente. El pabellón se convierte en un espacio recreativo atmosférico dentro de una exposición sobreexcitada de atracciones audiovisuales, de nuevas tecnologías y de restaurantes. Se presta especial atención a la recepción personal del visitante, al encuentro, al diálogo, al calor humano. Cualquier persona ávida de conocimiento encuentra "un oído abierto". El

11 GENERALKOMMISSARIAT. Schlussbericht des Generalkommissariates. Weltausstellung Expo 2000 Hannover 1.6.-31.10.2000. Die schweizerische Beteiligung mit "Klangkörper Schweiz “. Bundesamt für Kultur. Bern. 2001. Pág. 102-103. NOTA:

Nr 1. Lema: Mensch, Natur, Technik. Autor de la propuesta: Beutler Thiel GmbH, Basel.

Nr 2. Lema: Vier. Autor de la propuesta: Arch.-Büro Max Dudler, Zürich.

$\mathrm{Nr}$ 3. Lema: Panorama +. Autor de la propuesta: Architekturatelier Jürg Steiner, Berlin.

Nr 4. Lema: Une Promenade dans la Forêt. Autor de la propuesta: Atelier d’architecture - Oï \& Bauzeit + associés, La Neuveville.

Nr 5. Lema: Das Haus der Wandlungen. Autor de la propuesta: Studio A - D .Coma, O. Bisaz, N. Vital, Chur. Nr 6. Lema: Nemo. Autor de la propuesta: Interobjekta AG - Bohnen und Meyer Architekten, Zürich. $\mathrm{Nr}$ 7. Lema: Forum Heleticum. Autor de la propuesta: Schoch Marketing Communication, Uitikon-Zürich. Nr 8. Lema: Point. Autor de la propuesta: Fischer Architekten AG, Zürich.

$\mathrm{Nr}$ 9. Lema: $\mathrm{CH}$-Container. Autor de la propuesta: Arch.-Büro Widmer, Wehrle, Blaser. Solthurn. Nr 10. Lema: 2... Autor de la propuesta: Artelier d'architecture Pierre Bonet architecte, Carouge. $\mathrm{Nr}$ 11. Lema: Dans les aires, sur terre et sous terre. Autor de la propuesta: von Ballmoos, Kruker, Zürich. $\mathrm{Nr}$ 12. Lema: Zukunft. Autor de la propuesta: Wagner Graser AG, Zürich.

Nr 13. Lema: Carre 4. Autor de la propuesta: Arch.-Büro Roger Boltshauser, Zürich.

Nr 14. Lema: Loop. Autor de la propuesta: Jauslin Vehovar Wimmer. Zürich.

Nr 15. Lema: Batterie. Autor de la propuesta: Peter Zumthor. Haldenstein.

Nr 16. Lema: Klangspielhaus. Autor de la propuesta: Arch.-Büro Margit Althammer + René Hochuli, Zürich. Nr 17. Lema: Bleu. Autor de la propuesta: Monsieur Charles Duboux. Lausanne.

Nr 18. Lema: Kontraste. Autor de la propuesta: Werner Egli + Hans Rohr, Baden-Dättwil

12 AAVV. Botschaft über die Teilnahme der Schweiz an der Weltausstellung "Expo 2000 Hannover". Bundesblatt. Band 5. Heft 39. Geschäftsnummer 98.040. 22. Junio. Pág. 4670.

13 DUDEN. Diccionario alemán. https://www.duden.de/rechtschreibung/Batterie. Nota: El término Batterie tiene varios significados: a) la unidad más pequeña de las fuerzas de artillería y defensa aérea del ejército / b) almacenamiento de energía / batería / b) Grupo de dispositivos técnicos similares / c) un gran número de algo similar / d) Grupo de percusión de una banda u orquesta. 


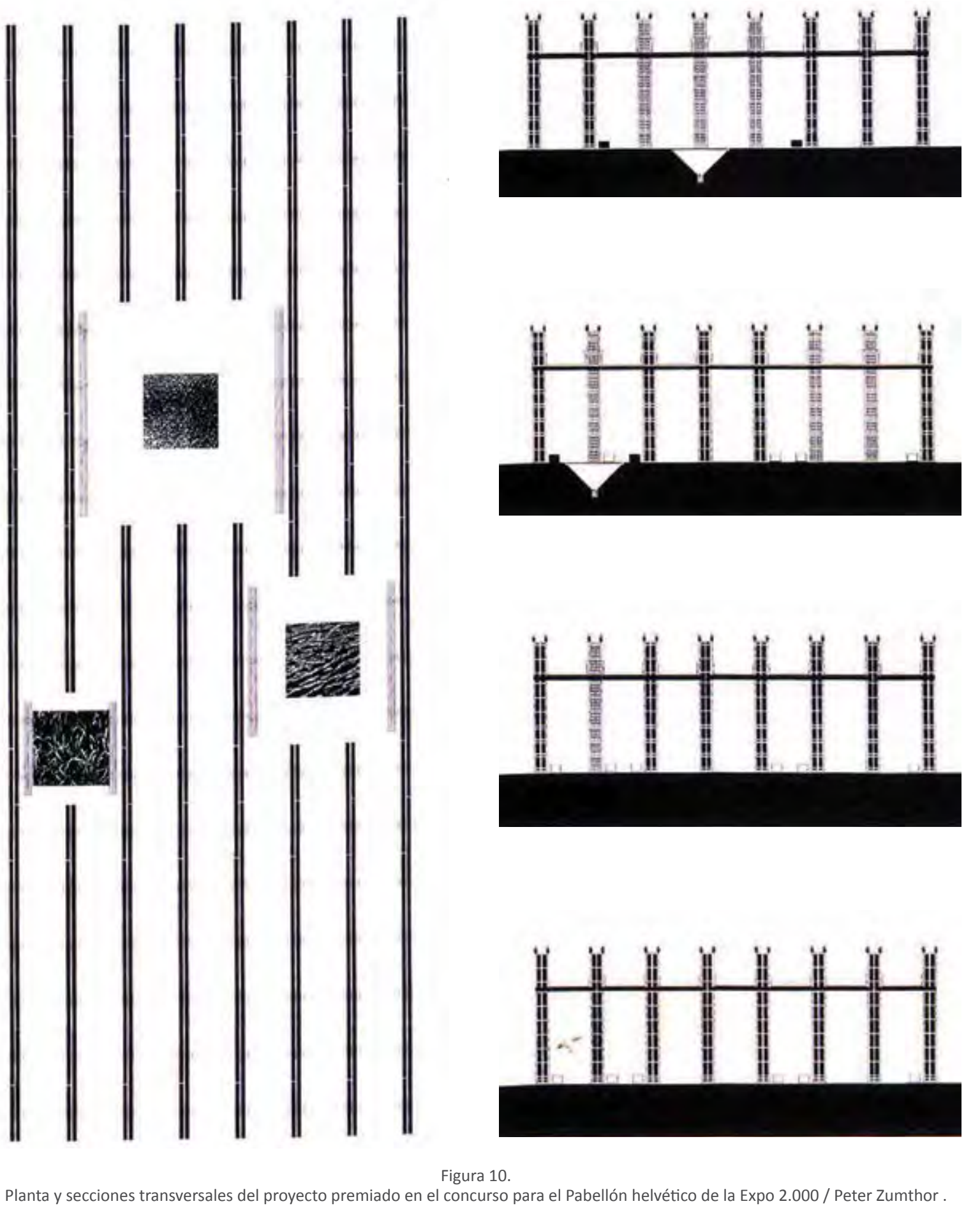


pabellón, en primer lugar, apela a los sentidos, la mera transferencia de información queda atrás. En el centro de atención está el desarrollo sostenible. Dentro del lema "humano - naturaleza - tecnología" de la exposición, el interés del visitante se concentrará en el segundo elemento, la naturaleza. La naturaleza es la madera. El pabellón está concebido como un inmenso laberinto, en el que los visitantes circulan entre pilas de madera y descubren cinco lugares distintos durante su viaje. Cada uno de estos lugares refleja un enfoque diferente de la naturaleza. Un acento especial se sitúa en los productos naturales. En un ambiente estimulante, puedes comer pan negro y Bündnerfleisch, disfrutar el queso de nuestros Alpes y beber leche y vino. Los juegos de colores atraen la atención, las palabras en neón azul, verde o rojo aparecen en las paredes de madera y son motivo de reflexión. Aquí es donde el multilingüismo de Suiza se convierte en algo propio. El pabellón también se compone de música, fragmentos de idioma, canciones. Los sonidos, que también se pueden escuchar fuera del pabellón, despertarán la curiosidad de aquellos que aún no se han aventurado en el laberinto. El huésped también podrá oler y tocar la madera recién cortada, en estrecha armonía con la naturaleza."14

El proyecto ganador consistía en la agrupación en paralelo de ocho pilas de listones de madera de abeto. A modo de recuerdo infantil, evocando a su progenitor ebanista, aparecen los secaderos de madera. Sistemas de apilamiento, almacenamiento temporal, proceso de secado, o la transformación de una materia natural en un material de construcción. Desde su origen, el pabellón se proyectó como una Natürlicher

14 AAVV. Botschaft über die Teilnahme der Schweiz an der Weltausstellung "Expo 2000 Hannover". Bundesblatt. Band 5. Heft 39. Geschäftsnummer 98.040. 22. Junio. Pág. 4671. Traducción de la autora: "Aus der Sicht der Jury überrascht das Konzept des Schweizer Pavillons durch Originalität. Es nimmt für sich in Anspruch, andersartig zu sein. Der Pavillon wird zum stimmungsvollen Erholungsraum in einer übererregten Expo audiovisueller Attraktionen, neuer Technologien und Restaurants. Ein spezielles Augenmerk gilt dem persönlichen Empfang des Besuchers, der Begegnung, dem Dialog, der menschlichen Wärme. Jeder Wissenshungrige stösst auf ein offenes Ohr. Der Pavillon spricht in erster Linie die Sinne an, die reine Informationsvermittlung tritt in den Hintergrund. Im Zentrum des Interesses steht die nach haltige Entwicklung. Innerhalb der Expothematik «Mensch - Natur - Technik» wird sich das Interesse des Besuchers vor allem auf das zweite Element, die Natur, konzentrieren. Natur, das ist zuerst das Holz. Der Pavillon ist als immenses Labyrinth konzipiert, in dem die Besucher zwischen Holzstapeln zirkulieren und im Verlaufe ihrer Reise fünf verschiedene Orte entdecken werden. Jeder dieser Orte widerspiegelt einen anderen Zugang zur Natur. Ein spezieller Akzent wird auf natürliche Produkte gelegt. In einer stimulierenden Umgebung isst man etwa schwarzes Brot und Bündnerfleisch, geniesst Käse aus unseren Alpen und trinkt Milch und Wein. Farbenspiele sprechen das Auge an, Wörter in blauer, grüner oder roter Neonschrift erscheinen auf den Holzwänden und vermitteln Denkanstösse. Hier kommt die Mehrsprachigkeit der Schweiz ganz besonders zur Geltung. Der Pavillon besteht auch aus Musik, Sprachfragmenten, Gesängen. Die Töne, welche auch ausserhalb des Pavillons zu vernehmen sind, werden die Neugierde derjenigenwecken, welche sich noch nicht ins Labyrinth gewagt haben. Der Gast wird auch das frisch geschlagene Holz riechen und berühren können - in engem Einklang mit der Natur." 


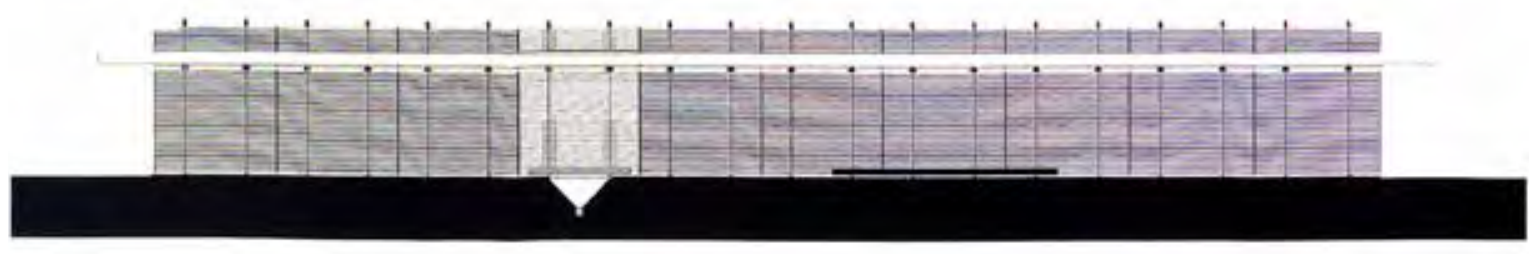

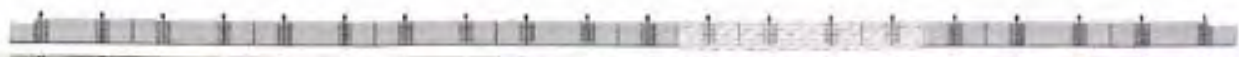
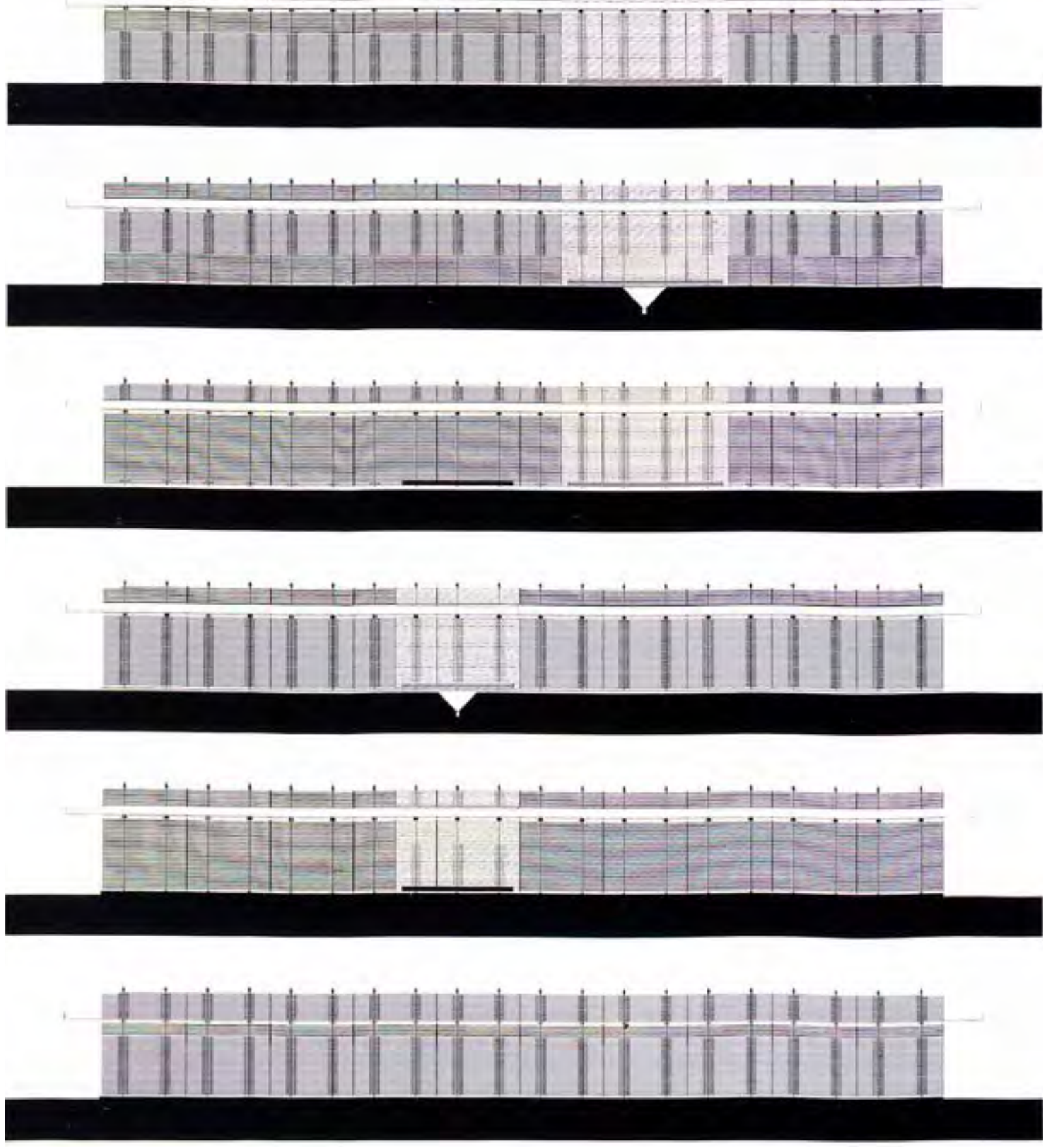

Figura 11.

Secciones longitudinales del proyecto premiado en el concurso para el Pabellón helvético de la Expo 2.000 / Peter Zumthor . 
Holztrocknung ${ }^{15}$, donde la madera se pudiese secar de forma natural durante la exposición, y posteriormente ser vendida como material de construcción.

Zumthor no sólo describe el espacio del pabellón desde la materia, la estructura, el orden, o la construcción; sino que incidirá en mostrarlo como un mapa de experiencias sensoriales al recorrerlo:

"(...) 1.200 metros cúbicos de madera de abeto, estratificados en paredes, ordenados linealmente, formando una estructura espacial abierta. Se entra a través de muchas entradas desde el oeste o el este. Pasaje. Tránsito. Caminos... Los itinerarios son estrechos, altos y largos. La lluvia tamborilea en el techo de chapa metálica. ... En el centro de la estructura de madera hay tres espacios no construidos..."16 Peter Zumthor

Batterie puede considerarse un dispositivo, una infra-estructura orgánica aparentemente generada mediante la disposición ordenada de una serie de listones de madera apilados y orientados en sentido oeste-este ${ }^{17}$. Un tablero organizado mediante un sistema de bandas. Un "pentagrama"18 de ocho paredes paralelas entre sí de $54 \mathrm{~m}_{\text {de longitud }}{ }^{19}$. Siete tránsitos estrechos con un ancho libre de paso de 2,50 $\mathrm{m}^{20}$. Espacios longitudinales y abiertos, con recorridos lineales únicamente diluidos por los tres vacíos; oquedades de un sistema urbano, lugares de reunión para diferentes tamaños de agrupaciones. En el suelo de estos vacíos, aparecen insertados una serie de pantallas que retransmitían diversos eventos diarios en directo desde Suiza.

15 Nota: Natürliche Holztrocknung, secado de madera, es un proceso para eliminar la humedad de la madera. En este caso por ventilación natural, Natürlich. Traducción de la autora:

16 GENERALKOMMISSARIAT. Schlussbericht des Generalkommissariates. Weltausstellung Expo 2000 Hannover 1.6.-31.10.2000. Die schweizerische Beteiligung mit "Klangkörper Schweiz". Bundesamt für Kultur. Bern. 2001. Pág.31-32. Traducción de la autora: “..1200 Kubikmeter Fichtenholz, zu Wänden geschichtet, linear geordnet, bilden eine offene räumliche Struktur. Man betritt sie durch viele Eingänge von Westen oder Osten. Passage. Durchgang. Durchführung...Die Gassen, die es begrenzt, sind schmal, hoch und lang. Auf die Blechwanne, die das Dach ist, trommelt der Regen... Im Zentrum der Holzstruktur sind drei Räume nicht gebaut, sondern ausgespart."

17 IDEM. Pág.31. Nota: En el libro Peter Zumthor Works: Buildings and Projects 1979-1997. Página 294. Se describe el pabellón con entradas en dirección norte-sur. Sin embargo, en el Schlussbericht des Generalkommissariates. Weltausstellung Expo 2000 Hannover 1.6.-31.10.2000. Die schweizerische Beteiligung mit "Klangkörper Schweiz". Página 31. Zumthor menciona las entradas en dirección oesteeste.

18 Nota: Realmente no sería un penta-grama, sino un "octo-grama"

19 GENERALKOMMISSARIAT. Schlussbericht des Generalkommissariates. Weltausstellung Expo 2000 Hannover 1.6.-31.10.2000. Die schweizerische Beteiligung mit "Klangkörper Schweiz". Bundesamt für Kultur. Bern. 2001. Pág.34.

20 Nota: Se dibuja el plano del proyecto premiado en el concurso para el Pabellón helvético de la Expo 2.000 para poder establecer el ancho 


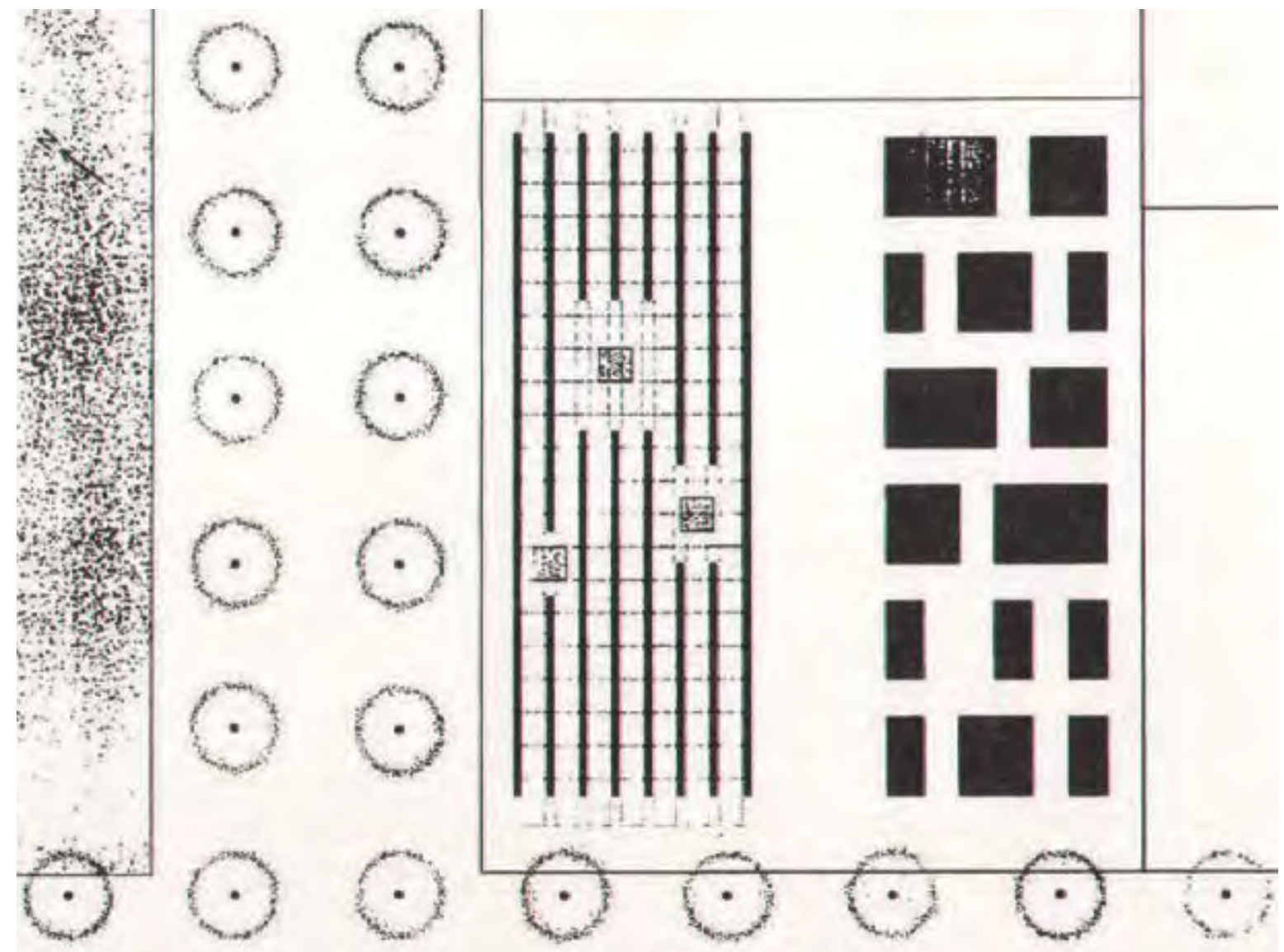

Figura 12.

Planta completa del proyecto premiado en el concurso para el Pabellón helvético de la Expo 2.000 / Peter Zumthor
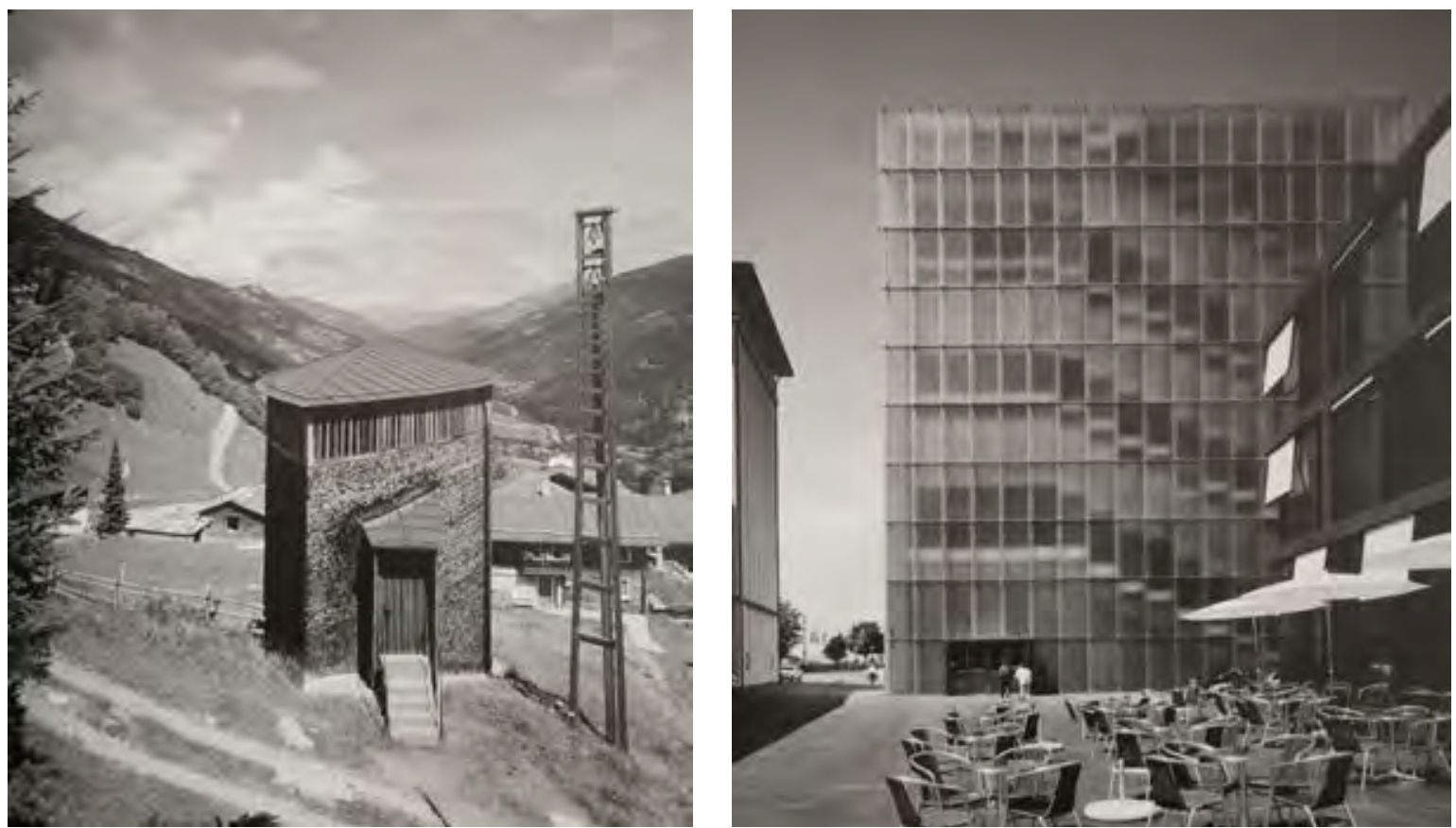

Figura $13-14$

Capilla San Benedicto / 1985 - 1988 / Peter Zumthor

Kunsthaus Bregenz / 1989 - 1997 / Peter Zumthor. 


\author{
"Peter Zumthorysu equipo pertenece al reducido grupo de personas, que \\ no han sucumbido a los pabellones. Ellos no construyeron ninguno. La \\ pila de listones es lo opuesto a un pabellón, el pueblito de contenedores \\ es un rechazo de la auto-presentación." ${ }^{21}$ Benedikt Loderer
}

La mayoría de las publicaciones, que incluyen la propuesta para el concurso del pabellón, muestran la disposición de las ocho pilas de madera de abeto sin tratar. Un lugar silencioso, restringido, reducido y protegido del ruido de la Expo 2.000 para la contemplación. Un espacio que permite vistas a través del apilamiento de las paredes donde el espectador se convierte en parte de la performance. Por el contrario, se suele obviar de la propuesta original la serie de quince contenedores adicionales ubicados frente al pabellón principal. Este ámbito se compone de seis filas, con tres tipos de contenedores diferentes de uno, dos o tres módulos; que son similares a los anchos de paso entre muros del pabellón principal. Estos elementos móviles, reconocibles y económicos; contenían actividades de servicio, espacios servidores destinados a la gastronomía, el comercio y la administración; así como todas las instalaciones auxiliares.

Ambos ámbitos, las bandas y los contenedores, tienen cualidades diferentes: materialidad, composición, disposición, formalización de los espacios, funcionalidad. Sin embargo, la retícula geométrica compositiva es la misma. No son dos entidades, sino dependientes una de la otra. Zumthor separó estas dos naturalezas; segregando la maquinaría instrumental, de comunicación y logística de la zona destinada a la experiencia sensorial. La disociación como medio de expresión arquitectónica es recurrente en algunos de sus proyectos. Unos años antes, en la propuesta ganadora del Kunsthaus, igualmente liberará todos los usos auxiliares de los espacios expositivos. Las áreas administrativas y de restauración se ubicaron en una pieza anexa e independiente conectada a la expositiva por medio de un vacío, una plaza. El esquema es equivalente a la propuesta ganadora, configurando un cordón umbilical entre ambos proyectos expositivos. La segmentación programática será también usual en otros proyectos como en el complejo termal en Vals donde el volumen principal incrustado en la montaña está des-conectado por un pasaje subterráneo al hotel existente; o en la capilla de San Benedicto en Graubünden donde la torre del campanario está disociada del volumen principal del templo.

21 LODERER, Benedikt. Die Schweiz als Kantonholzstapel: an der Weltausstellung in Hannover stellt sich die Schweiz als einem Bretterstapel vor. En: Hochparterre: Zeitschrift für Architektur und Design. 1997. Band 7. Heft 11. Pág. 23. Traducción de la autora: "Peter Zumthor und seine Leute gehören zu den wenigen, die nicht dem Pavillondenken verfallen sind. Sie bauen gar keinen. Der Bretterstapel ist das Gegenteil eines Pavillons, das Containerdörfli eine Absage an die Selbstdarstellung(...)" 


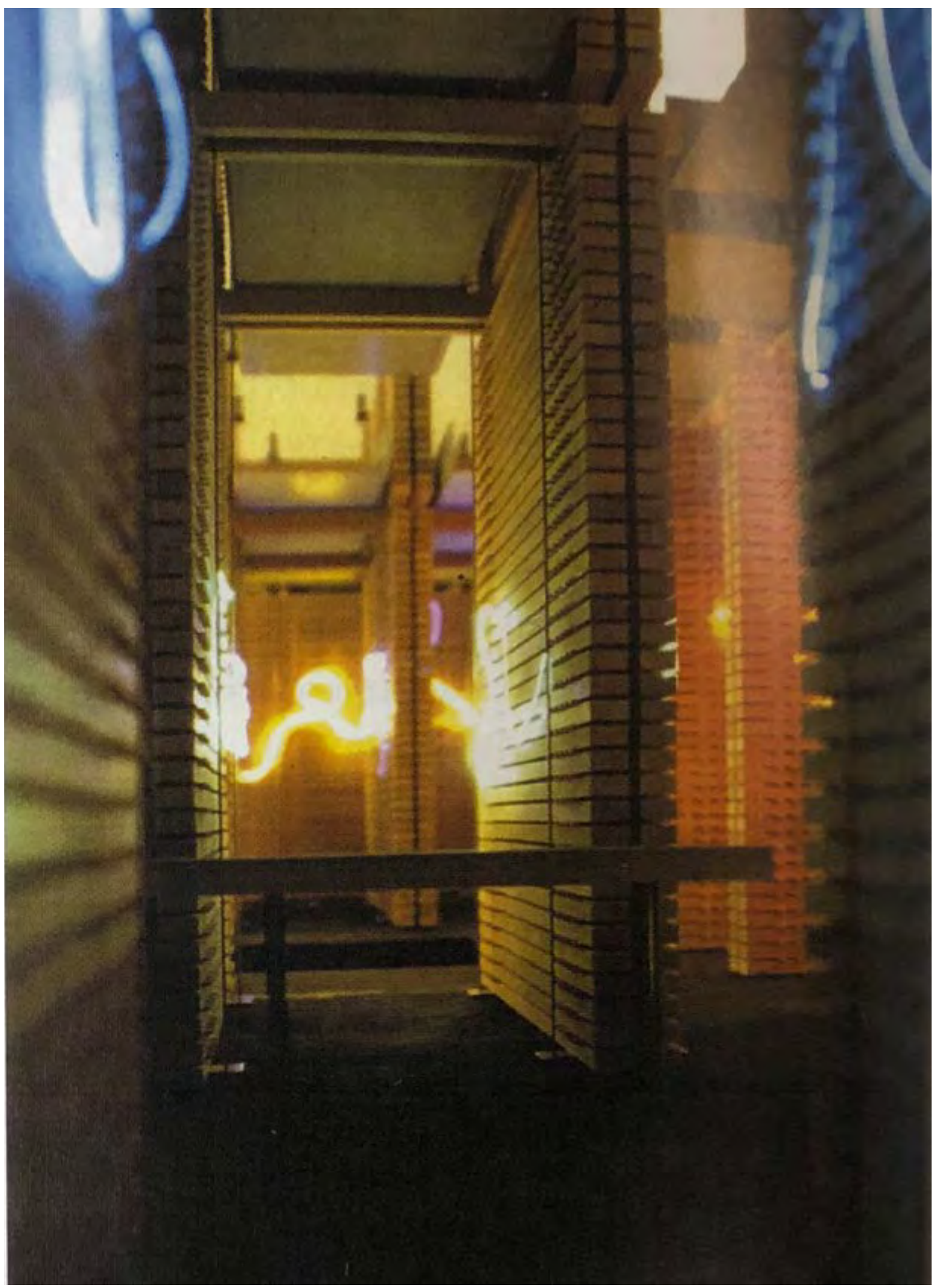

Figura 15.

Vista interior de la maqueta del proyecto premiado en el concurso para el Pabellón helvético de la Expo 2.000 / Peter Zumthor . 
"En el bullicio predecible de la Expo, el Pabellón Suizo será un oasis de descanso, reflexión y contemplación, un lugar de serenidad y apertura, una presencia discreta y no didáctica."22 Peter Zumthor

La geometría propuesta para el pabellón tiene un orden impuesto basado en un sistema completamente modular. Una forma que se caracteriza por la adición espacial, consiguiendo diversidad a través de la repetición de una unidad sencilla; del mismo material y de las mismas dimensiones. Zumthor establece un paralelismo visual. La percepción sucesiva de los espacios interiores es continua, lineal, direccional. Este sistema de entre-líneas interiores se interrumpe únicamente para insertar tres vacíos compatibles con el planteamiento propuesto; denominados "islas del silencio"23. El contenido programático se alojará por medio de la interrupción de las bandas; creando un escenario encadenado. Se trata de un espacio continuo y al mismo tiempo compartimentado. Linealidad y homogeneidad como estrategias operativas.

Alejándose de los pabellones tradicionales, propuso una "escenificación espacial", Rauminszenierung. Un soporte de múltiples relaciones entre el entorno y los visitantes, una relación recíproca entre lo que hay existente y lo que va a suceder. El edificio hace el lugar, experiencias etéreas donde el usuario entra en resonancia con el espacio y lo activa súbitamente.

22 ZUMTHOR, Peter. Peter Zumthor Works. Buildings and Projects 1979-1997. Birkhäuser. Basel, Boston, Berlin. 1999. ISBN: 3-7643-6099-2. Pág. 294. Traducción de la autora: "In the predictable bustle of the Expo, the Swiss Pavilion will be an oasis of rest, reflection, and contemplation, a place of serenity and openness, an unobtrusive, non-didactic presence."

23 GENERALKOMMISSARIAT. Schlussbericht des Generalkommissariates. Weltausstellung Expo 2000 Hannover 1.6.-31.10.2000. Die schweizerische Beteiligung mit "Klangkörper Schweiz". Bundesamt für Kultur. Bern. 2001. Pág. 32. Traducción de la autora: "(...)sind die drei ausgesparten Leeräume Inseln der Stille. " 


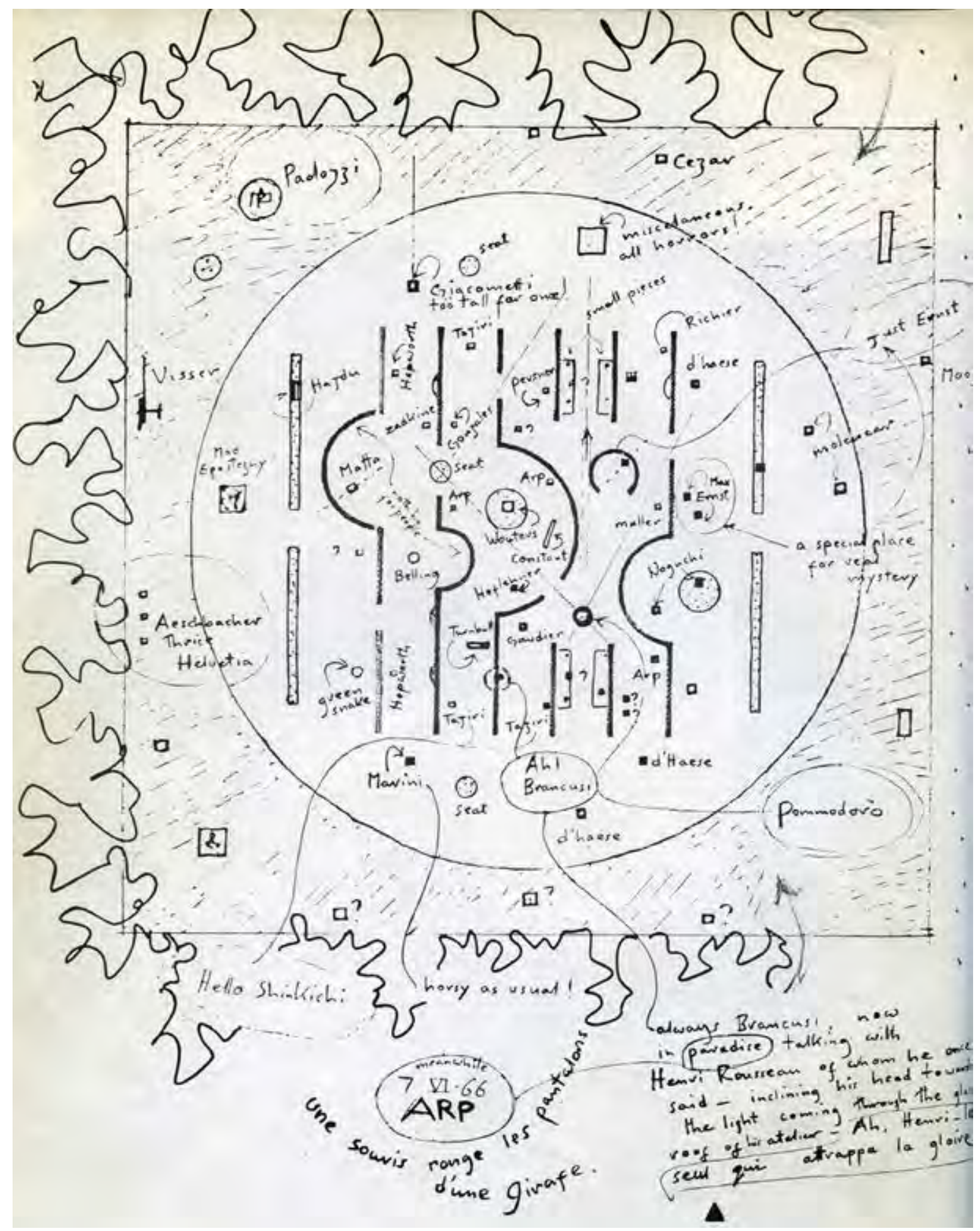

Figura 16.

Planta disposición esculturas / Pabellón Sonsbeek / Aldo van Eyck 


\title{
[Déjà vu]
}

\begin{abstract}
"Para mí la diferencia entre ciudad y paisaje probablemente reside en lo siguiente: la ciudad me estimula o me exaspera, me hace grande o pequeño, consciente de mí mismo, orgulloso, curioso, distendido, o bien un ser irritado, fastidioso... La ciudad me intimida. En cambio, cuando estoy en disposición, el paisaje me transmite libertad y paz. La sensación del tiempo en la naturaleza es otra."24 Peter Zumthor
\end{abstract}

La propuesta ganadora Batterie fue la "célula madre" del pabellón finalmente construido Klangkörperbau ${ }^{25}$. Ambos suponen el comienzo y culminación de un proceso evolutivo, el cual tiene algunas reminiscencias, resonancias y ecos conceptuales en otra especie, un ejemplo paradigmático de arquitectura efímera llevado a cabo 34 años antes a unos $300 \mathrm{~km}$ aproximadamente al oeste. Cómo si se tratase de un Déjà vu arquitectónico, emerge el pabellón temporal de Van Eyck construido en 1.966 en Arnhem.

Aldo van Eyck fue uno de los exponentes de la llamada Tercera generación ${ }^{26}$. Recogerá la inercia del empuje y superación de la tradición gracias a las nuevas posibilidades tecnológicas y de producción de la Primera generación hacia mediados del siglo XIX. Así mismo incorporó el desarrollo de "los nuevos programas y actitudes propios de la era de la máquina ${ }^{27}$ de la Segunda generación con el cambio de siglo.

El Pabellón original ${ }^{28}$ ubicado en el parque de Sonsbeek fue diseñado por Van Eyck para la V Exposición Internacional de Escultura. Fue predecesor de la experiencia del otro gran pabellón efímero obra de Gerrit Thomas Rietveld ${ }^{29}$ para la Tercera edición de la Exposición Internacional de Escultura celebrada en el 55. Así desde el 27 de

24 ZUMTHOR, Peter. Pensar la arquitectura. Editorial Gustavo Gili. S.L. Barcelona. 2010. ISBN: 978-84252-2730-1. Pág. 96

25 Licencia que ha sido realizada por los autores del artículo, juntando la palabra Klangkörper y la palabra Bau -construcción-; es decir el soporte físico de este gran instrumento atmosférico

26 DREW, Philip. Tercera generación. La significación cambiante de la arquitectura. Barcelona: Gustavo Gili. 1973. ISBN-13: 978-8425207563.

27 LÓPEZ-PELÁEZ, José Manuel. "En torno a la Tercera Generación. Perspectiva desde un centenario (1918-2018)”, Revista ZARCH, número 10. Junio 2018. ISSN: 2341-0531. Pág. 10-25.

28 GOITIA CRUZ, Aitor. Rietveld y van Eyck en el edén del Arte. Revista de Arquitectura de la Universidad CEU San Pablo. Numero 2. Mayo 2014. ISSN 2340-177X. Nota: El pabellón original de van Eyck fue desmontado unos meses después su inauguración. En 2006, se reconstruyó una réplica, con alguna variante como la solución de la cubrición, en el mismo jardín del Museo Kröller-Müller.

29 Aunque se trataba de arquitectura efímera, fue reconstruido e inaugurado un año después de la muerte del maestro y un año antes de la inauguración de la obra de Van Eyck. 


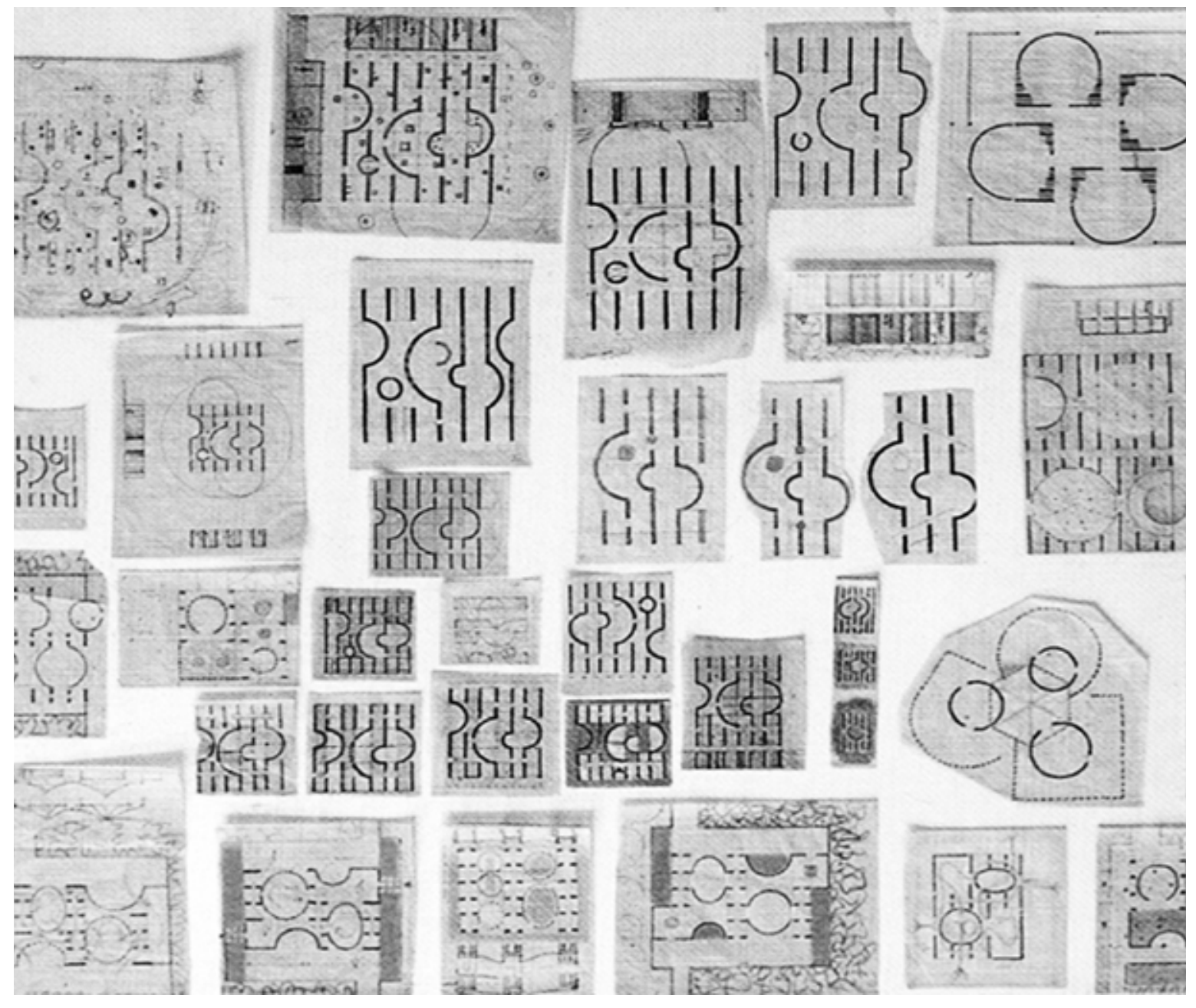

Figura 17.

Croquis inicial / Pabellón Sonsbeek / Aldo van Eyck / Fragmento
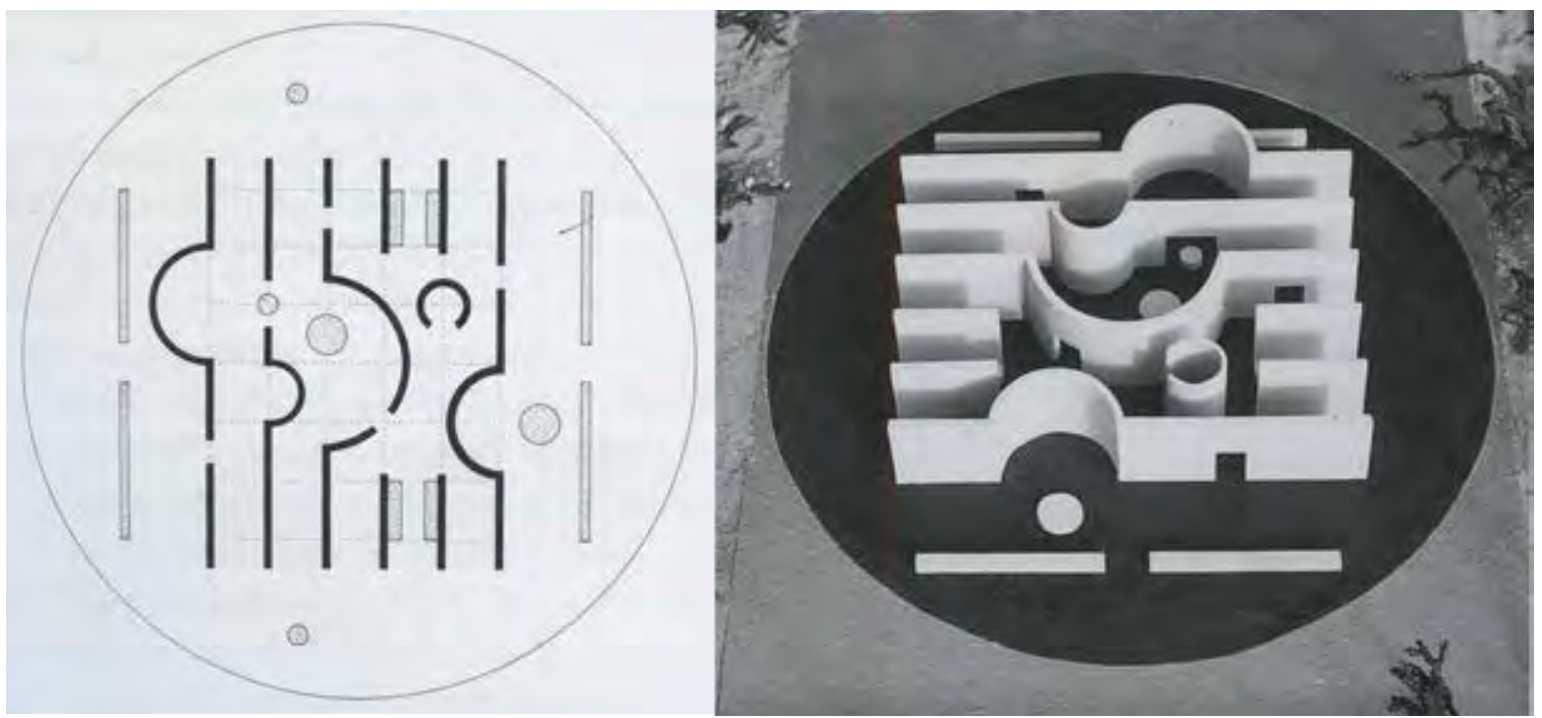

Figura 18.

Planta y maqueta / Pabellón Sonsbeek / Aldo van Eyck 
mayo hasta el 25 de noviembre de 1.966, la estructura propuesta por Van Eyck estuvo abierta al público dando soporte a varias esculturas, de muy diversa naturaleza y tamaño, de un grupo de artistas entre los que se hallaban "Arp, Brancusi, Pevsner, Gaudier Brzeska, Gonzales, Hepworth, Giacometti, Richier, Ernst, Matta, Noguchi, Tajiri, Caro, Turnbull, Constant, Wouters, Pomodoro, Paolozzi"30.

"Por lo tanto, decidí que el nuevo pabellón debería poseer algo de la cercanía, la densidad y la complejidad de lo urbano, que de hecho debería ser como una ciudad, en el sentido de que las personas y los artefactos se encuentran, convergen y chocan allí inevitablemente." ${ }^{131}$ Aldo Van Eyck

Los procesos de gestación del pabellón de Aldo van Eyck fueron fruto de numerosos dibujos sucesivos, aproximadamente 60 croquis. Su geometría y sus trazos se entrelazan con la propuesta coetánea del pabellón para la Iglesia Católica Romana Pastor van Ars en la Haya ${ }^{32}$. En las últimas etapas del proceso, la base del proyecto se consolida en una cuadrícula geométrica y simple como instrumento de composición.

El sistema espacial se compuso mediante seis muros rectilíneos orientados noreste/ suroeste de $4,00 \mathrm{~m}^{33}$ de altura, asentados sobre una losa circular. Estos dispositivos paralelos con un paso libre de 2,30 $\mathrm{m}^{34}$ fueron construidos con bloques de hormigón prefabricado de color gris claro. Su continuidad se interrumpió para dar cabida a una serie de protuberancias en forma de ábside, así como a cuatro huecos de paso, doorways, para transitar entre las diferentes bandas entre-muros del sistema. Todos los muros estuvieron subordinados a un sistema general invisible: tamaño, forma, dimensión, altura y proporción. El tablero de estas partituras estuvo tutelado por una modulación muy estricta. Una estructura de orden basada en una matriz modular de líneas paralelas. Estas "tapias" equidistantes se conformaron como respuesta al programa, pero al mismo tiempo mantuvieron su condición lineal. Mediante una

30 VAN EYCK, Aldo; LIGTELIJN, Vincent. Aldo van Eyck Works. Basel Birkhäuser. Holanda. 1999. ISBN 3 76436012 7.Pág. 135.

31 Idem. Pág. 134. Traducción de la autora: "I therefore decided that the new pavilion should possess something of the closeness, density and intricacy of things urban - that it should in fact be city-like, in the sense that people and artifacts meet, converge and clash there inevitably."

32 VAN EYCK, Aldo; LIGTELIJN, Vincent. Aldo van Eyck Works. Basel Birkhäuser. Holanda. 1999. ISBN 3 76436012 7.Pág. 145.

33 BOKERN, Anneke. Labyrinthische Klarheit: Rekonstruktion von Aldo van Eycks Sonsbeek-Pavilon im Skulpturengarten des Kröler-Müller-Museums Otterlo. En: Werk, Bauen + Wohnen. Neuchatel et cetera. Bd.93. 2006. file:///C:/Users/mOve\%20archlab/Downloads/wbw-004_2006_93_1307_d. pdf

34 MCCARTER, Robert. Aldo van Eyck. Yale University Press. New Haven. 2015. ISBN 978-0-300-15395-5. Pág. 148. 


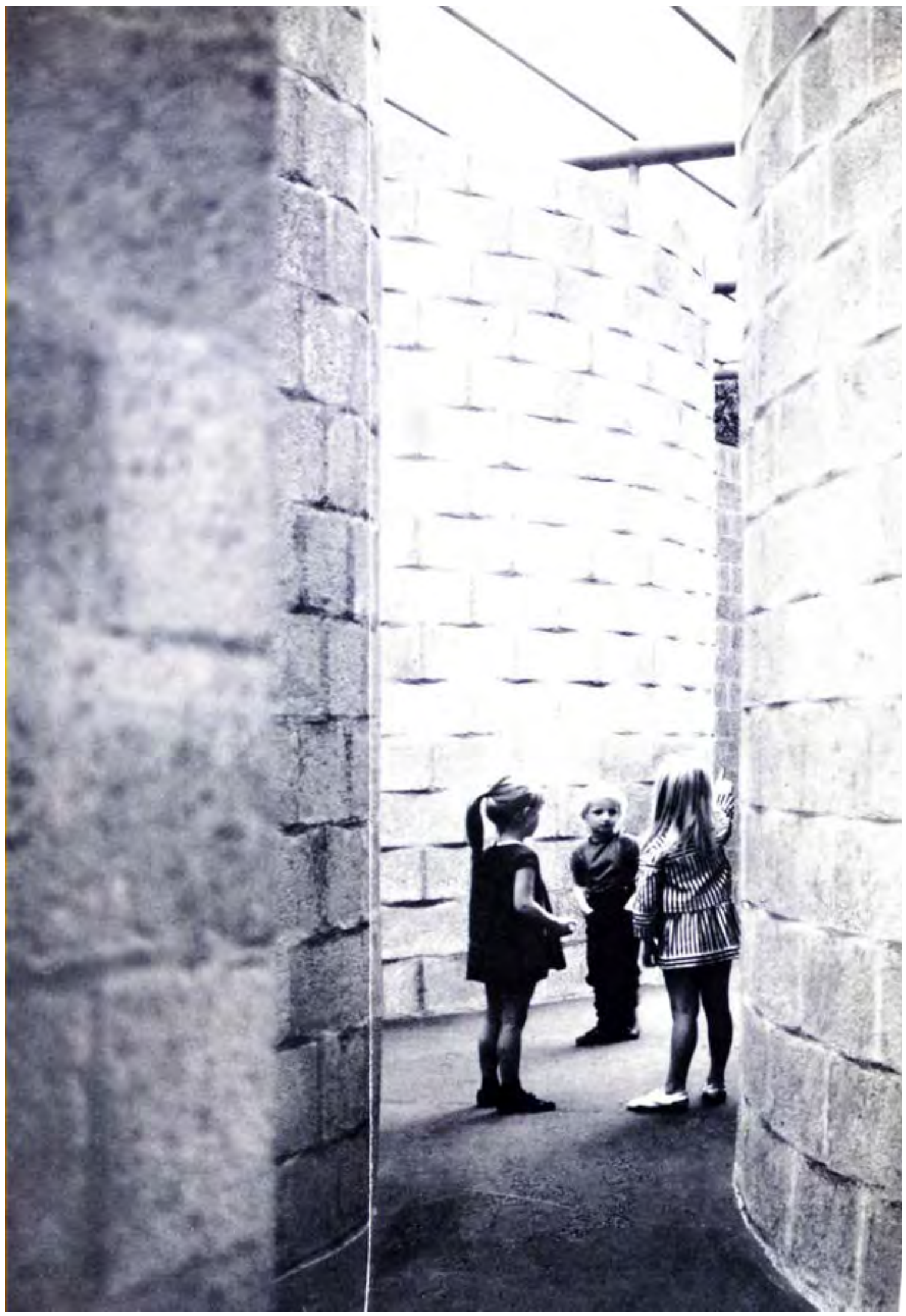

Figura 19.

Interior del Pabellón Sonsbeek / Aldo van Eyck 
serie de acciones: desplazamiento, estrechamiento, ensanchamiento y deformación de esta estructura lineal se generó una gran riqueza espacial. Se injertaron elementos semicirculares cóncavos y convexos de diferentes tamaños a la trama. Los tamaños de estos elementos radiales estuvieron a-cotados y vinculados a la trama principal ortogonal. Estas mutaciones arquitectónicas permitieron generar un interior fluido. Unas veces dilatado y otras comprimido, el patrón original predecible se transformaba en una entidad espacial compleja. Aparecen diversos lugares acordes con el uso, aplicando la geometría de una manera libre. Una composición aparentemente sencilla, finalmente múltiple. Surgen así nuevas conexiones, referencias y relaciones visuales. La disposición de los muros estructuró el pabellón como una serie sucesiva de paisajes. La mirada no solo se enfocaba en torno a un eje direccional. El recorrido no fue lineal, serpentea a través de la exposición mostrando objetos inesperados y estableciendo nuevas relaciones entre las obras escultóricas por medio del movimiento del visitante. Aparecen múltiples coreografías.

\section{"(..) había pedestales vacíos en los que el propio visitante podía sentarse y convertirse así en una 'escultura ${ }^{1135}$ Francis Strauven}

El pabellón original de Van Eyck no fue un soporte de esculturas de otros artistas; sino un sistema complejo de "pedestales" cuya materialidad contrasta claramente con las esculturas expuestas. En oposición con los "materiales trabajados" de las esculturas, emergen los "materiales en bruto" de los seis muros serpenteantes. Las esculturas expuestas se dispusieron por todos los espacios como reflejos de figuras humanas, estableciendo así un diálogo y simbiosis con los visitantes. Los bancos propuestos acentuaron esta circunstancia. Un espacio escenográfico donde las esculturas parecían observar a los curiosos que recorrían el laberinto; y viceversa en un desconcierto fantástico.

35 STRAUVEN, Francis. Aldo van Eyck: the shape of relativity. Architectura \& Natura. Universidad de Michigan. 1998. ISBN: 9071570614 . Pág. 496. Traducción de la autora: " there were empty plinths on which the visitor himself could sit and thus become a 'sculpture' 


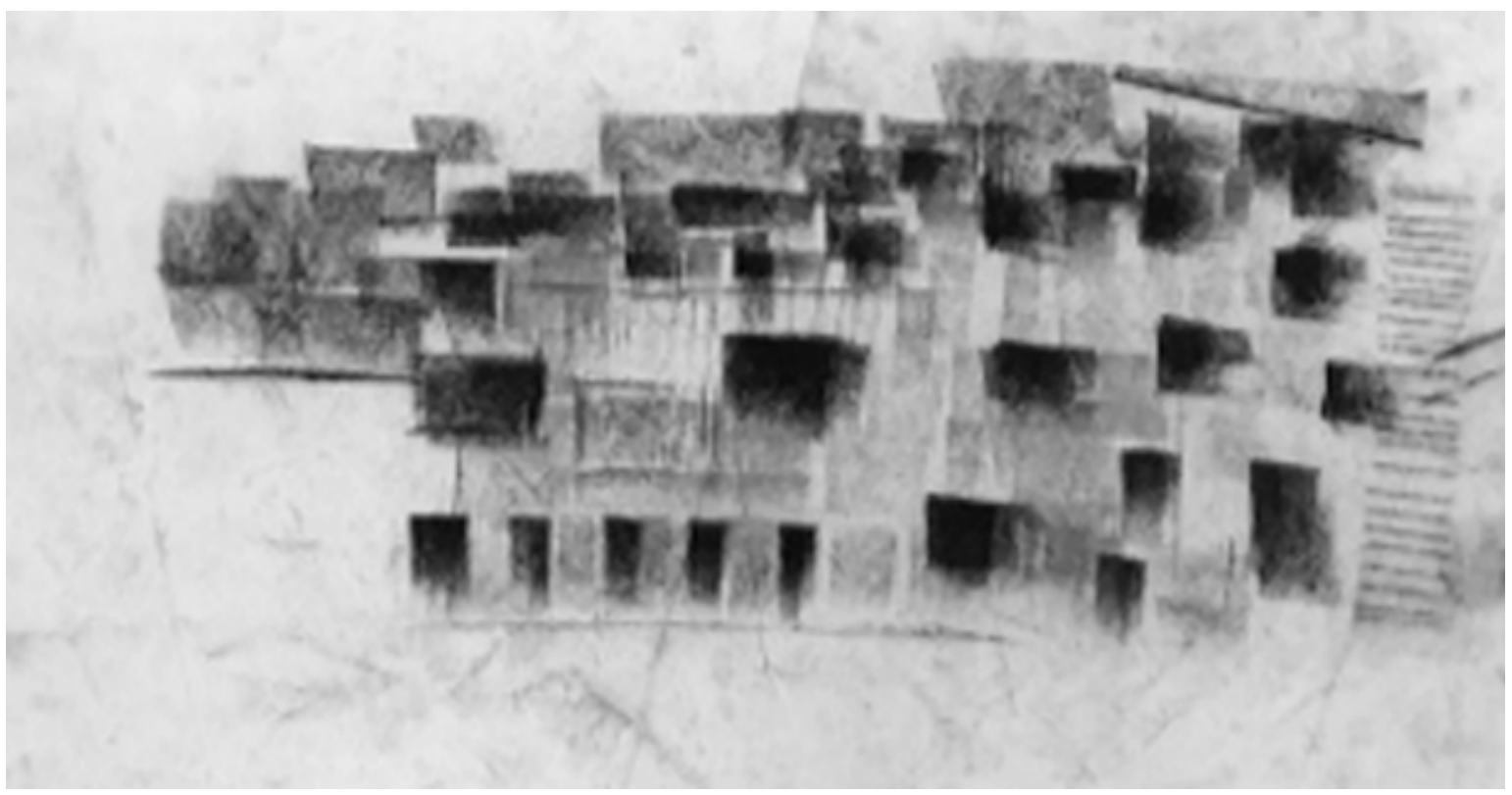

B

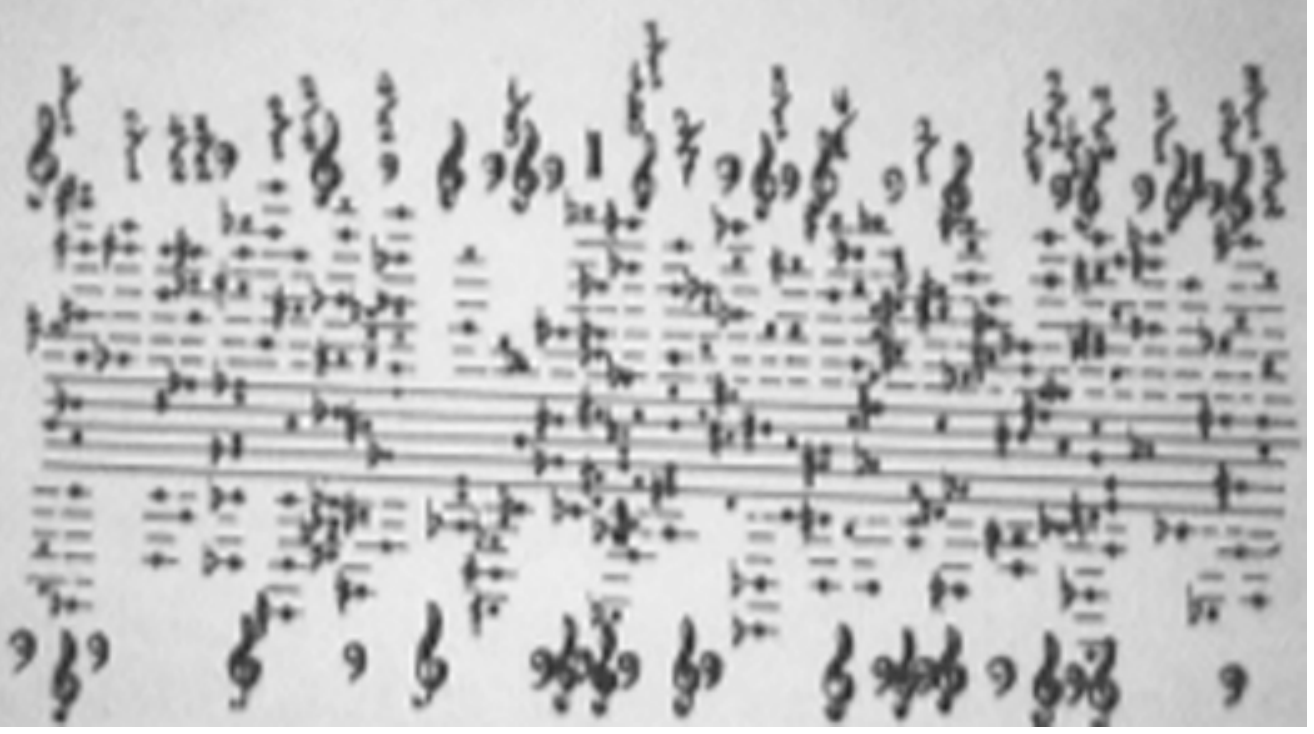

Figura 20.

Termas de Vals vs. Música / Peter Zumthor vs. John Cage 


\title{
[Partituras]
}

\author{
"He hablado del lugar, de la casa y de la ciudad como una serie \\ de lugares, a la vez del ámbito intermedio como del hogar del \\ hombre. ${ }^{\prime 36}$ Aldo van Eyck
}

Tanto la propuesta ganadora del Pabellón helvético en Hannover; como el Pabellón de esculturas en Sonsbeek interpretan sinfonías espaciales; son partituras afines. Un sistema de "pentagramas" de muros equidistantes y paralelos sobre los cuales se trazan las 'notas musicales'. El pentagrama como base compositiva del "compás musical". Una composición óptima y clara. Una geometría homogénea y al mismo tiempo compleja. Una partitura musical como modelo tridimensional. El compositor se expresa mediante partituras para crear sonoridad, notas; el espacio surge en cambio de líneas y trazos.

Zumthor, como gran apasionado de la música clásica, experimental y del jazz; convierte sus croquis iniciales de los Baños Termales de Vals en partituras equivalentes a las del compositor John Cage. Existen analogías cartográficas en relación con la estructura, el ritmo y sobre todo en la composición. En esta secuencia rítmica, brotan silencios, los vacíos que son parte de la misma partitura. Con la estructura definida sobre una cuadrícula; y sólo entonces, emerge la 'música`. Van Eyck también será un entusiasta de la música, especialmente de la obra de Johann Sebastian Bach. "Utilizó el concepto de fuga conscientemente ${ }^{\prime 37}$, con arreglos contrapuntísticos recurrentes, en el proceso de gestación del Orfanato de Ámsterdam.

\begin{abstract}
"La idea central era que la estructura no debía revelar lo que sucede en el interior hasta que uno se aproxima lo suficiente, acercándose desde los extremos. Visto desde los lados, parece cerrado y masivo, guardando secretos." ${ }^{138}$ Aldo van Eyck
\end{abstract}

36 VAN EYCK, Aldo. Beyond visibility about place and occassion the inbetween realm right - size and labyrinthian clarity. The Situacionist Times no4. 1963. Pág. 80. Traducción de la autora: "I have spoken of place, of house and city as bunches of places - both, of the Inbetween Realm as man's home realm"

37 STRAUVEN, Francis. Aldo van Eyck: The Shape of Relativity. Ámsterdam: Architectura \& Natura Press, 1998. ISBN: 978-90-71570-61-2. Pág. 310. NOTA: Mencionado en el artículo CAMPOS URIBE, Alejandro: LACOMBA MONTES, Paula. "Un paseo fotográfico por la casa de Aldo van Eyck: fragmento y montaje", Revista ZARCH, número 9. Diciembre 2017. Pág. 132-145. ISSN: 23410531.

38 VAN EYCK, Aldo. Il padiglione Sonsbeek. Domus. 460. Milano. 1968. Traducción de la autora: “Central to the idea was that the structure should not reveal what happens inside until one gets quite close, approaching it from the ends. Seen from the sides, it appears closed and massive - guarding secrets" 

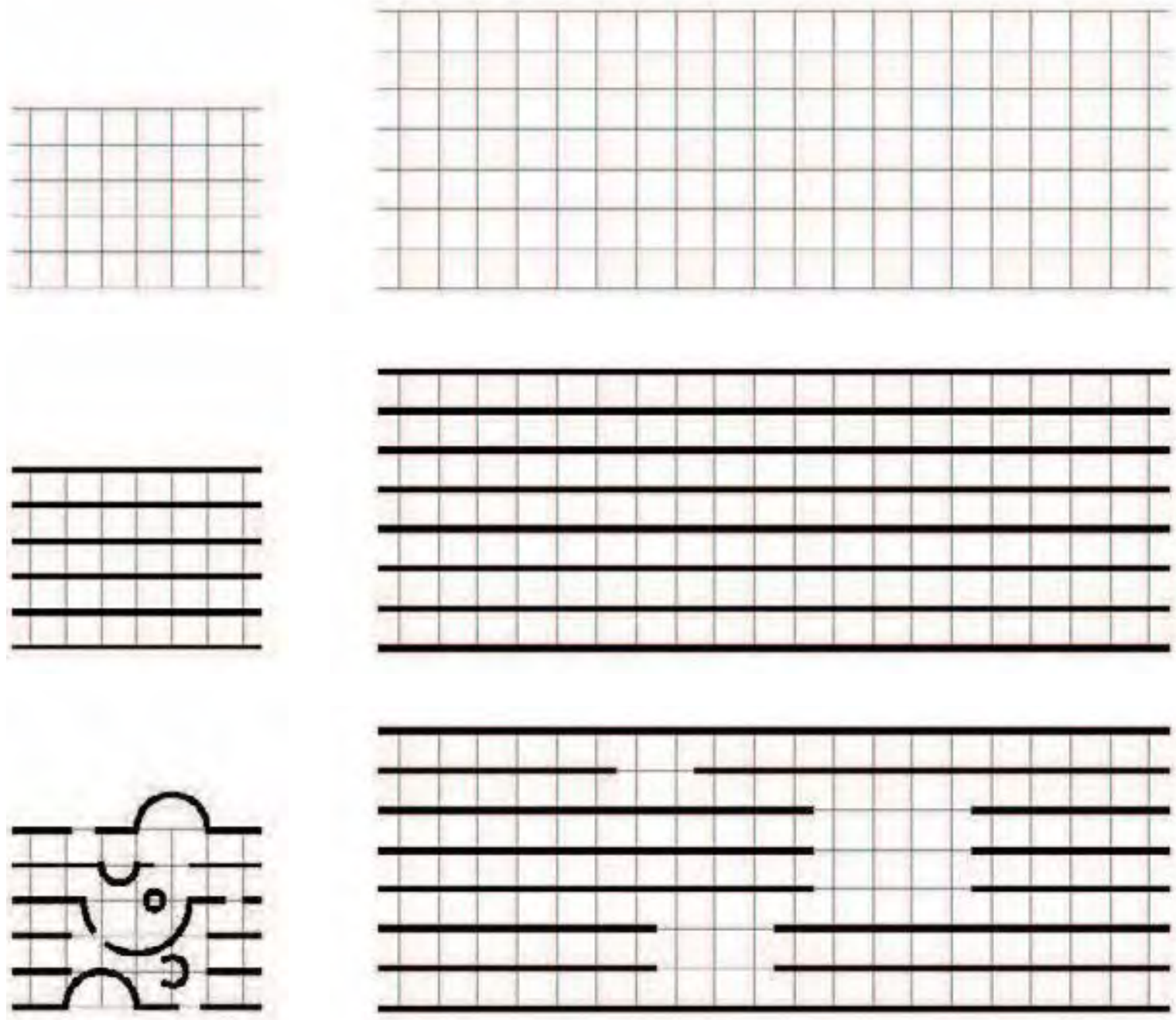

Figura 21.

Pabellón Sonsbeek vs Pabellón helvético propuesta ganadora

Dibujo de la autora
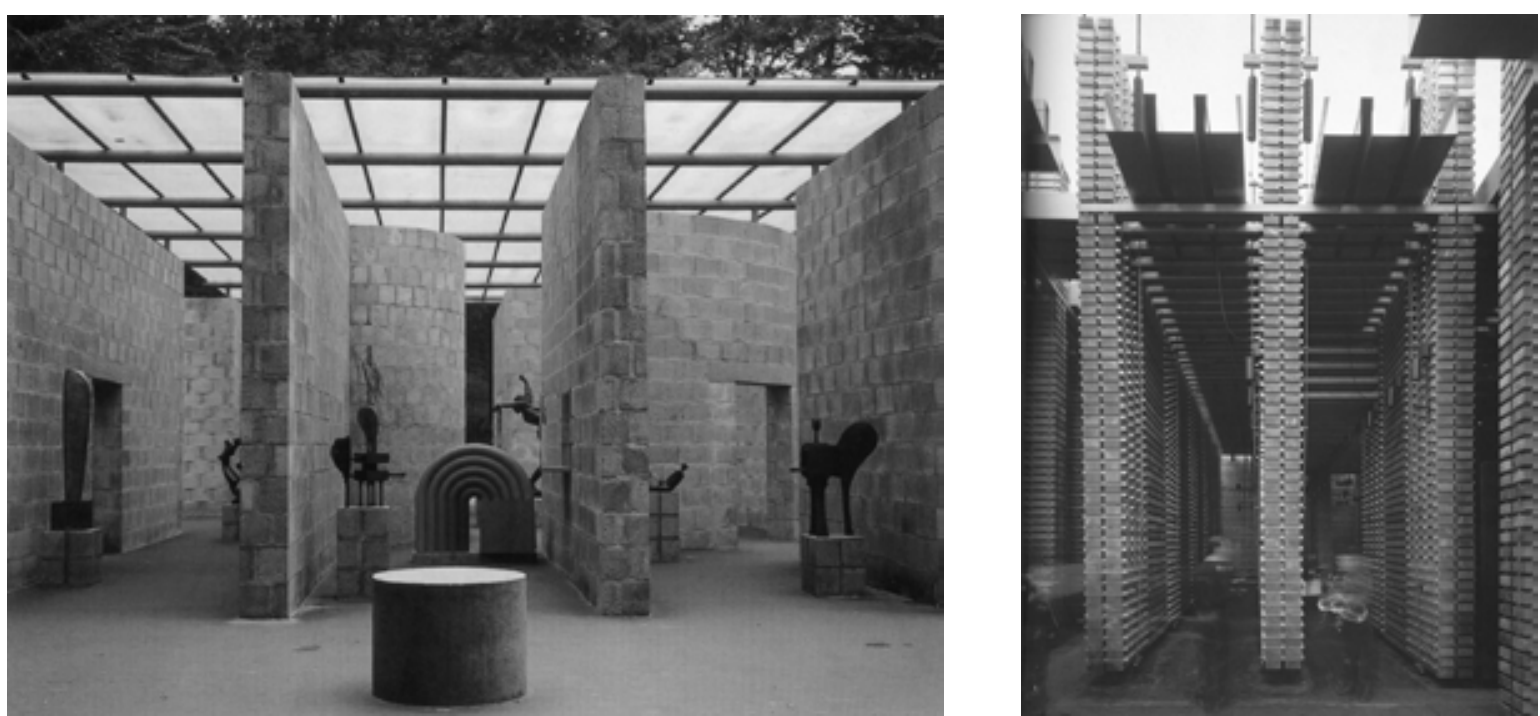

Figura 22 - 23.

Pabellón Sonsbeek vs Pabellón helvético propuesta ganadora 
Zumthor y van Eyck recurrieron a sistemas de pentagramas como herramienta compositiva. Un sistema de bandas para construir diversas sonoridades. El espacio interior se organiza dentro de un método concreto, un entre-lineado. Se trata de un espacio encadenado, continuo, que fluye por el interior del pabellón. Una retícula definida por muros paralelos en dirección longitudinal. Ambos pabellones consiguen una estructura compleja, basada en un sencillo patrón. El espacio, generado por el recorrido, es dinámico. Absorbe el movimiento de los habitantes, inspira al individuo a moverse por él. El recorrido como herramienta arquitectónica para experimentar el espacio y tiempo, música y ritmo. Un lugar de flujos que contiene actividades y por ende espacios diversos. Las mutaciones en los pasillos generan varios tipos de velocidad y percepción, como en cualquier sistema urbano. Ambos pabellones se convierten en un lugar a descubrir, en una partitura a interpretar.

Aunque Zumthor no hará mención a ello, existen algunas resonancias y ecos entre ambos proyectos. Tienen esquemas compositivos reconocibles, aunque no sean idénticos. Revelan una historia, cuyo tema principal es la relación con el espacio, la interacción entre la arquitectura, el entorno y el visitante. Se tratan de espacios lúdicos interactivos. El espectador con su movimiento se convierte en parte de la composición, de la arquitectura. Una serie de espacios con diferentes particularidades, una secuencia particular de experiencias espaciales. El juego de representación como herramienta de aprendizaje, una experiencia física. Un espacio para los sentidos, metáforas de susurros y juglares. Una niebla fenomenológica de límites difusos: arquitectura, exposición, interior-exterior, visitantes.... Pero con unos objetivos definidos y específicos, con una materialidad muy precisa y concisa.

La propuesta inicial de Zumthor para el pabellón de Suiza con el lema Batterie, incluso la versión definitiva construida Klangköperbau; y el pabellón de van Eyck en Sonsbeek son intrínsecamente estructuras narrativas efímeras. Instrumentos y escenarios respectivamente; lugares donde los visitantes representan súbitamente melodías y coreografías a través de las partituras arquitectónicas propuestas. 


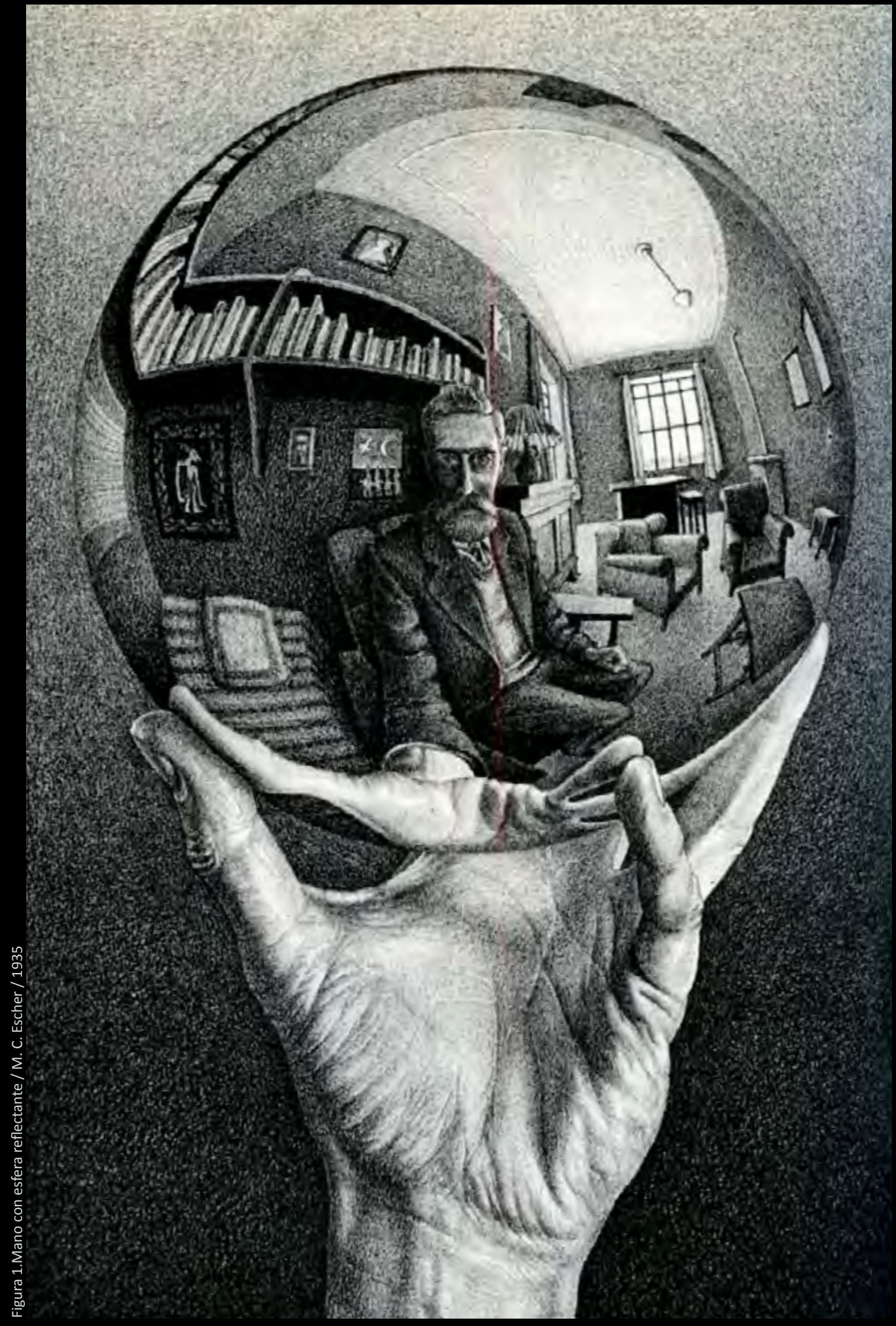




\section{BIOTOPO}

BIOTOP

"(...) la exposición puede ser concebida como una especie de mundo "reducido" donde

las naciones... permitirian al visitante recorrer el globo en ochenta horas..." ${ }^{1}$

\section{Aldolphe Démy}

DÉMY, Adolphe. Essai historique sur les expositions universelles de Paris. Éditeur A. Picard. Paris. 1907. Pag. 1033. Traducción de la autora: "C'est ainsi que l'Exposition pourrait être conçue comme une espèce de monde en raccourci où les nations disposées comme sur la mappemonde, ou mieux comme sur une projection cartographique et offrant, suivant l'expression de Florus, un tableau réduit de la terre, permettraient au visiteur de parcourir le globe en quatre-vingts heures." 


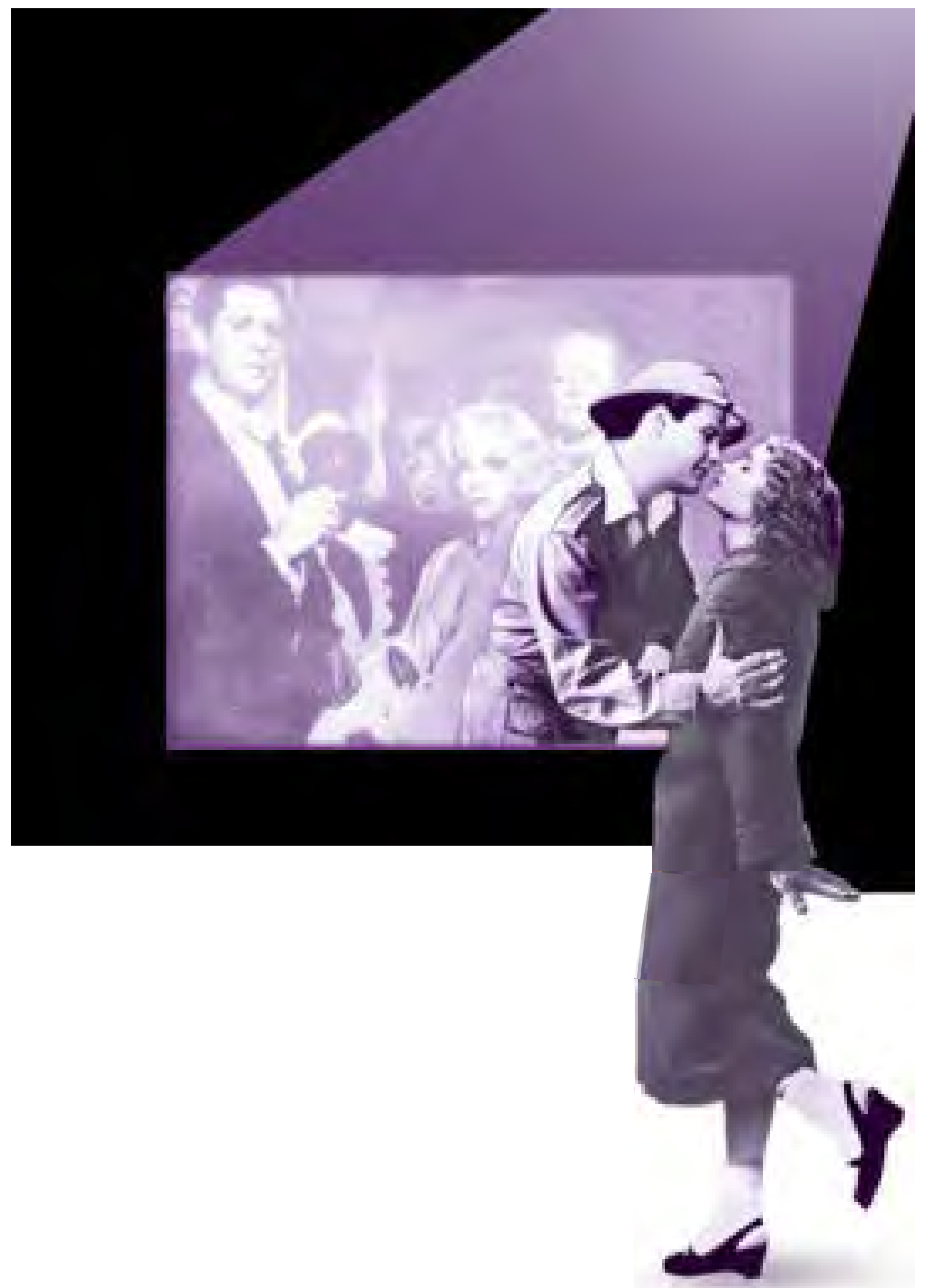

Figura 2.

Cartel de la película "The purple rose of Cairo" de Woody Allen / 1985 


\section{[La vuelta al mundo]}

Al igual que en The purple rose of Cairo ${ }^{2}$ de Woody Allen, una película dentro de una película; las Exposiciones Universales representan un mundo dentro del mundo. Un micro-mundo, una adaptación; el mundo entero en un solo lugar, como un lugar de encuentro, de intercambio. Como si se tratase de un escenario cinematográfico donde el conglomerado de los diferentes pabellones crea una escenografía, un telón de fondo, una follie arquitectónica. Como en un storyboard, los actores se mueven por la representación del mundo experimentando el montaje arquitectónico de un plató; determinando la percepción, temporizando las secuencias visuales, la velocidad, el ritmo, la visión, las pausas y rodando secuencias de eventos sucesivos. Al cosmopolita flâneur se le ofrece un recorrido por el recinto de la Expo por medio de una aventura, una experiencia sin un hilo narrativo concreto, varios escaparates con innovaciones tecnológicas, acumulación de productos exóticos, importaciones; exposición a la información, eventos, entretenimiento, consumo, publicidad, especialidades culinarias, espectáculos multimedia, clichés nacionales; todo ello cómo expresión de la diversidad. Una re-presentación fragmentada del mundo en un lugar específico durante un tiempo limitado. Se trata de un viaje a pie por el mundo, en el que los continentes se encuentran a pocos pasos unos de otros ${ }^{3}$.

\section{“(...) si alguien tuviera tres meses y fuera cada mañana a tomar notas, se ahorraría mucho tiempo leyendo y viajando."4 Gustave Flaubert \\ “(...) las exposiciones universales...estimulan al fabricante, hacen conocer el objeto y determinan al "amateur" a comprar (...)" Aldolphe Démy}

Las Exposiciones Universales suelen ser campos de experimentación arquitectónica y técnica, mecanismos mediáticos de comunicación, fuentes de inspiración para futuros desarrollos. La espacialidad es parte determinante de este juego estratégico. La capacidad constructiva y estructural, además de toda la logística, serán propósitos determinantes en el tablero donde se juegue la partida por la supremacía mundial.

2 Nota: The purple rose of Cairo. Película estadounidense de 1985 escrita y dirigida por Woody Allen.

3 STECKEWEH, Carl. Expo Architektur Dokumente. Beiträge zur Weltausstellung Expo 2000 in Hannover. Hatje Cantz Verlag. Ostfildern-Ruit. 2000. ISBN: 3775708596. Pág. 31.

4 FLAUBERT, Gustave. Gustave Flauberts gesammelte Werke: Briefe an Zeit- und Zunftgenossen. Volumen 9 de Gustave Flauberts gesammelte Werke. J.C.C. Bruns. Pág. 191. Traducción de la autora: "Einerlei, wer drei volle Monate Zeit für sich hätte und jeden Morgen hinginge und Notizen machte, ersparte sich in der Folge viel Lektüre und viel Reisen."

5 DÉMY, Adolphe. Essai historique sur les expositions universelles de Paris. Éditeur A. Picard. Paris. 1907. Pag. 731. Traduccion de la autora: "Les expositions...stimulent le fabricant, font connaitre l'object, déterminent l'amateur à l'achat." 


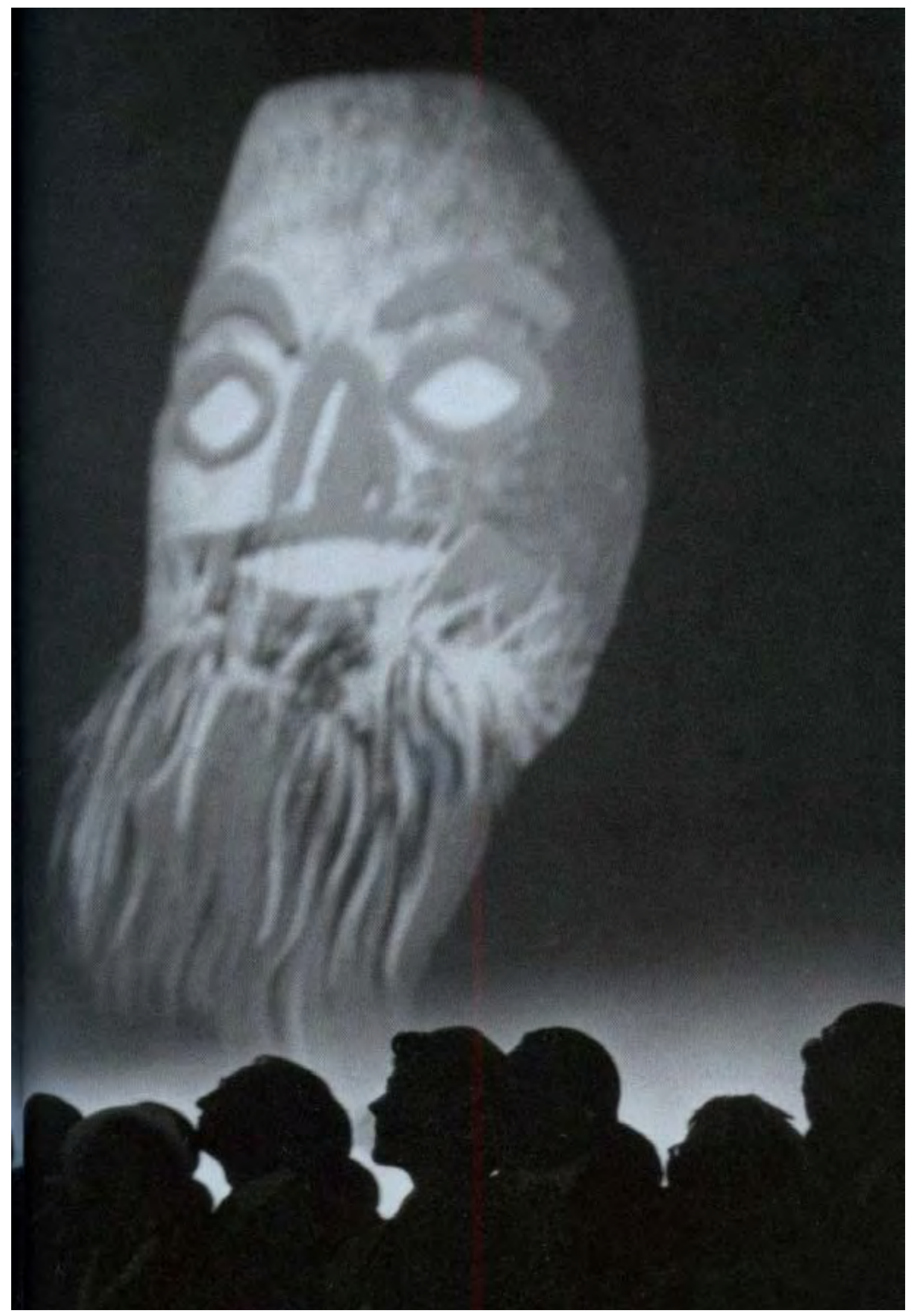

Figura 3.

Interior del Philips Pavilion / Expo 1958 / Le Corbusier 
“¿Qué es un estado, una nación? Ciertamente, un territorio, una población, una estructura administrativa y política, un gobierno, pero también una historia, una economía, la cultura, uno o más idiomas, un equipo de futbol, fronteras - la combinación de estos elementos." ${ }^{\prime 6}$ Ruedi Baur

El desafío mayor para los expositores es distinguirse del resto. Ser el punto de mayor atracción ${ }^{7}$. Hacer algo diferente, fuera de la serie. Siempre en busca de lo innovador, para revelar el carácter y construir la imagen representativa del país respectivo. Sin embargo, en una Exposición Universal, el mundo no siempre se muestra como es, sino como una puesta en escena de lo que uno imagina que es. Un mundo ilusorio, donde cada participante quiere ser una embajada de su país. Las naciones batallan; y compiten, por el dominio industrial, la atención de los inversores, así como por seducir a la masa de visitantes. En ocasiones estos mecanismos son superficiales, "sin requerir un esfuerzo mental"8; dando como resultado el kitsch, definido por Clement Greenberg como el arte de las masas ${ }^{9}$.

\begin{abstract}
"El escepticismo sobre el valor y el significado de las grandes exposiciones se puede encontrar hoy en día en todas partes. Aparte de las cuestiones organizativas y de tráfico, cada año más difícil de resolver, también hay una falta de entusiasmo por el progreso y la satisfacción por los logros de la civilización humana y la tecnología, que hicieron que las exposiciones internacionales y nacionales de principios de siglo fueran estas grandes manifestaciones. ${ }^{100}$ Benedikt Hubert
\end{abstract}

6 BAUR, Ruedi. Ausstellen - Vom Löffel bis zum Staat. En: Im Detail Ausstellen und Präsentieren: Museumskonzepte Markeninszenierung Messedesign. Institut für internationale ArchitekturDokumentation GmbH \& Co. KG. München. Birkhäuser.Verlag AG. Basel - Boston - Berlin. 2009 ISBN: 978-3-7643-9954-2. Pág. 19. Traducción de la autora: "Was ist ein Staat, eine Nation? Gewiss, ein Territorium, eine Bevölkerung, eine administrative und politische Struktur, eine Regierung, aber genauso eine Geschichte, eine Wirtschaft, die Kultur, eine oder mehrere Sprachen, eine Fussballmannschaft, Grenzen - die Verknüpfung dieser Elemente."

7 Idem. Pág. 19. Traducción de la autora: "der Punkt mit der grössten Anziehungskraft zu sein."

8 KÜCKER, Wilhelm. Die verlorene Unschuld der Architektur. Aufsätze und Reden 1980 bis 1987. Friedr. Vieweg \& Sohn Verlagsgesellschaft mbH. Braunschweig. 1989. ISBN: 3-528-08784-6. Pág. 101. Traducción de la autora: "Kitsch befriedigt oberflächliche 'sinnliche' Bedürfnisse auf das trefflichste, ohne ungewohnte geistige Anstrengung abzunötigen."

9 GREENBERG, Clement. Vanguardia y kitsch. (1939) En: Arte y Cultura. Ensayos Criticos. Ediciones Paidós. Buenos Aires. ISBN: 84-493-1260-4. Pág. 15 - 34.

10 HUBERT, Bendedikt. Architektur im Spiegel der Brüsseler Weltausstellung. En: Werk. H. 10/1058. Traducción de la autora: "Die Skepsis gegenüber Wert und Sinn der grossen Ausstellungen ist heute weitherum anzutreffen. Abgesehen von den organsisatorischen und verkehrstechnischen Fragen, die von Jahr zu Jahr schwieriger zu lösen sind, fehlt unserer Zeit weitgehend auch die Fortschrittbegeisterung und die Genugtuung über die Leistungen der menschlichen Zivilisation und Technik, die die internationalen und nationalen Ausstellungen der Jahrhundertwende zu jenen grossartigen Manifestationen werden liessen." 

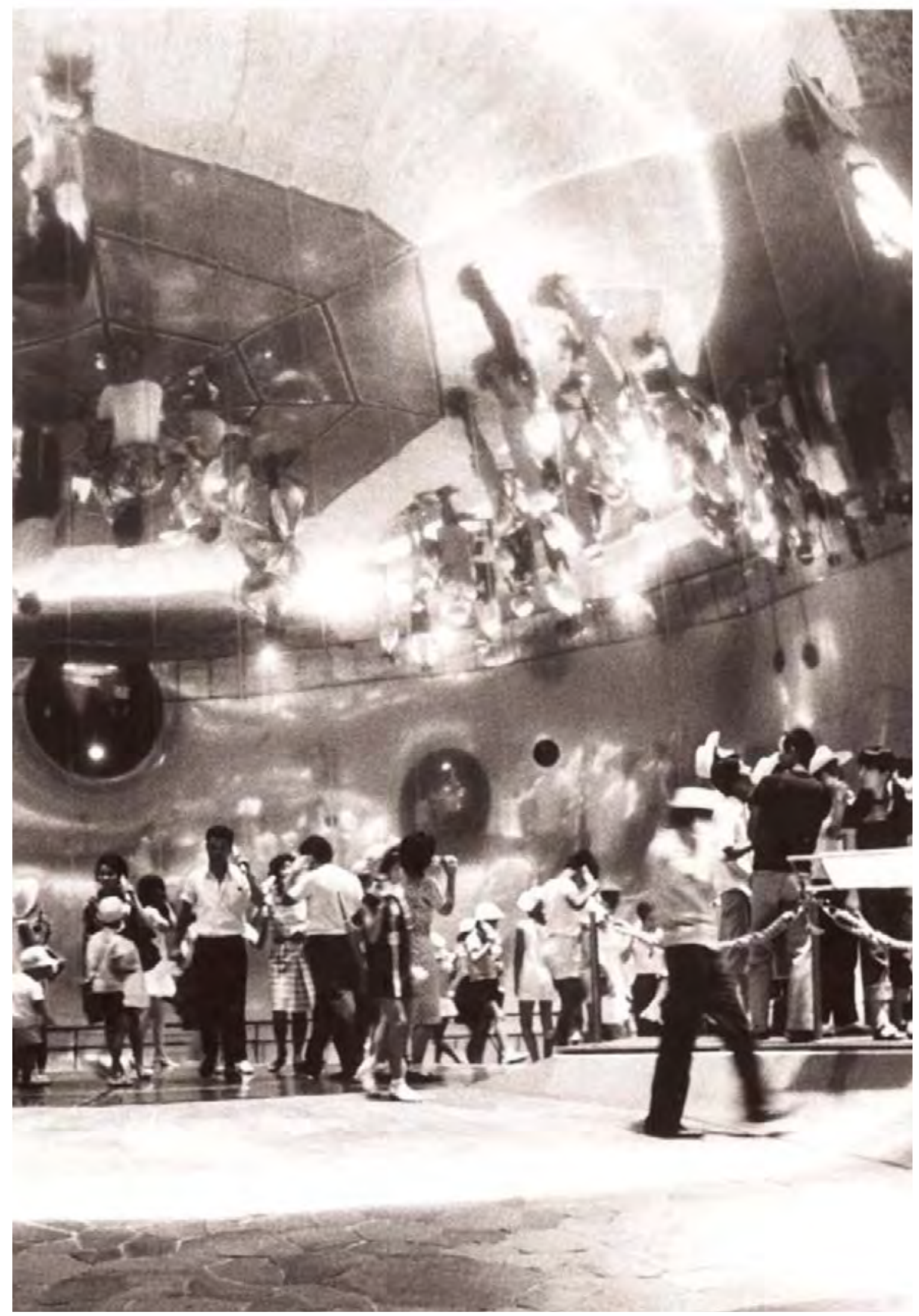

Figura 4.

Interior del Pepsi Pavilion / Expo 1970 / Osaka / E.A.T. 
Las Exposiciones Universales no son eventos didácticos, o educativos ${ }^{11}$, sino más bien para el entretenimiento. Como parques de atracciones del progreso técnico. Actualmente, debido a las nuevas capacidades de acceso a la información, han perdido su función como difusores específicos de información ${ }^{12}$. Parafraseando a Walter Benjamin; las exposiciones mundiales glorifican y ensalzan el valor de intercambio de los bienes, inaugurando una fantasmagoría en la que el hombre entra para distraerse ${ }^{13}$. Una industria del divertimento. Una reflexión sobre la apariencia y el ser, sobre la ilusión y la realidad.

11 KALMUS, Konstanze. Das Konzept der EXPO 2000 in Hannover. En: Ferrum: Nachrichten aus der Eisenbibliothek. Stiftung der Georg Fischer AG. Band 66. 1994.Pág. 26. Traducción de la autora: "Eine Weltausstellung ist keine didaktische Lehrschau. Ihr stehen alle mittel der modernen Ausstellungsgestaltung, der Elektronik und Kommunikationstechnik zur Verfügung. Sie kann das Moment der Unterhaltung ebenso nutzen wie das der Interaktion."

12 WEISS, Klaus-Dieter. Die Expo 2000 in Hannover stellt nicht nur sich selbst in Frage. Das Medium der Botschaft. En: Werk, Bauen + Wohnen. Band 87. Heft 9 Festivitäten: Hannover, Venedig, London. 2000. Pág. 13. Traducción de la autora: "Kurioserweise ist der Informationswert im Vergleich zu historischen Weltausstellungen dramatisch gesunken. Gehandelt werden Bilder, aber unsortiert und in Bruchstücken...Ein themenbezogener Erkenntniswert ist nicht feststellbar."

13 BENJAMIN, Walter. Libro de los Paisajes. Ediciones Akal. S.A. Madrid. 2004. ISBN: 978-84-460-19015. Pág. 42. Nota: "Las exposiciones universales ensalzan el valor de cambio de mercancías. Crean un marco en el que su valor de uso retrocede. Inauguren una fantasmagoría en la que penetra el hombre para hacerse distraer. La industria de recreo se lo facilita aupándole a la cima de la mercancía." 


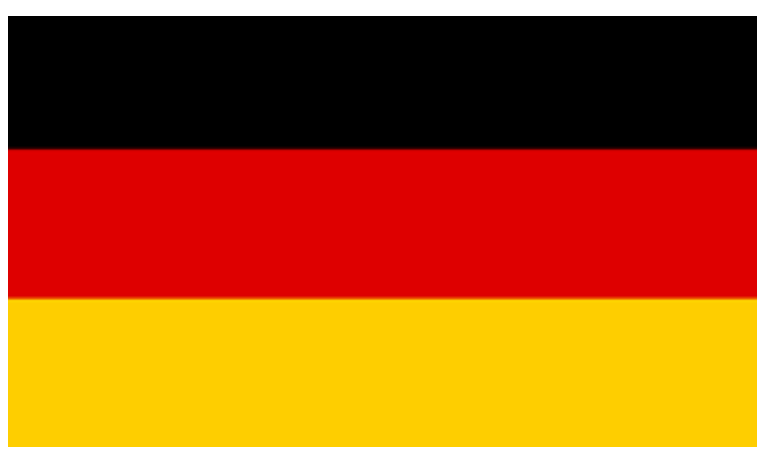

Bandera BRD

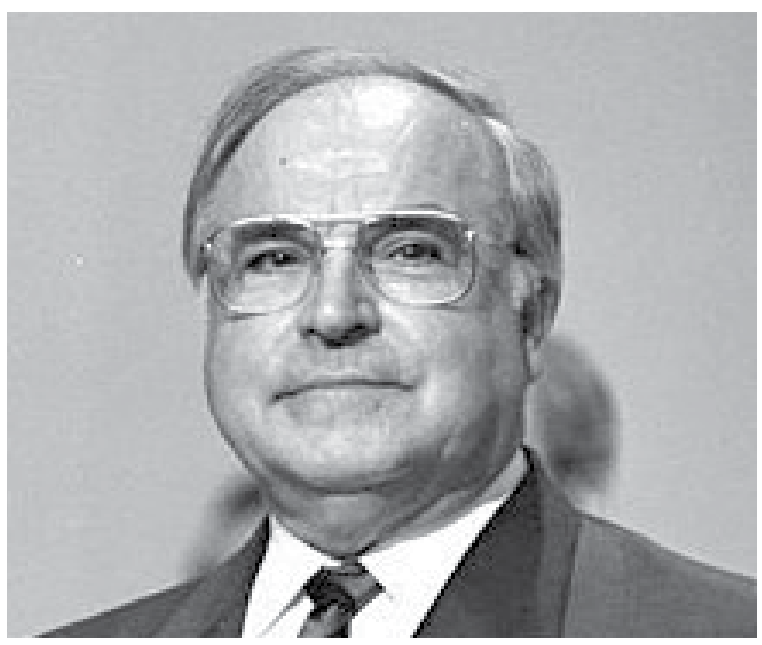

Helmut Kohl / Canciller de la BRD 1982-1998

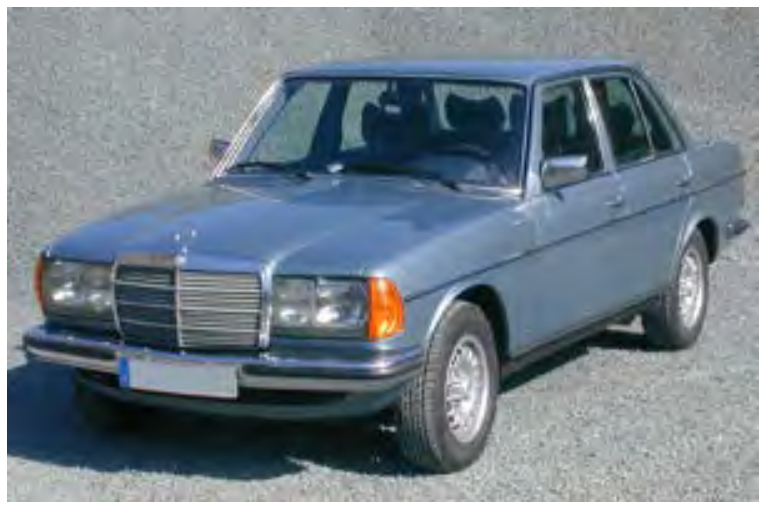

Mercedes

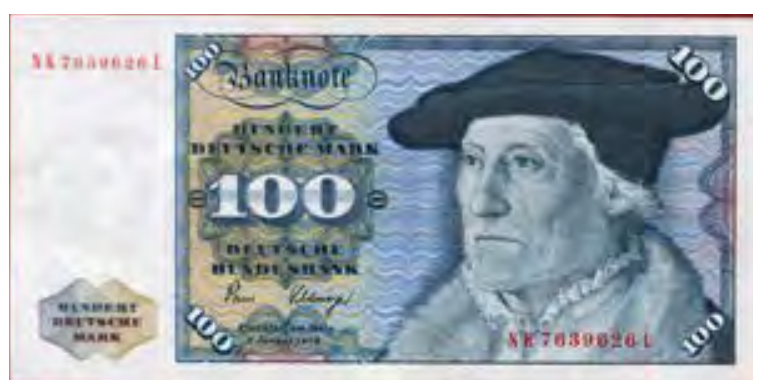

Billete de 100 DM de la BRD

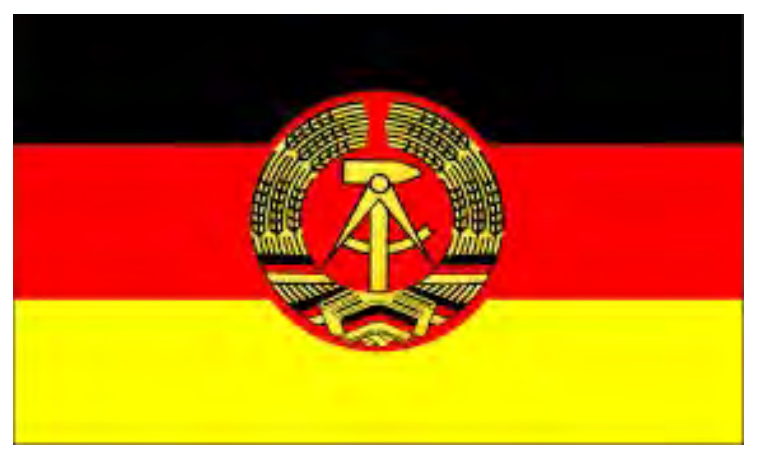

Bandera GDR

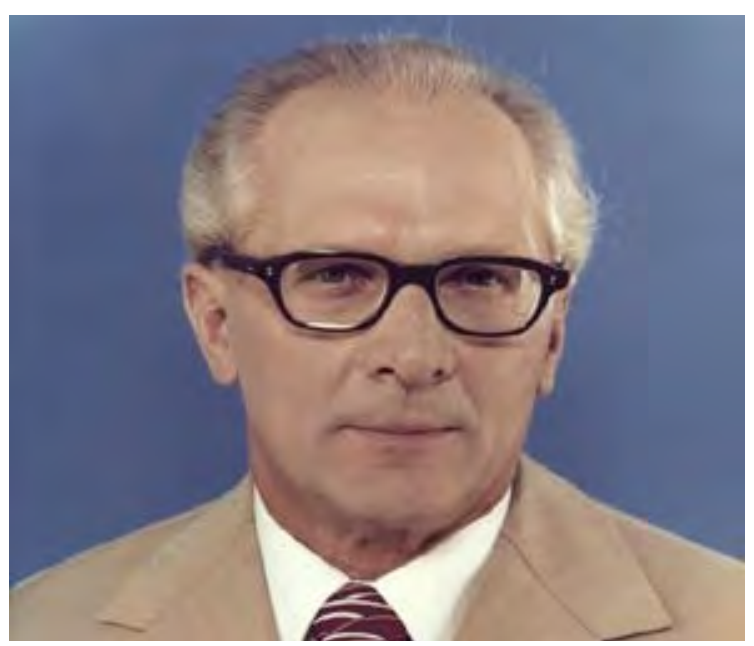

Erich Honecker / Presidente de la GDR 1976-1989

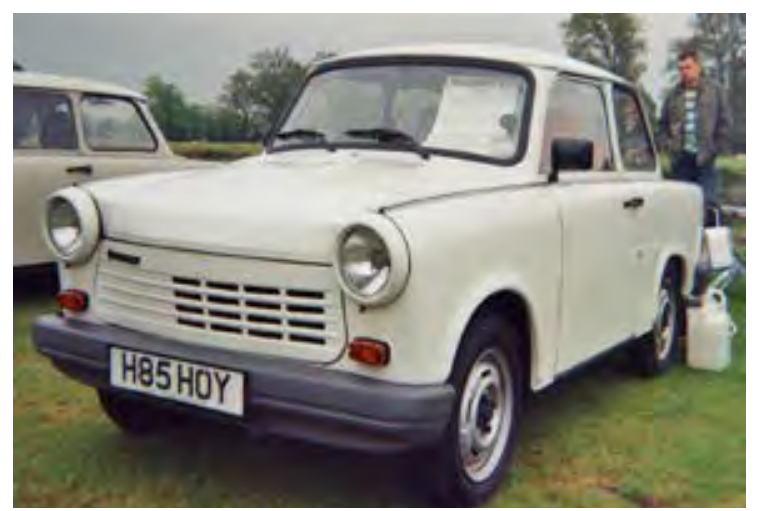

Trabant

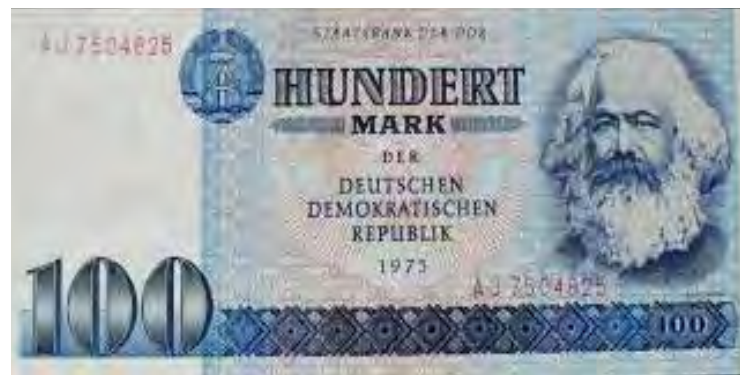

Billete de 100 Marcos de la GDR

Figura 5 - 12.

Comparación en imágenes / BRD y GDR 


\section{[Dos Alemanias]}

\section{"Nadie tiene intención de construir un muro"14 Walter Ulbricht}

Tras la derrota del Tercer Reich en la Segunda Guerra Mundial en 1945, los Aliados dividieron Alemania en cuatro zonas. El territorio oriental de la República Democrática Alemana RDA, estaba bajo el control de la Unión Soviética; mientras que el territorio occidental, República Federal de Alemania RFA, estaba dominada por Estados Unidos, el Reino Unido y Francia. La histórica capital de Alemania pasó a ser la capital de la RDA. A su vez la urbe de Berlín fue dividida en cuatro sectores fractales con la influencia de cada una de las potencias aliadas.

La RFA y la RDA representaban dos filosofías irreconciliables. Dos sistemas políticos, económicos e ideológicos diferentes. Por un lado, estaba el modelo capitalista y democrático; por el otro, el sistema comunista de la Unión Soviética con el sistema de economía planificada y partido único.

Una rivalidad entre ideologías irreconciliables que culminó en una separación física y política. Debido al rechazo de los desarrollos políticos en la RDA, la situación económica, la vigilancia y el acoso a la población, el bloqueo de Berlín, la restricción de la libertad de movimiento, la esperanza de mejores oportunidades de vida en Occidente entre otros; cerca de 3,5 millones de alemanes orientales huyeron a la RFA hasta 1961. Al borde del colapso, las autoridades comunistas decidieron construir una barrera de contención. El 13 de agosto de 1961, la RDA dividió Berlín en dos mitades con el muro protector antifascista para impedir la masiva fuga permanente de cerebros de Berlín Oriental y la RDA. El muro de Berlín - símbolo del Telón de Acero que dividió a Europa Occidental y al Bloque Oriental durante la Guerra Fría - fragmentó la ciudad física e ideológicamente en dos partes desde 1961 hasta 1989 durante 28 años.

Surgieron dos realidades diferentes, dos conceptos, dos identidades, dos culturas, dos modos de vida con una historia y un lenguaje común. La división llevó a duplicar diferentes estructuras, formas de gobierno, sistemas económicos, sistemas educativos, bienes de consumo, infraestructuras, arquitecturas, desarrollos urbanos

14 Nota: Esta es la frase que dijo el jefe de Estado y líder del partido de la RDA, Walter Ulbricht, en una conferencia de prensa celebrada el 15 de junio de 1961 en respuesta a una pregunta de un corresponsal del "Frankfurter Rundschau". Dos meses después se construyó el Muro de Berlín. Traducción de la autora: "Niemand hat die Absicht eine Mauer zu errichten" 


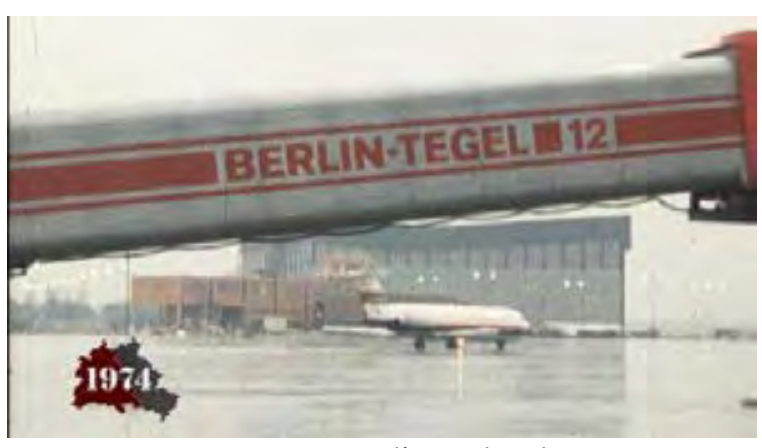

Aeropuerto Berlín Occidental

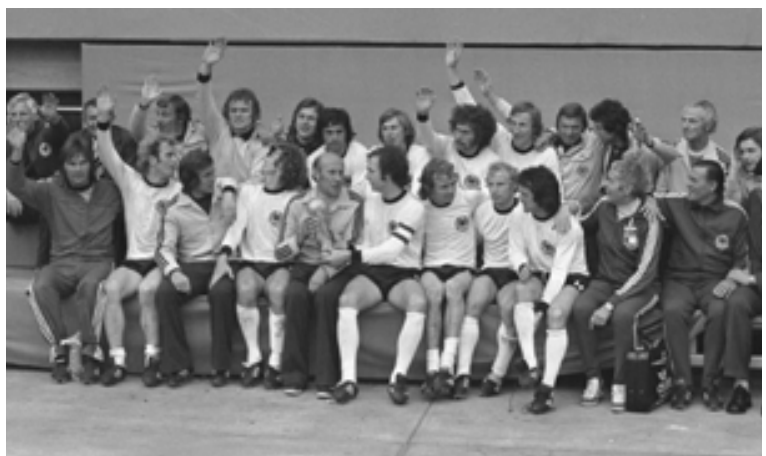

Selección de fútbol BRD

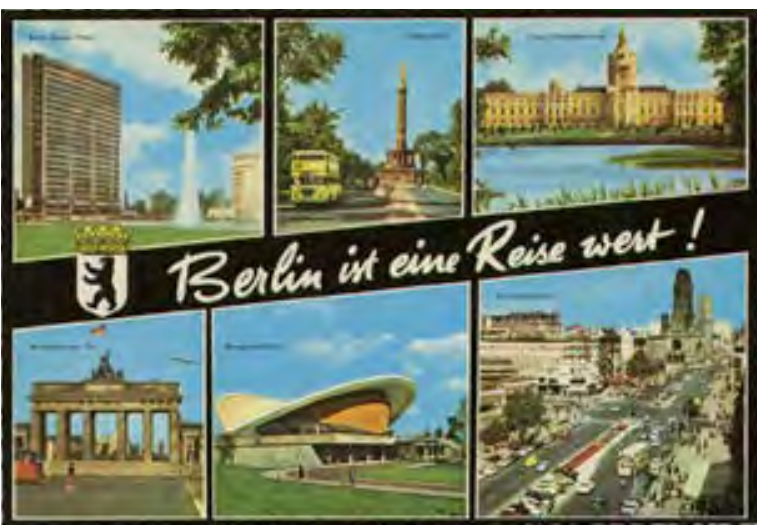

Carta postal BRD

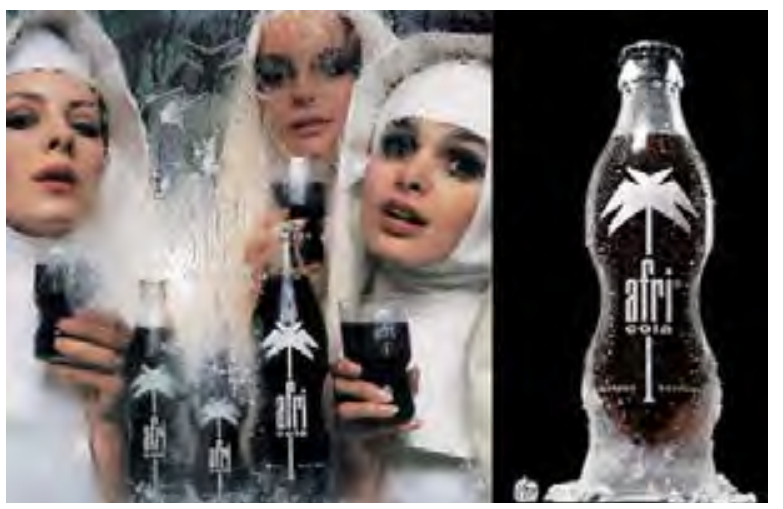

Bebida refrescante BRD

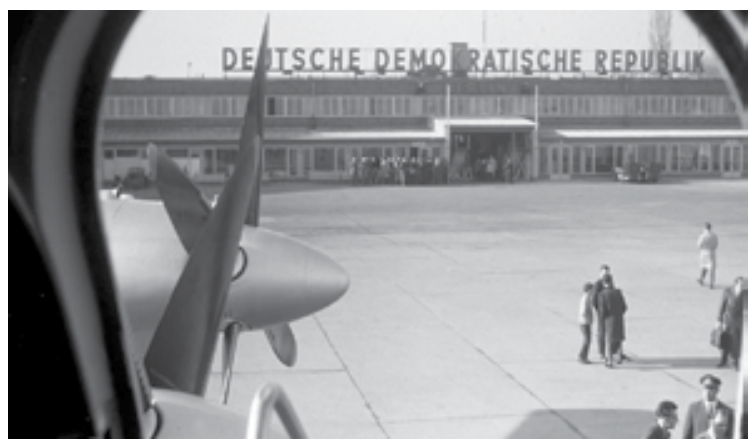

Aeropuerto Berlin Oriental

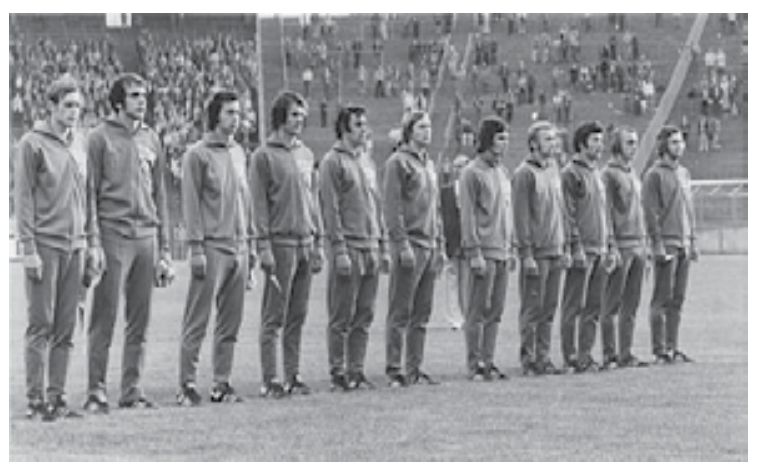

Selección de fútbol GDR
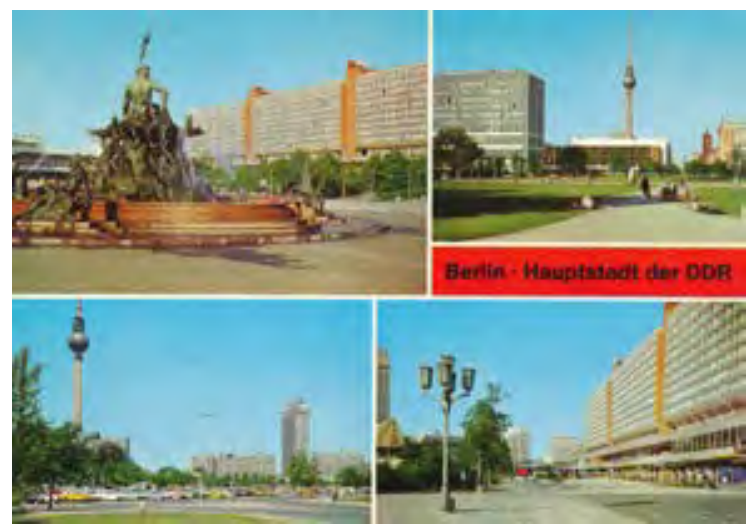

Carta postal GDR

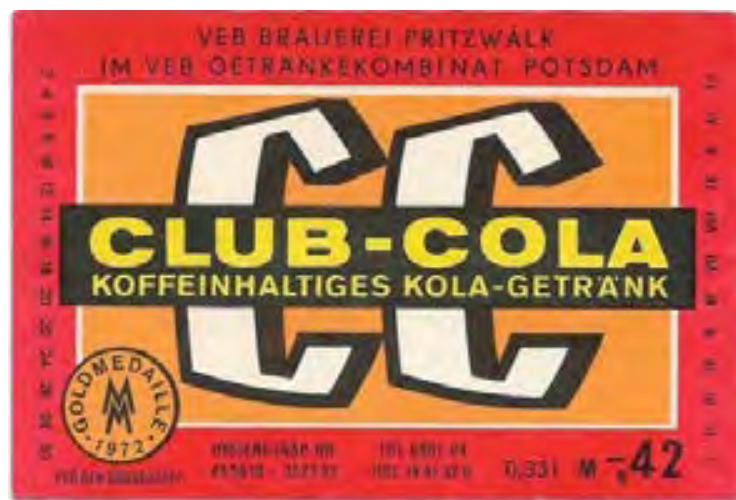

Bebida refrescante GDR

Figura $13-20$.

Comparación en imágenes / BRD y GDR 
entre otros ${ }^{15}$. La partición de Berlín en dos sectores, occidental y oriental, reflejó particularmente la división de la sociedad alemana. Berlín no era una ciudad, era una zona que se caracterizará por su bipolaridad. Anteriormente complementarias, cada fragmento tuvo necesidades propias construyéndose instituciones, edificios gubernamentales, edificios residenciales y culturales, instituciones educativas, edificios deportivos, centrales eléctricos, aeropuertos, parques. Una duplicación del patrimonio cultural. Una especie de necesidades paralelas pero paralelas con necesidades diferentes.

La influencia de la política de la Perestroika (reestructuración) y el Glasnost (transparencia) del entonces jefe de Estado soviético Mijaíl Gorbachov, la ineficacia del sistema económico de la RDA, las revoluciones en los países vecinos del Bloque del Este y los movimientos de oposición en el seno de la RDA desatarían reacciones en cadena que finalmente condujeron a la caída de la frontera interior alemana el 9 de noviembre de 1989. La reunificación de Alemania fue declarada solemnemente el 3 de octubre de 1990.

En este contexto histórico, tuvo su origen la primera Exposición Universal en suelo alemán. Ya el 14 de diciembre de $1988^{16}$, el Gobierno Federal alemán solicitó oficialmente la organización de una Exposición Universal Mundial para el año 2000. Una paradoja de un país aun dividido en dos bloques enfrentados, Occidental y Oriental, por una "frontera interna". Aunque la ciudad anfitriona deseada era Berlín ${ }^{17}$ occidental, en este momento no era viable por la delicada situación política de esta isla rodeada por territorio hostil. En su lugar se eligió Hannover, capital del Estado Federal de la Baja Sajonia, que contaba con un gran recinto ferial preexistente de unas 100 hectáreas con la posibilidad de ampliarse con 60 hectáreas más con unos terrenos no urbanizados. En la reunión plenaria del Bureau International des Expositions celebrada en París el 14 de junio de $1990^{18}$, se proclamó a la República Federal de Alemania, país organizador ${ }^{19}$ de la Exposición Universal 2000. La candidatura de Hannover ganó la ronda decisiva frente a la ciudad canadiense de Toronto. Irónicamente fue proclamada por un sólo voto de diferencia; siendo decisivo el voto positivo de la RDA que en ese momento todavía votaba como región independiente ${ }^{20}$.

15 Nota: Mientras que la RDA tomó a su vecino como punto de referencia para los bienes de consumo, se observó el efecto contrario en el ámbito del deporte.

16 Die Weltausstellung 2000 in Hannover. Chronologie. En: https://www.expo2000.de/index.php/expo2000/ehemaliger-webauftritt-expo2000.html

17 Nota: Berlín fue declarada nuevamente capital de Alemania tras la reunificación en 1990.

18 STECKEWEH, Carl. Expo Architektur Dokumente. Beiträge zur Weltausstellung Expo 2000 in Hannover. Hatje Cantz Verlag. Ostfildern-Ruit. 2000. ISBN: 3775708596. Pág. 32.FERNÁNDEZ-GALIANO, Luis. Hannover 2000. Arquitectura Viva. № 72. 2000. Pág. 28.

19 La Expo 2000 fue organizada por el Estado Federado de Baja Sajonia en colaboración con el Gobierno Federal

20 Con la retirada de la candidatura de Venecia quedaron Hannover y Toronto para la votación final. Así el resultado final fue 21 votos a favor de la ciudad alemana por 20 votos para la ciudad canadiense. 


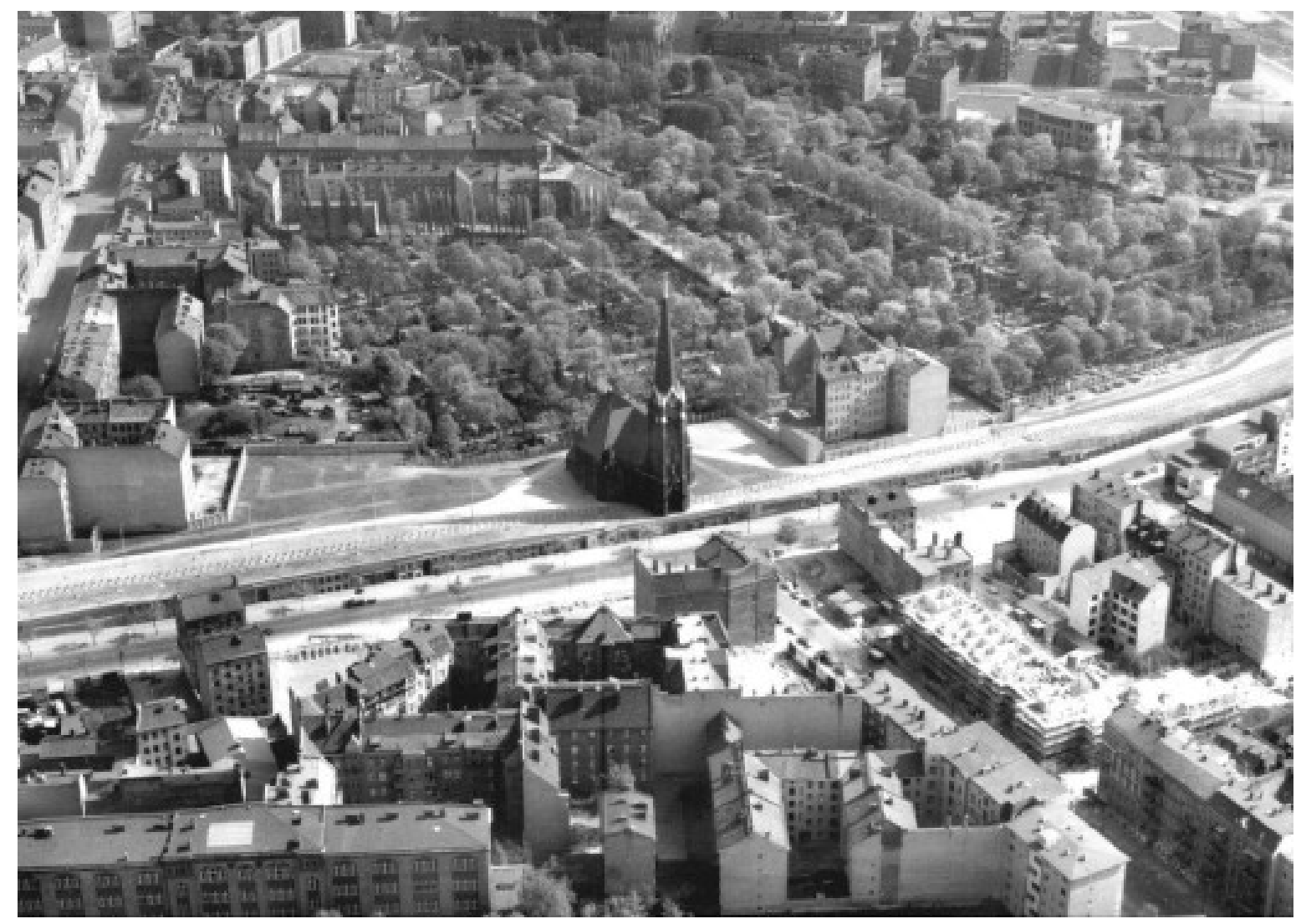

Figura 21.

Iglesia Evangélica de la Reconciliación / Berlín

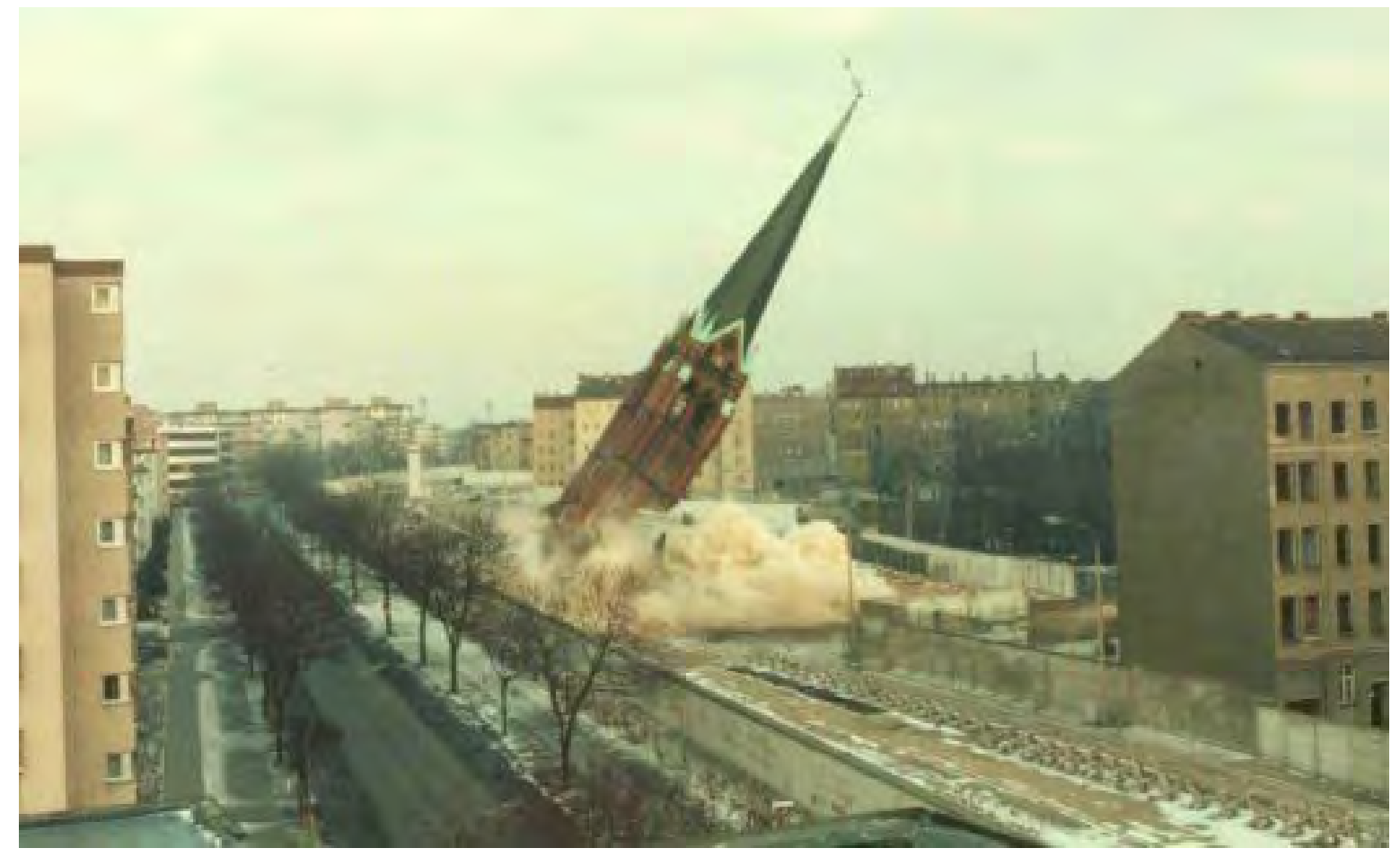

Figura 22.

Demolición de la torre / Iglesia Evangélica de la Reconciliación / Berlín / 1985 


\section{[Anomalía]}

Uno de los símbolos más relevantes de la división de Alemania fue la Iglesia Evangélica de la Reconciliación ${ }^{21}$ situada en la calle Bernauer Straße en el distrito berlinés de Mitte. Un edificio de estilo neogótico, inaugurado en 1894, construido a base de fábrica de ladrillo rojo según el proyecto del arquitecto Gotthilf Ludwig Möckel.

Al finalizar la II Guerra Mundial, la iglesia parcialmente dañada por las bombas de las fuerzas aliadas fue restaurada; restableciendo sus funciones desde 1950. Sin embargo, la inminente construcción del Muro de Berlín en 1961 interrumpió súbitamente su uso, dado que se ubicaba en la franja de la muerte, zona fronteriza dentro del sector soviético. Un espacio intermedio entre-muros de la ciudad dividida. La tierra de nadie donde Rem Koolhaas proyectó Exodus or the voluntary Prisoners of Architecture en 1971. La intersección entre dos sistemas políticos opuestos se convirtió en un lugar inaccesible tanto para los feligreses berlineses occidentales como orientales. El templo finalmente cayó en desuso, deteriorándose progresivamente. Inicialmente sólo la torre de $75 \mathrm{~m}$ de altura fue re-programada como puesto de vigilancia por los guardias fronterizos de la RDA. En 1985, "de acuerdo con el plan de acción para aumentar la seguridad y el orden y la limpieza en la frontera estatal con BerlínOeste $^{\prime 22}$, la Iglesia de la Reconciliación fue demolida por orden del gobierno de la RDA. El derrumbamiento de la torre se convirtió en estandarte de la segregación de Berlín, así como de sus habitantes.

La reunificación alemana puso fin a muchas anomalías geopolíticas de décadas atrás. En el décimo primer aniversario de la Caída del Muro de Berlín; el 9 de noviembre 2000, se inauguró un nuevo lugar para la asamblea cristiana ocupando el área de la Iglesia de la Reconciliación recuperada por la comunidad eclesiástica. La nueva Capilla de la Reconciliación ${ }^{23}$ conformada por una gran envolvente curvada en adobe con un entramado de lamas de madera de abeto, abraza a las dos alemanias en una única Alemania.

21 Nota: Versöhnungskirche

22 HEINKE, Lothar. 9. November 1989: Die Versöhnungskirche ist wiederauferstanden. En: Der Tagespiegel. 08.11.2000. https://www.tagesspiegel.de/berlin/9-november-1989-dieversoehnungskirche-ist-wiederauferstanden/177556.html. Traducción de la autora: "gemäss dem Massnahmeplan für die Erhöhung von Sicherheit und Ordnung und Sauberkeit an der Staatsgrenze zu Berlin-West"

23 Nota: Obra de los arquitectos Rudolf Reitermann y Peter Sassenroth. 


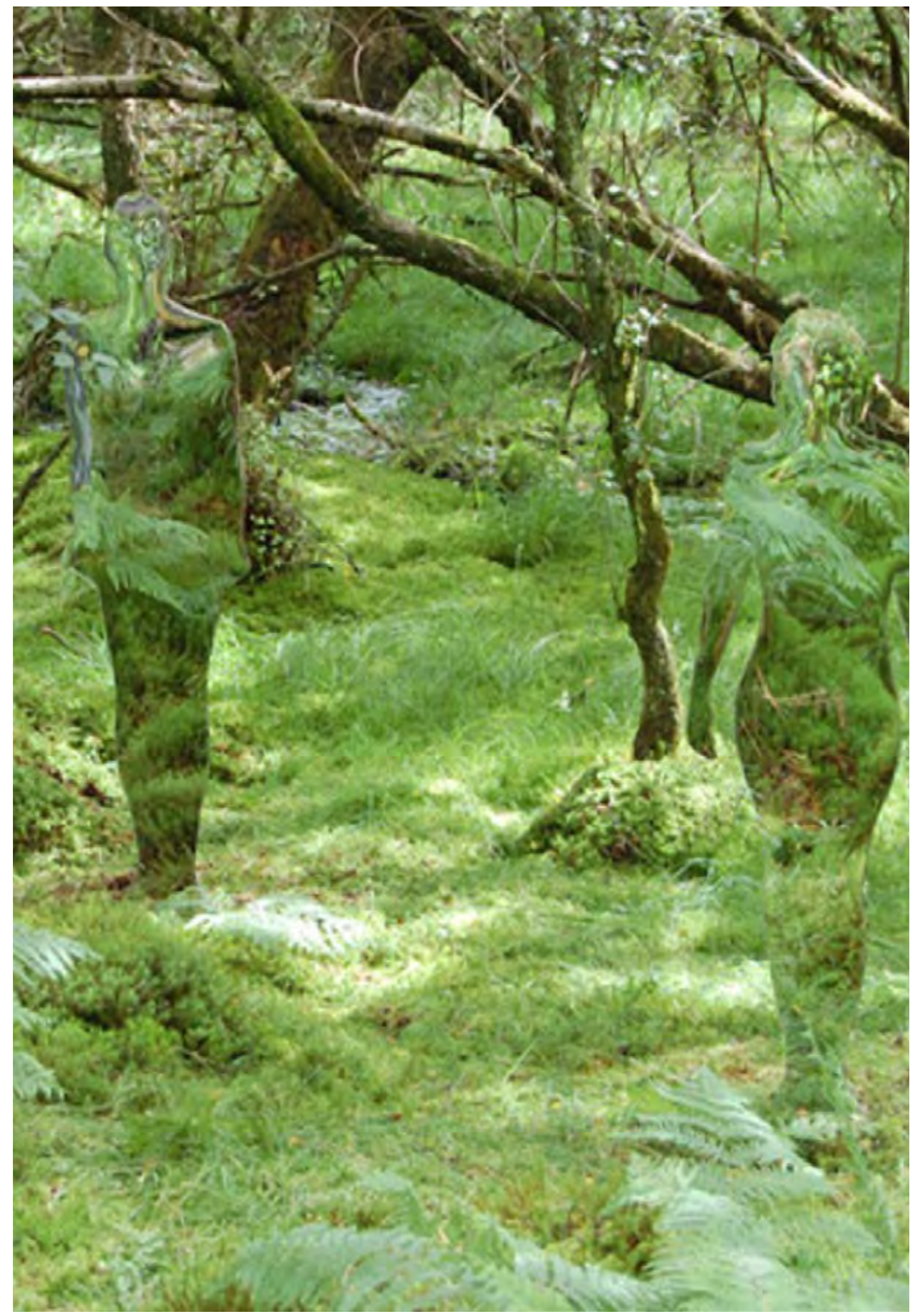




\section{[Río, Hannover $\left.{ }^{24}\right]$}

Una década después de la Reunificación se celebró la Expo del 2000 en Hannover, desde el 1 de junio hasta el 31 de octubre del 2000. El centro de interés de la muestra, además del desarrollo técnico, se centró especialmente en la conciencia global sobre la limitación de los recursos del planeta. La denominada Agenda 21, un acuerdo para promover el desarrollo sostenible del siglo XXI, fue firmado por 178 países $^{25}$ de la ONU en la Conferencia sobre Medio Ambiente y Desarrollo, celebrada en Río de Janeiro en 1992. La Agenda 21 fue un plan de acción estratégica cuyas pautas debían acometerse en diferentes niveles: mundial, nacional y local; en aras a conseguir un desarrollo más sostenible y respetuoso con el medio ambiente. Este se aplicó tanto a los países industrializados; como a los países en vías de desarrollo. Incluía objetivos, así como definiciones, como la lucha contra la pobreza, las políticas demográficas, el comercio y el medio ambiente, la basura, los residuos químicos, la política climática y energética, las necesidades agrícolas, la reducción del efecto invernadero, la cooperación financiera y tecnológica entre los países industrializados y los países en vías de desarrollo, la conservación y utilización racional de los bosques, la protección del ecosistema o la protección y administración de los recursos de agua; entre otros ${ }^{26}$.

Aunque la solicitud de Hannover para acoger la Expo 2000 ya había sido presentada al B.I.E. ${ }^{27}$ en 1988; los principios de la Agenda 21 fueron incorporados posteriormente. Consecuentemente, se incluyeron las declaraciones programáticas tanto en la conceptualización como en la ejecución de los proyectos de la muestra con el fin de promover un desarrollo sostenible.

"El lema hace referencia tanto a las oportunidades de desarrollo y progreso asociadas a los tres términos, así como al potencial de conflicto que contienen. El lema refleja, por un lado, la tensión entre los numerosos avances técnicos altamente beneficiosos en nuestro mundo, y, por otro lado, las intervenciones asociadas, en parte precarias, en el equilibrio

24 Nota: El titulo hace referencia a la pelicula "Paris, Texas" de 1984, dirigida por el alemán Wim Wenders.

25 FERNÁNDEZ, Andrea. Después de 20 años de la Cumbre de la Tierra, los objetivos no se han cumplido. En: ABC. Madrid. 18. junio 2012. https://www.abc.es/sociedad/abci-cumbre-tierralogros-201206180000_noticia.html

26 Nota: Agenda 21. Rio de Janeiro. 1992. En: file:///Users/move/Downloads/DOCUMENTOS\%20 CUMBRE\%20DE\%20LA\%20TIERRA\%201992.pdf

27 Nota: Bureau International d’Expositions 


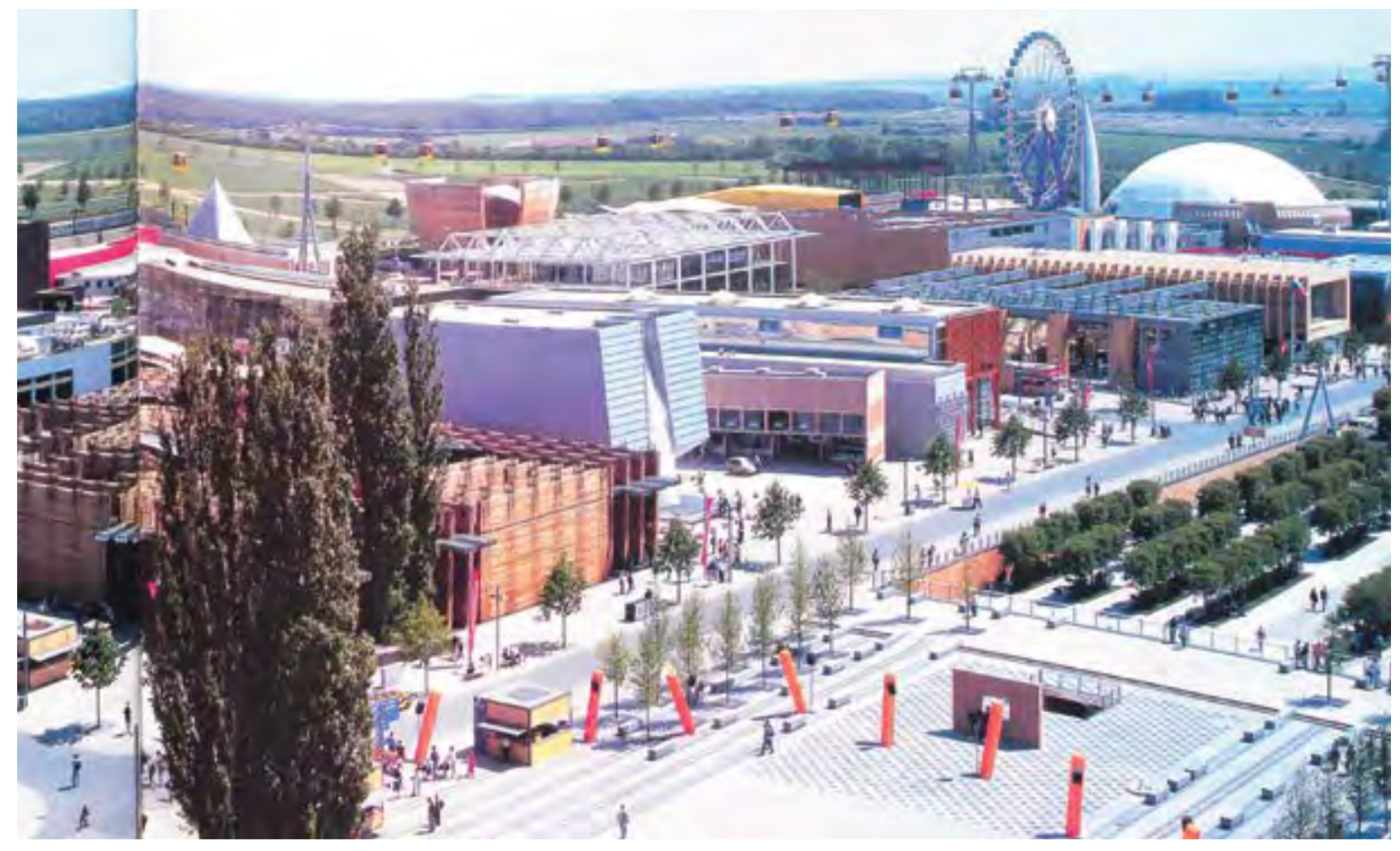

Figura 24.

Expo 2000

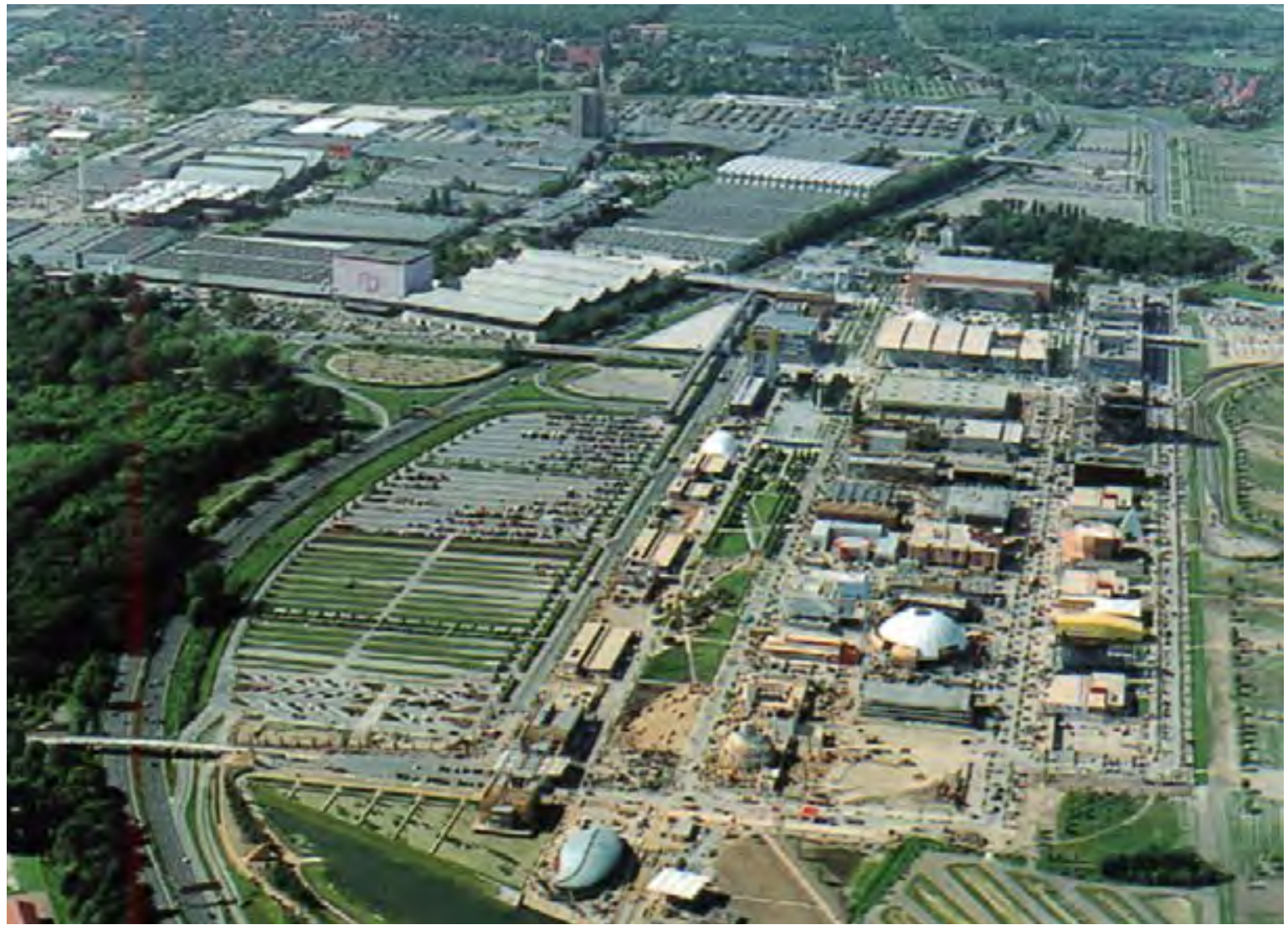

Figura 25.

Vista aérea del área de la Expo 2000 
natural de la Tierra. Un desarrollo aislado de las tres áreas

hombre - naturaleza - tecnología parece hoy tan imposible como

cuestionable, la necesidad de unificación y equilibrio armonioso

se hace cada vez más visible."28 Konstanze Kalmus

Bajo el lema Hombre-Naturaleza-Técnica; origen de un nuevo mundo, la Expo 2000 pretendía fomentar una conciencia nueva a través del uso responsable de los recursos naturales, el ahorro de la energía, una construcción sostenible, evitar la obsolescencia de la Expo tras la muestra. Todo ello para crear un equilibrio armonioso entre estas tres nociones; trilogía de una praxis sostenible.

28 KALMUS, Konstanze. Das Konzept der EXPO 2000 in Hannover. En: Ferrum: Nachrichten aus der Eisenbibliothek. Stiftung der Georg Fischer AG. Band 66. 1994.Pág. 24. Traducción de la autora: "Der Titel weist sowohl auf die mit den drei Begriffen verbundenen Entwicklungs- und Fortschritts-Chancen hin als auch auf das darin enthaltene Konfliktpotencial. In dem Titel spiegelt sich das Spannungsfeld wider zwischen einerseits den vielen höchst segensreichen technischen Entwicklungen in unserer Welt und andererseits den damit verbundenen zum Teil bedenklichen Eingriffen in das natürliche Gleichgewicht der Erde. Eine von einander isolierte Entwicklung der drei Bereiche Mensch - NaturTechnik erscheint heute ebenso unmöglich wie fragwürdig, der Bedarf nach Zusammenführung und harmonischem Ausgleich wird zunehmend sichtbar." Nota: Respuestas del Estado de Baja Sajonia y de la ciudad de Hannover a las preguntas del B.I.E. de París de julio de 1989 sobre la solicitud para la Exposición Universal de Hannover 2000. Pregunta 1 sobre el tema y la duración de la exposición. 


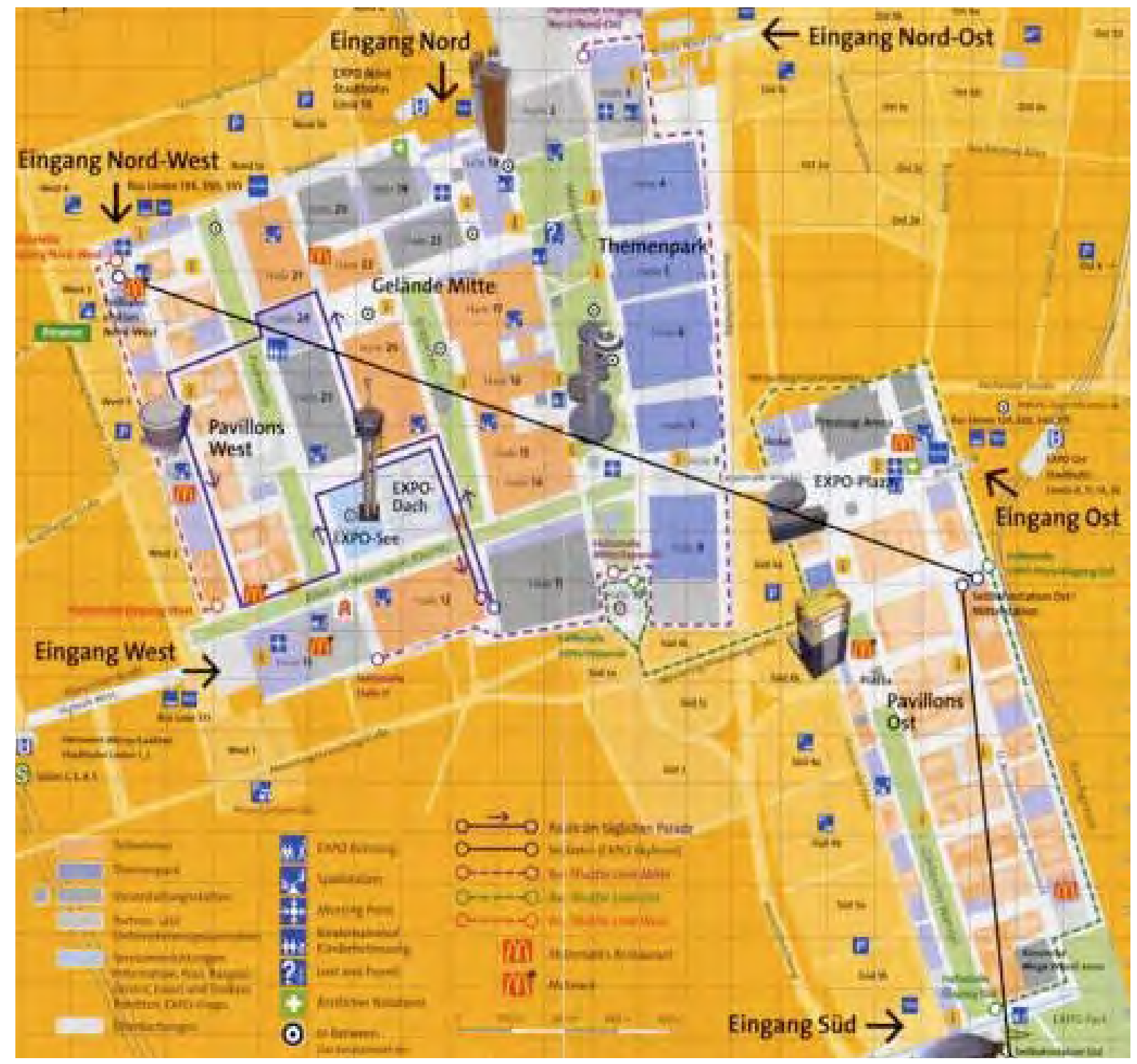

Figura 26.

Plano de situación / EXPO 2000

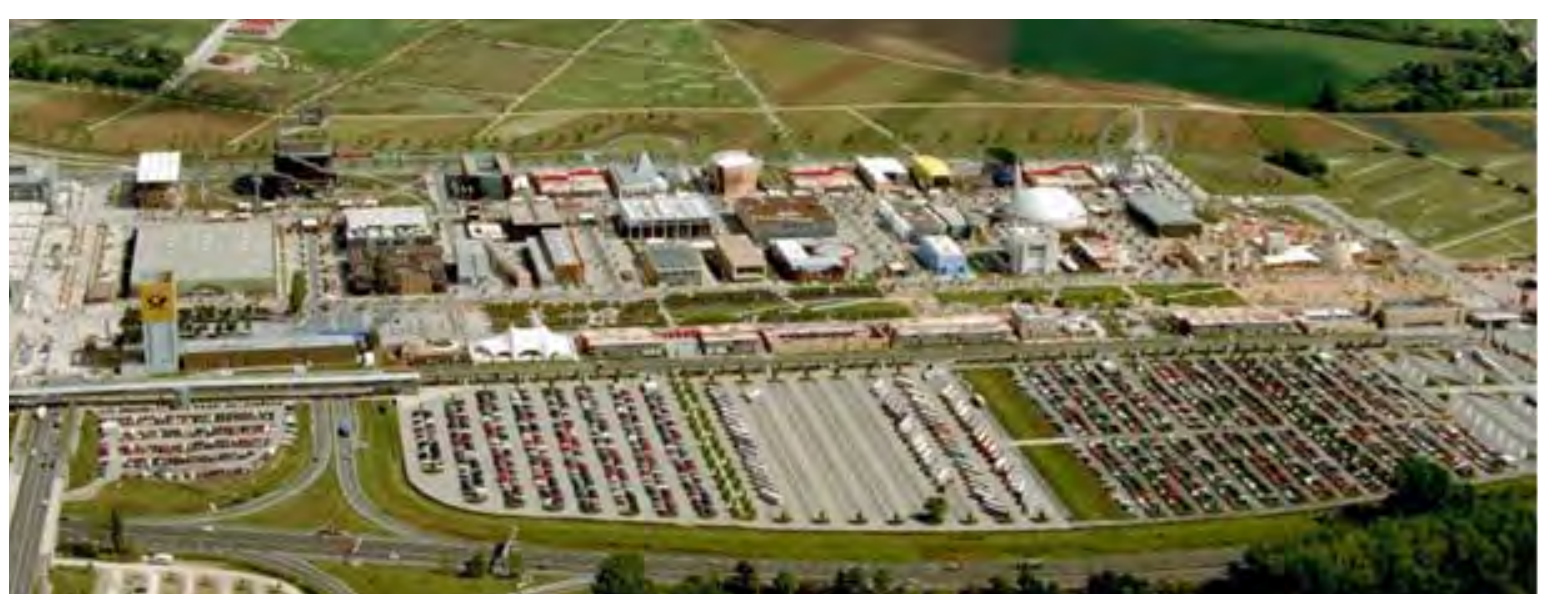

Figura 27.

Vista aérea del área de la Expo 2000 


\section{[Kronsberg]}

"(...) los planteamientos conceptuales de la Expo 2000 ofrecen la posibilidad de salvar a las exposiciones mundiales del destino de los dinosaurios, de perecer como animales primitivos sobredimensionados en un mundo hostil; ofrecen la oportunidad de darles una nueva estructura, con la cual las exposiciones universales puedan desempeñar un nuevo y significativo papel en la red de relaciones internacionales. ${ }^{\prime 29}$ Ted Allan

Siguiendo el modelo de desarrollo urbano sostenible propuesto por la Agenda 21; se planeó reducir al mínimo el impacto ambiental ${ }^{30}$, destinando a la muestra una superficie total de 160 hectáreas. Se amplió un recinto ferial existente de unas 90 ha del municipio de Laatzen, al sur-este de la ciudad de Hannover; con la anexión de dos terrenos adyacentes no urbanizados con una superficie conjunta de 70 ha aproximadamente, uno al oeste y otro al sureste. Los conceptos básicos para el diseño urbano de la Exposición Universal tuvieron su origen en la propuesta de los arquitectos suizos Michele Arnaboldi y Raffaele Cavadini de Locarno en colaboración con el paisajista Guido Hager de Zürich. Su proyecto fue el ganador de un concurso internacional convocado en 1992. Sin embargo, finalmente el plan director fue una responsabilidad colectiva entre los técnico ganadores en colaboración con un equipo alemán compuesto por el estudio de arquitectura Albert Speer \& Partner, el arquitecto Thomas Herzog y el paisajista Dieter Kienast ${ }^{31}$. El proyecto de urbanización ejecutado transformó sustancialmente la propuesta ganadora del concurso en gran medida por su escasa flexibilidad. No obstante hubo otras modificaciones no menos significativas como la movilidad del tráfico rodado, la planificación de los espacios abiertos y zonas verdes, las entradas de los visitantes ${ }^{32}$, el acceso principal, la ordenación y disposición de los pabellones. Adicionalmente como parte del concepto general, se incluyó un planeamiento adicional al este con 6.000 viviendas para acomodar a unos 15.000 residentes $^{33}$ en el nuevo desarrollo llamado Kronsberg ${ }^{34}$ bajo los mismos criterios de sostenibilidad de la Expo.

29 KALMUS, Konstanze. Das Konzept der EXPO 2000 in Hannover. En: Ferrum: Nachrichten aus der Eisenbibliothek. Stiftung der Georg Fischer AG. Band 66. 1994.Pág. 24. Traducción de la autora: "die konzeptionellen Ansätze für die Expo 2000 bieten die Chance, den Weltausstellungen das Schicksal der Dinosaurier zu ersparen, als überdimenisionierte Urtiere in einer feindlichen Welt unterzugehen; sie bieten die Chance, ihnen eine neue Struktur zu geben, mit der Weltausstellungen eine neue, bedeutungsvolle Rolle im Geflecht der internationalen Beziehungen spielen können."

30 Nota: Reducir al mínimo la urbanización de terreno nuevo.

31 CUADRA, Manuel. Hannover 2000. Arquitectura Viva. № 72. 2000. Pág. 19.

32 Nota: Todo el areal era accesible desde seis entradas principales.

33 Nota: Al comenzar la Expo, de las 6.000 planeadas, se habían completado 3.000 viviendas acompañado de zonas ajardinadas y transporte publico. En: http://www.upv.es/contenidos/CAMUNISO/info/U0511241.pdf

34 Nota: Aunque la idea de una planificación urbanística en esta zona se remonta a la época de los años sesenta, fue la Exposición Universal del año 2000 la que impulsó su desarrollo. 


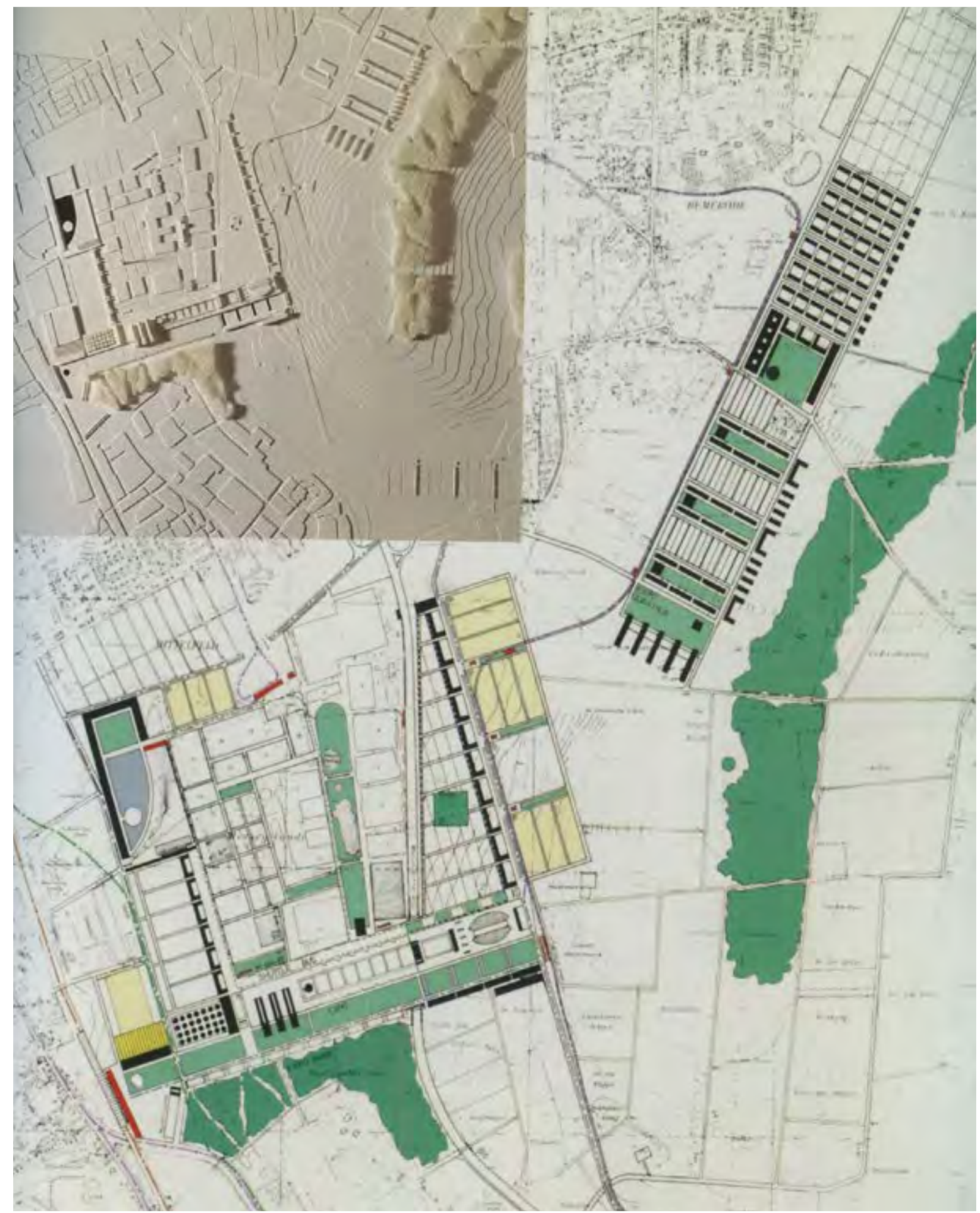

Figura 28

Primer premio del concurso internacional de ideas para el diseño urbano de la Exposición Universal 2000 / Michele Arnaboldi, Raffaele Cavadini, Guido Hager / 1992 


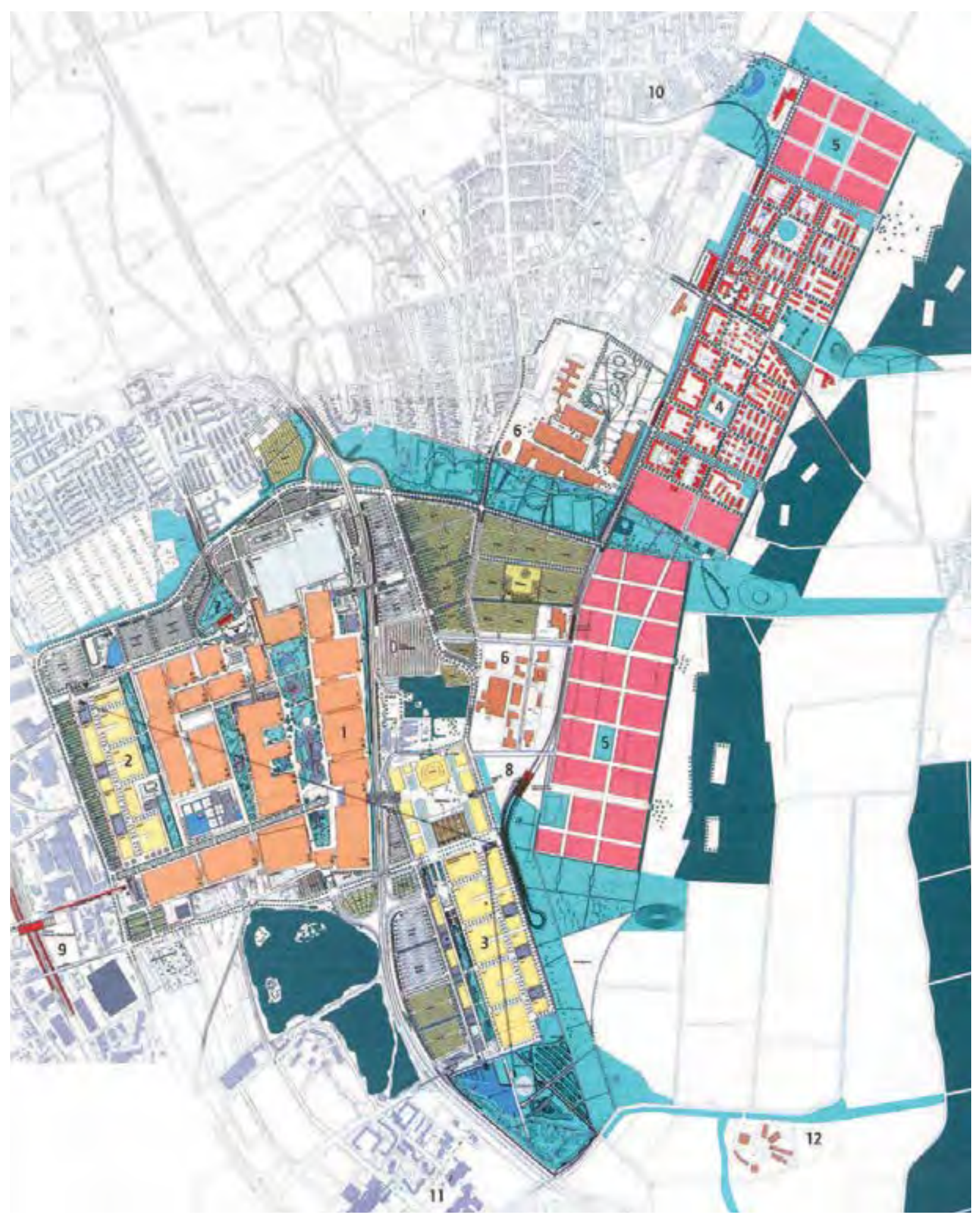

Figura 29.

Plan de uso para toda la zona del sur de Hannover / Albert Speer \& Partner 1. Recinto ferial existente

2. Zona oeste

3. Zona sureste

4. Nuevo barrio Kronsberg

5. Ampliación Kronsberg

6. Oficinas / Comercial

7. +8 . Tren ligero

9. Estación de tren Laatzen 


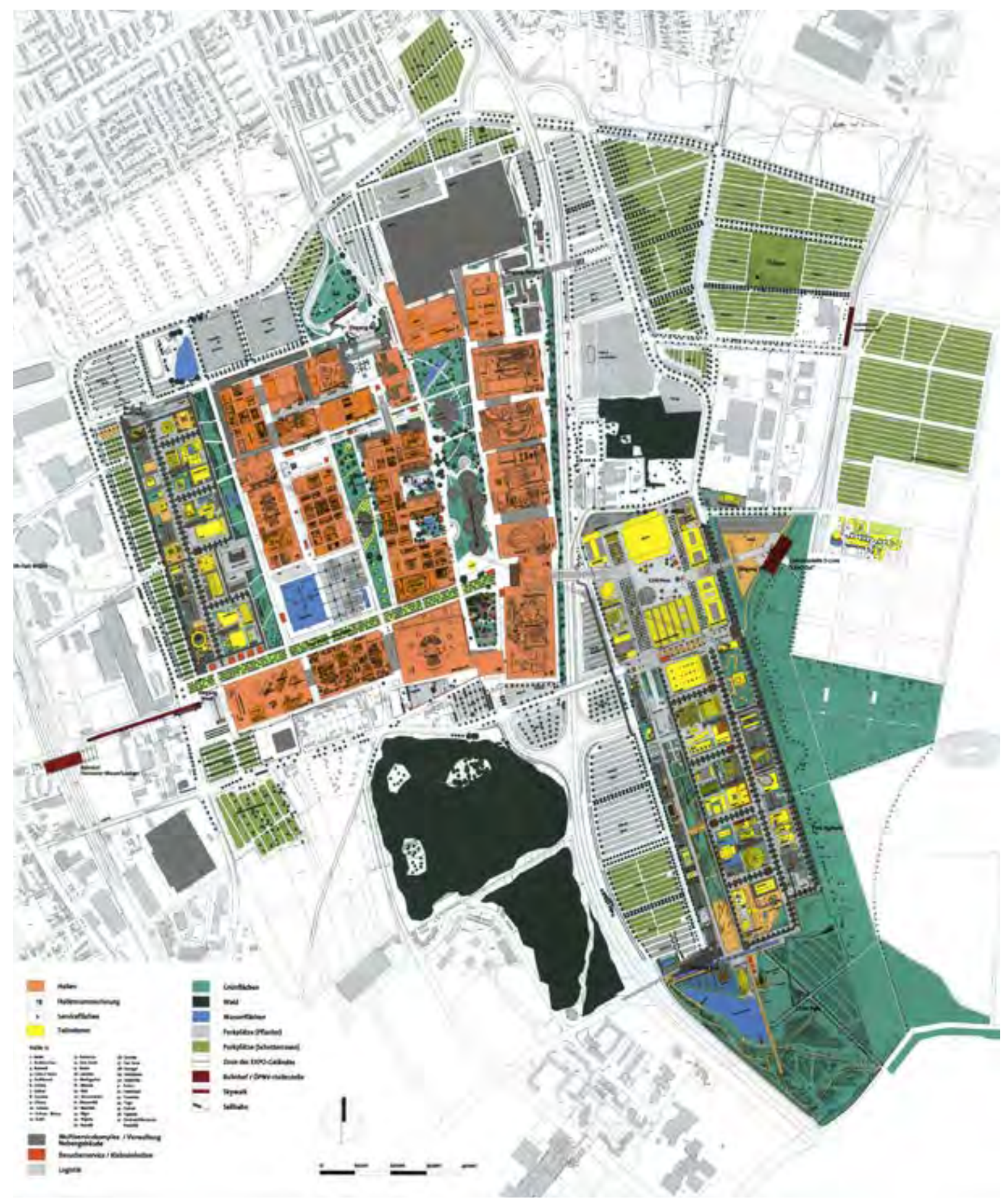




\begin{abstract}
"Una exposición mundial es como un meteorito que golpea un lugar y causa consecuencias violentas fuera de la ciudad"35 Hans-Norbert Mayer, Walter Siebel
\end{abstract}

El proyecto finalmente aprobado y ejecutado para la Expo 2000 se materializó a partir del rigor y claridad como reglas del juego a través de una geometría sencilla. Un entre-tejido con una amplia gama de propuestas y diferentes tejidos: parques, plazas, calles urbanas, espacio verde, edificación. Una mezcla de usos y escenarios a modo de contenedor de actividades múltiples. Un sistema organizativo con el fin de garantizar una infraestructura uniforme ${ }^{36}$.

La parcela existente contenía un recinto ferial compuesto por un conglomerado desordenado de naves de grandes dimensiones. Uno de los mayores retos de la actuación fue resolver la continuidad con la ampliación de mayor superficie hacia el sureste. Esta parcela denominada "Ost"; se encontraba segregada de las otras dos áreas por la autopista Hannover-Hildesheim, de cuatro carriles por sentido. Dado que uno de los objetivos principales era integrar y vincular este ámbito y las nuevas áreas residenciales con el recinto ferial preexistente en un único conjunto urbano; se construyeron dos conexiones entre ambas márgenes de la carretera: un puente peatonal de 30 metros de ancho y un teleférico interno.

Se ofreció a los países ${ }^{37}$ y expositores de la Expo 2000 la posibilidad de elegir libremente si querían ubicarse en las naves preexistentes a modo de escenografías interiores ahorrando costos y recursos; o por el contrario levantar pabellones propios. Más de un centenar de participantes, incluidos la mayoría de los países africanos, optaron por stands acondicionados en el interior de las naves feriales; sin embargo, el resto que sumaban casi un tercio ${ }^{38}$ decidieron representarse mediante la construcción de una arquitectura propia. Estos, los nuevos pabellones, se realizaron en las dos áreas anexas al recinto ferial; 18 en el terreno al oeste de 18 hectáreas y 30 en la extensión más grande al sureste siendo la mayoría de ellos países europeos ${ }^{39}$.

35 FÄRBER, Alexa. Weltausstellung als Wissensmodus. Ethnographie einer Repräsentationsarbeit. Lit Verlag. Berlin. 2006. ISBN: 3-8258-8139-3. Pág. 43. Traducción de la autora: "Eine Weltausstellung ist wie ein Meteor, der an einer Stelle einschlägt und aussenherum in der Stadt heftige Folgewirkungen auslöst."

36 STECKEWEH, Carl. Expo Architektur Dokumente. Beiträge zur Weltausstellung Expo 2000 in Hannover. Hatje Cantz Verlag. Ostfildern-Ruit. 2000. ISBN: 3775708596. Pág. 32.

37 Nota: La nación ausente más importante fue Estados Unidos, cuya no participación fue debida a la falta de financiación.

38 Nota: 48 países en total.

39 AAVV. Bericht über den Verlauf der Weltausstellung EXPO 2000 in Hannover (1. Juni bis 31. Oktober 2000). Deutscher Bundestag - 14. Wahlperiode. Drucksache 14/5883. 02.04.2001. Pág. 5. 

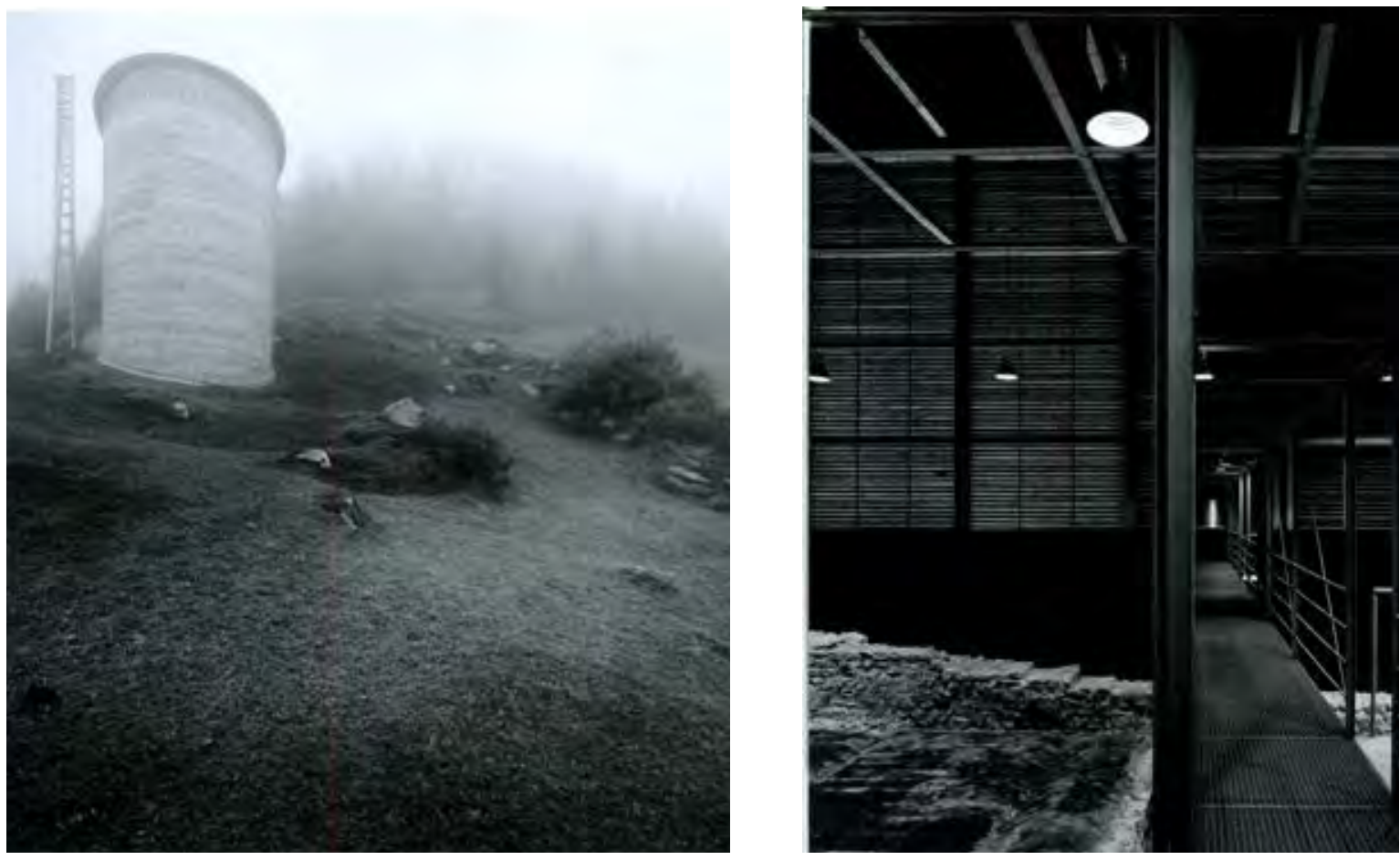

Figura 31 - 32

Capilla San Benedicto / Graubünden / 1985 - 1988 + Restos arqueológicos romanos / Chur / 1985 - 1986

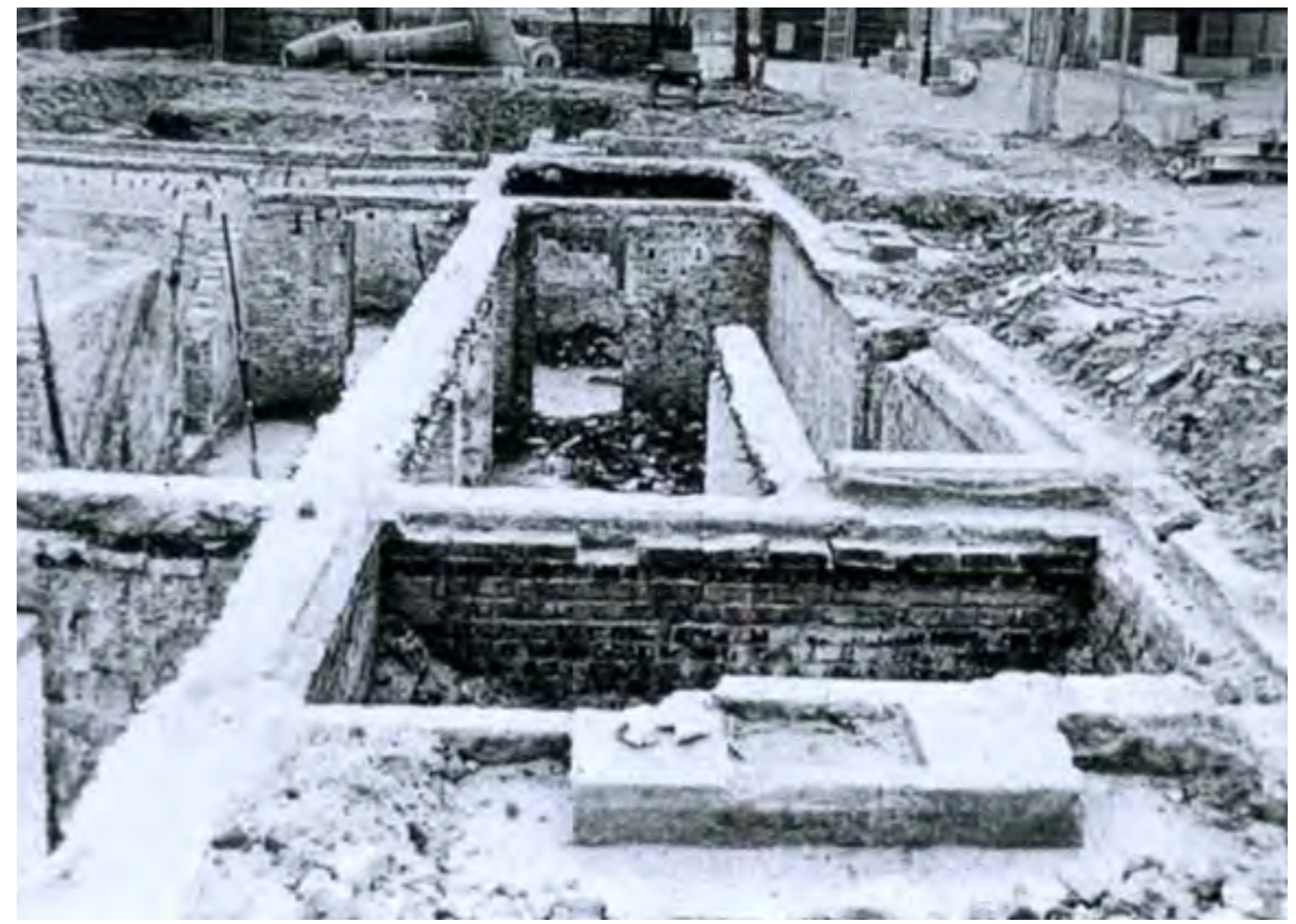

Figura 33.

Topografía del Terror / Berlín / 1993 - 2004 


\section{[Ost B 20]}

"Cuando me concentro en un determinado lugar, para el cual debo hacer un proyecto, sí intento sondearlo, comprender su estructura, su historia y sus características sensoriales, ya desde muy pronto empiezan a confluir en este proceso de visualización precisa imágenes de otros lugares: lugares que conozco y que alguna vez me han impresionado, imágenes de lugares cotidianos, o especiales, cuya forma llevo dentro de mi como un símbolo de determinados estados de ánimo y cualidades, e imágenes de lugares, o situaciones arquitectónicas..."40 Peter Zumthor

El lugar es esencial en la obra de Zumthor. El lugar como cúmulo de sus referencias, sus historias, sus entornos, sus preexistencias, las construcciones adyacentes, los paisajes circundantes, sus topografías, sus peculiaridades, las relaciones entre las personas, su iluminación, los materiales autóctonos, los olores, sus sonidos propios. Zumthor se apropia del lugar. Para él, el lugar se vuelve tangible, palpable, olfativo, comprensible.

El rastreo del lugar es habitual en sus intervenciones. La memoria como la basílica barroca en la ladera de un remoto valle de Graubünden donde construye la capilla San Benedicto en 1985 - 1988. La luz reflectante del Lago de Constanza en Bregenz donde cristaliza el Kunsthaus en 1989 - 1997. Redibuja los trazos de los Restos arqueológicos Romanos en el casco urbano de Chur mediante una sencilla envolvente de lamas de madera estratificada horizontalmente para su protección en 1985-86. "La forma hace referencia al lugar"41. También en el proyecto inacabado de la Topografía del Terror en 1993-04 situado en las excavaciones del antiguo recinto de las SS y la Gestapo en Berlín. Este lugar cargado de historia diseñado como "un lugar de aprendizaje y pensamiento, como un lugar de educación y debate intelectual sobre las condiciones y estructuras del sistema de terror nacionalsocialista ${ }^{142}$. Zumthor propuso una envoltura abstracta, un espacio vacío. Una infraestructura de tres plantas compuesta por dos cáscaras de lamas de hormigón blanco prefabricadas muy esbeltas.

40 ZUMTHOR, Peter. Pensar la arquitectura. Editorial Gustavo Gili. S.L. Barcelona. 2014. ISBN: 978-84252-2730-1. Pág. 41

41 ZUMTHOR, Peter. Atmósferas: entornos arquitectónicos - las cosas a mi alrededor. Gustavo Gilli. Barcelona. 2006. ISBN: 9788425221170 . Pág. 68.

42 Fachkommission des Berliner Abgeordnetenhauses. 1989. Traducción de la autora: "Lern- und Denkort, als Ort der Aufklärung und der geistigen Auseinandersetzung mit den Entstehungsbedingungen und Strukturen des nationalsozialistischen Terrorsystems" 


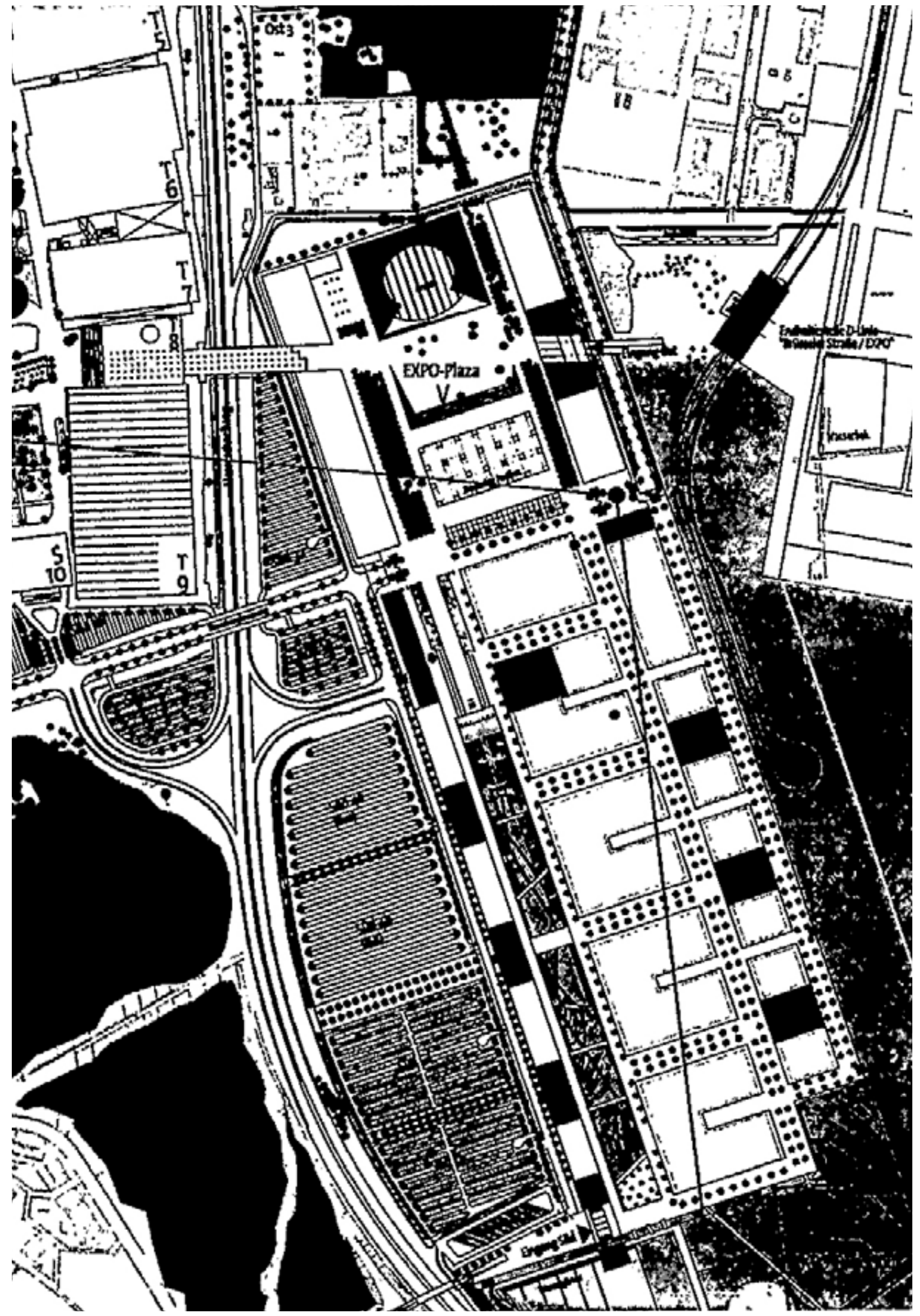


"Lo que yo experimento me marca y me forma de la misma manera que lo que a usted le marcan son sus experiencias, no hay diferencias. Cada edificio tiene su lugar, que en ocasiones es un no-lugar como la Expo 2000 de Hannover, entonces tiene uno que pensar en un no-lugar. He dado mi respuesta, mi interpretación de algo temporal, pero normalmente la arquitectura no es temporal, sino fija. Construyo en este lugar y contemplo el mundo. Esto es importante. Porque cada edificio debería hablar de su lugar y del mundo entero. Y como mundo entiendo lo que yo sé del mundo."43 Peter Zumthor

El lugar para el pabellón helvético de la Expo 2000 fue descrito por Zumthor como un "no-lugar". Este concepto del antropólogo francés Marc Augé ${ }^{44}$; se refería a los ámbitos sin condicionantes, sin memoria, sin identidad. La parcela estaba ubicada en la zona sureste ${ }^{45}$. La Gelände Ost tenía un esquema compositivo de tres bandas paralelas de pabellones orientadas norte-sur con diferentes anchos. La entrada se producía por el norte, cruzando el puente o desembarcando del teleférico interno. Así se llegaba a la Expo-Plaza central, un ágora donde se ubicaron todas las instituciones representativas del anfitrión, Alemania.

Al sur de la Expo-Plaza central se concentraban los diferentes pabellones nacionales en tres secuencias de manzanas: una al oeste que contenía algunos pabellones con grandes áreas verdes, una al este que contenían los pabellones de tamaño medio con algunas áreas verdes, y una franja central con los pabellones de mayor tamaño. Esta secuencia lineal estaba compuesta por cinco manzanas que se fragmentan según el número de naciones; oscilando entre el pabellón único francés hasta los cuatro pabellones. Resultado de dividir la manzana cuadrangular al sur de "Francia", surge la parcela en esquina Ost B 20 . El solar con una superficie de $3.037 \mathrm{~m} 2^{46}$ lindaba al

43 Entrevista a Peter Zumthor de Heide Wessely. En: Detail. Zeitschrift für Architektur und Baudetail. Nr. 1. 2001. Pág. 21. Traducción de la autora: "Was ich erlebe, beeinflusst und prägt mich so, wie das Sie prägt, was Sie erleben, da gibt es keinen Unterschied. Jedes Gebäude hat seinen Ort, manchmal ist das auch ein Unort wie die Expo 2000 in Hannover, dann muss man für einen Unort überlegen. Ich habe meine Antwort gegeben, meine Interpretation auf etwas Temporäres, aber in der Regel ist Architektur nicht temporär, sondern fix. Ich baue an diesem Ort und schaue in die Welt hinaus. Das ist wichtig. Denn jedes Gebäude müsste eigentlich von seinem Ort sprechen, aber auch von der ganzen Welt. Und mit der Welt meine ich das, was ich weiss von der Welt."

44 AUGÉ, Marc. Los no lugares. Espacios del anonimato. Una antropología de la sobremodernidad. Editorial Gedisa S.A.. Barcelona. 2000. ISBN: 84-7432-459-9.

45 Nota: A pesar de que Suiza no es miembro de la Unión Europea, prefería una parcela cerca de todos los pabellones nacionales europeos.

46 AAVV. Klangkörperbuch. Birkhäuser. Basel. 2000. ISBN: 3-7643-6324-X. Pág. 17. Nota: 52,10 m x 58,30 $\mathrm{m}$. Wohingegen in der folgenden Publikation eine Parzellengrösse von $3977 \mathrm{~m} 2$ angegeben wurde. AAVV. Botschaft über die Teilnahme der Schweiz an der Weltausstellung "Expo 2000 Hannover". Bundesblatt. Band 5. Heft 39. Geschäftsnummer 98.040. 22. Junio 1998. Pág. 4671. 


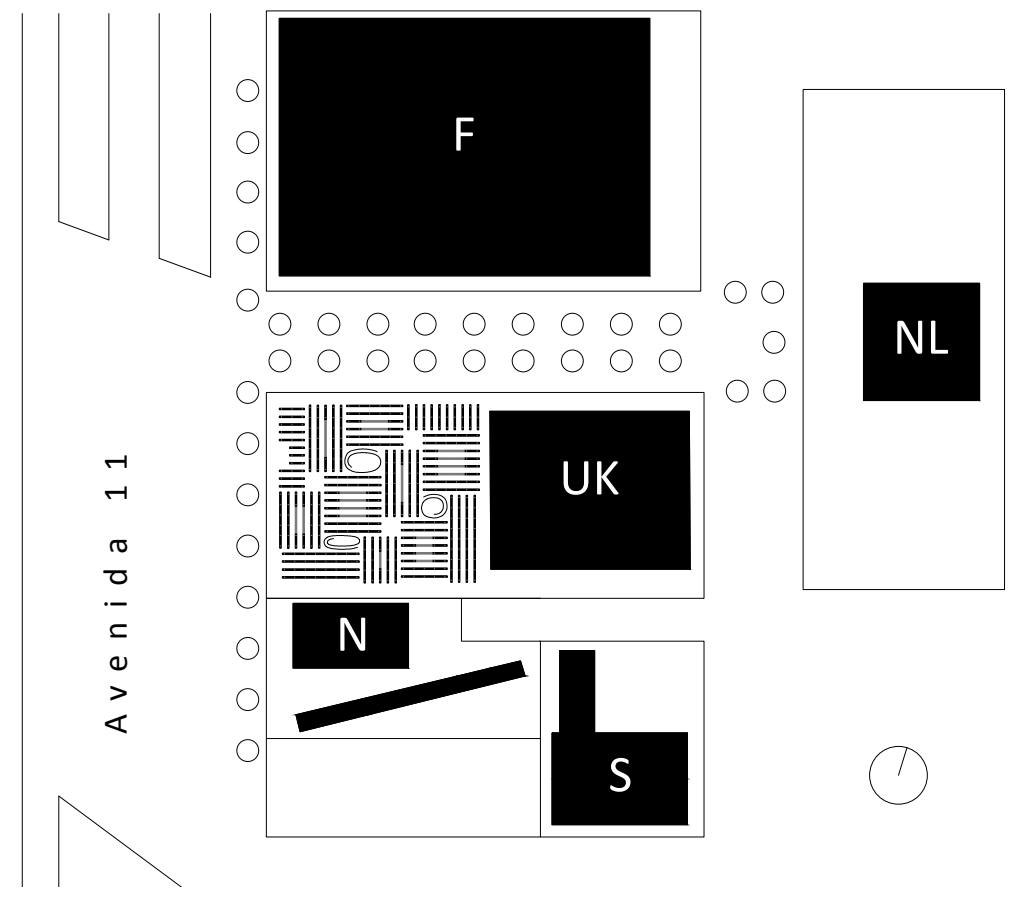

Figura 35 .

Pabellones adyacentes al pabellón helvético Dibujo de la autora

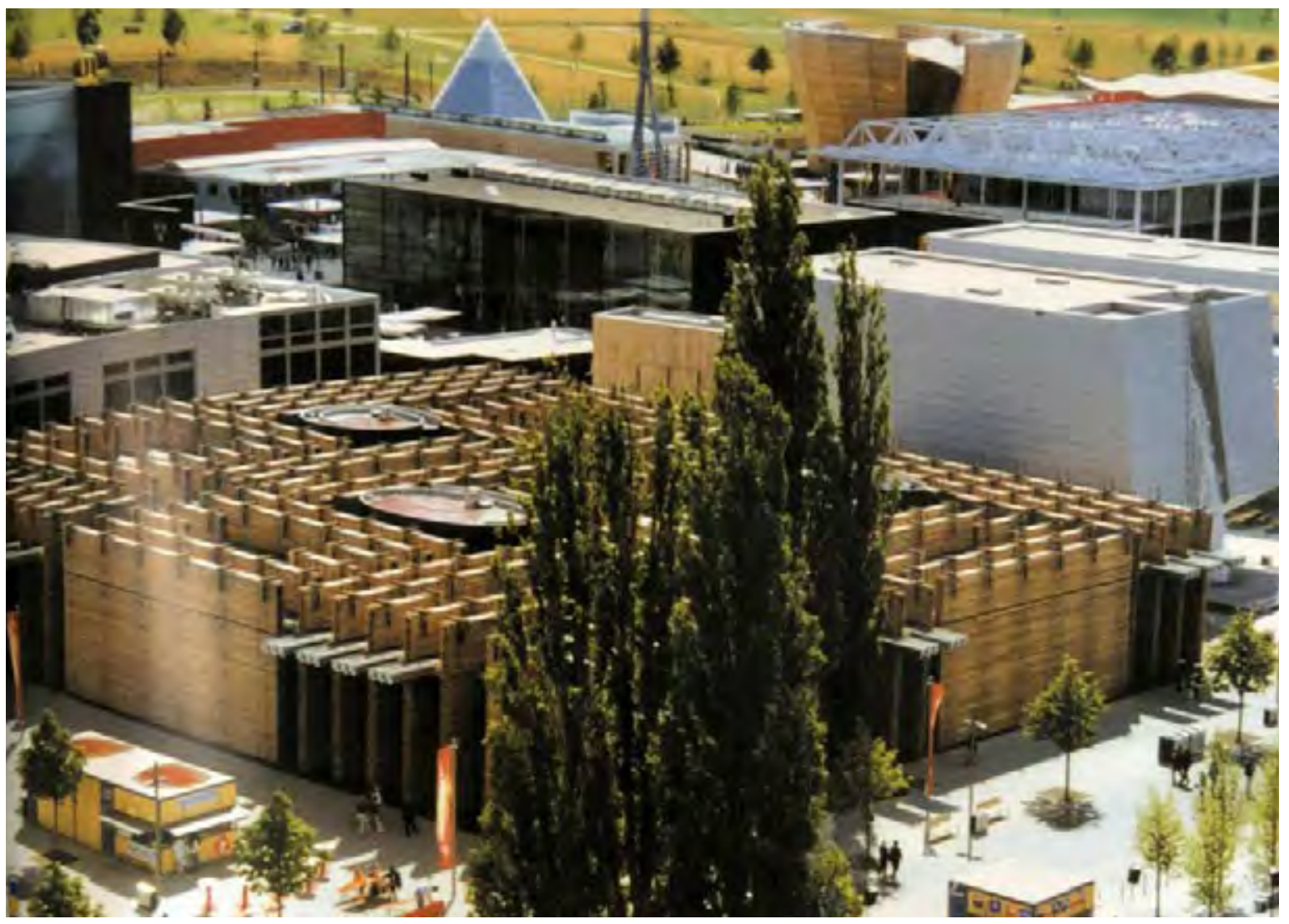

Figura 36.

Pabellón helvético / Peter Zumthor 
noreste con el pabellón de Gran Bretaña y al sureste con el de Noruega, mientras que en la esquina opuesta se ubicaba la propuesta de Suecia.

El área propuesta para el pabellón helvético tenía una posición privilegiada al suroeste con un frente de fachada a la Avenida 11. Una gran arteria a modo de bulevar que partía de la Expo-Plaza central. Mediante un sistema de calles perpendiculares este-oeste, genera un trazado ortogonal y geométrico regular, lejos de cualquier espontaneidad. Su anónima racionalidad permitió generar un marco adecuado capaz de contener diferentes tipos de construcciones efímeras. Este eje incrementaba el espacio destinado al transito así como la cualidad paisajística. Esta columna vertebral del conjunto con amplias arboledas, cosía todo el esqueleto urbano de la Expo 2000. Aunque los espacios no construidos, Freiraum, estaban rigurosamente trazados; estos se proponían como activadores de relaciones creando secuencias espaciales variables dadas las diversas arquitecturas. Este tablero discontinuo, vibrante y poroso, definido por las diferentes morfológicas de los pabellones; se trazó con la voluntad de reducir la huella ecológica y la menor perturbación de los ecosistemas nativos. Este "mini-manhattan", tenía su Central Park; es decir, su Expo-Park en su perímetro a diferencia del referente americano.

Zumthor no hizo ninguna referencia a las edificaciones vecinas. Aunque mediante la disposición de los accesos ${ }^{47}$; planteó una disposición hermética hacía los pabellones vecinos, mientras que las dos caras hacia el espacio público contuvieron un carácter de transito abierto. Sin embargo, la relación del pabellón helvético con su entorno siempre fue introvertida, a imagen y semejanza de su autor.

47 Nota: 50 acceso en total. 15 entradas al suroeste frente la Avenida 11 - 16 entradas al noroeste frente la Calle 11 y el pabellón francés - 9 entradas al noreste frente el pabellón de UK - 10 entradas al sureste frente el pabellón noruego 


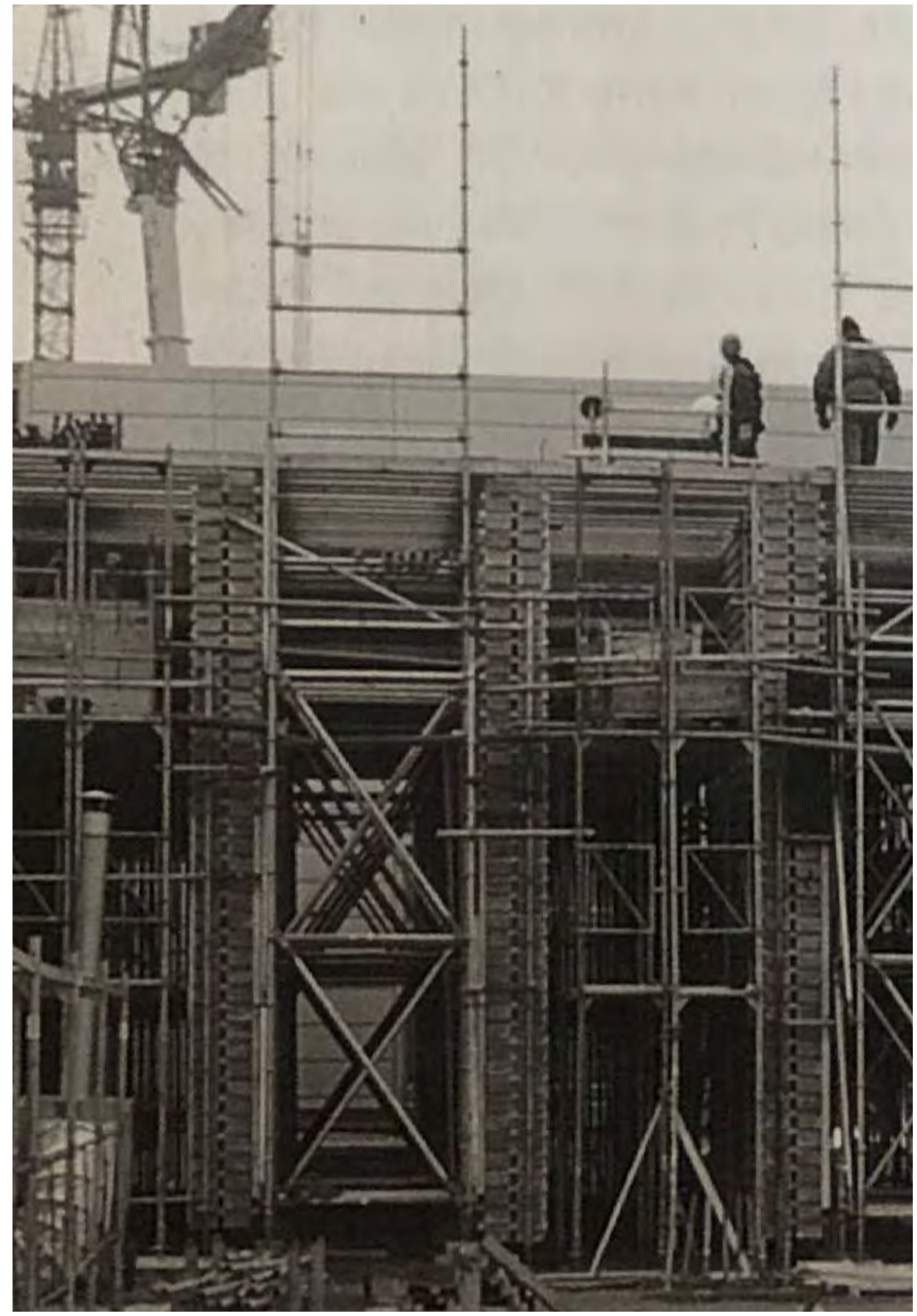

Figura 37.

Construcción / Pabellón helvético / Hannover / 2000 / Peter Zumthor 


\section{[Presupuesto]}

Los gastos netos de la participación de Suiza en la Expo 2000 fueron de 23,42 millones de francos suizos ${ }^{48}$ :

(en francos suizos)

1. Honorarios del arquitecto, comisarios, dirección de obra y otros expertos

$\begin{array}{lll}\text { Durante la construcción } & 1.774 .000 & \\ \text { Durante la Exposición } & 1.440 .000 & \\ \text { Subtotal } & \mathbf{3 . 2 1 4 . 0 0 0} & \mathbf{1 3 , 7 \%}\end{array}$

2. Construcción del pabellón con instalaciones, incluyendo el desmantelamiento

Adquisición de toda la madera $\quad 3.080 .000$

Otros $\quad 9.994 .000$

$\begin{array}{lll}\text { Subtotal } & 13.074 .000 & 55,9 \%\end{array}$

3. Gastos operativos

Gastronomía

731.000

Sonido y dirección

1.934 .000

Logística y alojamiento

1.216 .000

Subtotal

3.881 .000

$16,6 \%$

4. Comisariado general, incluyendo las gestiones pre y post Expo

Subtotal

2.653.000

$11,3 \%$

5. Diferentes eventos suizos en el pabellón

Subtotal

123.000

$0,5 \%$

6. Impuestos

Subtotal

473.000

$2,0 \%$

Presupuesto Total

23.418.000

$100 \%$

48 GENERALKOMMISSARIAT. Schlussbericht des Generalkommissariates. Weltausstellung Expo 2000 Hannover 1.6.-31.10.2000. Die schweizerische Beteiligung mit "Klangkörper Schweiz ". Bundesamt für Kultur. Bern. 2001. Pág.87. 


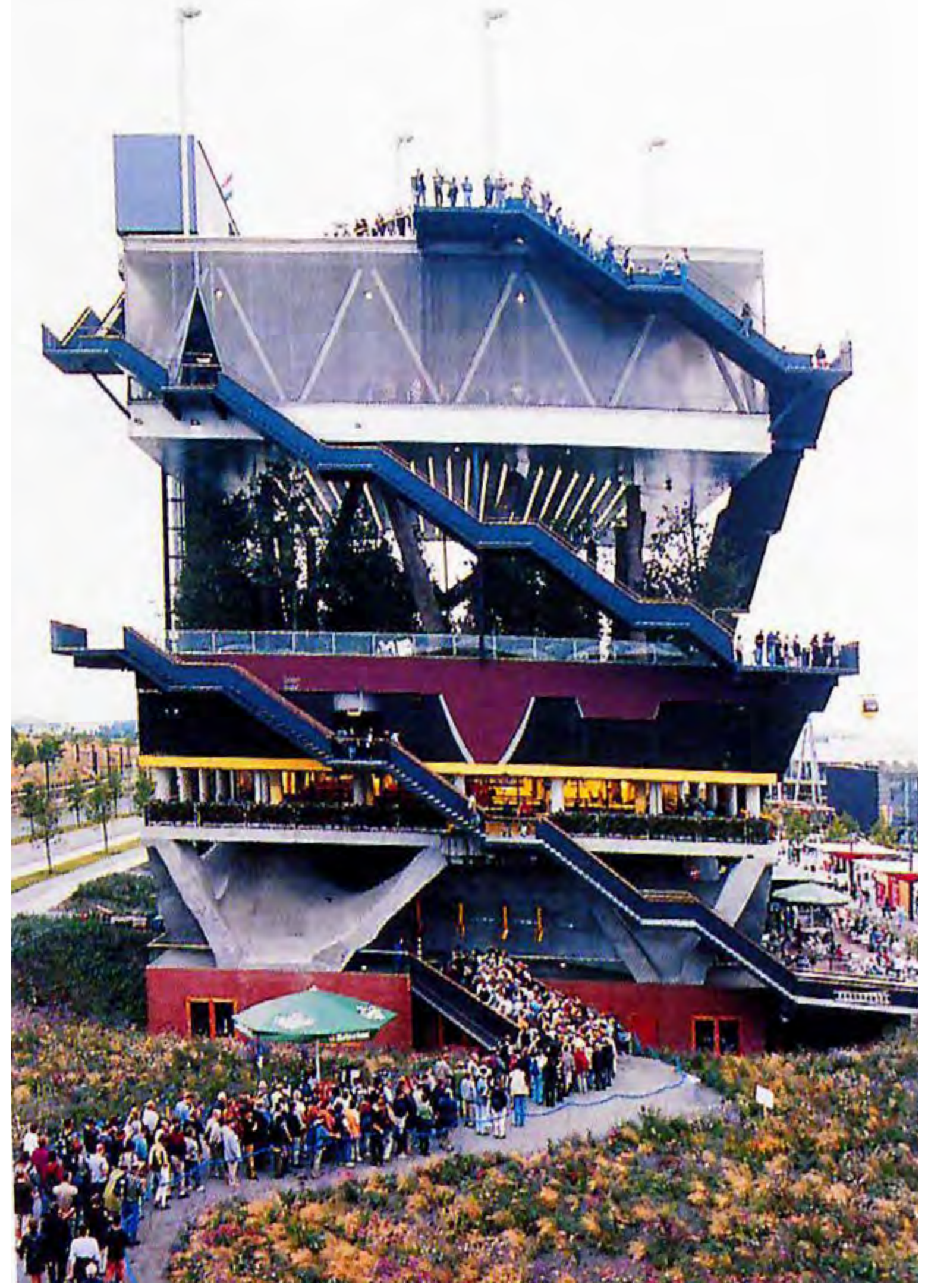

Figura 38.

Pabellón de los Países Bajos / Hannover / 2000 / MVRDV 


\title{
[Susurros y gritos]
}

\begin{abstract}
"(...) hay al menos dos construcciones que no pasaran inadvertidas, porque representan los extremos del debate contemporáneo... Entre los gritos holandeses y los susurros suizos, sin embargo, no es fácil imaginar diálogo alguno."49 Luis Fernández-Galiano
\end{abstract}

En el gran escaparate arquitectónico que supone cualquier Exposición Universal, se exhibieron varios pabellones de autor. Así Portugal contó con Álvaro Siza, quien repetía tras Lisboa en 1998, en colaboración con Eduardo Soto de Moura; Shigeru Ban proyectó la gran cubierta japonesa construida a base de tubos de papel; o el prisma español de fachadas quebradas de corcho, obra de los arquitectos Antonio Cruz y Antonio Ortiz. Sin embargo, entre todas las propuestas planteadas había dos pabellones que materializaron dos maneras de entender la arquitectura. La austeridad y el desarrollo exquisito del sistema de construcción del pabellón suizo frente al apilamiento de paisajes artificiales: flores, dunas, bosques y agua del pabellón de los Países Bajos, obra de MVRDV. Dos pabellones antagónicos, dos tendencias divergentes, lenguajes diferentes.

\footnotetext{
"...Zumthor evita cualquier exhibicionismo para reducir la representación de su país a un laberinto de listones de madera..." ${ }^{150}$ Luis Fernández-Galliano

“...los holandeses han conseguido cumplir las aspiraciones de una "joven arquitectura, que se echa de menos en el resto de la Expo. El resultado es un...Big Mac construido." ${ }^{151}$ Kaye Geipel
}

La propuesta holandesa, un contenedor publicitario ${ }^{52}$ en varios niveles que coronaba la exposición, fue el grito de un grupo de tres arquitectos jóvenes ${ }^{53}$. Winy Maas, Jacob van Rijs y Nathalie de Vries que ya habían construido varios proyectos relevantes en el año 2000, como la sede de la emisora pública VPRO y la residencia de ancianos WoZoCo, ambos realizados en 1997. El pabellón sándwich para la Expo 2000 traducía el paisaje de los Países Bajos en un ecosistema apilado. Materializó el

49 FERNÁNDEZ-GALIANO, Luis. Hannover 2000. Arquitectura Viva. № 72. 2000. Pág. 3.

50 Idem. Pág. 3.

51 GEIPEL, Kaye. Dilemas universales. Arquitectura Viva. № 72. 2000. Pág. 29.

52 Parafraseando a Robert Venturi y Denise Scott Brown.

53 En el año 1997 que comienzan a desarrollar el proyecto tras ganar el concurso, las edades de los tres estaban en torno a los 35 años. 


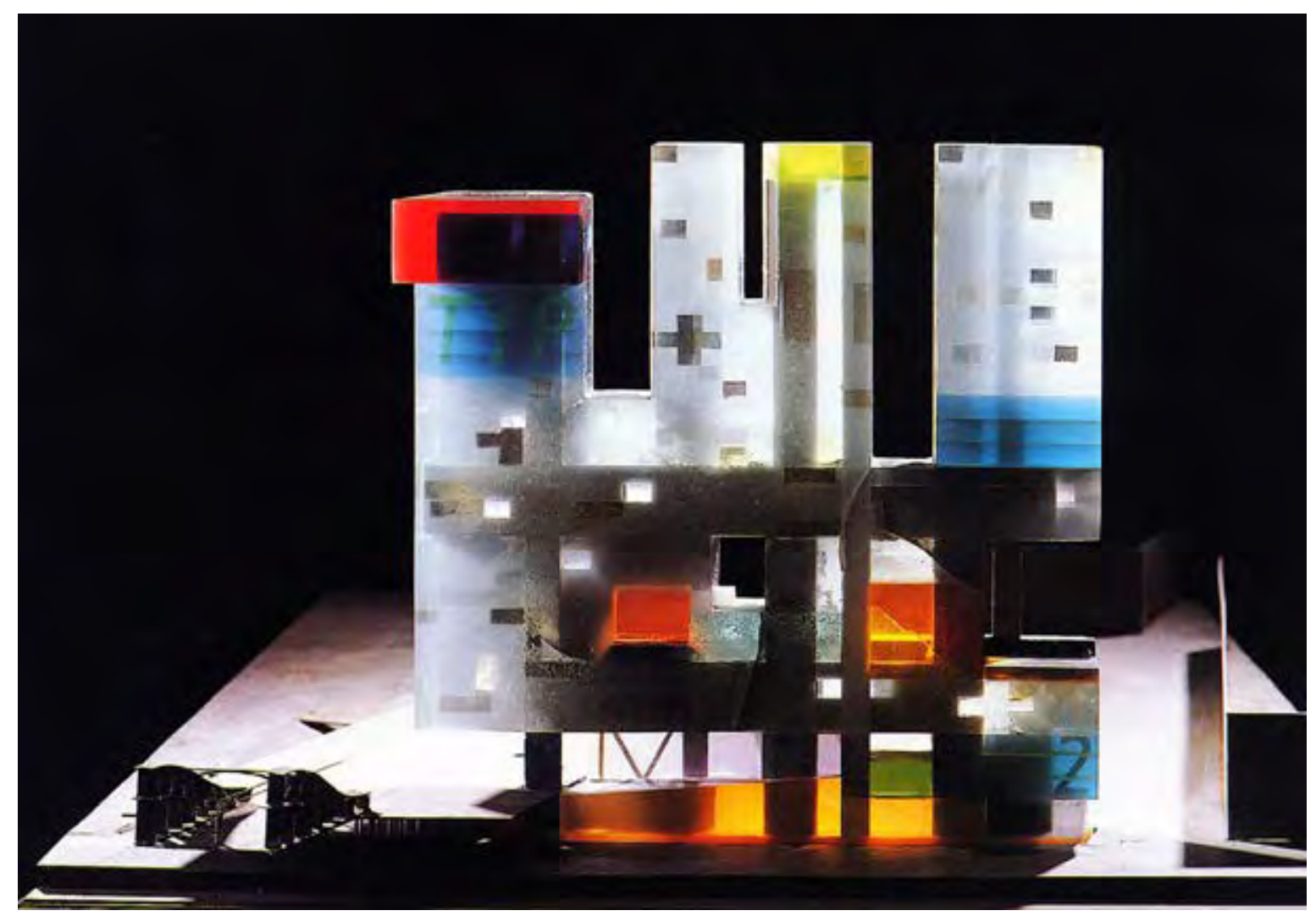

Figura 39.

Berlin Voids / 1991 / MVRDV

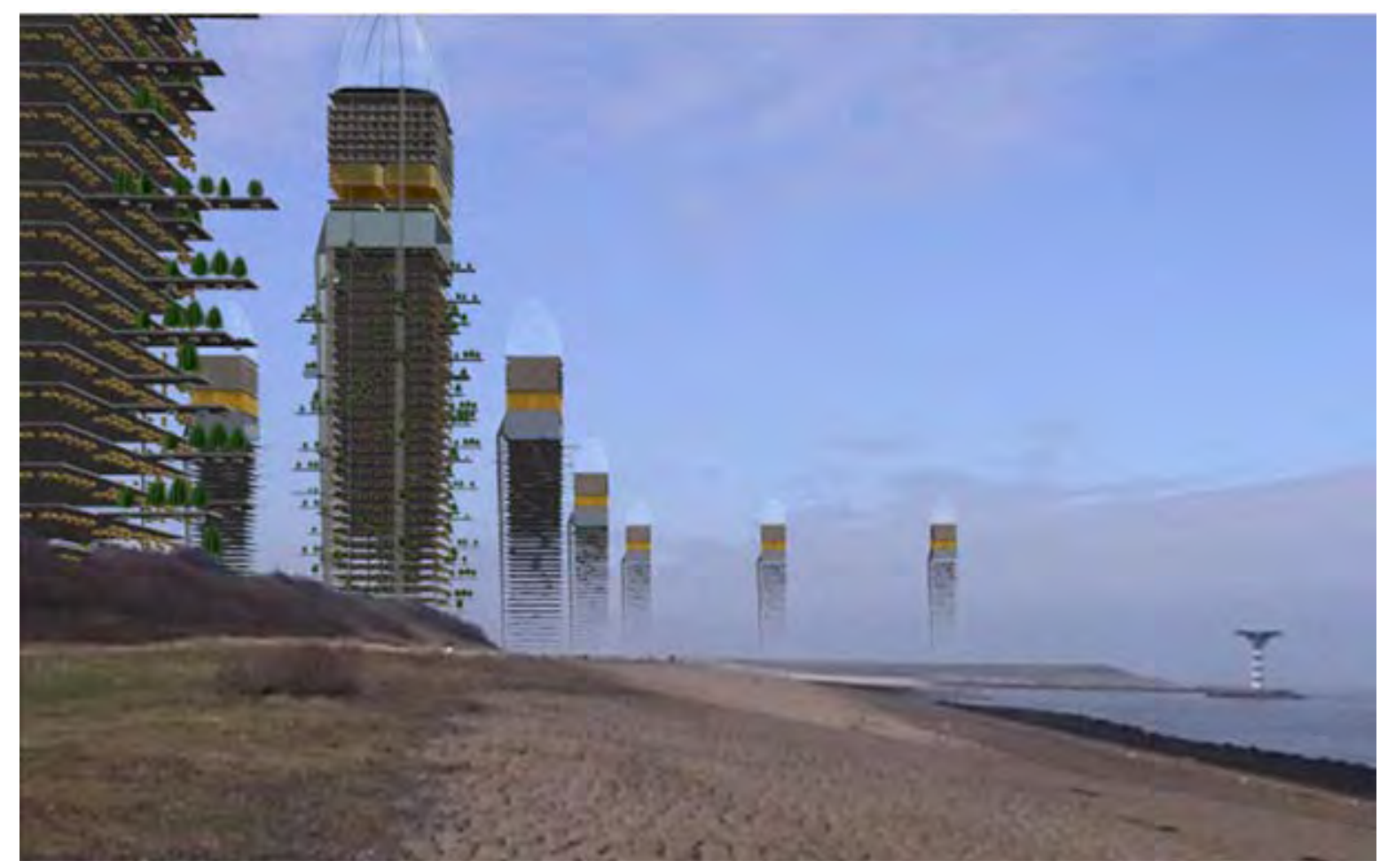

Figura 40.

Pig City / 2001 / MVRDV 
dicho holandés: "Dios creó el mundo y los holandeses crearon Holanda"54. Un collage, una secuencia de paisajes construidos. Su construcción es eficiente por su mínima huella ecológica, representación de uno de los países más densos del mundo. Su naturaleza artificial y la arquitectura se fusionan en varios estratos superpuestos, unificando las características de los landschappen holandeses creados artificialmente. Cinco paisajes diferentes apilados uno encima del otro en un edificio de $40 \mathrm{~m}$ de altura: dunas, grutas, agricultura, flores, abejas virtuales, ostras, bosque, lluvia, agua, tierra, viento, molinos, luz natural y artificial. Cada nivel tiene su propio carácter programático. Se trata de una arquitectura fragmentada pero agrupada verticalmente. La disposición aparentemente aleatoria de diferentes alturas y el uso de diferentes materiales crearon una estructura compleja. Aprendizaje durante los tres años que colaboraron en OMA hasta 1993, en el año 2000 muchas de las propuestas de MVRDV eran diagramas construidos. Desvinculados de prejuicios eran convertidos directamente en arquitectura. Sistemas arquitectónicos complejos condensadores de componentes sociológicos, fisiológicos, políticos, económicos, demográficos, urbanísticos entre otros. Sus arquitecturas eran comprensibles para todo el mundo.

El pabellón tiene su origen en una reflexión recurrente en los Países Bajos sobre las consecuencias derivadas de la alta densidad demográfica, buscando alternativas a los desarrollos urbanos horizontales expansivos. La estrategia del agrupamiento en vertical será frecuente en algunos proyectos predecesores como la propuesta premiada Berlin Voids en el concurso internacional Europan 2 de 1991, o como el contenedor de diferentes tipologías de viviendas de Silodam en Ámsterdam en 1995-02; y posteriores como las granjas verticales de cerdos Pig city en 2001. El Teorema ${ }^{55}$ descrito por Rem Koolhaas en Delirios en Nueva York bajo la idea de apilamiento. La ciudad vertical a través del ascenso como sistema de acumulación de estratos con programas independientes. Duch-burger ${ }^{56}$ como método de montaje cinematográfico; como un collage pop arquitectónico, como reencarnación del Downtown Athletic Club neoyorkino.

Sin embargo; Zumthor se propuso hacer lo contrario ${ }^{57}$ a lo que normalmente se espera. Sus referencias habitan en la literatura, en el cine, en la música, en el lugar, en la materialidad. Sus procesos de proyecto se basan en la reflexión abstracta, en la

54 Nota: "God schiep de aarde, maar de Nederlanders schiepen Nederland"

55 KOOLHAAS, Rem. Delirio de Nueva York. (1978). Editorial Gustavo Gili. S.L. Barcelona. 2004. ISBN: 978-84-252-1966-5. Pág. 82 - 85.

56 VAN WESEMAEL, Pieter. Architecture of Instruction and Delight: A socio-historical analysis of World Exhibitions as a didactic phenomenon. ISBN 90-6450-383-4. 010 Publisher. Rotterdam. 2001. Pág. 681.

57 BREYER, Nike. Entrevista con Peter Zumthor. Ich mache das Gegenteil. Taz. Die Tageszeitung. Ausgabe 6117. 12.04.2000. Pág. 13. Traducción de la autora: "Ich mache das Gegenteil" 


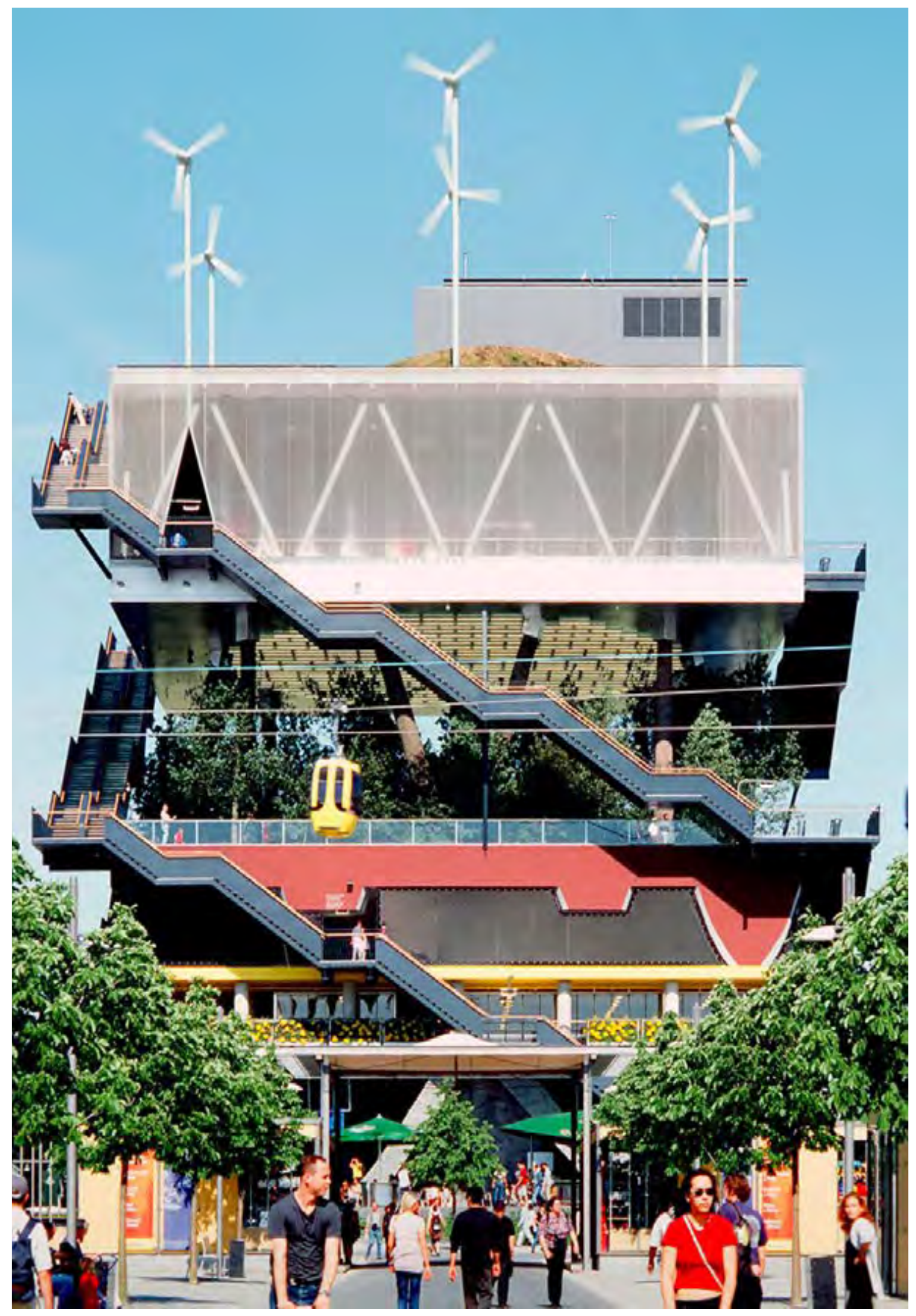

Figura 41.

Pabellón de los Países Bajos / Hannover / 2000 / MVRDV 

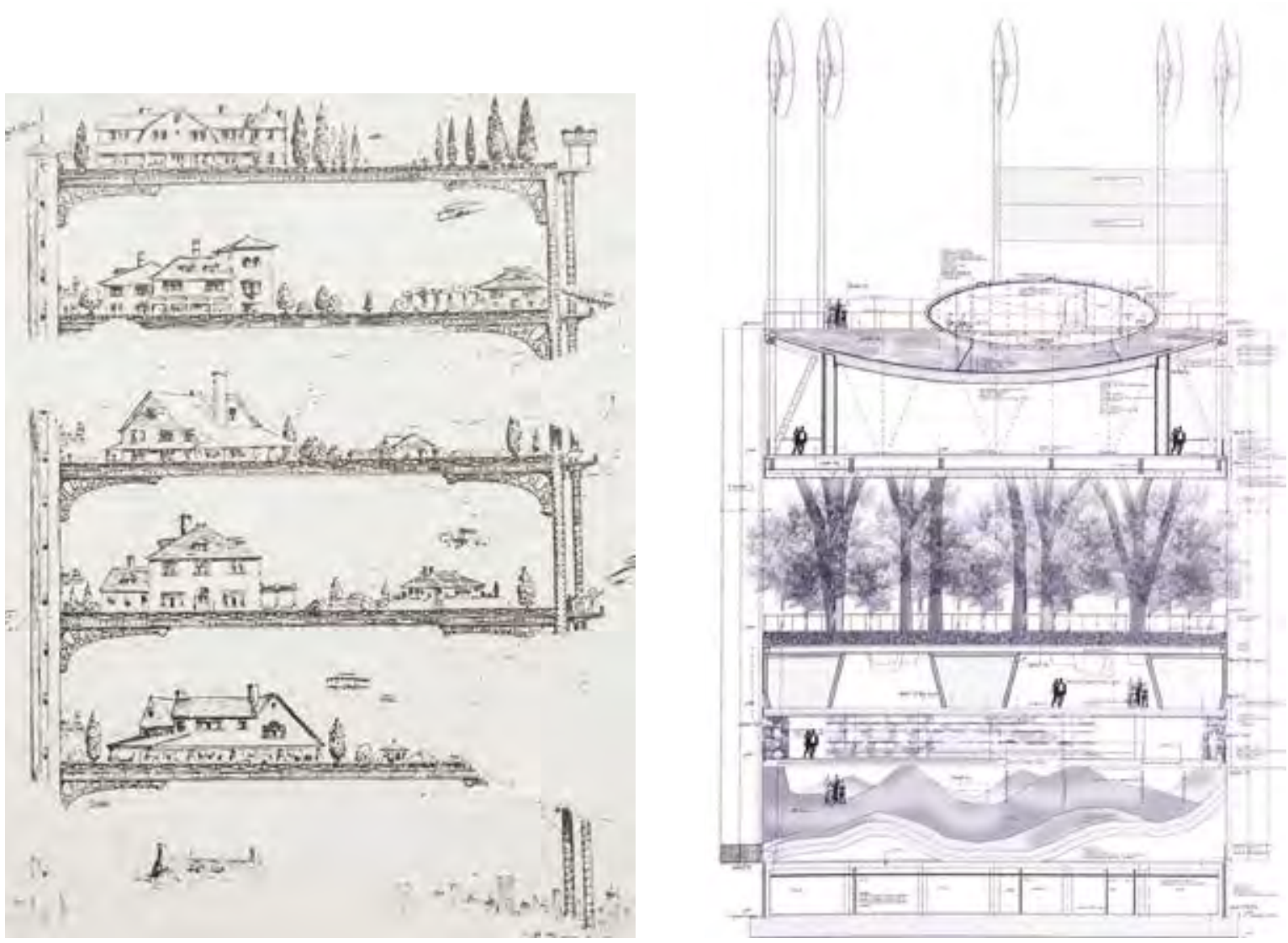

Figura $42-43$

Sección Pabellón de los Países Bajos
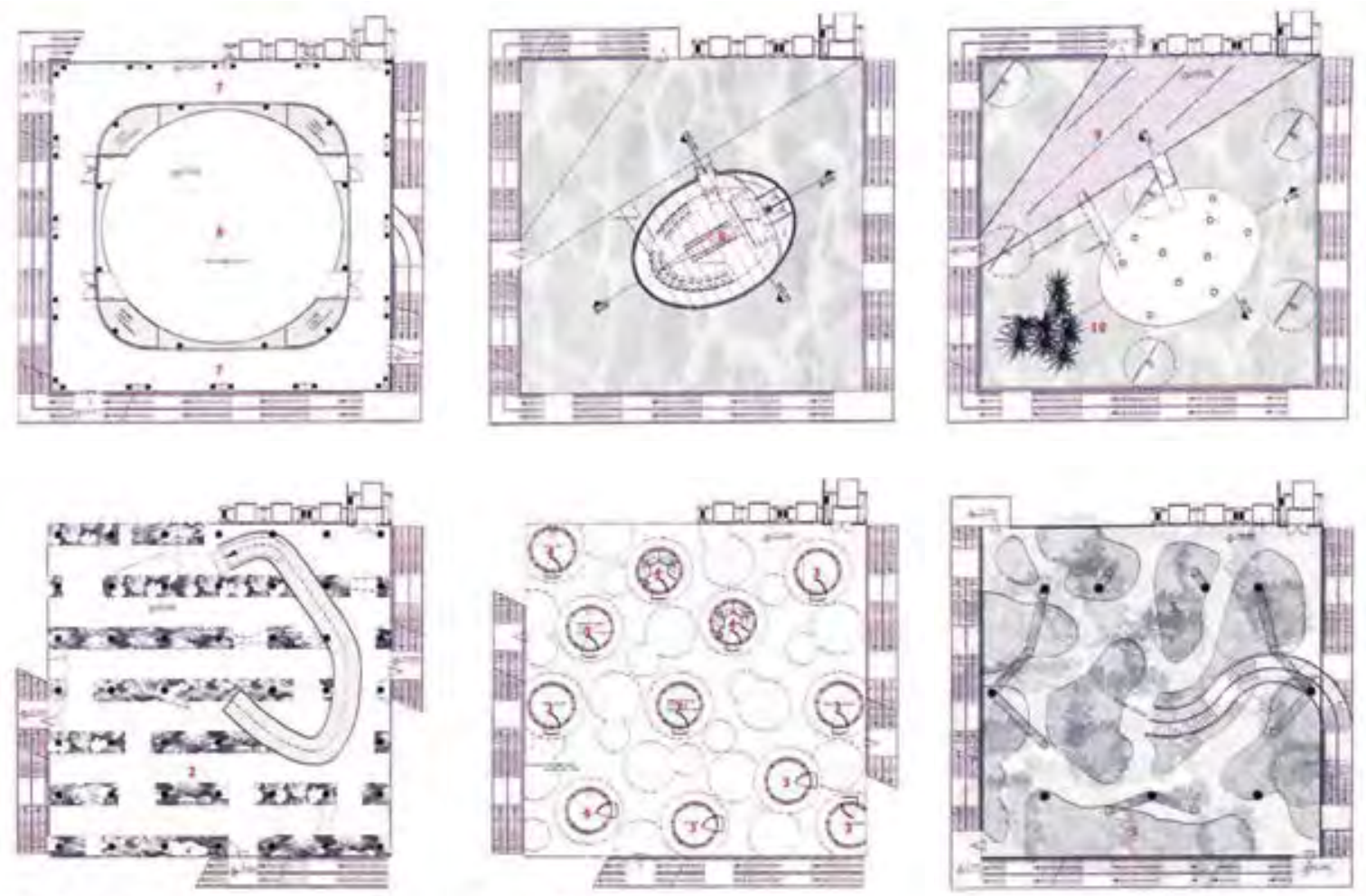

Figura 44.

Plantas Pabellón de los Países Bajos / Hannover / 2000/ MVRDV 


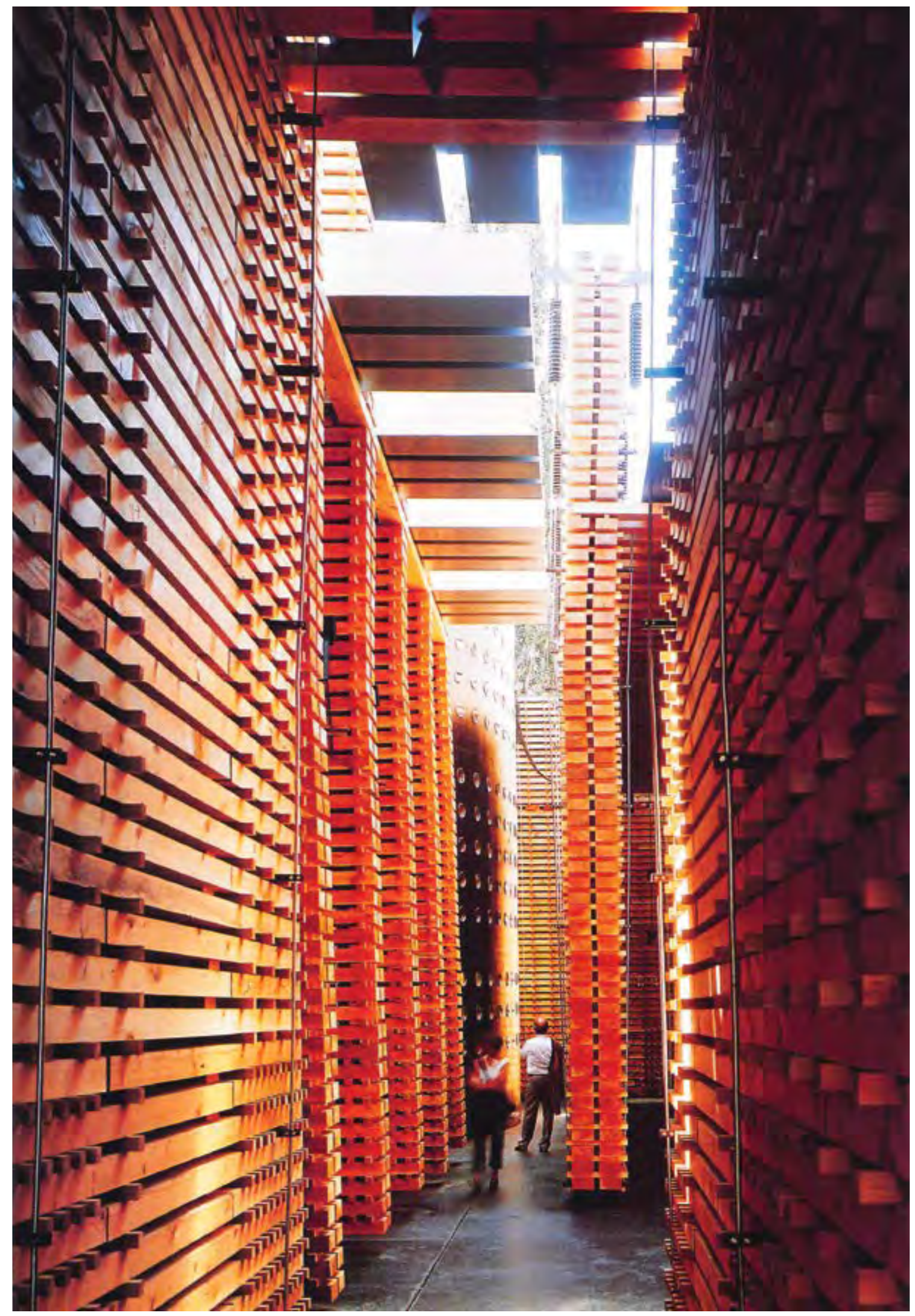

Figura 45. 
memoria, en la búsqueda de imágenes. Su arquitectura trasmite sensibilidad, claridad, silencio, precisión, atemporalidad, artesanía, minuciosidad. El pabellón helvético no se puede entender como un contenedor en el cual se desarrolla una exposición, sino que la arquitectura misma es la exposición. Los flujos generan el espacio, como experiencia en movimiento. El Klangkörper conforma un paisaje expansivo, a modo de conexiones. Una arquitectura al aire libre, abierta por todos lados, formada por un sistema sinuoso y permeable de pasillos y patios, cuyo lenguaje arquitectónico se basa en la geometría, rigor, proporción, iluminación, orientación, reducción, experiencias sensuales, repetición, el uso mínimo de materiales, creando un efecto espacial y complejo.

"No dejo nada en manos de otro, antes de que yo no siento que está bien. ${ }^{158}$ Peter Zumthor

Los dos pabellones, dos concepciones distintas del término apilar, operan con reglas distintas: vertical versus horizontal, extro-vertido versus intro-vertido, collage de diferentes materialidades versus acopio de un único material, movimiento dirigido y guiado versus laberíntica apropiación del espacio, acceso controlado versus límite difuso, artificial versus abstracto, visual versus sensualidad, Dutchburger ${ }^{59}$ versus Klangkörper Schweiz, grito versus susurro.

"En la Expo 2000 de Hannover, Suiza y los Países Bajos son los dos países cuyos pabellones son probablemente la oposición más consistente al marketing nacional convencional." ${ }^{\prime 60}$ Hubertus Adam

Sin embargo, paradójicamente ambas "antípodas arquitectónicas"61 revelan similitudes operativas. La estratificación como apilamiento, un juego aditivo. Sin embargo, mientras el pabellón holandés fue una yuxtaposición de ideas a través de la superposición de distintas naturalezas independientes, el pabellón helvético se limitó a un proceso constructivo acumulativo de elementos constructivos mediante la repetición continua de piezas iguales. Estratificación programática versus estratificación de piezas, apilamiento de paisajes versus apilamiento como aparejo.

59 VAN WESEMAEL, Pieter. Architecture of Instruction and Delight: A socio-historical analysis of World Exhibitions as a didactic phenomenon. ISBN 90-6450-383-4. 010 Publisher. Rotterdam. 2001. Pág. 681.

60 ADAM, Hubertus. Schichtung als Prinzip. En: Archithese Zeitschrift und Schriftreihe für Architektur. 5.00. September/ Oktober 30. Jahrgang. Pág. 38. Traducción de la autora: "Die Schweiz und die Niederlande sind auf der Expo 2000 in Hannover jene beiden Staaten, die sich mit ihren Pavillons wohl am konsequentesten dem herkömmlichen Nationenmarketing widersetzen."

61 ADAM, Hubertus. Glückliche Fügung. Der "Klangkörper Schweiz". En: Bauwelt 23. 2000. Pág. 56. Traducción de la autora: "(...) architektonische Antipoden (...)" 


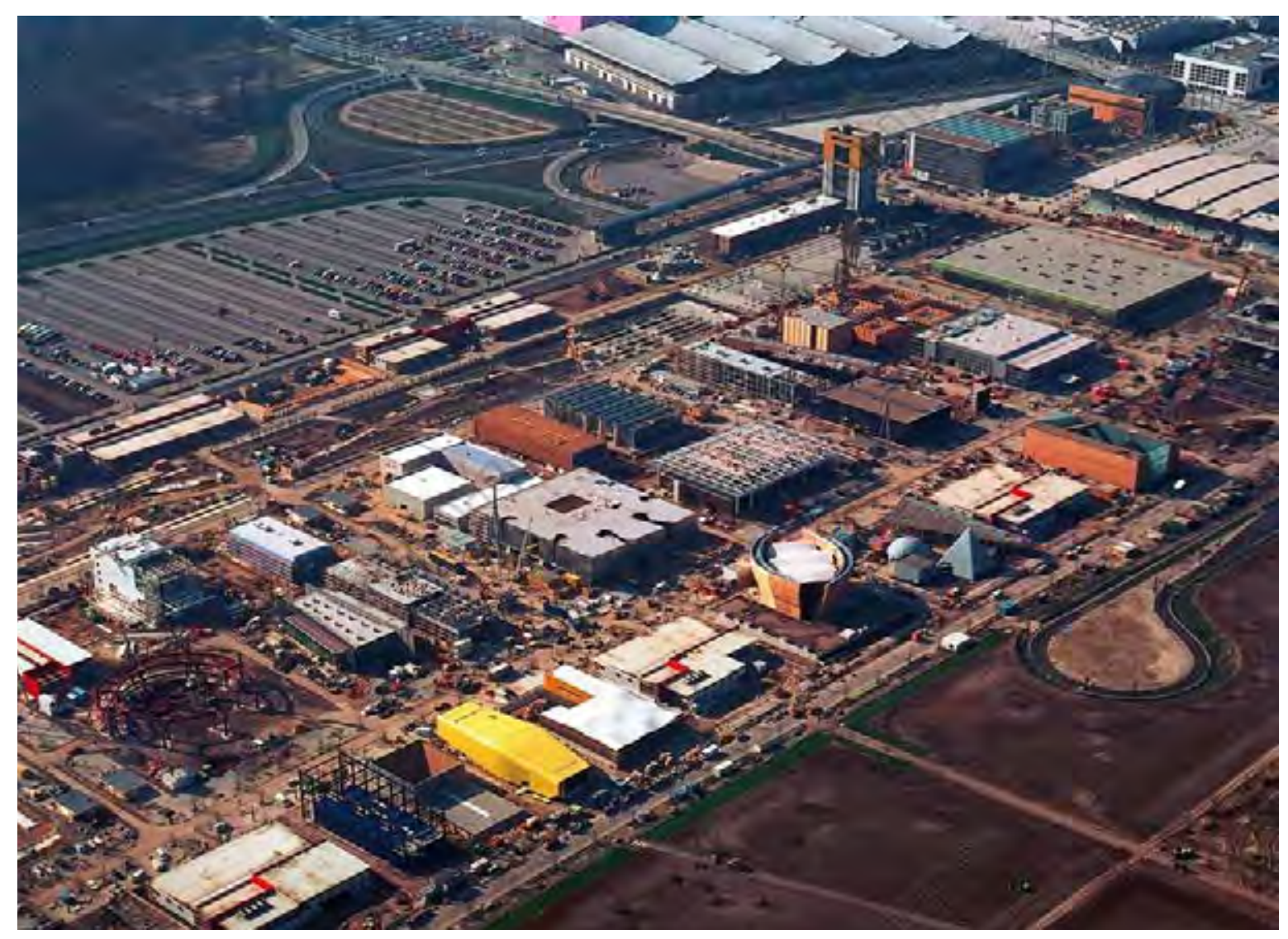

Figura 46.

Vista aérea del terreno de la EXPO 2000 aún en construcción

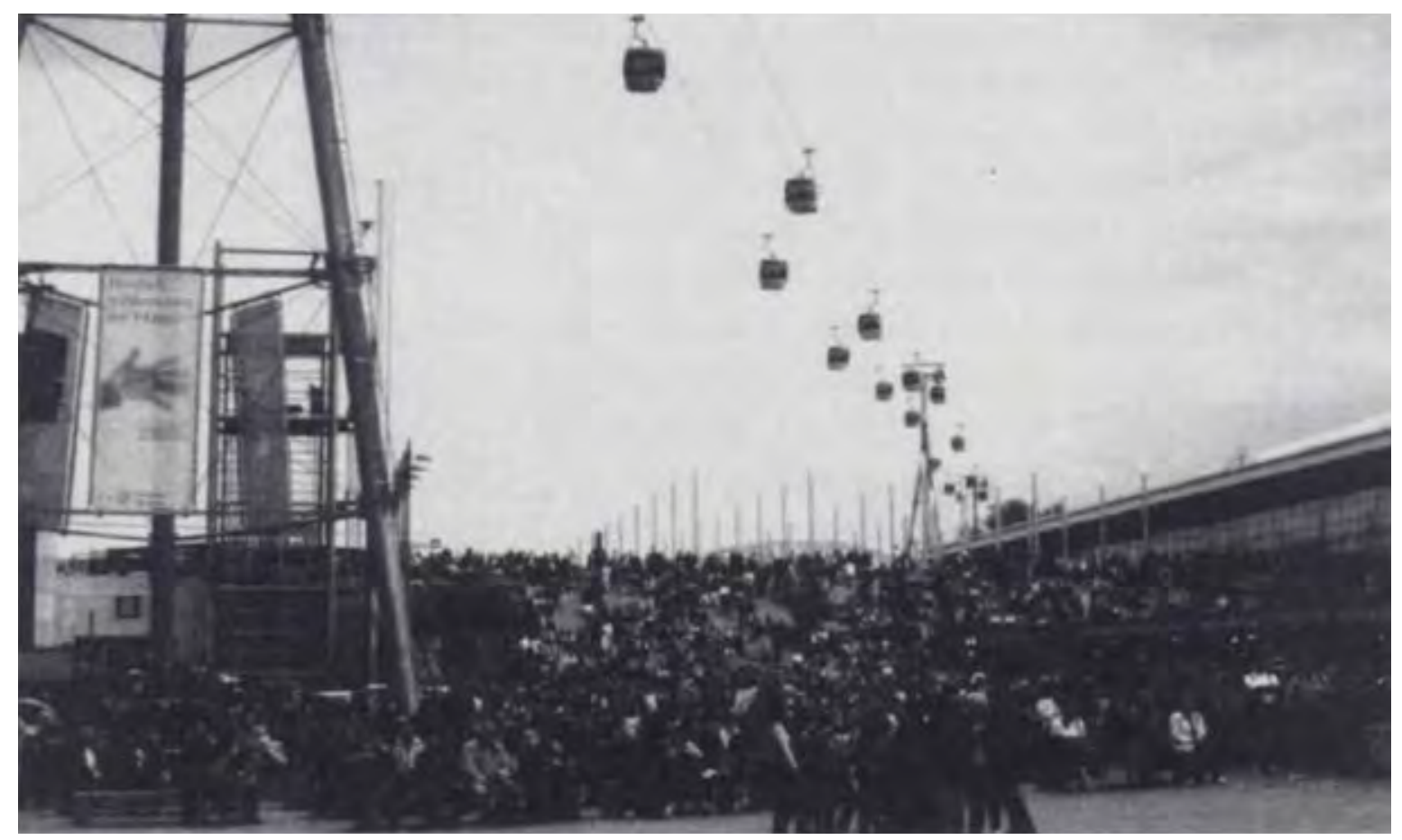

Figura 47.

Día de la inauguración / Expo 2000 
[Expo 2000 in numeris]

Categoría_Feria mundial de 1a categoría

Fecha de designación de sede_ 14 de junio de 1990

Lema_Hombre - Naturaleza - Técnica; origen de un nuevo mundo.

Localización_Hannover - Laatzen

Ubicación_ Recinto ferial + Ampliación

Superficie total de la Expo_ 160 hectáreas.

Ganador concurso para el diseño urbano_ Michele Arnaboldi y Raffaele Cavadini, Locarno y el paisajista Guido Hager, Zürich

Masterplan_Albert Speer \& Partner, el arquitecto Thomas Herzog y el paisajista Dieter Kienast; Michele Arnaboldi y Raffaele Cavadini, Locarno

Fecha de inauguración_ 1 de junio de 2000

Duración de la muestra_ 153 días

Países participantes_156

Países/Instituciones con pabellón propio_ 48 (incluyendo 18 en el área oeste y 30 en el área este)

Número de visitantes_aprox. 18,1 millones

Récord de asistencia_ 2 de octubre de 2000 - 290.000 visitantes

Extranjeros_ $17 \%$ (57\% de Europa, $43 \%$ Resto)

Horario de apertura_9:30 h - 21:30 h.

Entradas_Entrada de un día: DM 69 (aprox. $35 €$ )-

Tarjeta de noche: DM 15 (aprox. $8 €$ ) -

Fecha de clausura_ 31 de octubre de $\mathbf{2 0 0 0}$ 


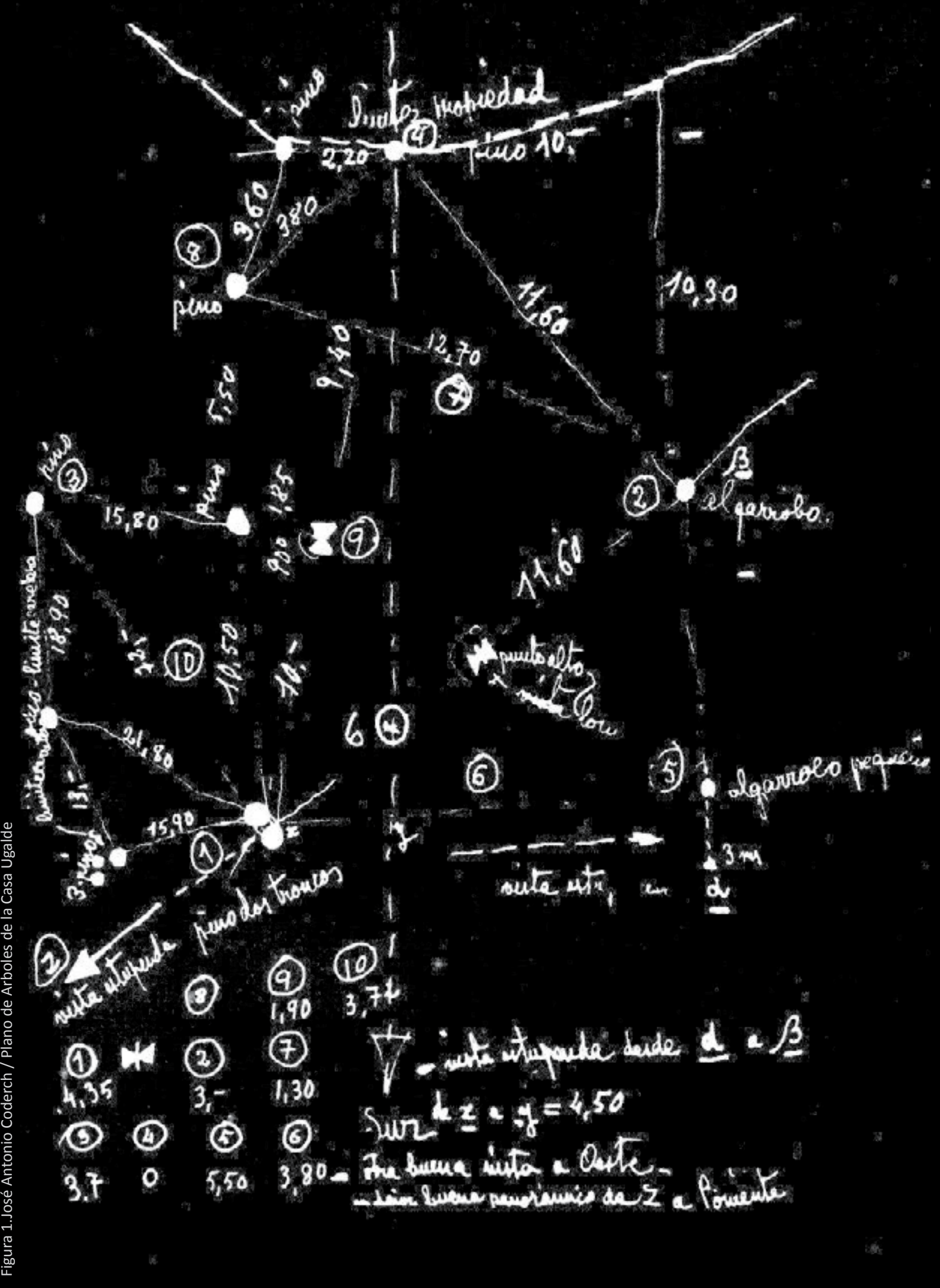




\section{ORGANISMO}

ORGANISMUS

“(...) un sistema es un conjunto de elementos heterogéneos (materiales o no), de distintas escalas, que están relacionadas entre sí. Con una organización interna que intenta estratégicamente adaptarse a la complejidad del contexto y que constituye un todo que no es explicable por la mera suma de sus partes. Cada parte del sistema está en función de otra; no existen elementos aislados." ${ }^{11}$ Josep María Montaner 


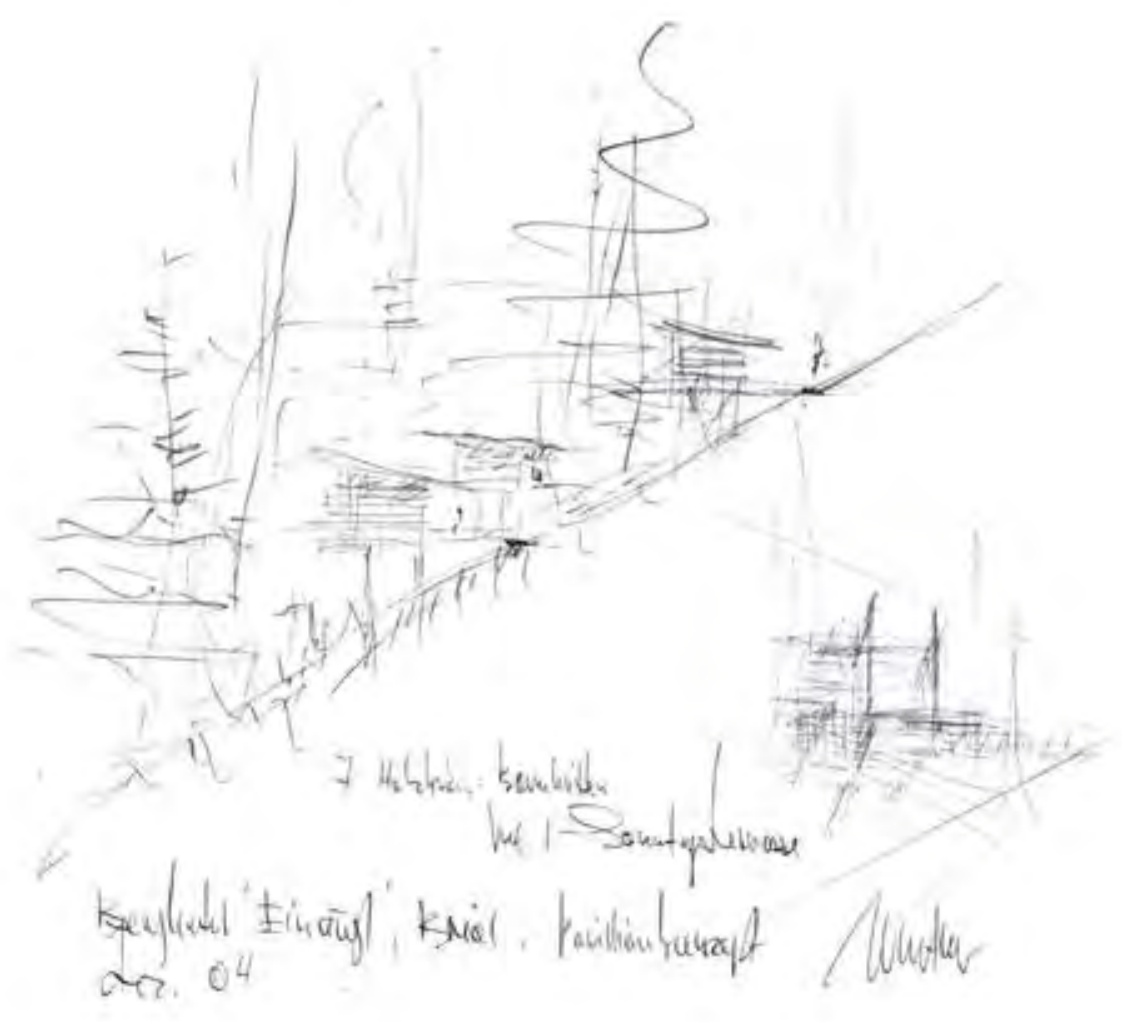

Figura 2.

Croquis inicial / Pensión Briol / Barbian-Dreikirchen, Italia / 2001 - / Peter Zumthor

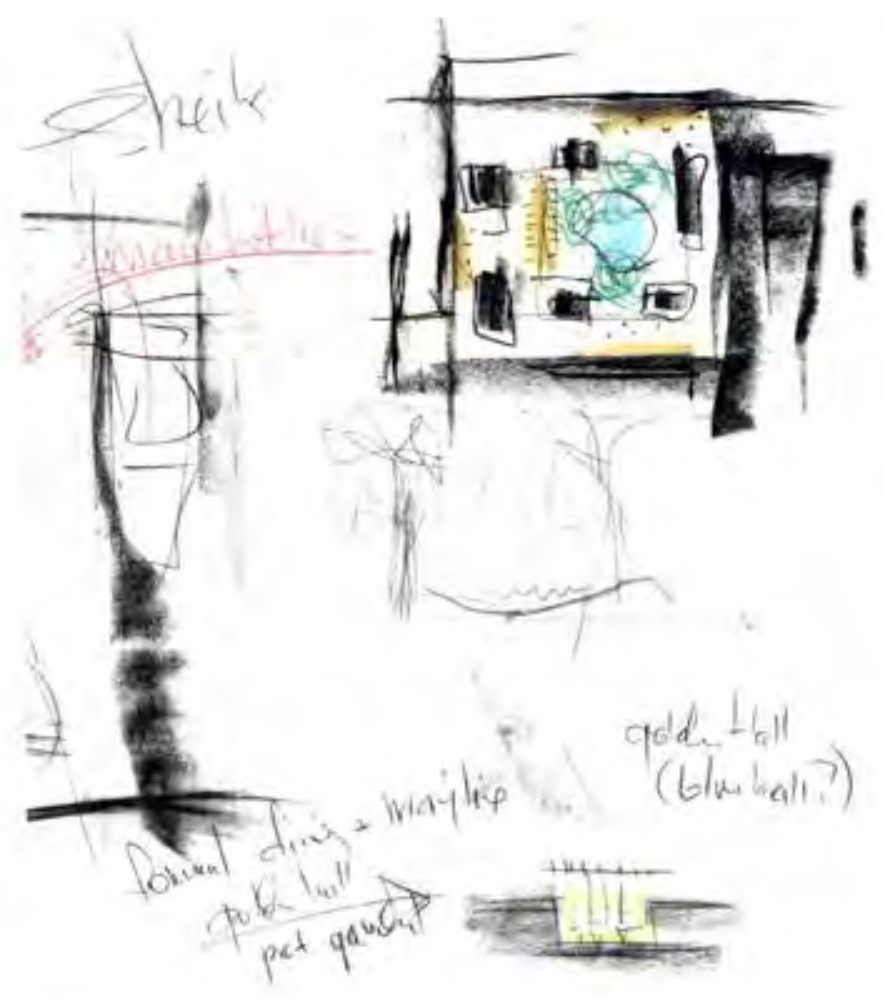

Figura 3.

Croquis inicial / House of Seven Gardens / Doha, Quatar / 2009 - / Peter Zumthor 


\section{[La idea trazada]}

"En mi trabajo son importantes los bocetos que señalan expresamente hacia una realidad que aún está en el futuro. Por ello, desarrollo mis dibujos buscando aquel punto delicado donde se hace perceptible la atmósfera fundamental deseada, sin que ésta se desvíe por lo accidental. Incluso el propio dibujo debe incorporar las cualidades del objeto buscado."2 Peter Zumthor

La concepción del Klangkörperbau está muy presente en varios dibujos iniciales de Zumthor. Se trata de una aproximación abstracta y sucesiva, reflejando su pensamiento sobre papel. Aún esquemáticos, sin medidas; pero con algunas anotaciones. Una reducida paleta de colores enfatizando los espacios interludios, los limites o la incidencia de la luz. Los trazos guardan similitud con una red espacial entretejida. Un entrelazado compuesto de la suma de ejes verticales y horizontales que se traban; como un juego geométrico de relaciones entre elementos.

Mediante una serie de leyes compositivas Zumthor establece un diálogo. Representa las intenciones, las estrategias arquitectónicas para transmitir ideas. Sus croquis iniciales se convierten en un instrumento para seducir, sugerir, analizar, formular estructuras e ideas. Son probetas para determinar las secuencias y la composición arquitectónica del espacio, sintetizando el concepto arquitectónico con las acciones proyectuales. Aparecen espacios tejidos, espacios construidos, espacios vacíos, espacios abiertos, espacios de experiencia. Un continuo variado y sinuoso.

Pero, aunque las representaciones bidimensionales son una herramienta esencial de la reflexión y expresión arquitectónica, lo primordial es la encarnación de la idea en un espacio tridimensional. Vivificar las imágenes y reflexiones ideadas; y definir, interpretar, concretar, edificar, ensamblar, levantar...

"De todos los dibujos que los arquitectos producen, prefiero los planos de obra. Los planos de obra son detallados y objetivos. Dirigidos a los especialistas que dan cuerpo material al objeto pensado, se ven libres de una dirección de la exposición asociativa (...) se caracterizan por la certidumbre y la confianza. Parecen decir: "Esto se hará exactamente asi"13 Peter Zumthor

2 ZUMTHOR, Peter. Pensar arquitectura. Editorial Gustavo Gili. S.A. Barcelona. 2010. ISBN: 978-84-2522730-1. Pág. 13

3 Idem. Pág. 18. 


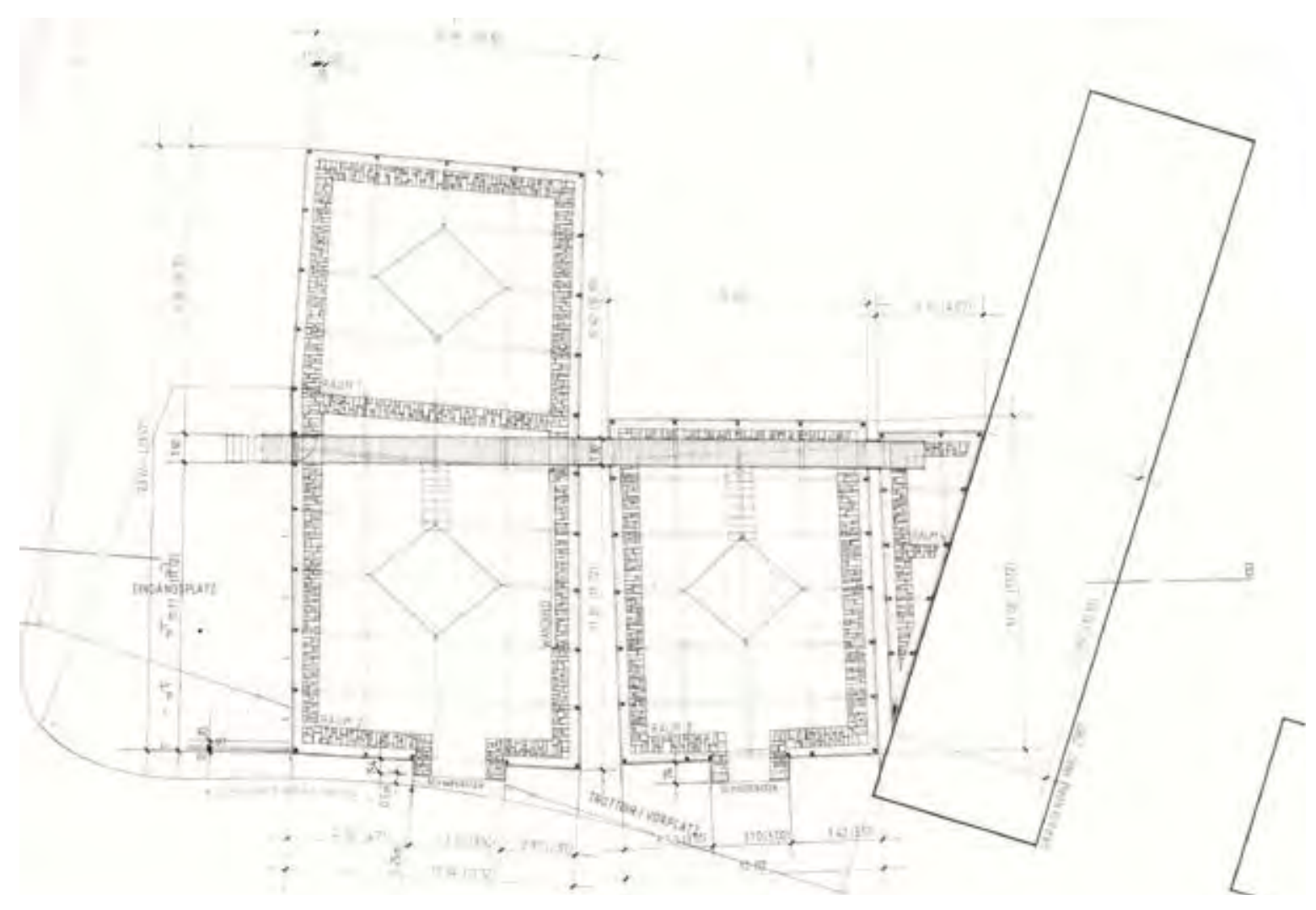

Figura 4.

Plano de ejecución / Restos arqueológicos romanos /Chur, Graubünden / 1985 - 1986 / Peter Zumthor

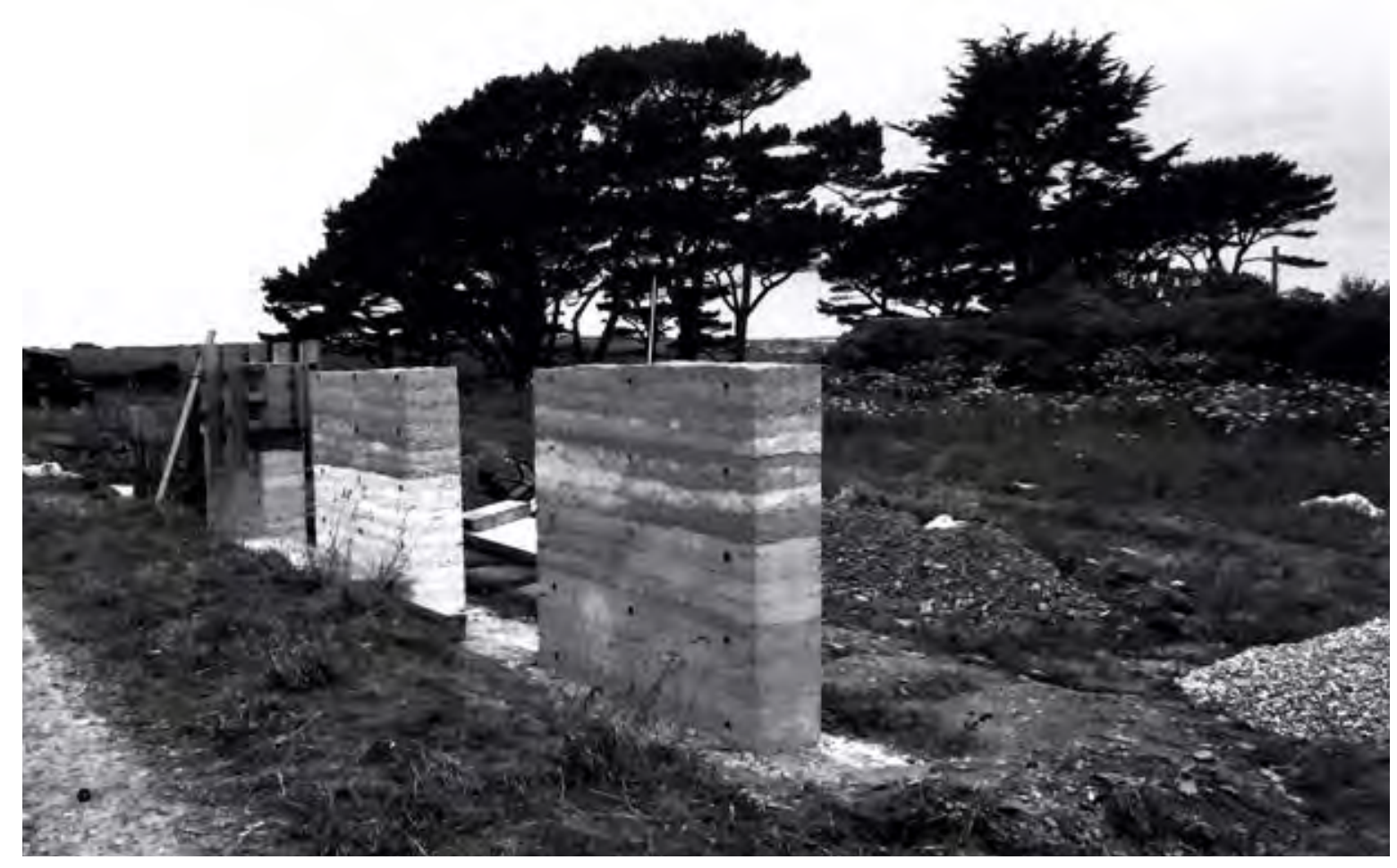

Figura 5.

Construcción / Chivelstone House / Devon, Inglaterra / 2008 - / Peter Zumthor 
Lo hermoso es el proceso de la construcción ${ }^{4}$. El croquis materializado en arquitectura a través de la síntesis entre espacio y masa; entre vacío y materia. De lo abstracto a lo concreto ${ }^{5}$. Zumthor se aproxima a la arquitectura explorando su materialidad, sus dimensiones, sus límites, sus encuadres, la medida de la disposición, las aperturas, la nitidez. Así puede alcanzar una meticulosa, e inquietante, precisión. Pero no solo atiende al significante construido: forma, materiales elegidos, leyes geométricas aplicadas; sino que también coloniza los significados con la creación de una cartografía semántica de impresiones sensoriales. Estos no eran previamente perceptibles pero emergen; como la luz, la sombra, el sonido y los ruidos ${ }^{6}$, el olor, la atmósfera. Sus fuentes de inspiración igualmente son la literatura, la música, el arte, la fenomenología o incluso las experiencias propias. Todo ello es un complejo proceso creativo progresivo, respuestas materializadas.

"Un proyecto sobre el papel no es arquitectura, sino únicamente una representación más o menos defectuosa de lo que es la arquitectura, comparable con las notas musicales. La música precisa de su ejecución. La arquitectura necesita ser ejecutada."

Peter Zumthor.

Como la música, la arquitectura requiere nitidez en las ideas generadas, precisión en el desarrollo y adecuación en la construcción. Ambas disciplinas se desarrollan para ser ejecutadas por otros, no sus autores; los cuales leen e interpretan las partiduras o los planos, respectivamente. El virtuosismo de la ejecución lo elevará más allá de su propia concepción abstracta.

4 ZUMTHOR, Peter. Atmosferas. Entornos arquitectónicos - Las cosas a mi alrededor. Editorial Gustavo Gili. S.A. Barcelona. 2006. ISBN: 978-84-2117-0. Pág. 31. Nota: "Encuentro hermoso construir un edificio"

5 ZUMTHOR, Peter. Pensar arquitectura. Editorial Gustavo Gili. S.A. Barcelona. 2010. ISBN: 978-84252-2730-1. Pág. 66. Nota: "La arquitectura es siempre un material concreto; no es abstracta, sino concreta."

6 ZUMTHOR, Peter. Atmosphären. En: Zeitschrift für Architektur und Städtebau. Archplus 178. 39. Jahrgang. ARCH+ Verlag GmbH. Aachen. Juni 2006. ISSN: 0587-3452. Pág. 35. Traducción de la autora: "Paradoxerweise arbeiten wir jedoch nicht an der Form, wir arbeiten zunächst an all den anderen Dingen: am Klang, an den Geräuschen, an den Materialien, am Körper der Architektur, der sich [...] aus der Konstruktion, der Anatomie, der Logik des Konstruierens zusammensetzt. Wir arbeiten an all diesen Dingen und schauen immer gleichzeitig auf den Ort und den Gebrauch."

7 ZUMTHOR, Peter. Pensar arquitectura. Editorial Gustavo Gili. S.A. Barcelona. 2010. ISBN: 978-84-2522730-1. Pág. 66. 


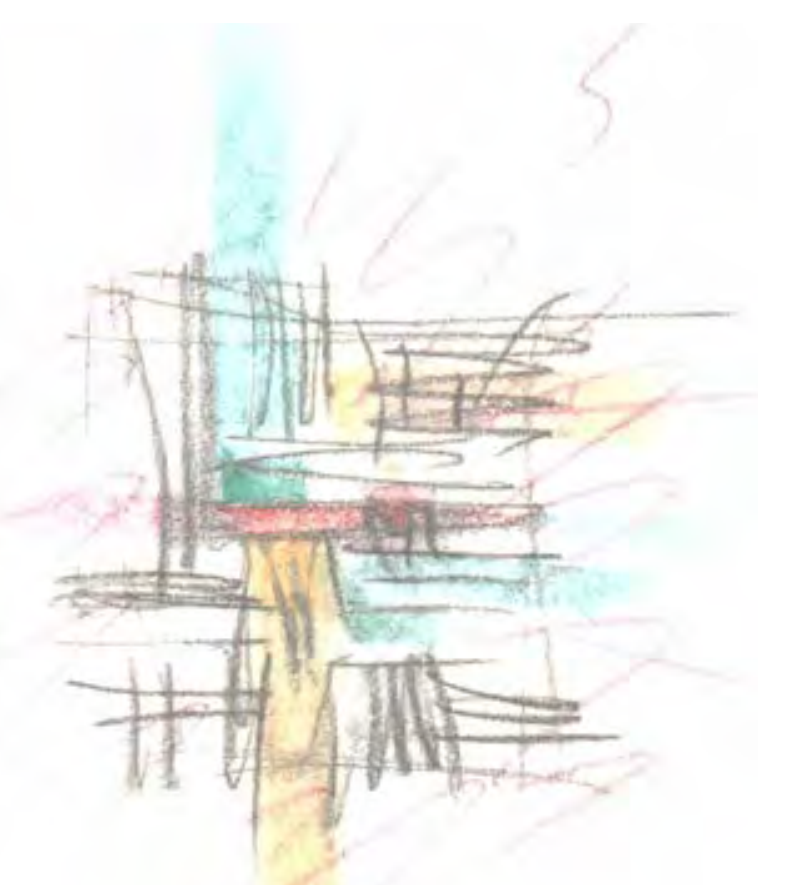

Figura 6.

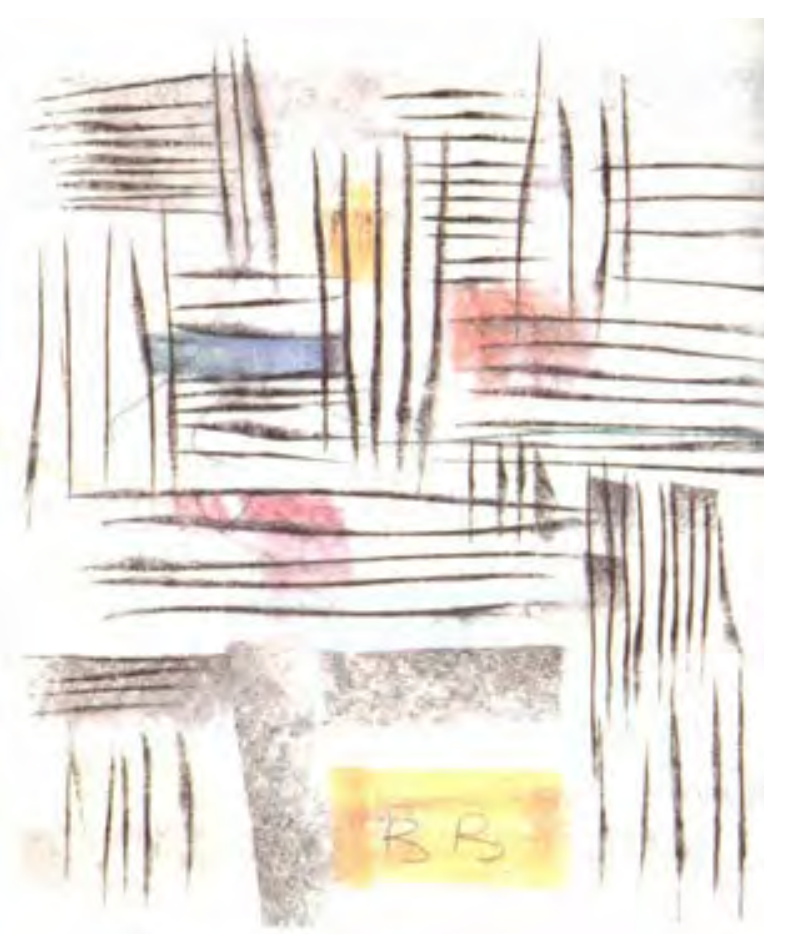

Figura 7. 


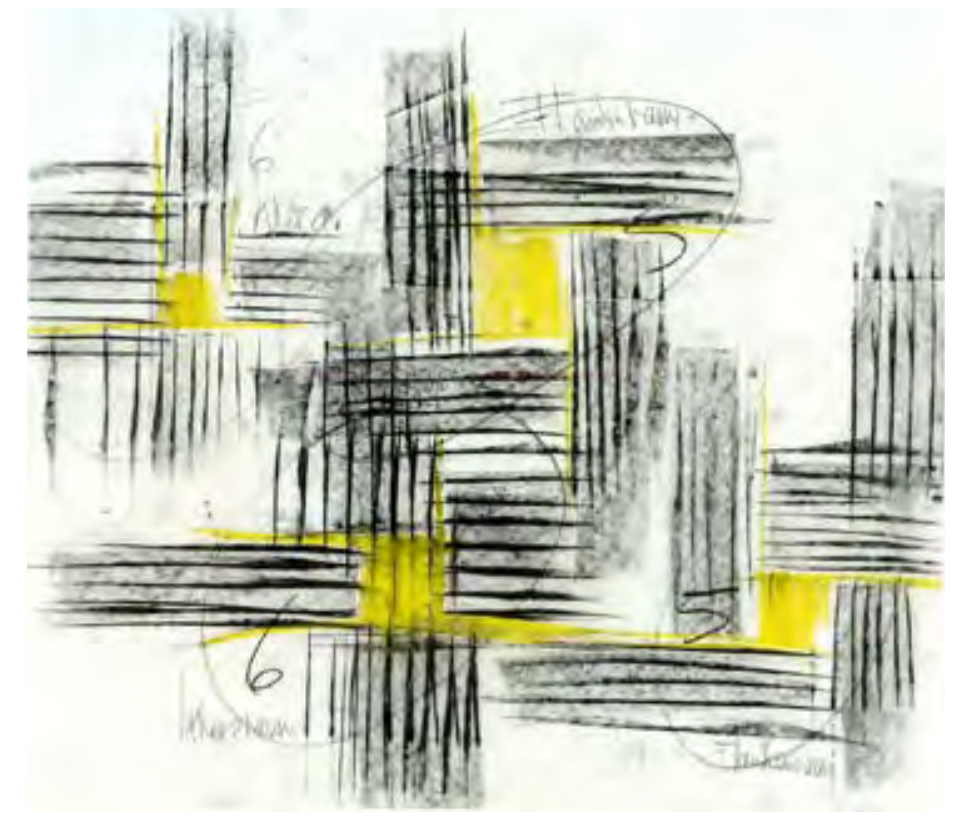

Figura 8.

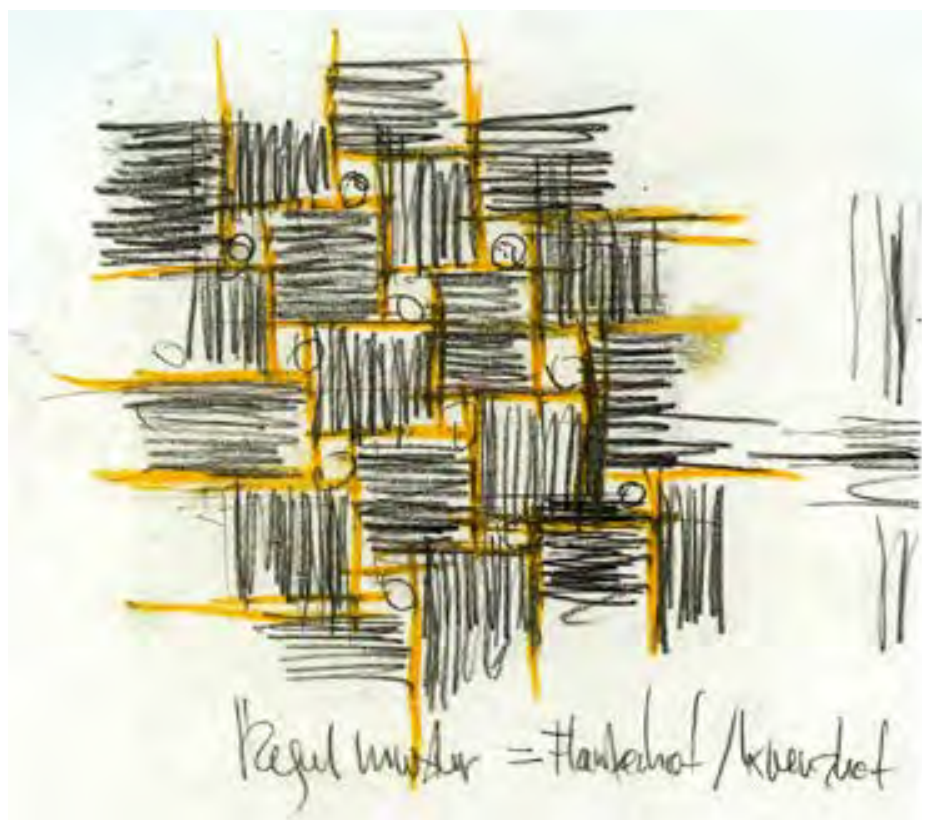

Figura 9.

Croquis inicial / Pabellón helvético / Peter Zumthor 



\section{[Puzzles]}

"Al principio el arte del puzzle parece un arte breve, un arte de poca entidad, contenido todo él en una elemental enseñanza de la Gestalttheorie: el objeto considerado -ya se trate de un acto de percepción, un aprendizaje, un sistema fisiológico o, en el caso que nos ocupa, un puzzle de madera- no es una suma de elementos que haya que aislar y analizar primero, sino un conjunto, es decir una forma, una estructura: el elemento no preexiste al conjunto, no es ni más inmediato ni más antiguo, no son los elementos los que determinan el conjunto, sino el conjunto el que determina los elementos: el conocimiento del todo y de sus leyes, del conjunto y su estructura, no se puede deducir del conocimiento separado de las partes que lo componen: esto significa que podemos estar mirando una pieza de un puzzle tres días seguidos y creer que lo sabemos todo sobre su configuración y su color, sin haber progresado lo más mínimo: sólo cuenta la posibilidad de relacionar esta pieza con otras (...)"1"8 Georges Perec

El pabellón ejecutado, Klangkörperbau, es arquitectura con un orden impuesto, un sistema completamente modular. El crecimiento por adición, repetición de unidades dimensional y materialmente idénticas. Como un puzzle, un collage espacial, un paisaje de acontecimientos, un espacio de situaciones y actividades. Un tablero de juego cuyas reglas predisponen la posición de las piezas generando diversas posibilidades y variantes. Un sistema complejo, repetitivo, no-jerárquico, variable, continuo.

$$
\begin{aligned}
& \text { "El sistema de construcción modular se basa en el desmontaje del } \\
& \text { edificio en partes individuales." }{ }^{\prime \prime} \text { Hans Schmidt }
\end{aligned}
$$

Zumthor introduce la presencia reguladora de la geometría como herramienta compositiva, como sistema de ordenación formal. Esta permite precisar y fijar la disposición y el crecimiento de los elementos en el pabellón. Se trata de "un sistema

8 PEREC, Georges. La vida instrucciones de uso. En: Georges Perec: poética narrativa y teoría literaria (selección de textos): la experimentación oulipiana. Anthropos Editorial. Barelona. 1992. ISSN: 11302089. Pág. 69.

9 SCHMIDT, Hans. Baukastensystem und Architektur. En: Deutsche Architektur 11. 1962. Pág. 170-175. Traducción de la autora: "Das Baukastensystem beruht auf der Zerlegung des Bauwerks in einzelne Teile..." 


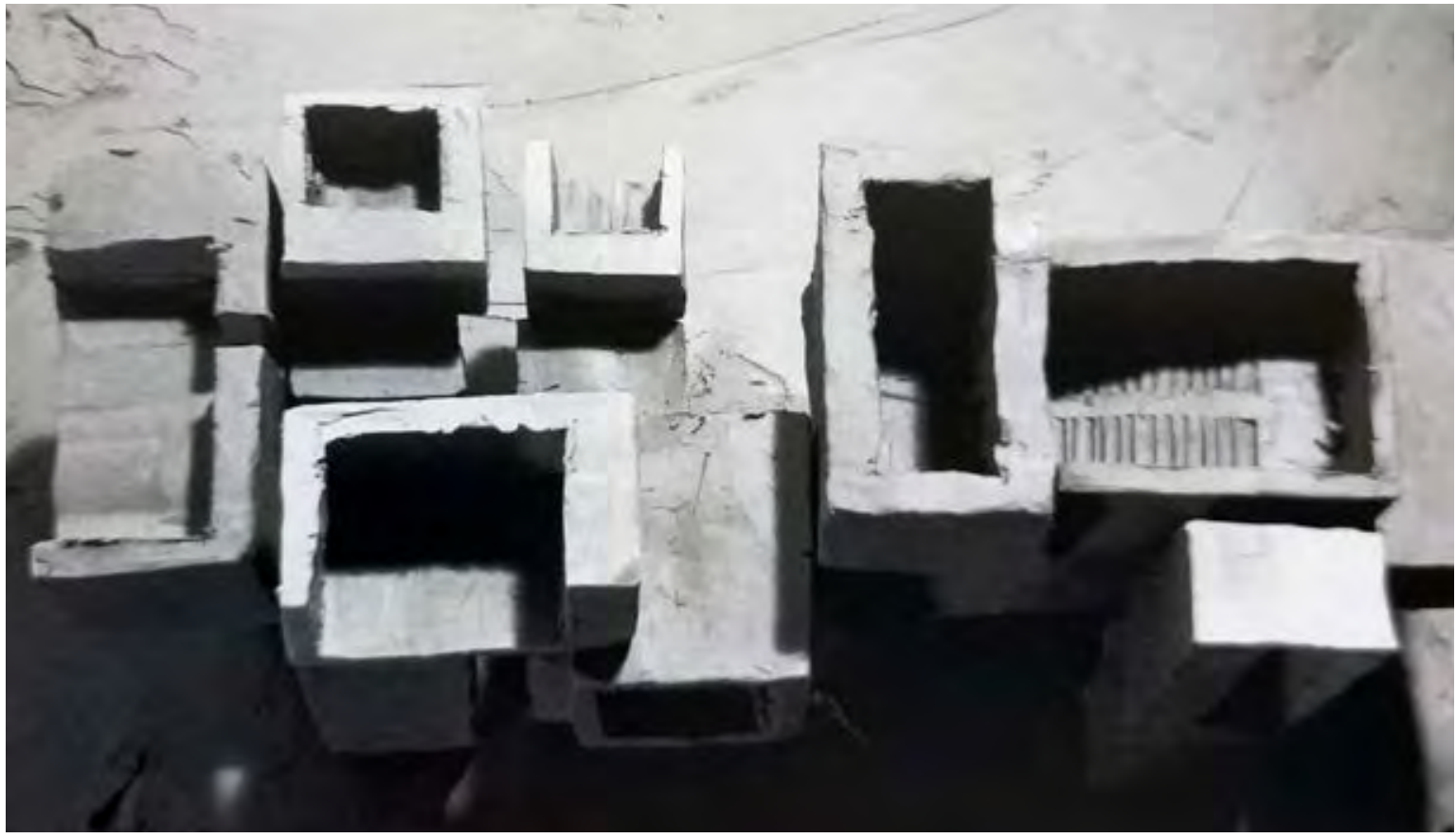

Figura 11.

Laban Centre for Movement and Dance / Londres, Inglaterra / 1997 / Peter Zumthor

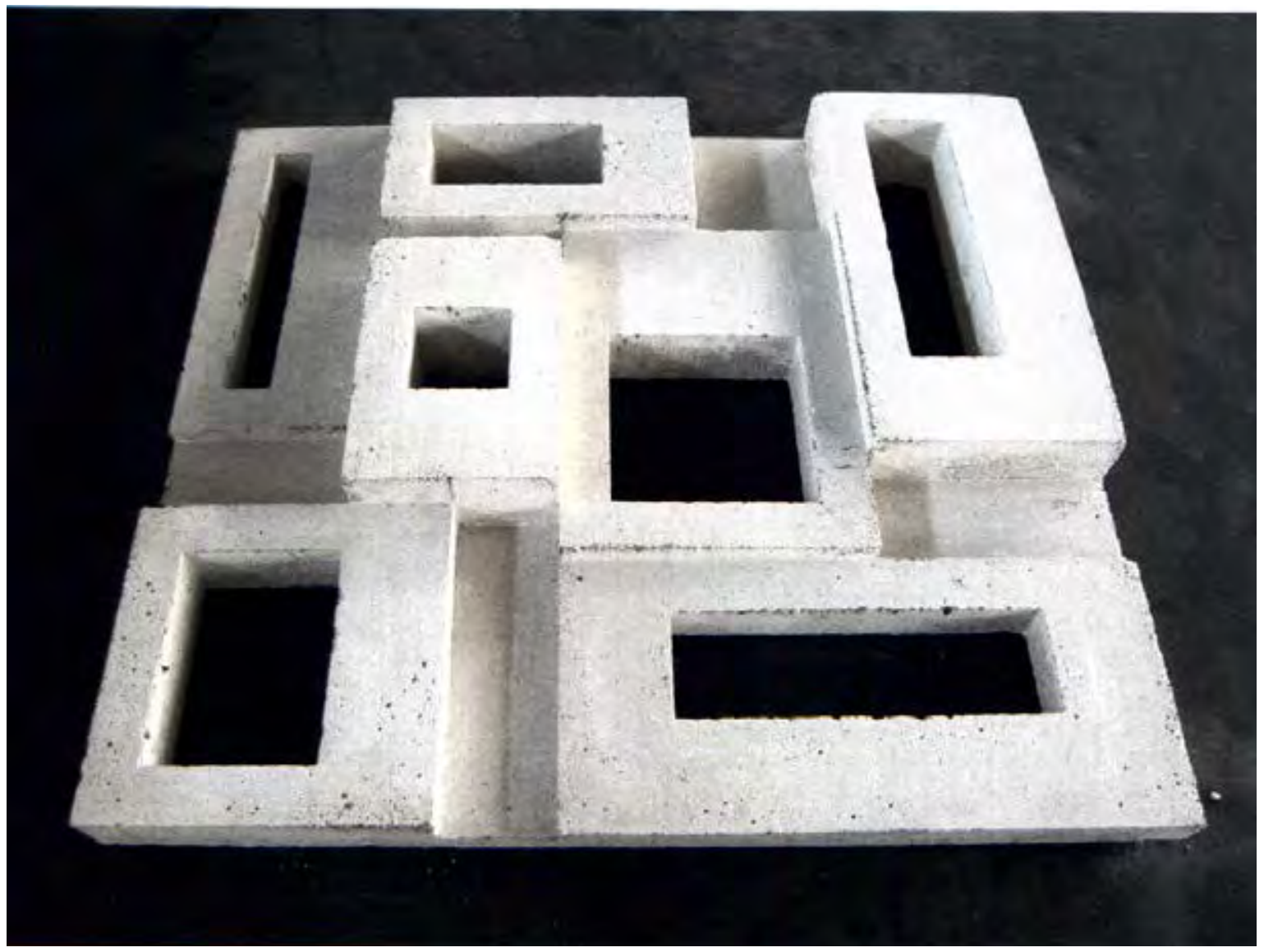

Figura 12.

House of Seven Gardens / Doha, Quatar / 2009 - / Peter Zumthor 
invisible de líneas de orden en ángulo recto, que otorgan coherencia a la composición de la planta"10. Una jenga donde cada pieza autónoma forma una parte indisoluble del tejido del pabellón.

Cómo una morfología urbana con sus diferentes componentes tipológicos, el conjunto del Klangkörper surge de las relaciones geométricas y repetitivas, creando un equilibrio entre la escala pequeña y grande, entre el orden y el caos, entre adición y substracción, entre las partes individuales y las partes agrupadas, entre el lleno y vacío, entre la ausencia y la presencia.

"La construcción es el arte de configurar un todo con sentido a partir de muchas particularidades."11 Peter Zumthor

"Orden sin diversidad puede resultar en monotonía y aburrimiento; diversidad sin orden puede resultar un caos"12 Francis D. K. Ching

Dentro de la reglamentación del juego, aparecen algunas modificaciones adaptativas para acomodarse dentro del entramado. Mutaciones funcionales, dimensionales, de orientación o incluso de proporción; cualifican los espacios con direccionalidad, flexibilidad programática y continuidad espacial.

El espacio es definido define mediante un proceso de reducción a elementos básicos y modulares, todos ellos en un único material enfatizando esta condición. Austeridad material como mecanismo para acentuar exclusivamente las propiedades de las superficies, y el juego de luces y sombras. Una misteriosa seriedad en los espacios ${ }^{13}$. Todo ello en la búsqueda de un efecto atmosférico místico sin distracciones inoperantes.

10 ZUMTHOR, Peter. Therme Vals. Scheidegger \& Spiess. Zürich. 2008. ISBN: 978-3-85881-704-4. Pág. 58. Nota: "invisible system of orderin lines that run at right angles to each other and lend cohesion to the composition of the floor plan"

11 ZUMTHOR, Peter. Pensar la arquitectura. Editorial Gustavo Gili. Barcelona. 2010. ISBN: 978-84-2522730-1. Pág. 11

12 CHING, Francis D.K. Architecture-form, space, \& order. 3rd ed. John Wiley \& Sons, Inc., Hoboken, New Jersey. 2007. ISBN 978-0-471-75216-5. Pág. 338. Traducción de la autora: "Order without diversity can result in monotony and boredom; diversity without order can produce chaos."

13 Entrevista a Tadao Ando. “Das Humane im Menschen fördern” En: Die Welt. 05.10.1999. https://www. welt.de/print-welt/article586338/Das-Humane-im-Menschen-foerdern.html. Nota: "Das bringt einen gewissen Ernst in die Räume. Aber ich denke, dass sie dem Individuum mehr Möglichkeiten der Entfaltung geben, dass sie ihn im besten Fall verändern. Auch wenn es ein hohes Ziel ist: Ich hoffe, dass die fehlende Ablenkung in meinen Gebäuden das Humane im Menschen fördert." Traducción de la autora: "Eso trae una cierta seriedad a los espacios. Pero creo que le dan al individuo más posibilidades de desarrollarse, que lo cambian en el mejor de los casos. Aunque es un objetivo alto: Espero que la falta de distracción en mis edificios promueva la humanidad en las personas." 


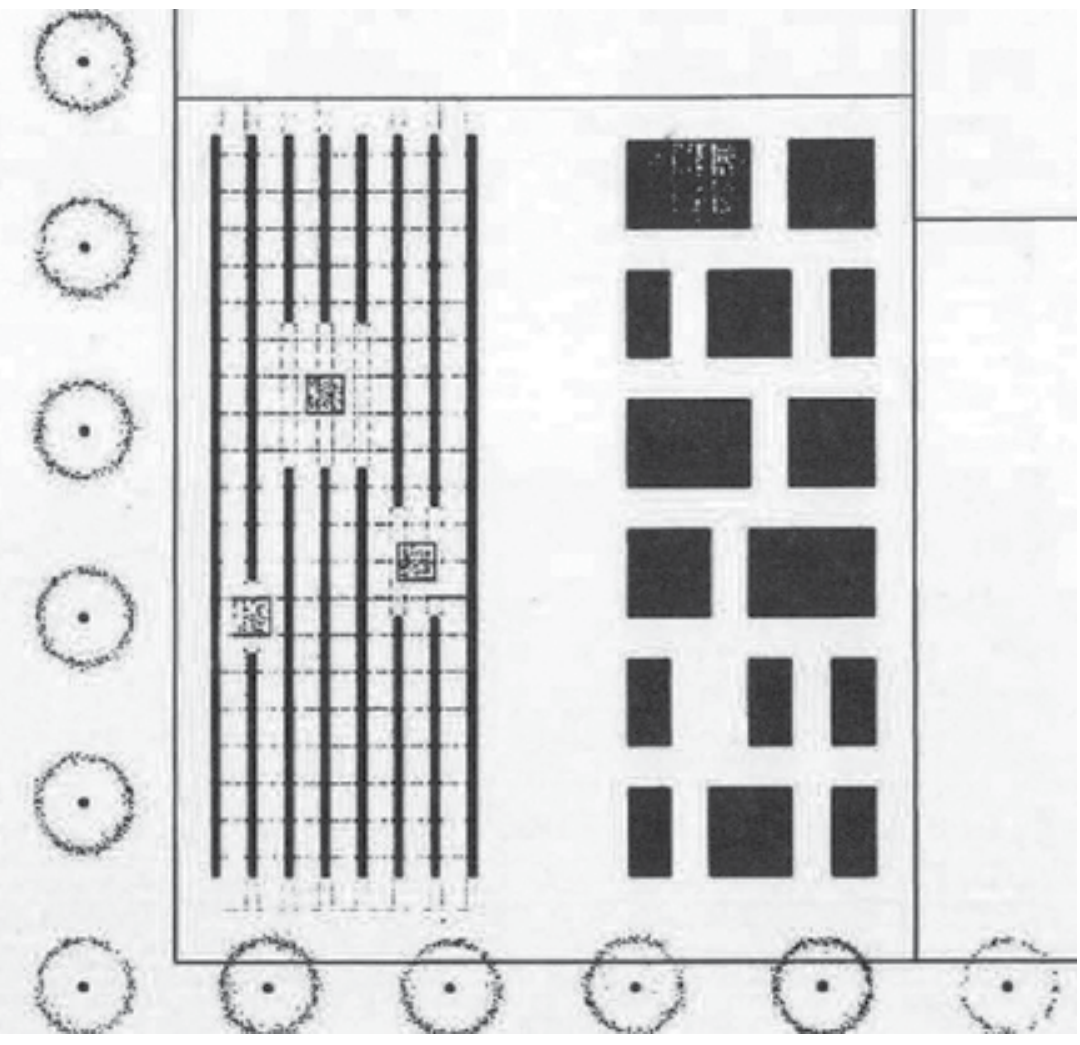

Figura 13.

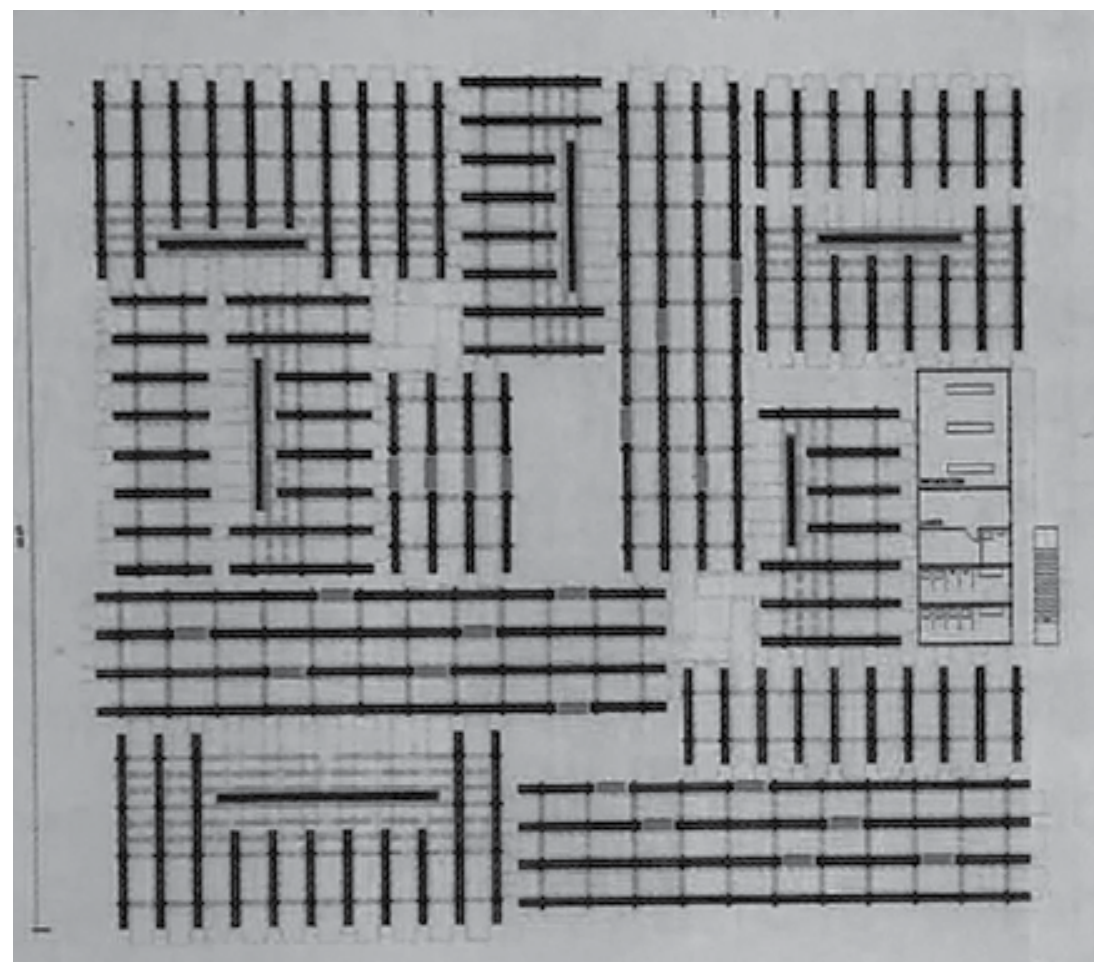

Figura 14. 


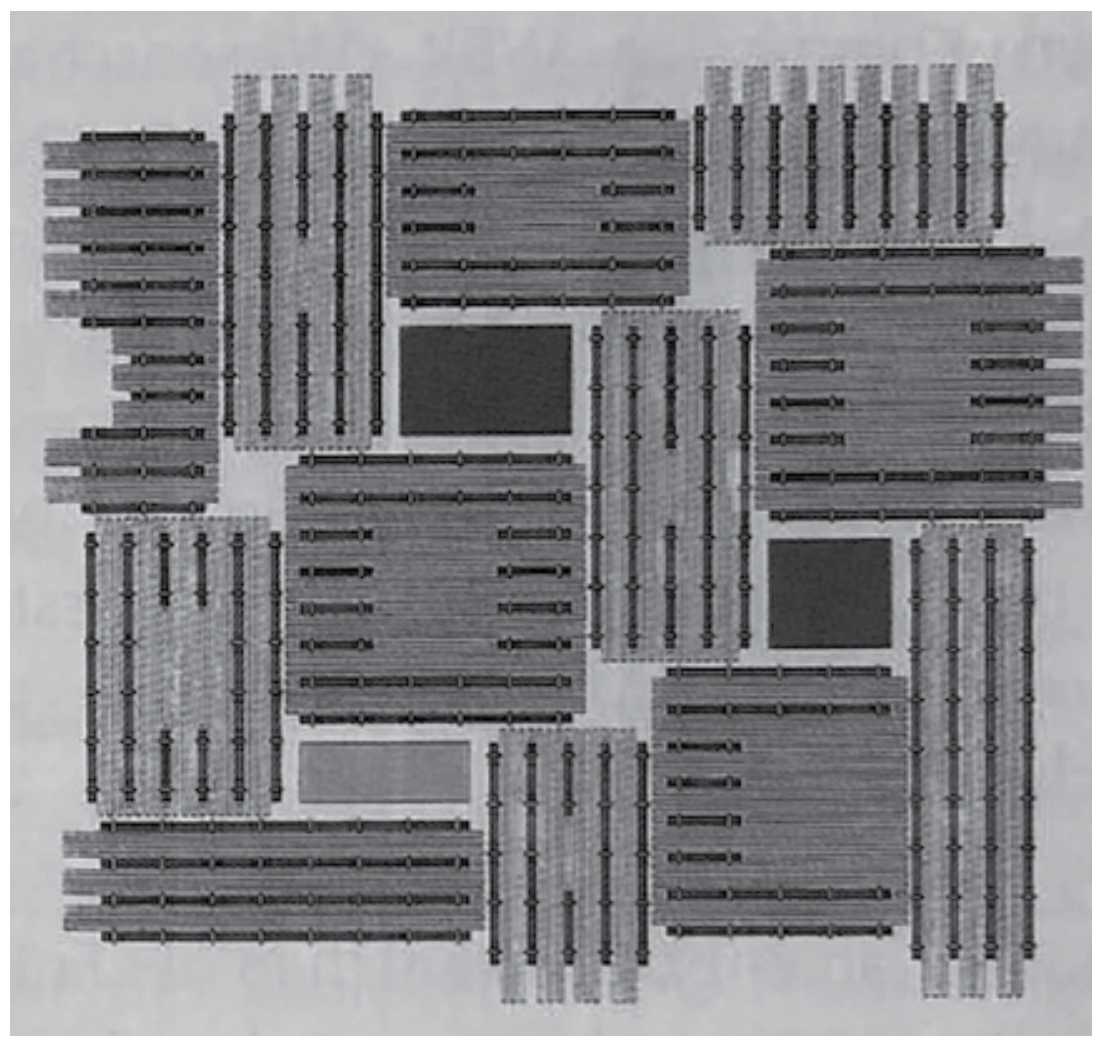

Figura 15.

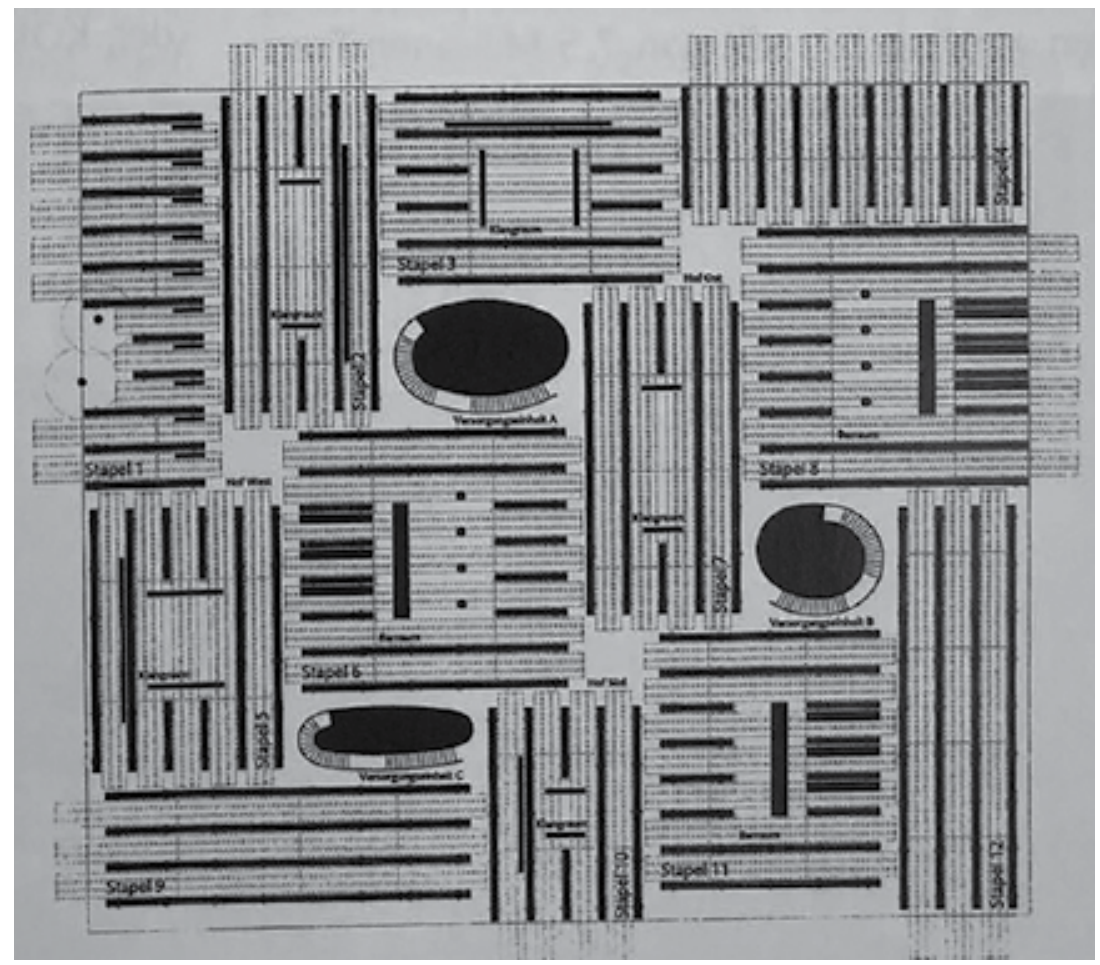

Figura 16.

Evolución de la planta de arriba a abajo. Desde el ámbito expositivo de la propuesta ganadora del concurso, dos aproximaciones intermedias del proceso y finalmente la distribución final del proyecto construido / Pabellón helvético / Peter Zumthor 


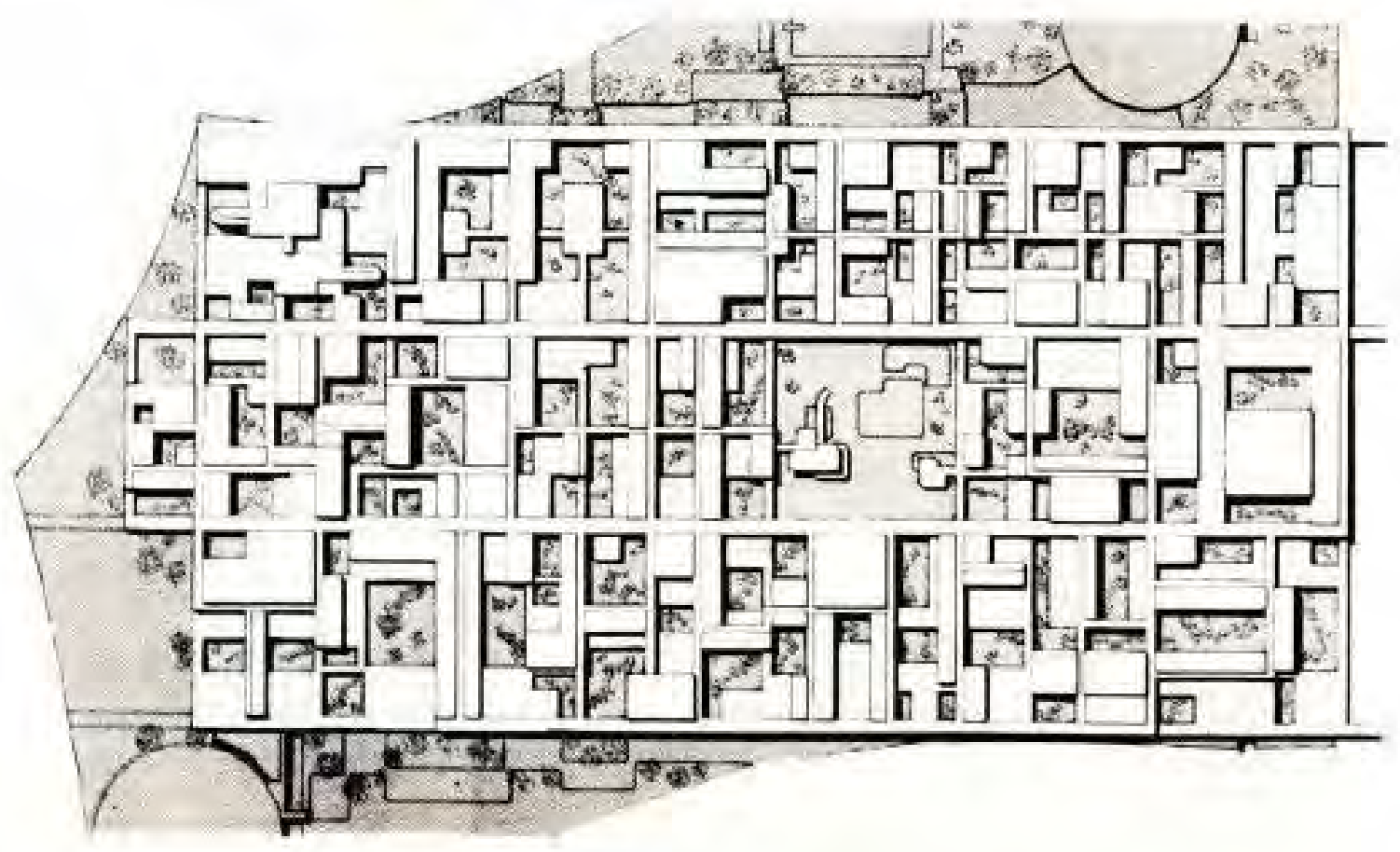

Figura 17.

Planta / Freie Universität de Berlín / Candilis, Josic, Woods

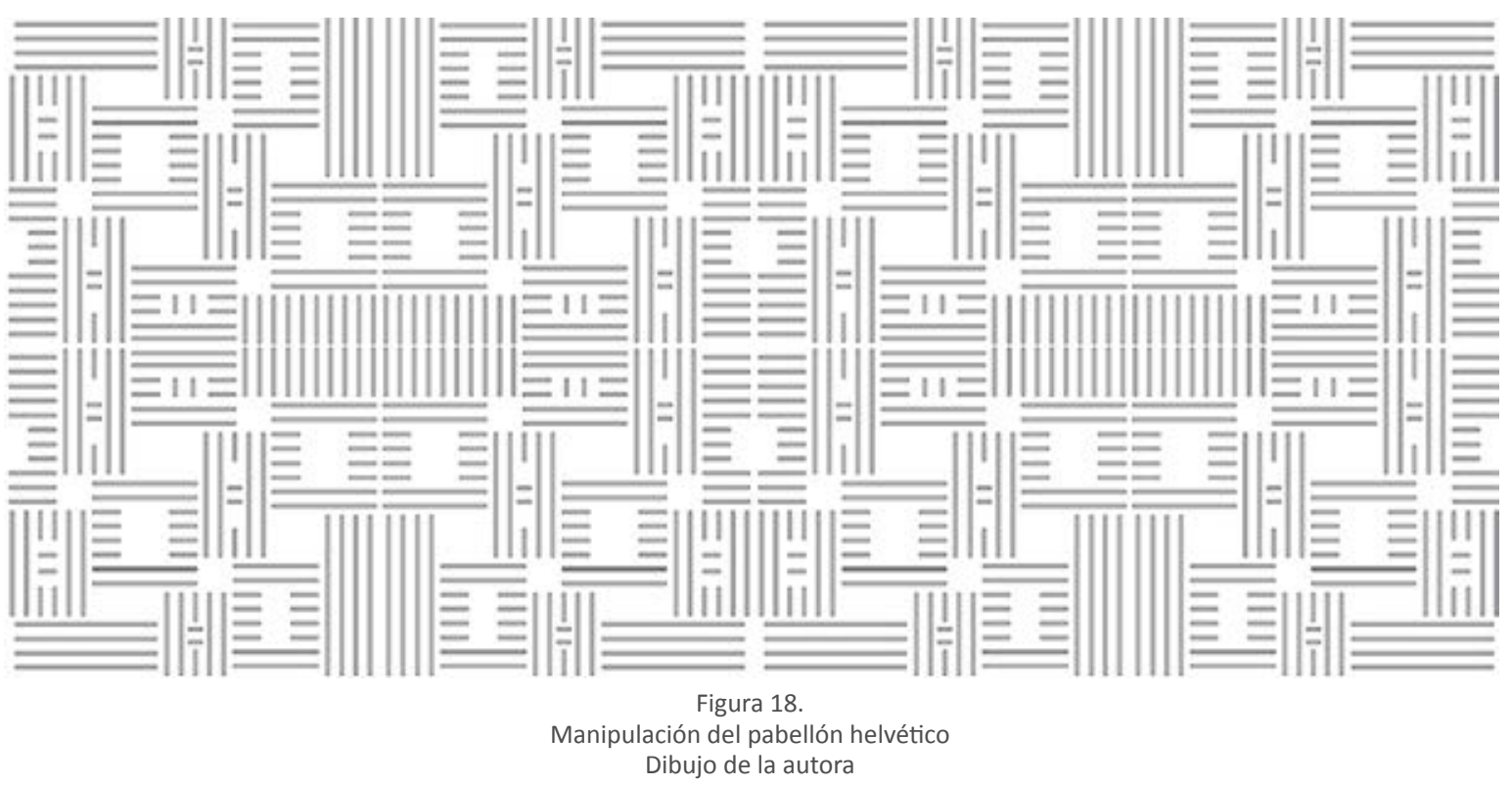




\title{
[Mat-building]
}

\begin{abstract}
"Se puede decir que el Mat-building personifica el carácter anónimo de lo colectivo, donde las funciones vienen a enriquecer lo construido y el individuo adquiere nuevas libertades de actuación gracias a un nuevo y cambiante orden, basado en la interconexión, los tupidos patrones de asociación y las posibilidades de crecimiento, disminución y cambio."14 Alison Smithson
\end{abstract}

El término inglés mat, alfombra o estera, alude al plano del suelo. En el artículo ${ }^{15}$ publicado en 1974 en la revista británica Architectural Design, Alison Smithson ${ }^{16}$ fusionará este concepto con la arquitectura, generando una nueva tipología, los Mat-Buildings. A través de un atlas visual de "edificios-alfombra" se definieron diversas condiciones arquitectónicas. Unas eran formales como la extensión horizontal, la complejidad compositiva o el crecimiento aditivo de edificios con alturas bajas; y otras contenían un ámbito más operativo como la posibilidad de crecimiento, decrecimiento, transformación o variación según las necesidades. Todo ello en un sistema basado en múltiples relaciones, conexiones, flujos, usos, movimientos; con unas reglas nítidas a través de la geometría y la repetición. Un proceso reconfigurable, una matriz como instrumento de interconexión.

\begin{abstract}
"La versión construida de la Universidad Libre de Berlín nos permite reconocer sus antecedentes $y$, dependiendo de la receptividad personal de cada uno, reconocer aquello que lo ha llevado hasta alli'17 Alison Smithson
\end{abstract}

La Freie Universität - Universidad Libre de Berlín-Dahlem fue unos de los ejemplos mencionados en el artículo. Este Mat-Building paradigmático, tuvo su origen en el aumento del número de estudiantes en Alemania tras el fin de la Segunda Guerra Mundial. La Universidad Libre de Berlín fue fundada por profesores y estudiantes

14 SMITHSON, Alison. Como reconocer y leer un mat-building. Evolución de la arquitectura actual hacia el mat-building. En: DPA. Documents de Projectes d'Arquitectura. Departament de Projectes Arquitectònics. U.P.C. Barcelona. 2011. ISBN: 978-84-615-5561-1.

15 SMITHSON, Alison. How to recognise and read mat-building. Mainstream architecture as it has developed towards the mat-building. En: Architectural Design. Vol XLIV. 9/1974. Pág. 573-590.

16 Nota: Tras la disolución del CIAM en 1959, en su última reunión en Otterlo, la generación joven -incluido el Team X-comenzó a organizar reformas y reuniones informales como reacción frente a las respuestas de CIAM, debido a la insatisfacción con los principios arquitectónicos de la posguerra, que se habían osificado bajo el modelo de la ciudad funcional. Entre los miembros se encontraban Alison y Peter Smithson, Aldo van Eyck, Georges Candilis, Shadrach Woods, Jaap Bakema, entre otros, quienes presentaron nuevos proyectos y se criticaron mutuamente en sus reuniones.

17 SMITHSON, Alison. Como reconocer y leer un mat-building. Evolución de la arquitectura actual hacia el mat-building. En: DPA. Documents de Projectes d'Arquitectura. Departament de Projectes Arquitectònics. U.P.C. Barcelona. 2011. ISBN: 978-84-615-5561-1. 


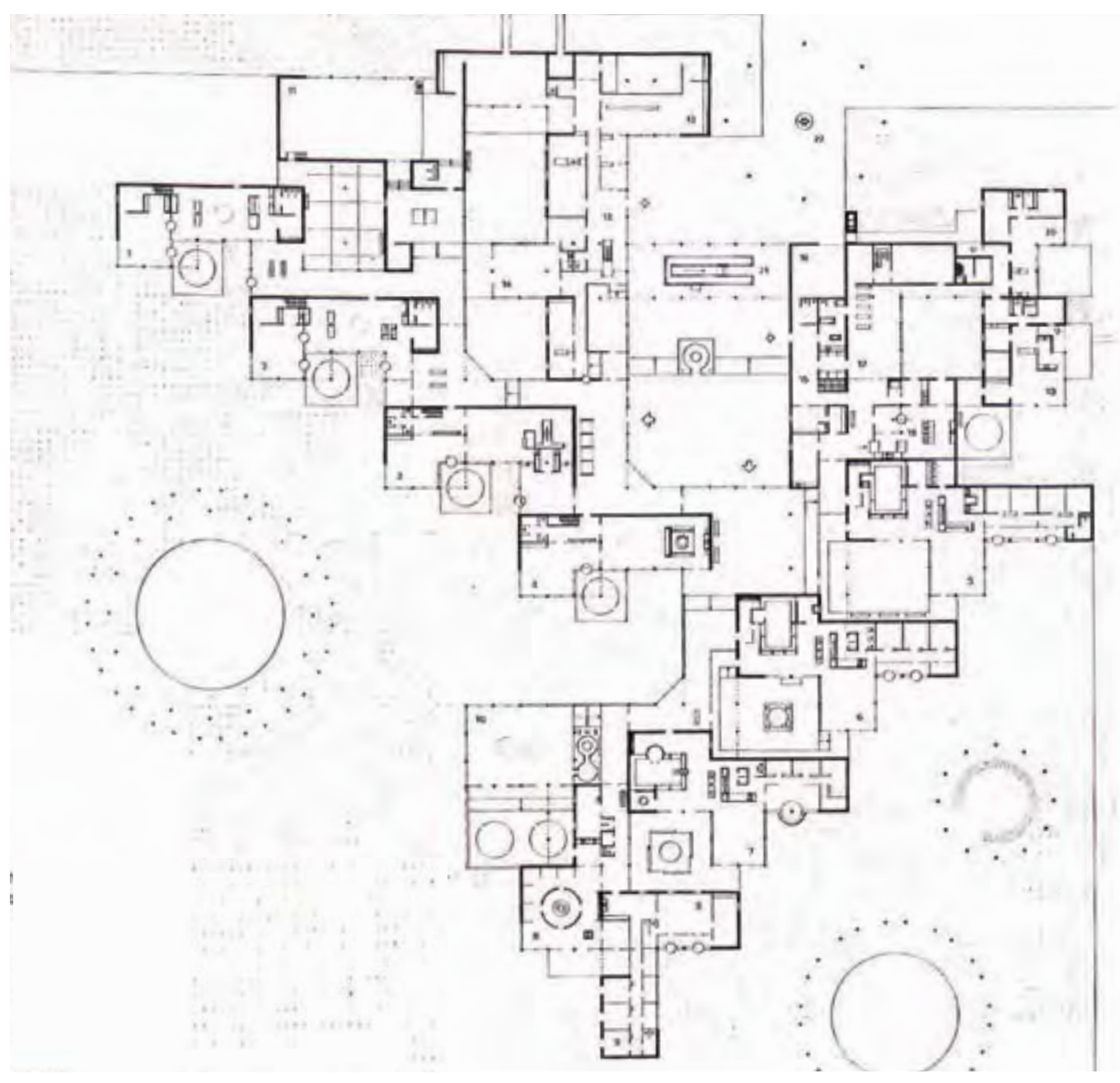

Figura 19.

Orfanato Municipal de Ámsterdam / 1955 - 1960 / Aldo van Eyck
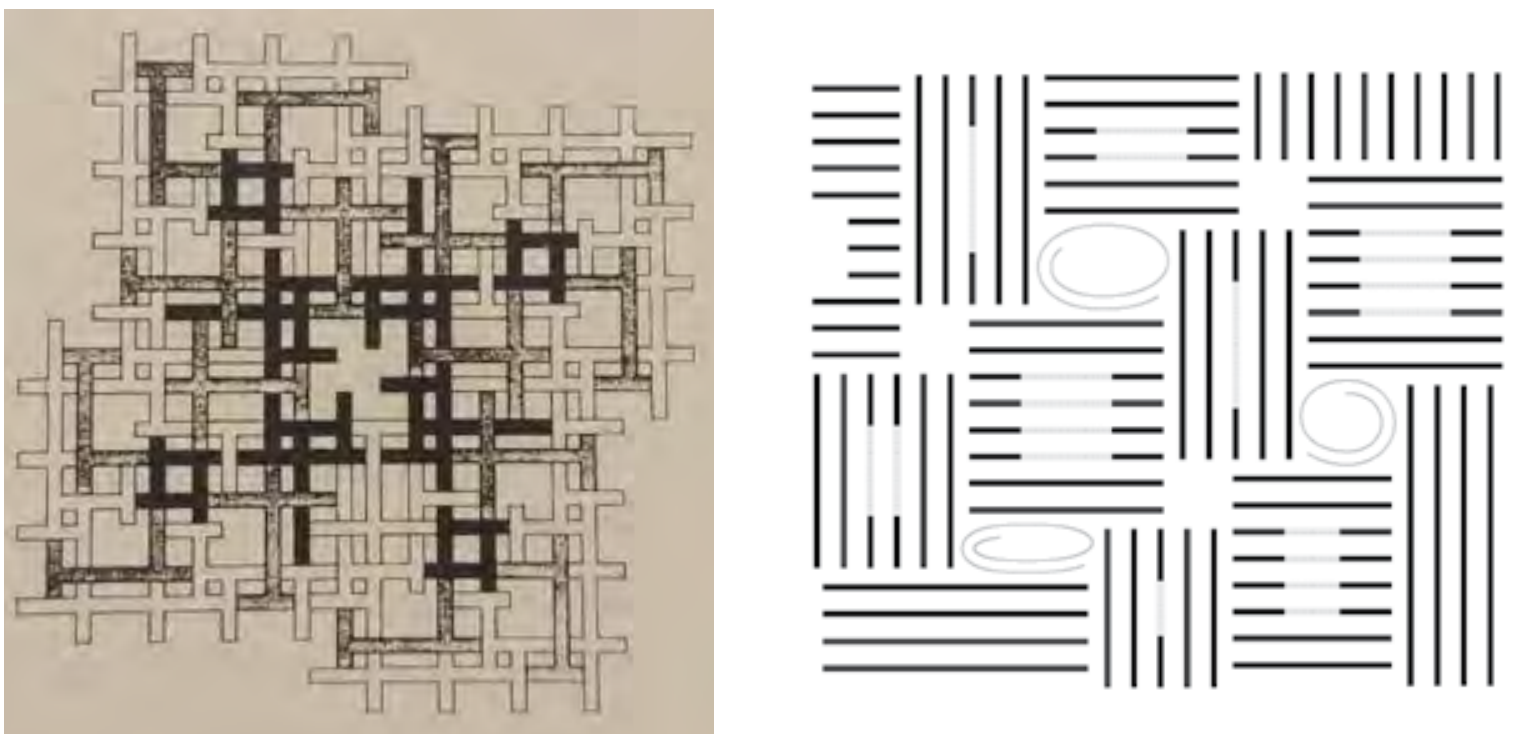

Figura 20 - 21.

Noah's Ark / 1962 / Piet Blom

Pabellón helvético / Peter Zumthor 
de la Humboldt Universität después de la división de la capital tres años más tarde. Inicialmente se alojó en unas residencias privadas, pero ante la necesidad de espacio en 1963 se convocó un concurso internacional de arquitectura ${ }^{18}$ para el desarrollo de una universidad central. Los discípulos de Le Corbusier; el griego George Candilis, el serbio Alexis Josic y el estadounidense Shadrach Woods fueron los autores de la propuesta ganadora.

El proyecto fue construido, en colaboración con el alemán Manfred Schiedhelm y el francés Jean Prouvé, en una fase inicial entre 1967-73 y otra final entre 1978-80. Con una densa organización y un sistema circulatorio estructurador, se mostraba como una reinterpretación del concepto vernáculo de $K_{a s b a h^{19}}$. Su esquema funcional no segrega entre zonas de residencia, trabajo, ocio y trafico. La denominada popularmente Rostlaube $^{20}$ de dos y tres plantas tipo cluster, tiene un sistema de construcción prefabricado cuyas dimensiones se derivan del Modulor,. Un organismo de extensión horizontal flexible y adaptable; un groundscraper ${ }^{21}$ de patios y bandas de comunicación.

Otras referencias descritas por Alison Smithson en su articulo fueron la Universidad de Toulousse (1971-73) o Fort Lamy (1964-65) también de Candilis-Josic-Woods, el Orfanato de Ámsterdam de Aldo van Eyck (1957-60), el Plan de Filadelfia de Kahn (1953-55), el Hospital de Venecia de Le Corbusier (1964), así como la Villa Imperial Katsura en Kioto, entre otros. Sin embargo, la propuesta académica Noah's Ark de Piet Blom en 1962 no fue considerado como un Matbuilding. En 1962 fue presentado por Aldo van Eyck en el Congreso de Royaumount como una mega-estructura de patrones entrelazados para dar una respuesta alternativa al desarrollo urbano. Algunos miembros de Team X consideraron que este proyecto estaba desvinculado del paisaje circundante; así como que era en sí mismo un sistema cerrado debido a "un resultado artístico más puro, mediante acciones como la repetición, rotación simetría, reflejo, alteración positiva/negativa y relacione de dichos elementos bajo el control de las matemáticas ${ }^{\prime 22}$. Alison Smithson lo describió como "un esquema rudimentario... completamente dogmático y alemán - completamente fascista ${ }^{\prime 23}$ por su estricto orden geométrico a base de una esvástica.

18 Nota: En el jurado del concurso destacaba la presencia de Jaap Bakema y Arne Jacobsen.

19 Nota: Los autores trabajaban en Marruecos y Argelia, a principios de los años cincuenta, dentro del ATBAT-Afrique.

20 Nota: Rostlaube - casita oxidada se deriva del material utilizado: acero corten

21 Nota: Según Shadrach Woods; rascasuelo versus rascacielo, horizontal versus vertical, groundscraper versus un organismo en altura. PINTRE, Basilio Tobías. Candilis, Josic, Woods: dos universidades. Zarch № 5. Zaragoza. 2015. ISSN: 2341-0531. Pág. 260.

22 PALACIOS LABRADOR, Luis. Hacia un método de configuración. Van Eyck / Blom / Hertzberger. Iniciadores y sucesores. Tesis doctoral. ETSAM - UPM. Madrid. 2017. Pág. 171.

23 STRAUVEN, Francis y LIGTELIJN, Vincent. Collected Articles and Other Writings 1947-1998. SUN Publishers. Amsterdam. 2008. ISBN: 978-90-8506-262-2. Pág. 436. Traducción de la autora: “Aldo, explain why you brought this ruddy scheme....This is completely dogmatic and German - completely fascist. Explain why you brought it." 


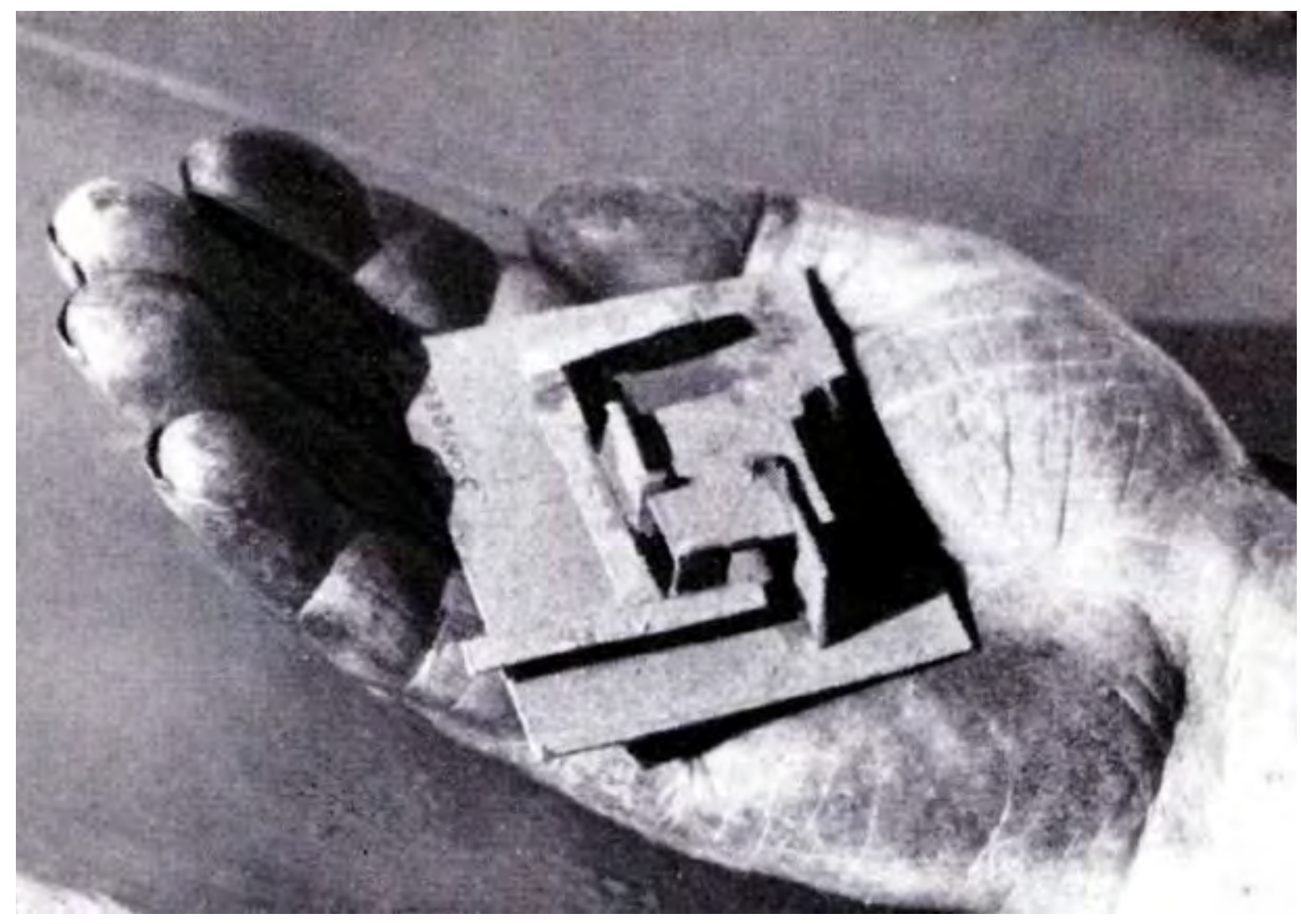

Figura 22.

Pabellón Sonsbeek / Arnhem / 1955 / Gerrit Rietveld
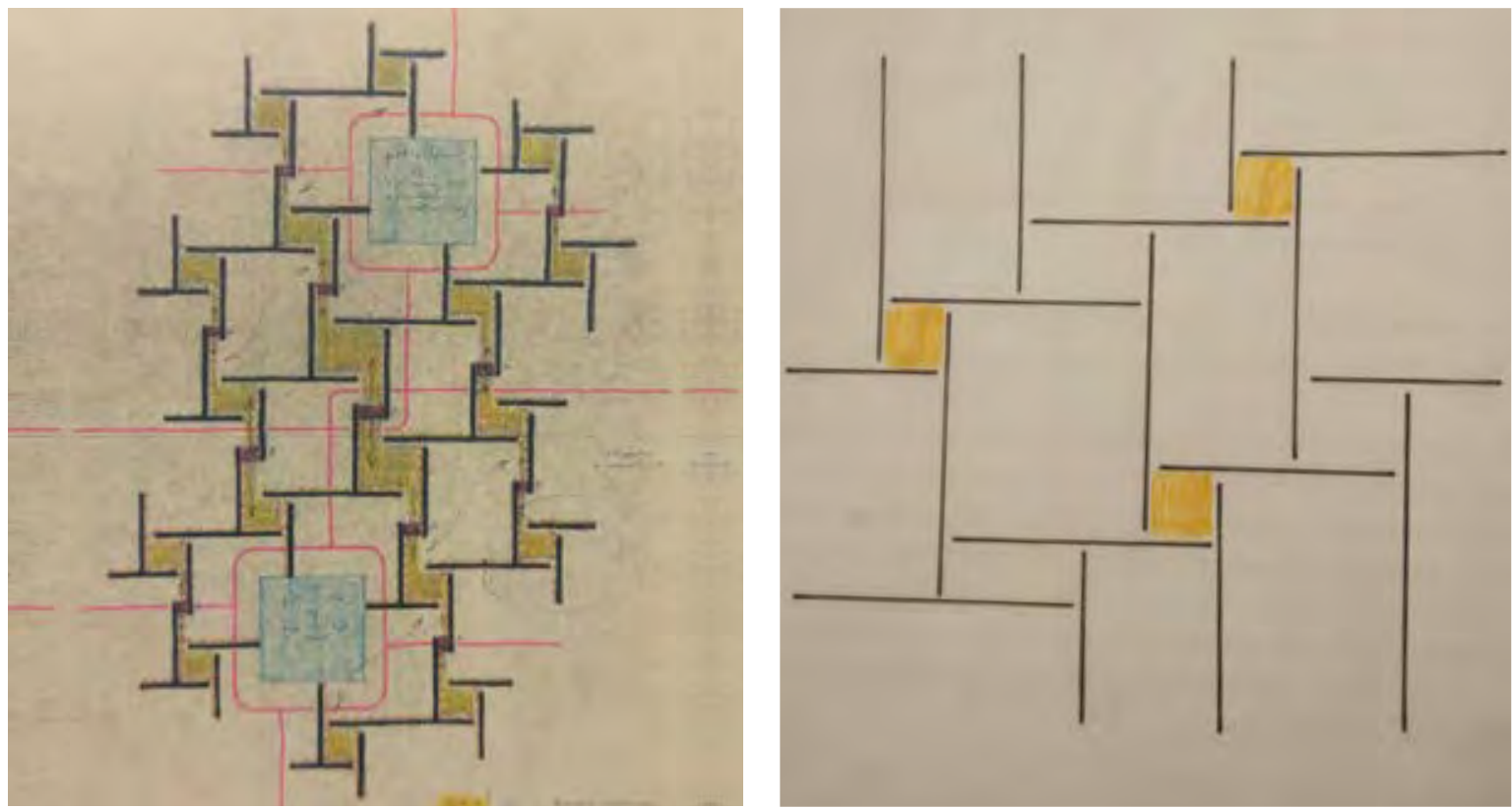

Figura 23 - 24

Buikslotermeer / 1962 / Aldo van Eyck

Esquema del pabellón helvético / Peter Zumthor 


\section{[Swastika]}

"Visto desde arriba, el edificio parece asomar espontáneamente desde el tejido de las calles, canales y pequeñas plazas, como una parte de una parcela amenizada por una ley de generación automática similar a la que hay tras el crecimiento de las ramas de un árbol."24 Roberto Gargiani

El método compositivo en esvástica ${ }^{25}$, fue recurrente durante el siglo pasado. Su capacidad de concentrar espacios en torno a un centro, además de su condición no axial, supusieron un campo alternativo de exploración compositiva y organizativa en planta. Proyectos paradigmáticos como la Casa de Campo de hormigón de 1923 de Mies van der Rohe, la Casa del desierto Kaufmann de 1946 en Palm Springs de Richard Neutra, la propuesta urbana no realizada para el distrito Buikslotermeer de Ámsterdam de 1962 de Aldo van Eyck, el pabellón Sonsbeek en Arnhem de 1955 de Gerrit Rietveld o incluso la Escuela de la Bauhaus de 1925-32 en Dessau de Walter Gropius fueron respuestas de ordenación rotatoria en molinillo.

Frank Lloyd Wright fue posiblemente uno los mayores impulsores modernos de este mecanismo compositivo. Sus estudios de organización de viviendas en altura como la propuesta no realizada de cuatro células por planta de la torre St. Mark de 1929, y la construida torre Price de 1955 son prueba de ello ${ }^{26}$. Así como en varios proyectos de viviendas unifamiliares como la Wingspread-Herbert F. Johnson House de 1938-39 en Racine (Wisconsin). Esta fue proyectada como residencia familiar para el propietario de la empresa Johnson Wax ${ }^{27}$. El centro de la casa es un espacio octogonal que contiene el calor del hogar, la chimenea coronada por una cúpula. A partir de este condensador se extienden cuatro ejes en esvástica. Cada aspa era una unidad independiente: espacios privados del dueño, para los niños, para los sirvientes y para los invitados y los $\operatorname{coches}^{28}$. Sus trazas en molinete son reminiscencias de otras

GARGIANI, Roberto, ROSELLINI, Anna. Beton Brut and inefable space, 1940-1965, Surface matrials and psychophysiology of visión. EPFL Press. Lausanne. 2011. ISBN: 978-2-940222-50-6. Pág. 576. Traducción de la autora: "Seen from above, the building seems to appear spontaneously from the fabric of streets, canals and small squares, like a part of that parcelling enlivened by an automtic generating law similar to the one behind the growth of the branches of a tree"

25 DAZA, Juan Carlos. Diccionario Akal de Francmasonería. Volumen 13. Ediciones Akal. 1997. ISBN: 9788446007388. Pág. 141. Nota: "Símbolo de gran antigüedad; Integra la cruz y los cuatro ejes en dirección rotatoria, como símbolo de la rotación axial (la rueda solar, con sus rayos y su movimiento), y al Dios del Sol"

26 Esquemas muy presentes en Sáenz de Oiza cuando proyectó Torres Blancas entre 1964-68.

27 Un año después de su sede corporativa, Johnson Wax Headquarters.

28 WRIGHT, Frank Lloyd. Humane Architektur. Bertelsmann Fachverlag. Gütersloh - Berlin. 1969. Pág. 238. 

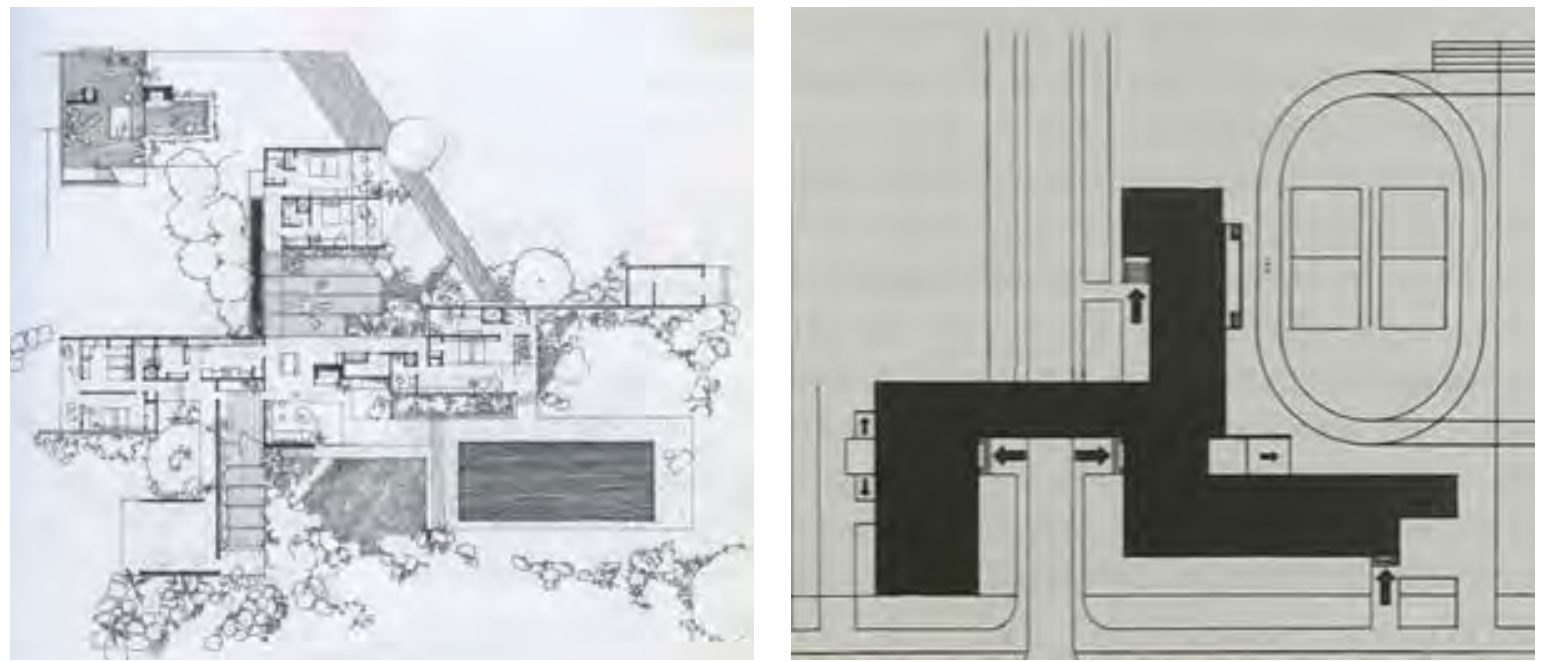

Figura $25-26$.

Casa del desierto Kaufmann / 1946 / Richard Neutra

Planta Bauhaus en Dessau / 1926 / Walter Gropius
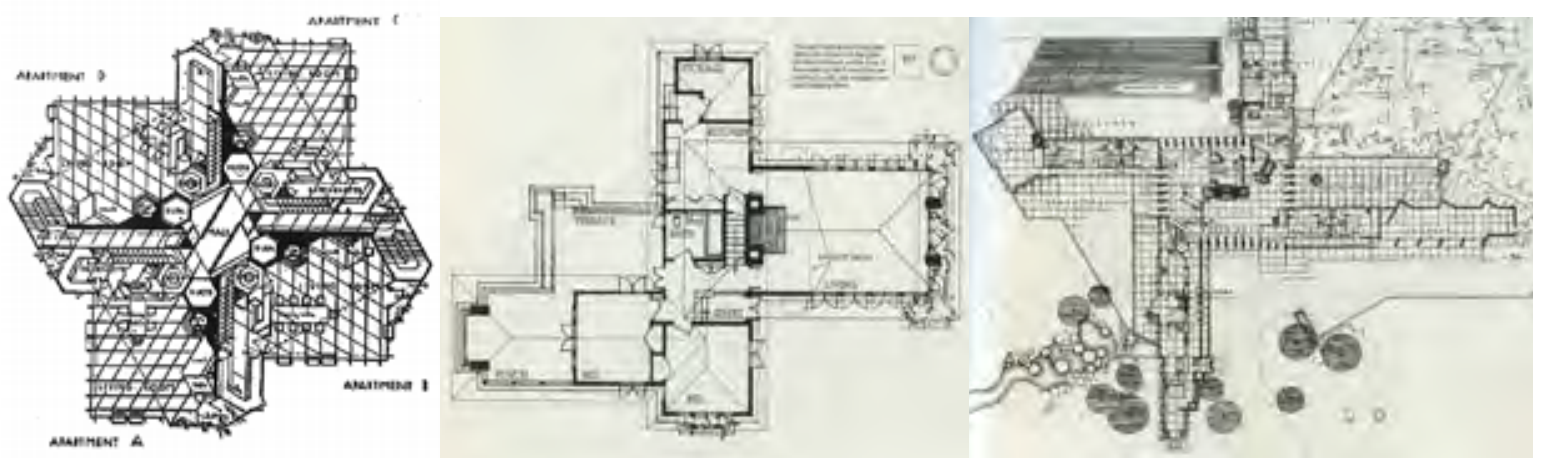

Figura 27 - 29

Torre de St. Mark / 1929 / Frank Lloyd Wright

Ernest Vosburgh Summer Residence / 1916 / Frank Lloyd Wright

Wingspread - Herbert F. Johnson House / 1938 - 1939 / Frank Lloyd Wright

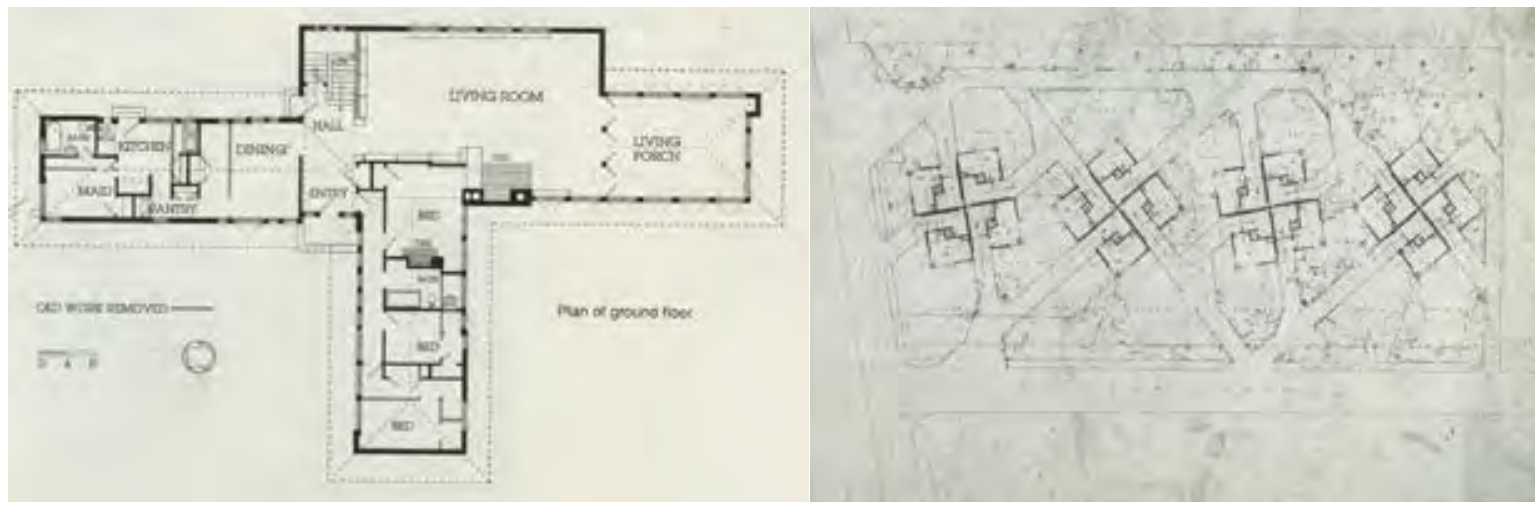

Figura 30 - 31

Sherman M. Booth Residence / 1915

Suntop Homes for Otto Mallery and the Todd Company / Pennsylvania / 1938/ Frank Lloyd Wright 

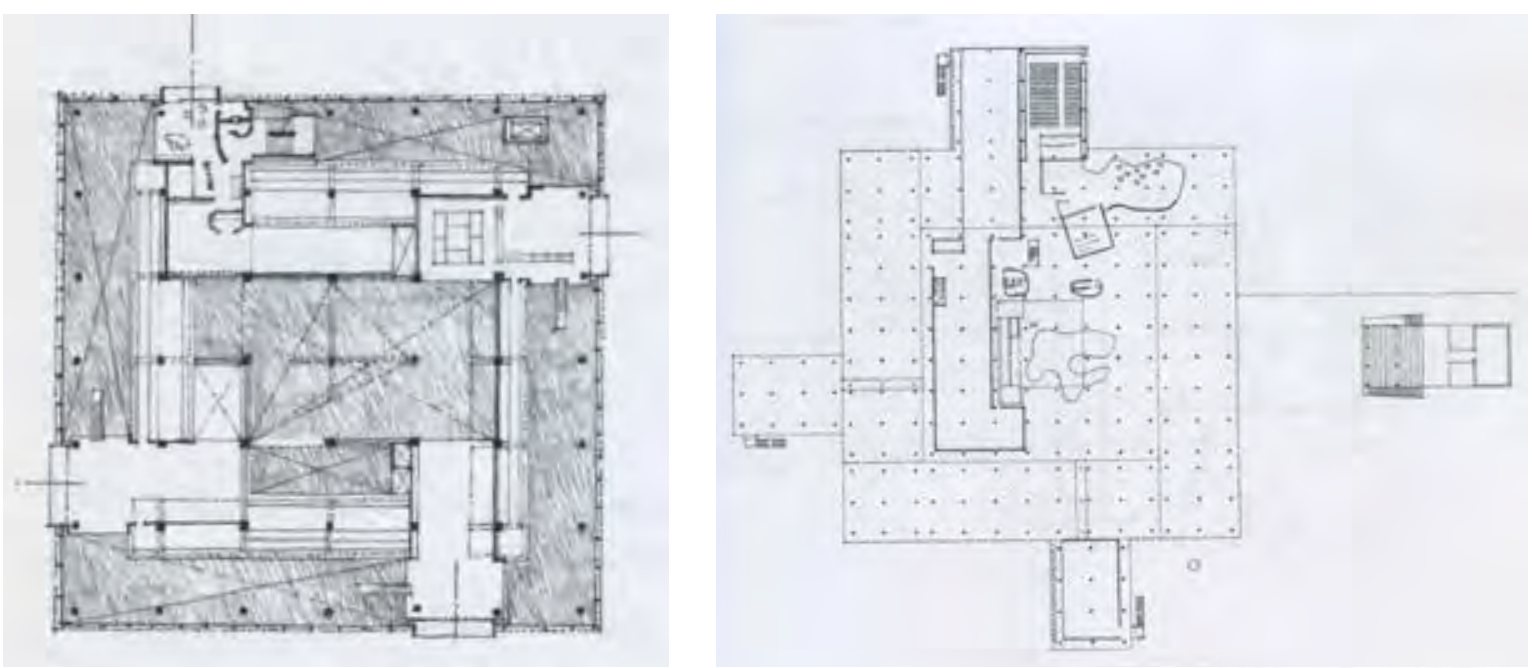

Figura 32 - 33.

Museo de Arte Occidental en Tokio / 1957 - 1959 / Le Corbusier

Senskar Kendra en Ahmedabad / 1955/ Le Corbusier

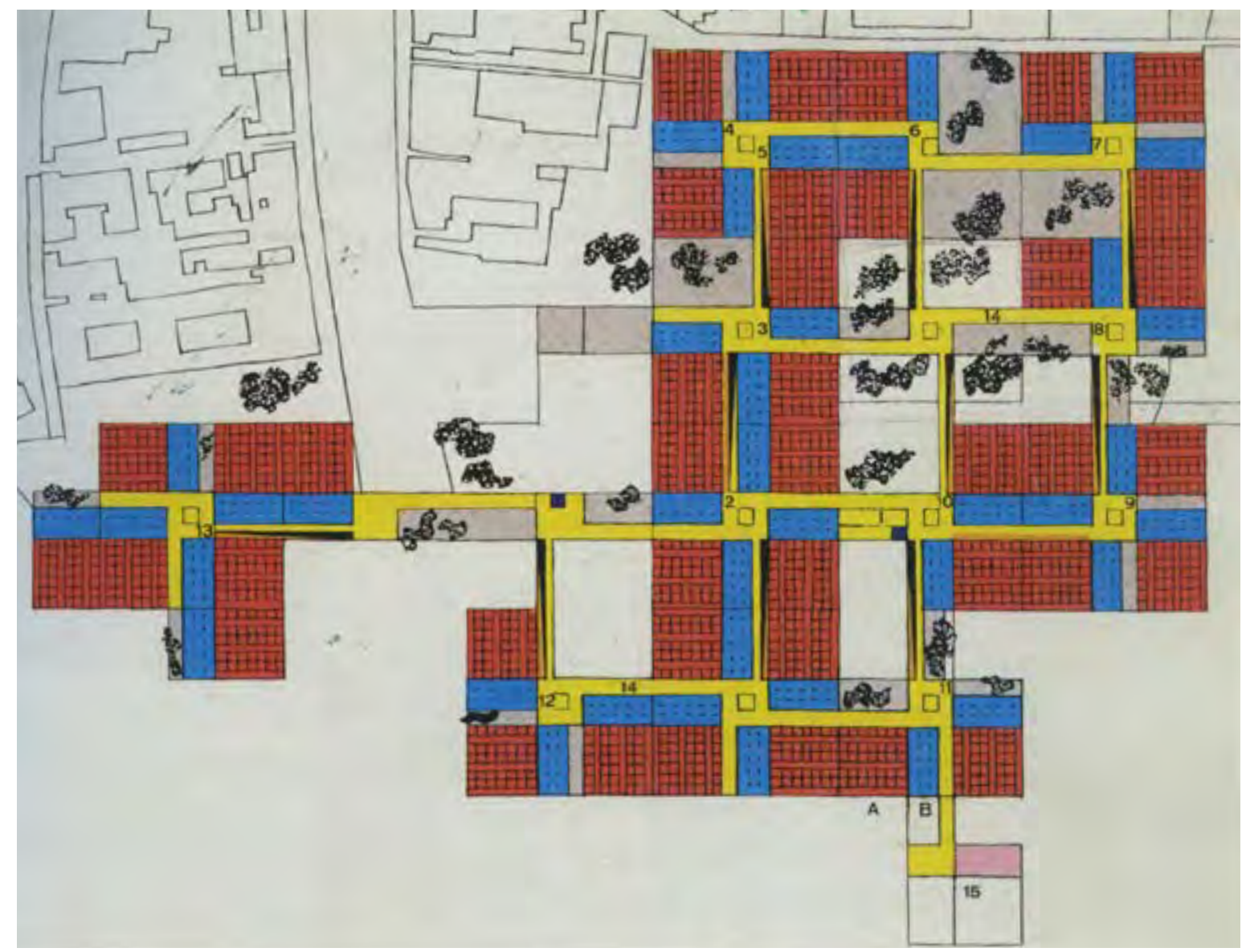

Figura 34.

Primer Proyecto / Hospital de Venecia / 1962 - 1965 / Le Corbusier 

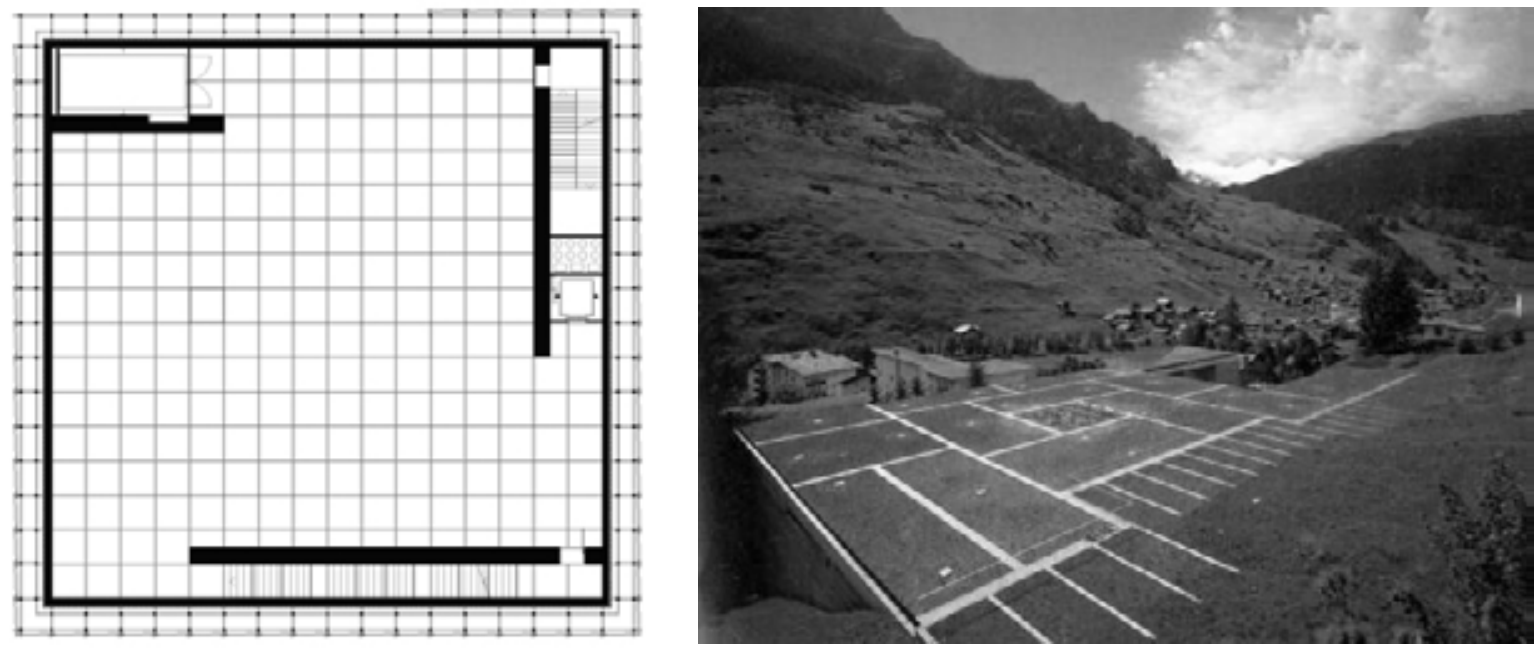

Figura 35 - 36.

Planta Primera, Segunda y Tercera / Kunsthaus Bregenz / 1989 - 1997 / Peter Zumthor Cubierta / Baños Termales de Vals / 1990 - 1996 / Peter Zumthor

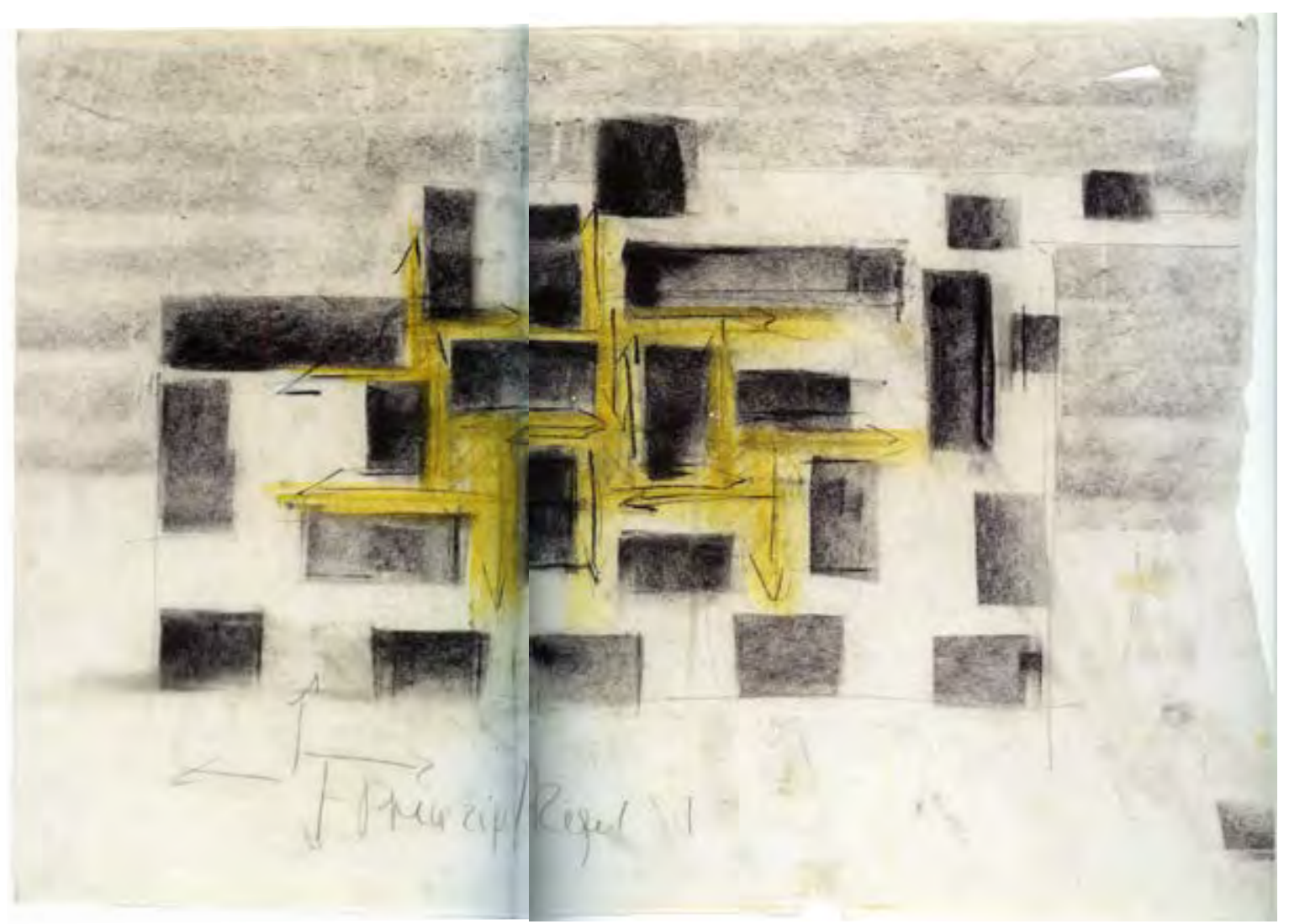

Figura 37.

Croquis conceptual / Baños Termales de Vals / 1990 - 1996 / Peter Zumthor 
Prairie-Houses; así como del Suntop Homes for Otto Mallery and the Todd Company. Mientras que en los proyectos verticales el centro de rotación es el lugar de la comununidad a cada uno de los apartamentos en los diferentes niveles; en las viviendas unifamiliares con sus horizontes, el núcleo será el calor-unidad.

Le Corbusier también recurrió en múltiples ocasiones a la disposición en esvástica como método compositivo. Una experiencia acumulada en varios proyectos, como en la serie de museos proyectados con una distribución en espiral en torno a un gran atrio central: Museo de Chandigarh de 1952; Museo Sanskar Kendra en Ahmedabad de 1954 y Museo de Arte Occidental en Tokio de 1957-59. Sin embargo, fue en la propuesta para el Hospital de Venecia de 1962-65 donde Le Corbusier exploró el apogeo de sus posibilidades, mutando a un sistema espacial reproductivo.

"La planta de museo de Ahmedabad es el origen del hospital, donde el crecimiento en espiral es dejado de lado, utilizando la manera de concebir un edificio de crecimiento ilimitado a partir de la sumatoria de partes. Es decir, de un modelo de edificio de crecimiento ilimitado en espiral cuadrada, derivado de un modelo orgánico, aprendido de la manera en la que crece una concha de caracol, Le Corbusier formula, al final de la vida, un nuevo modelo de edificio de crecimiento ilimitado, esta vez, jugando con el positivo y negativo del modelo de edificio resuelto en planta a partir de una esvástica." ${ }^{29}$

María Cecilia O’Bryne

La composición de la propuesta veneciana se basa en un módulo independiente y varias veces repetido ${ }^{30}$, la unité de bâtisse. Estas unidades se organizan alrededor de una plaza cuadrada, el campillo; desde donde se expanden cuatro aspas en forma de molinillo, las unites de soins. Una distribución rotatoria, en esvástica; que organiza y ordena todo el conjunto. Una ley de composición armónica; creando un patrón de adición flexible. Un organismo capaz de generar variaciones infinitas de movimiento y de repetición. Este sistema espacial expansivo en el paisaje es reflejo del complejo tejido morfológico de la ciudad italiana tradicional. De límites difusos, únicamente las condiciones del entorno existente lo circunscriben.

29 O'BRYNE, Maria Cecilia. El Hospital de Venecia de Le Corbusier: Mucho más que un mat-building. En: Mat-building. Departament de Projectes d'Arquitectura de la Universidad Politécnica de Catalunya. DPA 27/28. 2011. ISBN: 978-84-615-5561-1. Pág. 69.

30 Nota: Una referencia contemporánea es el proyecto del estudio Aranguren y Gallegos para el Parador de Alcalá de Henares en 2002-2007 


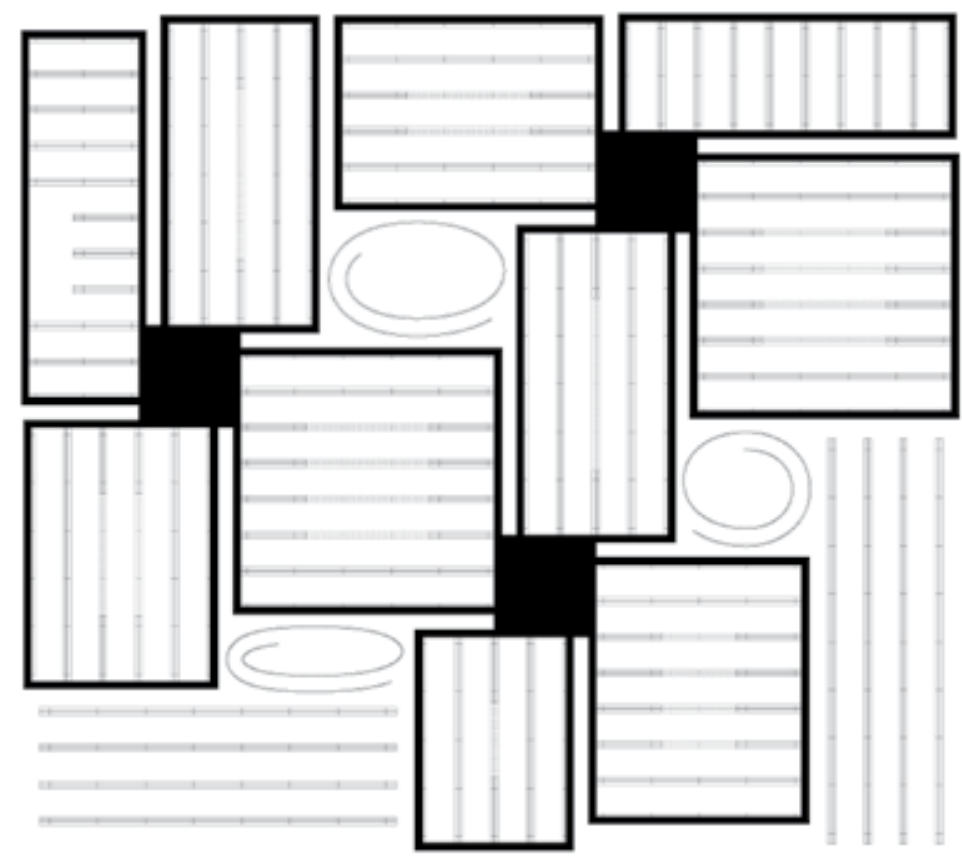

Figura 38.

Espacio libre para las unidades elípticas / Pabellón helvético Dibujo de la autora

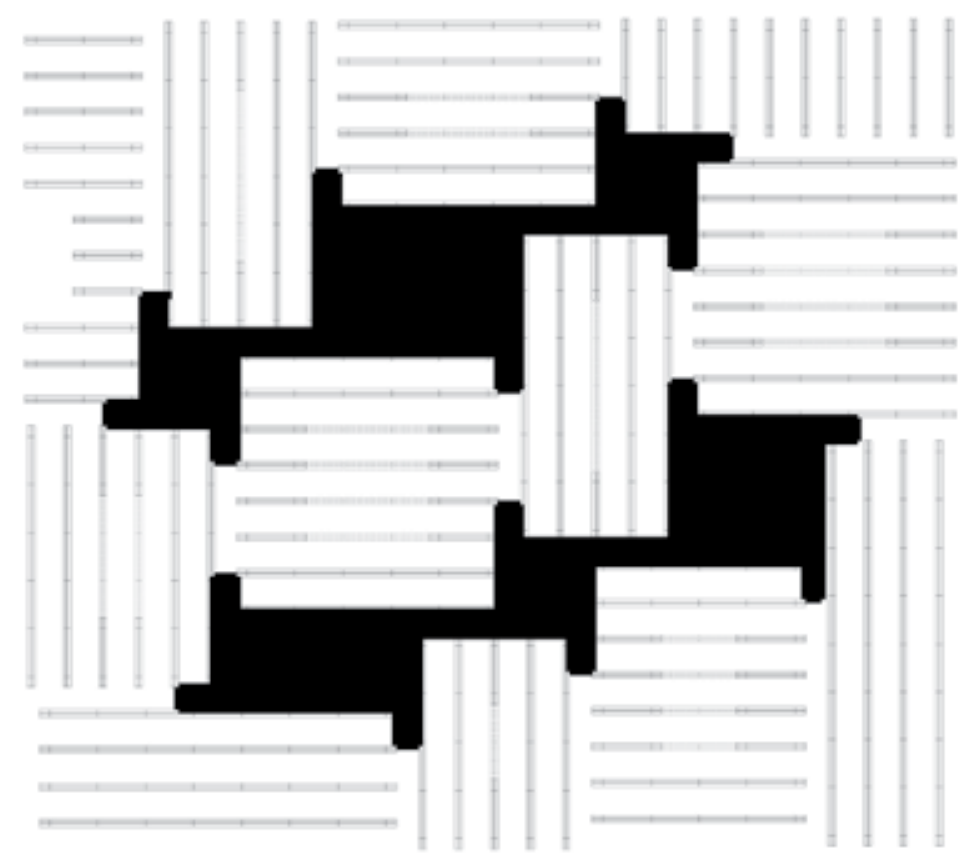

Figura 39.

Espacio esvástico/ Pabellón helvético Dibujo de la autora 
"El meandro, como lo llamamos, es un espacio vacío; un espacio negativo diseñado entre los bloques de piedra maciza. Trabajar en la forma y disposición de los bloques siempre significaba trabajar en el recorrido y la forma del meandro.... el meandro es un gran espacio compartido. La estructura de este espacio es como un tejido. Los pasadizos se ramifican por todos los lados y están entrelazados. Moverse en este espacio significa hacer descubrimientos." ${ }^{11}$ Peter Zumthor Termas Vals

Otro de los grandes maestros suizos, Peter Zumthor, no menciona de forma explícita la disposición en esvástica. Sin embargo, es un recurso experimentado en algunas propuestas construidas. En el Kunsthaus en Bregenz de 1989-97 dispone de tres muros de hormigón en molinete dentro de los espacios expositivos del cubo cristalino. Un sistema modular de 1,50 m concéntrico de experiencias espaciales a través de un recorrido unitario y progresivo. Circulaciones en espiral, ecos del Guggenheim de Nueva York. En los Baños Termales de Vals de 1990-96 la composición de los quince bloques también será en esvástica. Especialmente es visible en las dos grandes piscinas, la interior y exterior, que actúan como centros de rotación. La disposición de los bloques recuerda a un meandro geométrico no axial. Un espacio intermedio abierto y sinuoso que fluye a través del conjunto. La curiosidad determina el camino $^{32}$. De igual manera, los trazos de luz cenital entre las cubiertas de cada célula independientes dibujan y enfatizan su disposición.

Aunque posiblemente no sea evidente a simple vista; el esquema de composición y de circulación, del Klangkörper también es un sistema de rotación dextrógiro de cuatro aspas en torno a un vacío. A diferencia del Hospital de Venecia compuesto por la repetición aditiva de unitès siguiendo una trama global ortogonal reconocible delimitada por los centros; el Klangkörper teje un entramado más complejo a base de crecimientos sucesivos mediante la superposición de sus aspas. Sus tramas compositivas sobre las que se asientan son únicamente dependientes de su centro, lo que propicia la aparición de secuencias encadenas en esvástica.

31 ZUMTHOR, Peter. Therme Vals. Scheidegger \& Spiess. Zürich. 2008. ISBN: 978-3-85881-704-4. Pág. 73. Traducción de la autora: "The meander, as we call it, is the empty space between the fullness of the solid stone blocks; it is a designed negative space. Working on the shape and arrangement of the blocks always meant working on the course and shape of the meander....the meander is a large, shared space in which to circulate. The structure of this space is like a fabric. The passages branch off every which way end are intertwined. Moving around in this space meansmaking discoveries."

32 Idem. Pág. 55. Nota: "...the curiosity of the guest determines the course he or she chooses." 


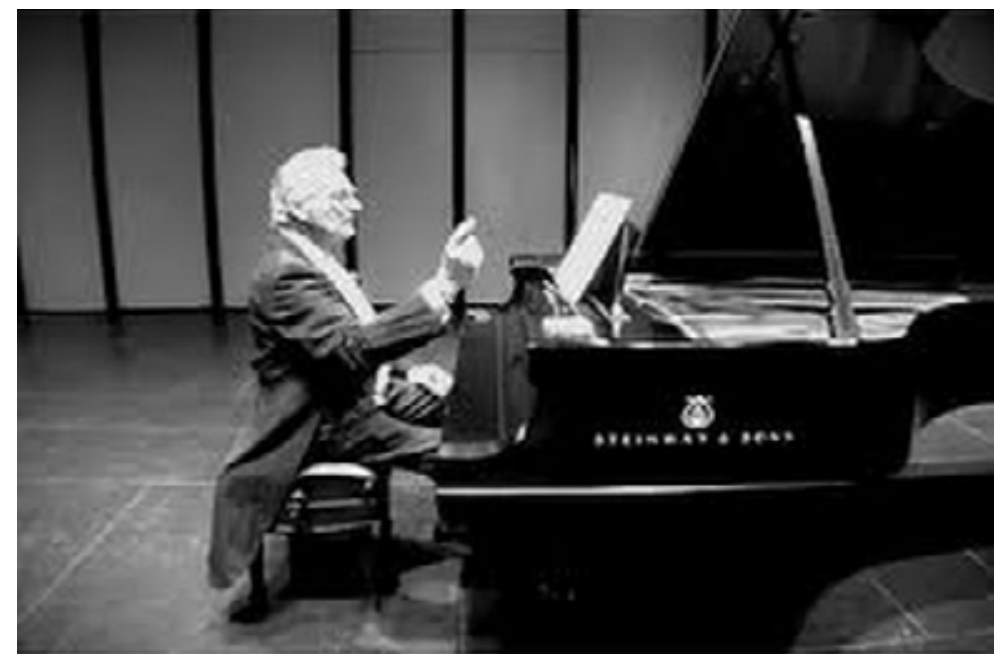

Figura 40.

4'33" de John Cage / 1952.

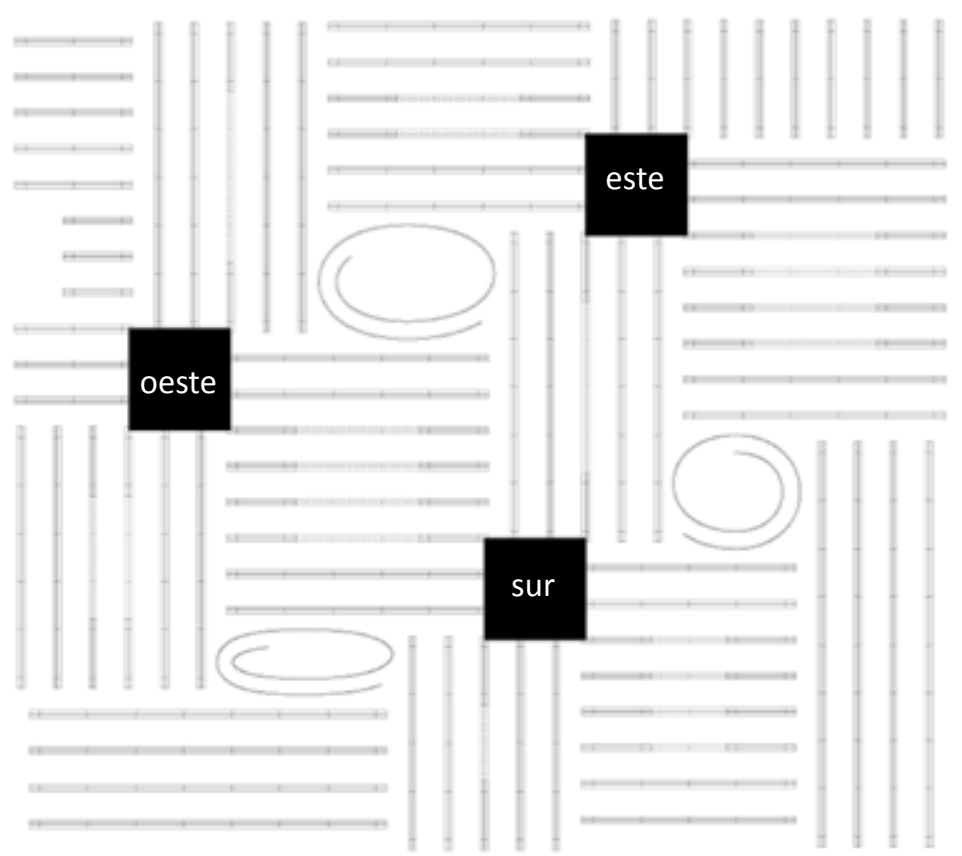

Figura 41.

Patios / Pabellón helvético

Dibujo de la autora 


\section{[Claros en el bosque]}

"El vacío no es nada. Tampoco es una falta. En la materialización plástica juega el vacío como un acto fundante que busca forjar lugares. ${ }^{\prime 33}$ Martin Heidegger

Los tonos, las melodías, los ritmos, las alturas, los sonidos, los tiempos e incluso los silencios; son fundamentales para la composición musical. Zumthor siempre sintió un gran interés por las obras experimentales de John Cage, y su exploración del silencio. La ausencia completa de sonido de la composición musical titulada 4'33" estrenada en 1952 en el Maverik Concert Hall; paradójicamente hace presente el silencio acompañándolo por diversos ruidos ambientales. El vacío, el silencio ... convertidos en protagonistas ${ }^{34}$.
"(...) dos aspectos opuestos del espacio, el lleno y el vacío, que no se consideran excluyentes entre sí, sino como equivalentes y son de igual valor y disfrutan de "igualdad de derechos" como aspectos o partes de un mismo todo."135 Bernhard Hoesli

El pabellón helvético, como composición musical; también se articula mediante tres silencios, tres patios. Cada uno de los tres vacíos abiertos cenitalmente en forma de cuadrado de 5,90 metros ${ }^{36}$ de lado; se expanden en las cuatro direcciones cardinales. Una composición en esvástica, espacios cruciformes a través de cuatro aspas de 1,41 metros ${ }^{37}$ de ancho. Estas grietas luminosas, también presentes en las termas, separan los diferentes Stapel, pero a la vez orquestan todo el conjunto.

"La arquitectura, por el contrario, es como una gran escultura excavada, en cuyo interior el hombre penetra y camina"38 Bruno Zevi 978-84-254-2993-4. Traducción de la autora: "Leere ist nicht nichts. Sie ist auch kein Mangel. In der plastischen Verkörperung spielt die Leere in der Weise des suchendentwerfenden Stiftens von Orten."

34 Bruno Zevi, Saber ver la arquitectura. Ensayo sobre la interpretación especial de la arquitectura. Editorial Poseidón. Barcelona. 1998. ISBN: 84-455-0080-5. Pág. 31.

35 ROWE, Colin y SLUTZKY, Robert. Transparency. Birkhäuser Verlag. Basel. Boston. Berlin. 1997. ISBN: 3-7643-5615-4. Pág. 96. Traduccion de la autora: "...two opposing aspects of space, solid and void, which are not seen as mutually exclusive but mutually presupposing each other and being of equal value and enjoying "equal rights" as aspects or parts of the same whole."

36 Nota: Dimensión resultante, tras re-dibujar la planta del pabellón facilitado por el Exposeeum Hannover

37 Según la memoria descriptiva del pabellón facilitado por el Exposeeum Hannover

38 ZEVI, Bruno. Saber ver la arquitectura. (1948) Ediciones Apóstrofe. Barcelona. 1998. ISBN: 84-4550080. Pág. 19. 


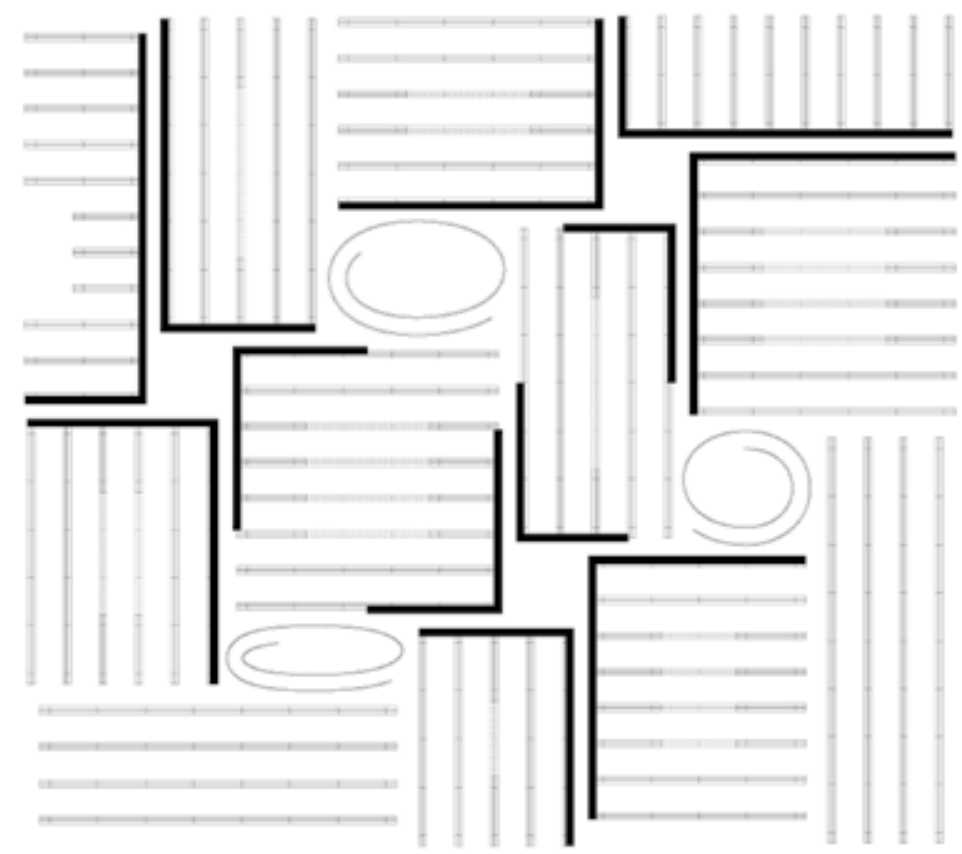

Figura 42.

Límite de los patios / Pabellón helvético

Dibujo de la autora

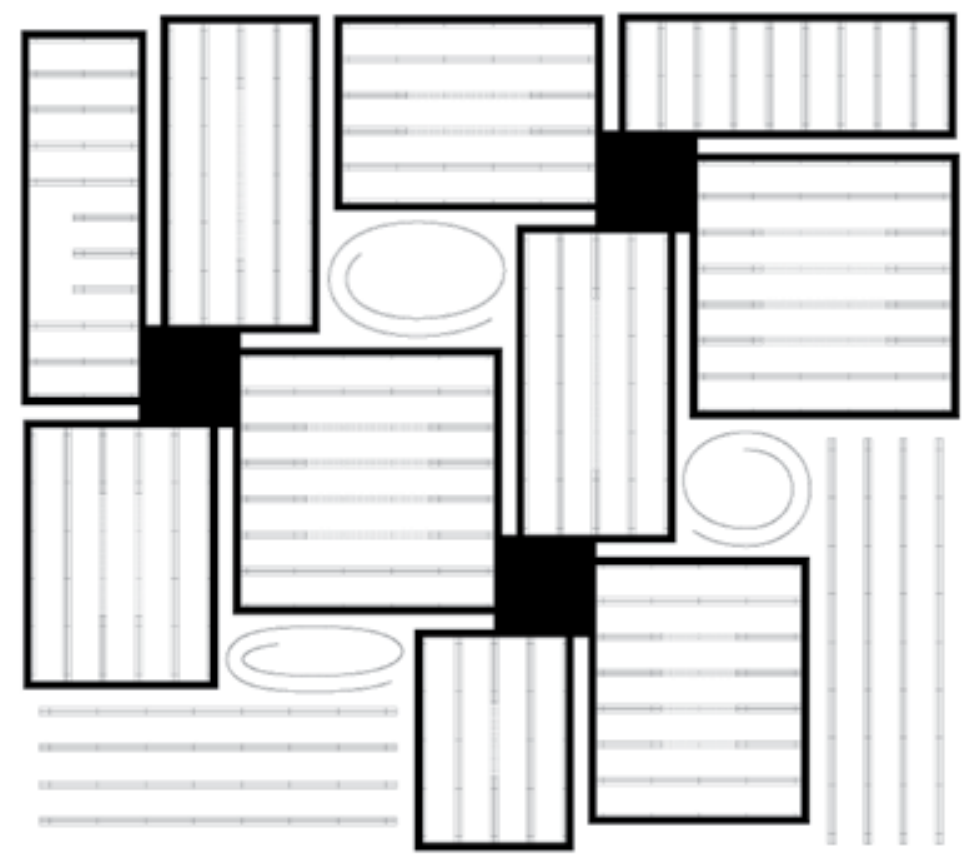

Figura 43.

Patios en relación con los Stapel / Pabellón helvético Dibujo de la autora 
Los tres vacíos son recursos para dotar orden, complejidad, variedad y regularidad a la composición. Como claros en el bosque actúan como mecanismos de orientación, de encuentro, de estancia, de reflexión, de relación; pero además son pozos de iluminación y ventilación. Estos tres atractores permiten múltiples recorridos, entrelazando las diferentes partes del pabellón. Distribuidores de flujos peatonales, intercambiadores donde cada visitante puede elegir su camino y la forma de explorar el pabellón. Cada itinerario conecta diferentes espacios, permitiendo la visión de las áreas adyacentes.

Este recurso no será nuevo para Zumthor. La Capilla de Campo Bruder Klaus de 200107, en Wachendorf, Alemania cuenta con un espacio de forma circular en su interior, sumergido en la oscuridad e iluminado únicamente por luz cenital. Un espacio vacío con una textura rugosa de muros de hormigón obtenida mediante la incineración de los troncos de arboles que sirvieron de encofrado. El Kunsthaus en Bregenz de 1989-97, en cambio, ofrece un espacio vacío, minimalista y contemplativo para el arte. O también los Baños Termales en Vals de 1990-96, que coinciden parcialmente en el tiempo con el proyecto del concurso para el pabellón helvético. Este proyecto semi-enterrado, similar a un sistema de cuevas geométricas, no busca visibilidad exterior. Su configuración espacial se desarrolla sobre todo en el interior. A modo de una caverna, Zumthor esculpe el espacio. No busca solamente la forma arquitectónica con el vacío como un espacio resultante; sino el vacío excavado se convierte en el material esencial de la composición y configuración. Un nuevo universo que crea un diálogo entre la masa y el vacío. Semejante al proyecto paisajístico Tindaya ideado en 1984 por Eduardo Chilliada, cuyo vacío construido en la montaña representa un limite difuso entre arquitectura y escultura.

En los baños termales quince bloques rectangulares de Gneiss, con dimensiones de 3-5 $\mathrm{m}$ de ancho y de largo 6-8 $\mathrm{m}$, sostienen la cubierta individualmente y no solidariamente. Compuestos según una estricta cuadrícula de líneas perpendiculares, se erigen como monolitos dispuestos en un sistema de molinetes. Estos se organizan en torno a las dos piscinas. Su interior alberga espacios íntimos reservados para actividades especiales como el baño frío, el baño caliente, el baño con pétalos de flores, el baño de sonido, entre otros. Cada uno es un mundo separado que guarda su propia experiencia. Alrededor de estos grandes volúmenes ahuecados se compone el vacío. Un espacio intersticial. Un negativo con forma de meandro. Un espacio entre masas. Un espacio abierto, lleno de posibilidades, lo que permite a las personas "moverse libremente, a su aire" ${ }^{39}$ a través de "ese misterioso vacío" ${ }^{40}$, alrededor de ese silencio.

39 ZUMTHOR, Peter. Atmosferas. Entornos arquitectónicos - Las cosas a mi alrededor. Editorial Gustavo Gili. S.A. Barcelona. 2006. ISBN: 978-84-2117-0. Pág. 43.

40 ZUMTHOR, Peter. Pensar la arquitectura. Editorial Gustavo Gili. Barcelona. 2010. ISBN: 978-84-252-2730-1. Pág. 22. 


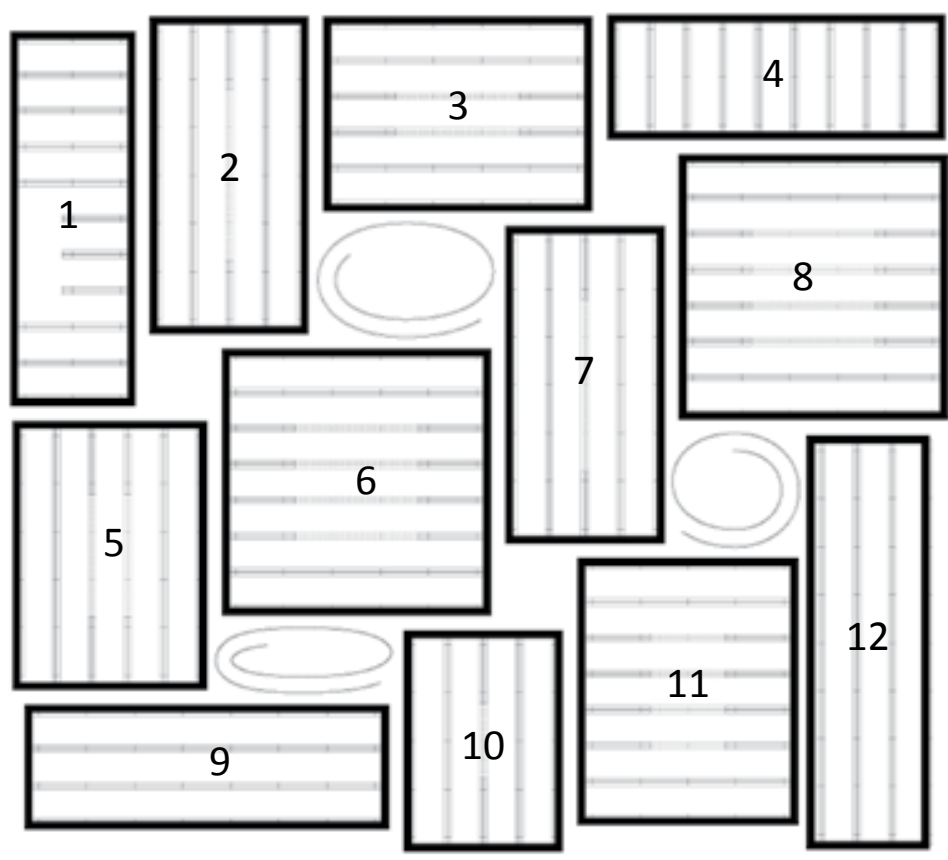

Figura 44.

12 Stapel - Conjuntos / Pabellón helvético

Dibujo de la autora
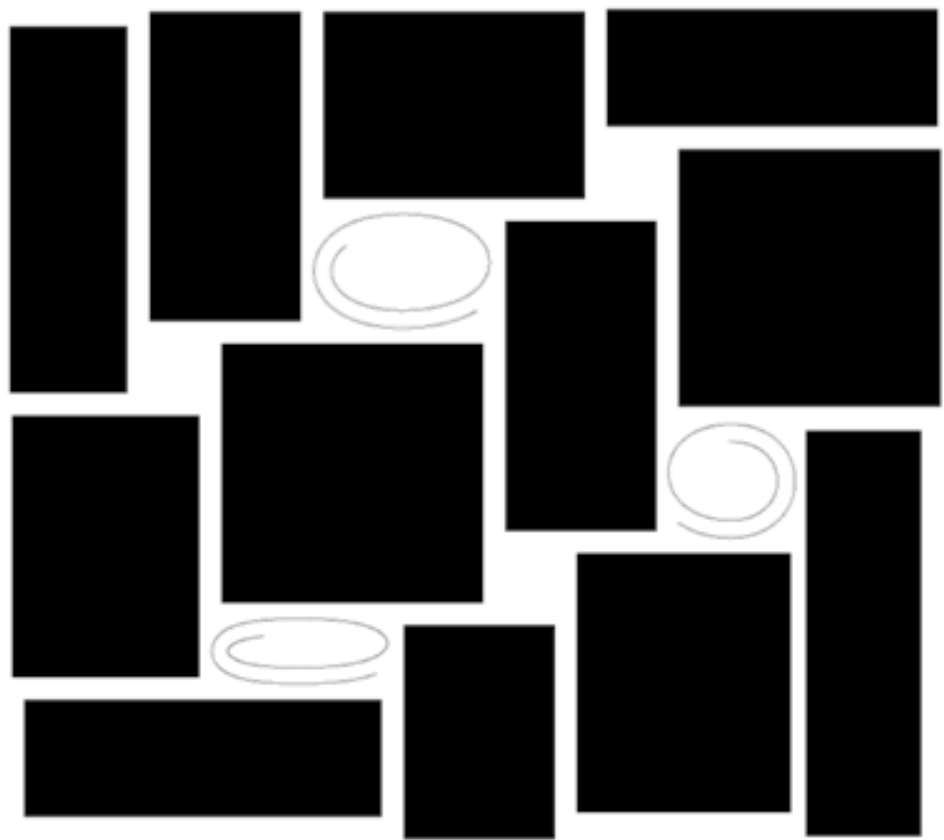

Figura 45.

Stapel - Conjuntos / Pabellón helvético

Dibujo de la autora 


\title{
[12 Stapel]
}

\author{
"La geometría enseña la regularidad de las líneas, las superficies y los \\ cuerpos en el espacio, y nos puede ayudar a entender cómo podemos \\ proceder con el espacio en la arquitectura."11 Peter Zumthor
}

El Klangkörper es una gran alfombra continúa compuesta por 12 Stapel. Estos son conjuntos estructuralmente independientes con bandas paralelas. Todos ellos conforman una agrupación de patrones perimetralmente rectangulares dispuestos en varias posiciones. Una concentración de diferentes células, en un mismo organismo. Los Stapel se agrupan en torno a los tres patios con una disposición en esvástica; es decir rotados 90 grados. Un organismo complejo de madera compuesto por 99 pilas de longitudes variables. Una retícula definida por muros paralelos en dirección longitudinal y trasversal.

Cada Stapel es una unidad autónoma compuesta por un mínimo de cuatro y un máximo de once pilas. Su espacialidad es netamente longitudinal, con secuencias lineales y equidistantes entre ejes de 2,245 $\mathrm{m}^{42}$. Estas bandas compositivas y estructurales, semejantes a los entre-muros de ladrillo de la Villa de Madame Manorama Sarabhai ${ }^{43}$, generan un espacio fluido y fragmentado al mismo tiempo. Entre estas unidades, aparece una serie de espacios intermedios secuenciales itinerantes de $1,41 \mathrm{~m}^{44}$ de ancho. Estos recorridos, los más estrechos de todo el pabellón entre las pilas de madera, hilan un entre-tejido arquitectónico con estrictas reglas de composición geométrica.

Las dimensiones de cada Stapel vienen determinadas por las pilas, así como el espacio entre ellas. Todo ello conforma un puzzle de diversas piezas. En los lados cerrados, los testeros, las pilas determinan su longitud. Estas bandas de tablones apilados se conforman como si fuesen trenes; siendo el resultado de la adición de módulos intermedios de 3,00 m [M_in] y finales de 0,66 m [M_ex]. Una secuencia numérica dimensional que comienza desde la pila más pequeña $\left(x 1\left[M_{-} e x\right] /+/ x 2\left[M_{-} i n\right] /+/ x 1\right.$

41 ZUMTHOR, Peter. Pensar arquitectura. Editorial Gustavo Gili. S.A. Barcelona. 2010. ISBN: 978-84-2522730-1. Pág. 21.

42 Según los planos facilitado por el Exposeeum Hannover

43 Nota: La planta baja de la Villa Sarabhai se compone de muros equidistantes y paralelos que sostienen las unidades abovedadas. No únicamente estructural, estos articuladores en cadena lineal sirven para dividir el espacio en varias áreas como para dotar orden, permitiendo al mismo tiempo un recorrido flexible.

44 Según los planos con fecha de 10 de junio 1999, facilitado por la empresa constructora Nüssli, los espacios intermedios itinerantes eran de 1,25 m con unos módulos finales de 0,74 m [M_ex]. Sin embargo, en los planos con fecha de 25 de octubre 1999, facilitado por el Exposeeum Hannover, aparecen otra medida: $1,41 \mathrm{~m}$ y 0,66 $\mathrm{m}$. Probablemente estos cambios de parámetros dimensionales se deben a las exigencias básicas de seguridad en caso de incendio. a la evacuación por incendio. 


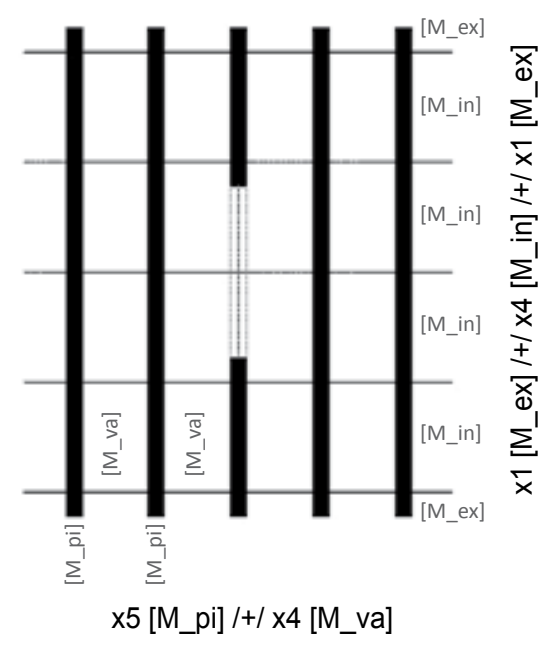

Figura 46.

Secuencia numérica dimensional de los Stapel/ Pabellón helvético Dibujo de la autora

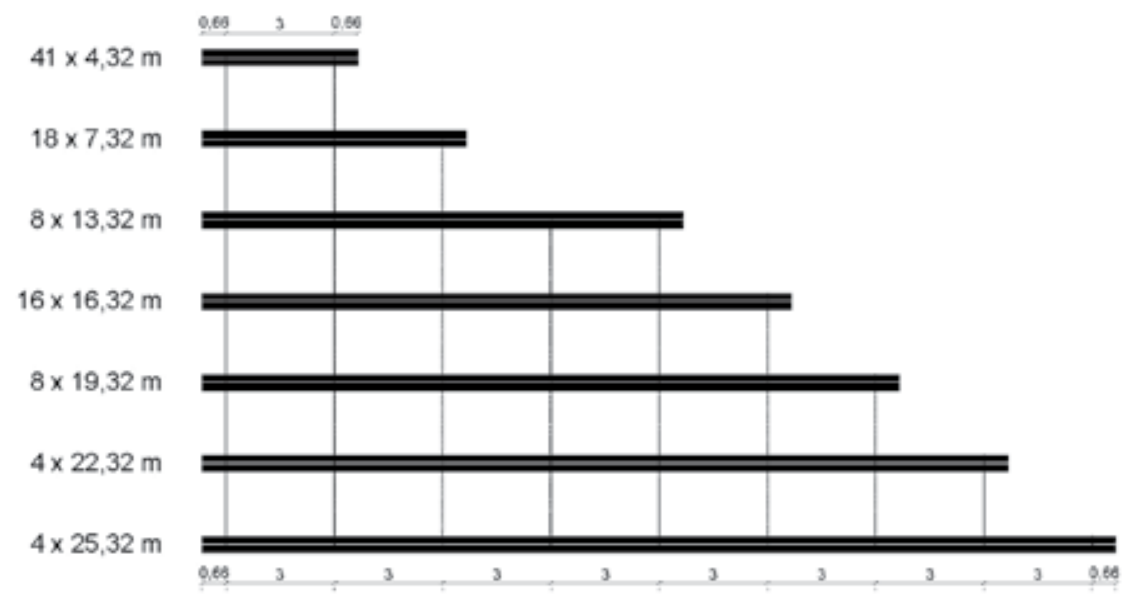

99 Stapel

Figura 47.

Diferentes longitudes de los Stapel / Pabellón helvético Dibujo de la autora
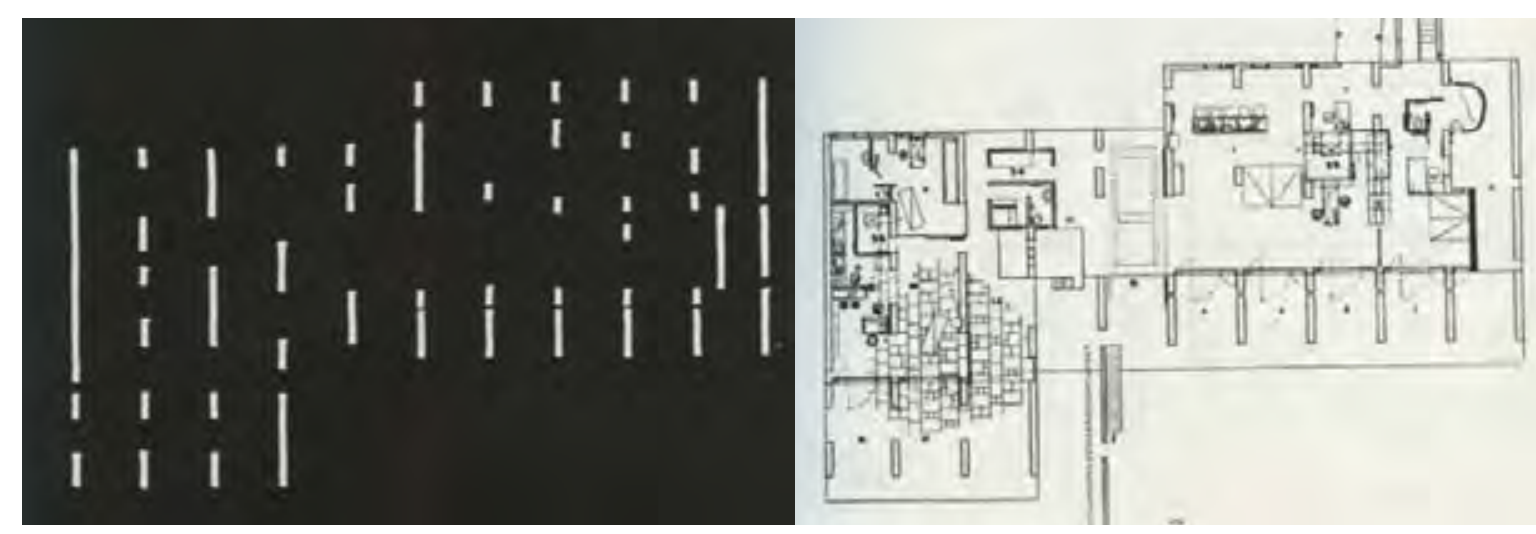

Figura 48.

Planta de la Villa Sarabhai / Le Corbusier / 1955 
[M_ex] ) con una longitud de $7,32 \mathrm{~m}^{45}$; hasta la de mayor largo $\left(x 1\left[M_{-} e x\right] /+/ x 6\left[M \_i n\right]\right.$ /+/x1 [M_ex] ) con 25,32 $\mathrm{m}^{46}$. En los lados abiertos, los Stapel se componen como un pentagrama de paredes equidistantes y el espacio entre las mismas. Los perfiles de las pilas con un ancho de 0,445 m [M_pi] y el vacío entre-pilas de 1,80 m [M_va]. Aparecen composiciones desde 4 pilas más tres vacíos ( $x 4$ [M_pi] / +/ x3 [M_va] ) de 7,16 m; hasta 11 pilas con diez vacíos de 22,84 m ( x11 [M_pi] /+/x10 [M_va] ).

Ocho de los doce Stapel tienen horadados sus interiores. Estas oquedades situadas en una posición central se crean con las mismas reglas. En la dirección de las pilas siempre se garantizan como mínimo que dos vacíos, más una pila ( x2 [M_va] /+) $x 1$ [M_pi] ). Sin embargo en las filas de pilas diseccionadas, se conservan siempre una longitud constante en los extremos compuesta de dos módulos extremos y uno intermedio $\left(x 1\left[M_{-} e x\right] /+/ x 1\left[M_{-} i n\right] /+/ x 1\left[M_{-} e x\right]\right)$ de longitud 4,32 m. Estas reglas garantizan que el perímetro del vacío esté consolidado, siendo un lugar recogido del exterior; así como propio de cada Stapel. Sin embargo, estas dos operaciones de recorte no pueden ser aplicadas en todos los conjuntos de bandas por su estrechez en uno de sus lados. Aparecen así cuatro Stapel que no contienen un espacio interior.

Todos los Stapel se componen con las mismas reglas. Una misma lógica compositiva, así como constructiva. Un sistema de bandas para construir diversas sonoridades. Definición del esquema en esvástica como primer paso, repetición del mismo en todas direcciones, mutación de los Stapel según las condiciones de contorno del solar. Todo este proceso genera nueve tipologías dimensionales diferentes de las 12 unidades totales. Dos tipologías están duplicadas (Stapel 2 y 7 / Stapel 6 y 8), ya que no han sufrido ninguna transformación en el proceso, clonándose en diferentes posiciones. Otra tipología se repite (Stapel 3 y 5), pero se disponen en el sistema rotadas una con respecto a la otra.

El pabellón helvético es un sistema compositivo complejo, gestado a base de adición de operaciones sencillas. Aunque a simple vista no son descifrables, están presentes y permiten articular todos los Stapel. A través de este mecanismo surgen espacios muy heterogéneos: abiertos - cerrados, amplios - estrechos, cubiertos - abiertos, de movimiento rápido - lento. Un paisaje de complejidad. Un lugar de encuentro, de movimiento, de uso, de intercambio, de consumo, de estancia, de actividades diversas. Un organismo al mismo tiempo compacto y permeable, fluido. Un universo difuso de experiencias, de conocimientos y de intereses, un laberinto sin esquinas. 


\section{[Mitosis]}
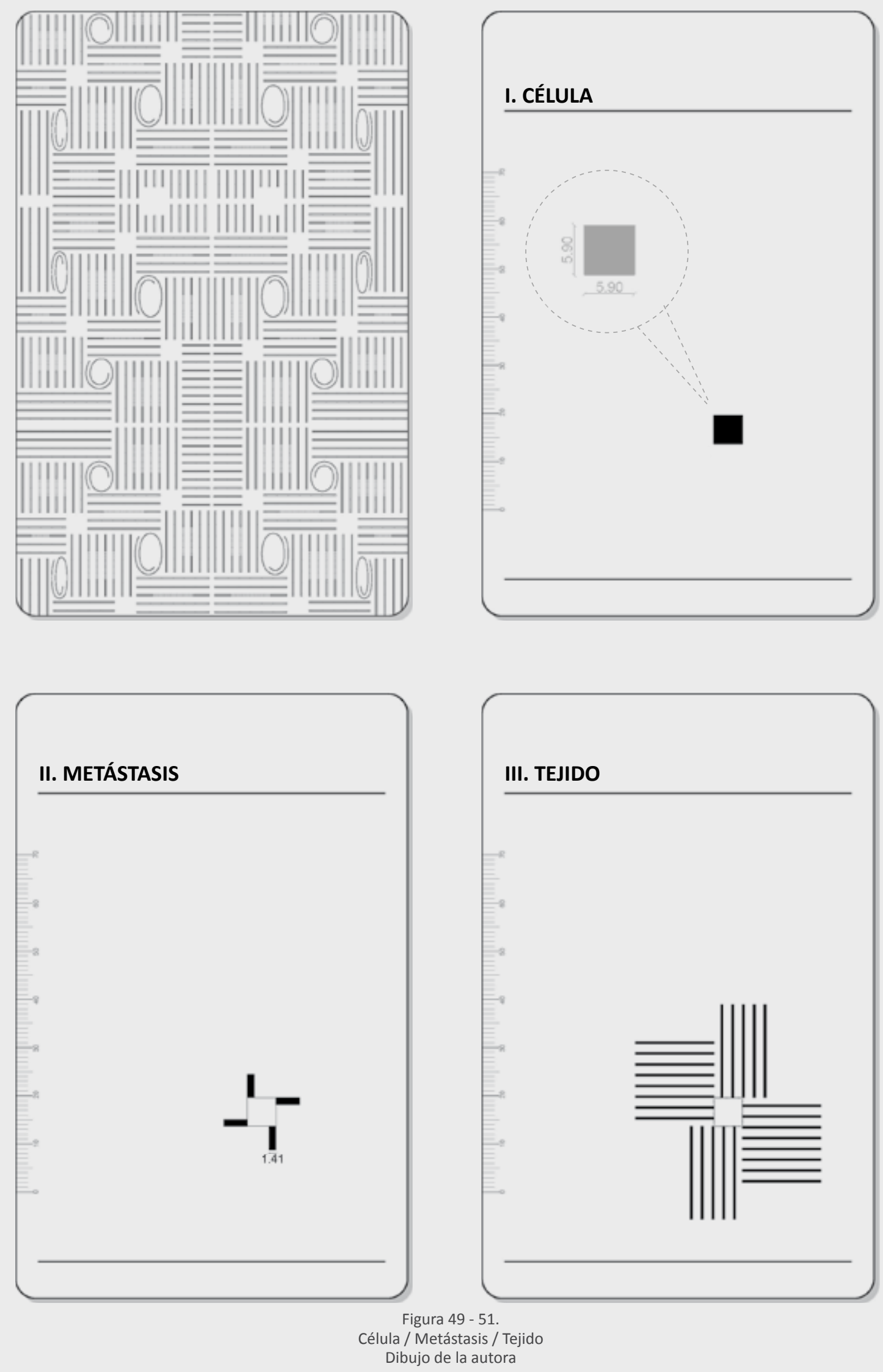

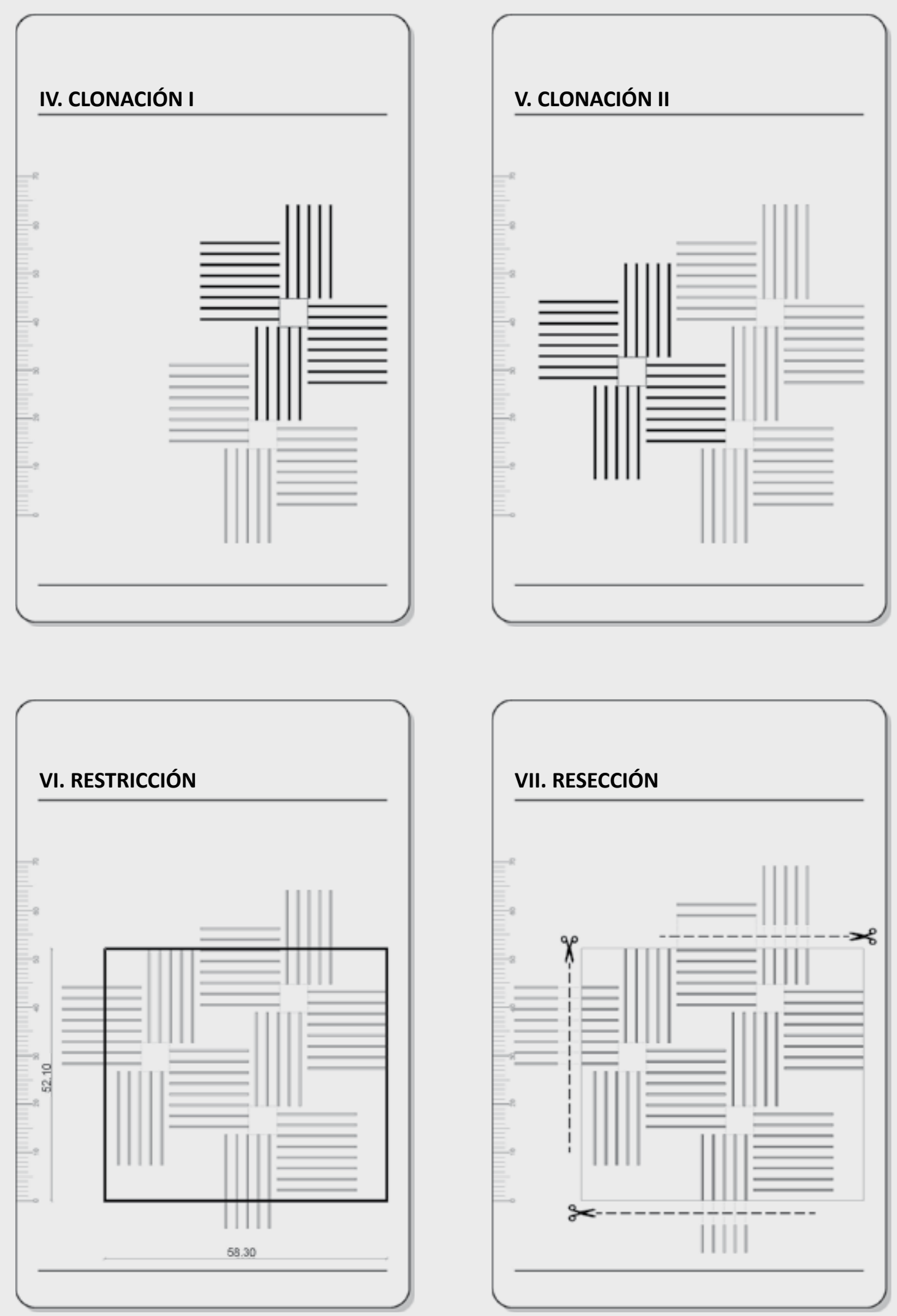

Clonación I / Clonación II / Restricción / Resección 

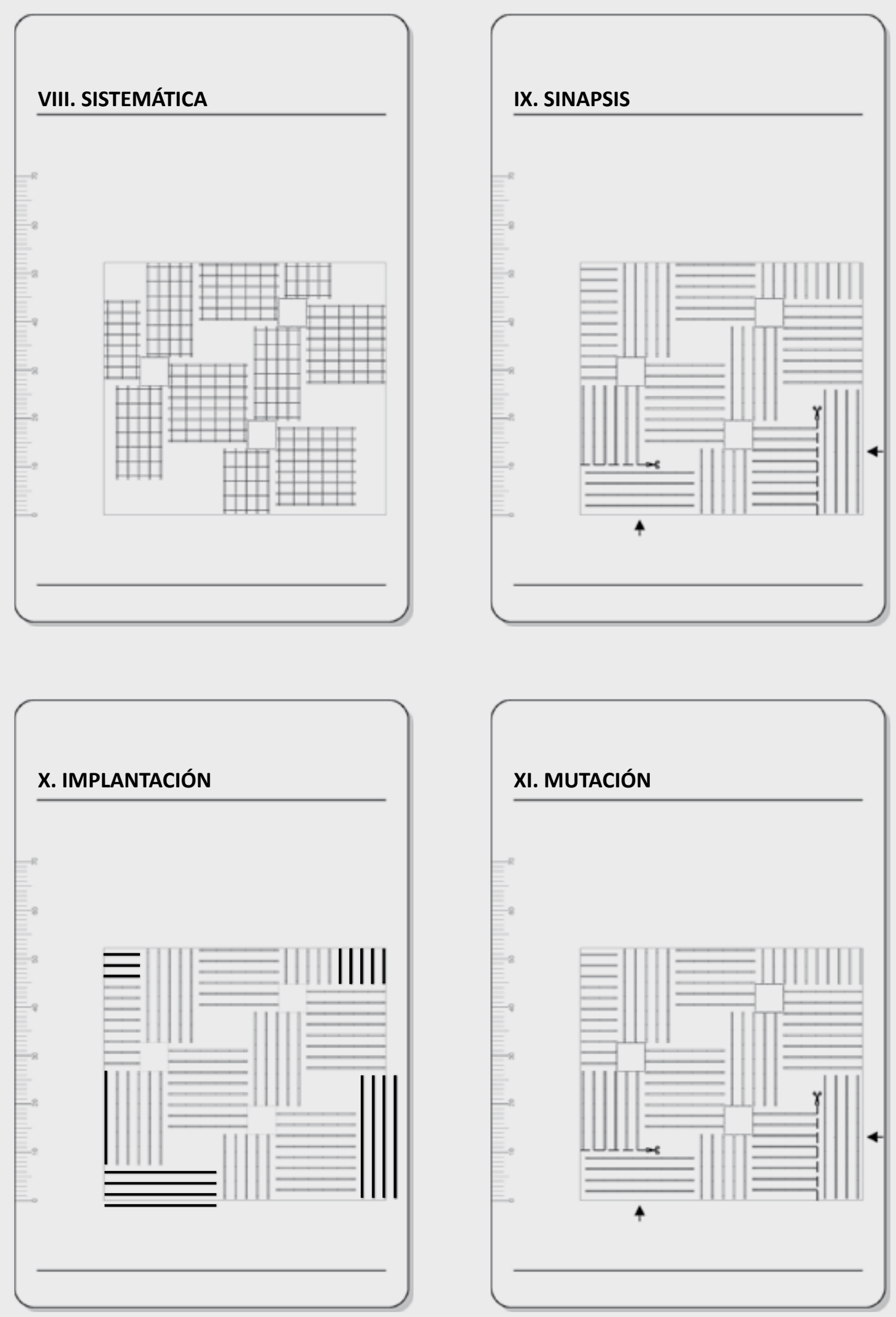

Figura 56 -59.

Sistemática / Sinapsis / Implantación / Mutación Dibujo de la autora 

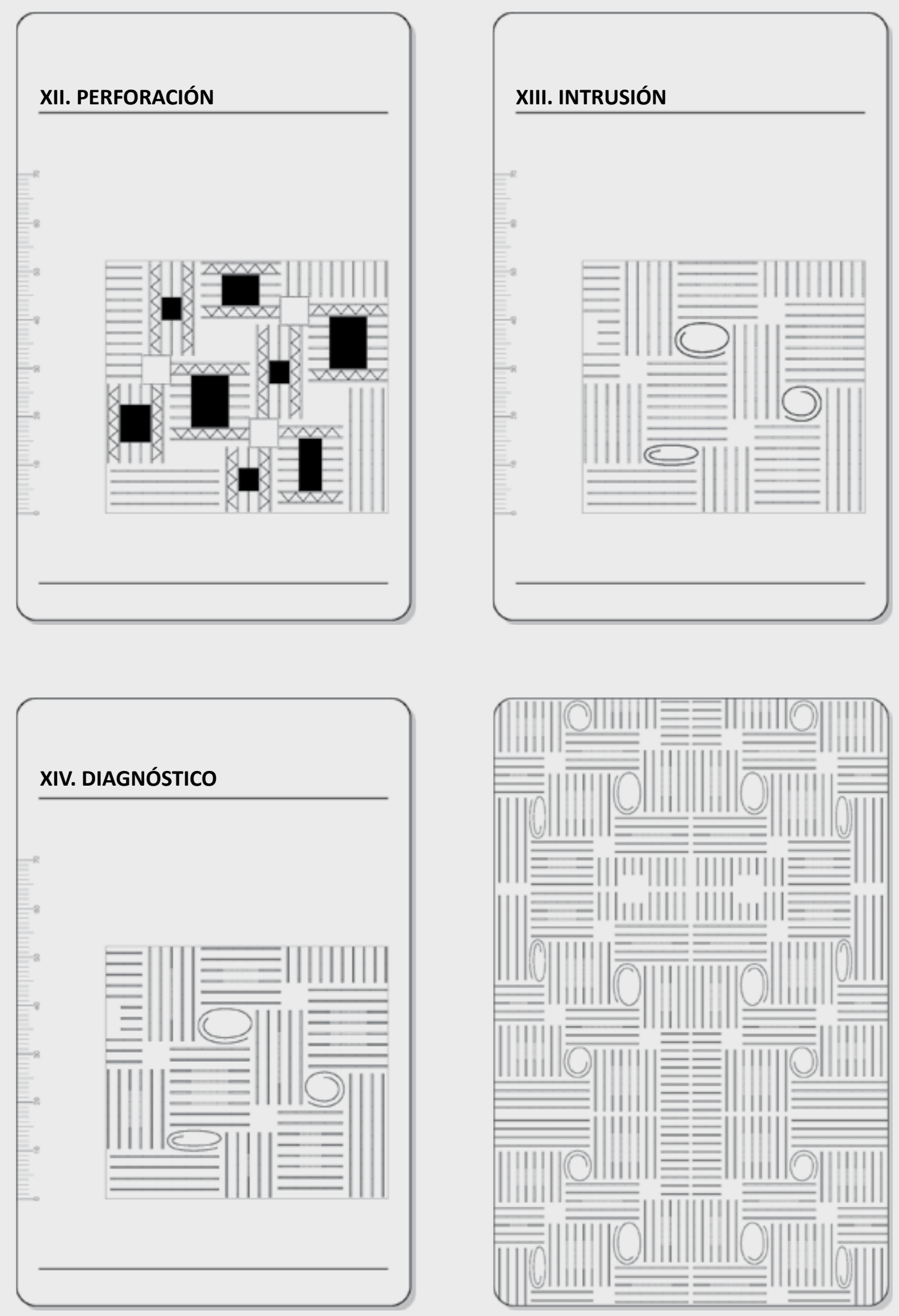


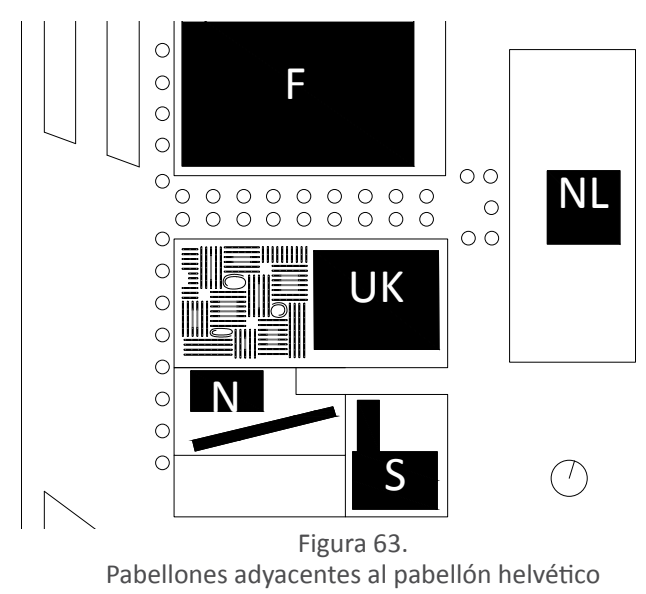

Dibujo de la autora
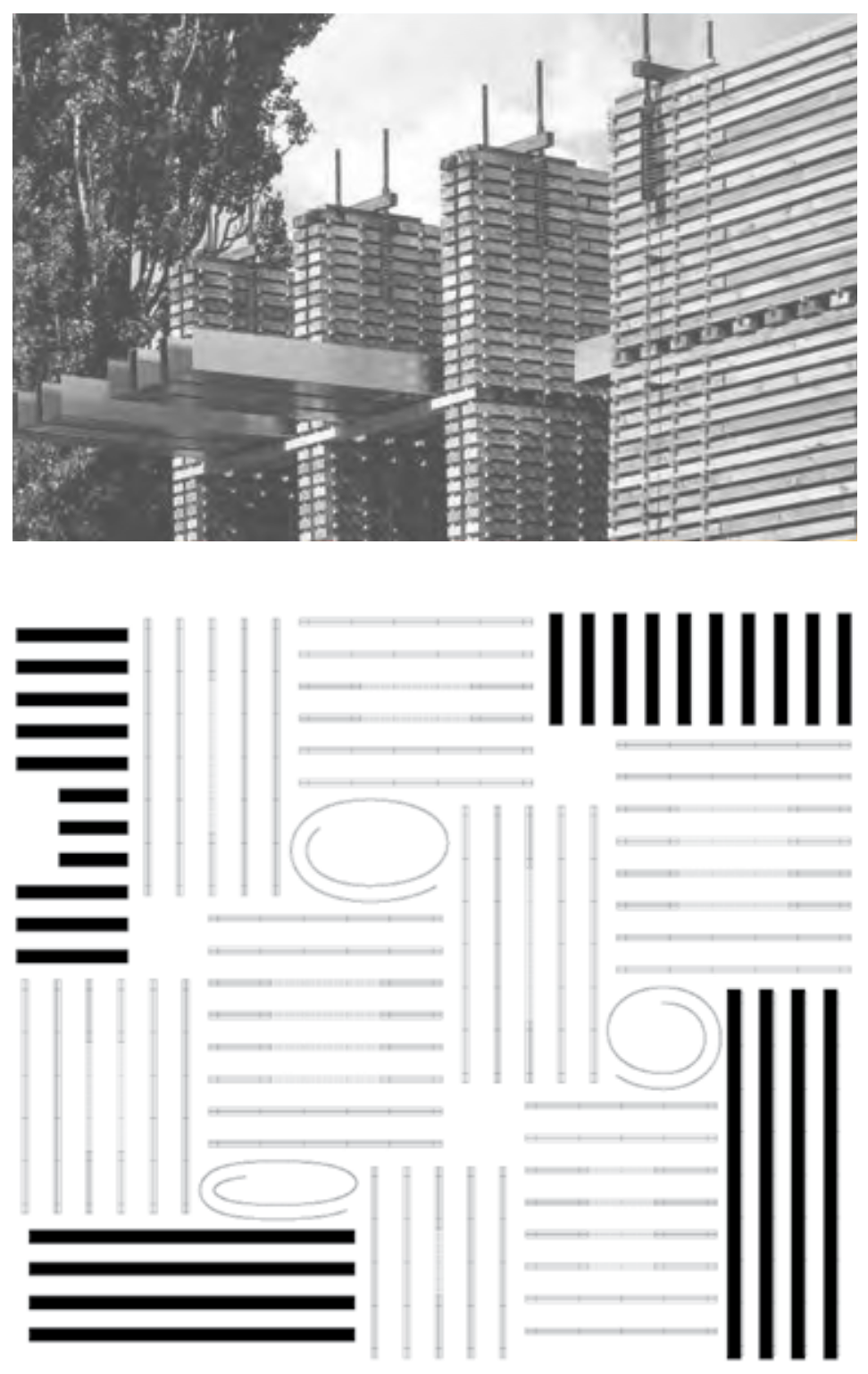

Figura $64-65$.

Conjuntos en esquina / Pabellón helvético 


\section{[Cuatro esquinas]}

"El protagonista ya no es el objeto aislado sino las relaciones que entre objetos pueden establecerse para determinar un lugar"47 Josep Montaner

El Klangkörper es un gran contenedor. No es un pabellón al uso sino un nodo de actividades múltiples. Un espacio poli-programado. Un sistema abierto, accesible, permeable, ventilado; con sinergias de los espacios adyacentes dentro del mismo, así como un constante intercambio con su entorno. Un espacio líquido y diverso que fluye por las distintas áreas operativas del conjunto. Un sistema circulatorio que se contorsiona y dilata proporcionando diferentes sensaciones, perspectivas y relaciones espaciales al recorrerlo. Un sistema operativo reprogramable según necesidades específicas. Oquedades donde poder albergar experiencias: música, gastronomía, caminar o estar, entre otras. Lugares a modo de condensadores de diferentes actividades.

Los vértices del pabellón están definidos por cuatro Stapel ${ }^{48}(1,4,9$ y 12). Se tratan de una organización lineal a base de bandas en cada una de las cuatro esquinas. Una partidura espacial continua, sin interrupciones, sin espacios excavados. Son esclusas de acceso, de recorrido diá-logo, un lugar de transición entre el interior y el exterior del pabellón. El Klangkörper tiene dos condiciones dada su ubicación en esquina de manzana: una hacía el espacio público de circulación de la exposición y otra hacia los pabellones vecinos. Frente a la Avenida 11 y la Calle 11 en una disposición más permeable; los Stapel 1 y 4 contienen las bandas con la menor longitud dentro del sistema, 7, $32 \mathrm{~m}\left(x 1\left[M_{-} e x\right] /+/ x 2\left[M_{-} i n\right] /+/ x 1\right.$ [M_ex] $)$ de longitud 4,32 m. Con un carácter escenográfico de transito abierto hacia el exterior están compuestos de 11 y 10 pilas respectivamente. Hacía los linderos, las bandas presentan una composición más cerrada, casi hermética. Los Stapel 9 y 12 contienen las pilas más largas, 22,32 $\mathrm{m}\left(x 1\left[M_{-} e x\right] /+/ x 7\left[M_{-} i n\right] /+/ x 1\left[M_{-} e x\right]\right)$ y $25,32 \mathrm{~m}\left(x 1\left[M_{-} e x\right] /+/ x 8\left[M_{-}\right.\right.$in] $\left./+/ x 1\left[M_{-} e x\right]\right)$ respectivamente. Ambas concepciones binarias son una dicotomía entre abierto - cerrado, largo - corto, estrecho - ancho, frontal - trasero, ofensivo defensivo. Un organismo adaptado a su contexto.

47 MONTANER, Josep María. Sistemas arquitectónicos contemporáneos. Gustavo Gili. Barcelona. 2008. ISBN: 978-84-252-2190-3. Pág. 151.

48 Nota: En las esquinas noroeste y noreste, que lindan con la avenida 11. Boulevard y la calle 11. Strasse Ost, se encuentran los conjuntos con la mínima longitud dentro del sistema: 7,32 metros; mientras que en las esquinas suroeste y sureste, próximos a los pabellones de Noruega y Gran Bretaña, se sitúan los dos conjuntos con la máxima longitud: 26,32 metros. 


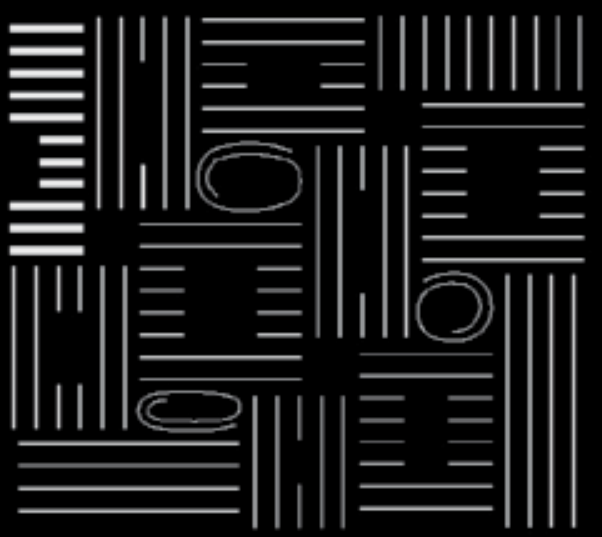

STAPEL 1

Tipo de madera: Pino

Paredes: 11

Uso: Conjunto en esquina

Dimensiones: $\mathbf{7 , 3 2} \times \mathbf{2 2 , 9 0} \mathrm{m}$

(1) $\left.\quad\right|_{0} \quad 1 \quad 1 \quad 1 \quad|r|$ 
[Stapel 1]

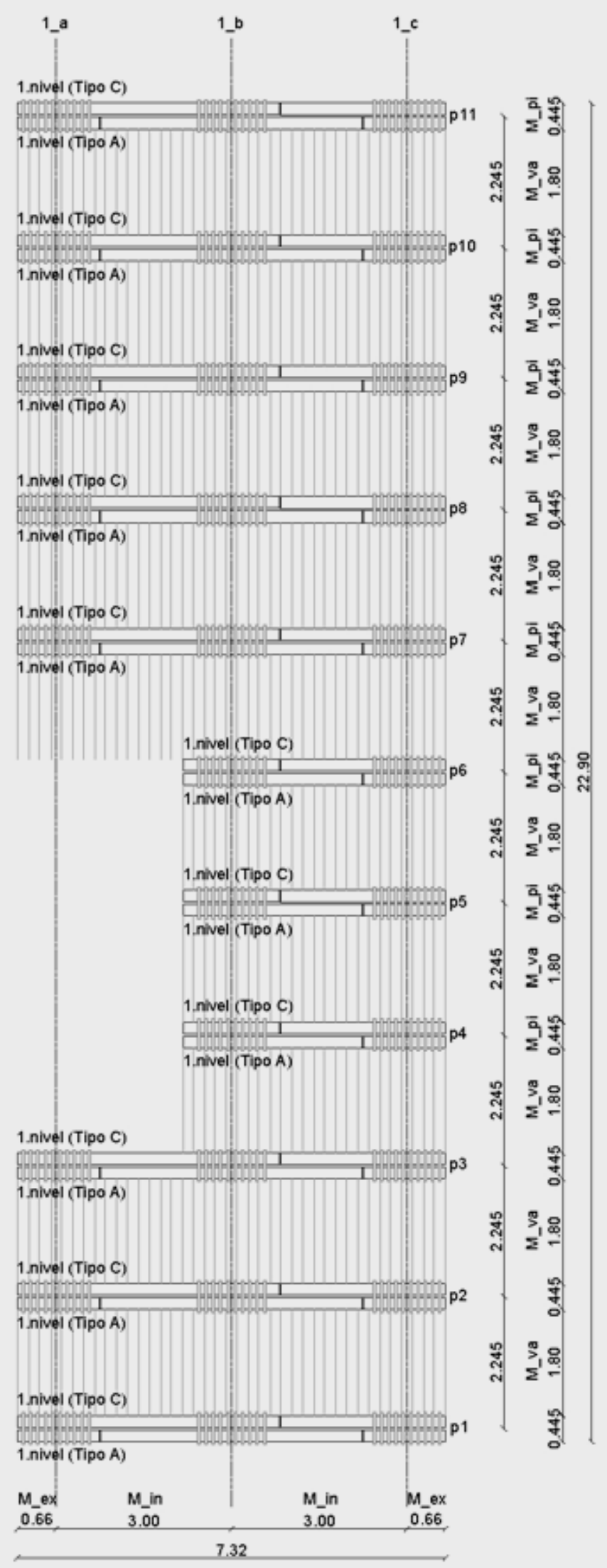

Figura 66.

Planta / Stapel 1

Dibujo de la autora 

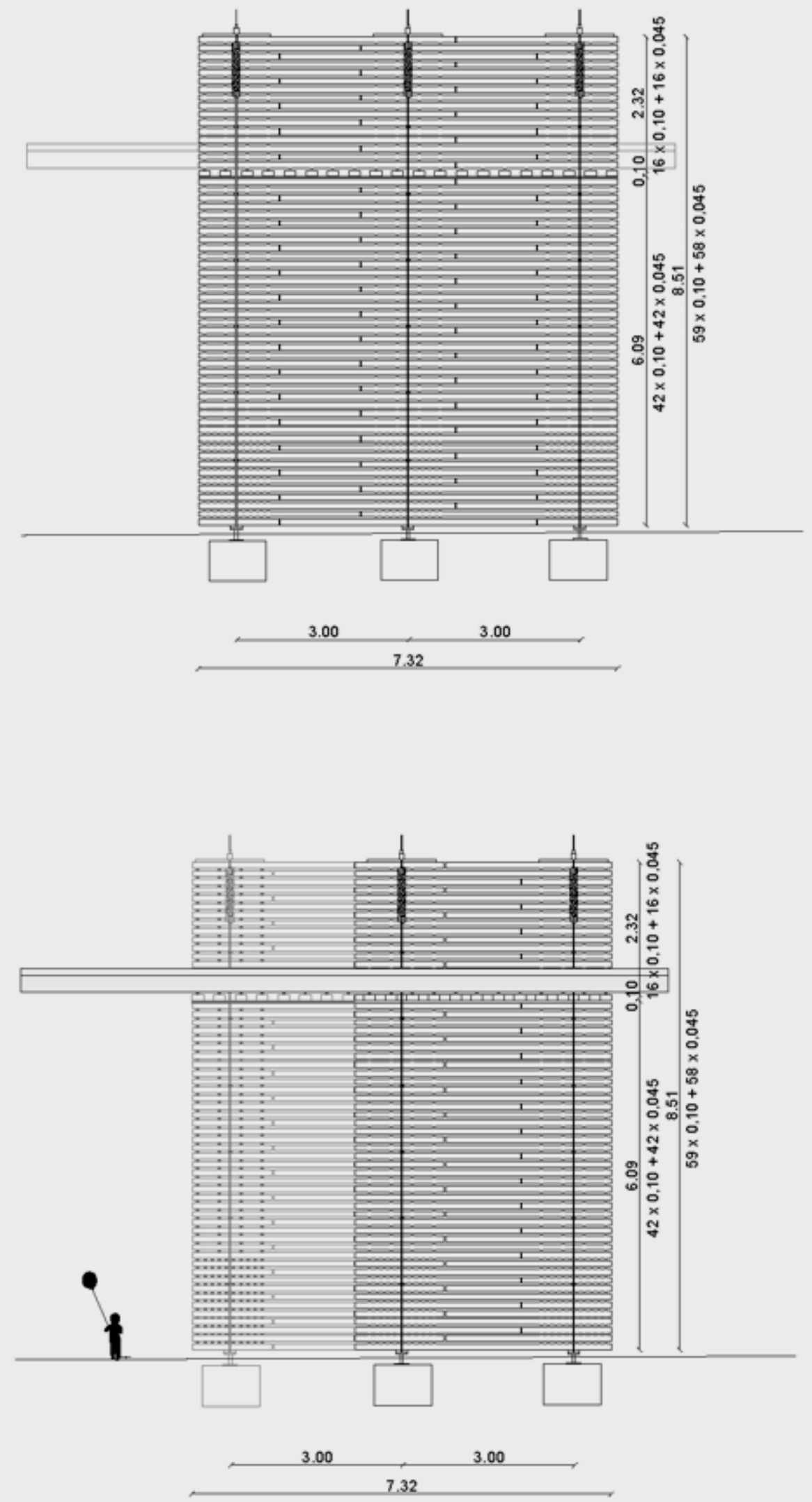

Figura $67-68$.

Alzado + sección longitudinal / Stapel 1

Dibujo de la autora 


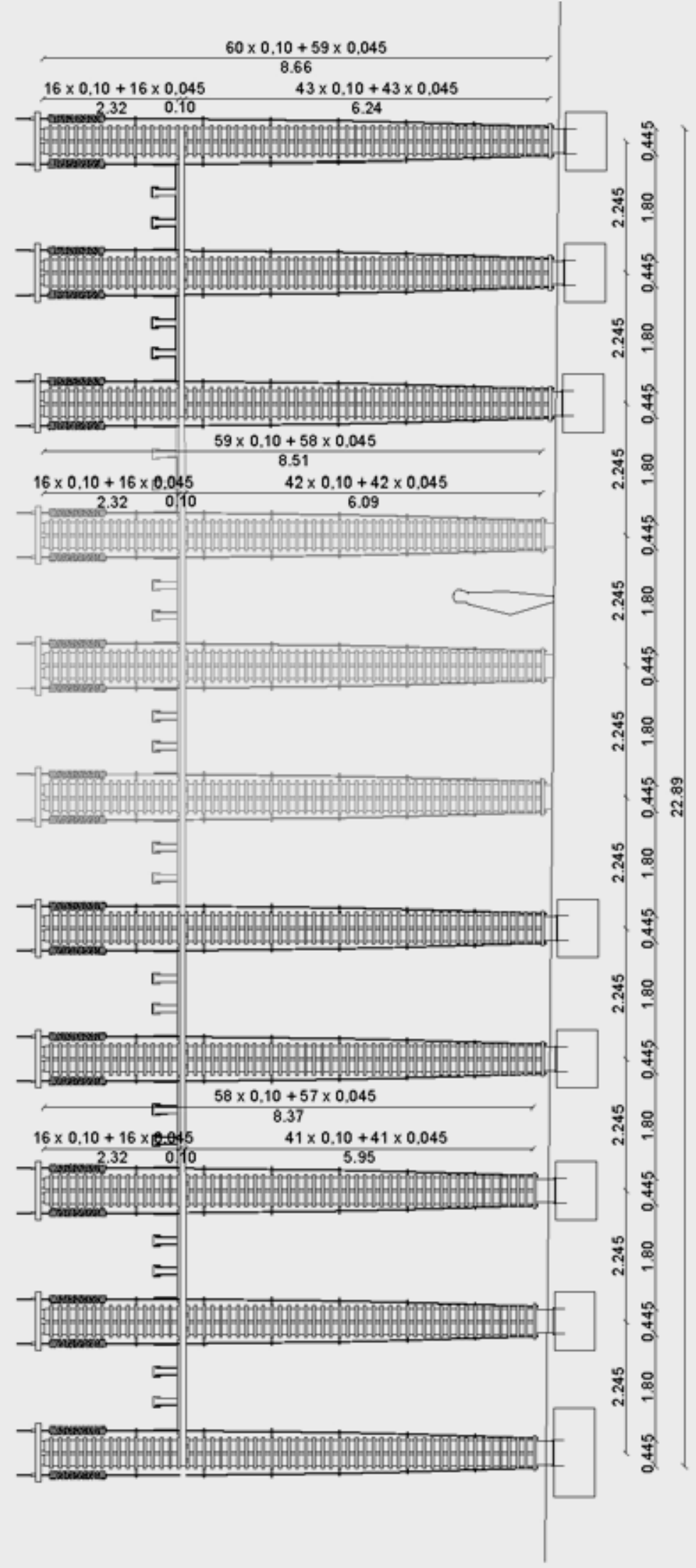

Figura 69.

Alzado oeste / Stapel 1

Dibujo de la autora 


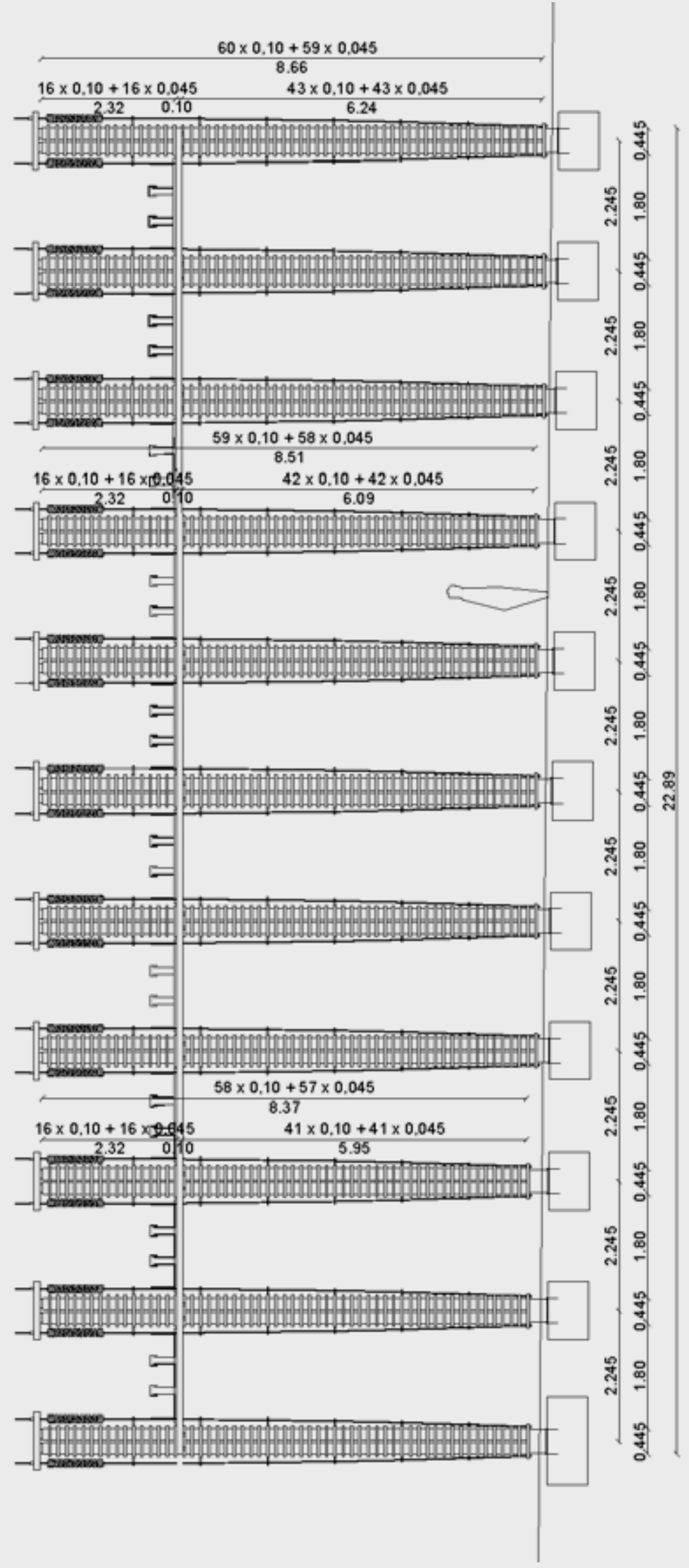

Figura 70.

Alzado / Stapel 1

Dibujo de la autora 
| 


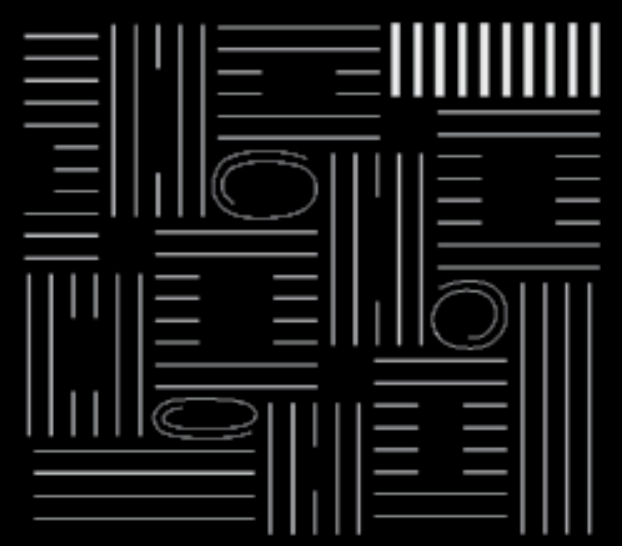

STAPEL 4

Tipo de madera: Alerce

Paredes: 10

Uso: Conjunto en esquina

Dimensiones: $\mathbf{7 , 3 2} \times \mathbf{2 0 , 6 5} \mathrm{m}$

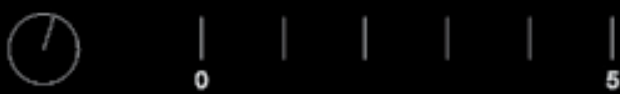


[Stapel 4]

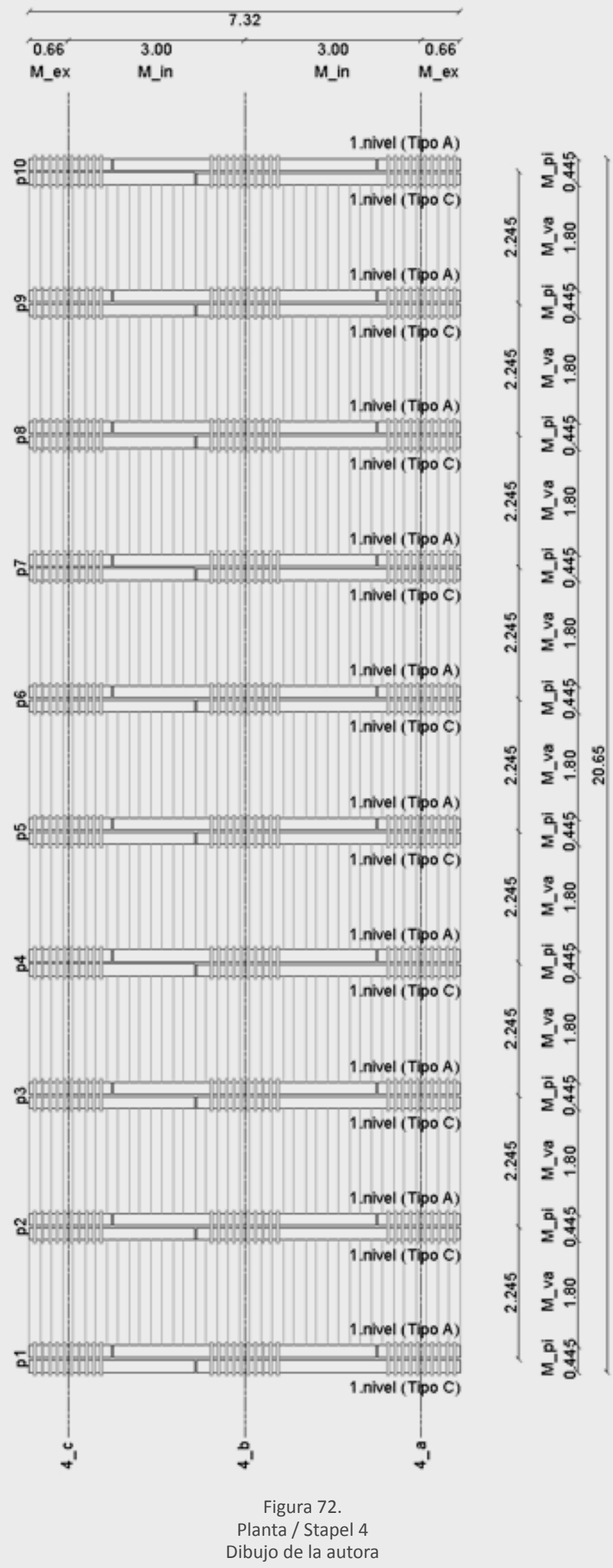



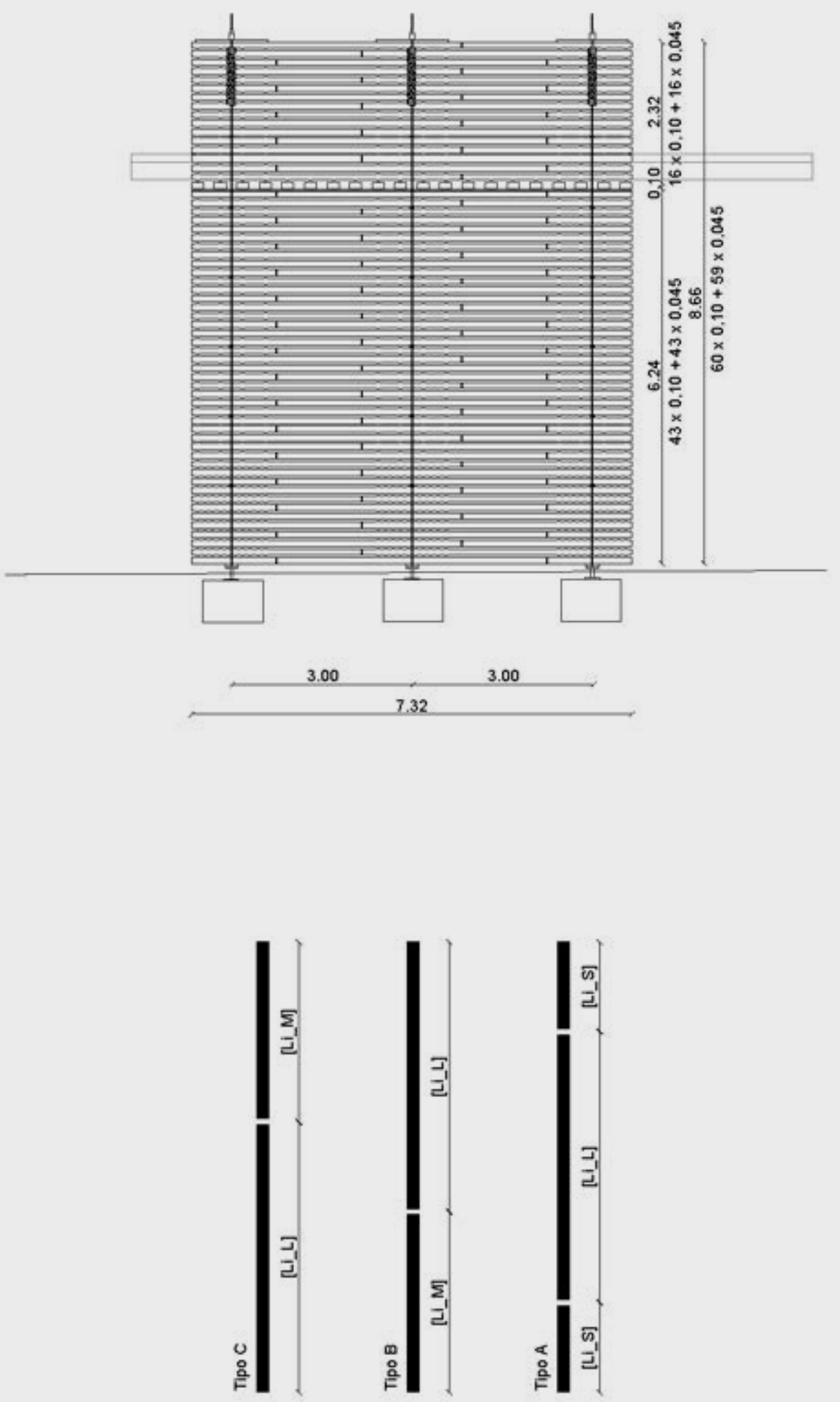

Figura $73-74$.

Alzado longitudinal + Sistema compositivo de los listones de madera / Stapel 4 Dibujo de la autora 


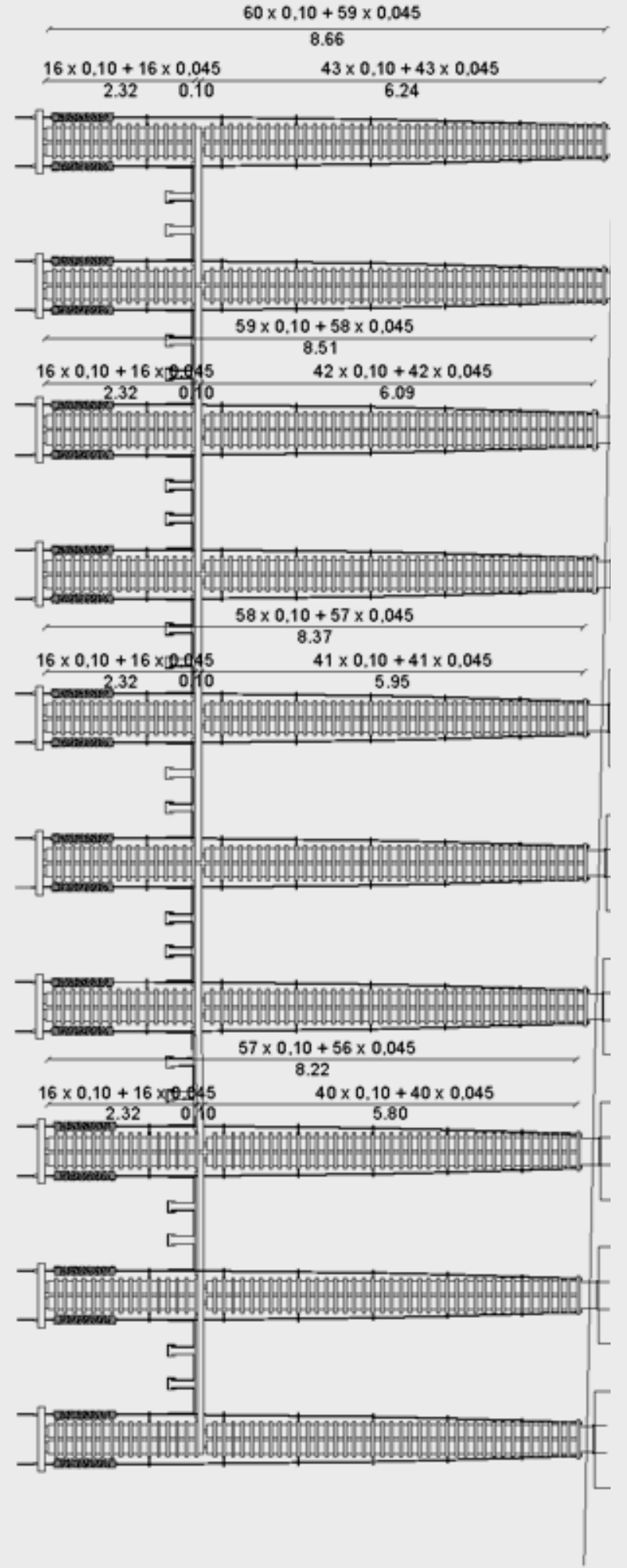

Figura 75.

Alzado transversal / Stapel 4

Dibujo de la autora 


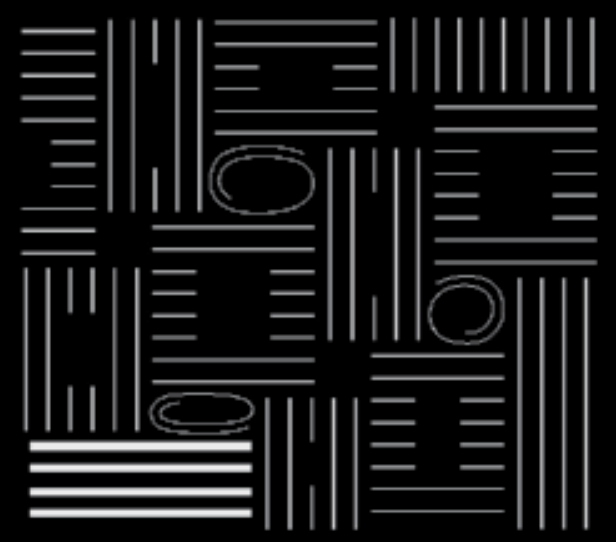

STAPEL 9

Tipo de madera: Pino

Paredes: 4

Uso: Conjunto en esquina

Dimensiones: 7,18 x 22,32 m

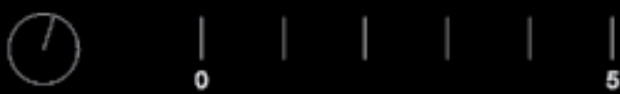


[Stapel 9]

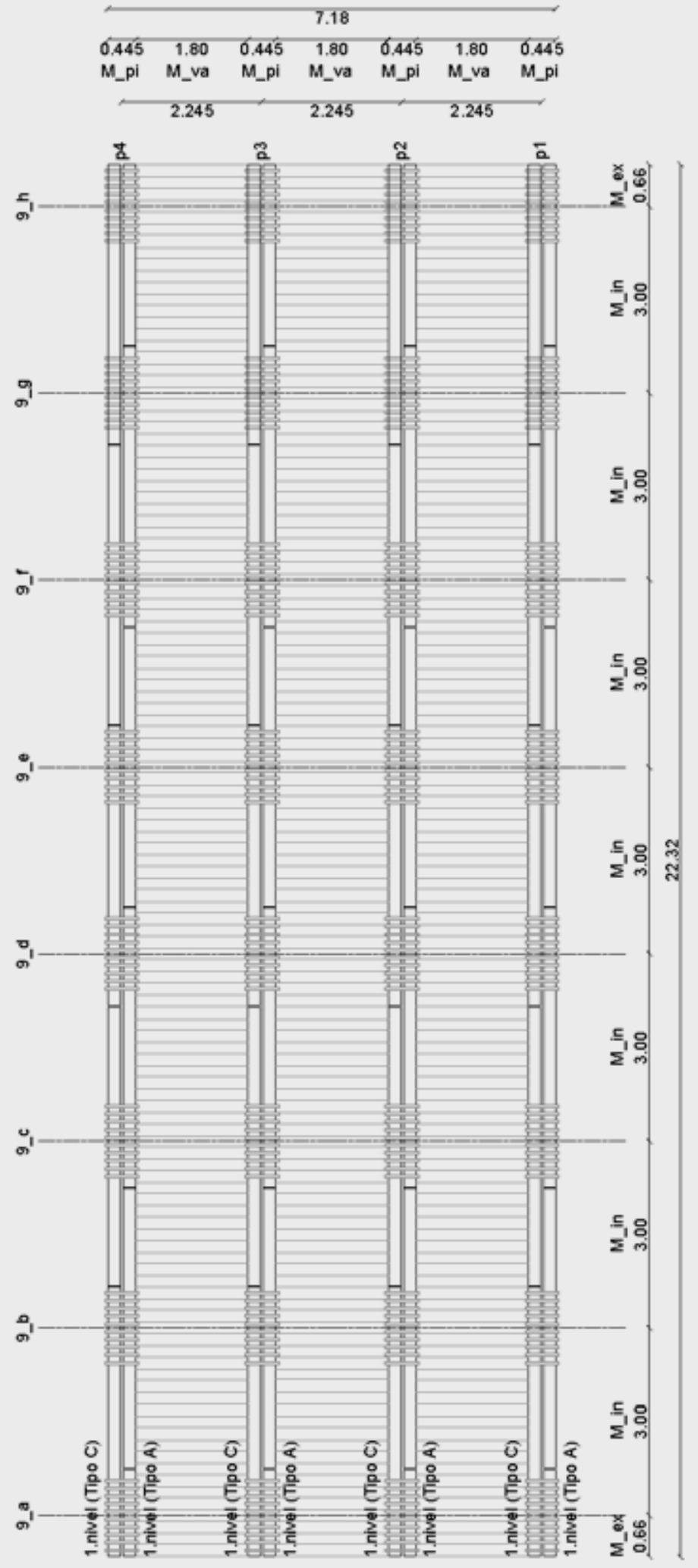

Figura 76.

Planta / Stapel

Dibujo de la autora 

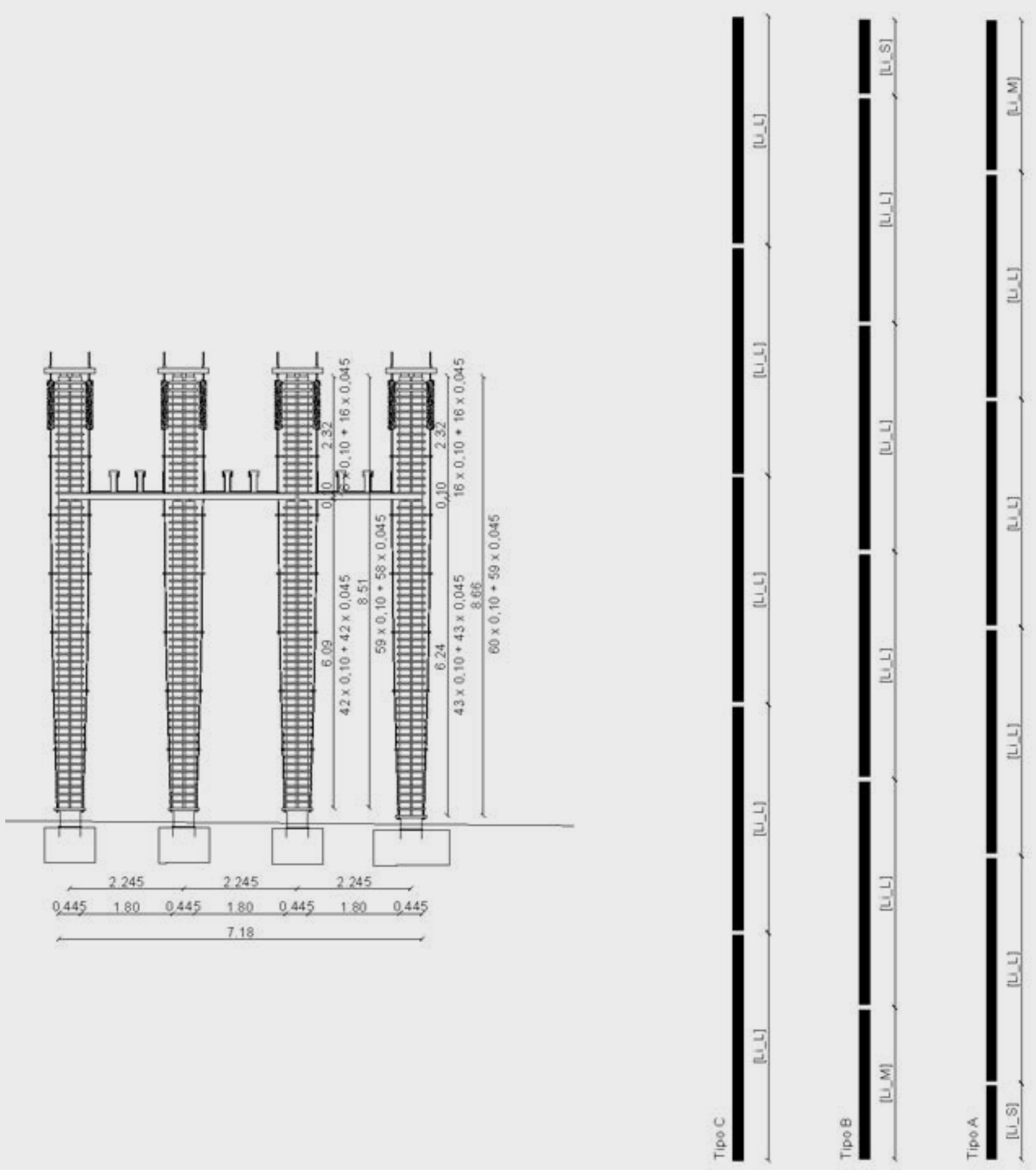


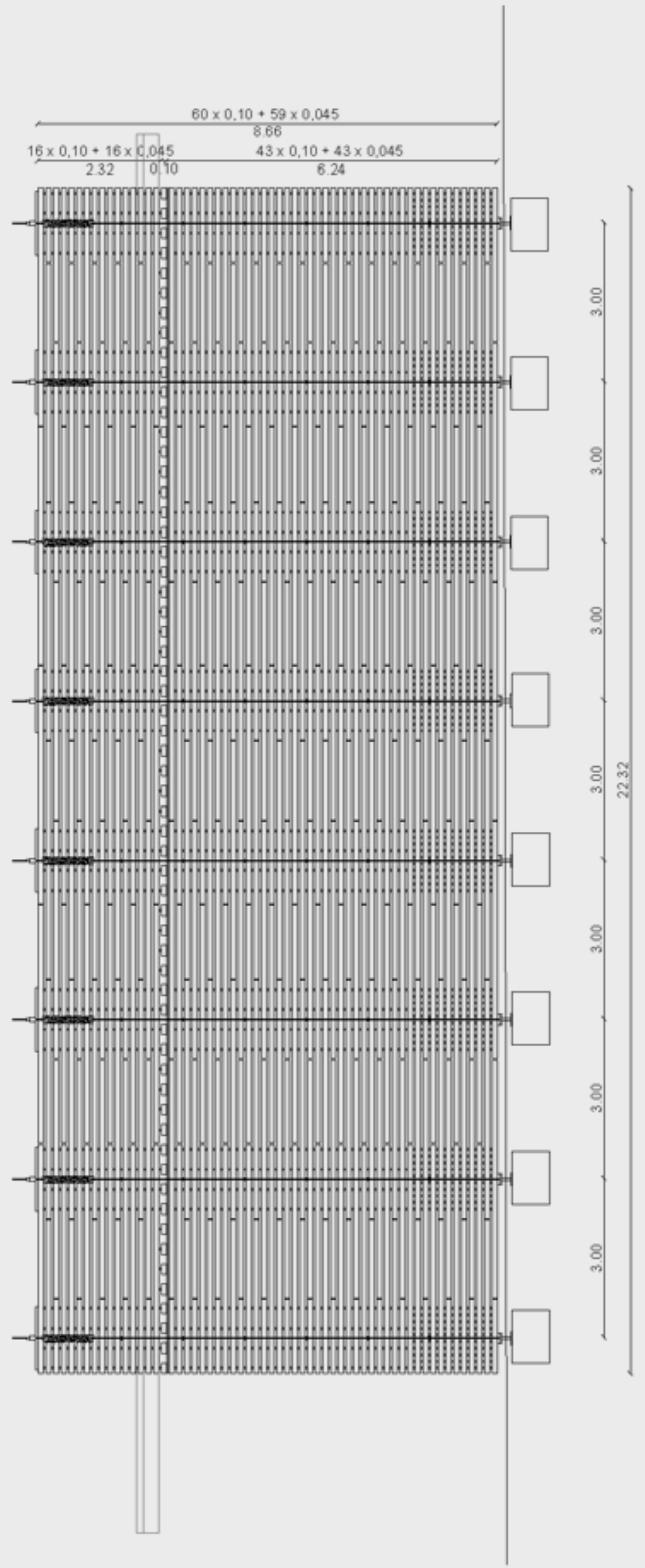

Figura 79.

Alzado longitudinal / Stapel 9

Dibujo de la autora 


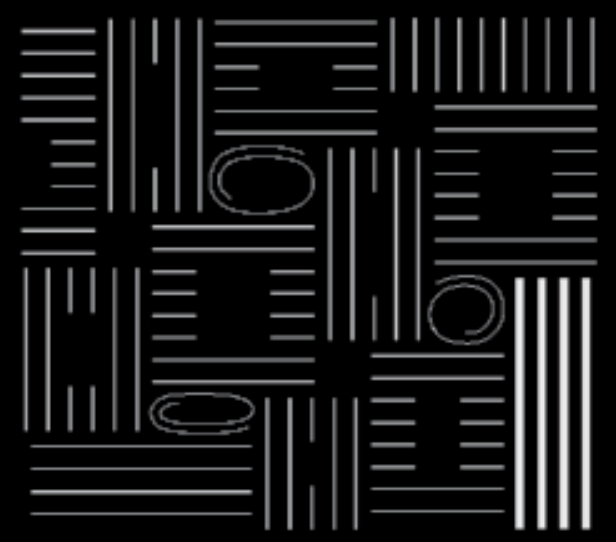

STAPEL 12

Tipo de madera: Alerce

Paredes: 4

Uso: Conjunto en esquina

Dimensiones: 7,18 x 25,32 m

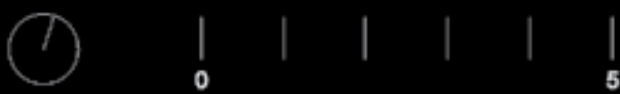


[Stapel 12]
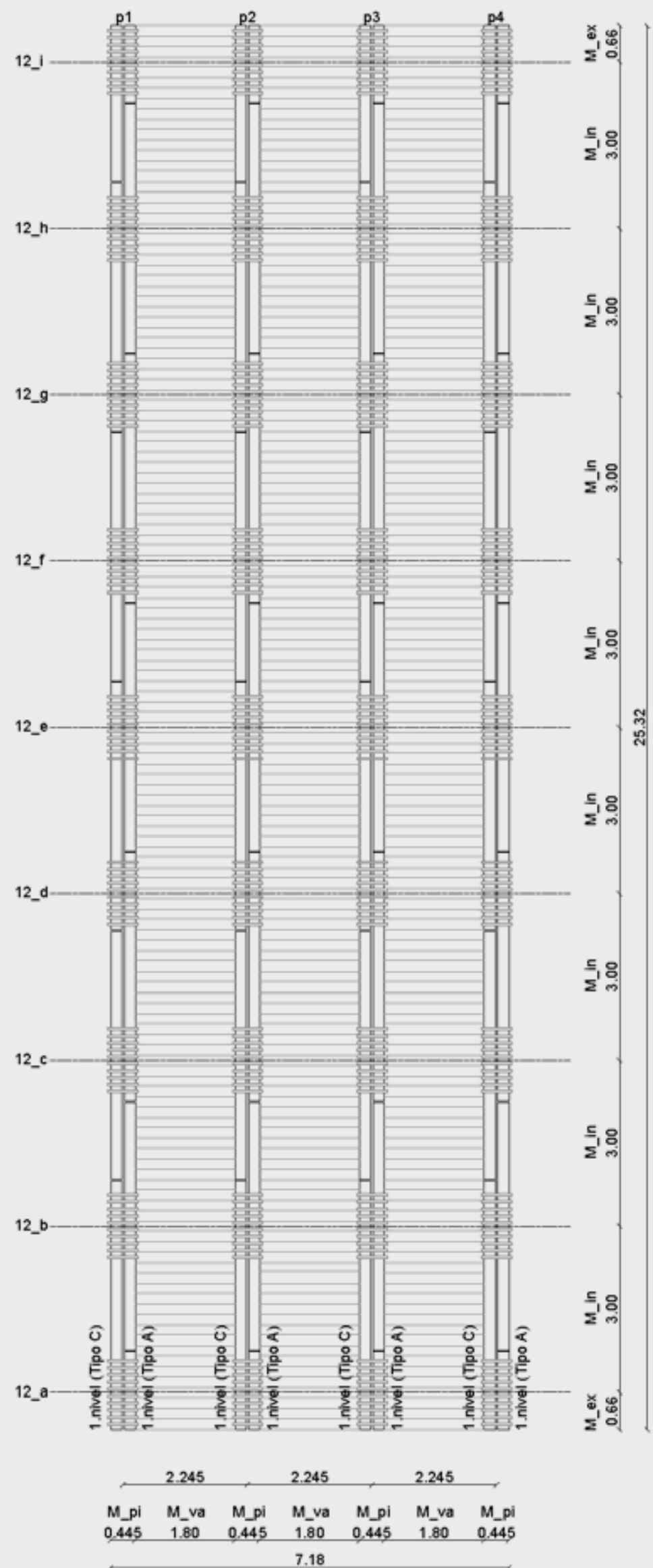

Figura 80.

Planta / Stapel 12

Dibujo de la autora 

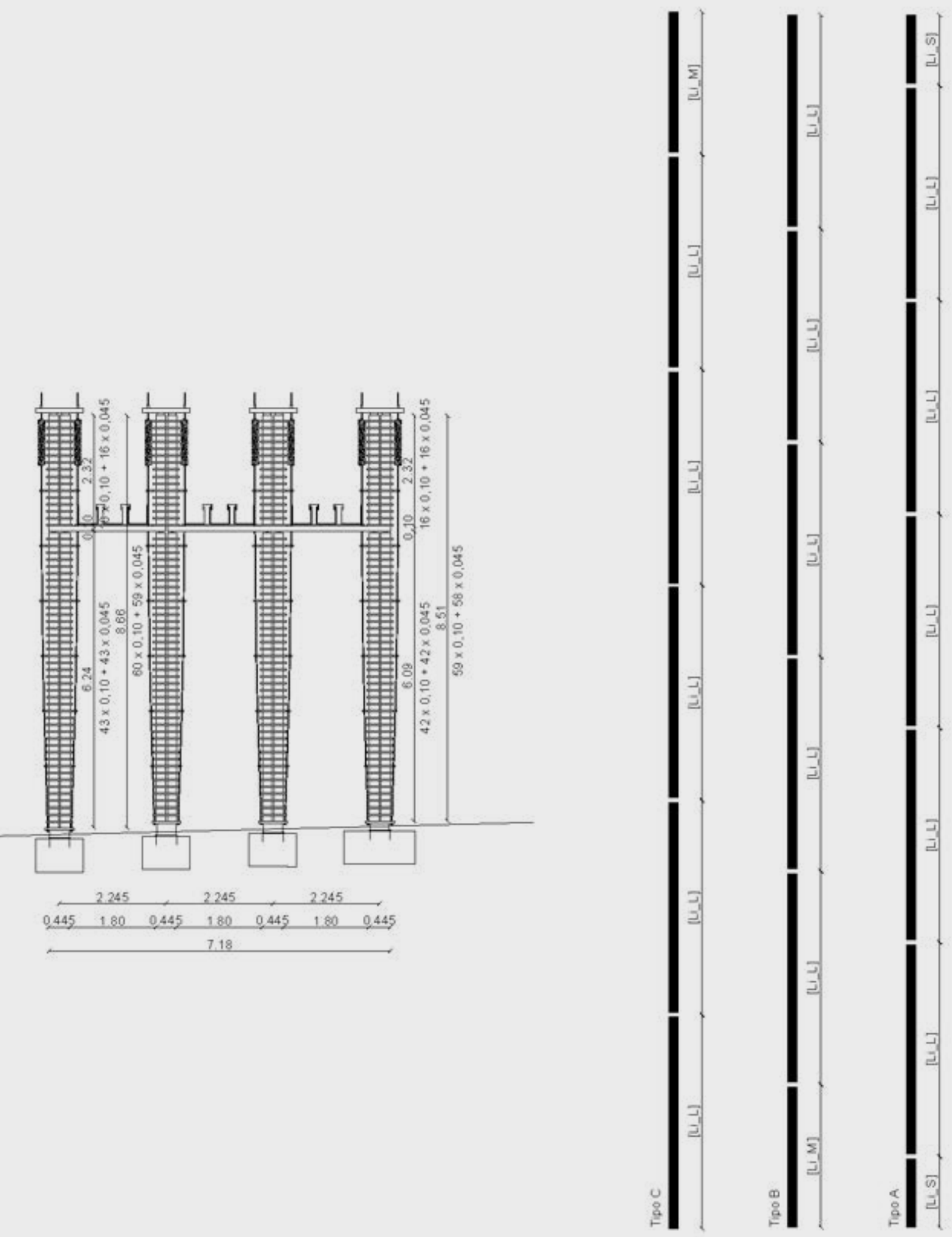


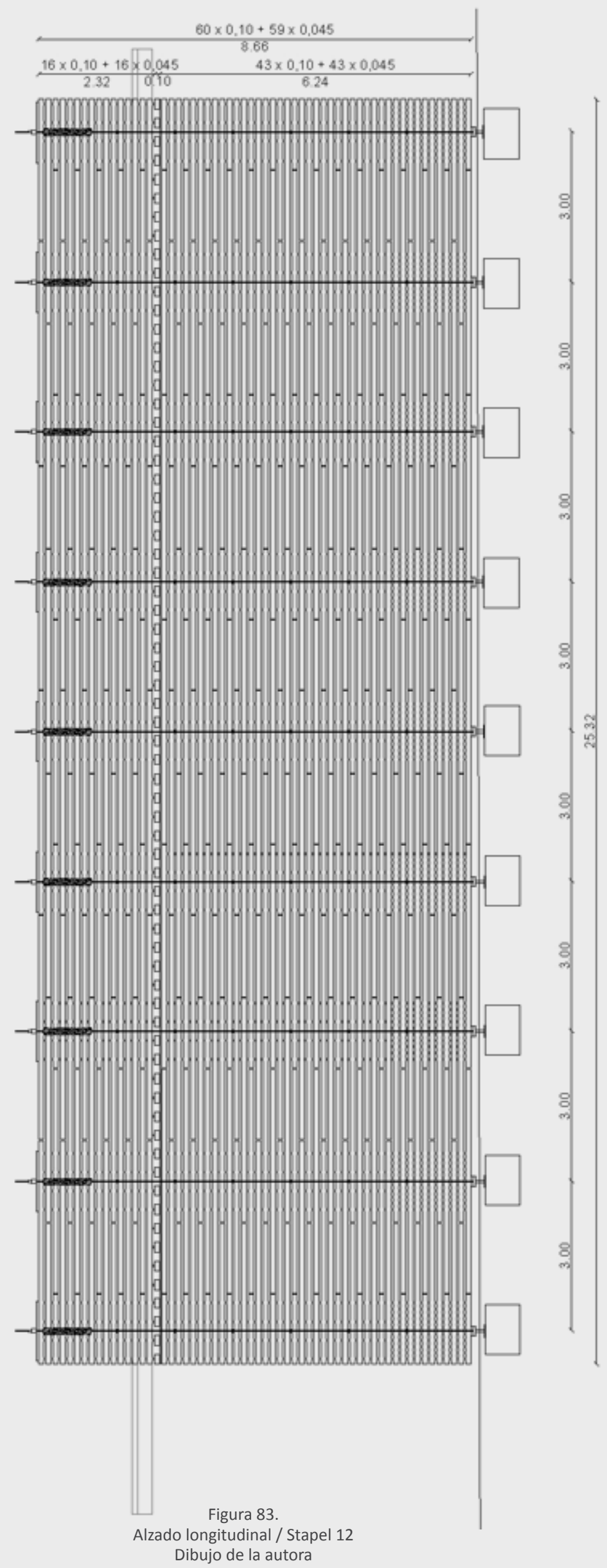



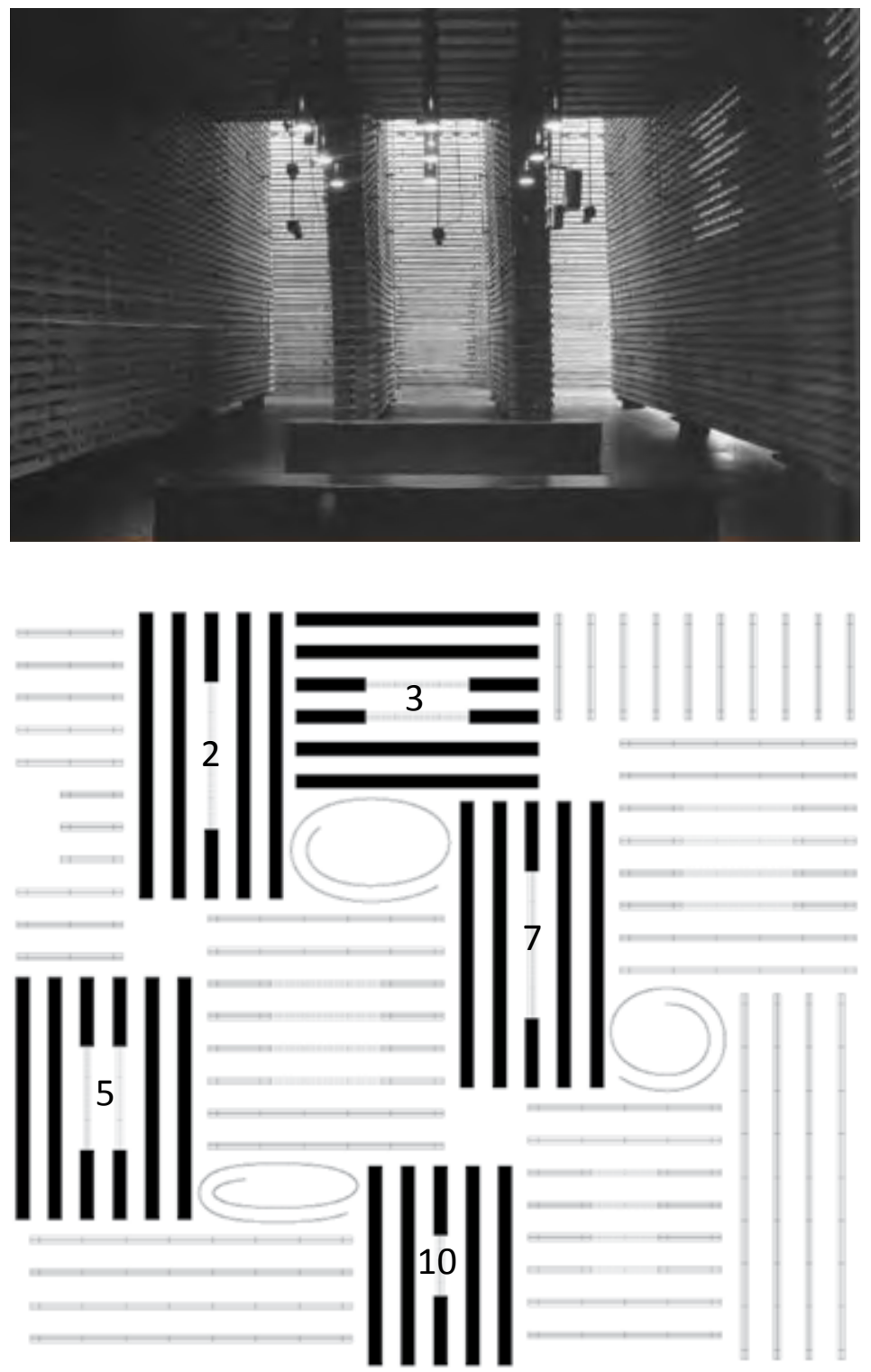

Figura 84 - 85

Espacio sonoro / Pabellón helvético 


\section{[Espacios sonoros]}

"iOid! Todo espacio funciona como un gran instrumento, mezcla los sonidos, los amplifica, los transmite a todas partes. Tiene que ver con la forma y con la superficie de los materiales que contiene y con cómo se han aplicado. ${ }^{49}$ Peter Zumthor

El resto de Stapel que no se ubican en los vértices, contienen oquedades con programas sugeridos. Lugares geométricamente definidos sin elementos delimitadores, ambientes cubiertos sin interrupciones. No existen puertas o ventanas. Espacios protegidos, refugios para pararse y estar. Escenarios experimentales donde poder sentir a Suiza. Estas capillas sensoriales se dividen en dos tipos de percepciones vinculadas al oído, los espacios sonoros; y con el gusto, los espacios gastronómicos.

Los espacios sonoros se ubican en los Stapel 2, 3, 5, 7 y 10. El centro se interrumpe por medio de la fragmentación de las bandas para dar cabida al contenido programático. Las pilas de estos espacios se orientan en dos direcciones: noreste/suroeste y noroeste/sureste. Las luces de estos espacios varían entre 4,045 m ( x1 [M_pi] /+) $x 2$ [M_va] ) de los Stapel 2,4 y 10; hasta los 6,29 m (x2 [M_pi] /+/ x3 [M_va]) de los Stapel 3 y 5 . La altura libre es de 5,365 $\mathrm{m}^{50}$ dado que el entramado de su cubierta se resuelve en cuatro niveles. Los espacios son de diferentes largos: 4,68 m (Stapel 10); 7,68 m (Stapel 3 y 5) ó 10,68 m (Stapel 2 y 7). Estos Klangräume contienen en el área central dos místicos bancos macizos negros ${ }^{51}$ perpendiculares a las pilas donde poder deleitar la música en directo. 


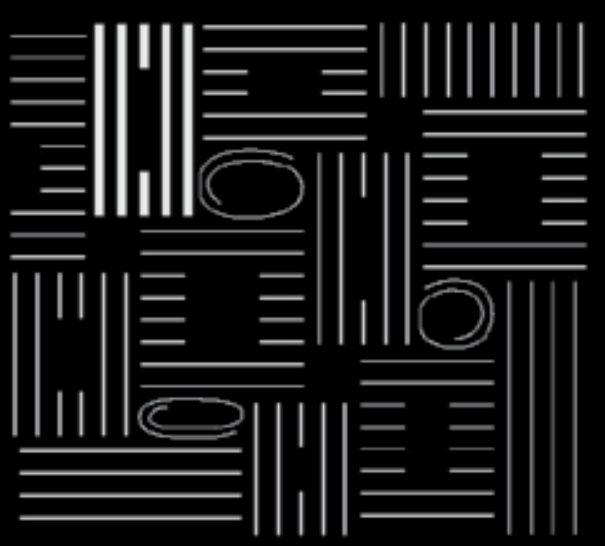

STAPEL 2

Tipo de madera: Alerce

Paredes: 6

Uso: Espacio sonoro

Dimensiones: $\mathbf{9 , 4 3} \times \mathbf{1 9 , 3 2} \mathrm{m}$

Oquedad: 4,045 x 10,36 m

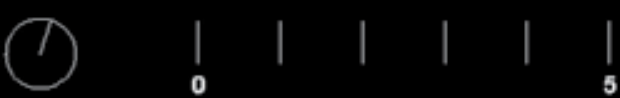


[Stapel 2]

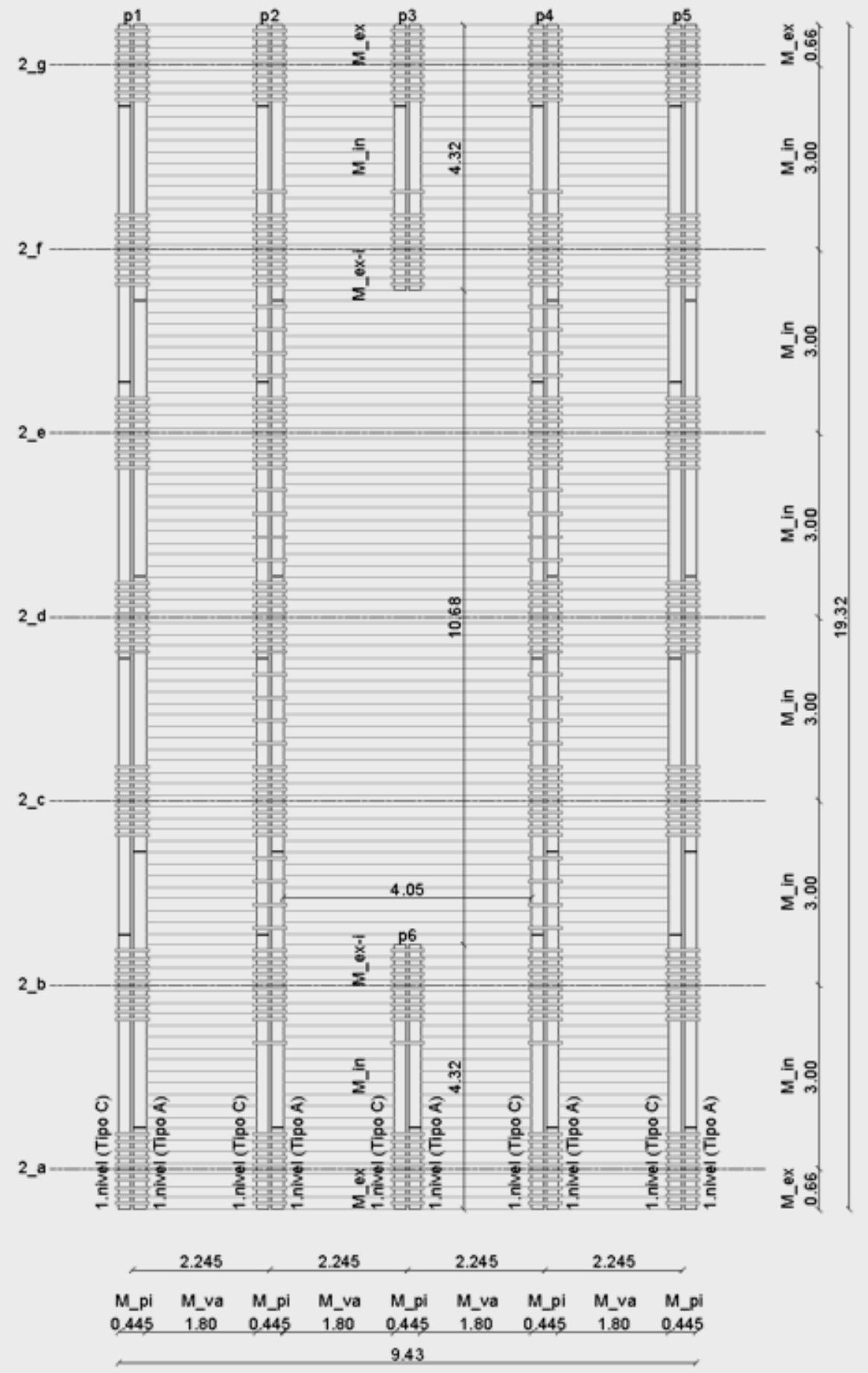

Figura 86.

Planta / Stapel 2

Dibujo de la autora 

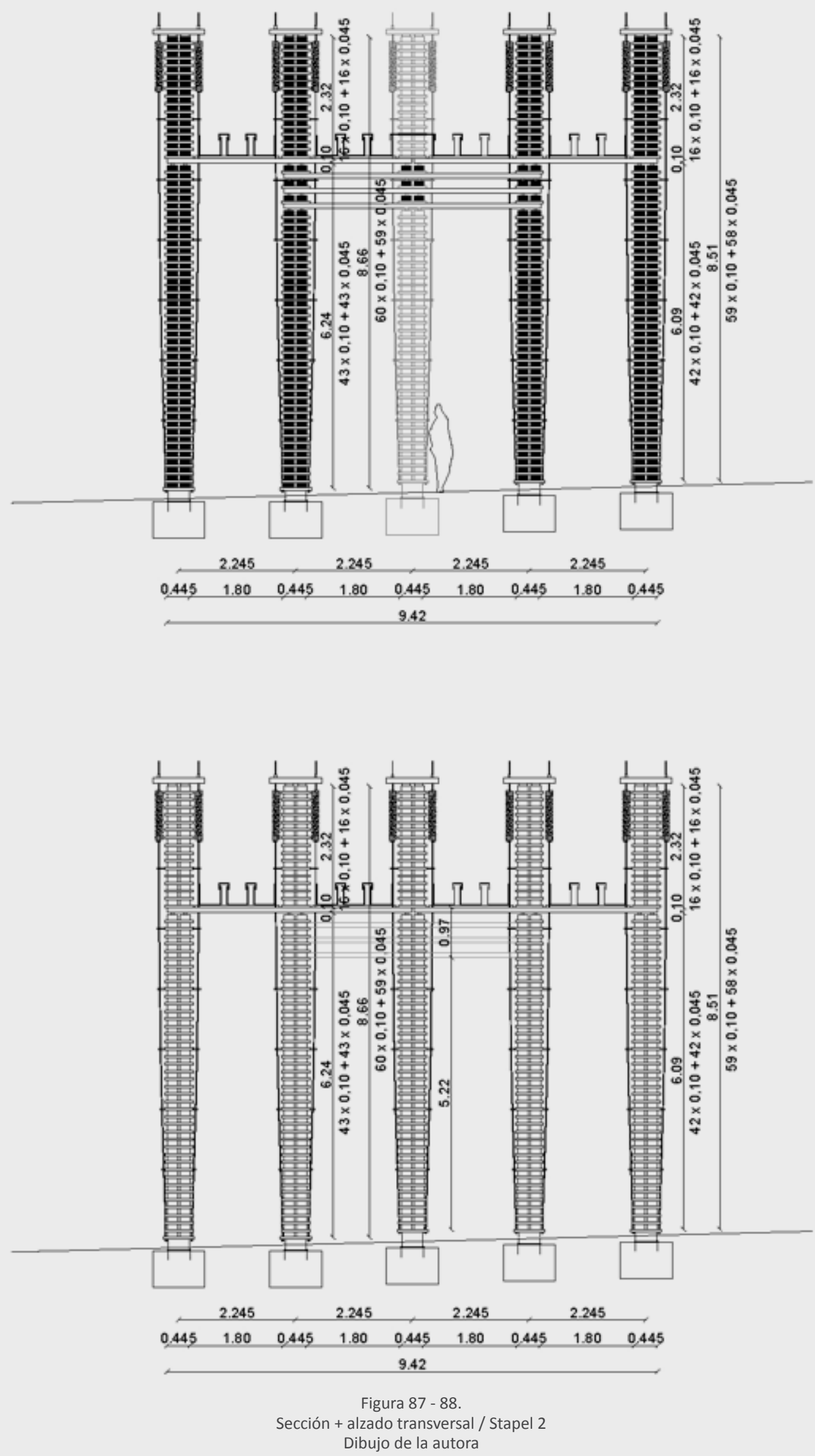


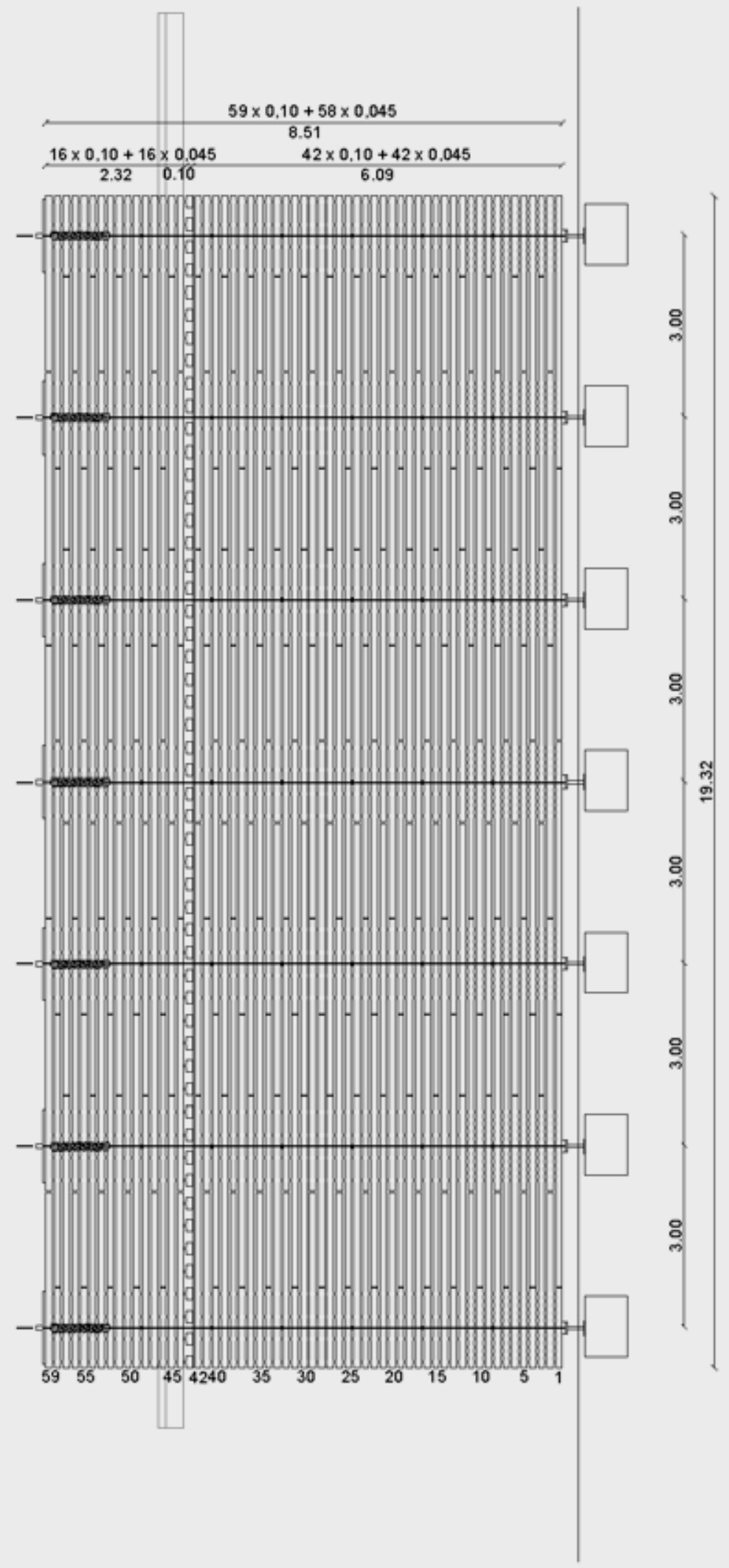

Figura 89.

Alzado longitudinal / Stapel 2

Dibujo de la autora 


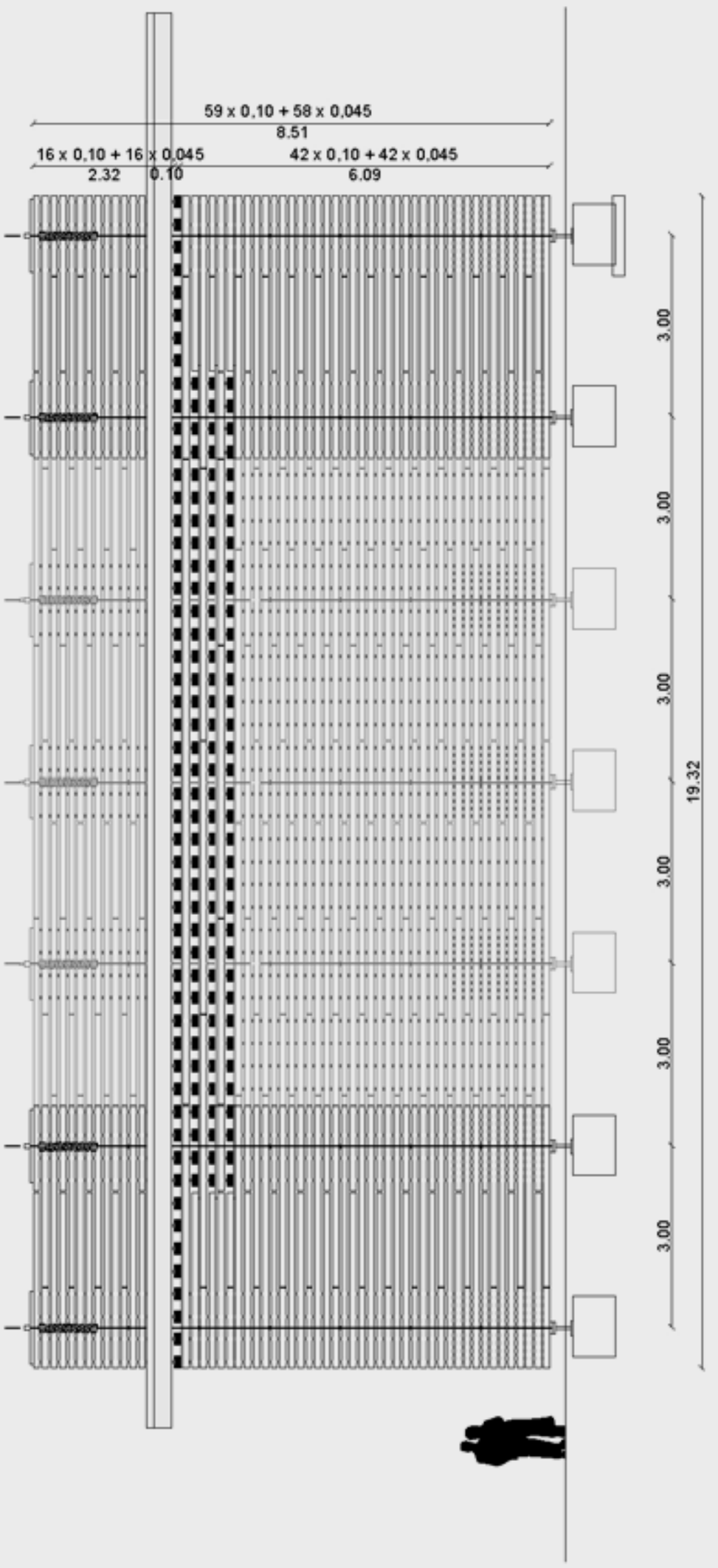

Figura 90.

Sección longitudinal / Stapel 2

Dibujo de la autora 


$$
\|
$$




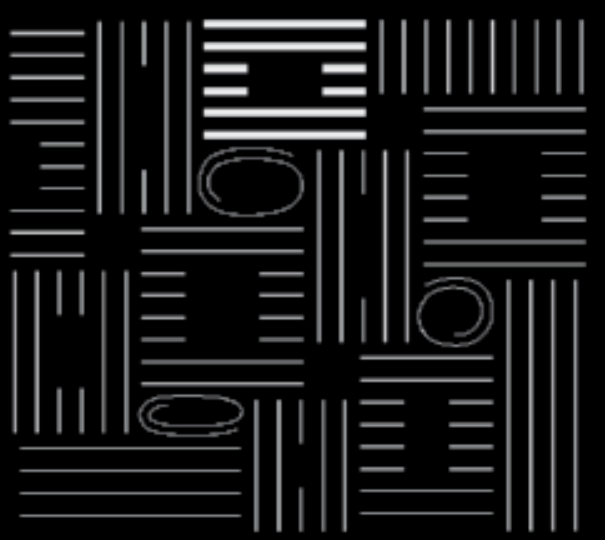

STAPEL 3

Tipo de madera: Pino

Paredes: 8

Uso: Espacio sonoro

Dimensiones: 11,67 x 16,32 m

Oquedad: $6,29 \times$ 7,68 m 
[Stapel 3]

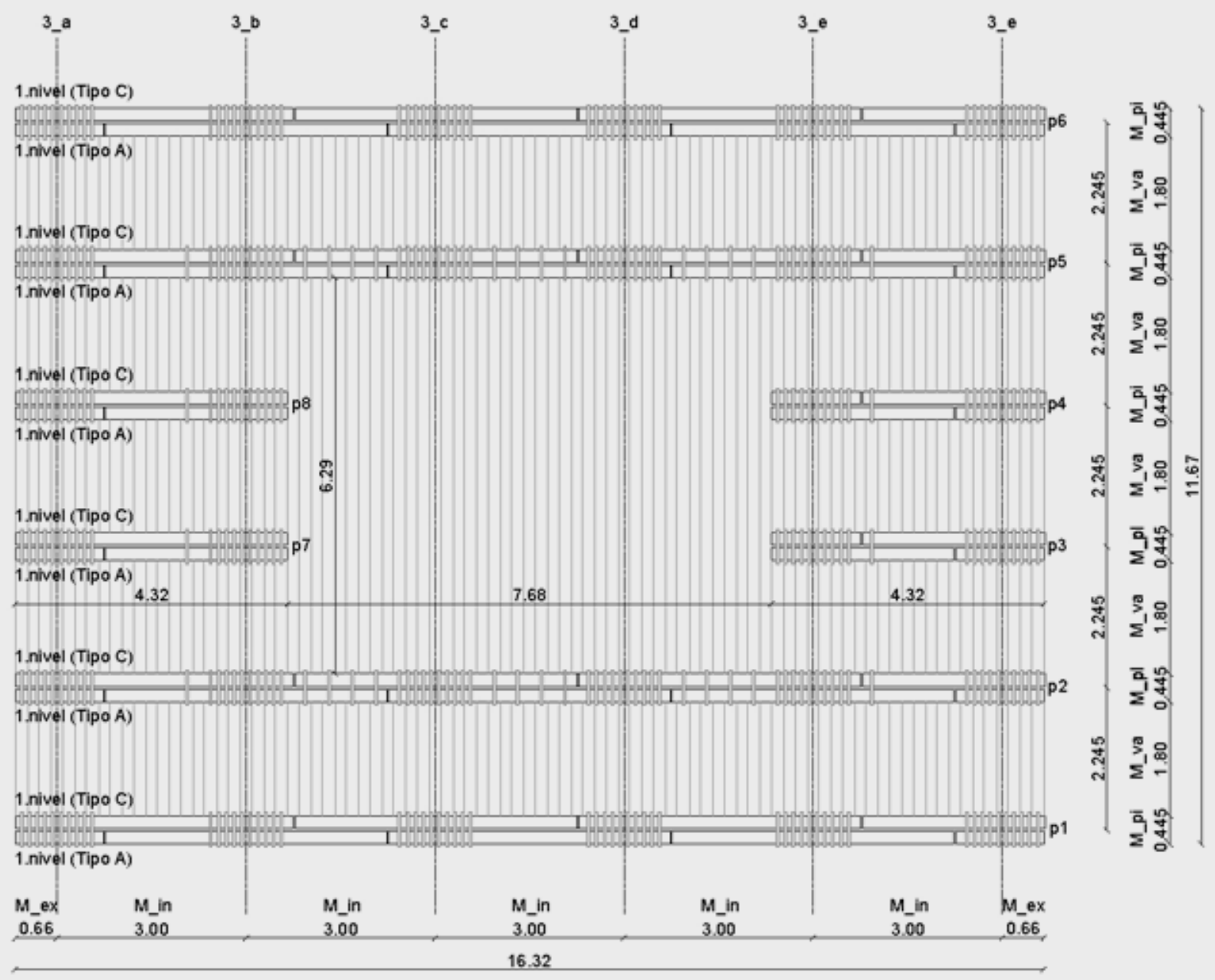



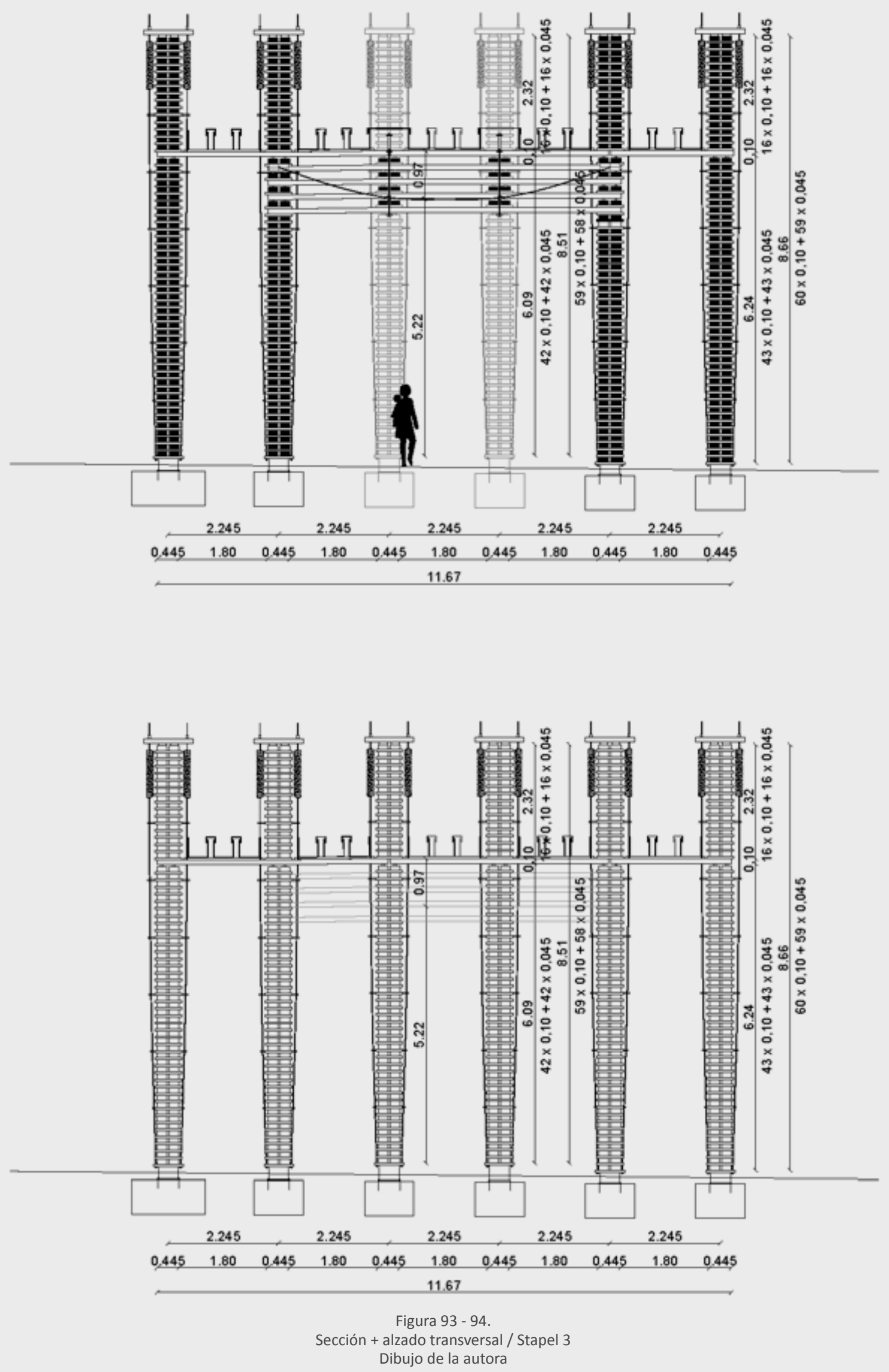


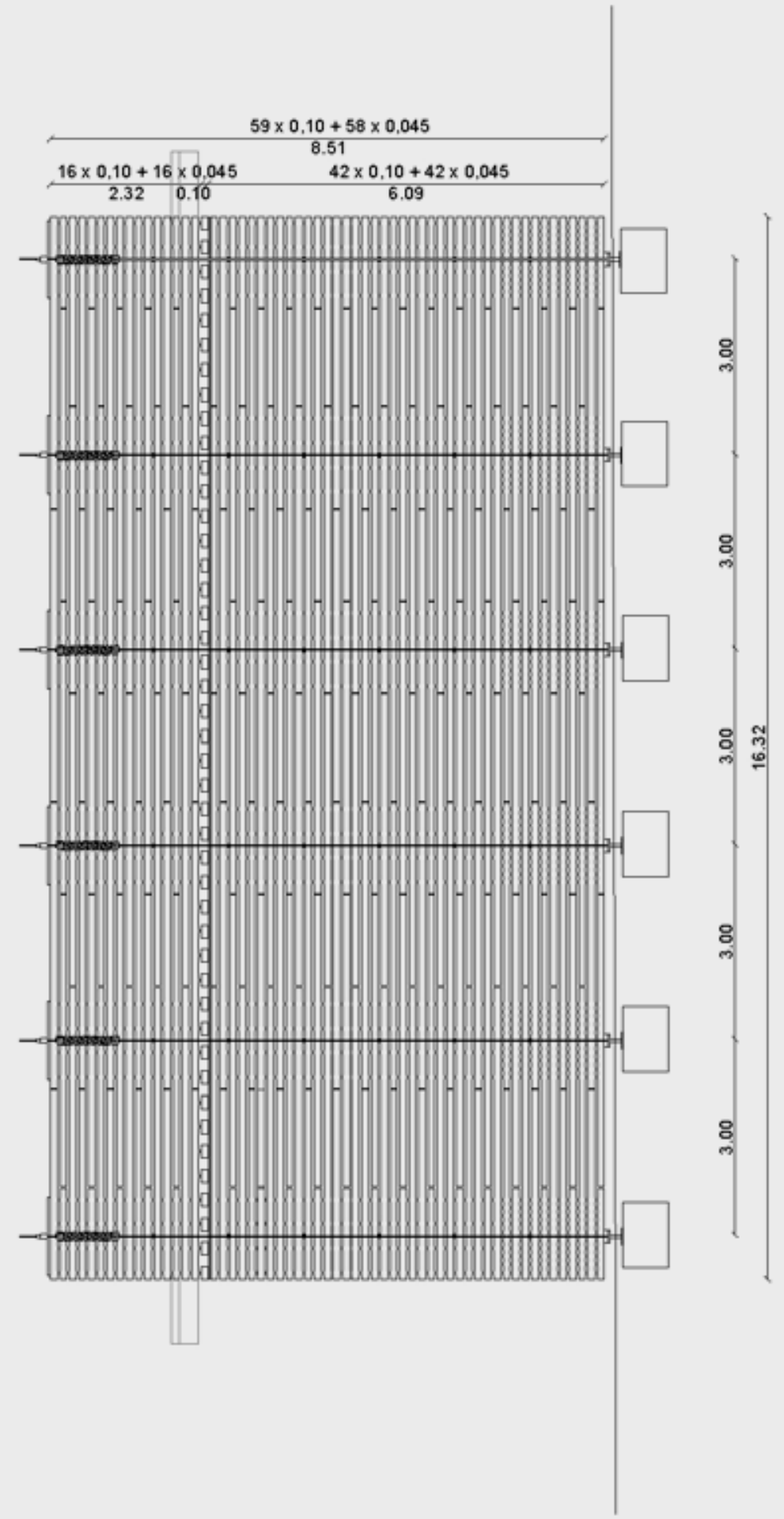

Figura 95.

Alzado longitudinal / Stapel 3

Dibujo de la autora 


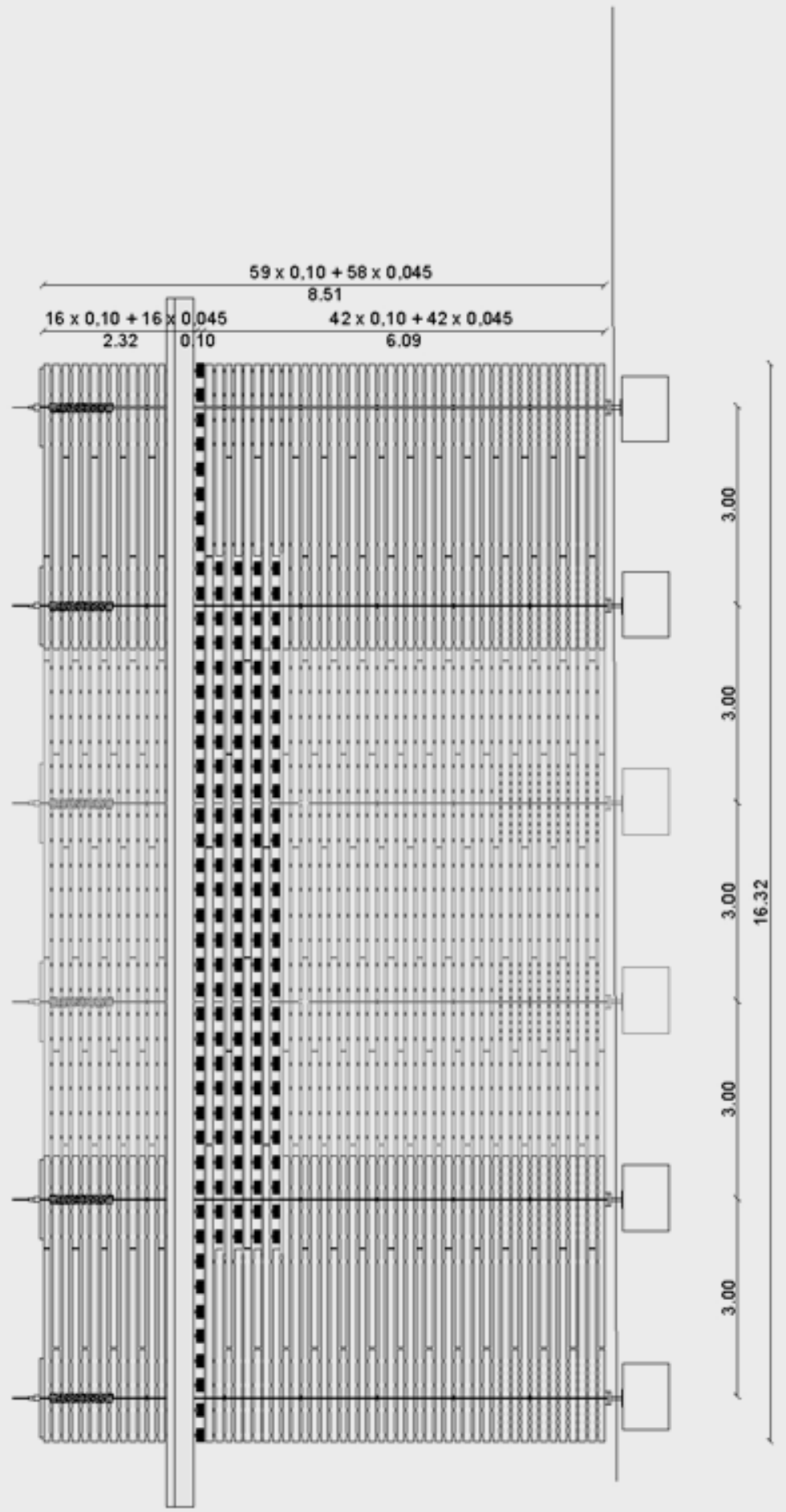

Figura 96.

Sección longitudinal / Stapel 3

Dibujo de la autora 


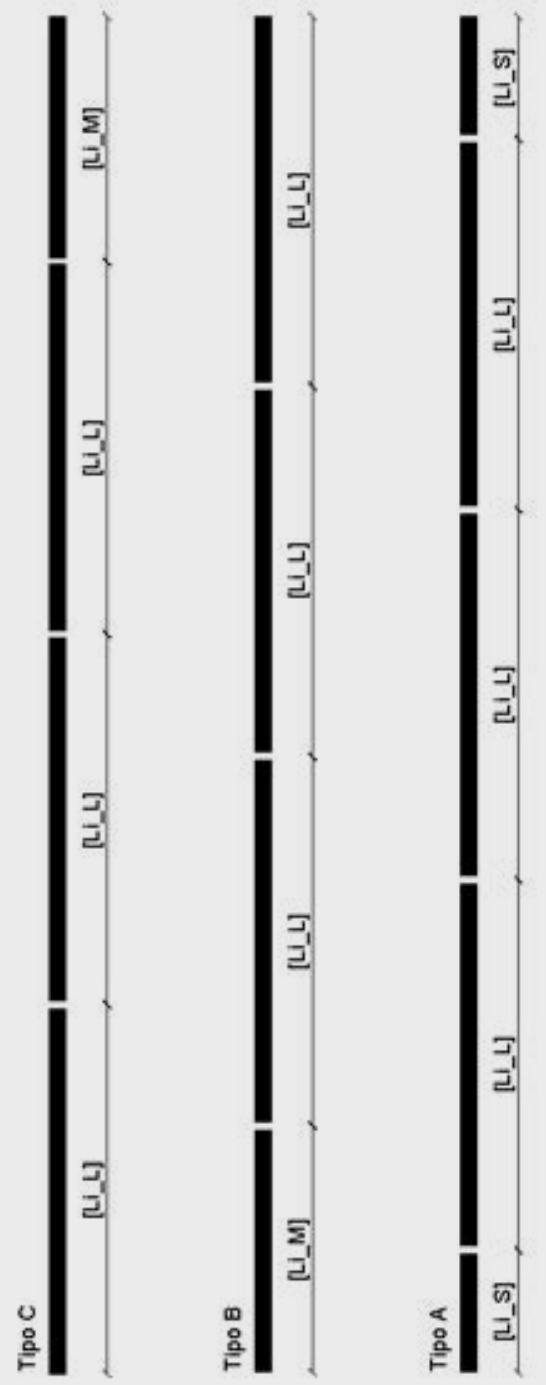




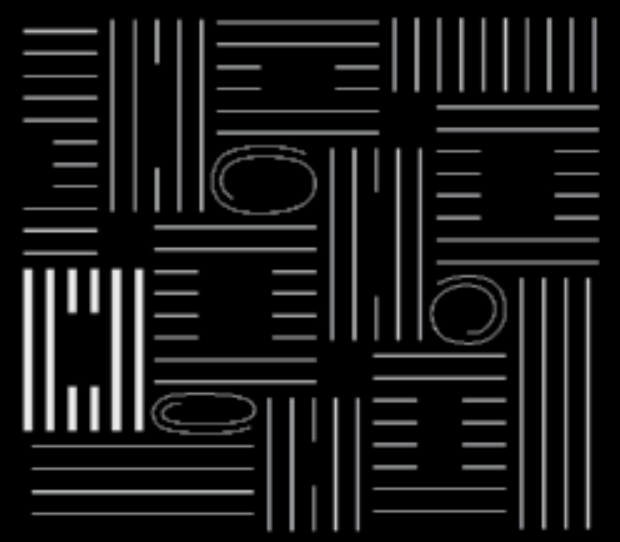

STAPEL 5

Tipo de madera: Alerce

Paredes: 8

Uso: Espacio sonoro

Dimensiones: 11,67 x 16,32 m

Oquedad: $6,29 \times$ 7,68 m 
[Stapel 5]

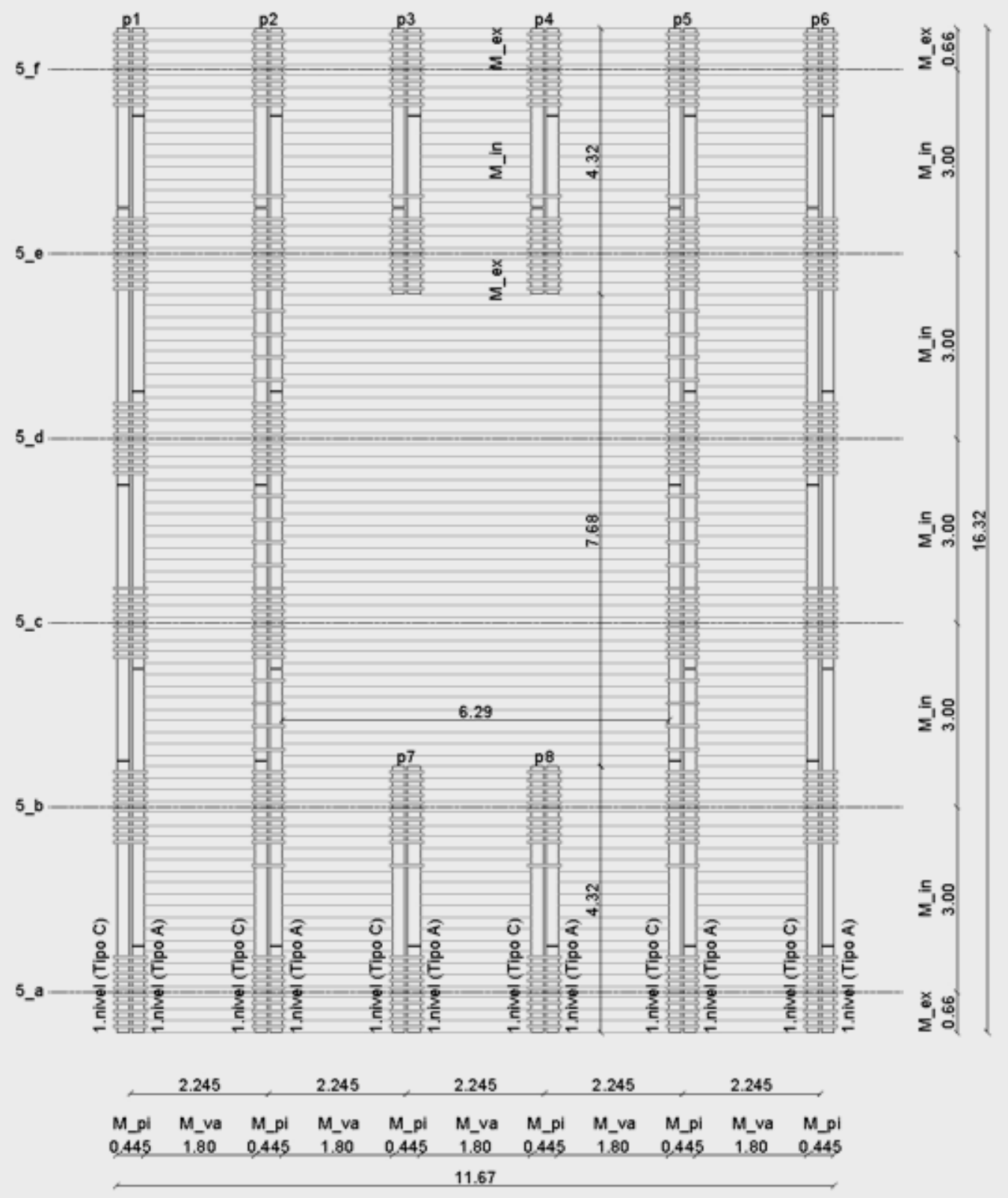



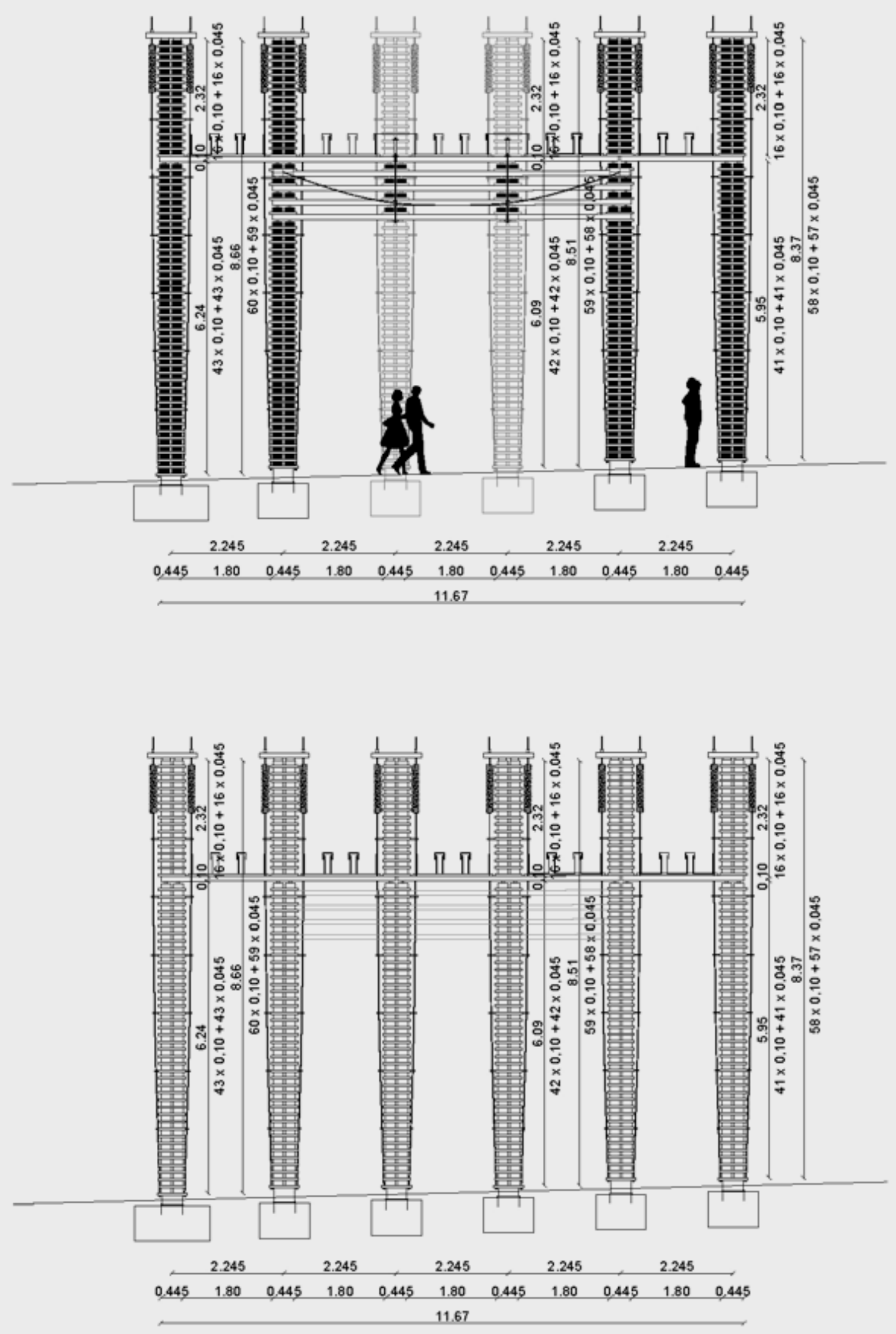

Figura 99 - 100

Sección + alzado transversal / Stapel 5

Dibujo de la autora 


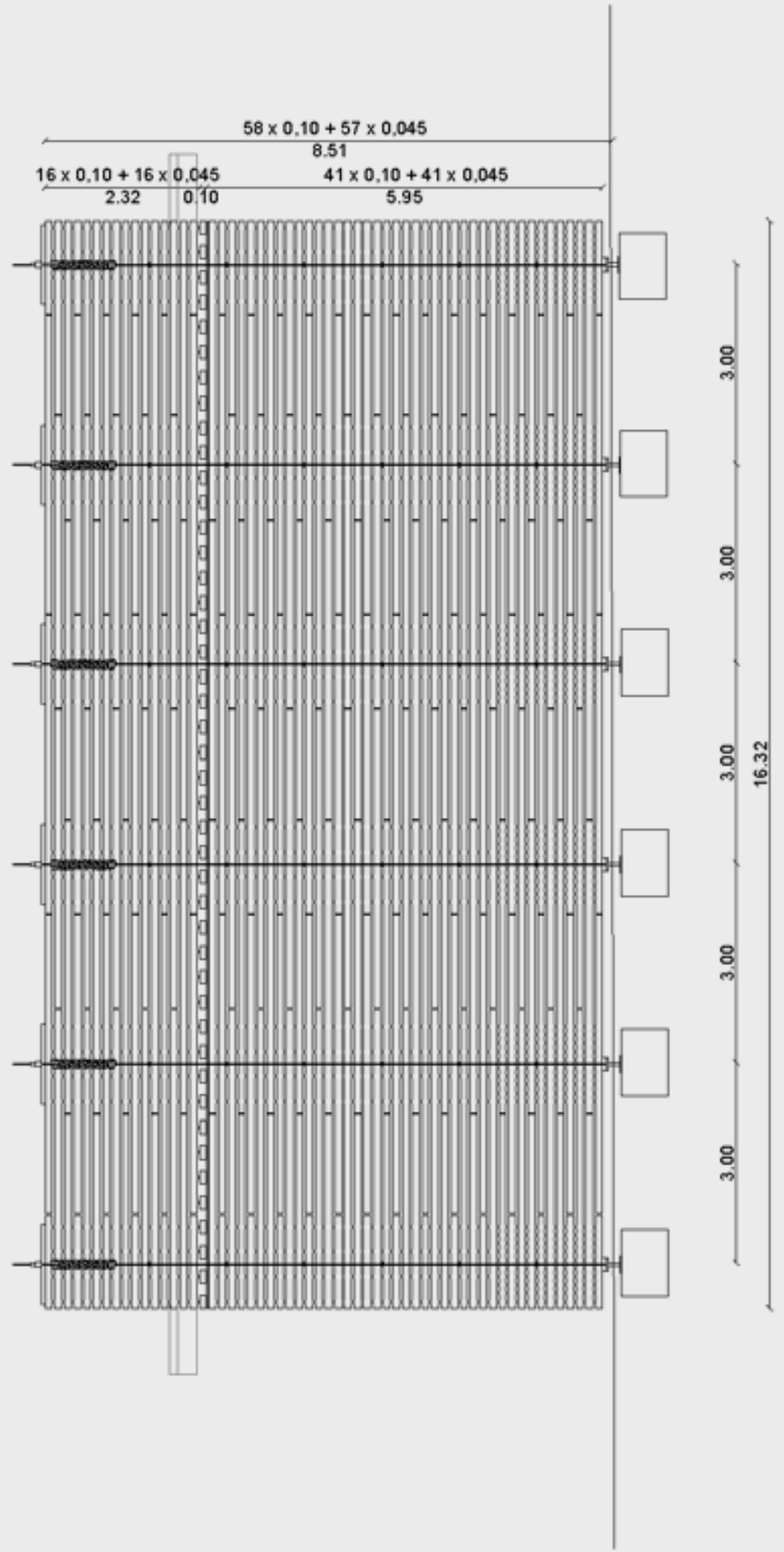

Figura 101.

Alzado longitudinal / Stapel 5

Dibujo de la autora 


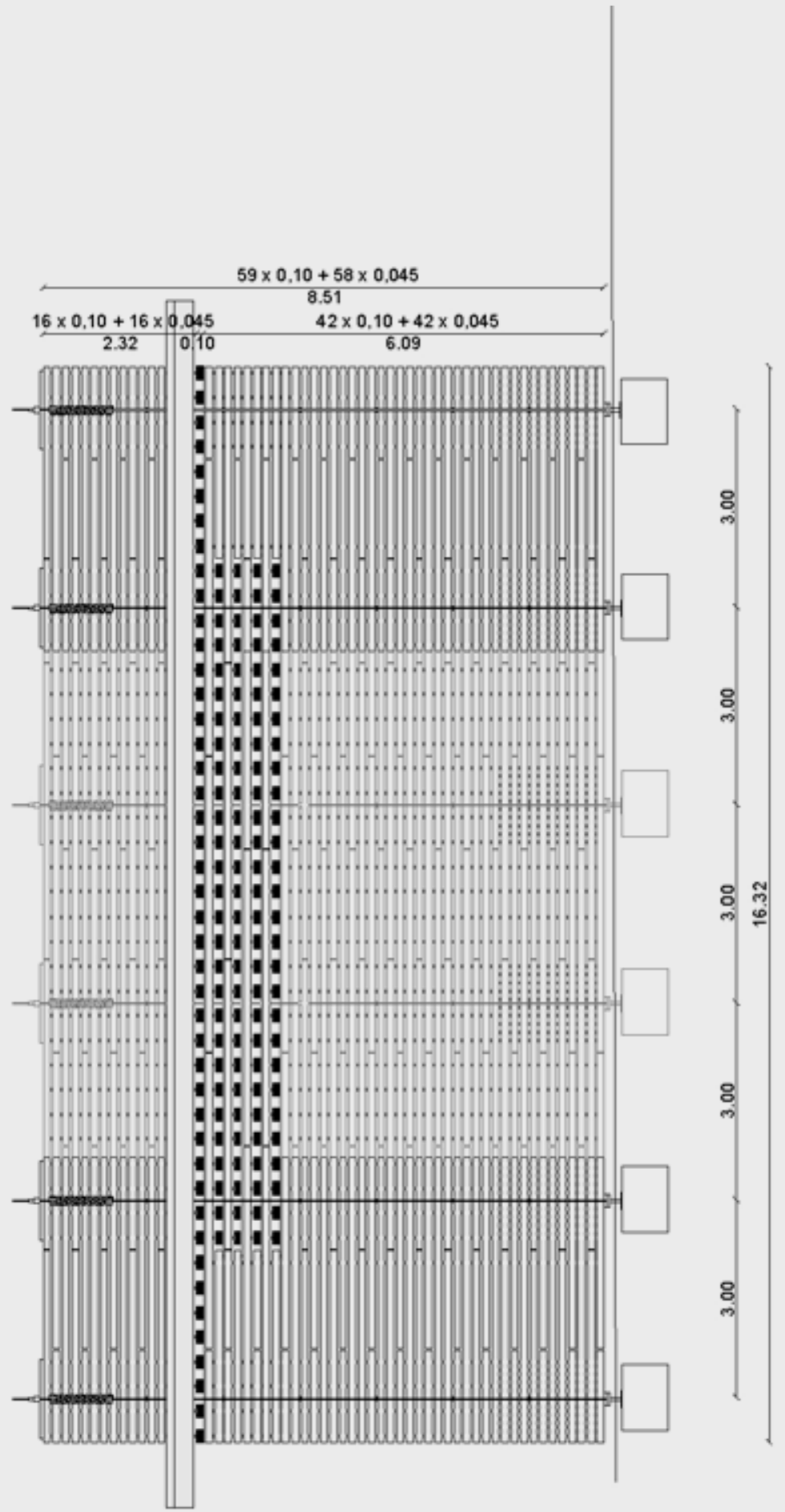

Figura 102.

Sección longitudinal / Stapel 5

Dibujo de la autora 


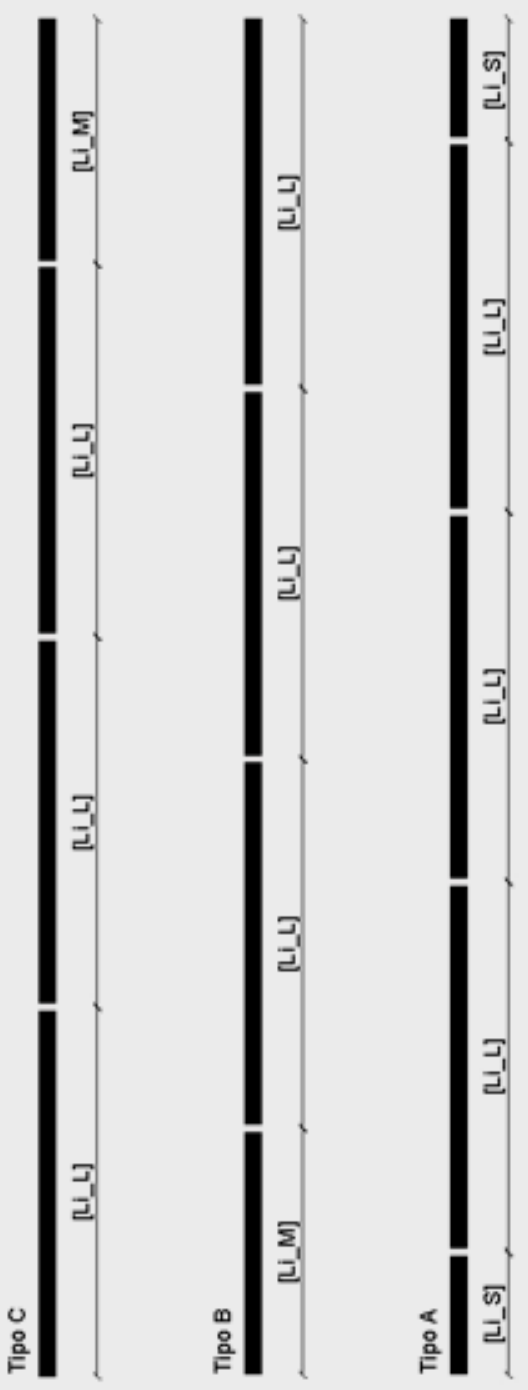




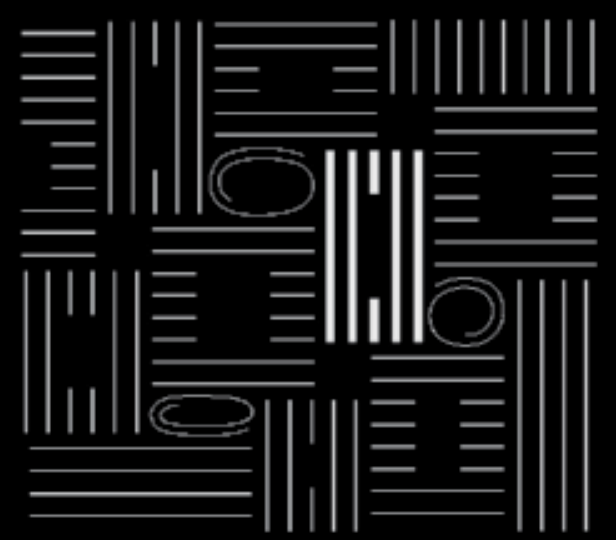

STAPEL 7

Tipo de madera: Alerce

Paredes: 6

Uso: Espacio sonoro

Dimensiones: $\mathbf{9 , 4 3} \times \mathbf{1 9 , 3 2} \mathrm{m}$

Oquedad: 4,045 x 10,36 m

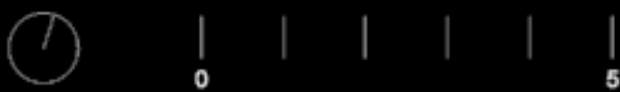


[Stapel 7]

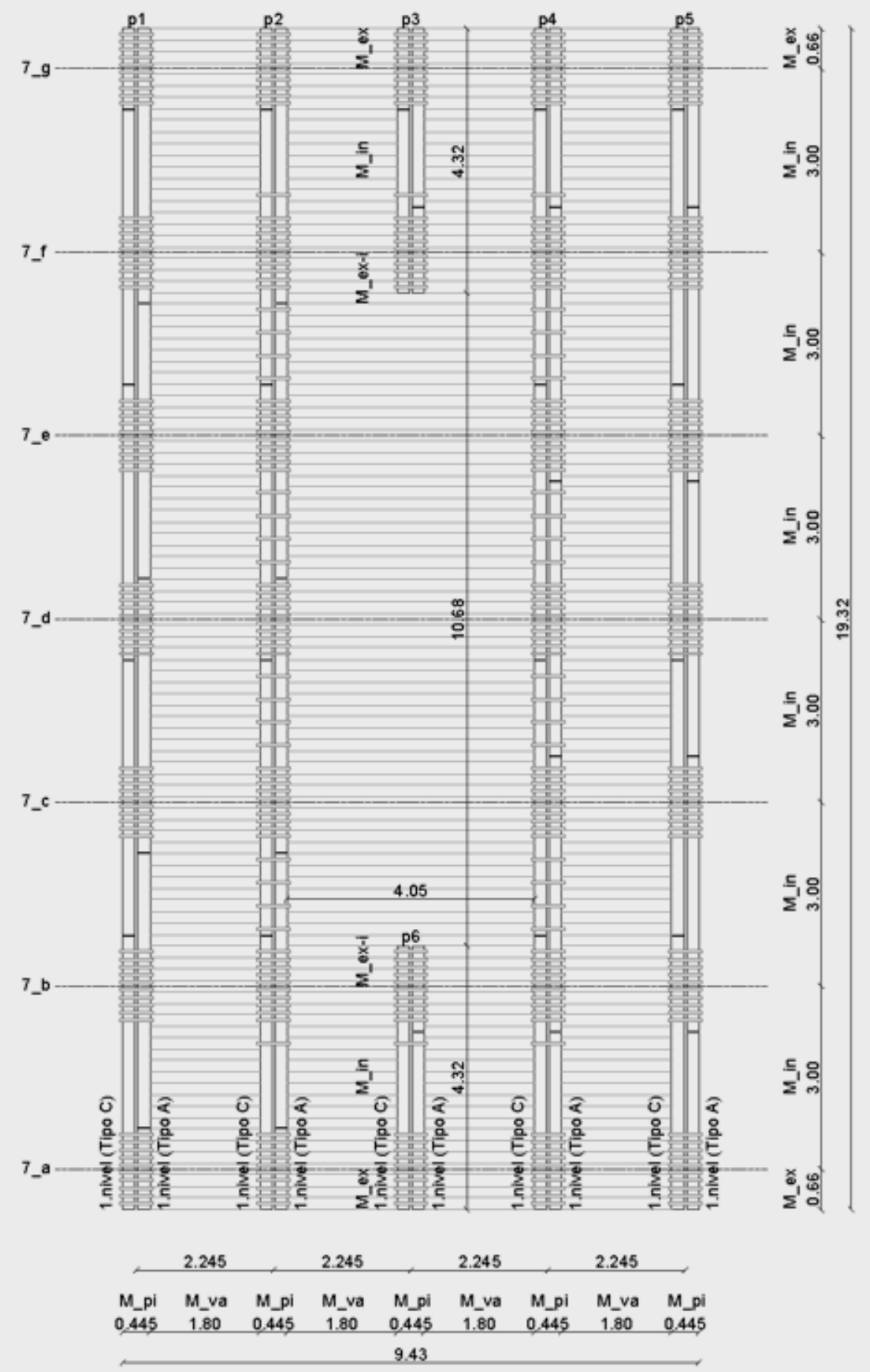

Figura 104.

Planta / Stapel 7

Dibujo de la autora 

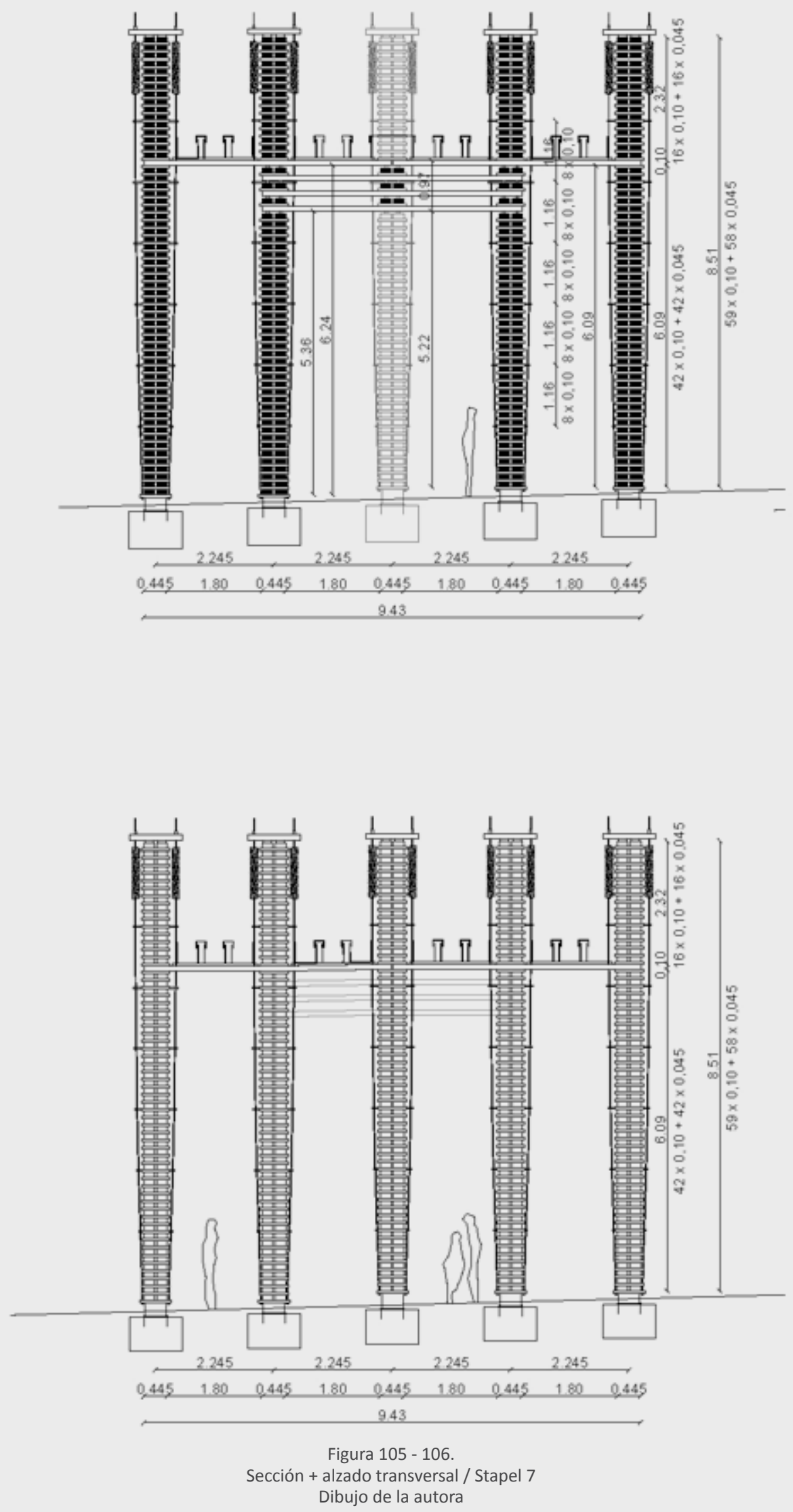


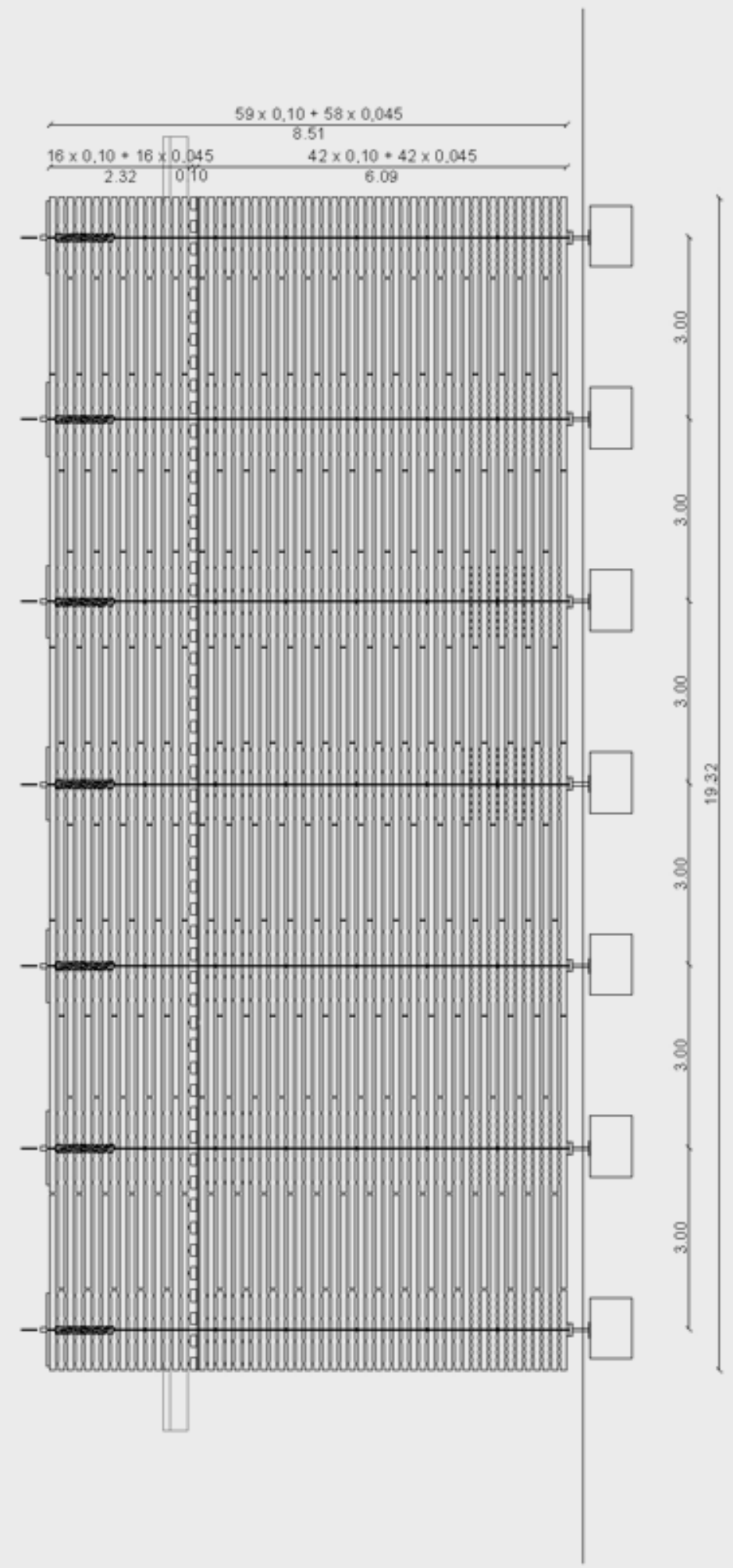

Figura 107.

Alzado longitudinal / Stapel 7

Dibujo de la autora 


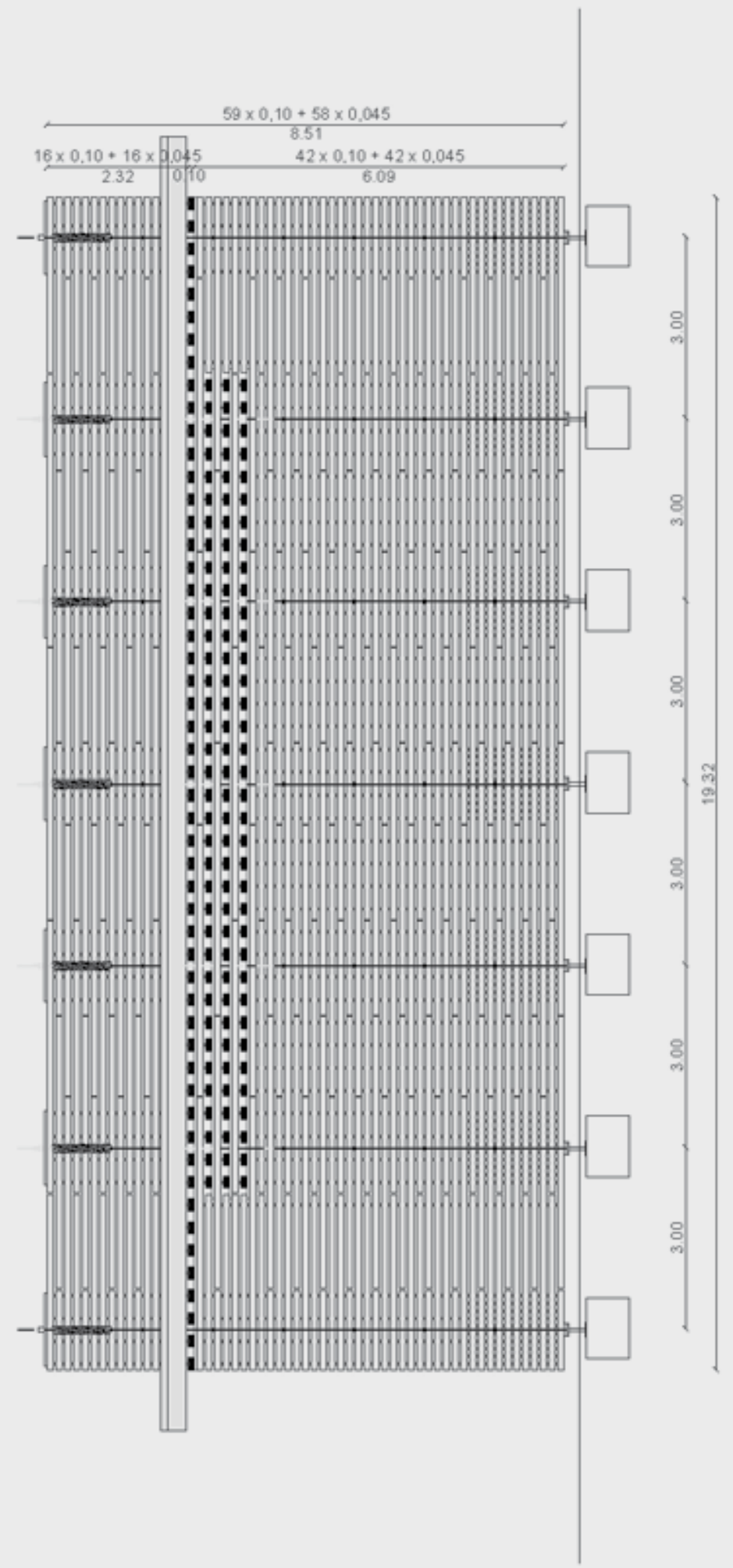

Figura 108.

Sección longitudinal/ Stapel 7

Dibujo de la autora 


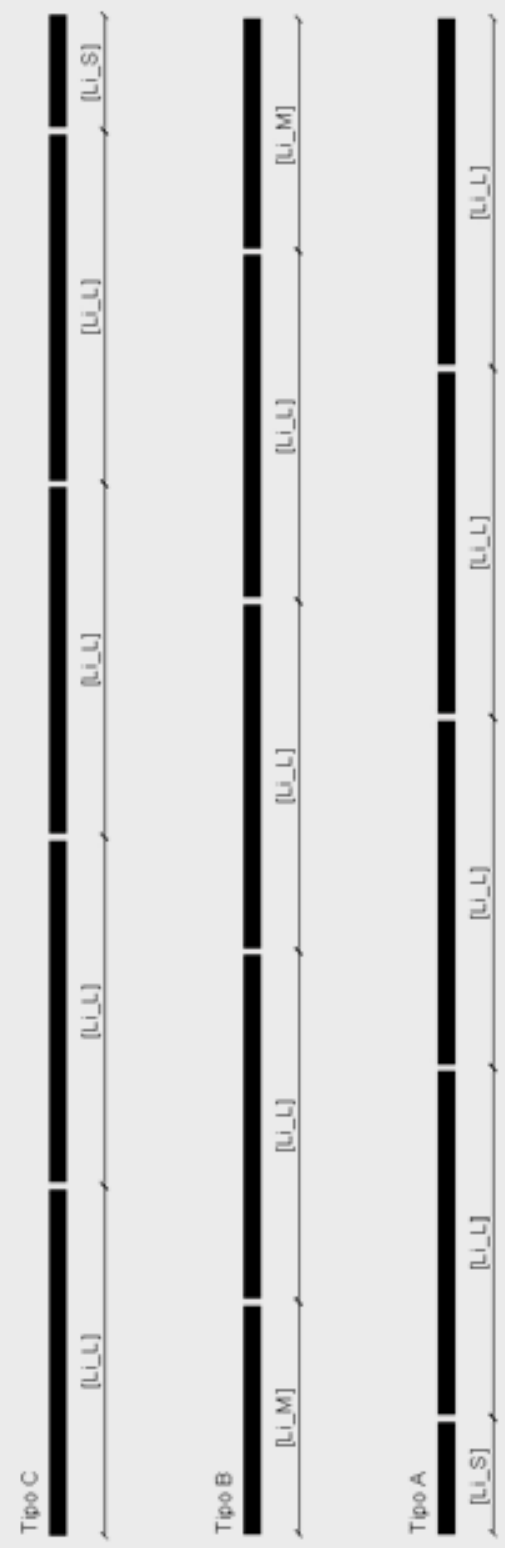

Figura 109.

Sistema compositivo de los listones de madera / Stapel 7 Dibujo de la autora 


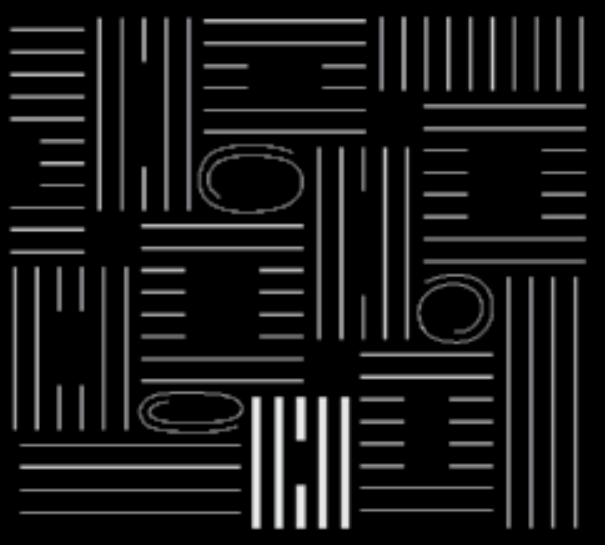

STAPEL 10

Tipo de madera: Alerce

Paredes: 6

Uso: Espacio sonoro

Dimensiones: 9,43 x 13,32 m

Oquedad: 4,045 x 4,68 m

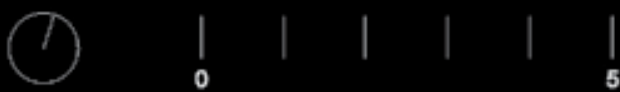


[Stapel 10]

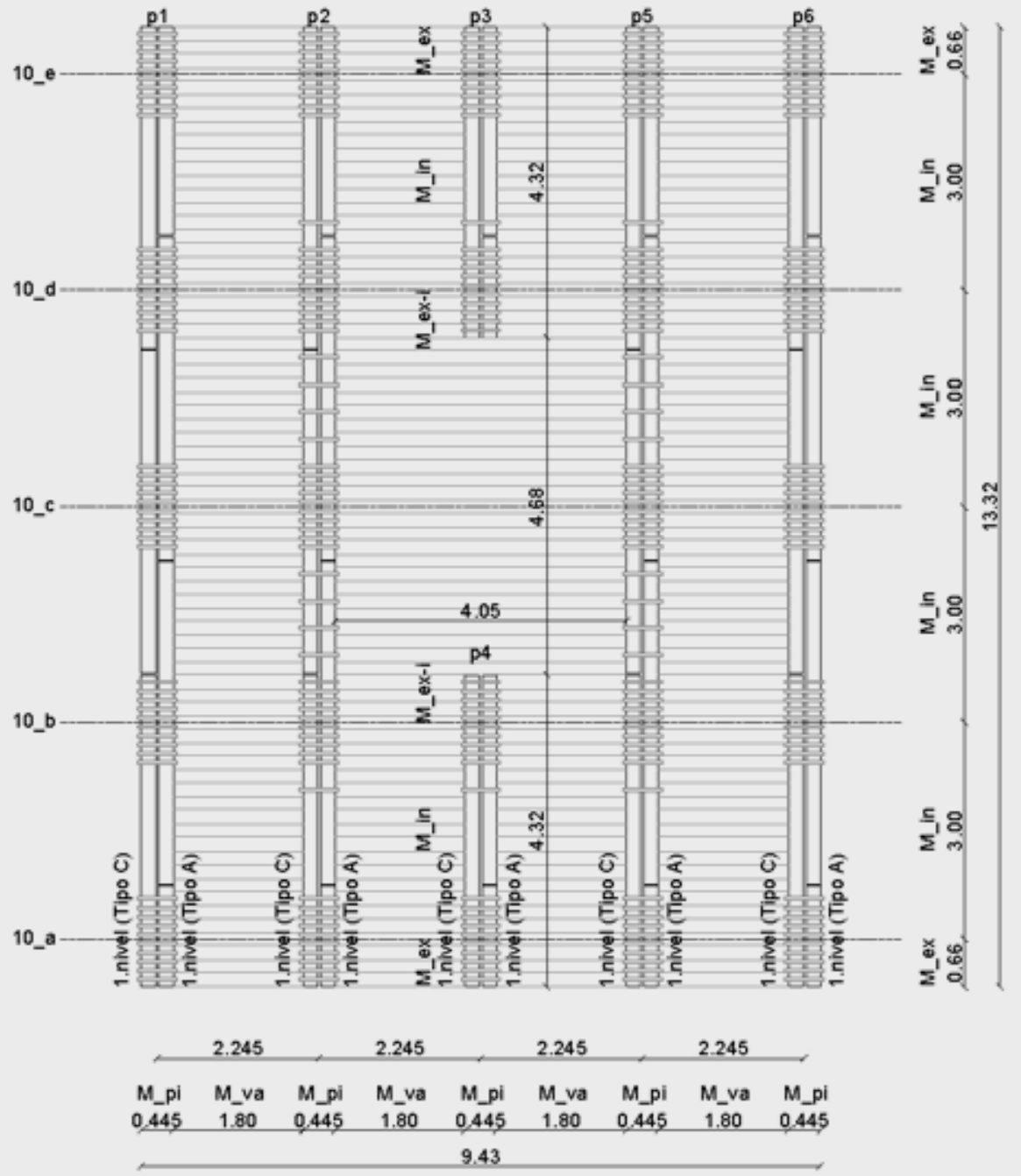



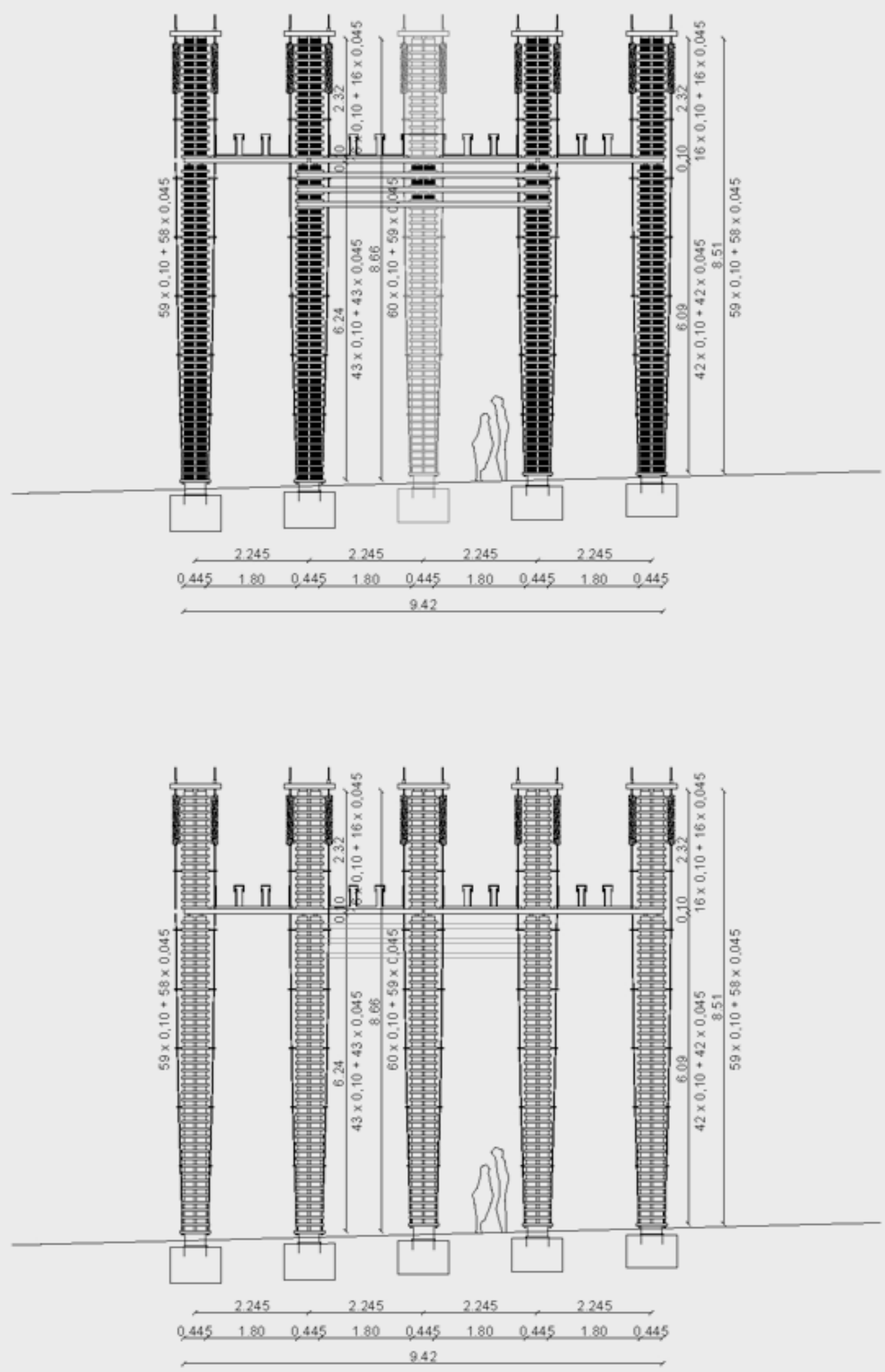

Figura 111 - 112

Sección + alzado transversal / Stapel 10

Dibujo de la autora 


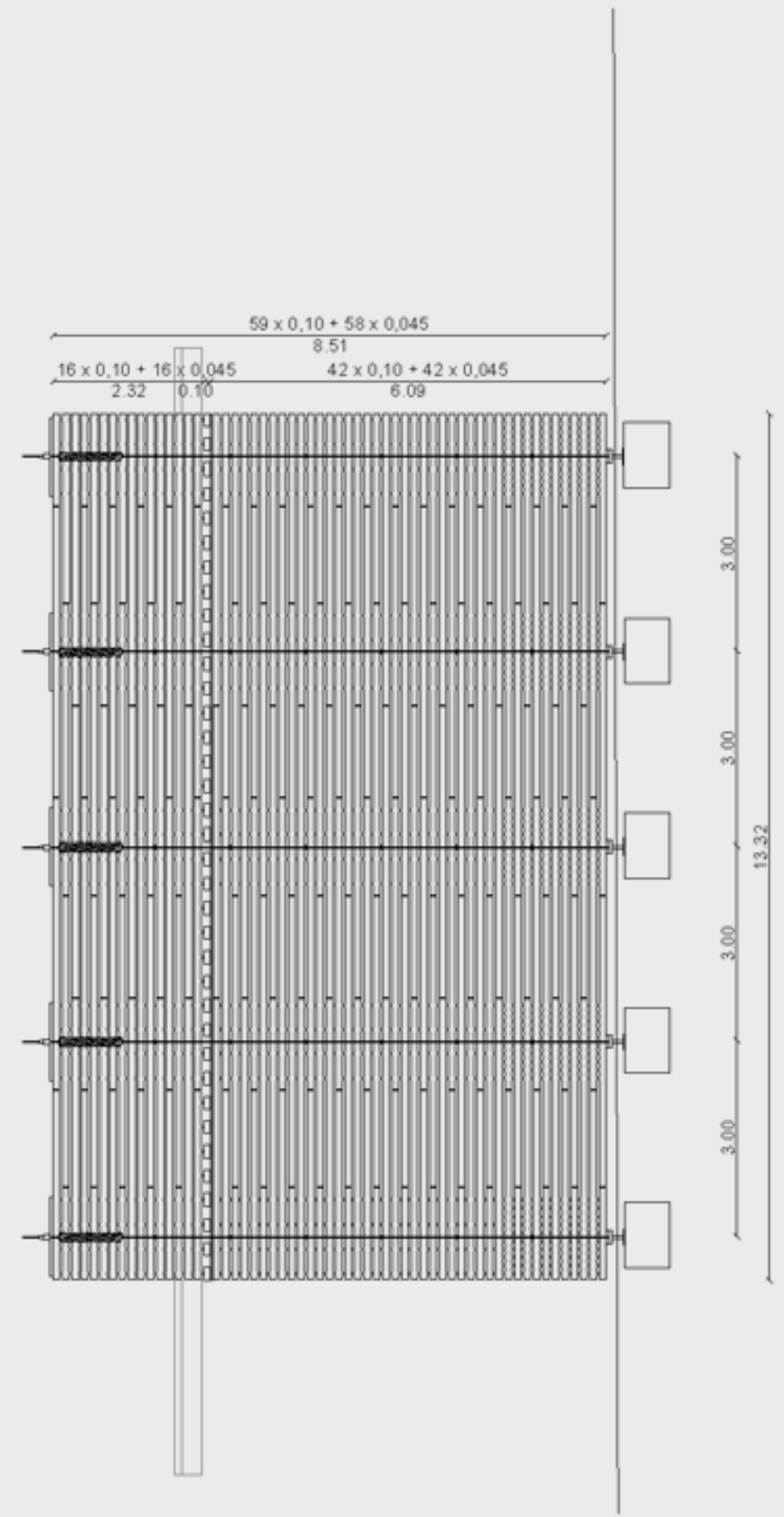

Figura 113.

Alzado longitudinal / Stapel 10

Dibujo de la autora 


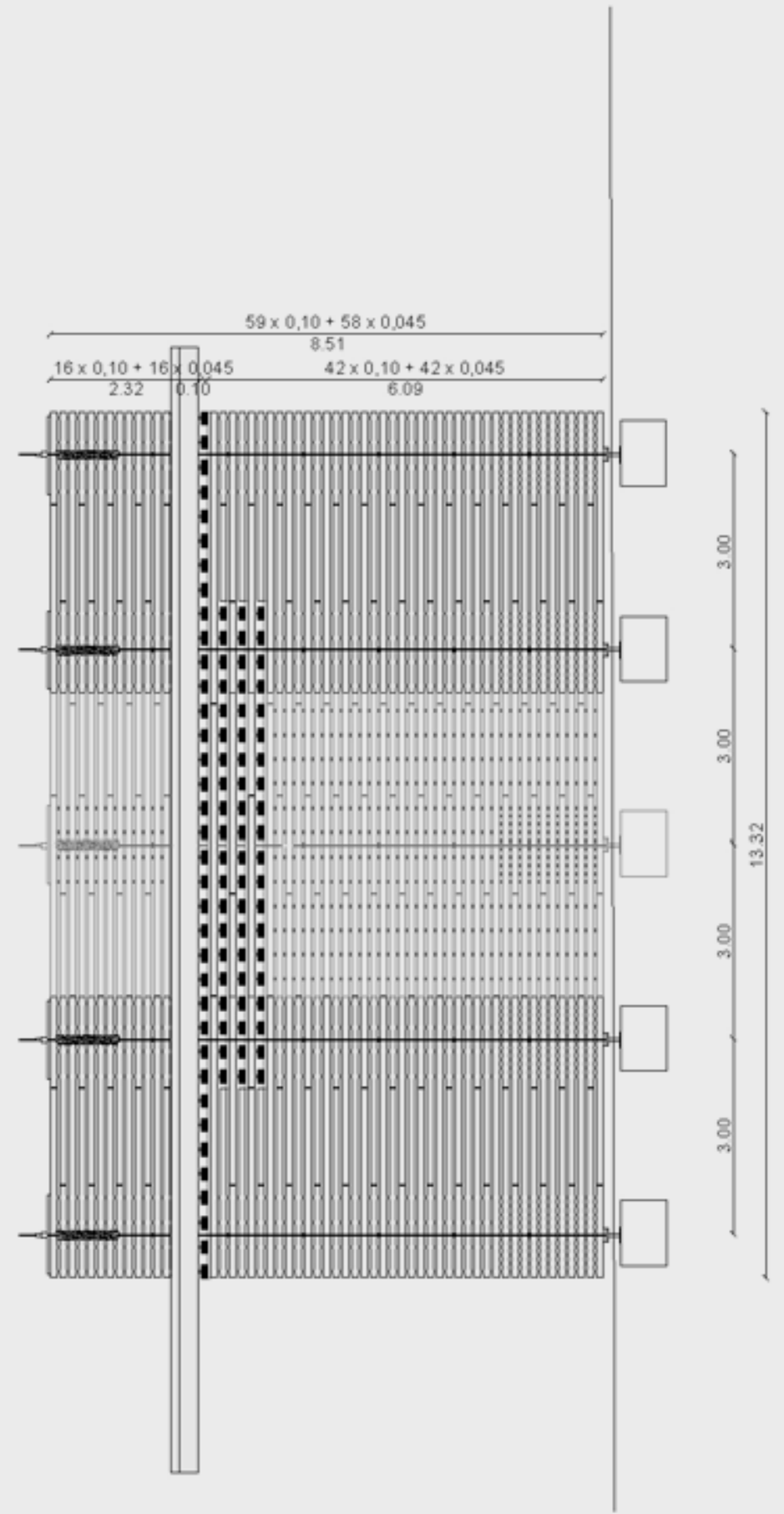

Figura 114.

Sección longitudinal / Stapel 10

Dibujo de la autora 


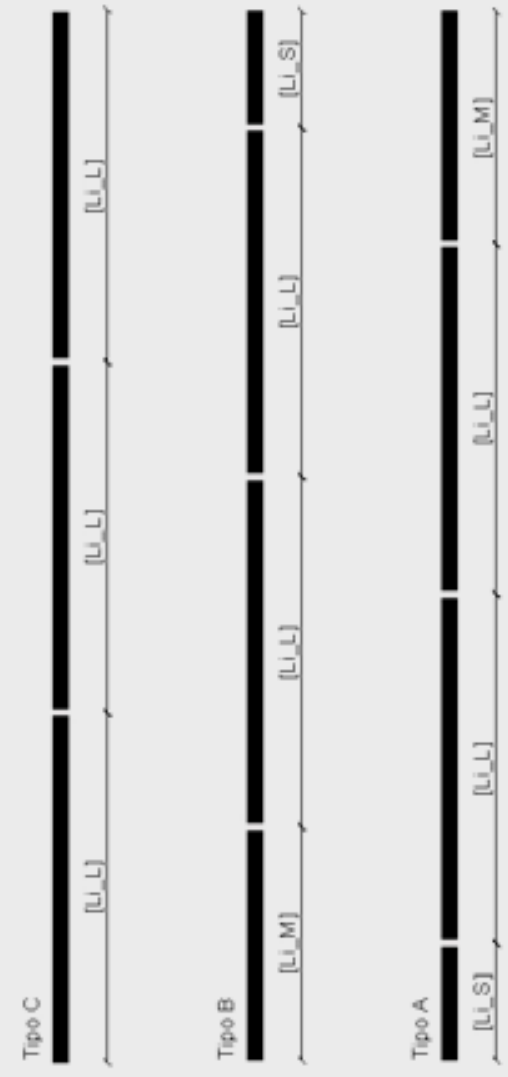

Figura 115.

Sistema compositivo de los listones de madera / Stapel 10 Dibujo de la autora 


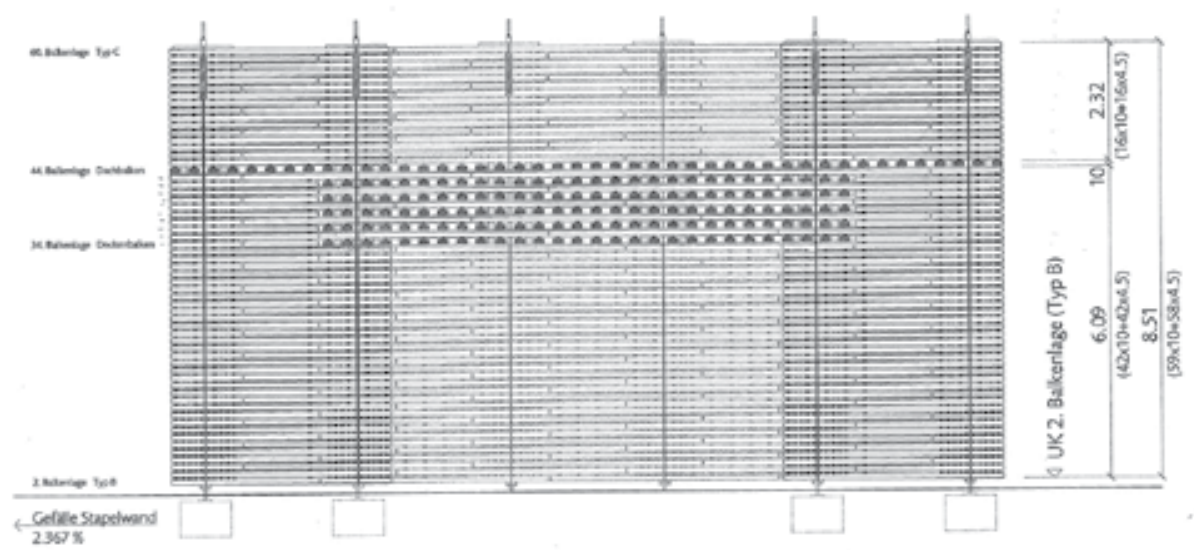

Figura 116.

Sección longitudinal Stapel 8 / Pabellón helvético
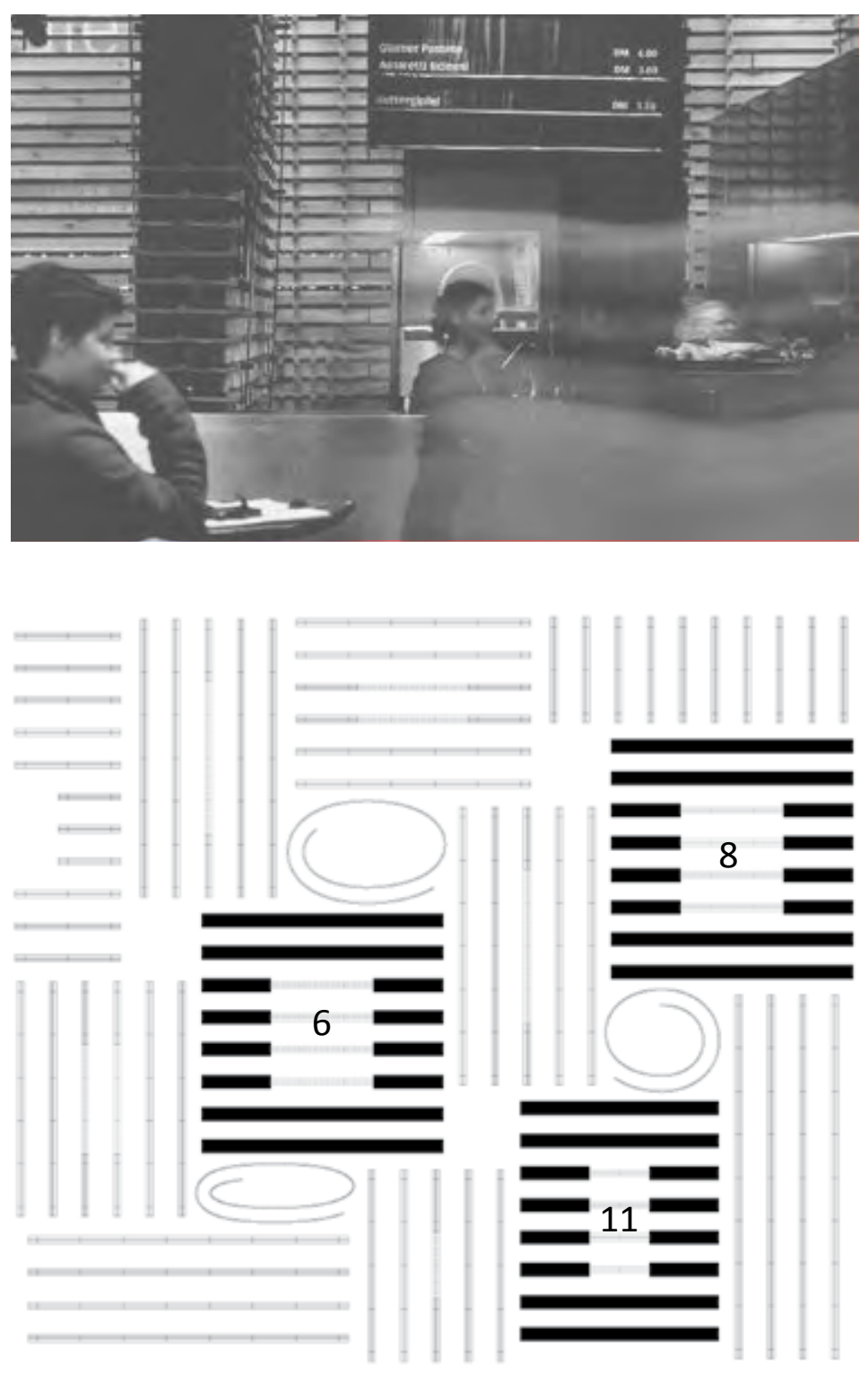

Figura 117 - 118

Espacios gastronómicos / Pabellón helvético 


\section{[Espacios gastronómicos]}

Los Stapel 6, 8 y 11 contienen los espacios gastronómicos. Al igual que los espacios gastronómicos, están configurados mediante un sistema espacial con transiciones fluidas. Allí el visitante podía degustar una selección culinaria de la cocina suiza. Los tres octo-gramas, ocho pilas; tienen orientación noreste/suroeste. El 6 y 8 tienen una longitud de 16,32 m (x1 [M_ex]/+/x5 [M_in] /+/x1 [M_ex]); y el 11, 13,32 m( $\left.x 1\left[M_{e} e x\right] /+/ x 4\left[M_{-} i n\right] /+/ x 1\left[M_{-} e x\right]\right)$. Siete bandas entre pilas, cinco de las cuales se relacionan directamente con el espacio interior. La configuración del mobiliario condiciona las relaciones de cada pasillo; siendo un lado mucho más permeable que el otro donde se ubica la barra y los tres armarios logísticos -almacenamiento, tratamiento y lavado de vajilla- de acero cromado de tres $\mathrm{m}$ de altura ${ }^{52}$. Todos los Barräume tienen luces de 10,78 m (x4 [M_pi] /+/x5 [M_va] ). Su estructura de seis niveles verticales de entramados de madera permite una altura libre de 4,75 $\mathrm{m}^{53}$ aproximadamente ${ }^{54}$. El espacio más pequeño (Stapel 11) con una longitud de 4,68 $m$ es bastante ajustado; mientras que los dos más grandes (Stapel 6 y 8), dado que son 3 m [M_in] más largos, permiten albergar una zona de mesas altas fijas al suelo.

El recorrido de los visitantes por el pabellón transitará entre constantes compresiones y descompresiones espaciales. Existen los espacios de recorridos netamente verticales y estrechos ${ }^{55}$ con una altura libre de 6,25 $\mathrm{m}^{56}$. Sin embargo en las oquedades dentro de los Stapel, el espacio deja de ser claramente vertical. La eliminación de algunos módulos interiores de las pilas desencadena que la superficie del espacio, tanto en ancho como en largo, aumenten sustancialmente. Las nuevas demandas estructurales, derivadas de salvar vanos mayores, implica que las alturas libres se reduzcan. Todas estas diversas mutaciones perceptivas generan un complejo interior por descubrir; lleno de inesperadas sorpresas. Mientras los espacios altos y estrechos del pabellón reducen la sociabilidad ${ }^{57}$; los espacios amplios con techos más bajos invitan a permanecer, a quedarse; comer y escuchar conjuntamente; son áreas de activación.

55 Nota: Entre los Stapel con paso de 1,41 m. Entre las pilas dentro de los Stapel de 1,80 m. Con una altura libre de 6,25 m. Encima se encuentran los grandes canalones.

56 CONZETT, Jürg. Stapellauf. Pavillon der Schweiz in Hannover. En: Deutsche Bauzeitung db. Vol. 134. Nr. 9. 2000. Pág. 94. Nota: Según los dibujos facilitados por Exposseum Hannover la altura será 6,235 metros en vez de 6,25 metros.

57 Nota: En unos pocos espacios altos y estrechos se encuentran unos bancos (ubicados cerca del exterior en los Stapel 1, 2, 3, 5 y 10), que actuan como elementos de descanso, pero constituyendo una experiencia individual. 


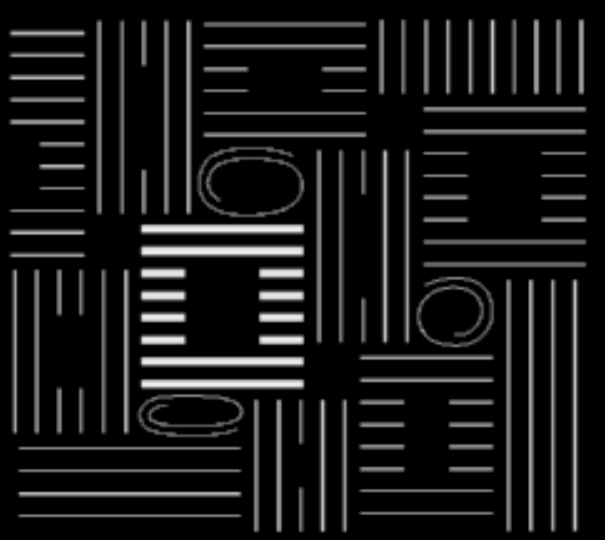

STAPEL 6

Tipo de madera: Pino

Paredes: 12

Uso: Espacio gastronómico

Dimensiones: 16,16 x 16,32 m

Oquedad: 7,68 x 10,78 m

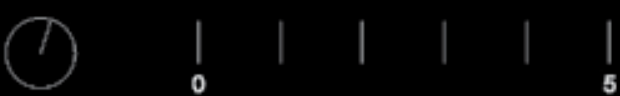


[Stapel 6]

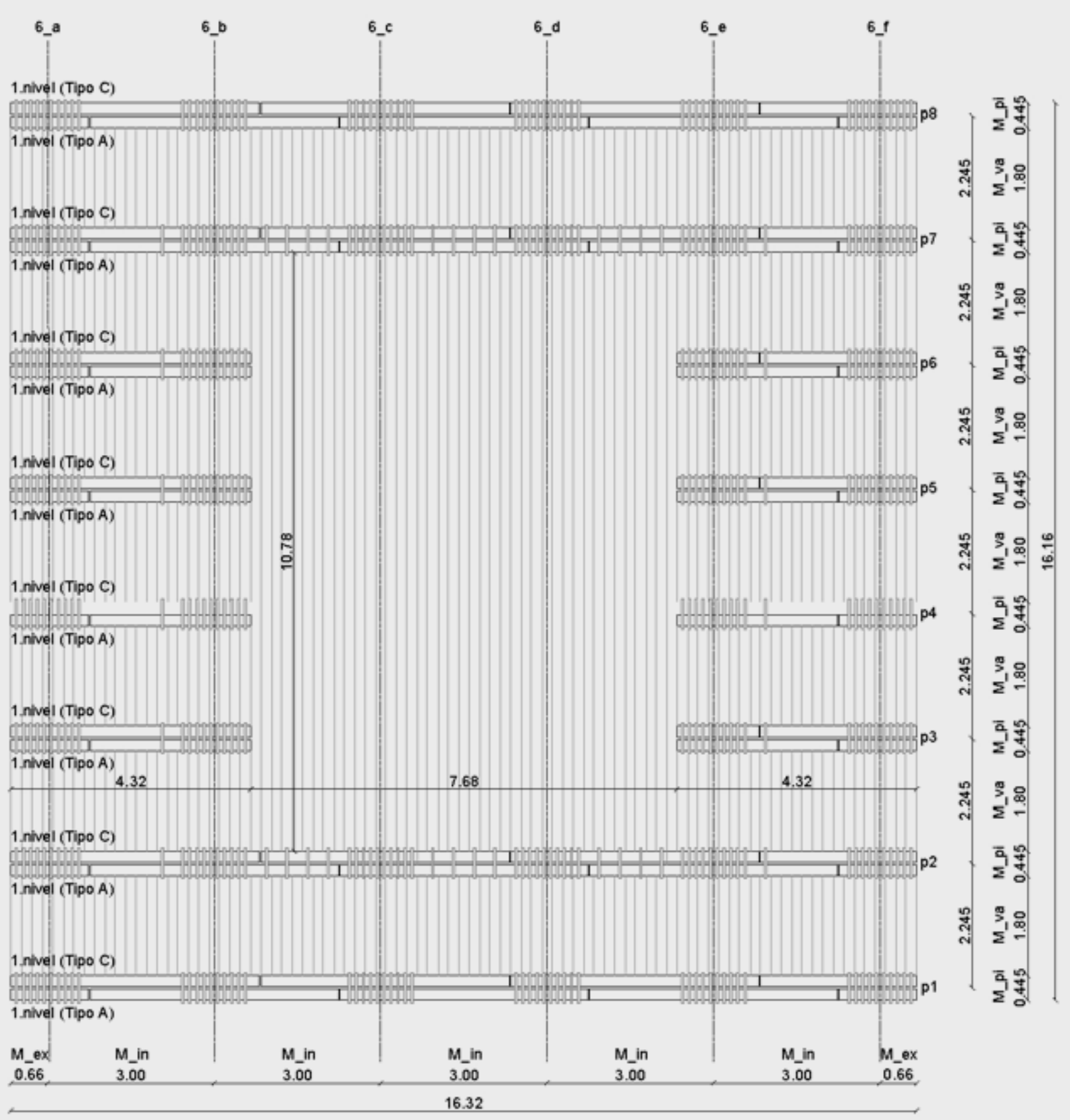



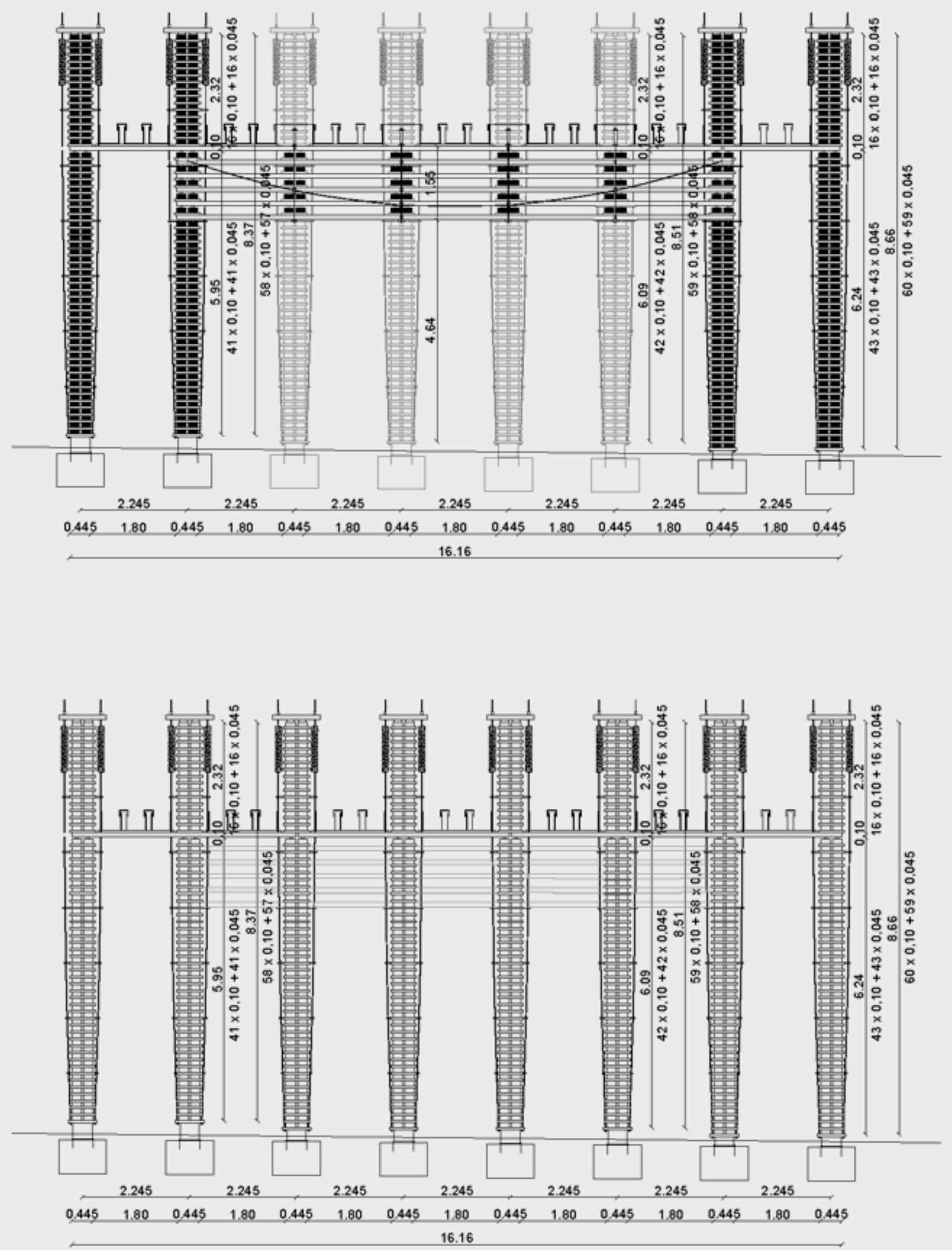

Figura 120 - 121

Sección + alzado transversal / Stapel 6

Dibujo de la autora 


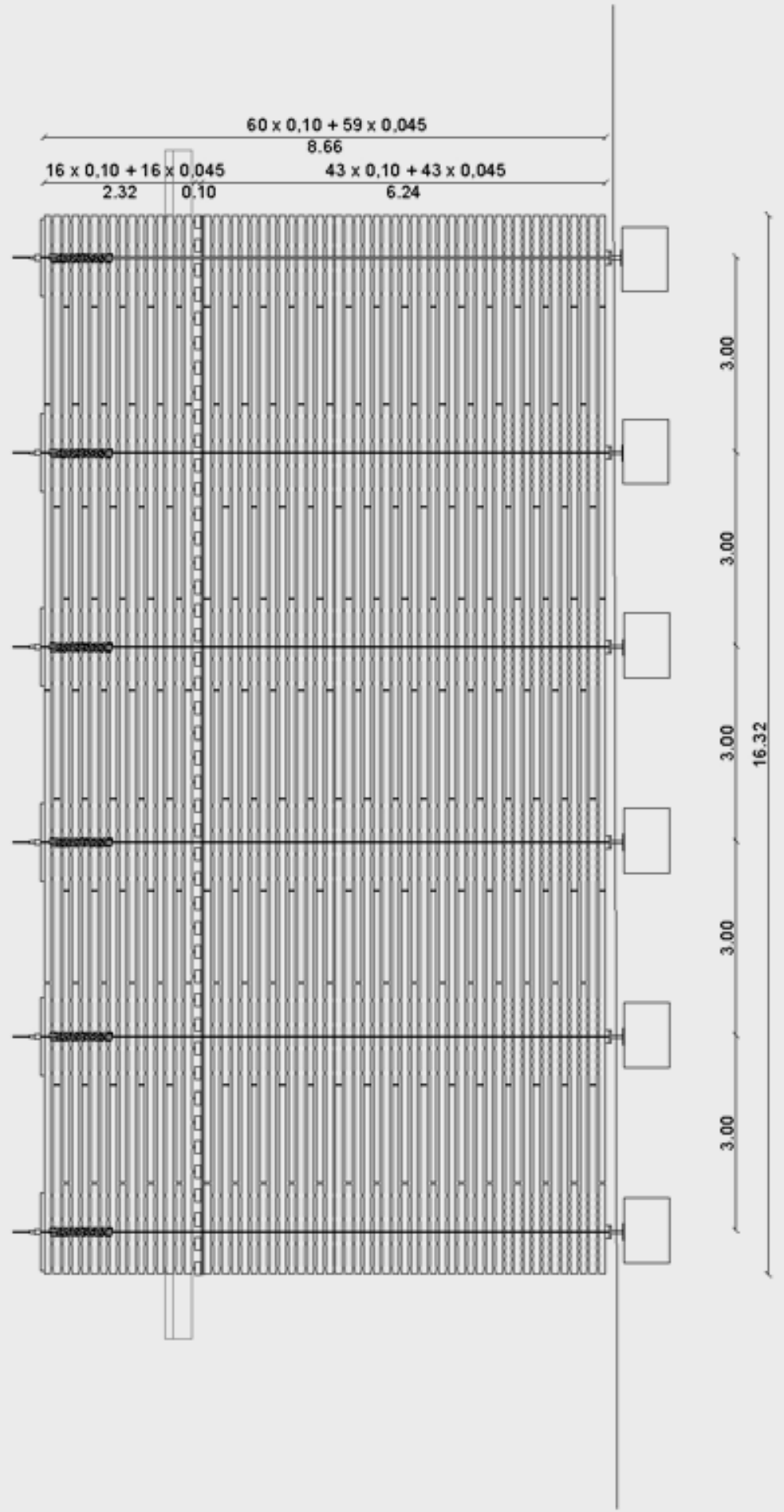

Figura 122

Alzado longitudinal / Stapel 6

Dibujo de la autora 


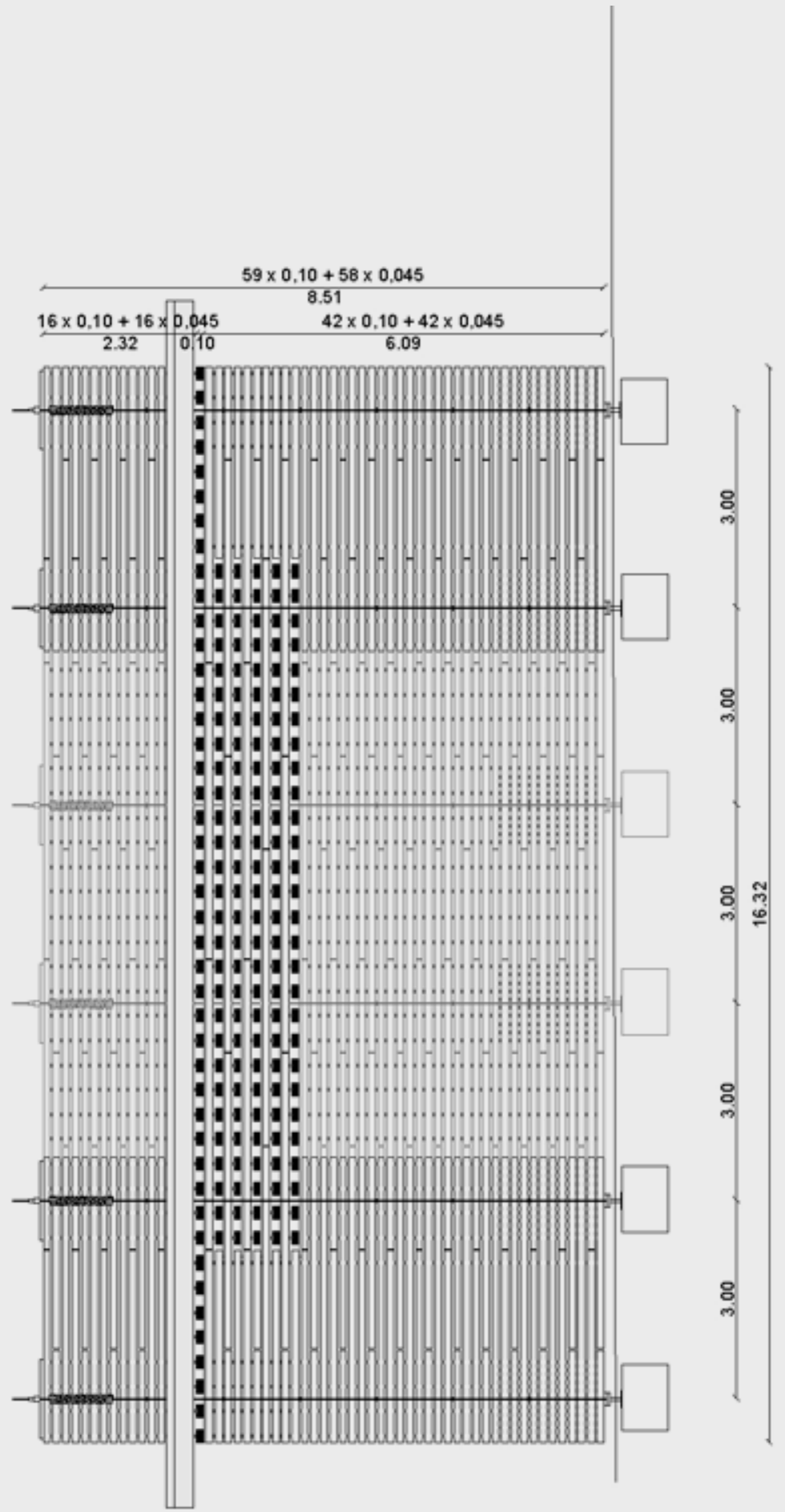

Figura 123.

Sección longitudinal / Stapel 6

Dibujo de la autora 


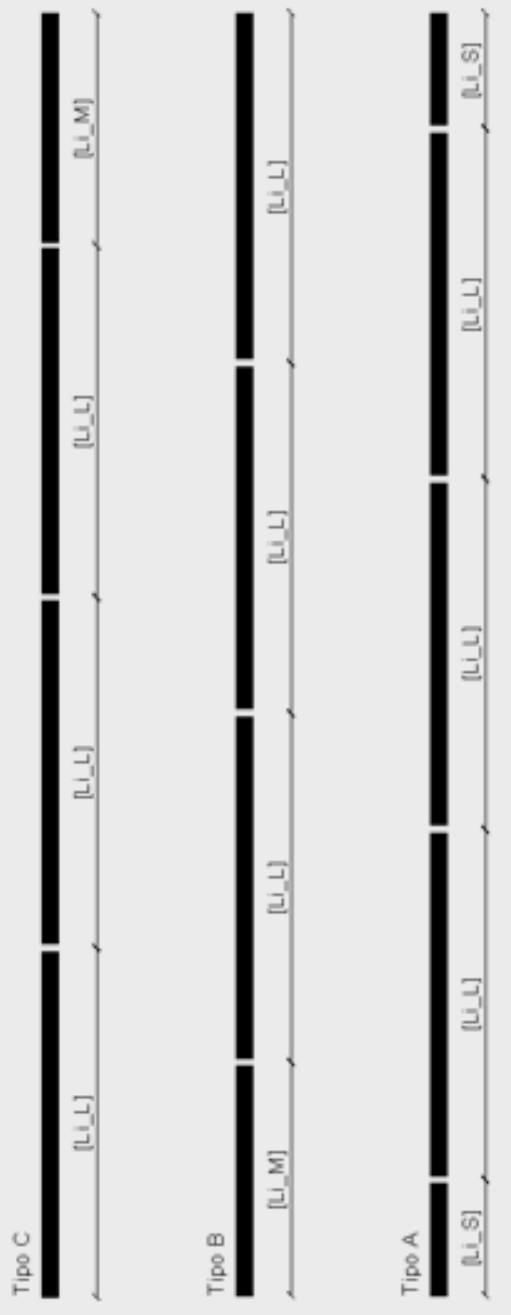

Figura 124.

Sistema compositivo de los listones de madera / Stapel 6 Dibujo de la autora 


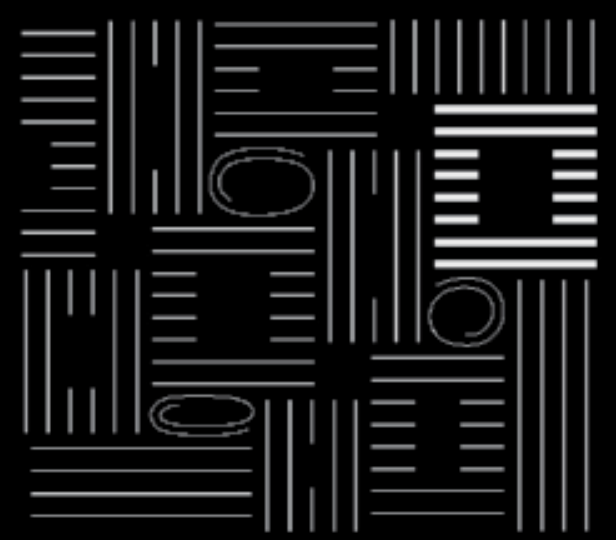

STAPEL 8

Tipo de madera: Pino

Paredes: 12

Uso: Espacio gastronómico

Dimensiones: 16,16 x 16,32 m

Oquedad: 7,68 x 10,78 m

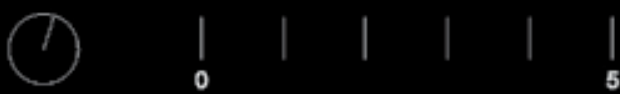


[Stapel 8]

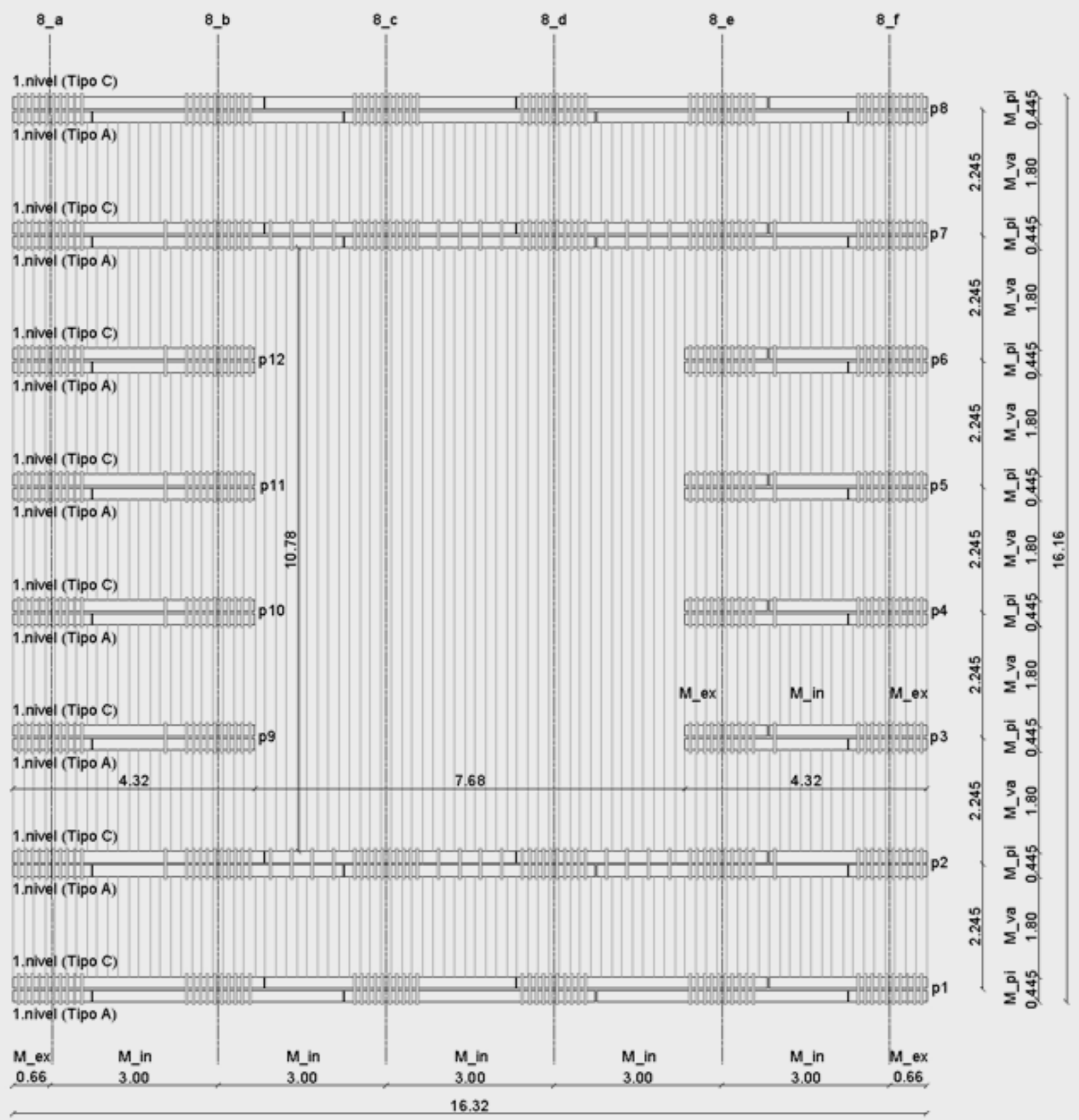



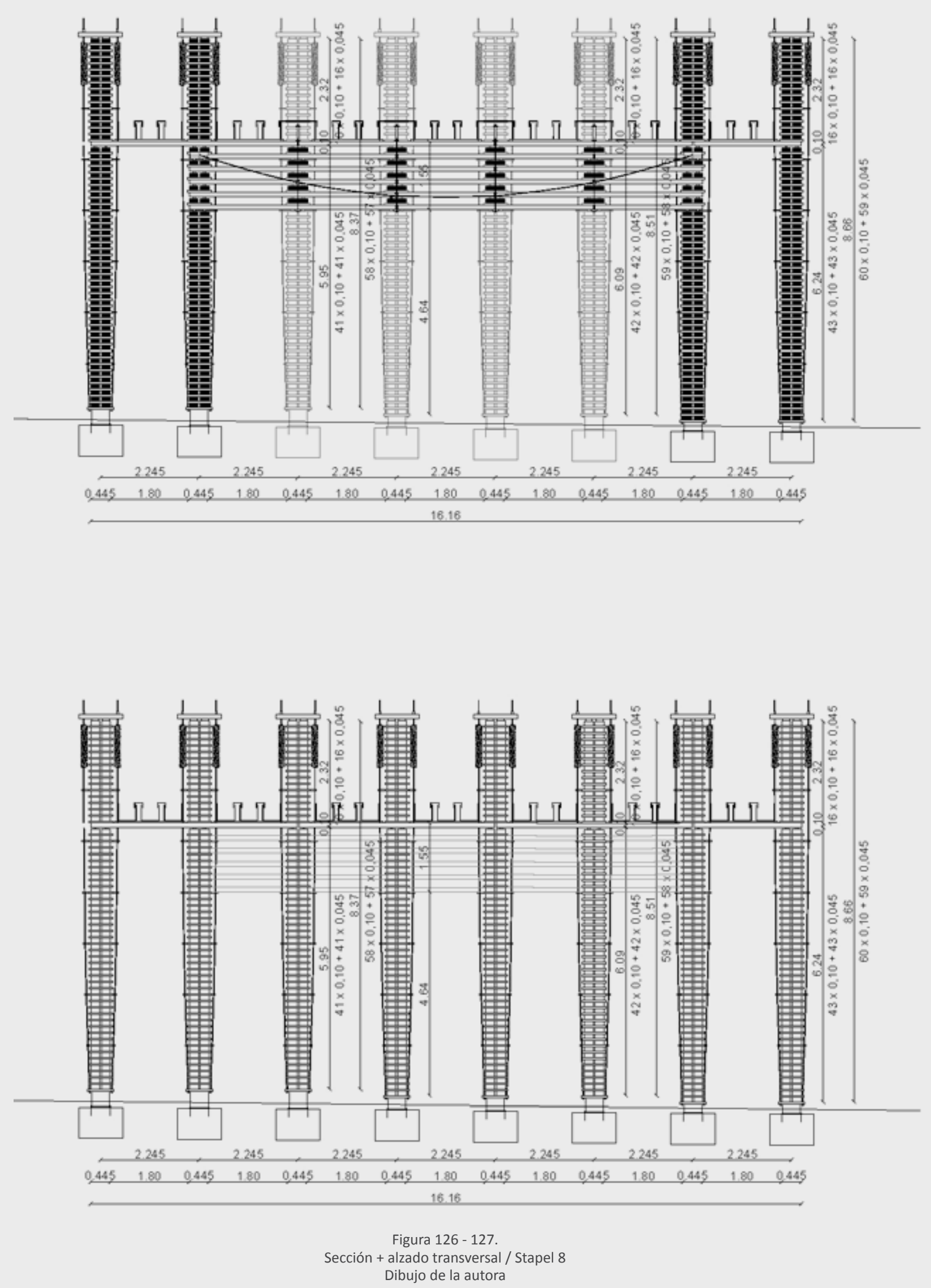


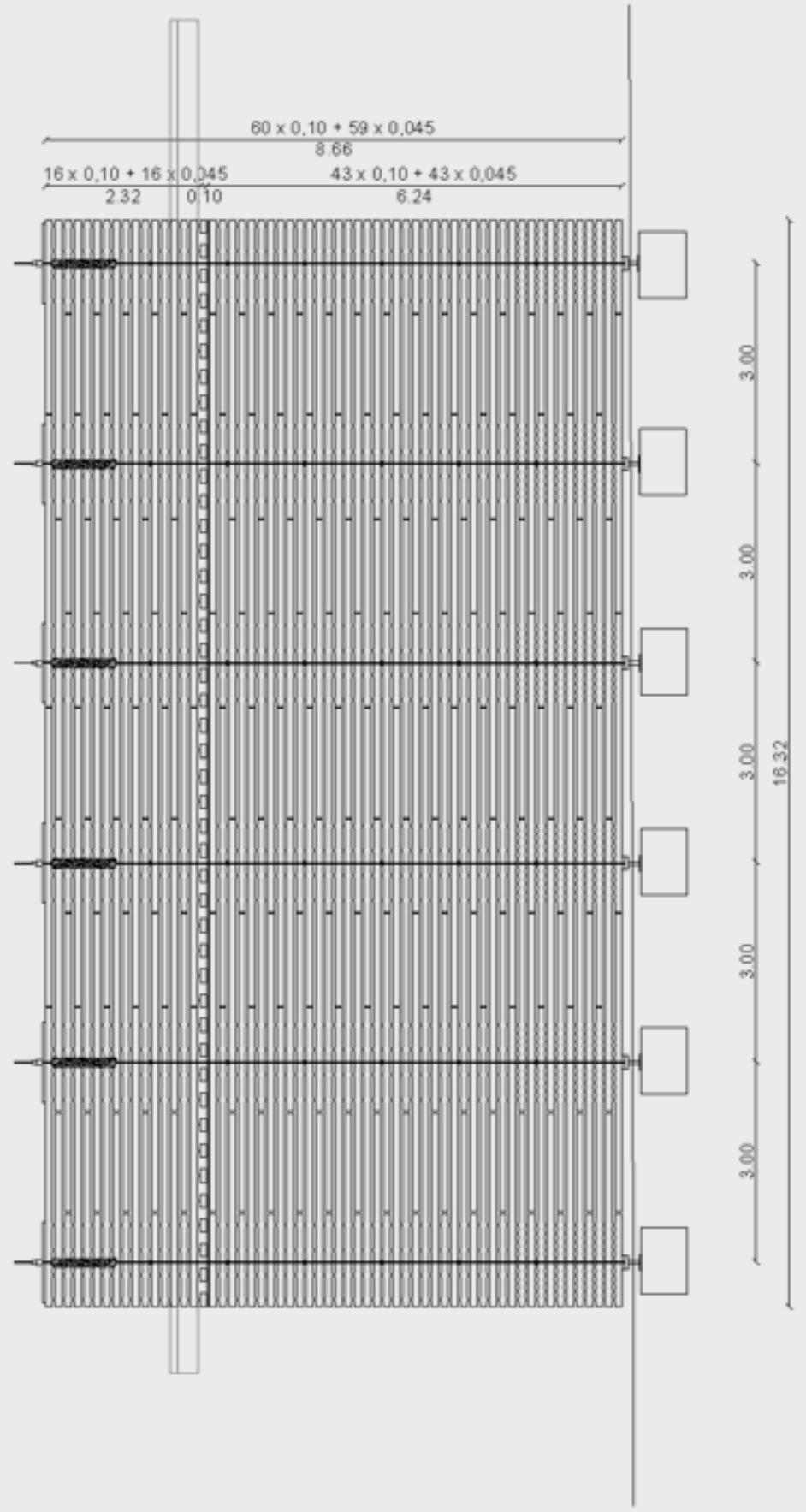

Figura 128.

Alzado longitudinal / Stapel 8

Dibujo de la autora 


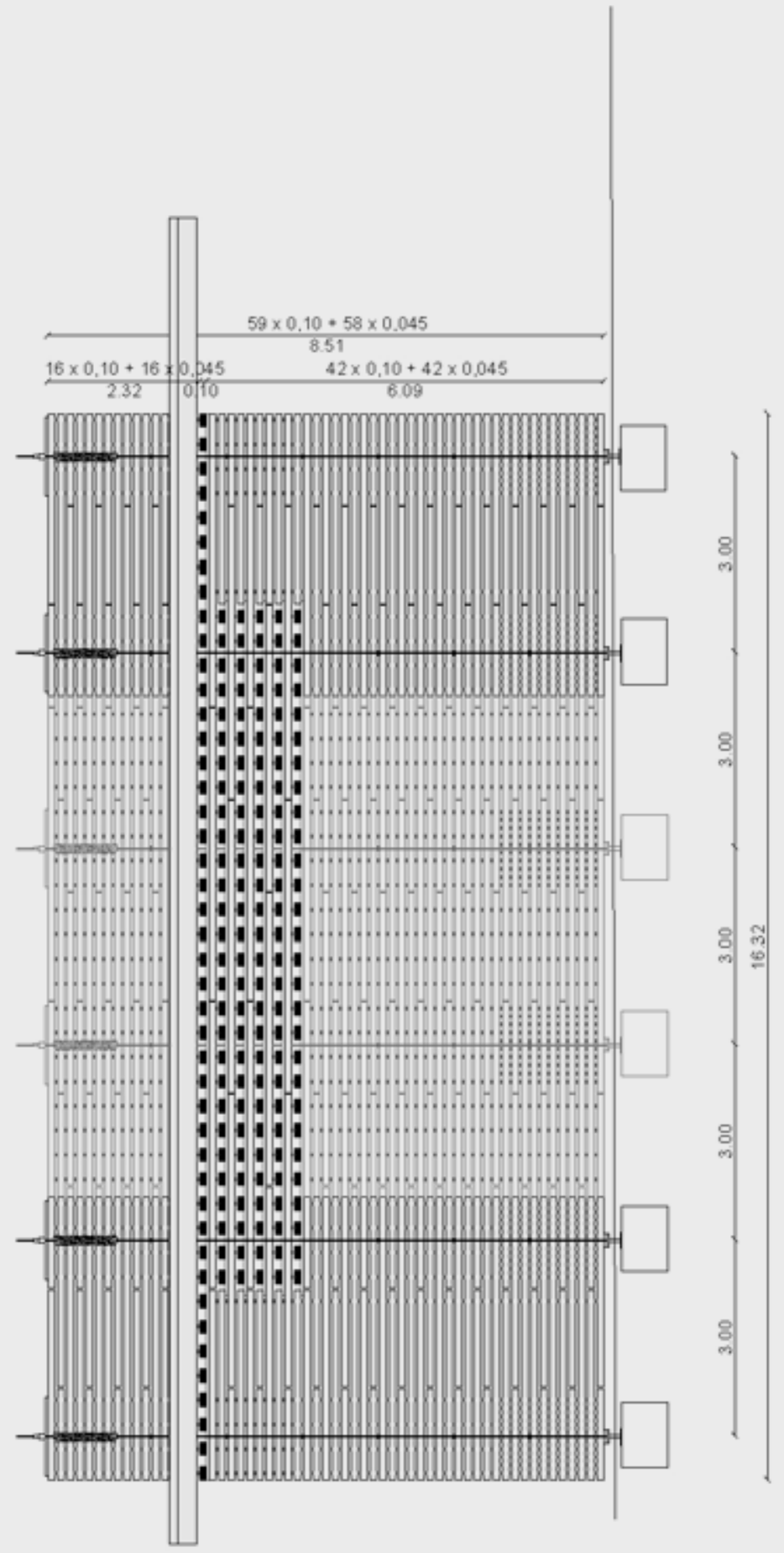

Figura 129.

Sección longitudinal / Stapel 8

Dibujo de la autora 


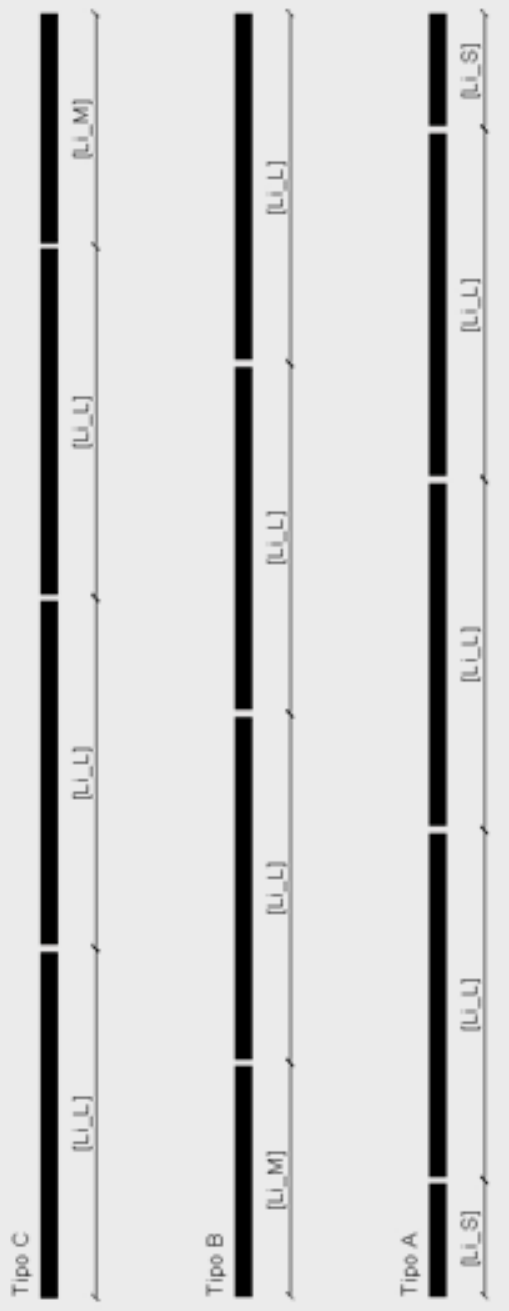




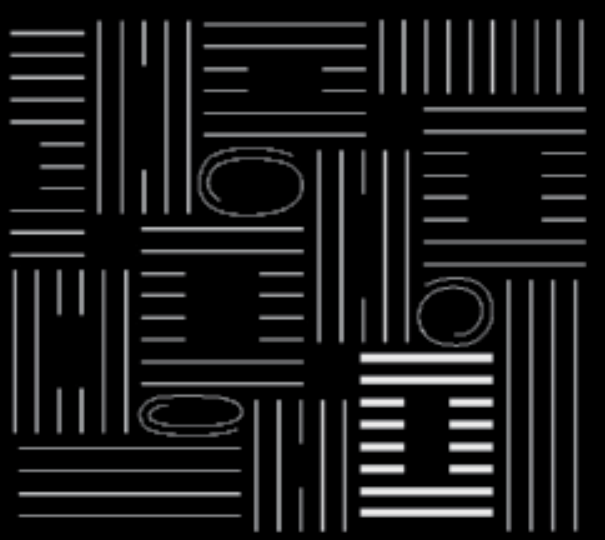

STAPEL 11

Tipo de madera: Pino

Paredes: 12

Uso: Espacio gastronómico

Dimensiones: 13,32 x 16,16 m

Oquedad: 4,68 x 10,78 m

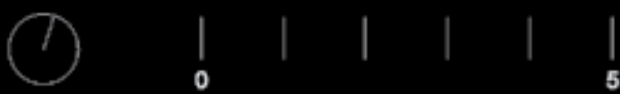


[Stapel 11]

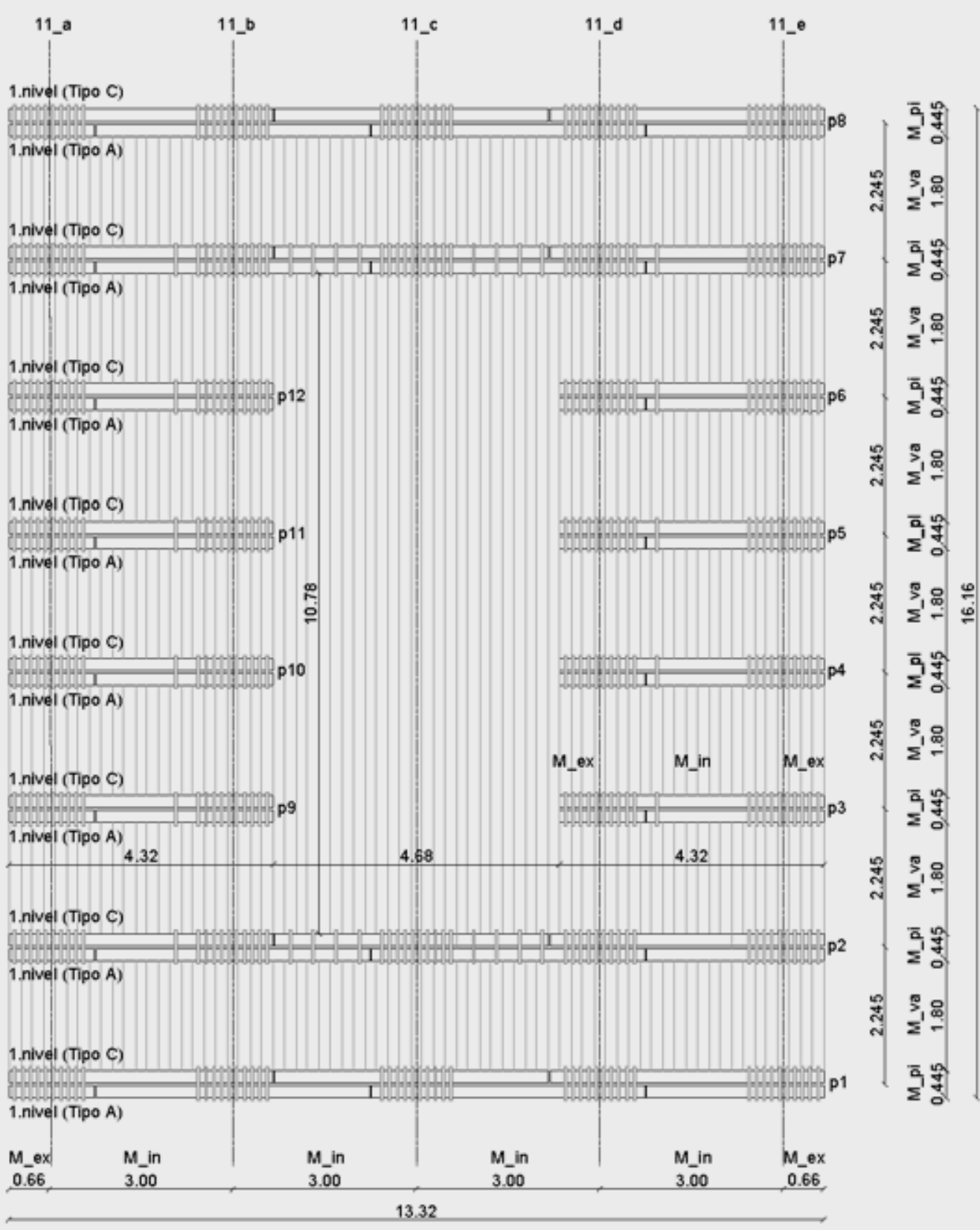



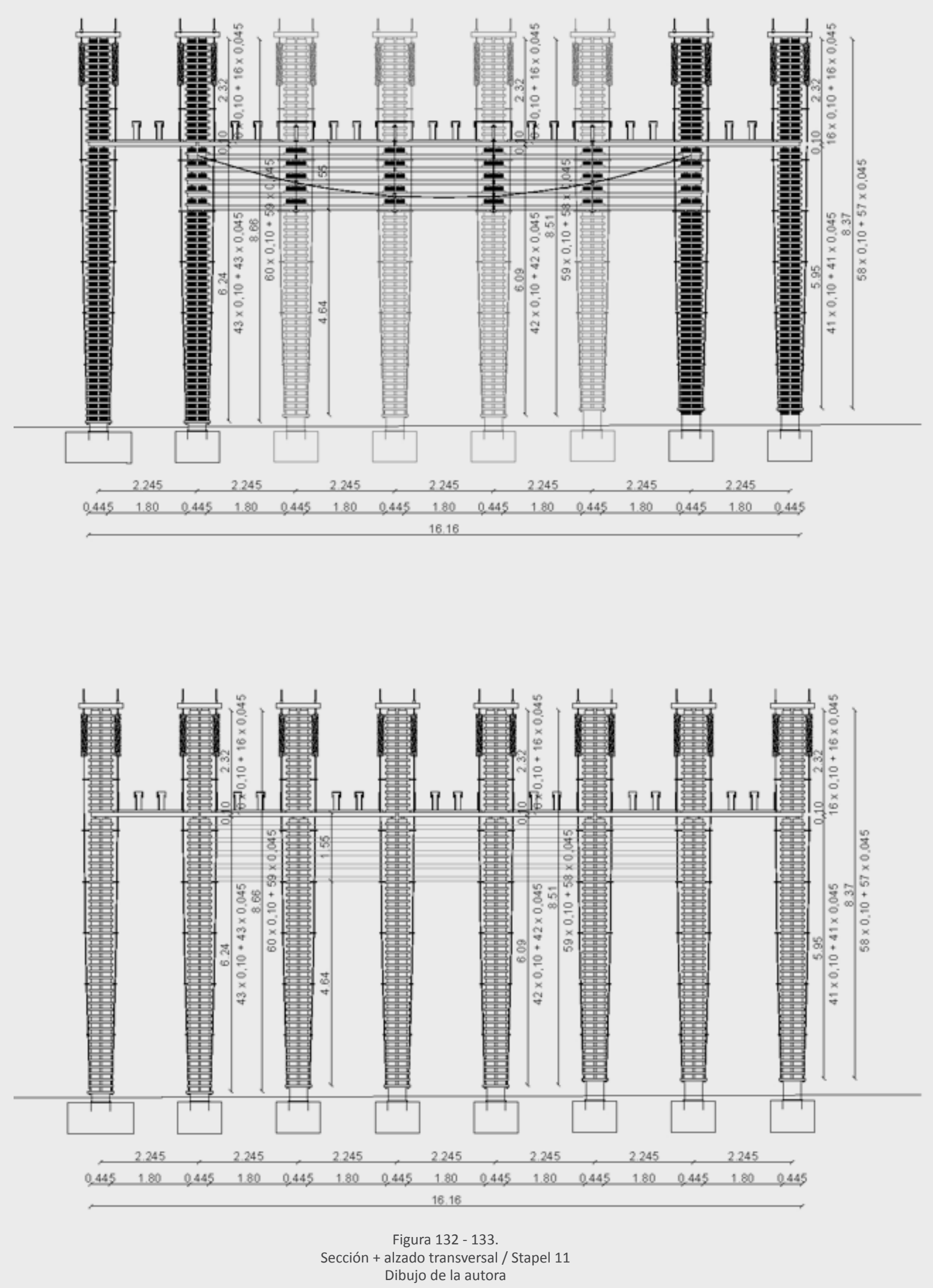


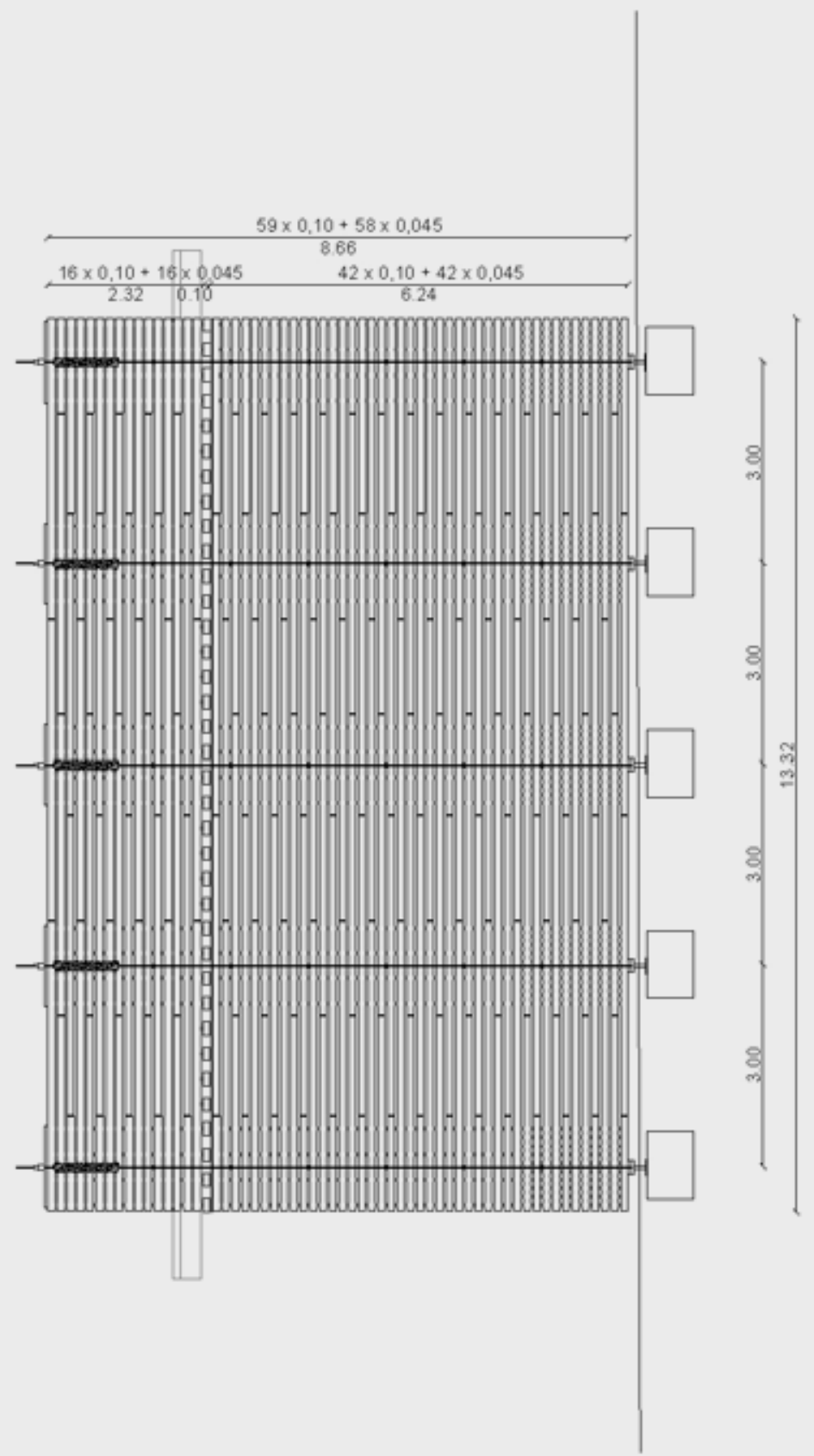

Figura 134.

Alzado longitudinal / Stapel 11

Dibujo de la autora 


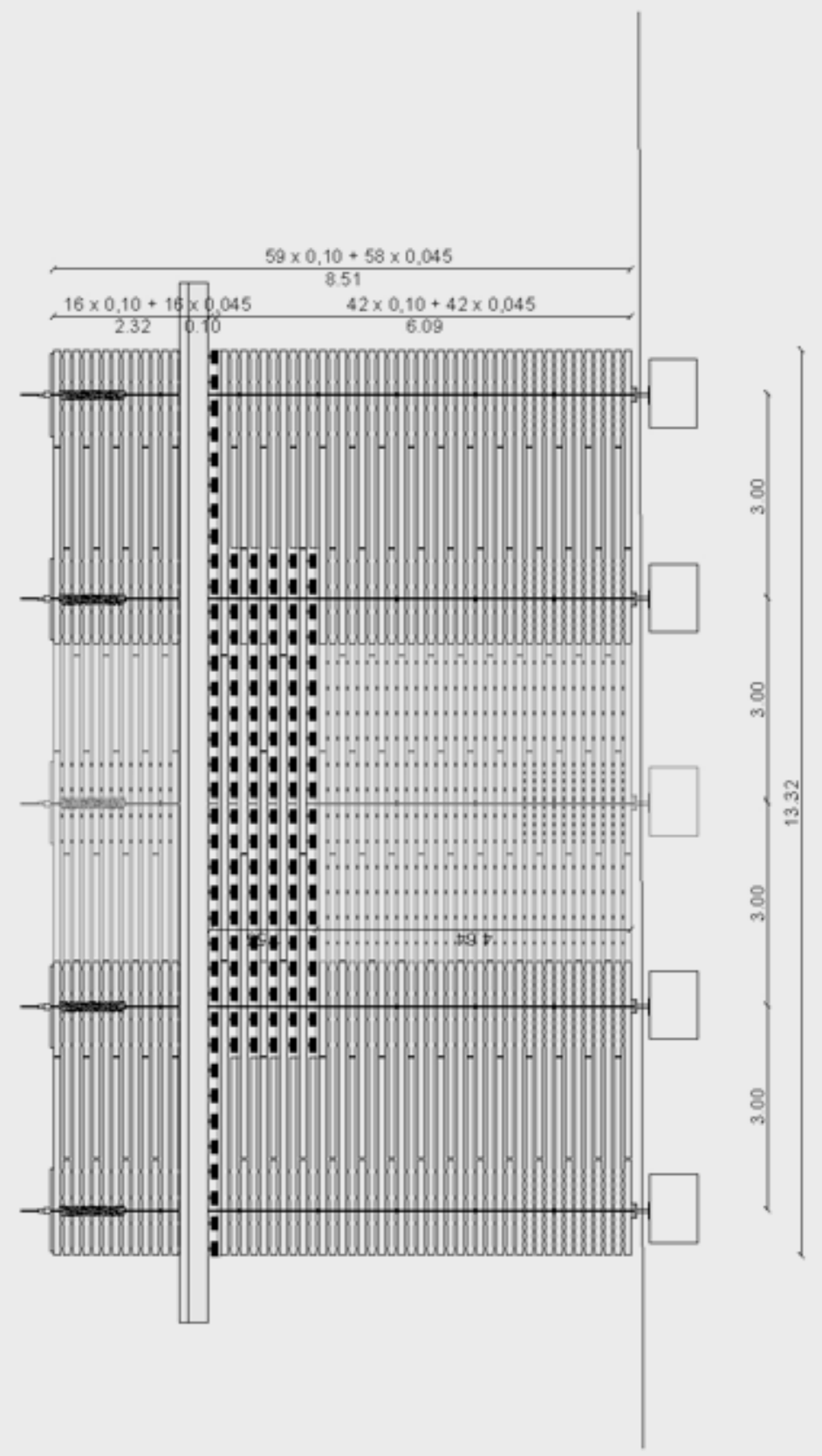

Figura 135.

Sección longitudinal / Stapel 11

Dibujo de la autora 


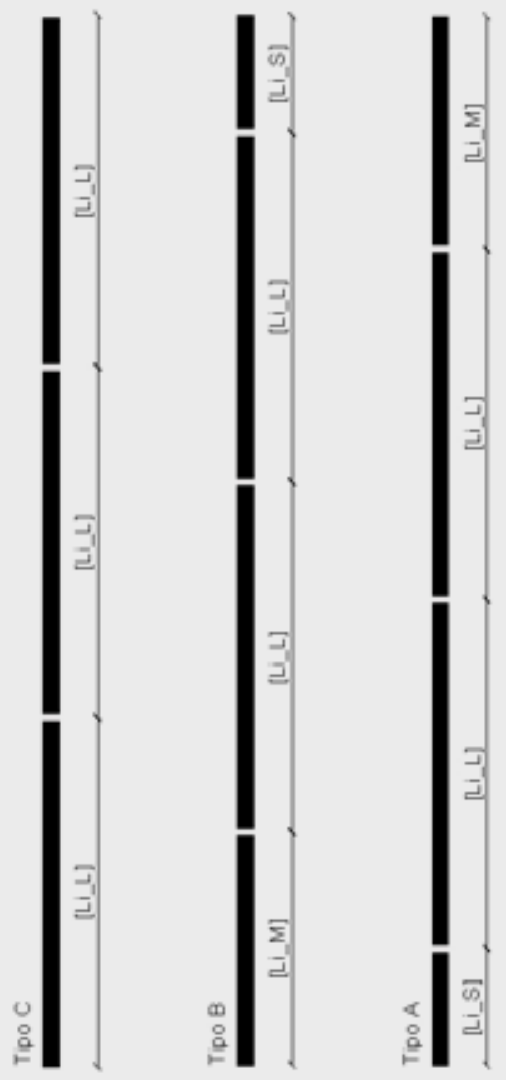

Figura 136.

Sistema compositivo de los listones de madera / Stapel 11 Dibujo de la autora 


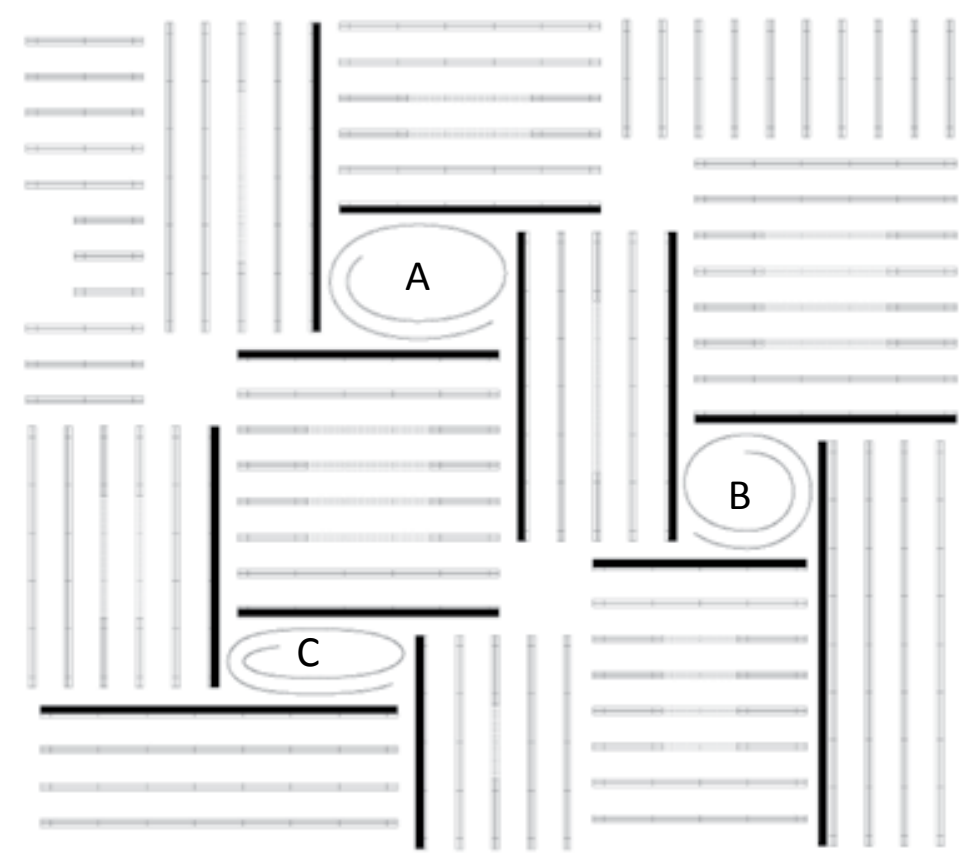

Figura 137.

Límite de los espacios libres para las unidades elípticas / Pabellón helvético

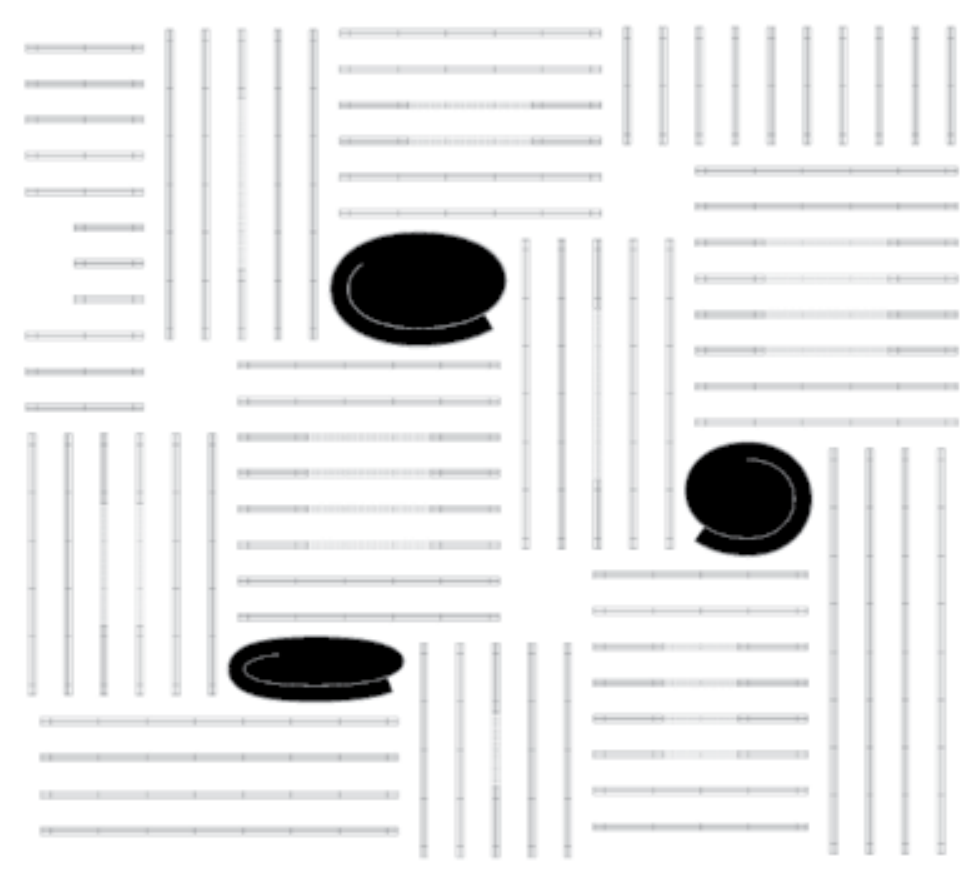

Figura 138.

Unidades elípticas / Pabellón helvético 


\section{[Intrusos]}

"Tres unidades negras se encuentran en los patios... Su planta en forma de espiral se compone de dos elipses diferentes cada una. ${ }^{158}$ Peter Zumthor

Dentro del pabellón surgen tres volúmenes independientes en forma de espiral que ofrecen un contrapunto al patrón geométrico estricto del Klangkörper. Sus distintos emplazamientos vienen determinados por la disposición de los Stapel. En los puntos del sistema donde se encuentran los testeros ${ }^{59}$ de cuatro pilas en esvástica; se producen una serie de espacios restantes de diferentes dimensiones ${ }^{60}$. En estos tres vacíos se inserta un intruso en cada uno de ellos. Estas unidades de servicio, Versorgungseinheiten, son contenedores destinados a la gastronomía, la información, el comercio, la administración, al almacenaje; así como contienen todas las instalaciones auxiliares. A diferencia de los 15 contenedores adicionales ubicados frente al pabellón principal en la propuesta ganadora del concurso Batterie; las tres unidades construidas colonizan el espacio del pabellón.

El Versorgungseinheit $A$ está ubicado entre los Stapel 2, 3, 6 y 7. Esta unidad de servicio, cuyas dimensiones son 7,31 m de ancho y 11,04 m de largo, ubica en planta baja una cocina. El Versorgungseinheit B está emplazado entre los Stapel 7, 8, 11 y 12. Esta unidad, cuyas dimensiones son 7,31 $\mathrm{m}$ de ancho y 8,04 $\mathrm{m}$ de largo, contiene un espacio de almacenaje y de basuras en planta baja. El Versorgungseinheit $C$, entre los Stapel 5, 6,9 y 10 , está dedicado en planta baja a información y venta de libros. Esta unidad es la más alargada y forzada de todas, 4,31 m de ancho y 11,04 m de largo.

Zumthor recurre a la idea de la espiral frente a la composición en paralelo de las pilas de madera. Una curva abierta que gira alrededor de uno de los extremos, generando un desarrollo ascendente a modo de recorrido unitario. Una escalera estrecha de color rojo, con ancho de paso constante para una persona recorre toda la edificación en tres niveles. La planta baja es más alta, con una altura libre de 2,82 m; que los dos niveles superiores con un mayor nivel de privacidad, de 2,645 m. Este sistema de comunicación ubicado en el perímetro, concéntrico, es similar al desarrollado para el Kunsthaus.

58 AAVV. Klangkörperbuch. Birkhäuser. Basel. 2000. ISBN: 3-7643-6324-X. Pág. 65. Traducción de la autora: "Drei schwarze Versorgungseinrichtungen stehen in den Flankenhöfen. Ihr spiralförmiger Grundriss setzt sich zusammen aus je zwei verschiedenen Ellipsen."

59 Nota: A diferencia de los patios - claros en el bosque, que se componen mediante los frentes abiertos de los Stapel.

60 Nota: Hof A: 9,06 x 12,795 m; Hof B: 9,06 x 9,795 m, Hof C: 6,06 x 12,795 m 

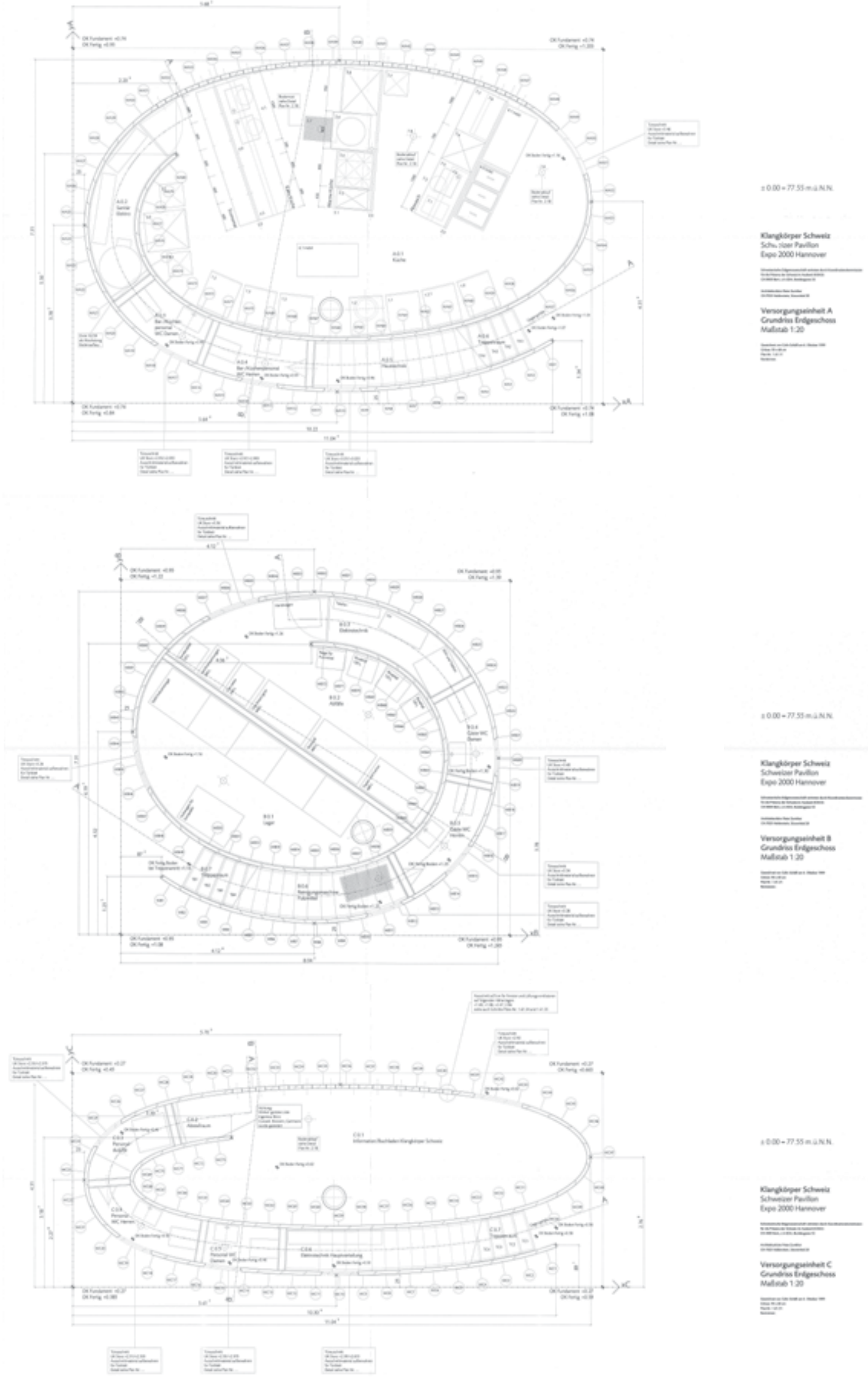

Figura 139 - 141.

Planos originales / Unidades elípticas A, B y C / Architekturbüro Zumthor 
Las tres "folies" son construcciones al uso; son intrusos del sistema. Contienen cerramientos conformados con madera maciza laminada, encolada y lacada con una pintura acrílica negra; puertas e incluso ventanas, aperturas en forma de ojo de buey, Bullaugen. Son contenedores con geometrías elípticas, sin fachadas principales o traseras; sin revelar que pasa en su interior. Frente al estricto trazo lineal de todo el conjunto; estos elementos se insertan como otra capa, con otras leyes. Una operación semejante a la que Sir Norman Forster llevó a cabo años más tarde en la ampliación de la biblioteca filológica de la Universidad Libre de Berlín de 2001-05. Ambas son "contra-composiciones" para incorporar "una nueva dimensión oblicua a la composición ortogonal" ${ }^{\prime 1}$. Operan como las diagonales en las obras de Theo van Doesburg en la búsqueda de equilibrio entre lo pre-visible y lo im-pre-visible, entre relajación y tensión, entre la libertad y el sistema ${ }^{62}$.

61 VAN DOESBURG, Theo. Malerei und Plastik. 1926/27 En: Jaffé, Hans Ludwig C, Mondrian und der Stijl. Köln. 1967. Pág. 208. Traducción de la autora: "Door nieuwe materialen en toepassing van nieuwe constructie-methoden (spanningsconstructie, enz) kan de architectuur, althans optisch, eveneens een anti-statisch karakter krijgen...Voegt aan de othogonale, peripherische compositie, een nieuwe schuine dimensie toe lost zoodoende de spanning horizontaal-verticaal, op reeële wijze op. Invoering van hellingsvlakken, dissonant -vlakken, in oppositie met gravitatie en architectonischstatische structuur.". Traducción de la autora: "La contra-composición elemental (antiestática)... añade una nueva dimensión oblicua a la composición ortogonal y periférica. Aquí disuelve la tensión horizontalmente-verticalmente de una manera real. Introducción de superficies inclinadas, superficies disonantes frente a la gravedad y estructura arquitectónicamente."

62 ZUMTHOR, Peter. Therme Vals. Scheidegger \& Spiess. Zürich. 2008. ISBN: 978-3-85881-704-4. Pág. 59. Nota: "We tried to find the right balance between relaxation and tension, between freedom and system. At one point, I remember taking a renewed interest in the composition of Piet Mondrian's paintings. 
[Anotaciones]

unidades
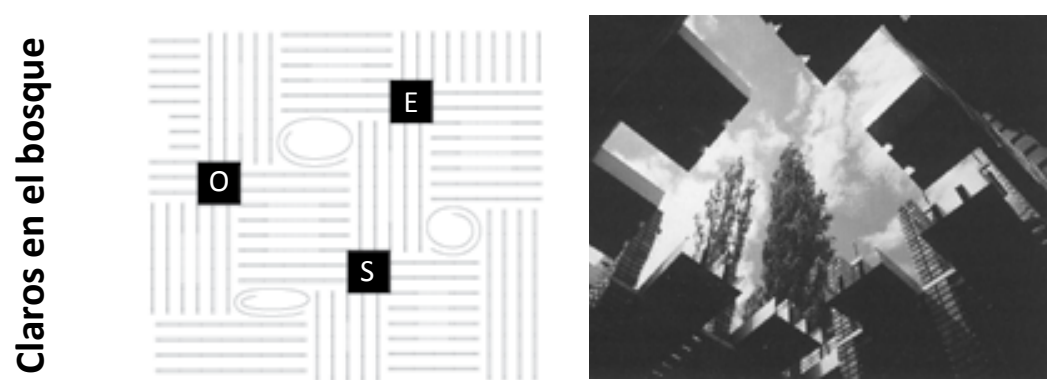

Hof Ost - patio este

Hof West - patio oeste

Hof Süd - patio sur
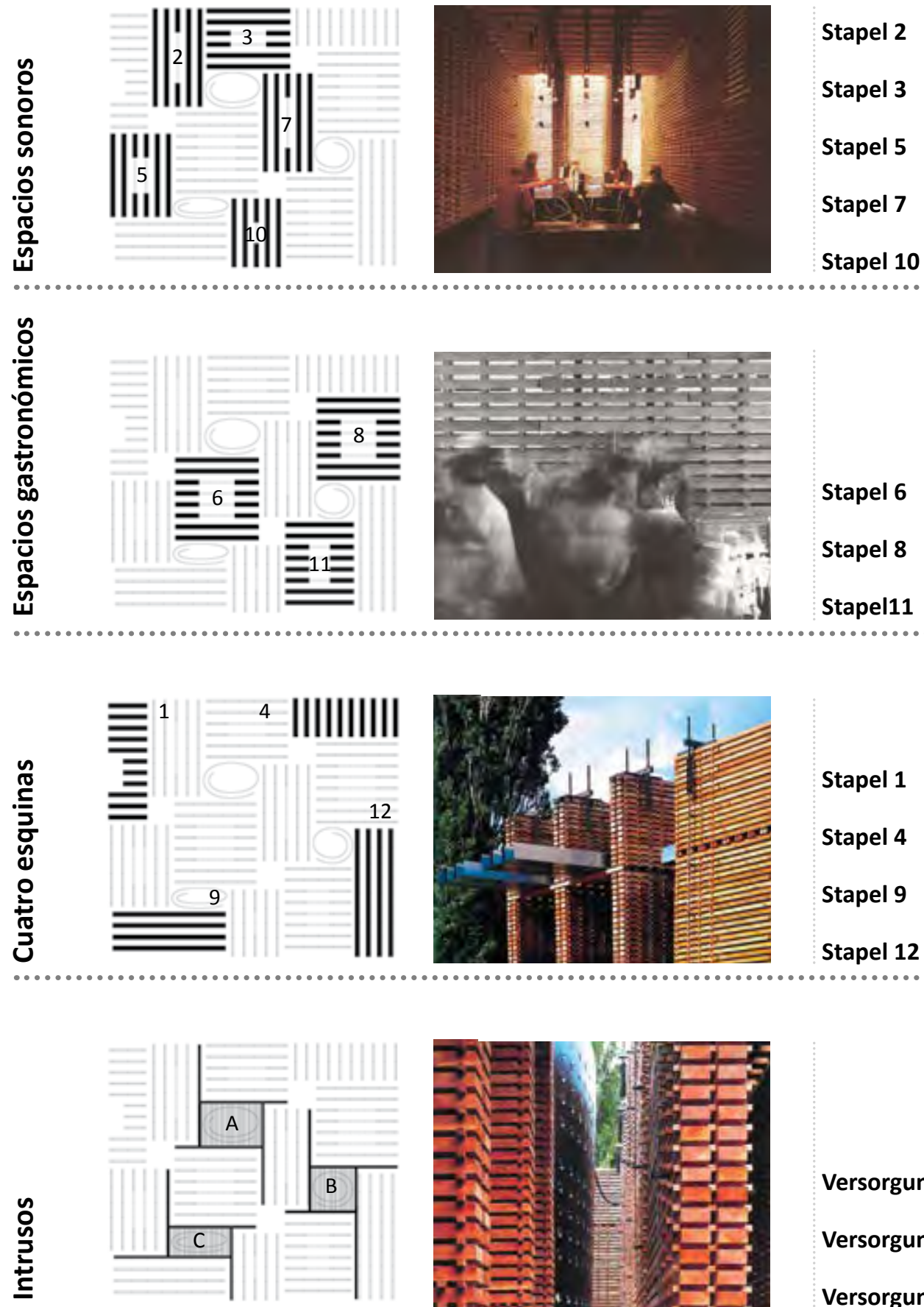

Versorgungseinheit A

Versorgungseinheit B

Versorgungseinheit C 


$\begin{array}{llll}\text { noroeste-sureste } & 5 \text { pilas } & 19,32 \mathrm{~m} \\ \text { suroeste-noreste } & 6 \text { pilas } & 16,32 \mathrm{~m} \\ \text { noroeste-sureste } & 6 \text { pilas } & 16,32 \mathrm{~m} \\ \text { noroeste-sureste } & 5 \text { pilas } & 19,32 \mathrm{~m} \\ \text { noroeste-sureste } & 5 \text { pilas } & 13,32 \mathrm{~m}\end{array}$

$10,68 \times 4,045 \mathrm{~m}$

$43,20 \mathrm{~m}$

$13,32 \mathrm{~m}$

$7,68 \times 6,29 \mathrm{~m}$

$48,31 \mathrm{~m}$

$7,68 \times 6,29 \mathrm{~m}$

$48,31 \mathrm{~m}$

$10,36 \times 4,045 \mathrm{~m}$

$43,20 \mathrm{~m}$

$4,68 \times 4,045 \mathrm{~m}$

$18,93 \mathrm{~m}$

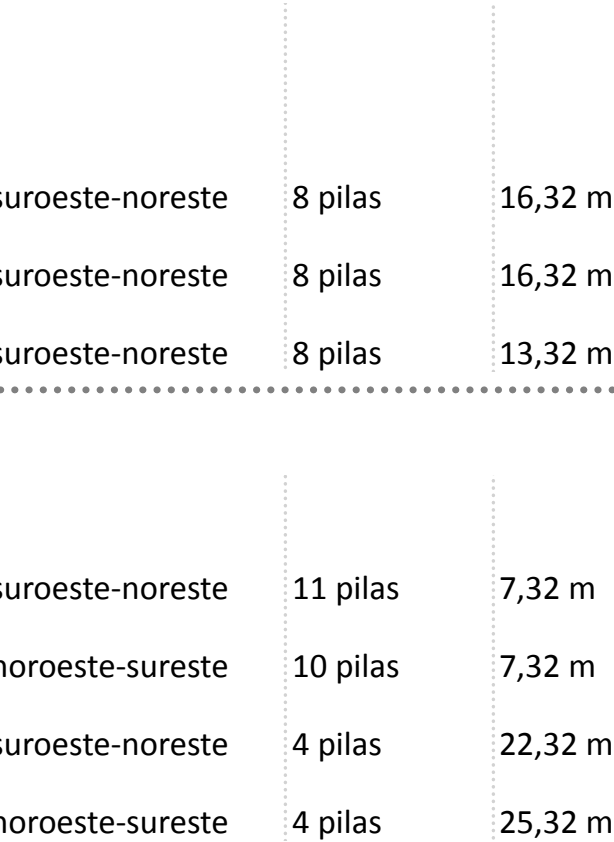

$7,68 \times 10,78 m \quad 82,79 m$

$7,68 \times 10,78 m \quad 82,79 m$

$4,68 \times 10,78 m \quad 50,45 m$
$115,92 \mathrm{~m} 2$

$6,06 \times 12,795 \mathrm{~m}$
$9,06 \times 9,385 \mathrm{~m}$

$85,03 \mathrm{~m} 2$

$9,06 \times 12,795 \mathrm{~m}$ 


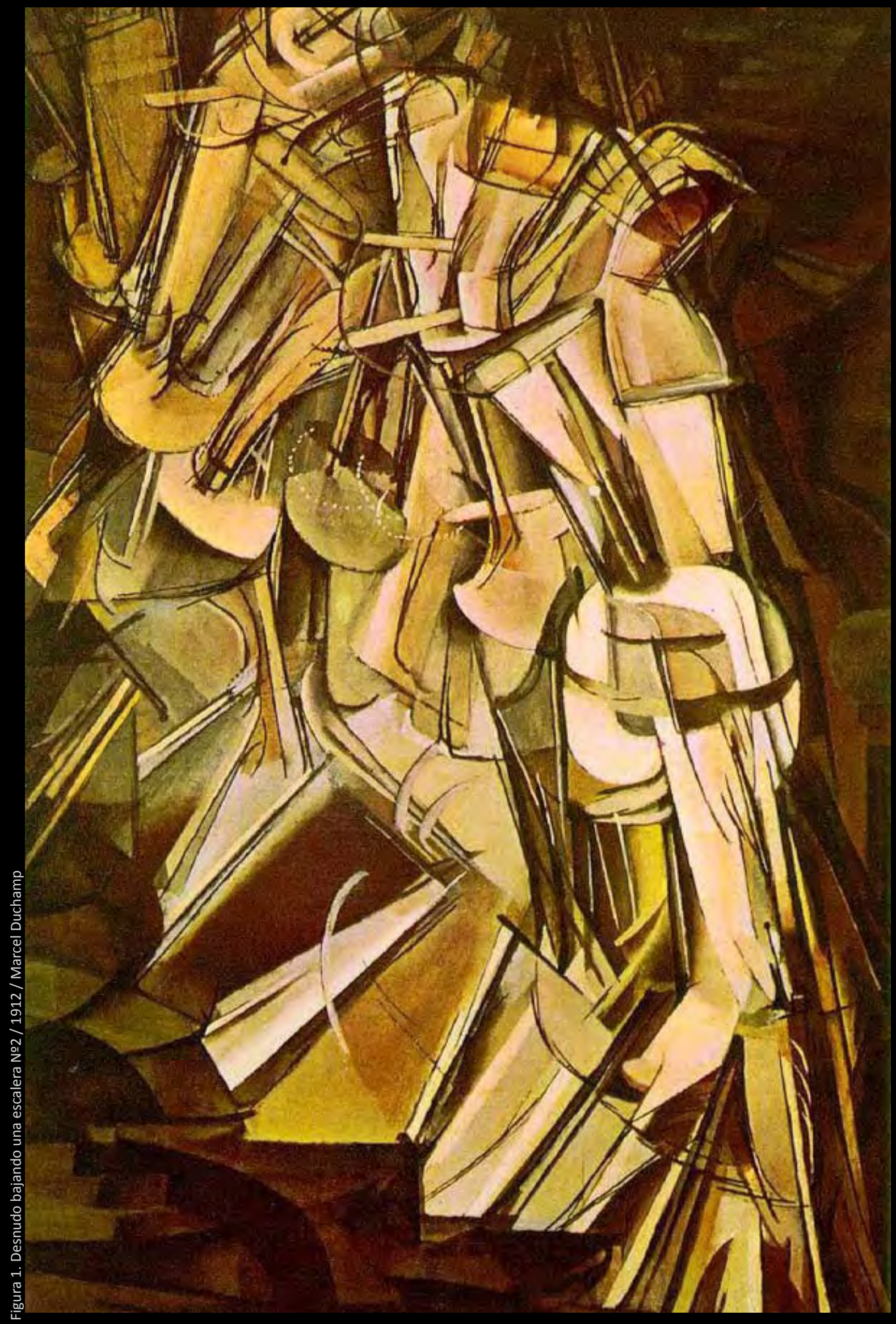


STORYBOARD

STORYBOARD

"La arquitectura se camina, se recorre (...)"

Le Corbusier 

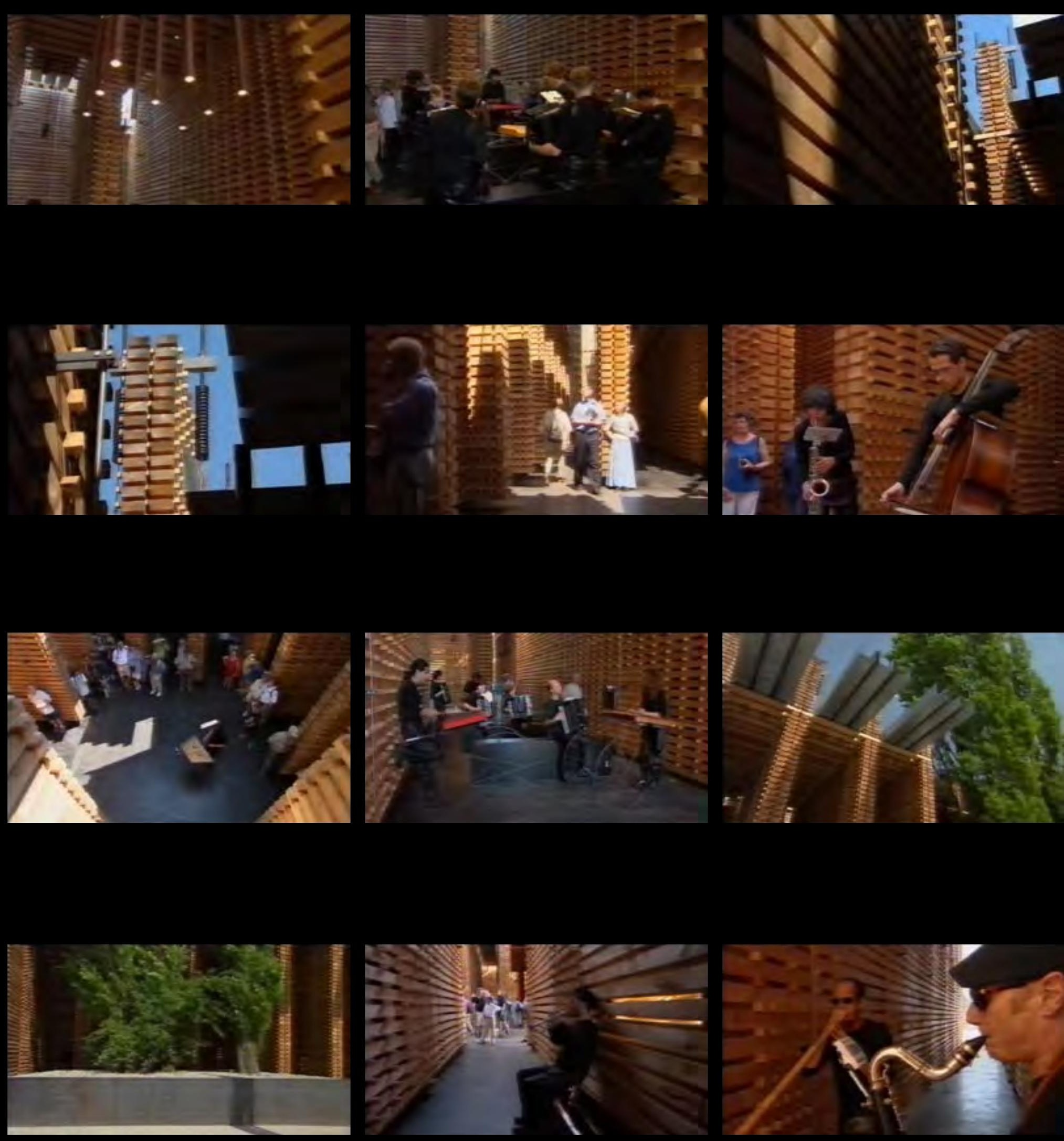

Figura 2 - 25.

Imagenes del Documental "Klangkörperklang" 

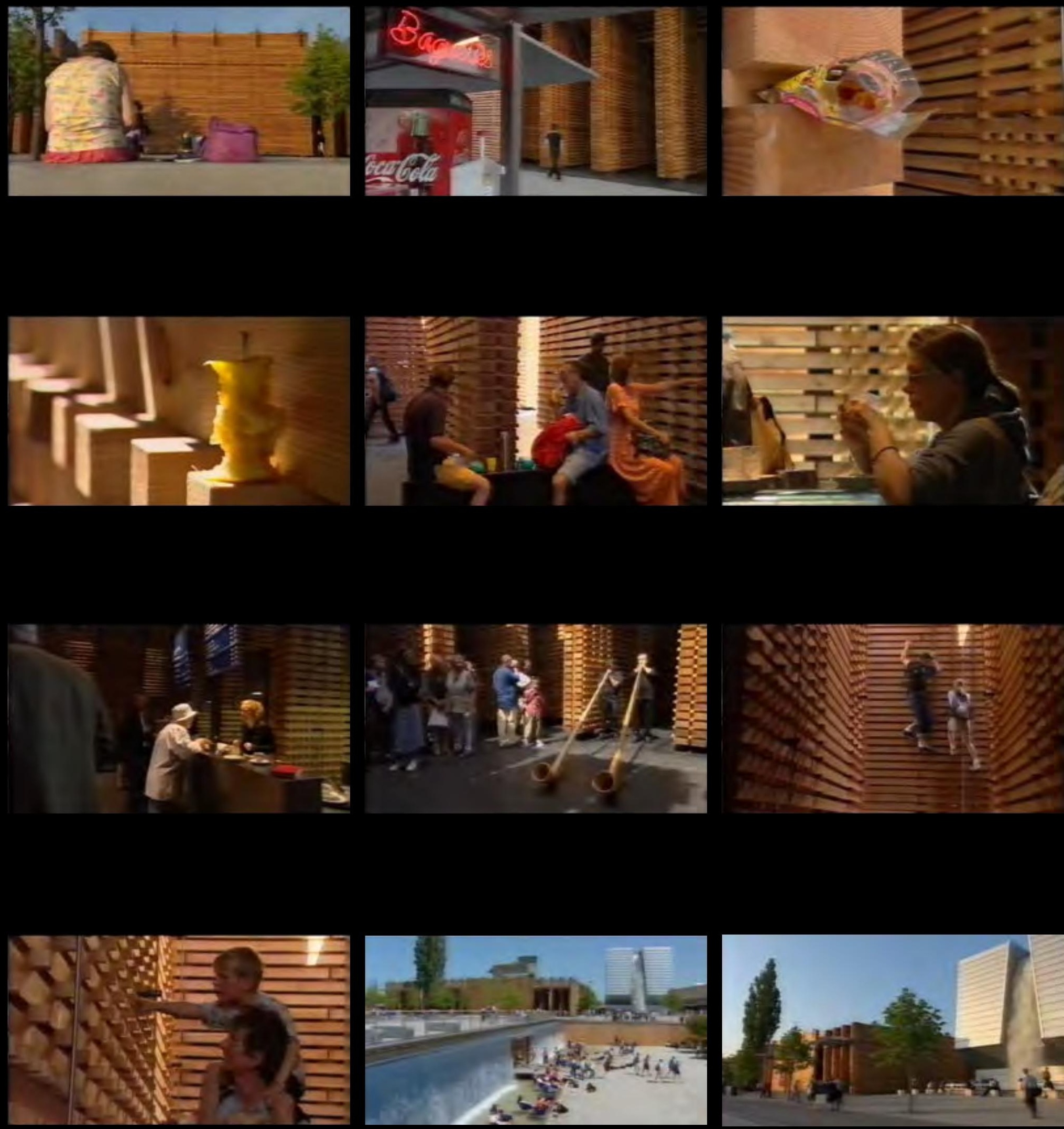

Figura 26 - 49.

Imagenes del Documental "Klangkörperklang" 

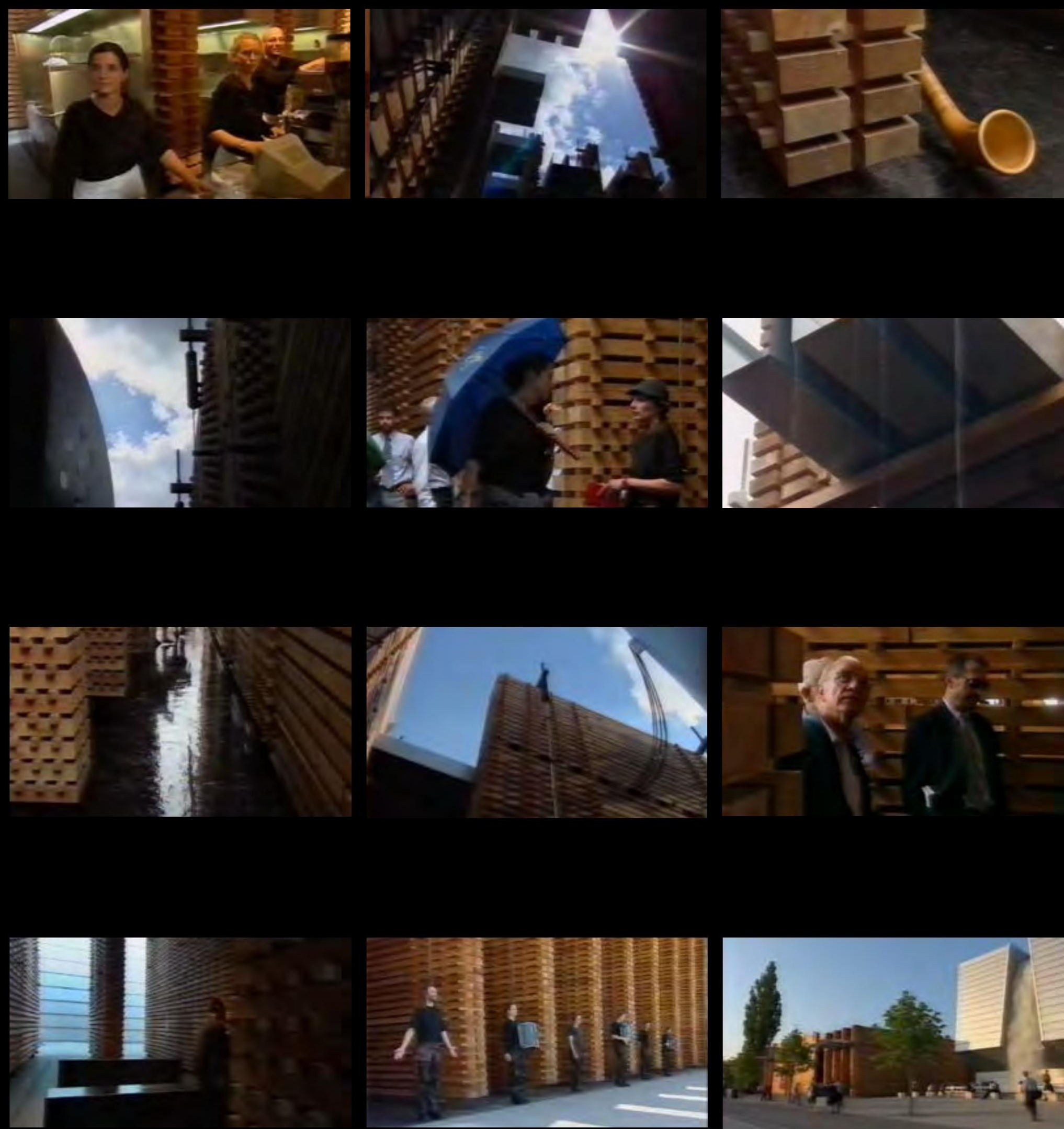

Figura $50-73$

Imagenes del Documental "Klangkörperklang" 


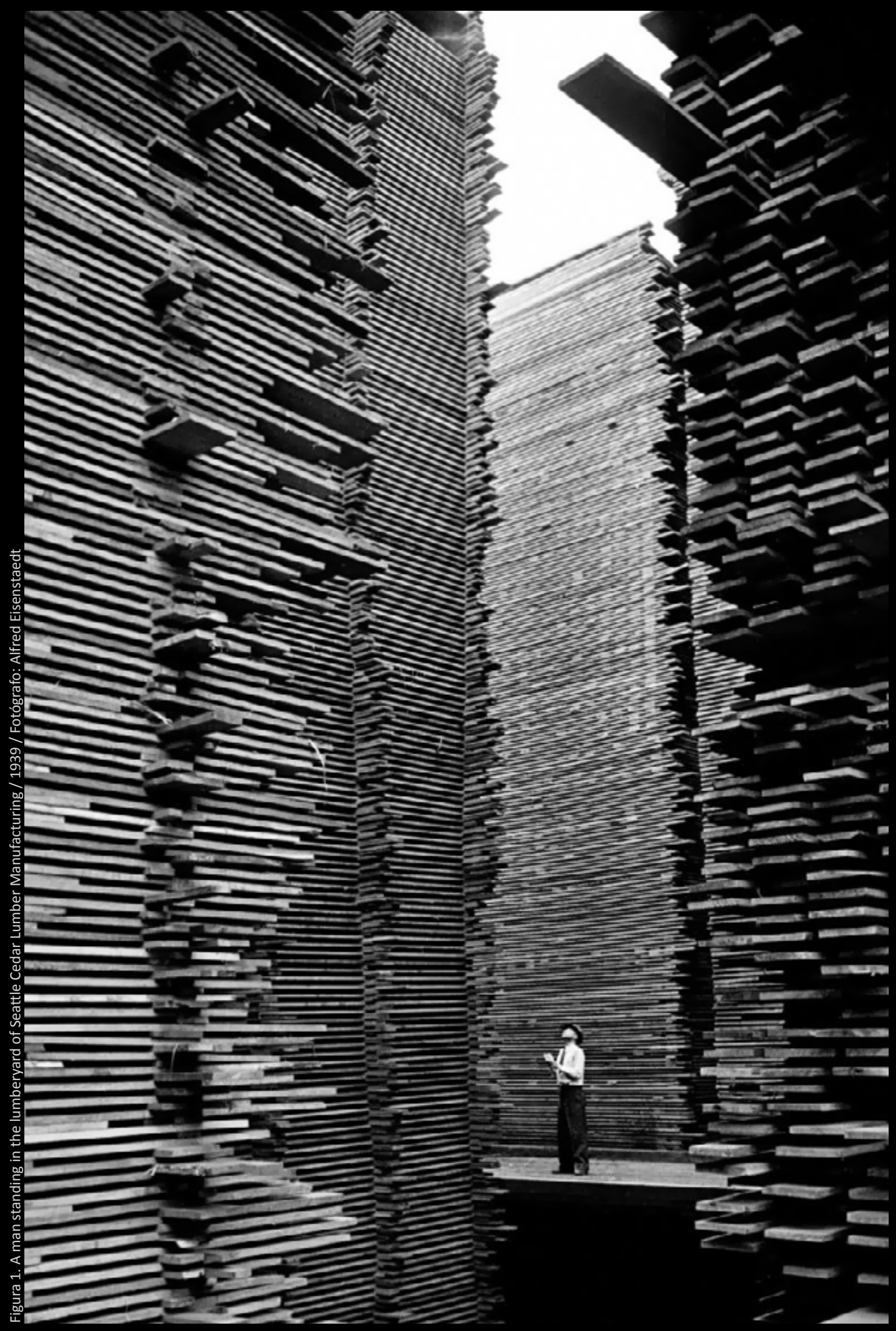


ANATOMÍA

ANATOMIE

"Como la piedra o la tierra, la madera es un material cultural elemental de la humanidad.

Determina nuestro espacio vital en varias formas de procesamiento y apariencia, por ejemplo, como una casa, una cerca, muebles, electrodomésticos o papel. Se disuelve lentamente con el tiempo, pero vuelve a crecer." ${ }^{\prime 1}$

Peter Zumthor Verarbeitungs- und Erscheinungsformen, z. B. als Haus, Zaun, Möbel, Gerät oder Papier. Es löst sich mit der Zeit langsam auf, wächst aber wieder nach." 


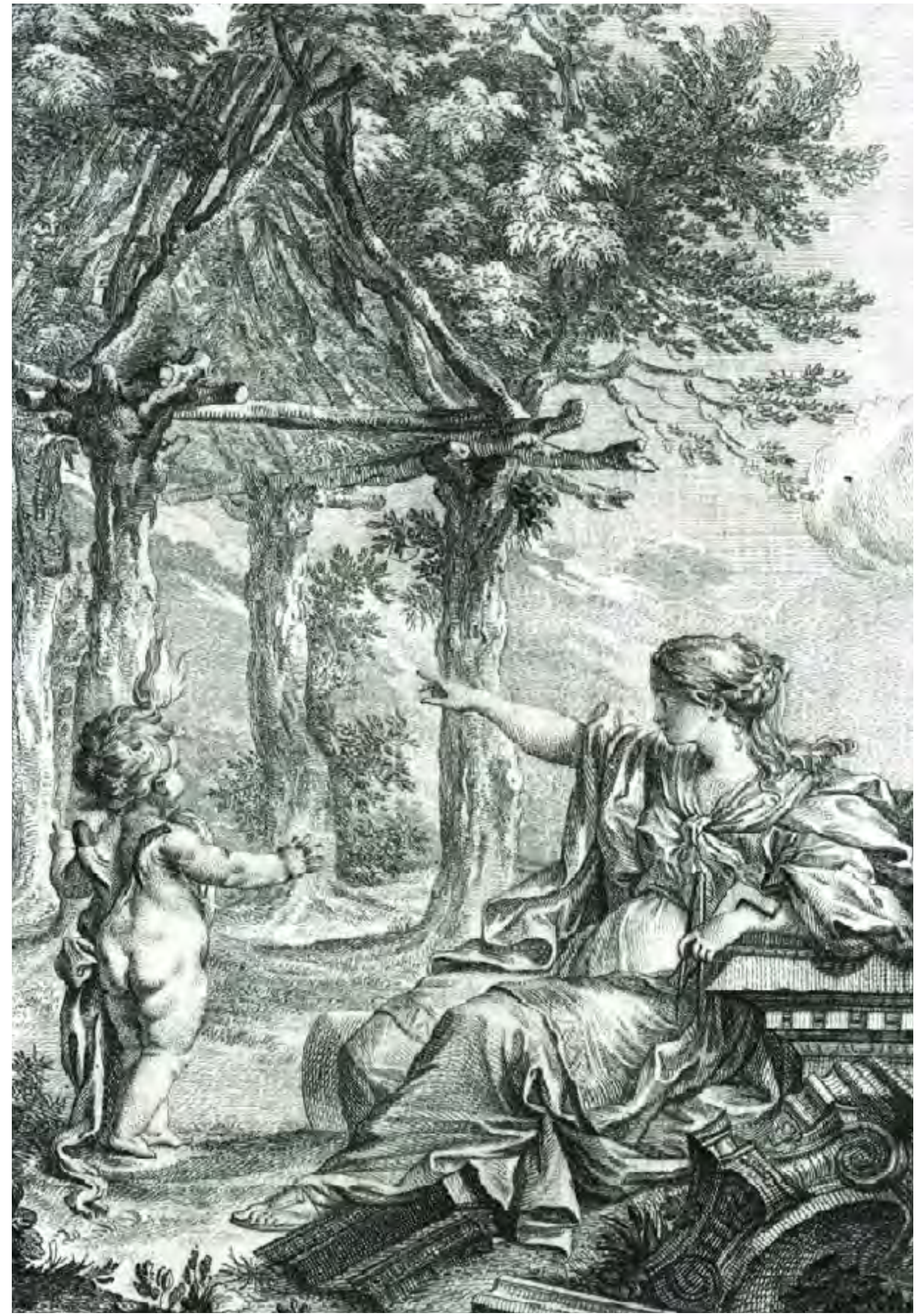

Figura 2

Grabado alegórico de la cabaña primitiva de Vitruvio / Charles Eisen 


\title{
[Materia prima]
}

\author{
"Si no tuviéramos la madera, entonces no tendríamos fuego; \\ entonces tendríamos que comer toda la comida cruda y congelarnos \\ hasta morir en invierno; no tendríamos casas, ni cal, ni ladrillos, ni \\ vidrio, ni metales. No tendríamos ni mesas ni puertas, ni sillones ni \\ electrodomésticos." ${ }^{2}$ Wolf Helmhard von Hohberg
}

La construcción con madera está ligada al origen de la arquitectura. En Los Diez Libros de Arquitectura ${ }^{3}$, Marco Vitruvio mostró a la cabaña primitiva como el origen de lo construido, como uno de los fundamentos teóricos de la historia arquitectónica. La arquitectura en sintonía con la naturaleza.

La importancia de la madera como material idóneo para la construcción de la arquitectura ya fue descrita en 1682 por el barón y escritor austriaco Wolf Helmhard von Hohberg. Uno de los materiales de construcción más antiguos, un recurso natural. Un tejido vegetal leñoso de larga duración que crece anualmente; renovable, abundante, firme, resistente, ligero, flexible y anisótropo hasta cierto punto y fácil de trabajar. Además de sus favorables propiedades materiales y de su potencial técnico, constructivo, ecológico, económico; contiene una condición sensorial y sensual.

En 1755, se publicó la segunda edición de Essai sur l'Architecture ${ }^{4}$ escrita por el abate jesuita francés Marc-Antonie Laugier. La portada incluía el Grabado alegórico de la cabaña primitiva de Vitruvio ${ }^{5}$ como representación de la idea vitruviana. En la imagen, una mujer sentada en las ruinas de un templo señalando un andamiaje de troncos y ramas de árboles. Una cubierta a dos aguas sustentada en los troncos de cuatro árboles. Una estructura hecha de materiales de construcción naturales sin tratar, creando un refugio. Según Laugier, la arquitectura adoptó sus motivos directamente de los propios de la naturaleza. La complejidad de la construcción se reduce a sus características básicas. Arquitectura y naturaleza se encuentran y forman una unidad.

2 VON HOHBERG, Wolf Helmhard. En: Zeitschrift für Architektur und Städtebau. Arch+ $193 \mathrm{Holz}$. Arch+ Verlag. 2009. ISBN: 978-3931435219. Pág. 13. Traducción de la autora: "Hätten wir das Holz nicht, dann hätten wir kein Feuer; dann müssten wir alle Speisen roh essen und im Winter erfrieren; wir hätten keine Häuser, hätten weder Kalk noch Ziegel, kein Glas, keine Metalle. Wir hätten weder Tische noch Türen, weder Sessel noch Haushaltsgeräte."

3 VITRUVIO POLIÓN, Marco. Los diez libros de arquitectura. Alianza Editorial. Madrid. 1995. ISBN: 84206-7133-9.

4 LAUGIER, Marc-Antoine. Essai sur l'architecture. (1755). Minkoff. Genéve. 1972

5 Nota: Obra de Charles Eisen 


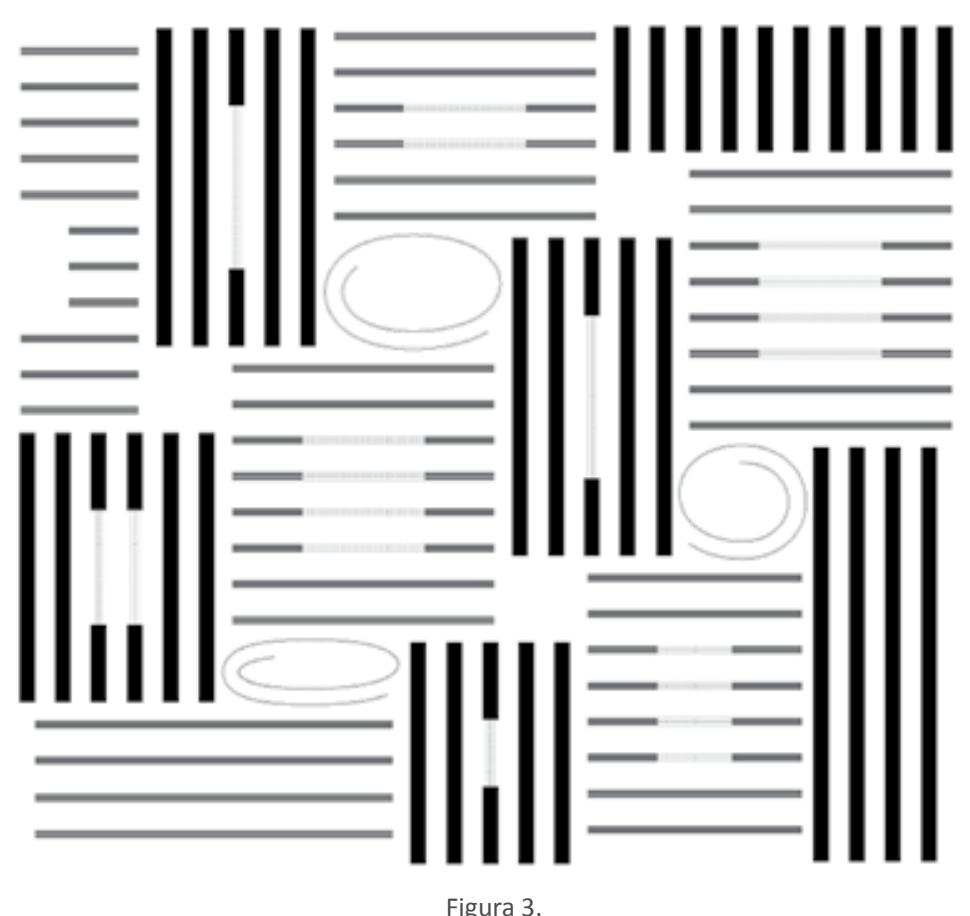

Esquema listones / Alerce N-S/ Pabellón helvético Dibujo de la autora

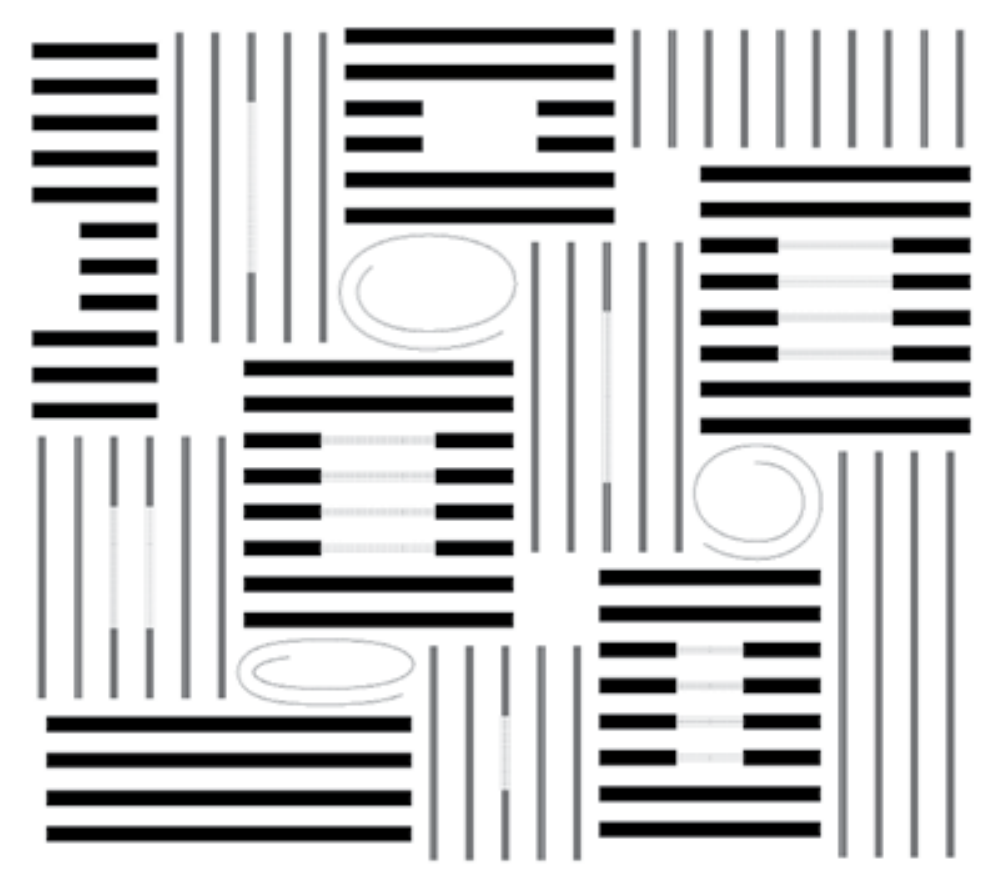

Figura 4.

Esquema listones / Pino E-O / Pabellón helvético

Dibujo de la autora 


\begin{abstract}
"Ocuparse de las leyes propias de cosas concretas - como montaña, piedra o agua - teniendo como telón de fondo una tarea constructiva que entraña la posibilidad de captar algo de la esencia originaria y "civilizadoramente inocente" por así decirlo - de esos elementos, y luego expresarlo, desarrollando así una arquitectura que brota de las cosas y vuelve a las cosas."6 Peter Zumthor
\end{abstract}

Ya en la primera propuesta presentada al concurso convocado ${ }^{7}$, Zumthor tuvo claro la materialidad. Las ocho pilas serían de listones de madera de abeto. Esta variedad de la familia de las coníferas es ligera, blanda, poco resinosa, con una textura uniforme y aspecto mate. Recién serrada tiene un color entre blanco y amarillo, que bajo exposición solar se oscurece considerablemente modificando su tonalidad entre marrón y amarillo. Convertir el pabellón en un gran instrumento musical transitable fue decisivo para la elección de la madera de abeto debido a su uso para la fabricación de instrumentos de cuerda cómo el violín Stradivarius. Sin embargo, al ser muy poco resistente a la acción de hongos e insectos, no es indicada para estar a la intemperie; por lo que fue descartado.

Procedentes de bosques autóctonos de varias regiones de Suiza ${ }^{8}$, se propusieron especies alternativas específicas como el alerce. Dada su escasa disponibilidad en ese momento, se decidió considerar otra especie complementaria, el pino. Finalmente se usó alerce para los Stapel en dirección N-S; y en la E-O se sustituyó por pino Douglas. El alerce y el pino Douglas son especies que se usan tanto en la construcción como en la fabricación de instrumentos musicales.

El alerce se caracteriza por un color amarillento con tonalidades rojizas. Se trata de una madera imputrescible, fácil de trabajar, dura y al mismo tiempo flexible, con una buena resistencia a hongos, a la humedad y al fuego; así como una durabilidad natural a la intemperie. La madera dura del alerce es apropiada para sonidos amortiguados -gedämpft.

La madera de pino Douglas tiene una apariencia similar a la madera de alerce. Una madera semiblanda, fácil de trabajar, versátil, con gran resistencia a los productos químicos y una buena elasticidad. El duramen tiene un color amarillo rojizo que oscurece rápidamente bajo la acción del sol hasta un tono marrón rojizo. La madera del pino Douglas es óptima en cambio para instrumentos de cuerda pulsada.

ZUMTHOR, Peter. Pensar la arquitectura. Editorial Gustavo Gili. Barcelona. 2009. ISBN: 978-84-252-2327-3. Pág. 31. Nota: Un condicionante previo del concurso.

AAVV. Klangkörperbuch. Birkhäuser. Basel. 2000. ISBN: 3-7643-6324-X. Pág.99 


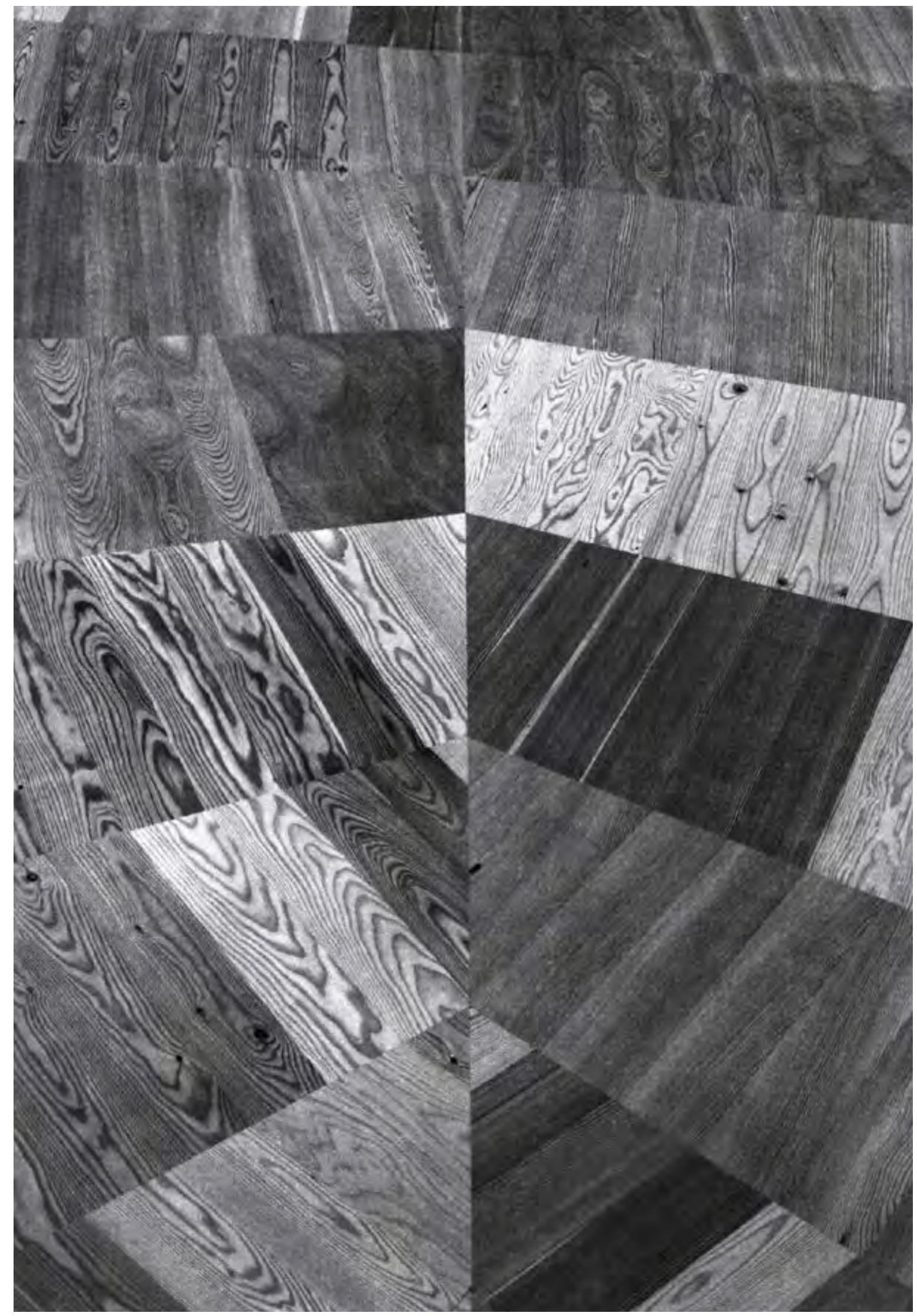

Figura 5.

Capilla San Benedicto / Graubünden / 1985 - 1988 / Peter Zumthor 


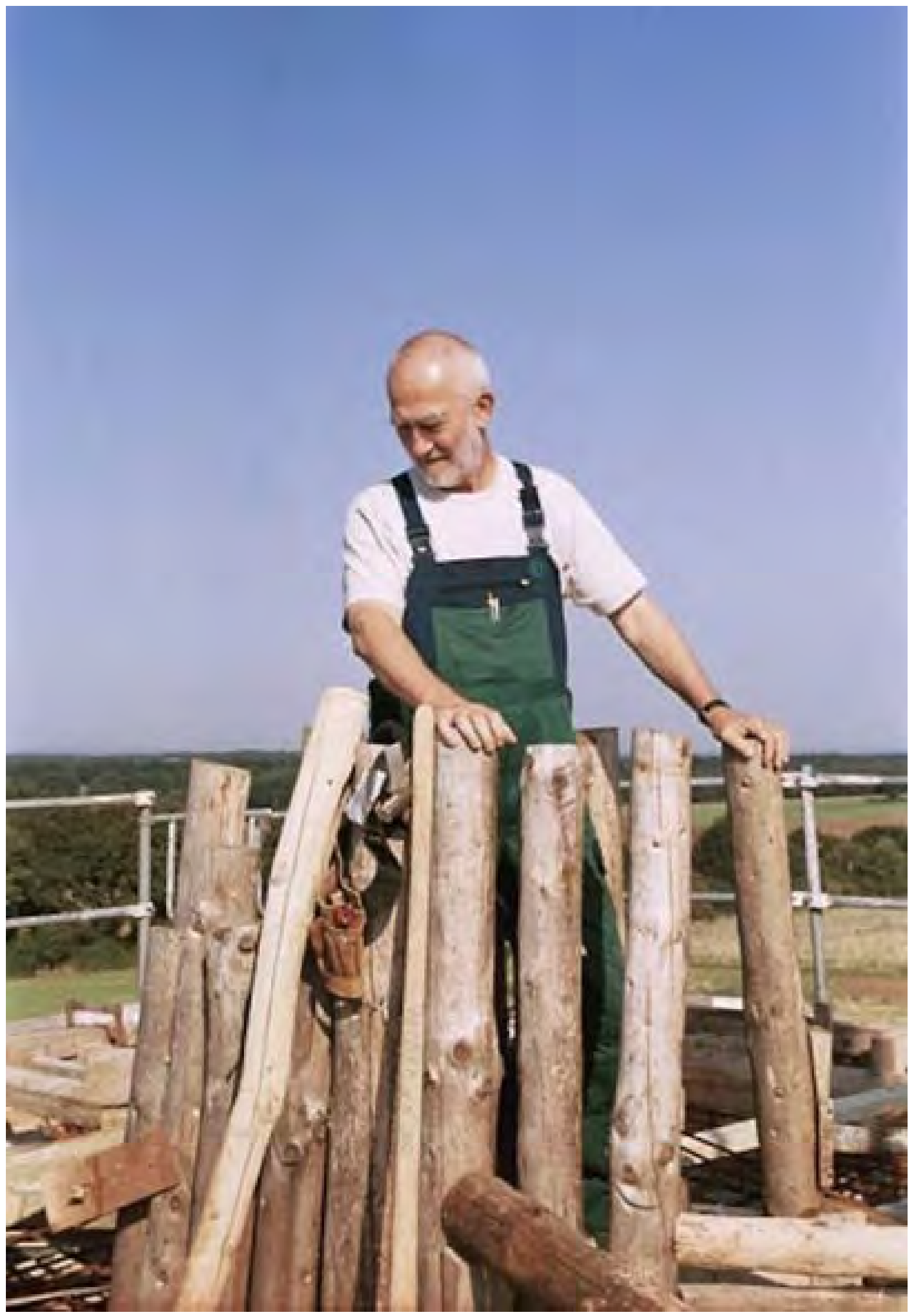

Figura 6.

Peter Zumthor / Capilla de Campo Bruder Klaus / Wachendorf, Alemania / 2001 -2007 / Peter Zumthor 


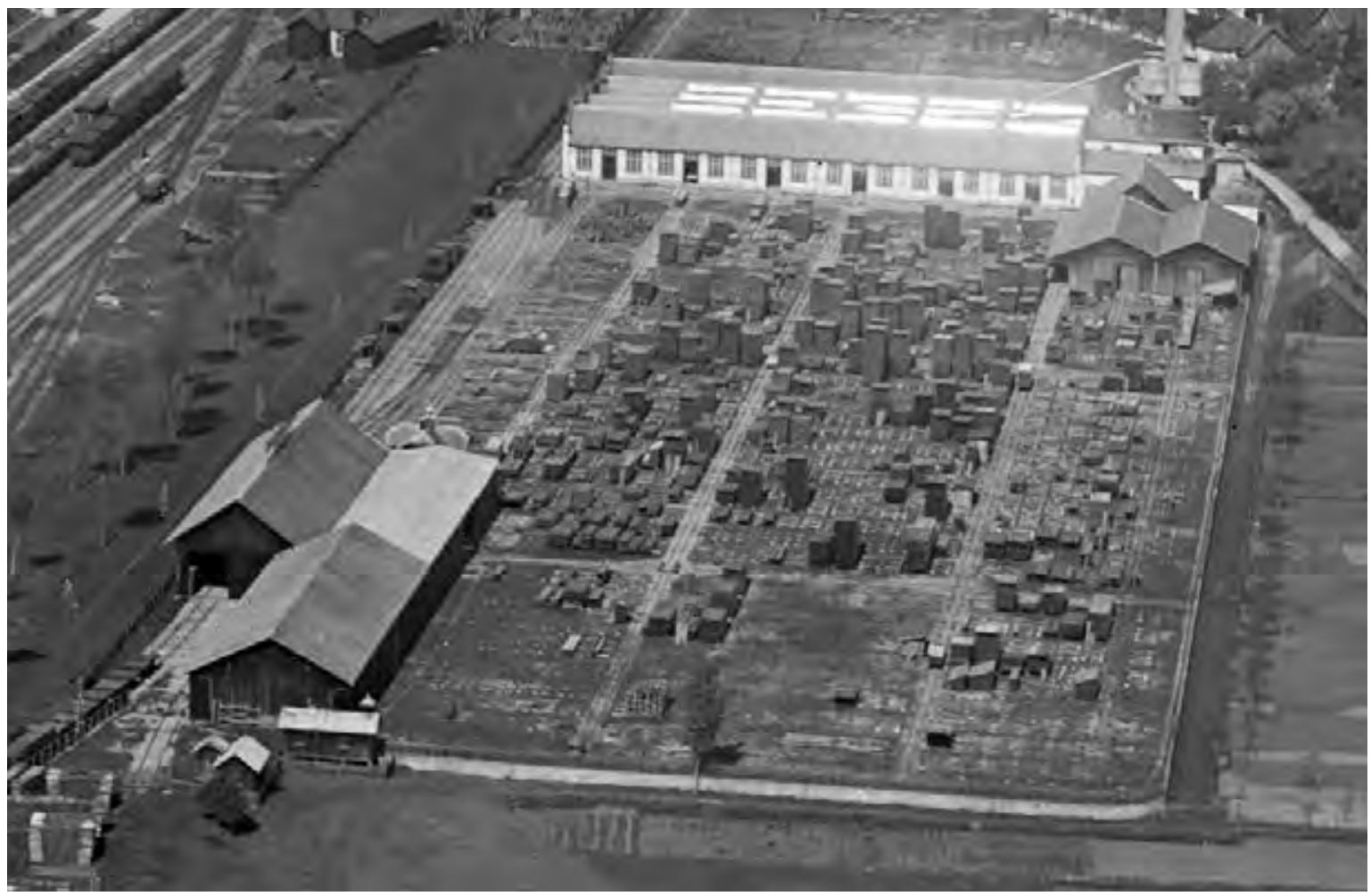

Figura 7.

Foto aérea de un secadero de madera en St. Margrethen / Fragmento / 1924 / Fotógrafo: Walter Mittelholzer

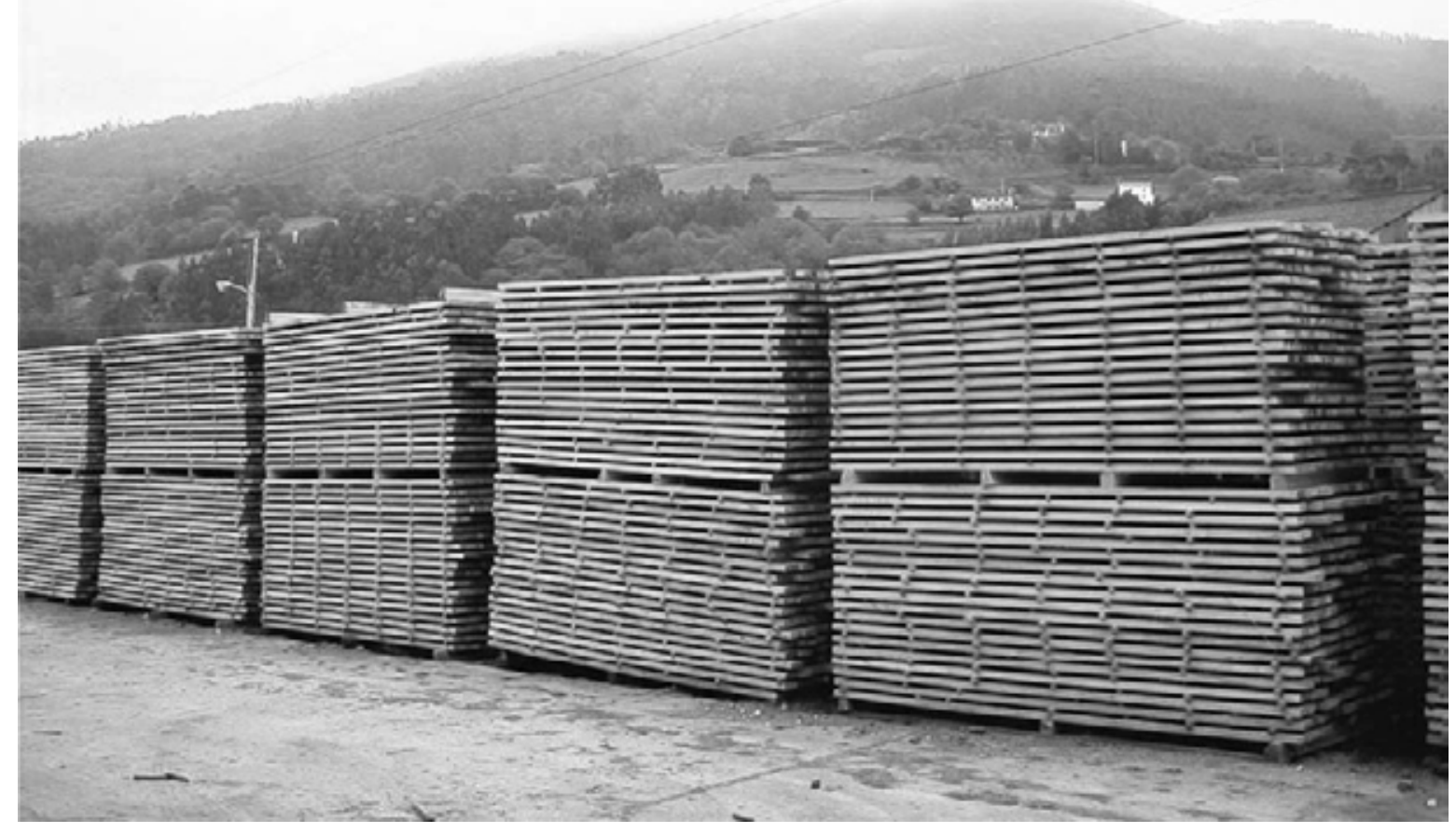

Figura 8.

Secado de madera al aire libre 


\title{
[Holzlager?]
}

\author{
"Mi preferencia son los materiales y las construcciones que \\ envejecen maravillosamente. Un edificio de madera irradia \\ permanencia, presencia y cierta serenidad hacia el tiempo."10 \\ Peter Zumthor
}

Zumthor esculpe el espacio desde su materialidad, como la piedra y el agua en los Baños Termales de Vals de 1990-96; o el vidrio y la luz en el Kunsthaus de Bregenz de 1989-1997. Poder participar en el concurso para el pabellón de Suiza para la Expo 2000 fue un impulso, entre otras razones, para volver a tallar madera como gran masa biológica.

Memoria de su etapa juvenil junto a su padre, recurre al símil de los secaderos de madera. El pabellón helvético se construyó con madera recién aserrada, atendiendo a las necesidades de un organismo vivo que se dilata y contrae según las condiciones climáticas del lugar. Sus sistemas de apilamiento, el almacenamiento provisional, los procesos de secado, el mágico momento de transformación en que el material natural se convierte en un material de construcción. Desde su origen, el pabellón se proyectó como un secadero donde la madera se pudiese secar de forma natural durante la exposición y posteriormente ser vendida como material de construcción.

Los secaderos naturales, Holzlager, funcionan mediante la deshumificación de la materia sin ayuda técnica inmediatamente después del aserrado. Siendo el método más antiguo, sencillo y más económico; es un procedimiento natural de larga duración. El proceso de secado depende de las condiciones climáticas locales: temperaturas, precipitaciones, niveles de humedad, vientos y circulación del aire; pero también del tipo de la madera ${ }^{11}$, su dureza, del tipo de corte entre otros. El objetivo es reducir el contenido de humedad de la madera aserrada para lograr niveles equivalentes con las condiciones ambientales circundantes. Esto ayudará a excluir variaciones dimensionales posteriores debido a la deformación, a la hinchazón o a la contracción. Para el proceso de secado de la madera a la intemperie es fundamental facilitar una

9 Nota: Holzlager es el término aleman para Secadero de madera.

10 ZUMTHOR. Peter. En: Zehn Argumente für den Holzbau. Verlag Hochpaterre. Lignum Holzwirtschaft Schweiz. https://www.lignum.ch/files/images/Downloads_deutsch/Zehn_Argumente_fuer_den Holzbau.pdf. Pág. 5. Traducción de la autora: "Meine Vorliebe gilt Materialien und Konstruktionen, die schön altern. Ein Bau aus Holz strahlt Dauer aus, Präsenz und eine gewisse Gelassenheit gegenüber der Zeit."

11 Nota: Tipo de secado al aire libre: Pino - 4-5 meses / Alerce - 3-7 meses. 


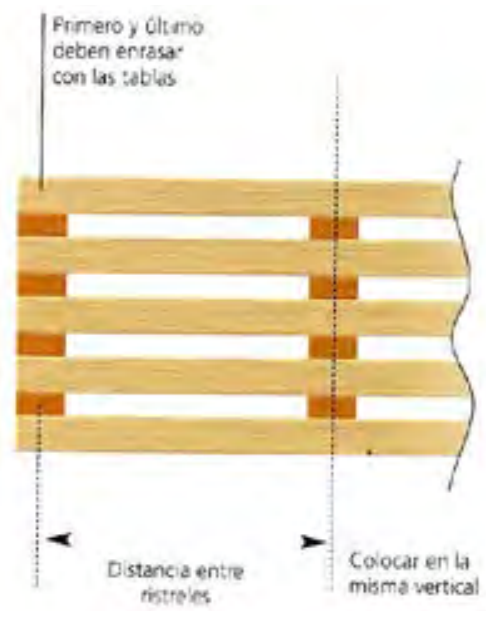

Figura 9

Colocación de los separadores
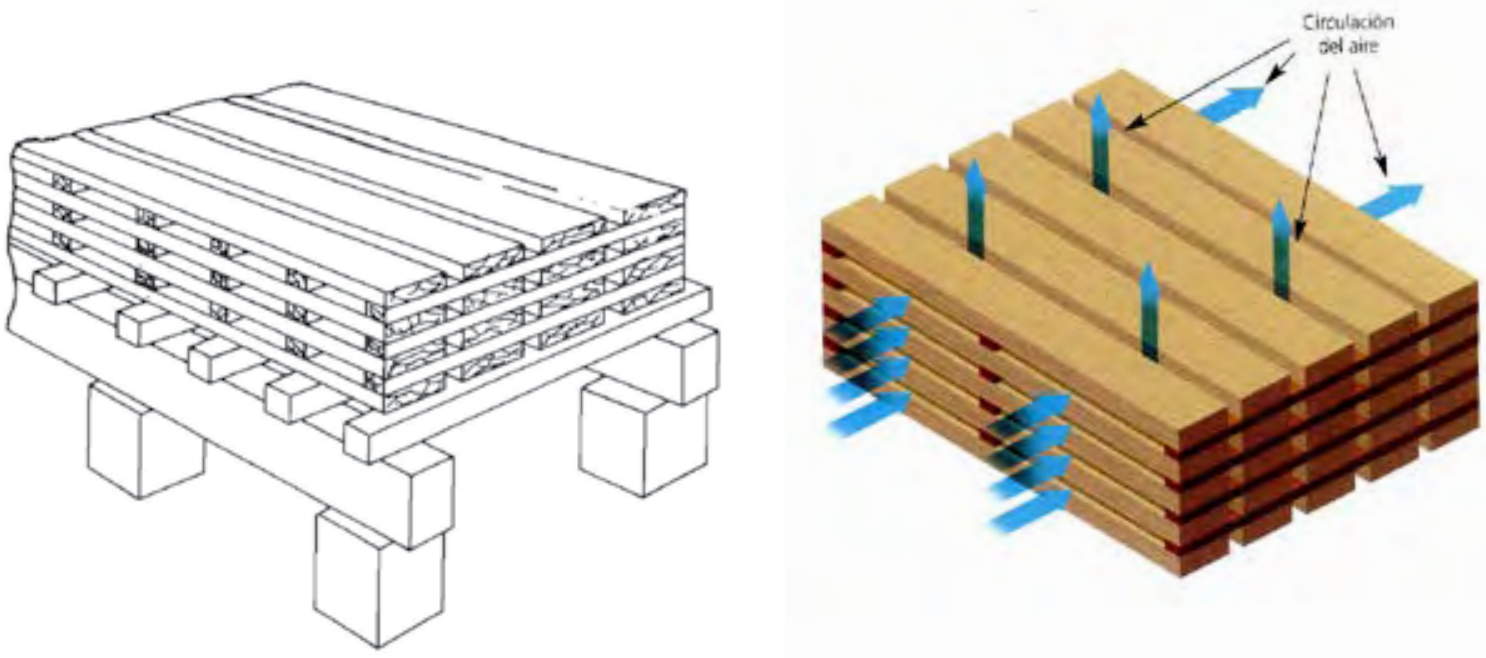

Figura 10 - 11.

Disposición de las piezas en el suelo

Colocación de los listones de madera en un secadero natura
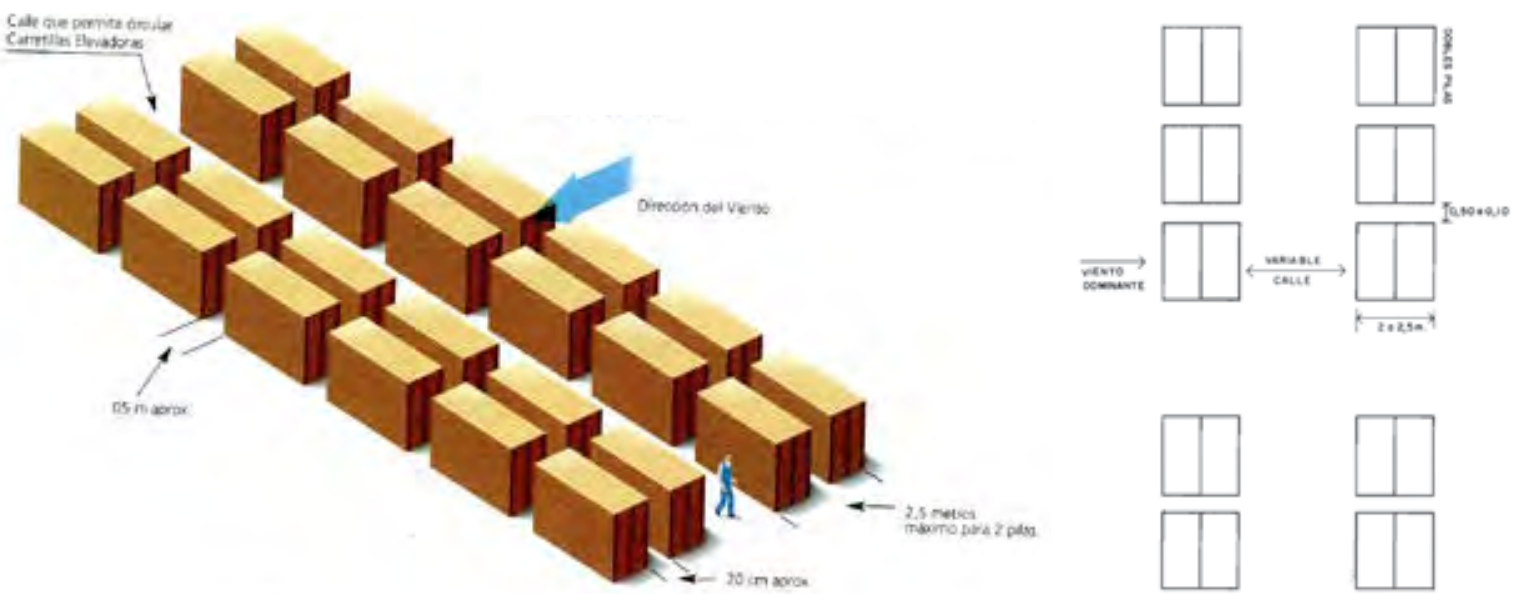

Figura 12 - 13

Formación de las calles

Disposición de las pilas 
buena y uniforme circulación natural de aire en todas las partes. Un apilamiento correcto y una estratificación adecuada serán cruciales para un buen secado. El área de apilamiento debe estar liberada de barreras y permitir el acceso sin obstáculos del viento desde la dirección principal.

El sistema más común es el apilamiento horizontal. Sobre una base plana, libre de malezas, impermeable y con sistemas de evacuación del agua de lluvia; se sitúan las pilas alineadas generando por una parte calles más anchas y por otra vías transversales más estrechas que permiten un fácil acceso. Un espacio libre en forma de pozo de ventilación entre dos pilas adyacentes permite una mejor circulación del aire en las superficies cortadas en todas las direcciones tanto en horizontal como en vertical. Distanciados del suelo $30-50 \mathrm{~cm}^{12}$ aproximadamente, se apilan los tableros o tablas recién aserrados horizontalmente. Pieza sobre pieza separados por unos separadores transversales que generan circuitos de aire entre las tablas acelerando la perdida de humedad. Para impedir el vuelo de los listones por empuje o succión, los últimos separadores deben estar enrasados con los extremos de las pilas ${ }^{13}$. El resto de los separadores se distancia de forma uniforme, alineados verticalmente unos sobre otros para repartir la carga de manera homogénea. Cada estrato debe estar compuesto por madera del mismo tipo y grosor para evitar deformaciones diferenciales. Las tablas en ningún caso se juntan entre sí, dejando una distancia entre ellas, para permitir el aireado.

La altura máxima recomendada de estas "torres", colocando las pilas en filas paralelas juntas de dos en dos $^{14}$, oscila entre 1-4 $\mathrm{m}^{15}$. Es aconsejable reforzar su estabilidad mediante la colocación de pesos encima de las planchas para que la carga sea uniforme en toda la pila con el fin de evitar asentamientos diferenciales ${ }^{16}$.

12 CIGALAT FIGUEROLA, Enrique; SOLER BURILLO, Manuel. Guía de las principales Maderas y de su secado. Opti Thermal, S.L. Valencia. 2003. ISBN: 84-8476-149-5. Pág. 40.

13 Idem. Pág. 46

14 ALVAREZ NOVES, Humberto. Secado de la madera al aire. Hojas divulgadoras. Num. 19/84. Ministerio de agricultura, pesca y alimentación. Madrid. 1984. ISBN: 84-341-0374-5. Pág. 17.

15 Idem. Pág. 17.

16 CIGALAT FIGUEROLA, Enrique; SOLER BURILLO, Manuel. Guía de las principales Maderas y de su secado. Opti Thermal, S.L. Valencia. 2003. ISBN: 84-8476-149-5. Pág. 40. 


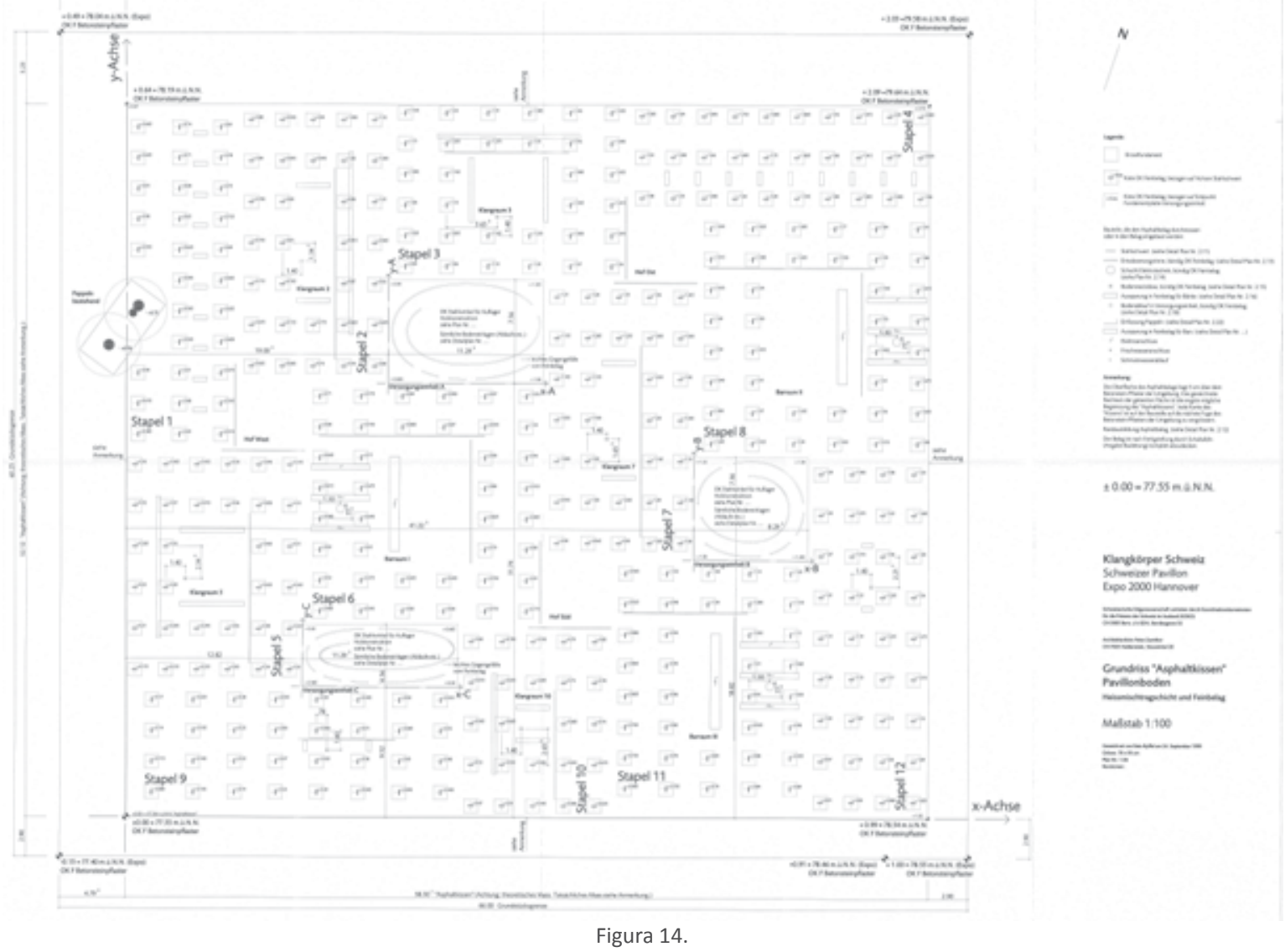

Plano original del pavimento asfáltico / Pabellón helvético / Hannover / 2000 Proyecto de ejecución / 24 de Septiembre 1999.
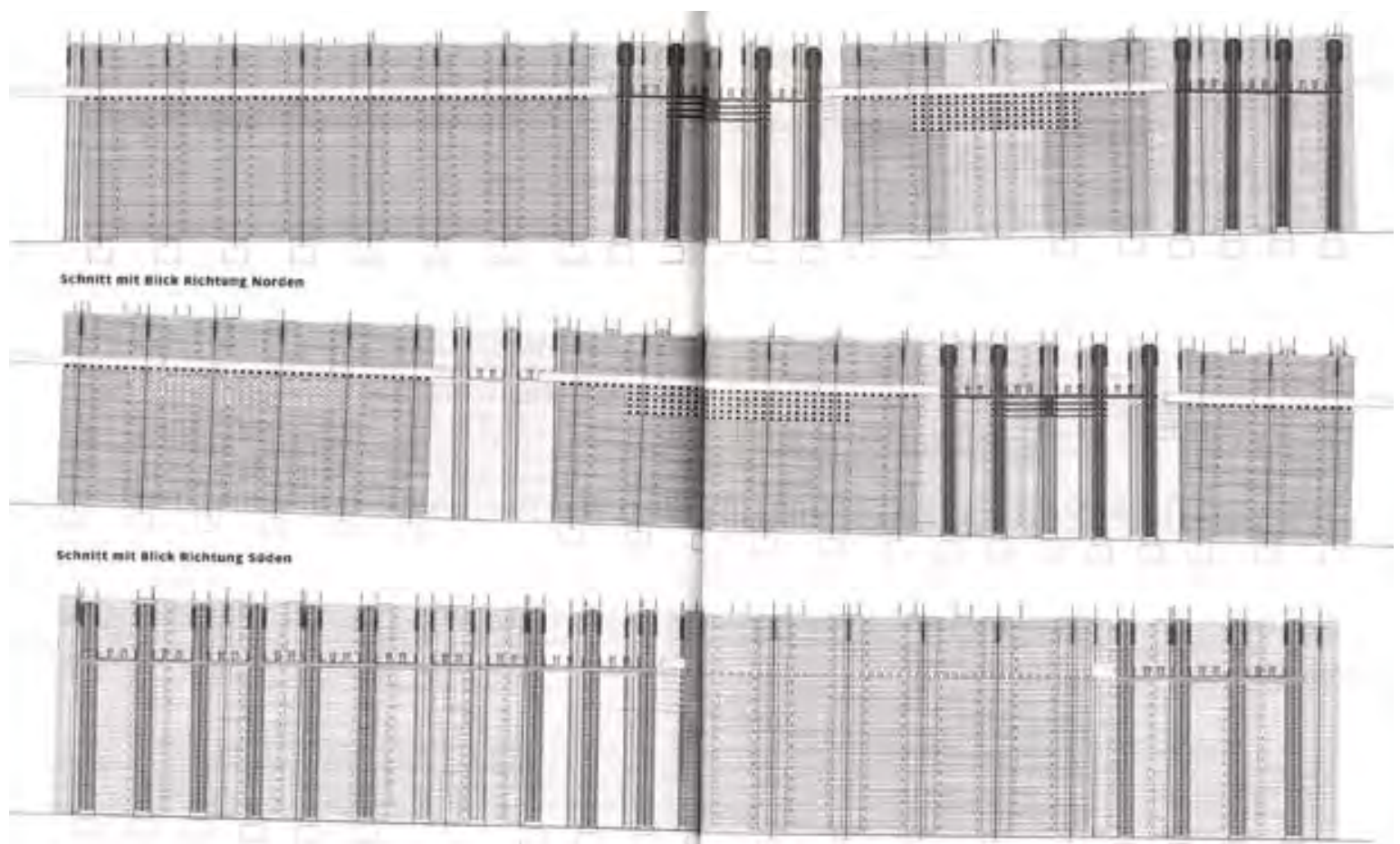

Figura 15.

Desnivel / Pabellón helvético / Hannover / 2000 
"La construcción es el arte de configurar un todo con sentido a partir de muchas particularidades... Para mí, el núcleo propio de toda tarea arquitectónica reside en el acto de construir... Siento respeto por el arte del ensamblaje, por las aptitudes de los constructores, artesanos e ingenieros." ${ }^{18}$ Peter Zumthor

El lema Batterie usado en el concurso del Pabellón helvético y cuya semántica en alemán ${ }^{19}$ hace alusión en gran medida a su condición constructiva; poco a poco, en las sucesivas transformaciones irá desapareciendo. Todo ello en la búsqueda de lograr un espacio netamente sensorial. Zumthor se referirá al pabellón construido como Klangkörper ${ }^{20}$; es decir, caja sonora, enfatizando su condición fenomenológica. Desde el concepto de a-pila-miento como sistema formal y constructivo; la nueva denominación se orientará hacía una condición de soporte sonoro, de espacio fluido. Un dispositivo coherente en términos del continente y del contenido, una atmósfera vinculada a la experiencia de los sentidos.

Las diversas mutaciones del proyecto, desde su simiente en 1996 hasta su inauguración cuatro años después, fueron constantes. Algunas fueron sugeridas por el jurado del concurso a modo de recomendaciones, y otras muchas fueron consideraciones del propio de Zumthor.

Estas se llevaron a cabo en diferentes áreas. Logísticas, integrándose todas las instalaciones auxiliares en el cuerpo principal. Tecnológicas, reemplazándose las luces de neón por proyectores que arrojaban frases sobre las pilas. Ambientales, sustituyéndose los altavoces que transmitían en varios idiomas y dialectos suizos por música en directo. Simbólicas, se omitieron fotografías, carteles e imágenes directas de Suiza. Materiales, en la propuesta del concurso se propuso la construcción de todo el pabellón en madera de abeto, pero finalmente se usó madera de pino y de alerce. Presupuestarias, solicitándose una partida adicional dado el incremento del volumen de la madera y al sofisticado sistema de montaje de las pilas. Los gastos

17 Nota: Sohle es el término alemán para el nivel inferior de un terreno firme y solido, obtenido mediante la excavación. Tras el vaciado se replantea la cimentación que sirve para la ejecución de la obra.

18 ZUMTHOR, Peter. Pensar la arquitectura. Editorial Gustavo Gili. Barcelona. 2009. ISBN: 978-84-2522327-3. Pág. 11.

19 AAVV. Botschaft über die Teilnahme der Schweiz an der Weltausstellung "Expo 2000 Hannover". Bundesblatt. Band 5. Heft 39. Geschäftsnummer 98.040. 22. Junio. Pág. 4670.

20 AAVV. Klangkörperbuch. Birkhäuser. Basel. 2000. ISBN: 3-7643-6324-X. Pág. 131 


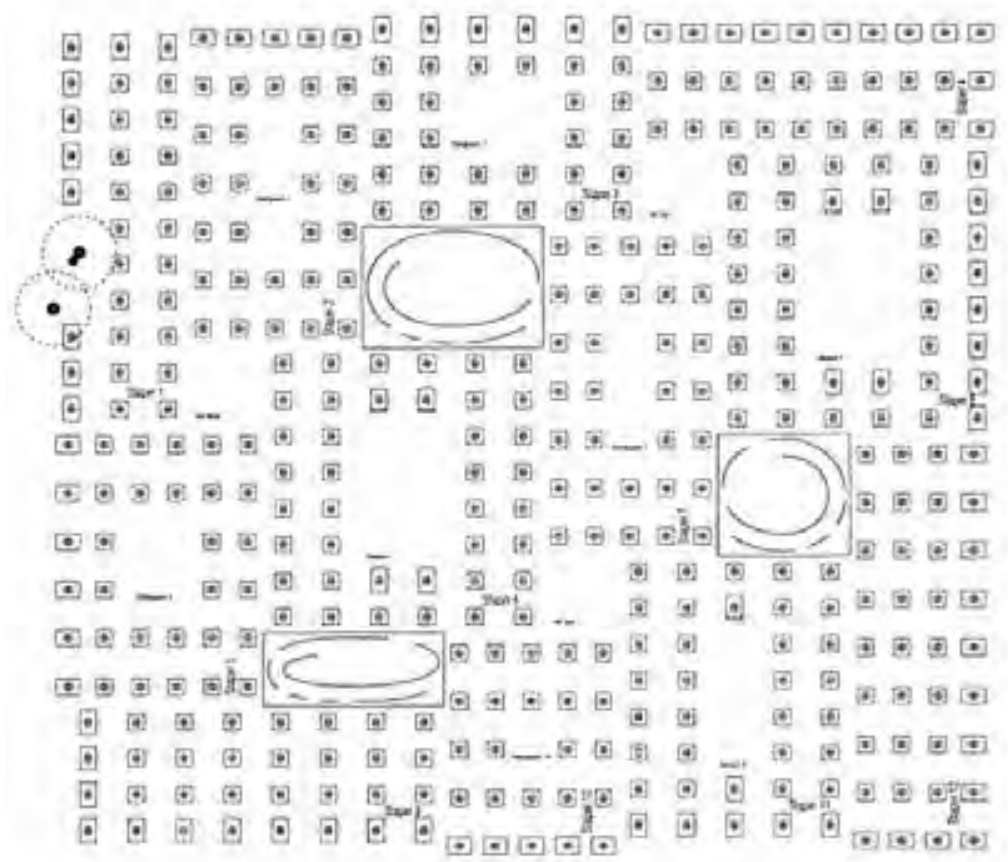

Figura 16.

Plano de cimentación / Pabellón helvético / Hannover / 2000

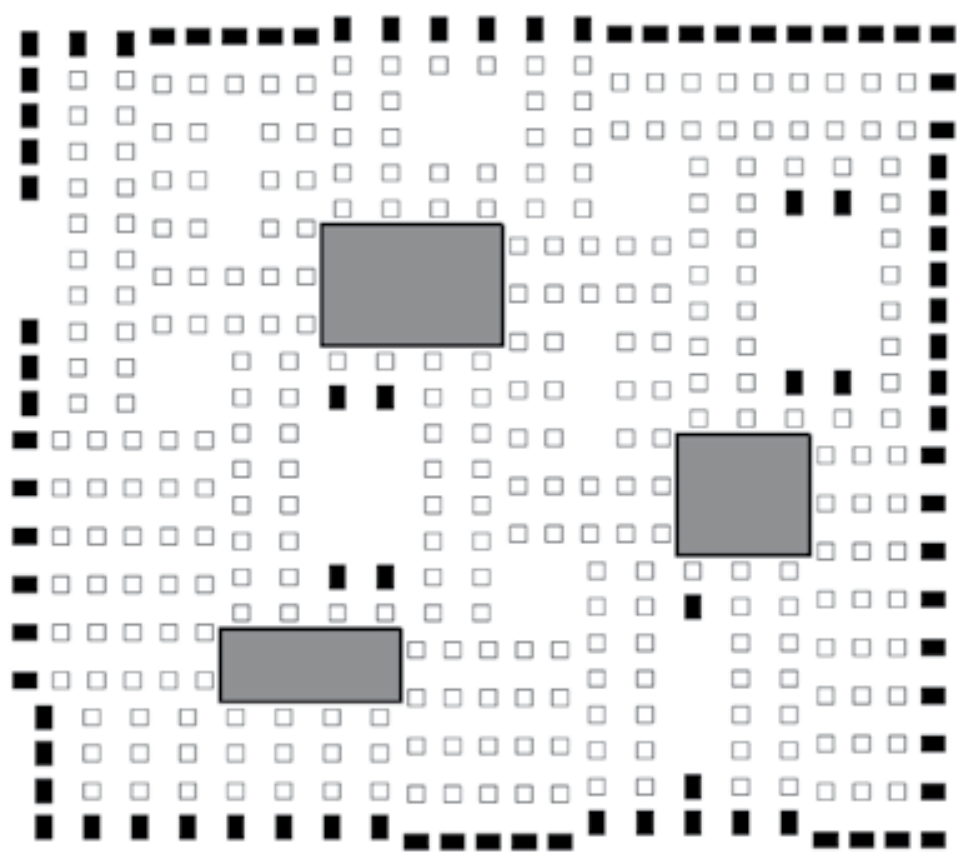

Figura 17.

Cimentación / Zapatas de 1,00 x 1,00 m + zapatas de 1,50 × 1,00 m - losas armadas / Proyecto construido Dibujo de la autora 
netos, incluyendo las actividades a desarrollar, finalmente ascendieron a 23,42 millones de francos suizos ${ }^{21}$ de los 18 iniciales. Compositivas, mitosis de la "célula madre" expositiva inicial en doce unidades ${ }^{22}$. Formales, reconfigurándose su perímetro para adaptarse al solar definitivo con una dimensión de 52,10 × 58,30 $\mathrm{m}^{23}$. Incluso topográficas, ya que la parcela definitiva tenía una pendiente en diagonal del 2,5 \% aproximadamente ${ }^{24}$. La aparición de este infortunio obligó a introducir un sistema tolerante a la inclinación de las pilas de listones en las dos direcciones. Todas las paredes del laberinto estuvieron ligeramente torcidas en un sentido y en otro con lo que espacialmente el proyecto era más complejo.

Todas estas mutaciones, lejos de convertirse en condicionantes, fueron enormemente evolutivas. El Klangkörper se comenzó a construir en octubre de 1999. En primer lugar se realizaron los movimientos de tierras para poder ejecutar los dos sistemas diferenciados de cimentación. Los tres espacios elípticos Versorgungseinheiten, arquitecturas en tres niveles "pesadas", se resuelven mediante sendas losas armadas in situ que trasladaban las cargas directamente al terreno ${ }^{25}$.

Los sistemas constructivos "ligeros" de las pilas de madera emergen en una matriz de 396 zapatas aisladas prefabricadas evitando la succión de los mismos. La distancia de tres metros entre ejes de zapatas es constante y similar a la modulación interna de las pilas. Estos bloques macizos, sin armado con una altura de $65 \mathrm{~cm}$ y apoyados en $5 \mathrm{~cm}$ de hormigón de limpieza; son de dos tamaños en planta. La mayor parte de las zapatas son cuadradas de $100 \times 100 \mathrm{~cm}$. Sin embargo, las del perímetro exterior o de borde de patio con una distancia mínima de $15 \mathrm{~m}$ aumentan su dimensión $50 \mathrm{~cm}^{26}$ en la dirección perpendicular a las pilas para contrarrestar las acciones de cargas superiores en los pies expuestos de las pilas, Einspannmoment ${ }^{27}$, por una mayor exposición a viento .

21 GENERALKOMMISSARIAT. Schlussbericht des Generalkommissariates. Weltausstellung Expo 2000 Hannover 1.6.-31.10.2000. Die schweizerische Beteiligung mit "Klangkörper Schweiz". Bundesamt für Kultur. Bern. 2001. Pág. 87.

22 Esquema fractal de composición que evoca la propuesta de Le Corbusier para un hospital en Venecia de 1965.

23 AAVV. Klangkörperbuch. Birkhäuser. Basel. 2000. ISBN: 3-7643-6324-X. Pág. 17.

24 Idem. Pág. 211.

25 Nota: Versorgungseinheit A - 11,295 m x 7,56 m / Versorgungseinheit B - 8,295 m x 7,56 m / Versorgungseinheit C - 11,295 $\mathrm{m} \times 4,56 \mathrm{~m}$.

26 AAVV. Klangkörperbuch. Birkhäuser. Basel. 2000. ISBN: 3-7643-6324-X. Pág. 228. Nota: Estas zapatas son de dimensiones $100 \times 150 \times 70 \mathrm{~cm}$

27 Nota: Einspannmoment - momentos de sujeción es la carga transmitida mediante un momento a los soportes. La sujeción evita tanto la rotación como el desplazamiento. 

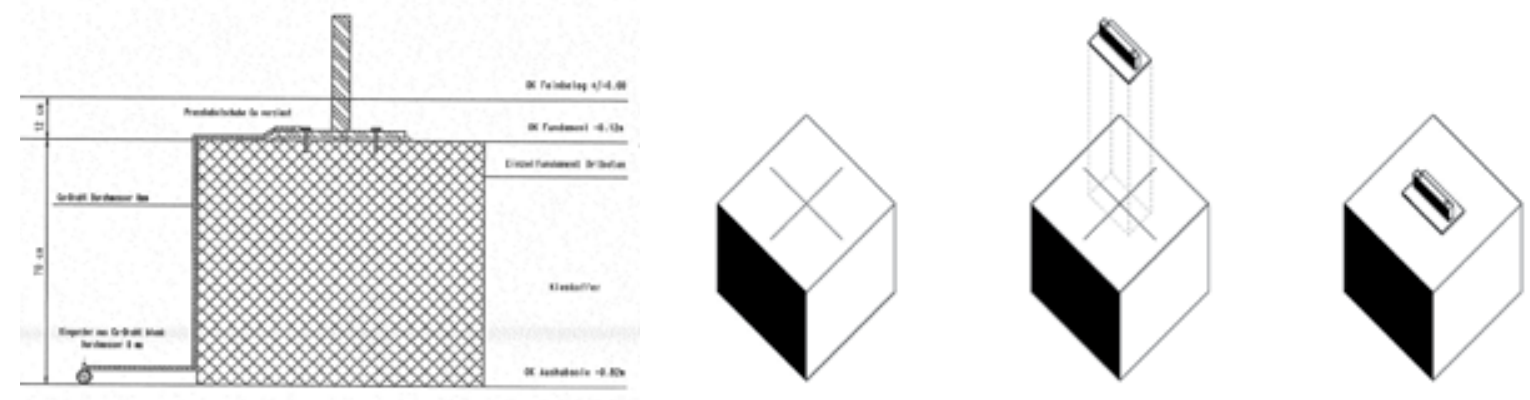

Zapata + placas de acero de anclaje en forma de T invertida Dibujo de la autora

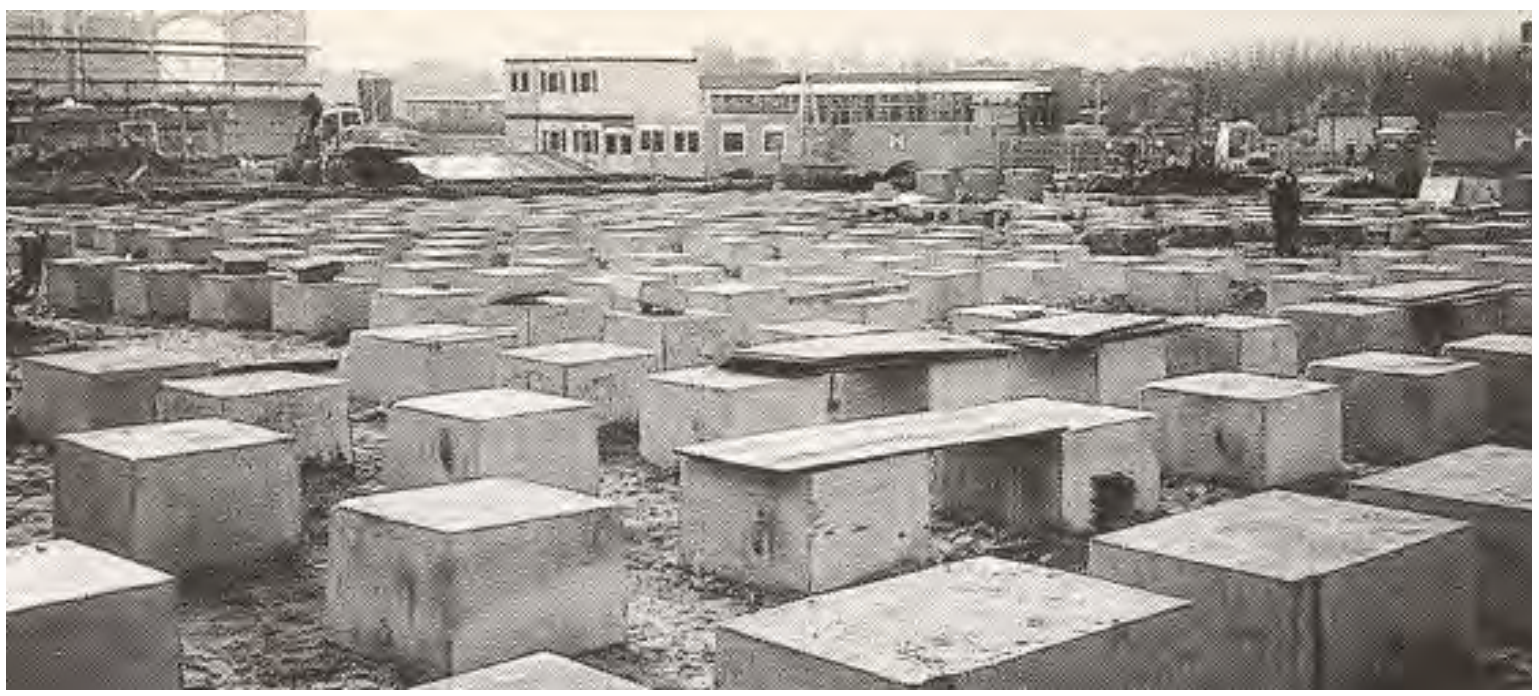

Figura 20.

Cimentación por zapatas / Pabellón helvético / Hannover / 2000

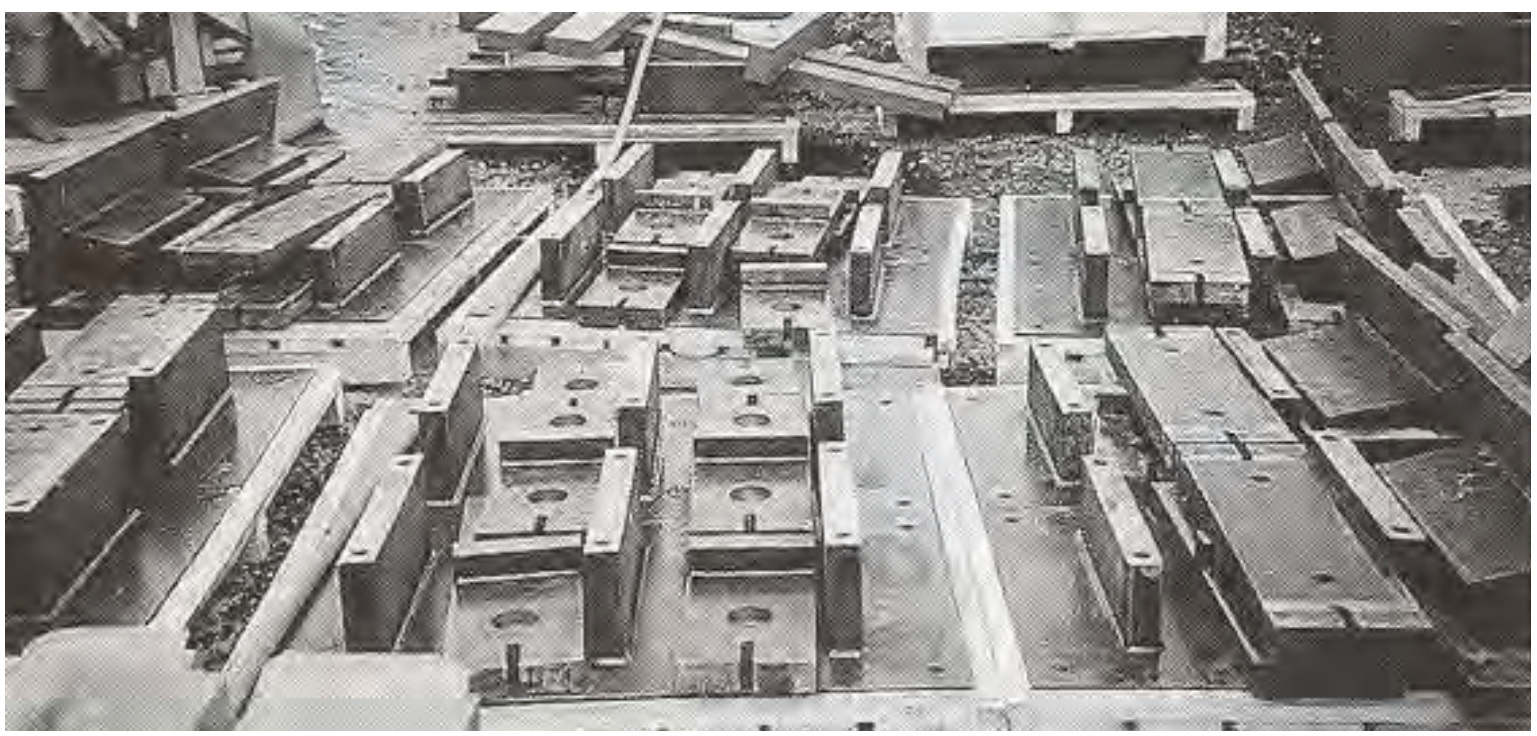

Figura 21.

Placas de acero de anclaje en forma de T invertida / Pabellón helvético / Hannover / 2000 
Una vez fueron colocados los diferentes bloques de zapatas en el terreno, se procedió a la instalación de los diferentes sistemas enterrados, especialmente el saneamiento. Posteriormente se ensamblaron las diferentes placas de anclaje metálicas en forma de $\mathrm{T}$ invertida en cada una de las zapatas. Estos conectores realizados en diferentes alturas permitían nivelar las pilas, independientemente de la pendiente natural del suelo.

Una solera continua de unos $8 \mathrm{~cm}$ de espesor por encima de la cimentación se ejecutó sobre una capa de grava asentada en una base arenosa. Una vez garantizada la estabilidad de este tablero estructural que llegaba hasta los cuatro linderos; se procedió a verter un pavimento asfáltico de doble capa de $3 \mathrm{~cm}$ de espesor. Sellado mediante una emulsión bituminosa de cierre de poros en color antracita. El asfalto, mezcla artificial bituminosa de substancias minerales, tenía la ventaja que es "resistente, elástico, impermeable, resistente a las heladas y, debido a que es caliente y líquido, puede verterse sin juntas sobre grandes superficies ${ }^{\prime 28}$. Esta alfombra oscura, topográficamente inclinada enrasandose con los niveles perimetrales del terreno original, tenía insertados una serie de canaletas lineales de drenaje que recogían el agua. Estas estaban conectadas al sistema de saneamiento pluvial de la Expo. Su configuración garantizaba que el agua no discurriera ni por los espacios gastronómicos, ni los sonoros.

Esta gran planicie continúa conformada por materiales mayoritariamente acuosos y amorfos será la base de todo el entramado superior del pabellón. 


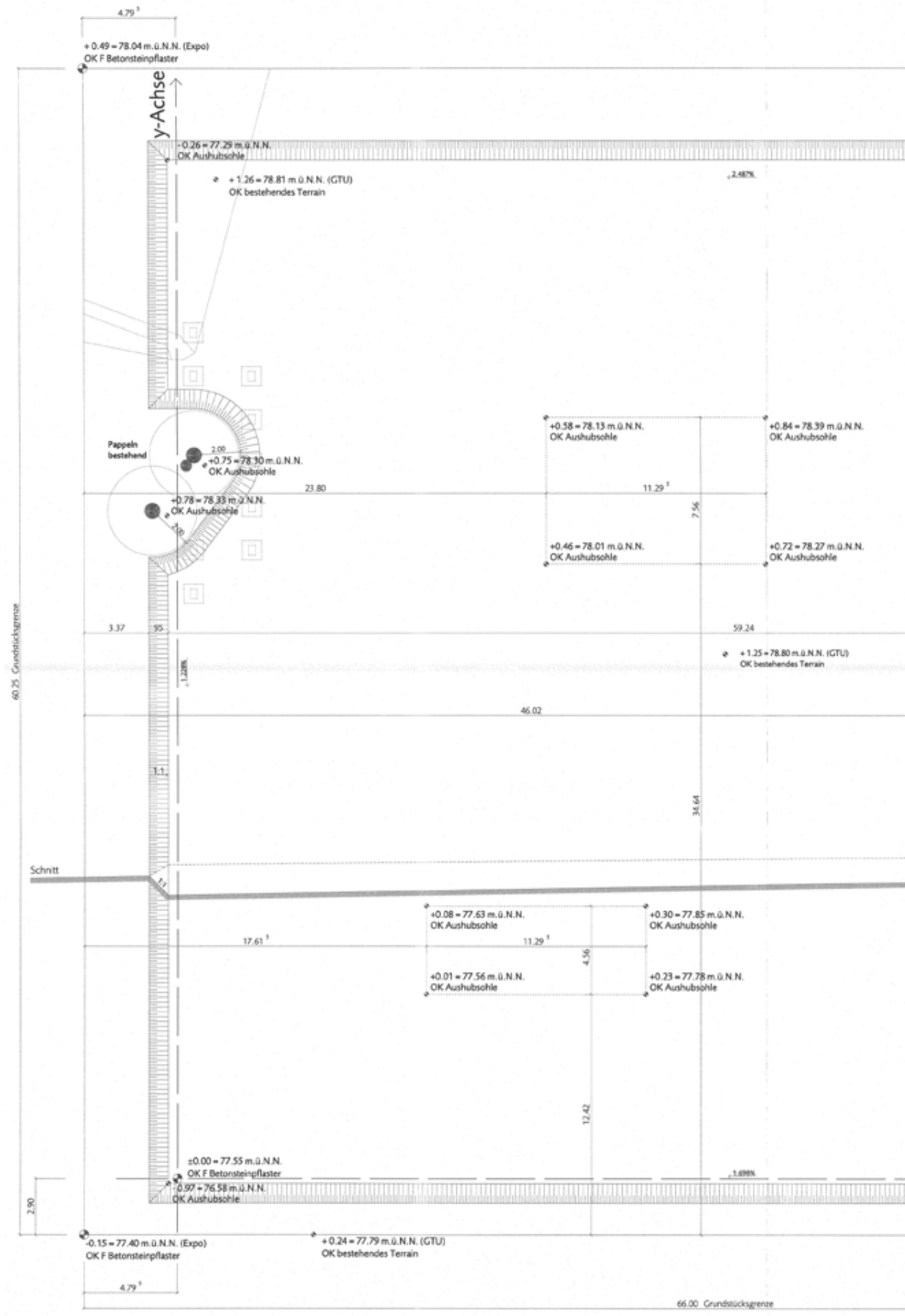

Figura 22.

Plano original de excavación / Pabellón helvético / Hannover / 2000 Proyecto de ejecución / 24 de Septiembre 1999 
$479^{5}$

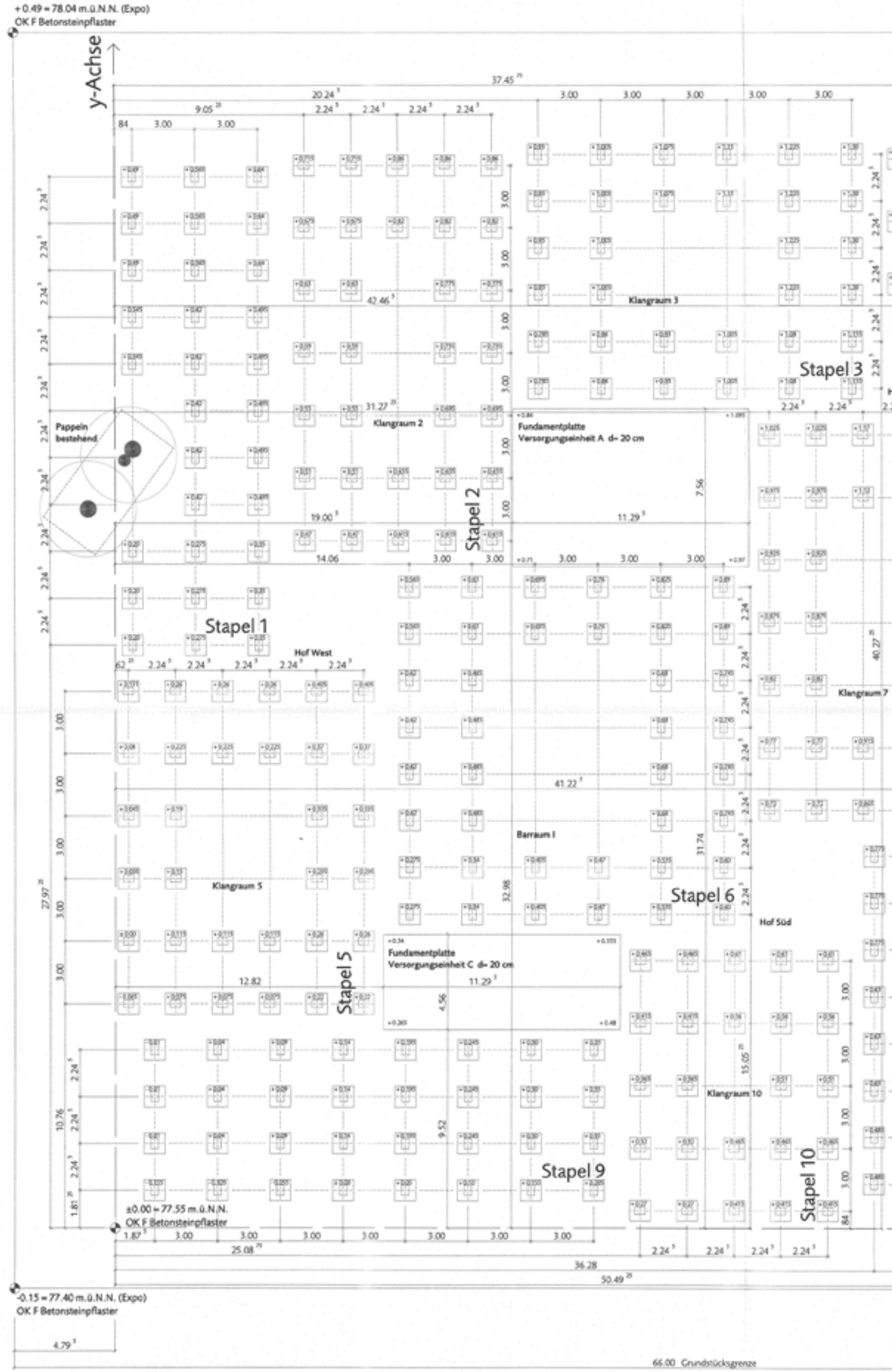

Figura 23.

Plano original de cimentación / Pabellón helvético / Hannover / 2000 Proyecto de ejecución / 24 de Septiembre 1999 


OKF Betonsteingfluster

OKF Betonsteinglaster

$224^{\prime}, 224^{\prime}, 224^{\prime}, 224^{\prime}, 224^{\prime}, 224^{\prime}, 224^{\prime}, 224^{\prime}, 224^{\prime}$

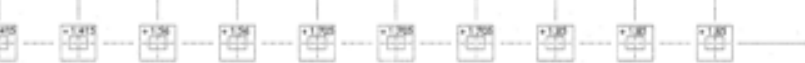
300

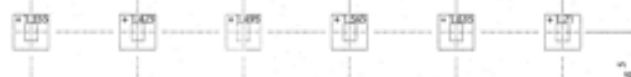
ont

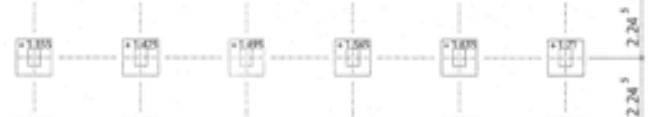

$224^{4}$

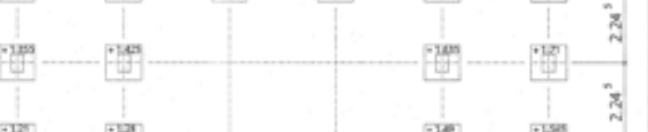

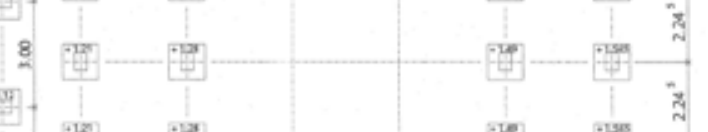

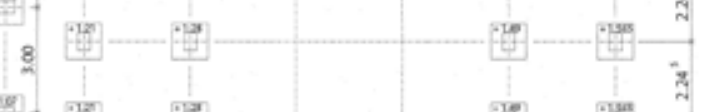

-19]- -

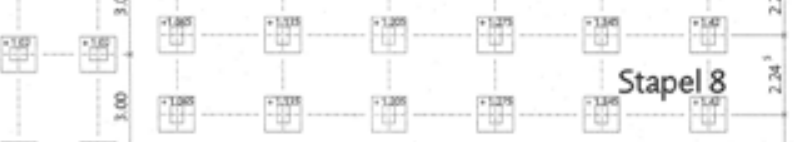

ogs

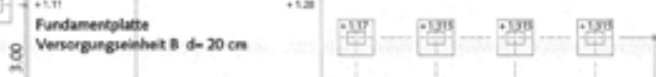

$\frac{1}{1}$

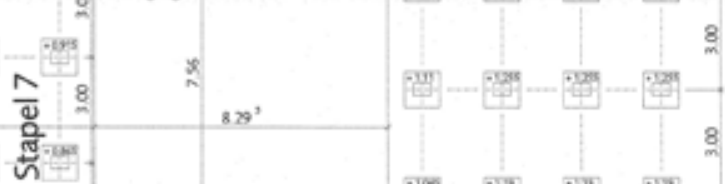

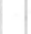

$\pm 0.00=77.55$ m.ū.N.N.

Klangkörper Schweiz

Schweizer Pavillon

Expo 2000 Hannover

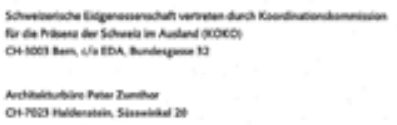

Grundriss

Fundamente

Maßstab 1:100

ondise

x-Achse 


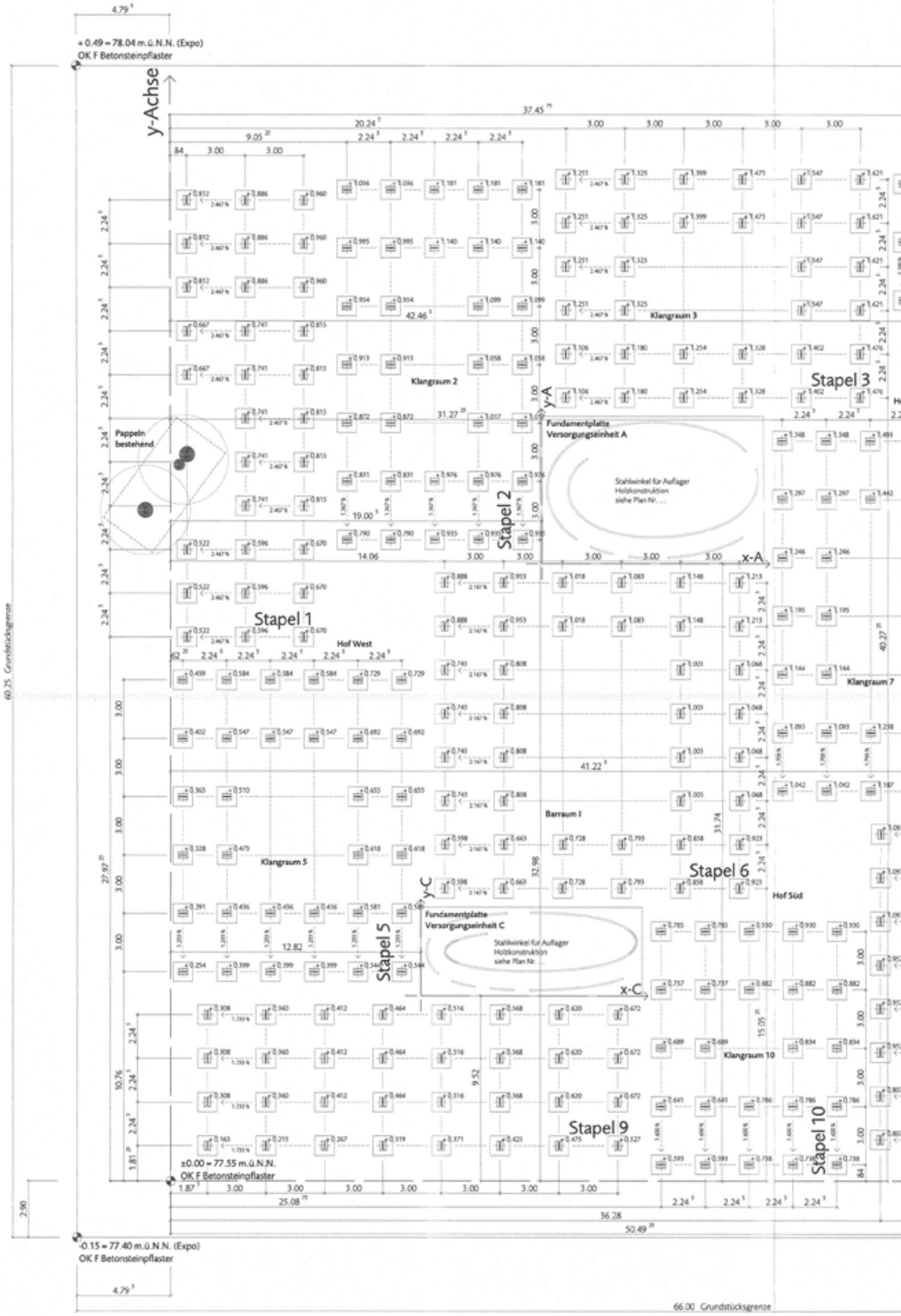

Figura 24.

Plano original de placas de acero de anclaje en forma de T invertida / Pabellón helvético / Hannover / 2000 Proyecto de ejecución / 24 de Septiembre 1999 


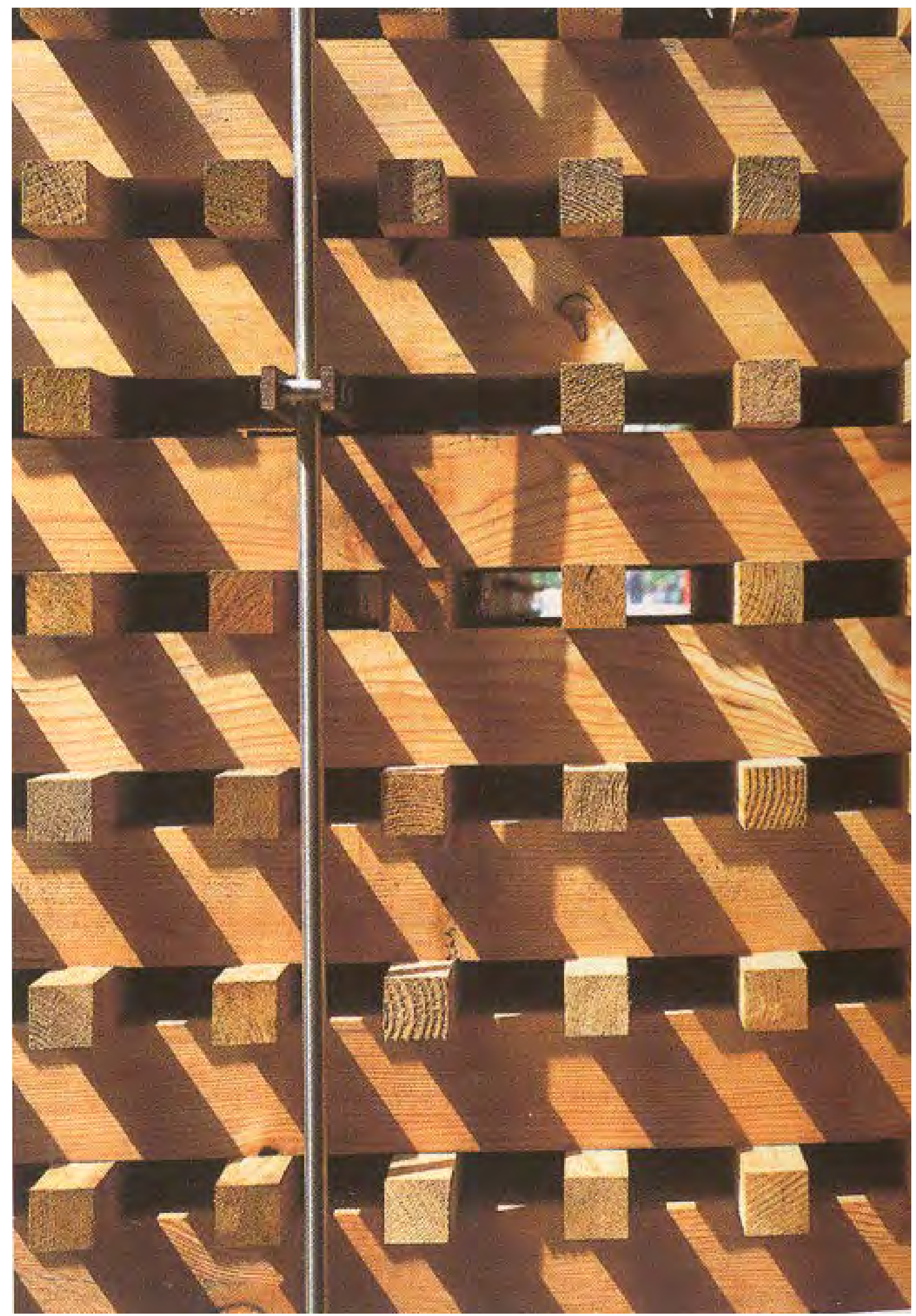

Figura 25.

Pabellón helvético / Hannover / 2000 


\title{
[Fragmentos fugaces]
}

\author{
“(...) la idea discontinua conlleva la idea tectónica de arroparse, \\ cubrirse, asentarse, cerrarse, etc. La arquitectura tiene un carácter \\ móvil, nómada, que nace de la necesidad espacial del lugar donde se \\ asienta... La idea de continuum está conectada con el pensamiento \\ estereotómico, donde la materia es un todo en la idea. En el muro \\ confluye todas las partes..." ${ }^{\prime 29}$ Jesús Mạ Aparicio Guisado.
}

Gottfried Semper ${ }^{30}$ enunció la dicotomía entre estereotómico y tectónico. Lo tectónico como la unión de componentes ligeros, lineales; y lo estereotómico como la acumulación de elementos pesados, la masa y el volumen. En alemán existen dos términos para determinar estos conceptos, aparentemente similares, pero muy dispares semánticamente: Wand-tabique- lo ligero; y Mauer-muro-; lo pesado.

Lo estereotómico está relacionado con la gravedad, la carga, la pesadez. Se trata de un elemento continuo, grueso, macizo. En cambio, la pared ligera, y discontinua; en lo tectónico. El pabellón helvético de Zumthor cuenta con dos procesos constructivos antagónicos; dos sensibilidades distintas. Mientras el mundo inferior del pabellón está compuesto por bloques macizos prefabricados de hormigón; el mundo superior crea una cualidad espacial a través de Wände compuestos por listones entrelazados de madera.

Para Semper, la madera era un material netamente tectónico; ya que se aproxima los valores de un mueble, con estructuras más ligeras. La forma de apilamiento del Klangkörperbau de Zumthor protege y permite al mismo tiempo establecer conexiones visuales entre el interior y el exterior. La luz se canaliza mediante el intercambio de elementos opacos y abiertos, permitiendo así unas divisiones horizontales que funcionan como celosía. Las paredes actúan como filtros de aire y luz; continuidad y unidad entre los distintos espacios, un espacio con límites difusos, con y a la vez sin interrupciones. 

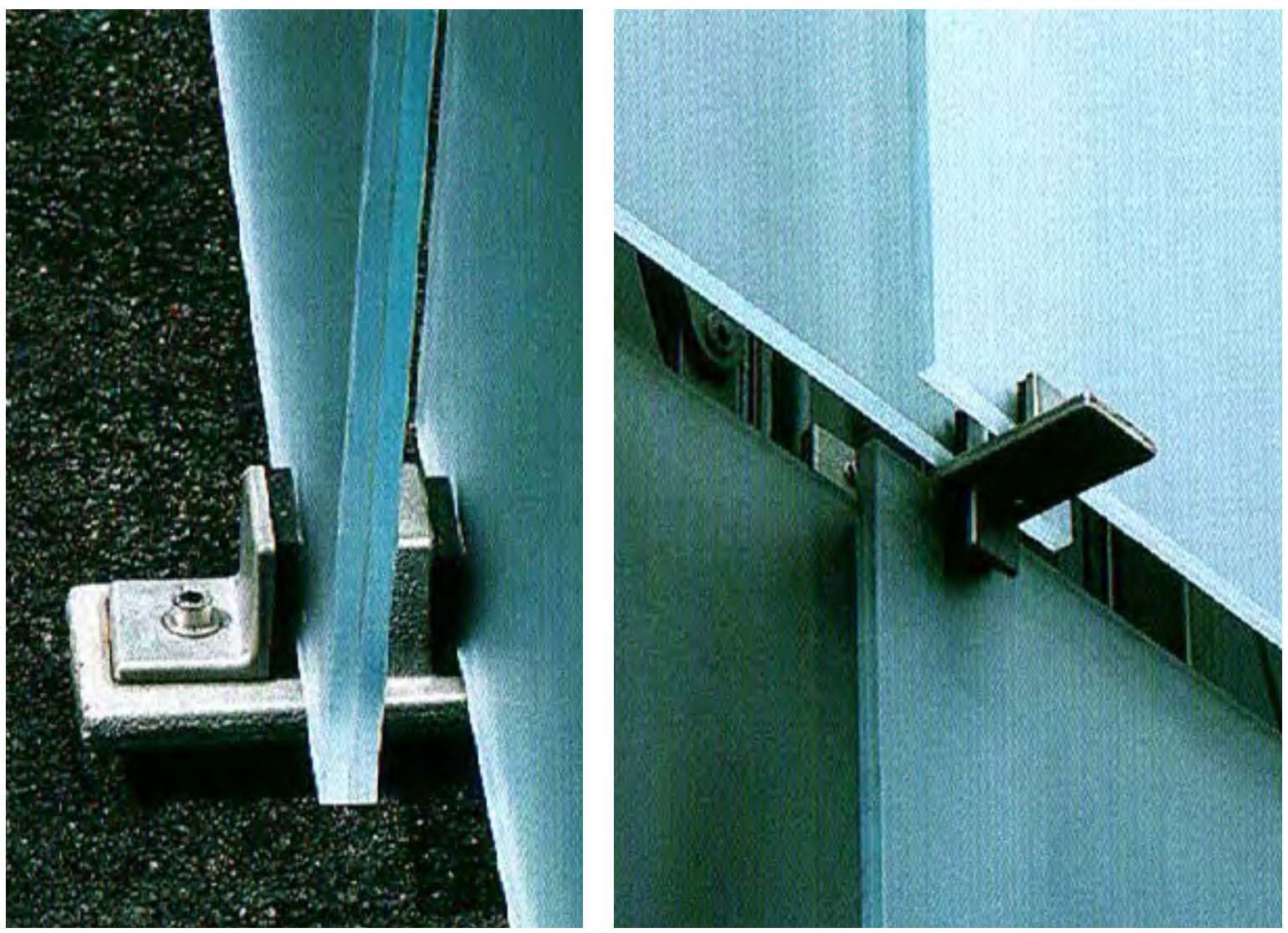

Figura $26-27$

Mensula / Kunsthaus Bregenz / Austria / 1989 - 1997 / Peter Zumthor
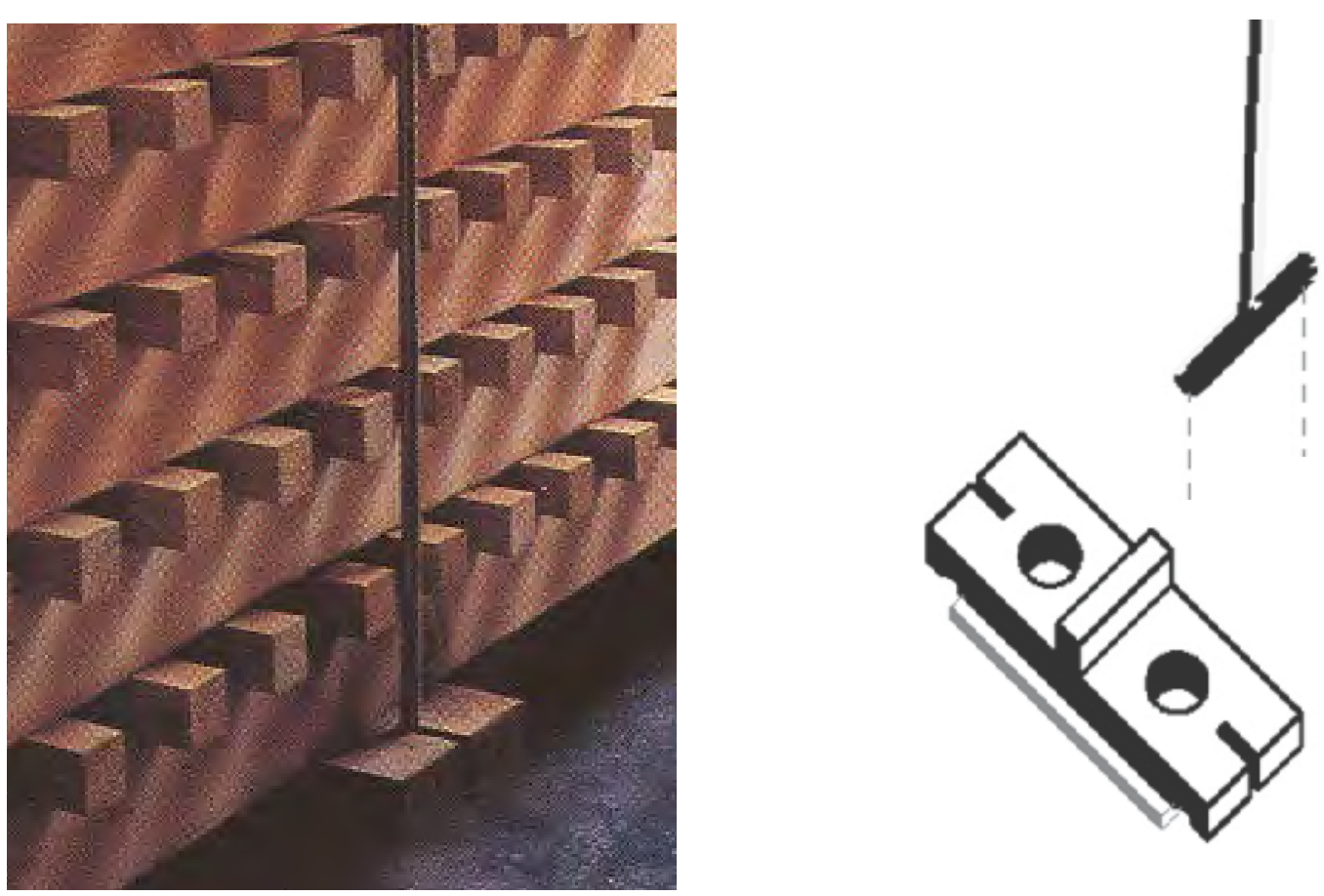

Figura 28 - 29.

Sistema de anclaje inferior / Pabellón helvético / Hannover / 2000 Dibujo de la autora 


\section{[El arte del ensamblaje]}

\section{"La tectónica se convierte en el arte de unir cosas. "Arte" entendido} como tekne en todo su conjunto, que indica tanto tectónica como ensamblaje, no sólo de las partes de un edificio, sino también de objetos e incluso de obras de arte en su sentido más amplio. Respecto a la comprensión antigua de la palabra, la tectónica se refiere a la construcción o realización de un producto artesanal o artístico (...) ${ }^{131}$ Adolf Heinrich Borbein

Como confeso perfeccionista, Zumthor lleva el detalle a un nivel exquisito. Por ejemplo las piezas en ménsula de acero cromado donde descansan las solapadas escamas exteriores de vidrio traslúcidos en el Kunsthaus de Bregenz son buena prueba de ello. Estas sutiles pestañas muestran la precisión y minuciosidad con la que trabaja. El punto siempre crítico de sujeción del vidrio en las envolventes se resuelve con un audaz sistema de una levedad inquietante. La construcción como arte de orfebrería.

El entramado del Klangköperbau se parece al minucioso mecanismo de un reloj suizo por el esmerado y delicado cuidado de sus componentes. Las pilas de madera levitan ligeramente sobre la plataforma compacta negra mediante unos anclajes singulares. El aire circula libremente, como en un secadero natural, impidiendo la absorción de agua subterránea y de la humedad superficial. Las pletinas de acero diseñadas, Stahlschwerter, tenían un espesor de $50 \mathrm{~mm}^{32}$ para poder resistir los esfuerzos no sólo del peso propio de los listones de madera, sino sobre todo la acción de los tensores. Estas se anclaban mediante dos tornillos roscados a las placas de anclaje de las zapatas en dos rehundidos donde se embebían las cabezas de los mismos. En la parte superior una aleta en la dirección de las pilas se elevaba con una doble función; servir de guía de la primera fila de listones así como dotar de rigidez a la pieza en el sentido de los vanos. Los cantos de esta pieza contienen una hendidura a cada lado donde colocar posteriormente los tirantes en forma de T invertida. Al igual que los anclajes de las zapatas, se fabricaron en acero sin tratar permitiendo que su corrosión les otorgase un aspecto terroso.

31 BORBEIN, Adolf Heinrich. Tektonik. Zur Geschichte eines Begriffs der Archäologie. Archiv für Begriffsgeschichte. 26. Nr.1. 1982. en: FRAMPTON, Kenneth. Estudios sobre cultura tectónica. poéticas de la construcción en la arquitectura de los siglos XIX y XX. (1995). Ediciones Akal. Madrid. 1999. ISBN: 84-460-1187-5. Pág.15.

32 AAVV. Klangkörperbuch. Birkhäuser. Basel. 2000. ISBN: 3-7643-6324-X. Pág. 233. 


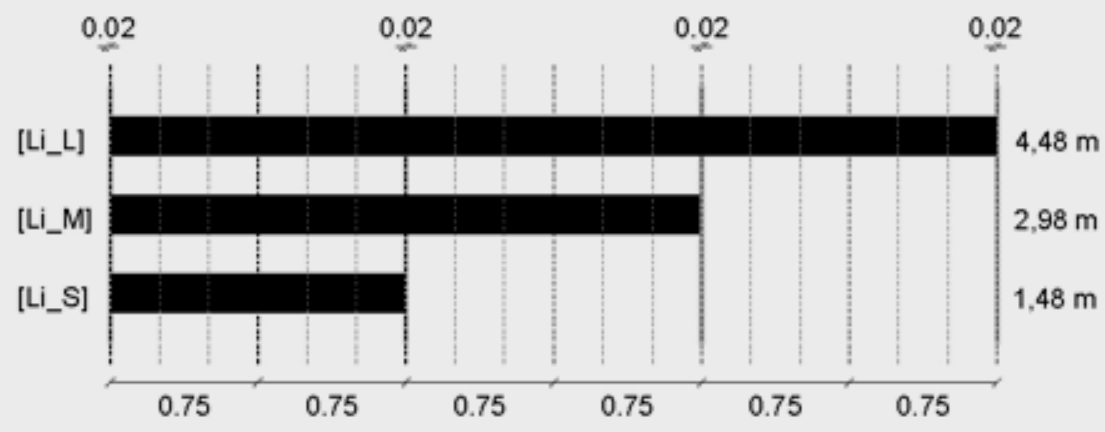

Figura 30.

3 tipos de listones de madera de diferentes longitudes en planta / Proyecto de ejecución Dibujo de la autora

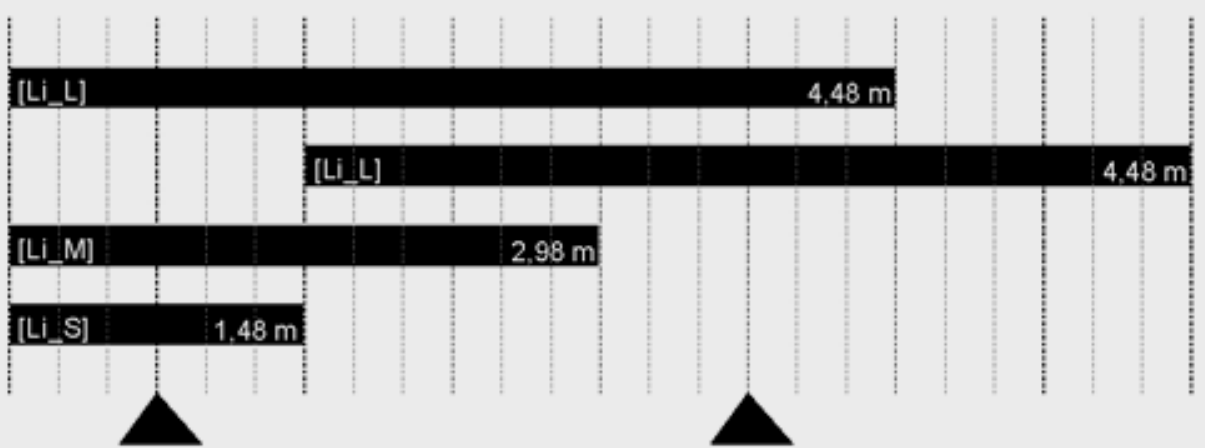

Figura 31.

Apoyo de los 3 tipos de listones de madera de diferentes longitudes en planta / Proyecto de ejecución Dibujo de la autora
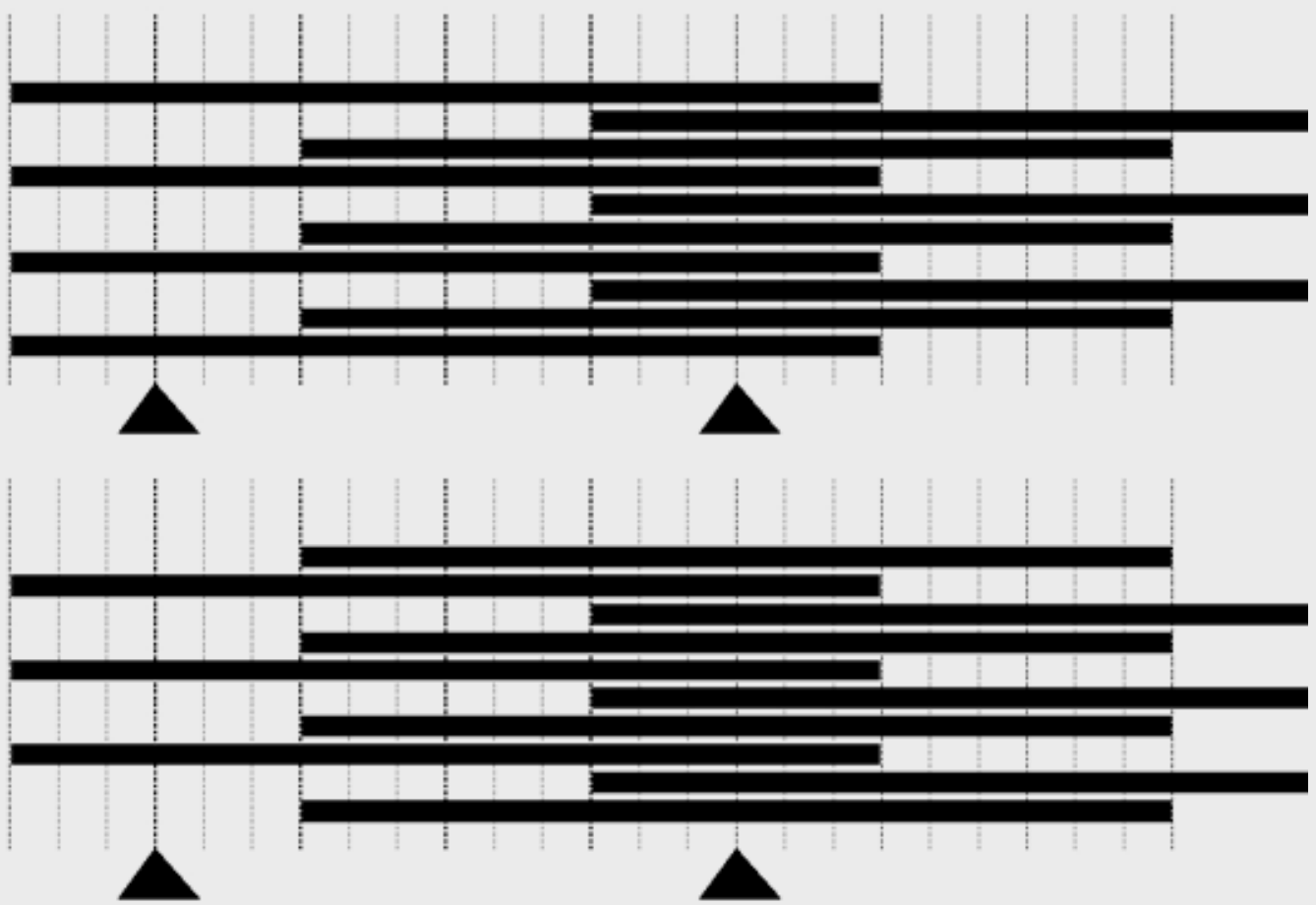

Figura 32.

Partituras arquitectónicas en sección / Proyecto de ejecución 
Tras ejecutarse todo el sistema de enraizamiento, se procedió a llevar a cabo la compleja construcción de las pilas de madera. El método fue capa a capa mediante la disposición de una serie de listones apilados, un juego aditivo de componentes en equilibrio. El puzzle de este complejo sistema en ningún caso estuvo conformado por elementos aleatorios, sino que fue un rompecabezas que operaba con la modulación y la repetición para conformar cada pila. En planta son como convoyes de trenes, mientras que en sección fue en zigzag.

El proyecto de ejecución se basó en un sistema modular de ejes paralelos equidistantes $75 \mathrm{~cm}$. Una modulación repetitiva que permitía acompasar el crecimiento y la disposición de las pilas. Todas las variaciones se generaron con sólo tres tipos de longitudes diferentes de listones: dos, cuatro y seis módulos de $75 \mathrm{~cm}$. Símil de los sistemas de secado natural; los testeros de estos elementos de sección de $10 \times 20$ cm se separon entre sí $2 \mathrm{~cm}$ para permitir el aireado por ambas caras. Finalmente las longitudes de las tres piezas fueron:

$\begin{array}{ll}{\left[L i_{-} L\right]=[75 \mathrm{~cm} \times 6 \text { módulos }]-[2 \mathrm{~cm} \text { de los extremos }]=} & 448 \mathrm{~cm} \\ {\left[L i_{-} M\right]=[75 \mathrm{~cm} \times 4 \text { módulos }]-[2 \mathrm{~cm} \text { de los extremos }]=} & 298 \mathrm{~cm} \\ {\left[L i \_S\right]=[75 \mathrm{~cm} \times 2 \text { módulos }]-[2 \mathrm{~cm} \text { de los extremos }]=} & 148 \mathrm{~cm}\end{array}$

El proceso de composición horizontal se llevó a cabo mediante secuencias de listones unos tras otros. A modo de sumatorio de partes, aparecen tres combinaciones diferentes, siempre con la condición de usar el máximo número de los listones de mayor medida [Li_L]. Una secuencia numérica dimensional capaz de conformar todas las pilas, desde la más pequeña hasta la mayor de longitud. En este sistema matemático modular, había tres secuencias posibles:

Tipo A

Extemo A [Li_S]

Intermedio Secuencia de listones de $448 \mathrm{~cm}$ - [Li_L]

Extemo B [Li_S], [Li_M] o [Li_L]; según longitud de la pila

Tipo B

Extemo A [Li_M]

Intermedio Secuencia de listones de $448 \mathrm{~cm}-\left[L i \_L\right]$

Extemo B [Li_S], [Li_M] o [Li_L]; según longitud de la pila

Tipo C

Extemo A [Li_L]

Intermedio Secuencia de listones de $448 \mathrm{~cm}-\left[L i \_\right.$]

Extemo B [Li_S], [Li_M] o [Li_L]; según longitud de la pila 

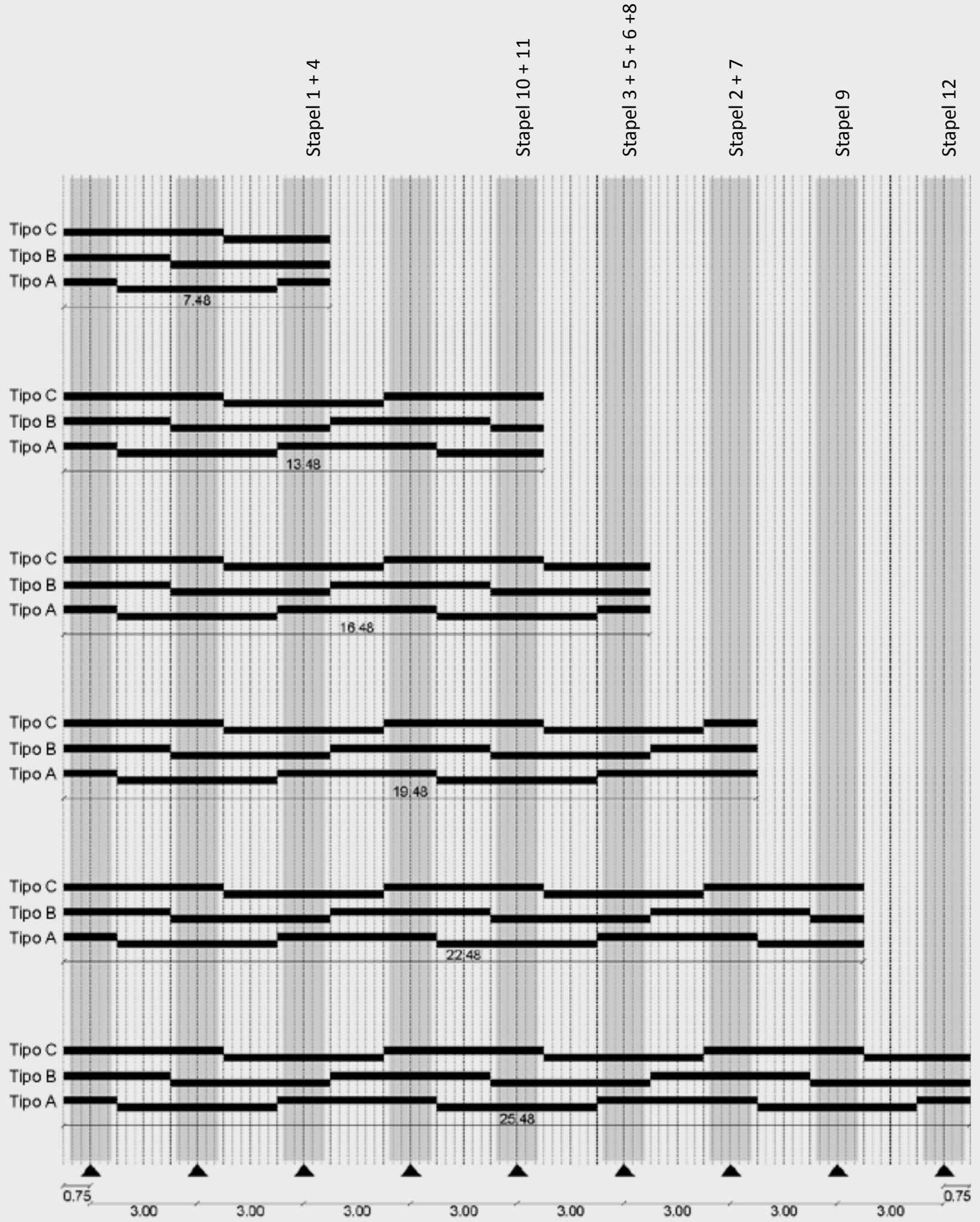

Figura 33.

Composición de las pilas según los tres tipos de listones de madera de diferentes longitudes en planta / Proyecto de ejecución Dibujo de la autora 
Para obtener una mayor estabilidad del conjunto, cada pila se proyectó con dos filas paralelas de listones separadas por una cámara de aire de 4,5 cm. El ancho total, sumando los dos listones de $20 \mathrm{~cm}$, fue 44,5 cm [M_pi ${ }^{33}$. El primer nivel siempre se compone por la secuencia Tipo A y la Tipo C; es decir la Secuencia Tipo AC.

En vertical las tres secuencias Tipo A, B y C se repitieron sucesivamente en el mismo orden. Su operación aditiva generó sucesiones repetidas consecutivas Tipo AC, BA y $\mathrm{CB}$; creando un ritmo en zigzag. Un patrón homogéneo y a la vez complejo. Todas las pilas, y por extensión todos los Stapel, se construyeron con las mismas instrucciones.

Este sistema melódico perfectamente orquestado, tuvo que alterarse debido a la exigencia de aumentar los anchos de los recorridos de evacuación. Los pasos se ampliaron de 1,25 m a 1,41 m. Todo ello implicó sacrificar las relaciones modulares iniciales. Esta modificación, a poco de comenzar a construirse el pabellón, produjo el acortamiento de las pilas $16 \mathrm{~cm} ; 8 \mathrm{~cm}$ en cada extremo. El modulo final de extremo [M_ex] alteró su longitud de $75 \mathrm{~cm}$ a $66 \mathrm{~cm}$, con lo que el sistema pasó a tener dos piezas mas.

En vez de las tres piezas originales, para la construcción del pabellón helvético se usaron cinco que surgen de las sucesivas operaciones de recortes:

[Li_L $]=[75 \mathrm{~cm} \times 6$ módulos $]-[2 \mathrm{~cm}$ de los extremos $]=\quad 448 \mathrm{~cm}$

[Li_L2] $=[75 \mathrm{~cm} \times 6$ módulos $]-[2 \mathrm{~cm}$ de los extremos $]-[8 \mathrm{~cm}$ recorte $]=440 \mathrm{~cm}$

[Li_L3] $=[75 \mathrm{~cm} \times 6$ módulos $]-[2 \mathrm{~cm}$ de los extremos $]-[16 \mathrm{~cm}$ recorte $]=432 \mathrm{~cm}$

[Li_M2] $=$ [75 cm x4 módulos] $-[2 \mathrm{~cm}$ de los extremos] $-[8 \mathrm{~cm}$ recorte $]=290 \mathrm{~cm}$

[Li_S2].= [75 cm X2 módulos] $-[2 \mathrm{~cm}$ de los extremos $]-[8 \mathrm{~cm}$ recorte $]=140 \mathrm{~cm}$

Para construir todo este aparentemente simple mecanismo, con complejas combinaciones, se tuvo que hacer uso de unas plantillas reutilizables -Schablonende madera. Estas estuvieron unidas a andamios de acero tubular de $150 \times 150$ $\mathrm{cm}^{34}$ para poder servir como guías precisas de las 99 paredes. Dependiendo de la topografía del solar, cada pila estuvo tejida por entre 6-59 capas de listones. Un conjunto compuesto por doce Stapel conformados por 370.000 listones y 168.000 separadores $^{35}$.

33 Nota: Se compone de 0,20 m + 0,045 m +0,20 m =0,445 m [M_pi]

34 CONZETT, Jürg. Stapellauf. Pavillon der Schweiz in Hannover. En: Deutsche Bauzeitung db. Vol. 134. Nr. 9. 2000. Pág. 101.

35 Idem. Pág. 101. 

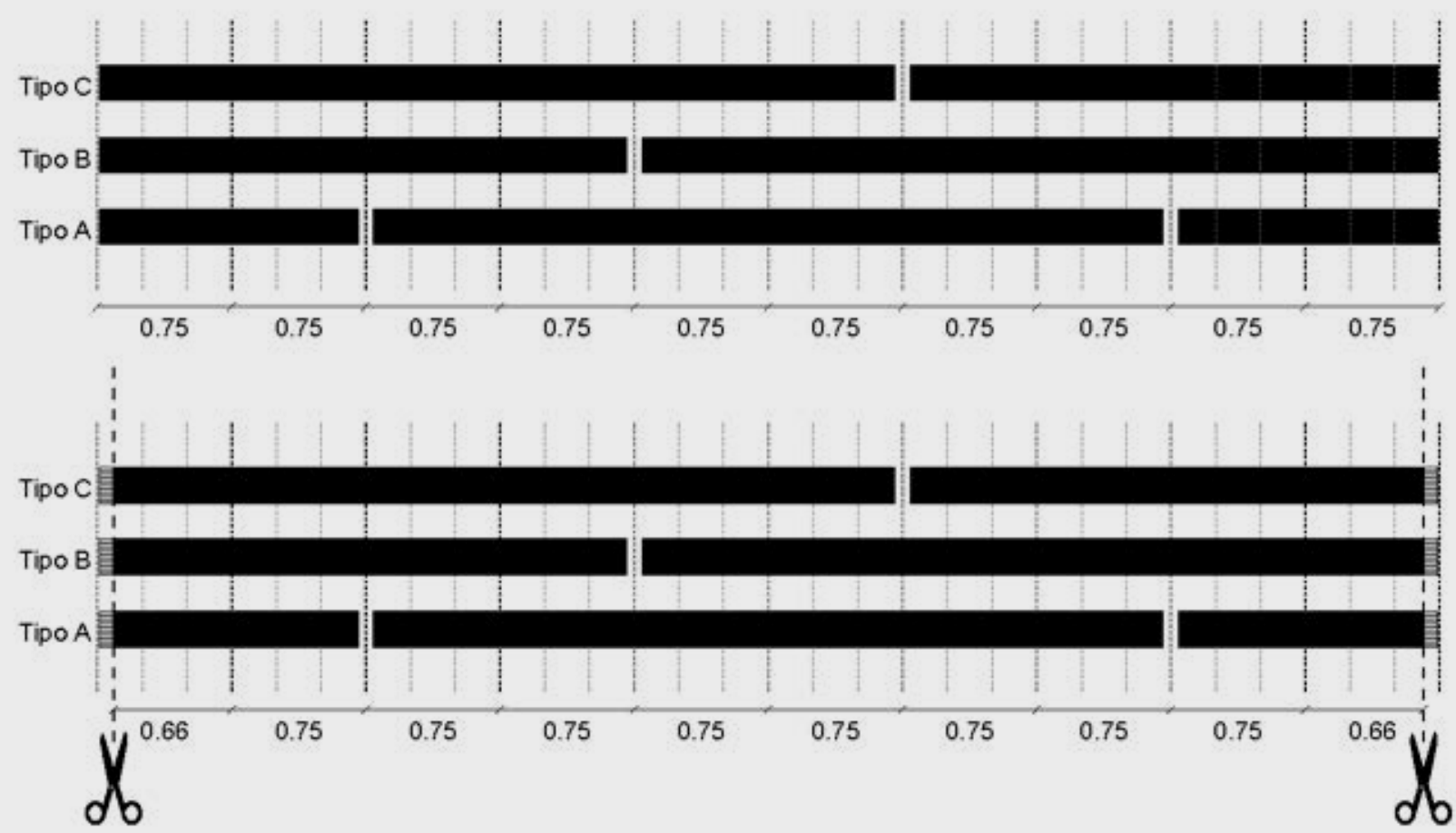

Figura 34.

Proyecto de ejecución versus Proyecto construido

Secuencia de listones en planta / Nivel 1: Tipo A / Nivel 2: Tipo B / Nivel 3: Tipo C / Ejemplo Stapel 1

Dibujo de la autora
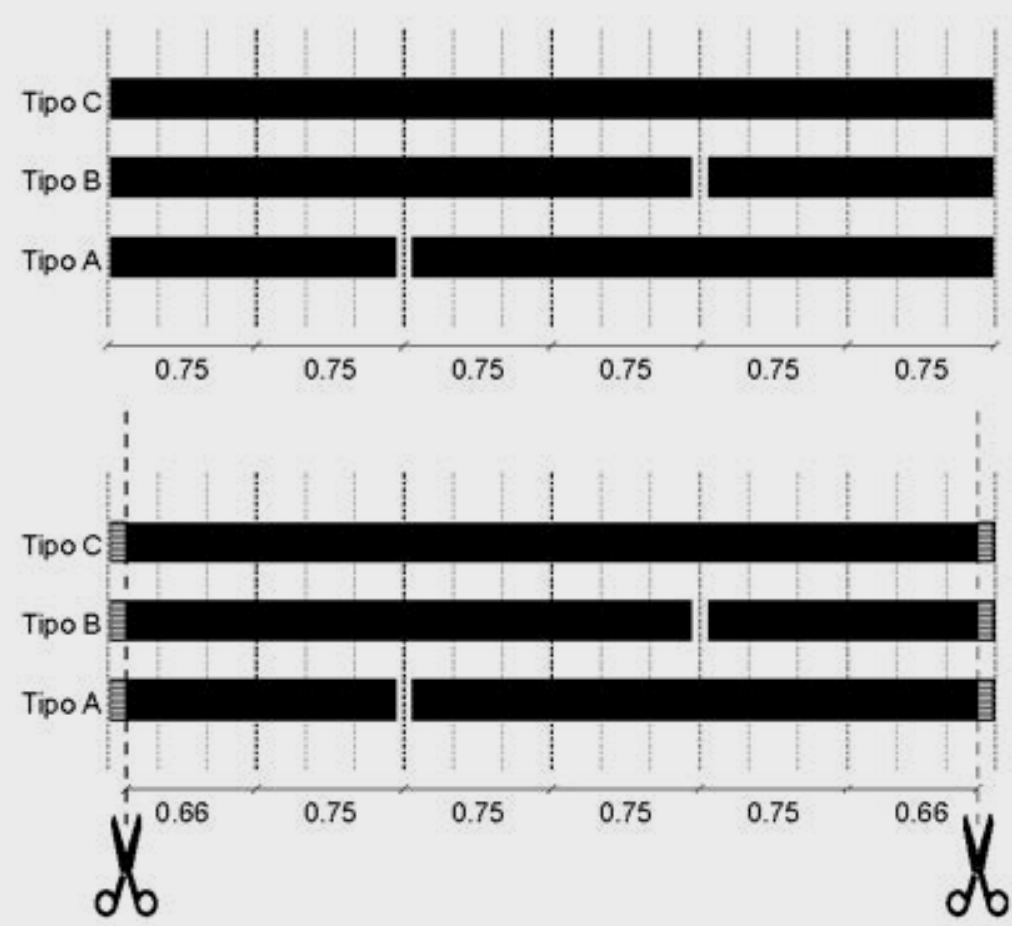

Figura 35.

Proyecto de ejecución versus Proyecto construido

Secuencia de listones en planta / Oquedades / Nivel 1: Tipo A / Nivel 2: Tipo B / Nivel 3: Tipo C / Ejemplo Stapel 2 Dibujo de la autora 

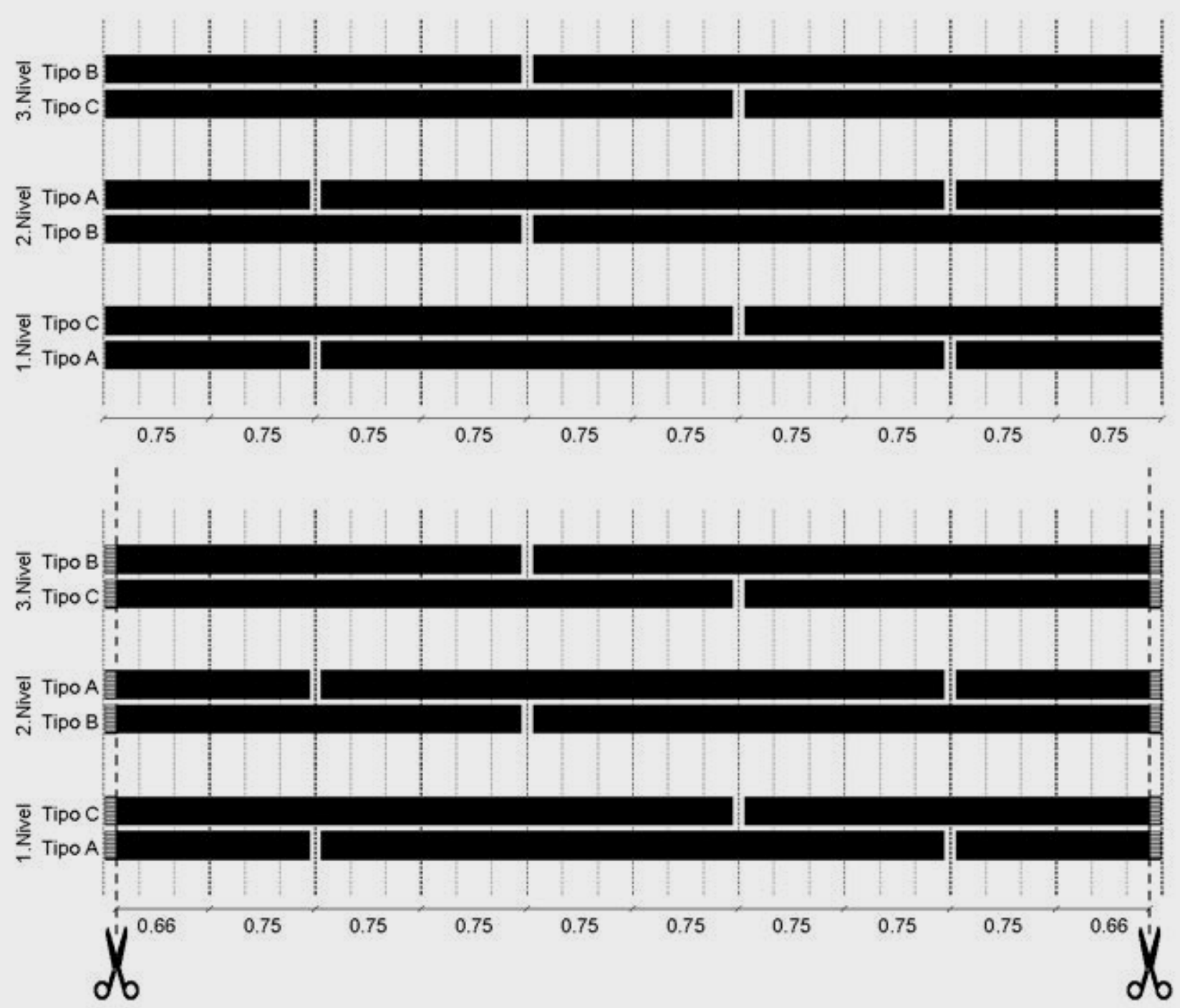

Figura 36.

Proyecto de ejecución versus Proyecto construido

Paralelas de listones en planta / Nivel 1: Tipo AC / Nivel 2: BA / Nivel 3: CB / Ejemplo Stapel 1 Dibujo de la autora

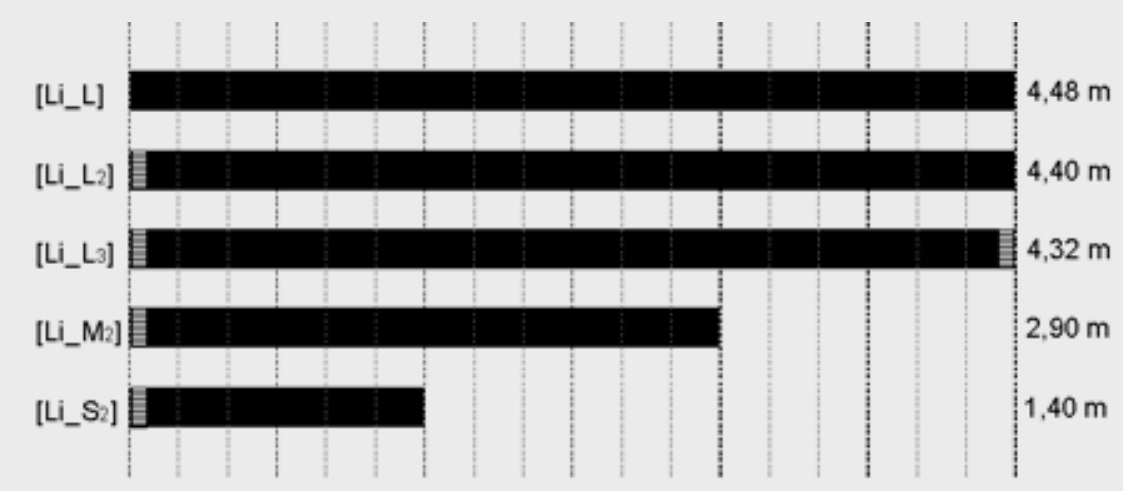

Figura 37.

Proyecto construido

Tipos de listones de madera de diferentes longitudes en planta Dibujo de la autora 

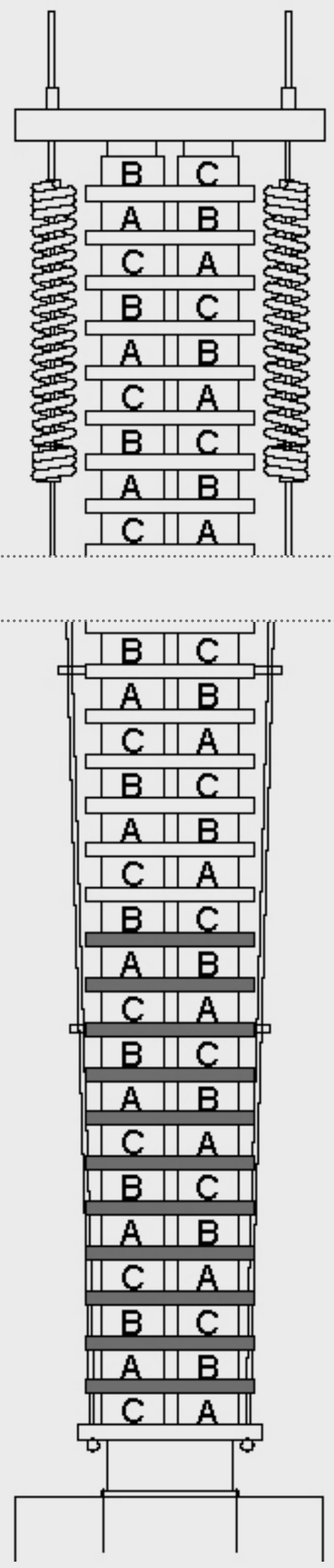

Figura 38.

Secuencias repetidas Tipo AC, BA y CB en sección Dibujo de la autora 


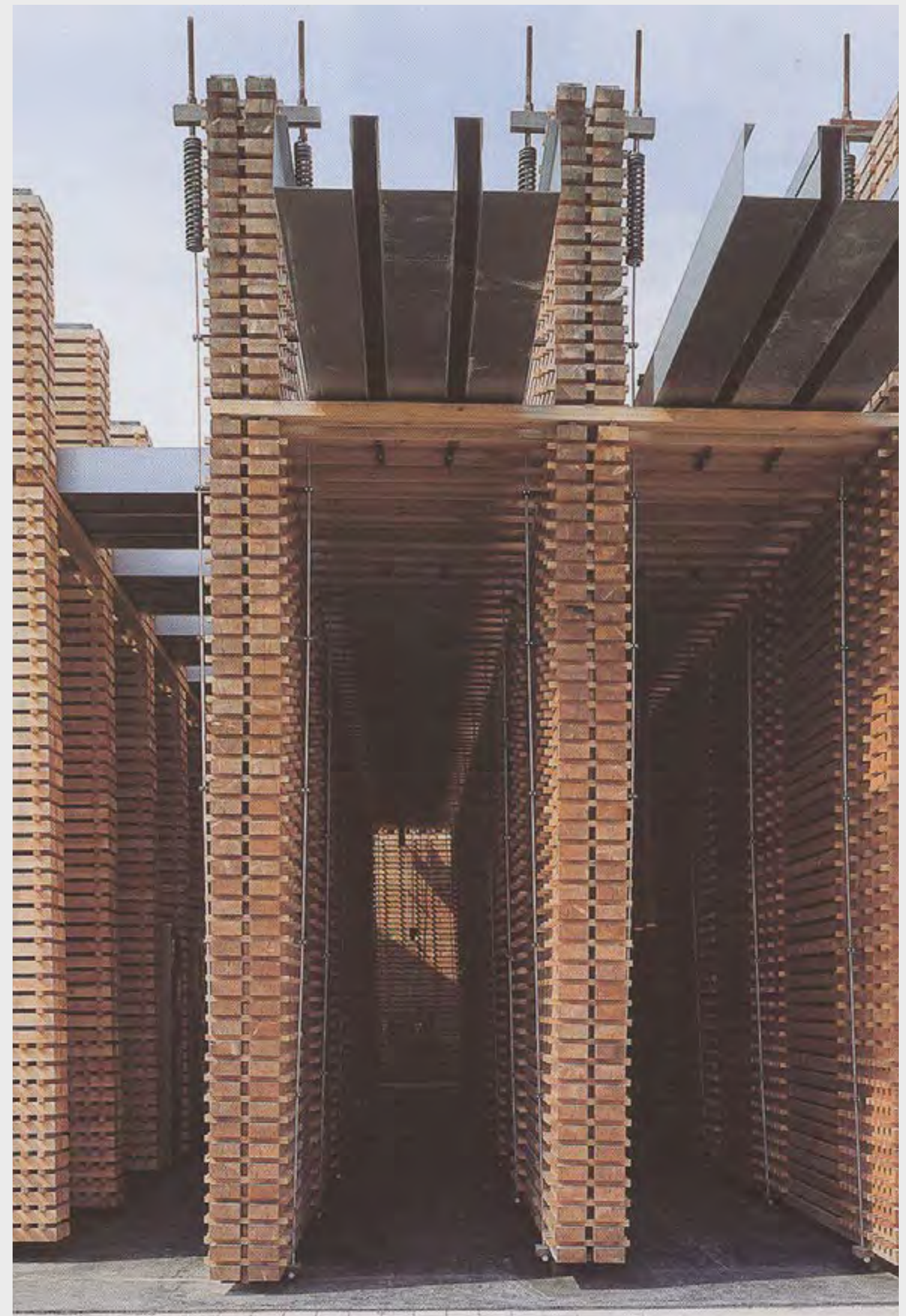

Figura 39.

Pabellón helvético / Hannover / 2000 


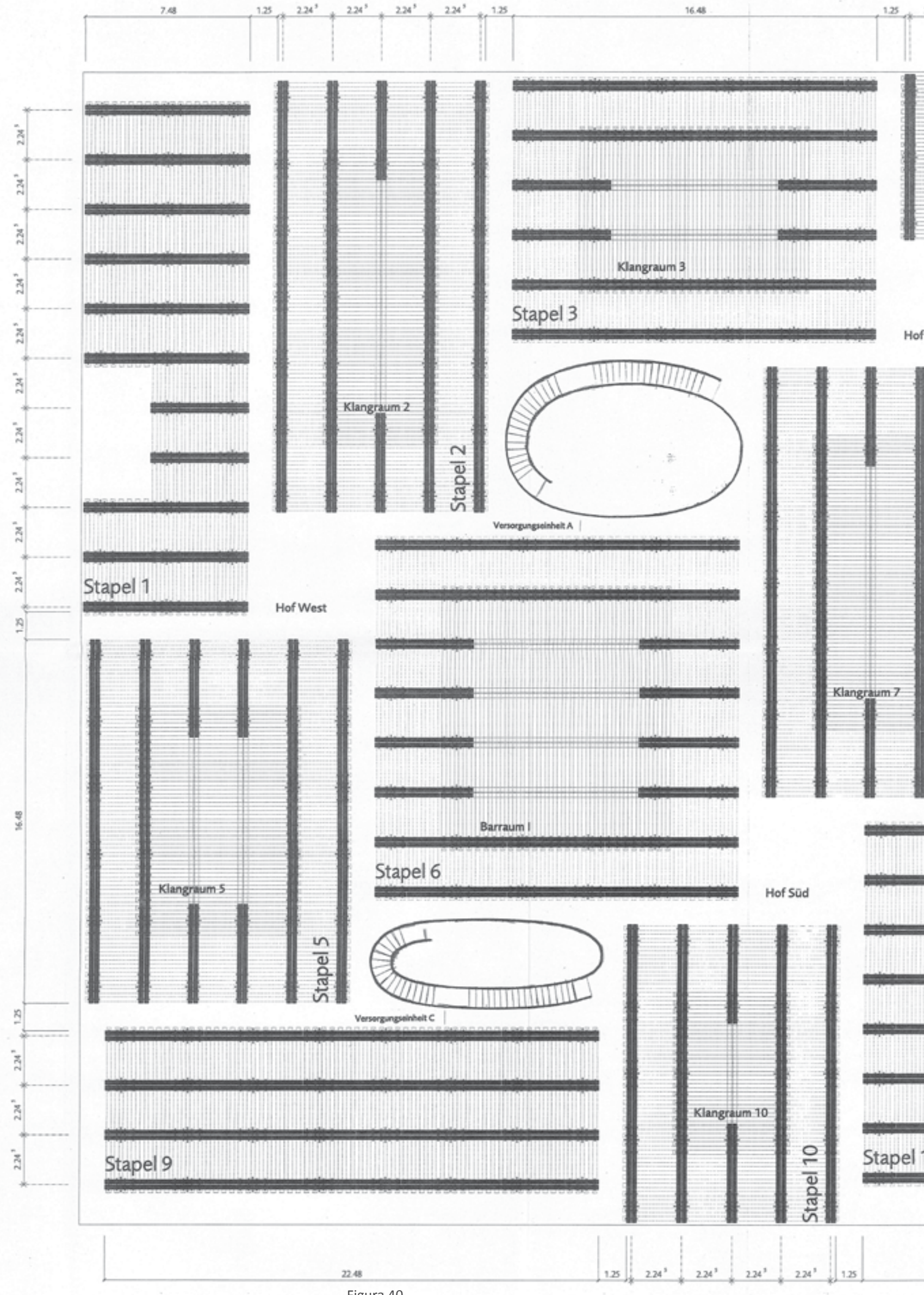



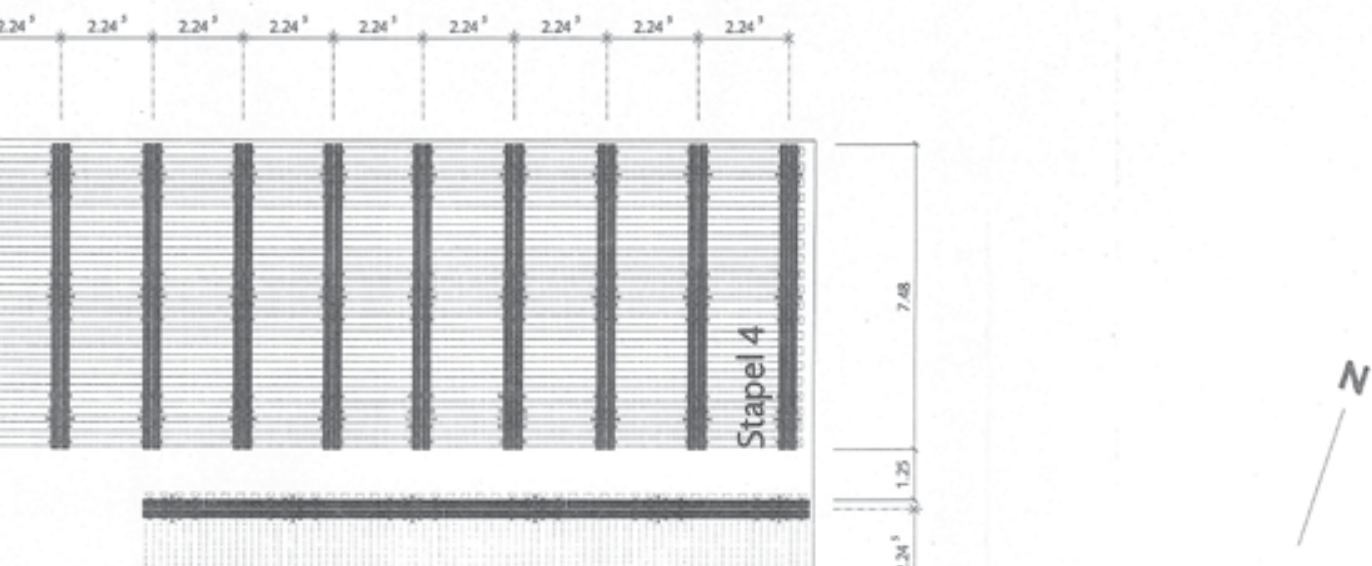

Klangkörper Schweiz

Schweizer Pavillion

Expo 2000 Hannover

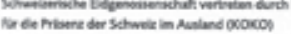

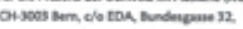

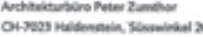

Holzstapelplan

Grundriss

Maßstab 1:100

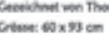

Mensis. 1.91 . 


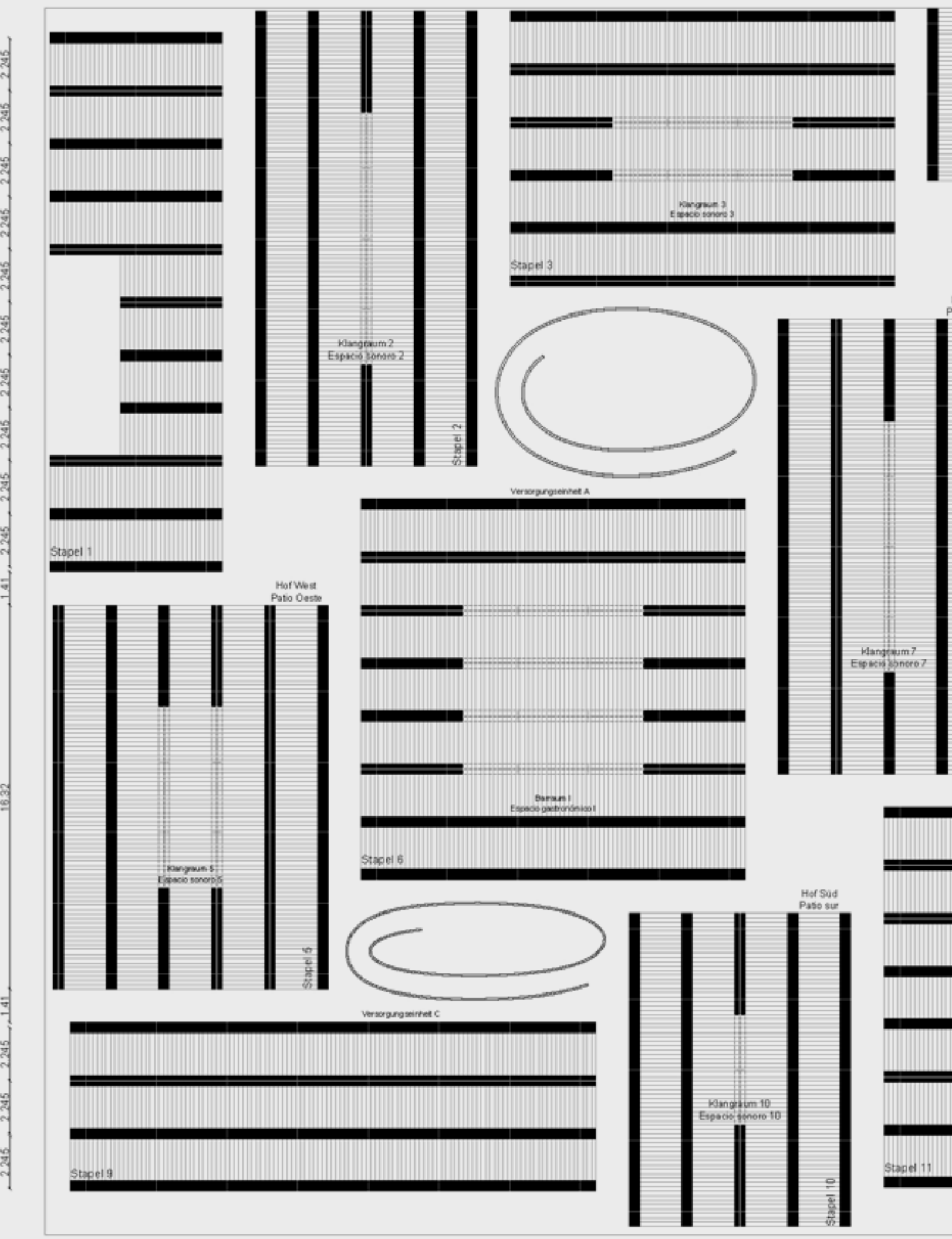

2232

Figura 41.

Plano / Pabellón helvético / Hannover / 2000

Proyecto construido

Dibujo de la autora 


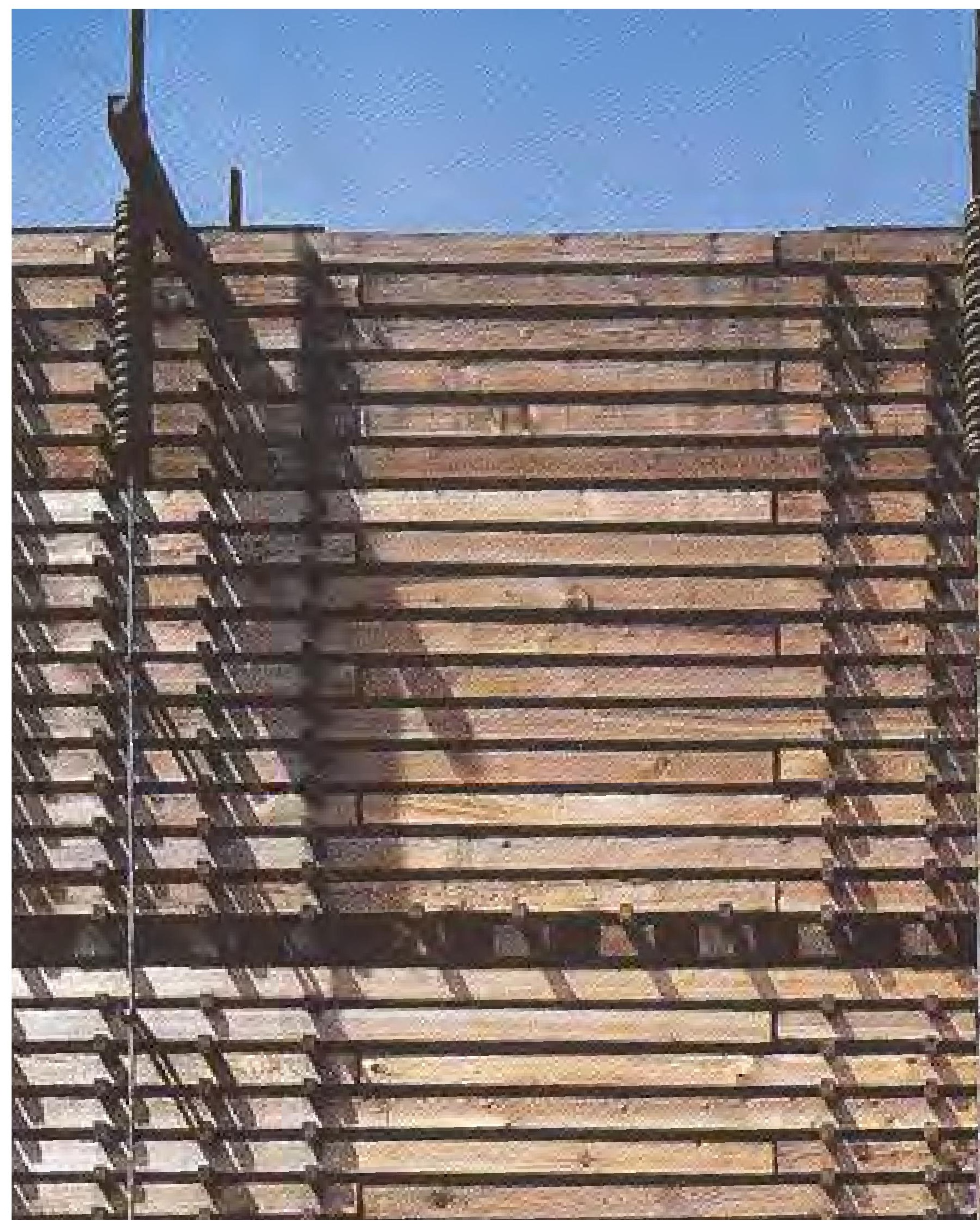




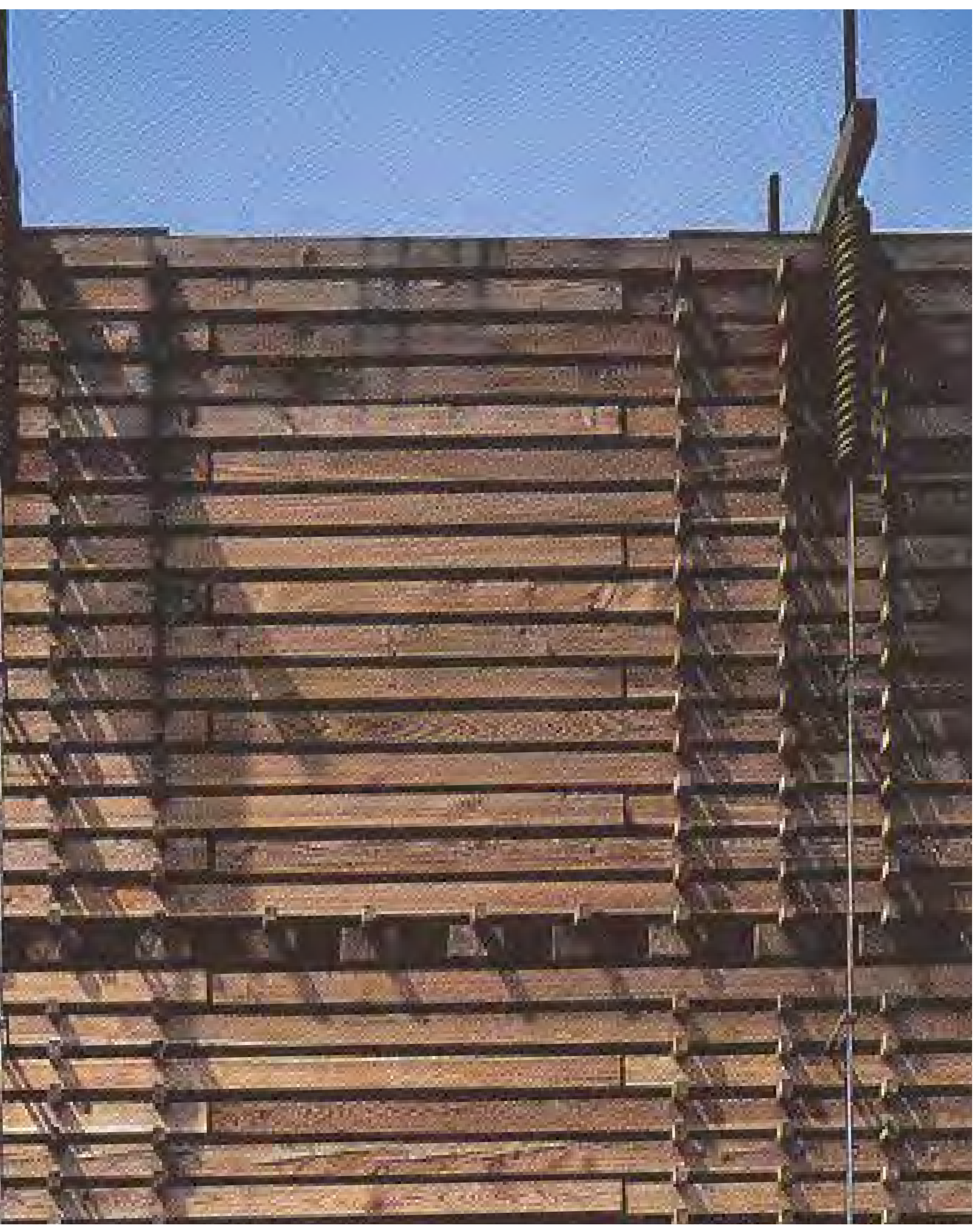



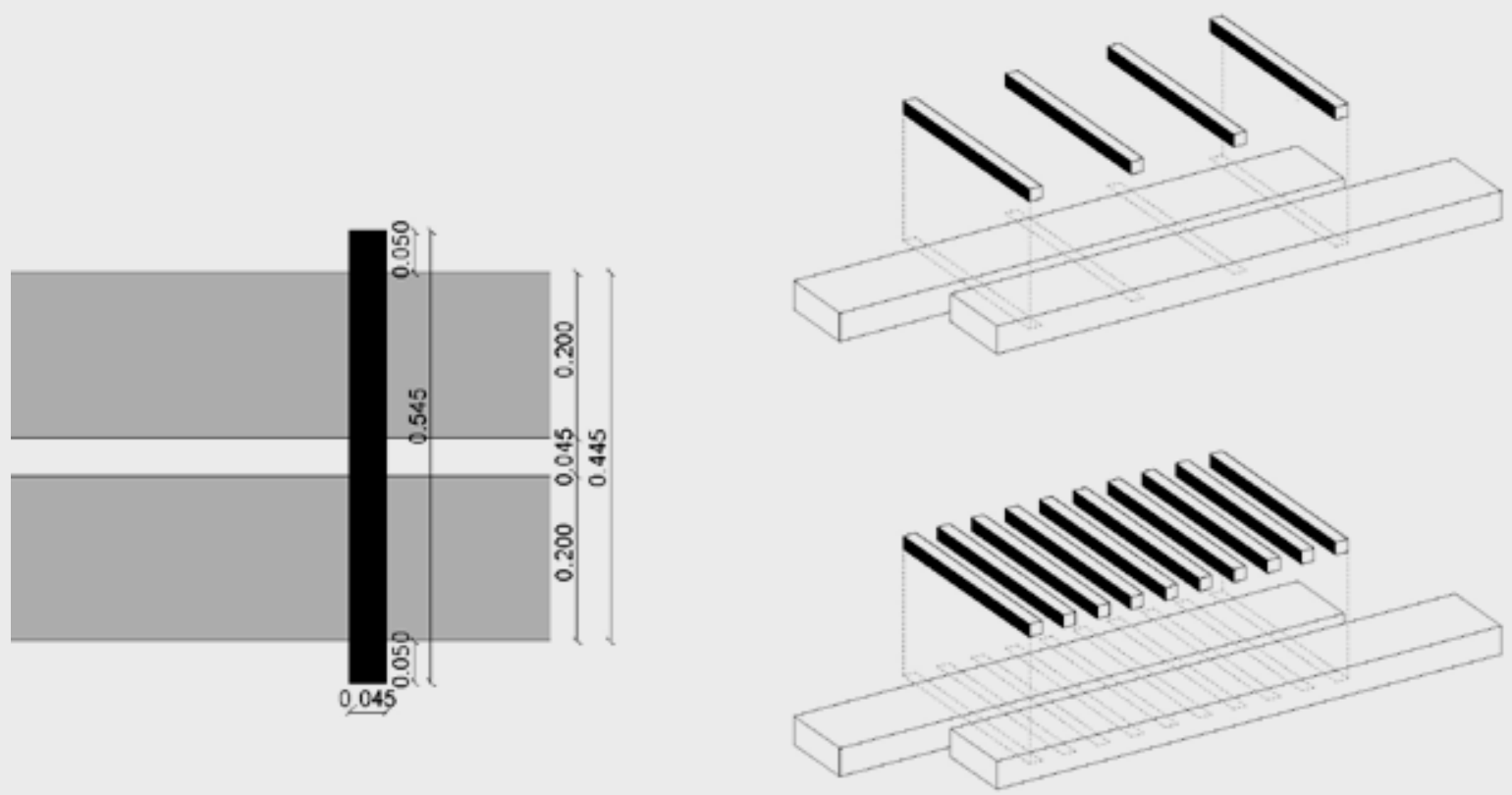

Figura 43 - 44

Separadores

Dibujo de la autora
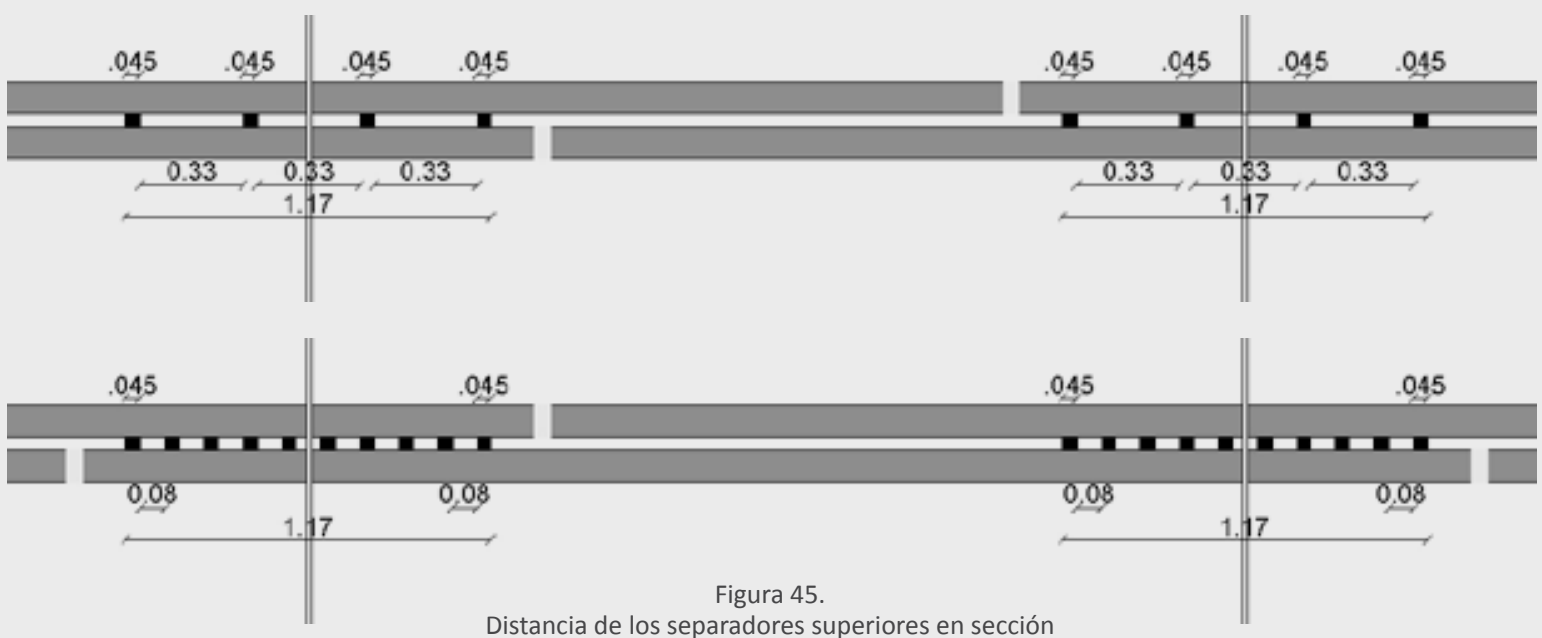

Distancia de los separadores superiores en sección

Distancia de los separadores en las últimas once capas inferiores en sección

Dibujo de la autora

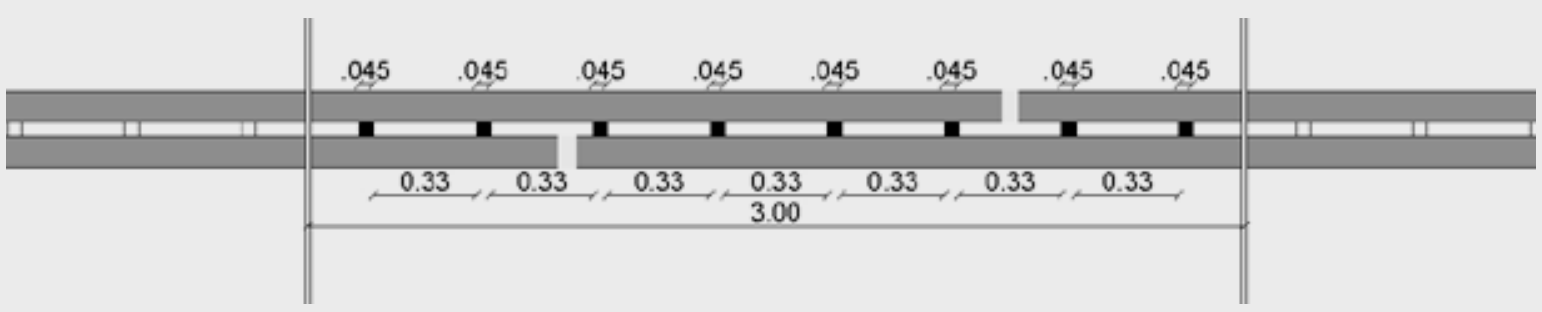

Figura 46.

Distancia de los separadores en sección / Oquedades

Dibujo de la autora 


\section{[Separadores]}

“¿Cómo es que hay más madera y luego menos en la parte superior?

Alli tiene más maderas, porque el peso que está sobre ella tiene que ser distribuido hasta este punto. Y allí necesita mucha madera. Todo niño puede imaginárselo. Y el peso, para que las vigas no se doblen alli." ${ }^{\prime 36}$ Peter Zumthor

En los Baños Termales de Vals, el aparente e irregular ${ }^{37}$ despiece horizontal de las lajas de $\mathrm{Gneis}^{38}$ son una composición de partituras mediante un ritmo uniforme e ininterrumpido de $15 \mathrm{~cm}^{39}$. Una combinación de tres placas con grosores de 31, 47 y $63 \mathrm{~mm}$, donde las tres juntas de mortero de $3 \mathrm{~mm}$ cada una permiten la permuta.

En el pabellón helvético los listones estaban colocados uno encima de otro a una distancia constante sin mecanización entre capas, sin placas, sin clavos, sin tornillos, sin adhesivos. La junta horizontal se generó por ausencia. Esto se logró mediante unas cuñas entre listones. Unos separadores de 4,5 x 4,5 x 54,4 $\mathrm{cm}^{40}$ colocados transversalmente en una franja estructural de 1,17 $\mathrm{m}$. De cara a reducir el grado de desviación y distribuir el peso de cada pila adecuadamente de arriba a abajo, estos separadores se ubicaron alineados verticalmente en cuatro filas con una separación uniforme entre ellos de $33 \mathrm{~cm}$. Debido a las acciones de viento y peso propio, se intensificó notablemente en las once juntas inferiores entre-listones, las más próximas a las pletinas, pasando de cuatro a diez y reduciendo su separación significativamente a $8 \mathrm{~cm}$.

En las pilas que limitan las oquedades con mayores demandas estructurales, se reforzaron con separadores alineados en todos los niveles. A diferencia del sistema original los separadores se ubicaron en toda la superficie distanciados $33 \mathrm{~cm}$, y no sólo en las franjas estructurales de los apoyos. Todo ello para evitar la aparición de momentos en los listones derivados de los esfuerzos de apoyo de la cubierta.

36 Entrevista a Peter Zumthor. Schweizer Pavillon auf der Expo 2000. Deutsche Welle / Germany. 2000. http://euscreen.eu/item.html?id=EUS_5889F89D47CB4E518230541F53CB1A96. Minutos: 1:30 1:46. Traducción de la autora: "Wieso hat es da mehr Hölzer und oben dann weniger? Da hat es mehr Hölzer, weil das Gewicht, dass da daraufliegt muss da verteilt werden auf diesen Punkt. Und da braucht es viele Hölzer. Das kann sich jeder Bub vorstellen. Und das Gewicht, dass die Balken da nicht durchbiegen"

37 Nota: Compuesto de tres alturas, dos profundidades y diferentes largos

38 Nota: Las lajas finas de piedra de gneis autóctono, junto con el hormigón armado, forman la base del llamado Valser Verbundmauerwerks.

39 Nota: Esta medida corresponde a la altura de un escalón.

40 AAVV. Klangkörperbuch. Birkhäuser. Basel. 2000. ISBN: 3-7643-6324-X. Pág. 233. 


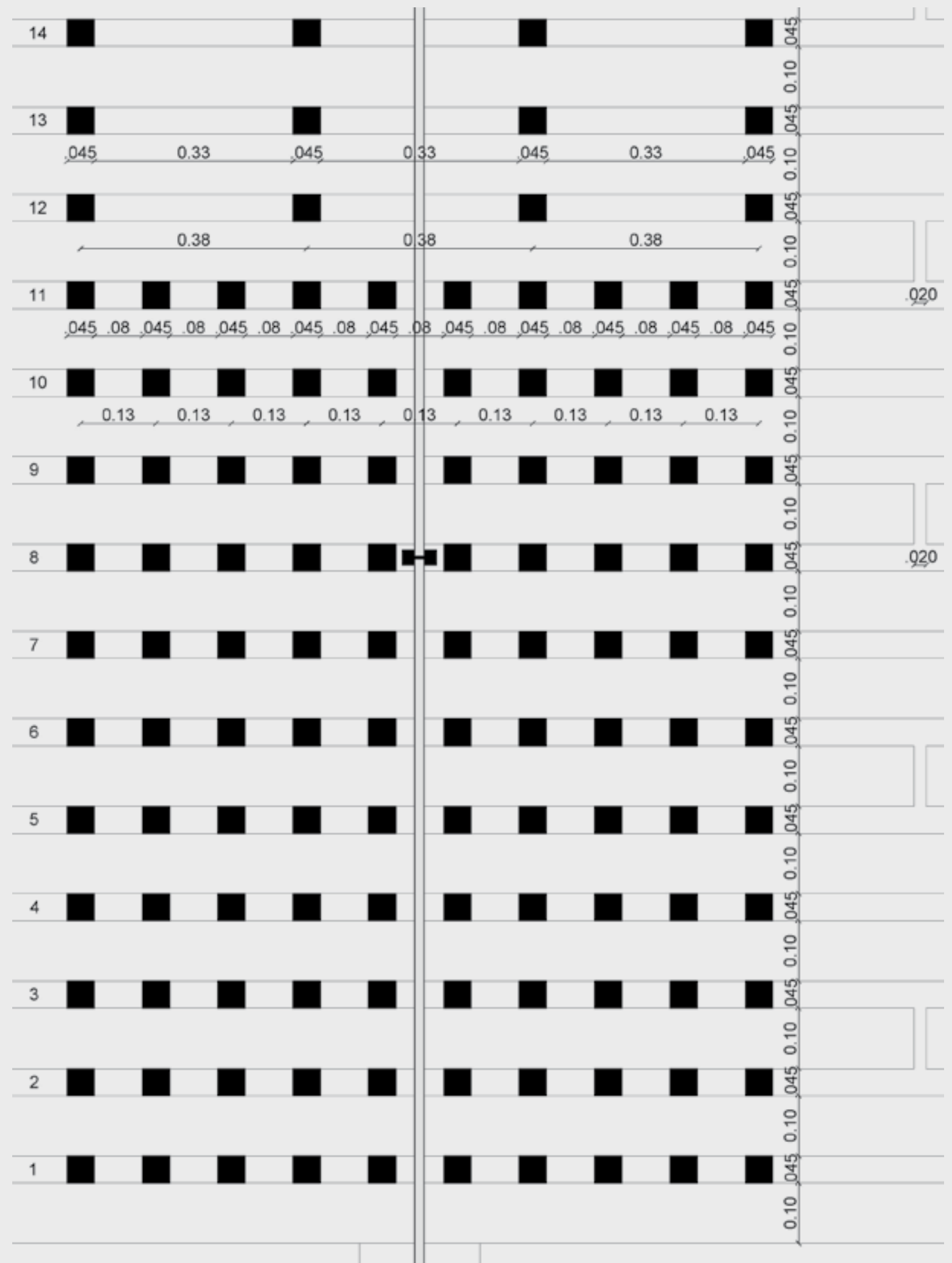

Figura 47.

Separadores 


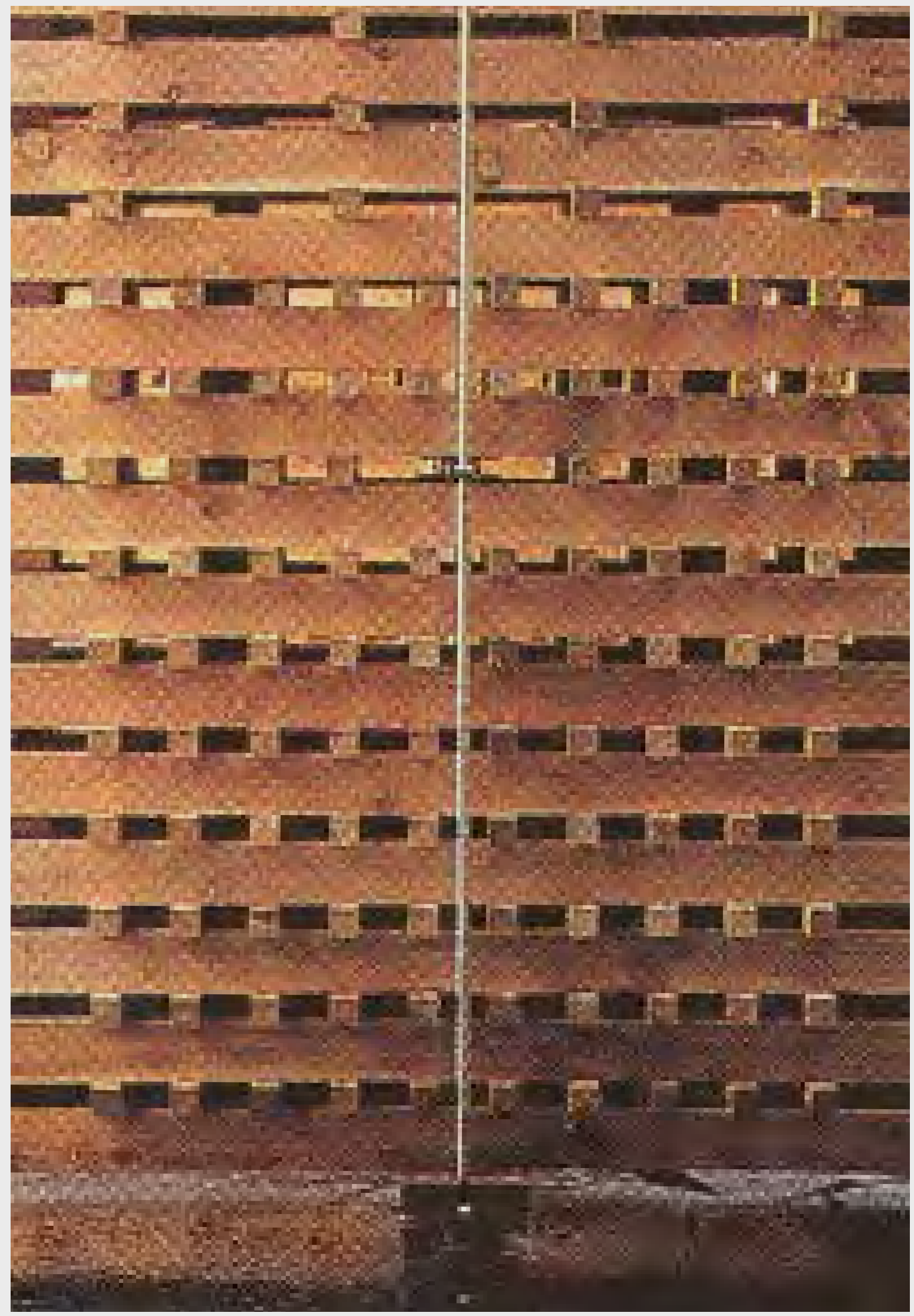




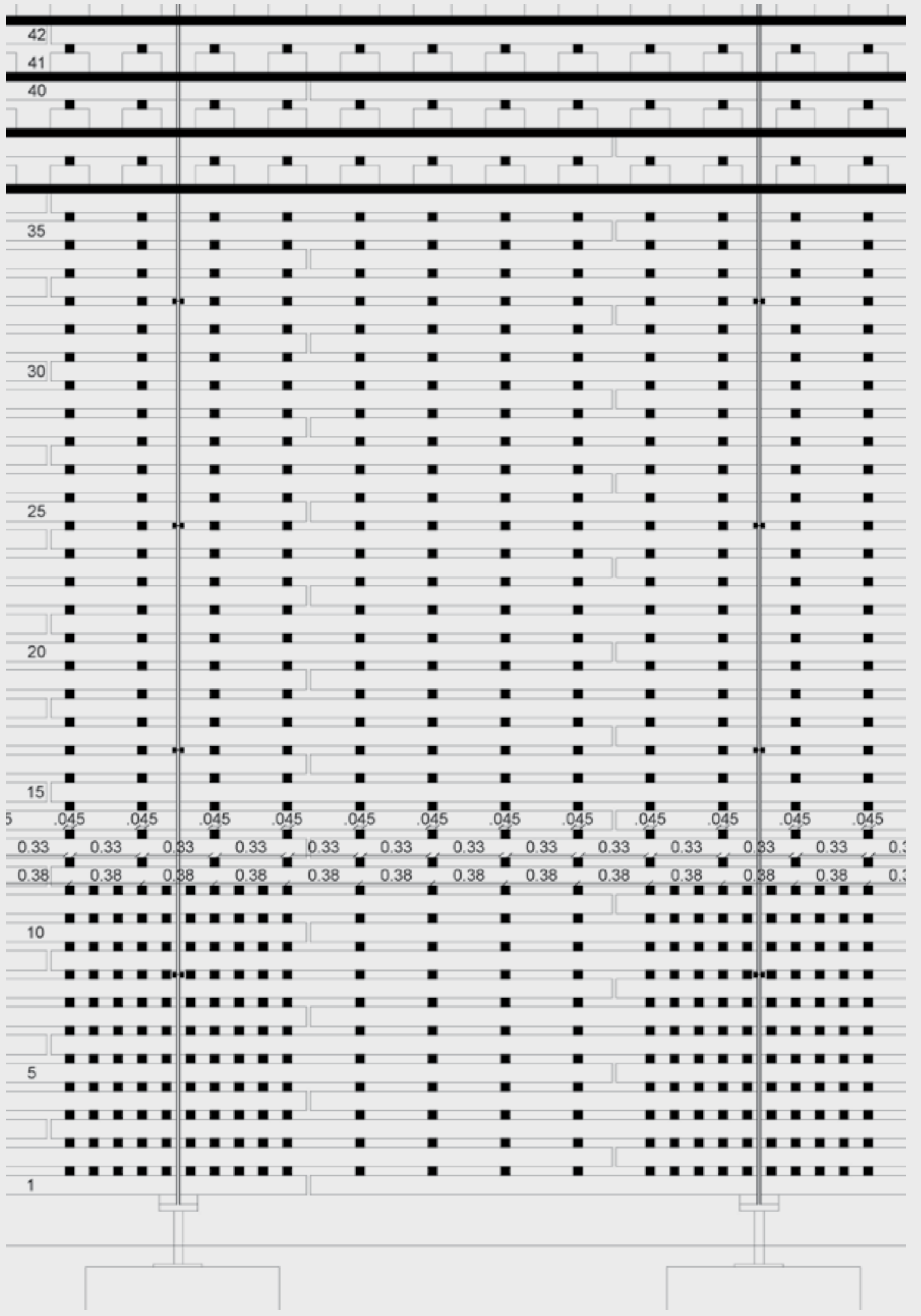




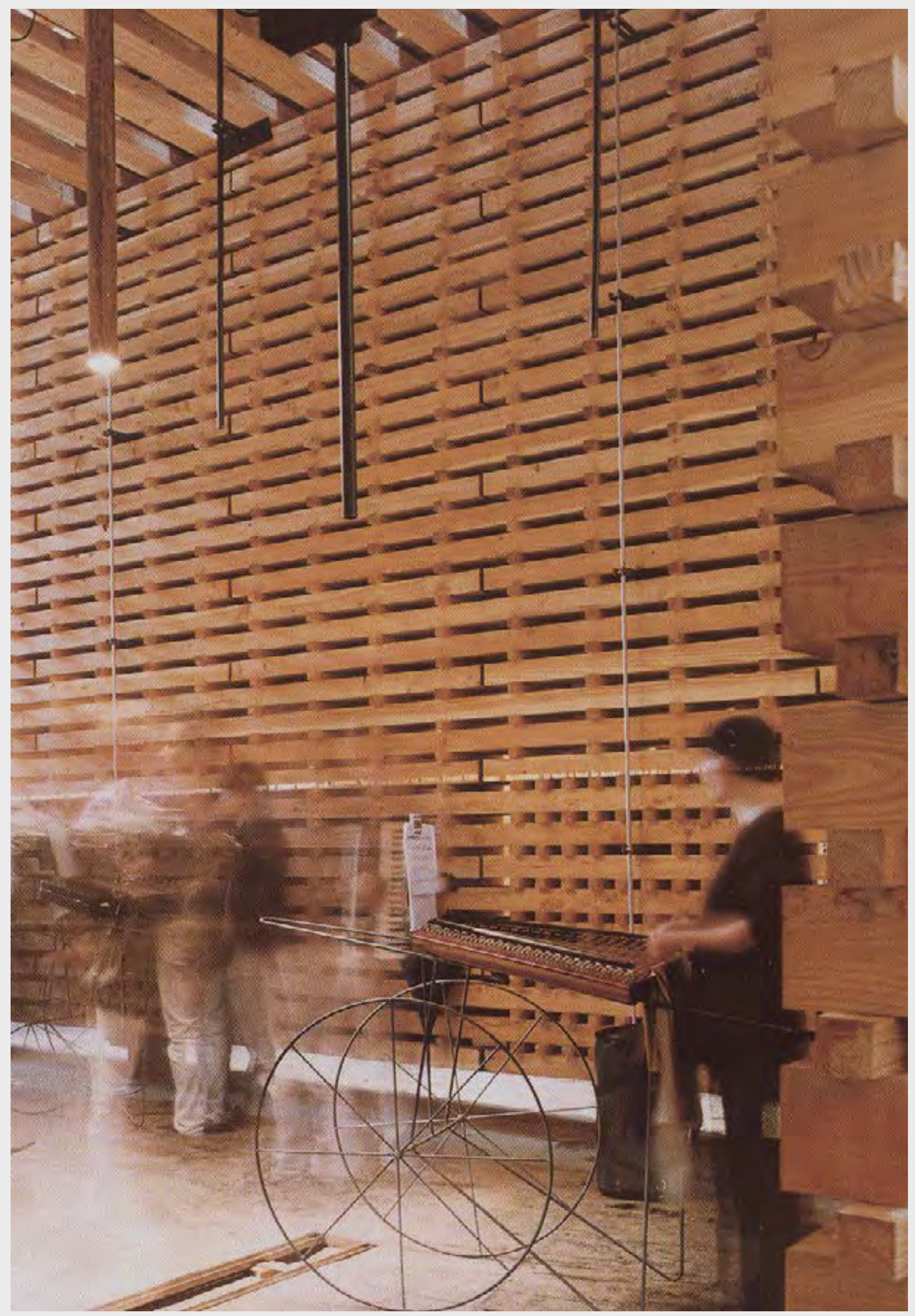

Figura 50.

Espacio sonoro / Separadores 

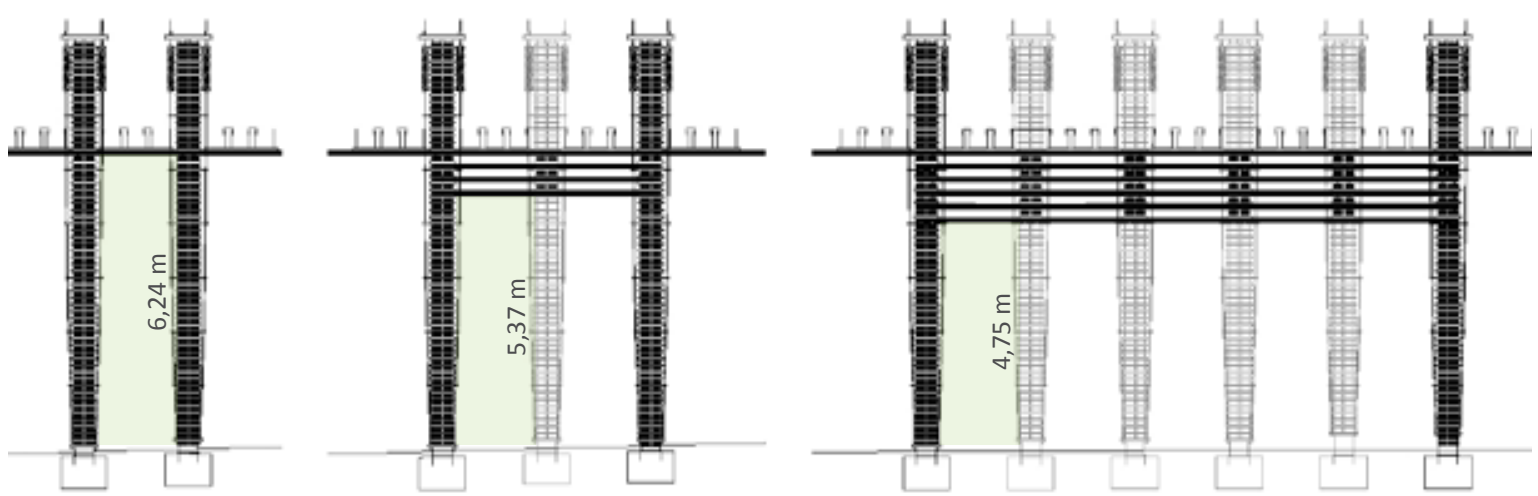

Figura 51.

Cubrición / Pasillos - Espacios sonoros - Espacios gastronómicos Dibujo de la autora

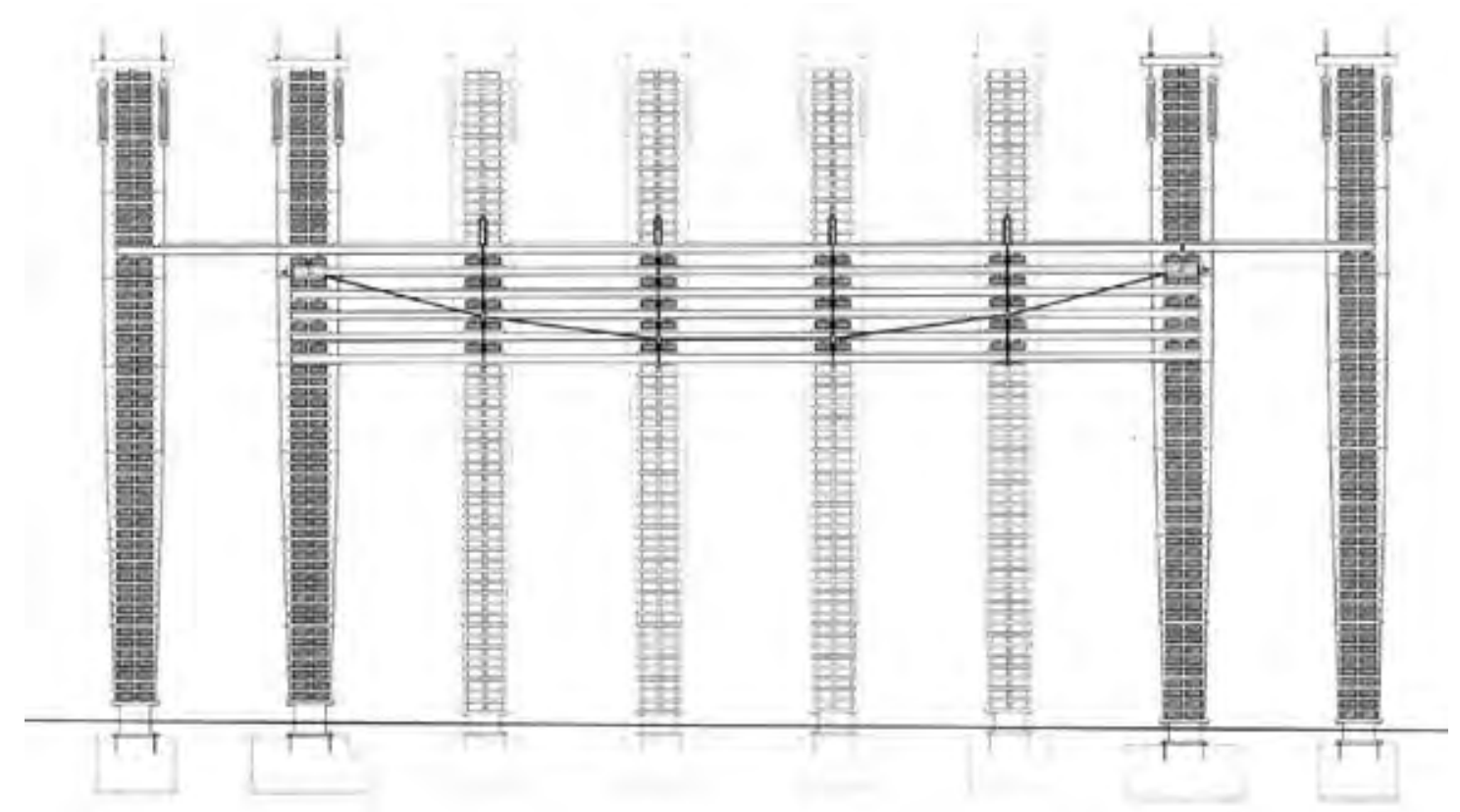

Figura 52.

Unterspannung
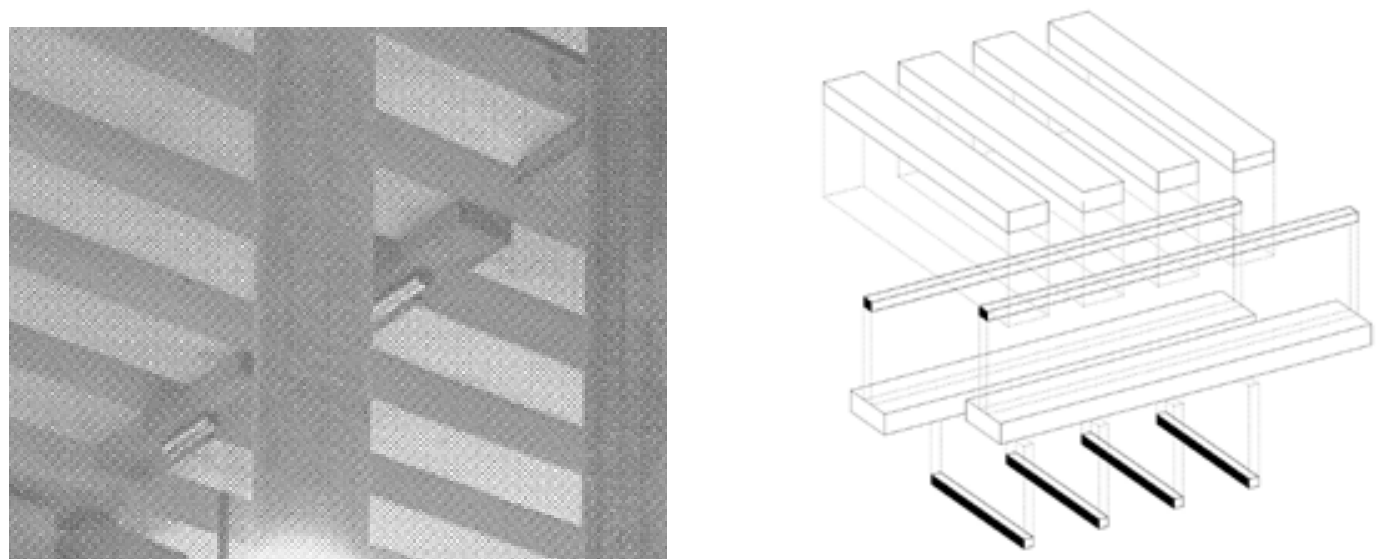

Figura 53 - 54

Detalle / Unterspannung

Construcción de la cubierta sobre separadores colocados dirección longitudinal 


\section{[Fragmentos de cubierta]}

La fragmentación, al igual que en los Baños termales de Vals, será el recurso para resolver la cubrición del Klangköperbau. Interrumpida por su propia composición y la presencia de las pilas. No existía una respuesta homogénea en todos los espacios, sino que fue resolviéndose según el espacio que cobijaba, y sus circunstancias. Un sistema constructivo de matices según la percepción de los diversos paisajes geométricos de la luz y penumbra. El plano horizontal de protección se desarrolló en tres estrategias distintas: sin cubrición en los patios, parcial en los espacios entrebandas; y completa en los vacíos interiores de los conjuntos de secuencias paralelas.

En cada Stapel; las pilas estuvieron conectadas perpendicularmente a sus hermanas paralelas por otros listones a modo de vigas horizontales formando un marco rígido. La repetición modular de la cubierta nació del ritmo impuesto por el apilamiento. Con la misma sección de los listones horizontalmente apilados, los listones viga se replicaron colocándose según una modulación constante de separación entre ellos en todos los casos de $19 \mathrm{~cm}^{41}$.

Los espacios entre-bandas con ancho libre de $1,80 \mathrm{~m}$ se construyeron con un único nivel de listones de madera, de longitud 2,20 m, a 6,24 $\mathrm{m}^{42}$ de altura de los 8,66 $\mathrm{m}^{43}$ totales de las pilas. La geometría de las diferentes capas requirió una atención especial durante el apilamiento; por ello se usó la misma sección de los separadores habituales en forma transversal. La construcción de la cubierta descansa sobre una serie de separadores más largos de longitud colocados en la misma dirección de los listones longitudinales, ofreciendo una superficie de apoyo continua.

En los vacíos de los conjuntos, se eliminaron algunos módulos interiores de las pilas para dar cabida al contenido programático. Esto desencadenó nuevas demandas estructurales salvando vanos mayores. Para resolverlo se incrementó el número de niveles de listones, y se redujo la altura libre, dotando al sistema de soporte de un mayor canto para contrarrestar su peso propio y el efecto de empuje/succión. Este sistema estructural acumulativo de listones entrelazados tendrá dos variantes según la luz a salvar. Una cuando se elimine una sola pila; y otra de dos hasta cuatro pilas recortadas introduciendo una ayuda mecánica al sistema, Spannweite.

41 Nota: Separadores de 4,50 cm + Listón de $10 \mathrm{~cm}+$ Separadores de 4,50 cm

42 Nota: Las medidas dependen tanto de la cota del suelo como del cambio dimensional de las pilas debido a la disminución del contenido de humedad de las maderas.

43 Idem 


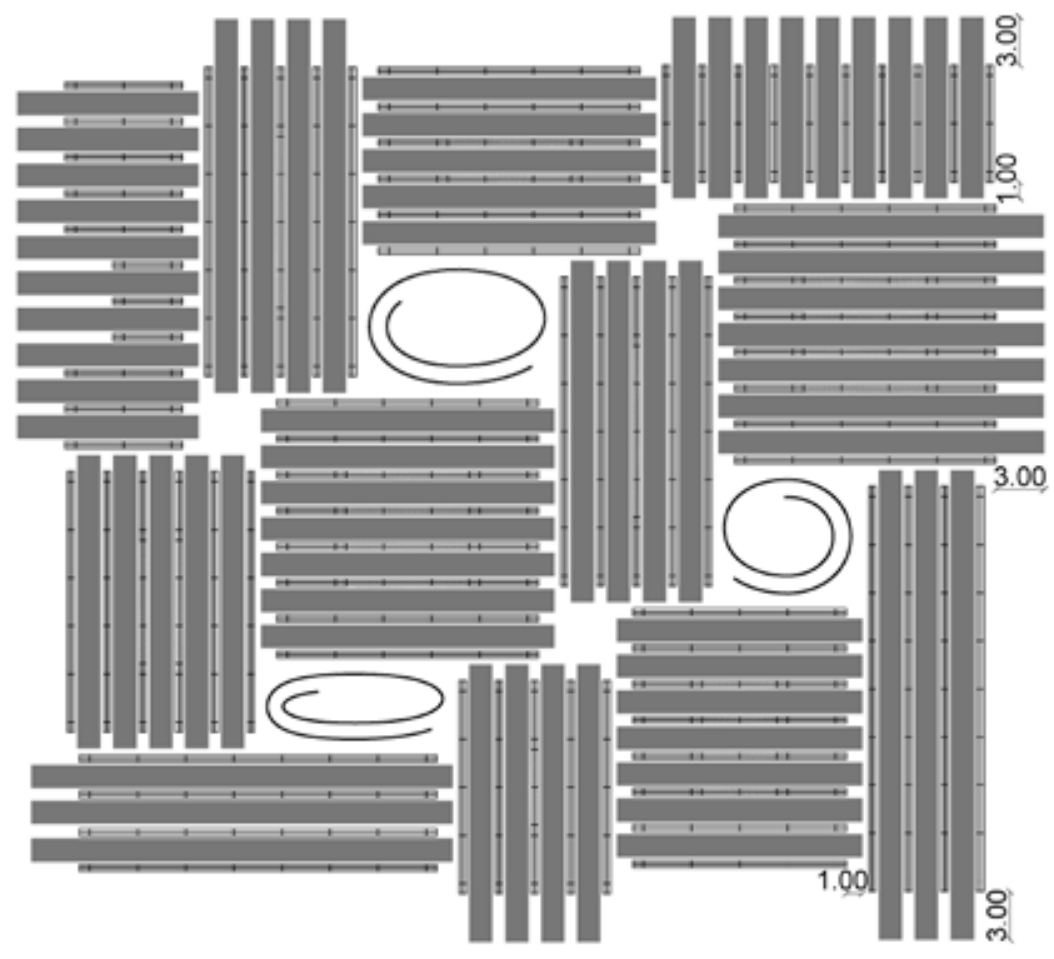

Figura 55.

Canalones de acero / Pabellón helvético / Hannover / 2000 Dibujo de la autora

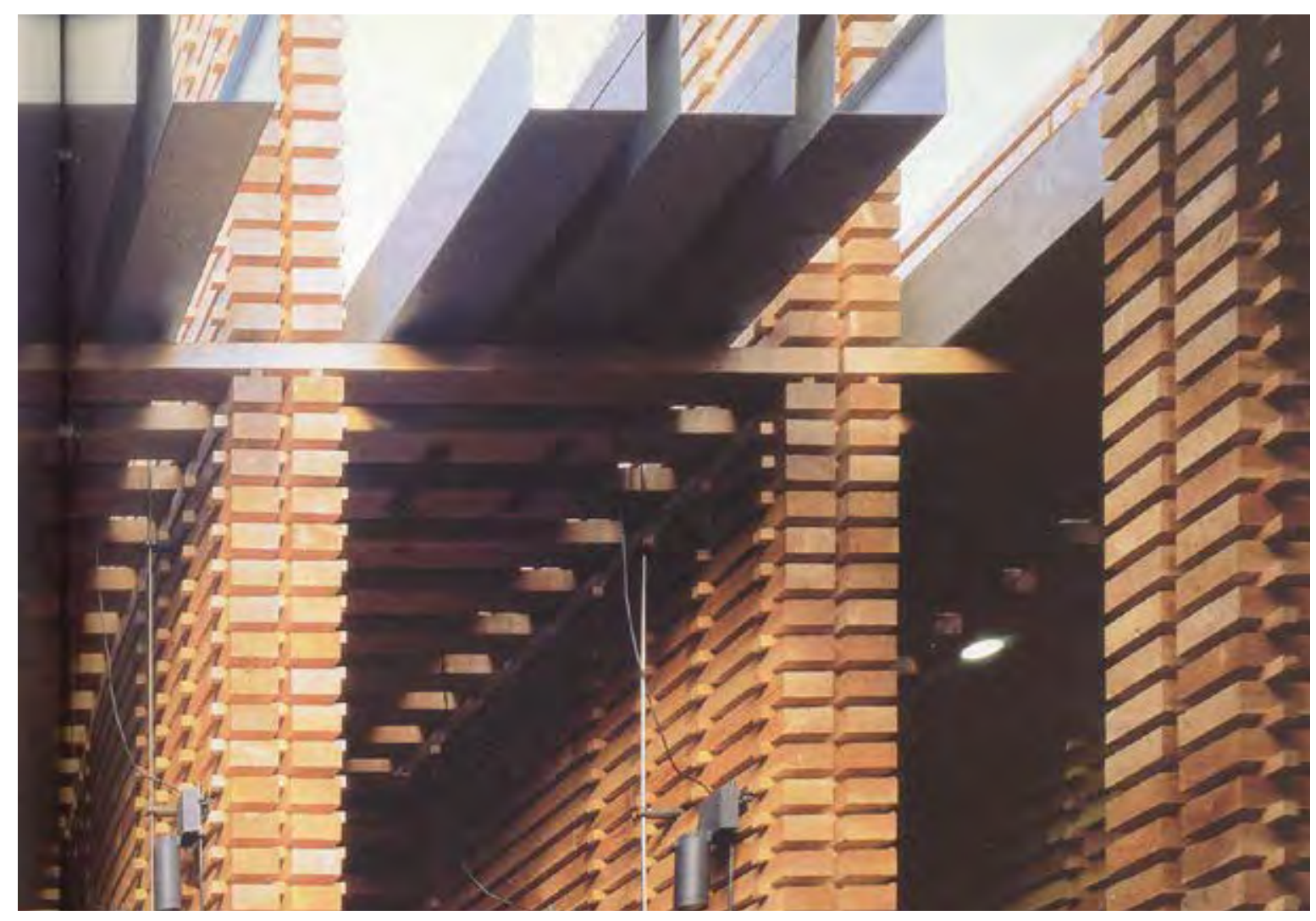

Figura 56.

Cubierta / Pabellón helvético / Hannover / 2000 
En las oquedades interiores más estrechas, ( $\left.x 1\left[M_{-} p i\right] /+/ x 2\left[M_{-} v a\right]\right)$, el sistema portante estuvo conformado por un entramado de cuatro niveles verticales apilados. La luz de 4,45 m, transversal a las pilas, permitió que se pudiese resolver con listones completos. La altura libre se redujo $90 \mathrm{~cm}$, comprimiéndose el espacio a 5,365 $\mathrm{m}^{44}$.

Sin embargo, en las oquedades mayores, (x2 [M_pi] /+/x3 [M_va] ) y $\left(x 4\left[M \_p i\right] /+/ x 5\right.$ [M_va]), dado que sus luces no eran salvables con listones de una sola pieza se aumentó a cinco o seis niveles de listones la cubierta y se introdujo un mecanismo complementario de tracciones. Esto permitió aumentar la eficacia de todo el paquete estructural. A modo de puente colgante, pero por debajo del cordón rígido Unterspannung ${ }^{45}$; se introdujo de forma alterna entre las juntas de los listones un sistema de tirantes de acero de 22 $\mathrm{mm}^{46}$ de diámetro para conformar los montantes y el cordón inferior de las cerchas. Este sistema estructural oculto comprimió la altura en estos lugares $149 \mathrm{~cm}$, hasta una distancia libre de 4,75 $\mathrm{m}^{47}$

Aunque el paquete de cubierta fue variable; el nivel de acabado fue constante en todos los Stapel. Las agrupaciones de tres canalones de acero galvanizadas prefabricados de 3 $\mathrm{mm}^{48}$ de espesor se apoyaron en el sistema de entramado de listones vigas de madera a una altura de 6,34 $\mathrm{m}$. Estos tres perfiles plegados en forma de $U$ concatenados se sujetaron mediante abrazaderas mecánicas atirantadas similares a las cerchas. Ubicadas a eje, se separaron de los muros dejando resbalar la luz al interior, ventilando el interior, y permitiendo pasar los tensores. Estos grandes canalones avanzaron más allá del límite del sistema portante de listones mediante un voladizo de $1 \mathrm{~m}$ aproximadamente. Los aleros también fueron protecciones parciales entre los diferentes Stapel $e$ incluso en los patios interiores. En el perímetro exterior, su vuelo aumentó hasta los $3 \mathrm{~m}$ generando grandes marquesinas de acceso. Estos grandes umbrales se convirtieron en iconos paradigmáticos de la apariencia del pabellón desde la Expo.

Las grandes pilas, y sus cumbres a la intemperie sin protección, también fueron parte de dicha imagen colectiva. El último nivel de listones se solidarizó mediante grapas metálicas para impedir su deformación por lo que fue la más expuesta a las acciones exteriores y por lo tanto la más castigada por la acción del tiempo.

44 Nota: Dependiendo de la cota del suelo

45 AAVV. Klangkörperbuch. Birkhäuser. Basel. 2000. ISBN: 3-7643-6324-X. Pág. 251.

46 CONZETT, Jürg. Stapellauf. Pavillon der Schweiz in Hannover. En: Deutsche Bauzeitung db. Vol. 134. Nr. 9. 2000. Pág. 98.

47 Nota: Dependiendo de la cota del suelo

48 AAVV. Klangkörperbuch. Birkhäuser. Basel. 2000. ISBN: 3-7643-6324-X. Pág. 46. 


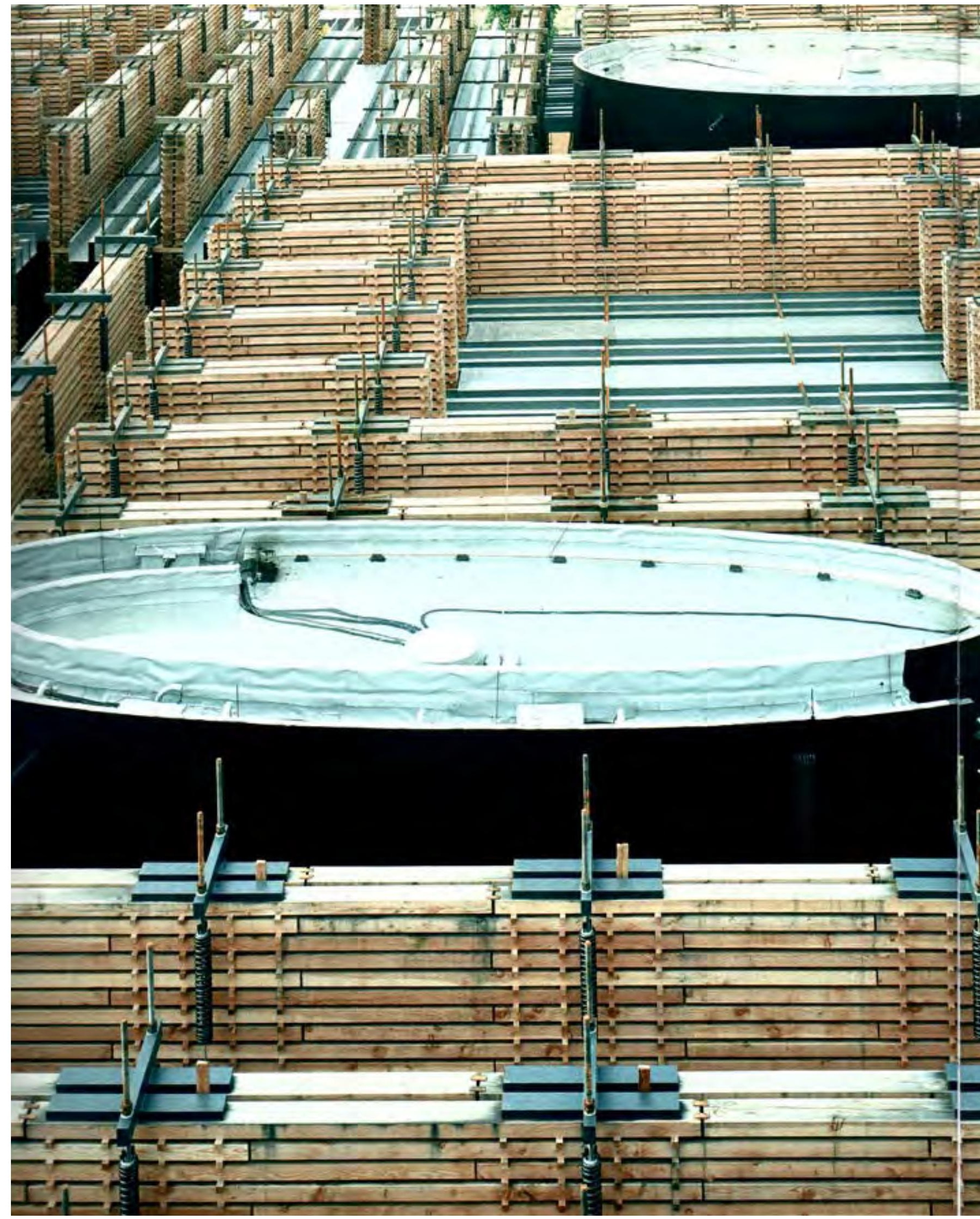



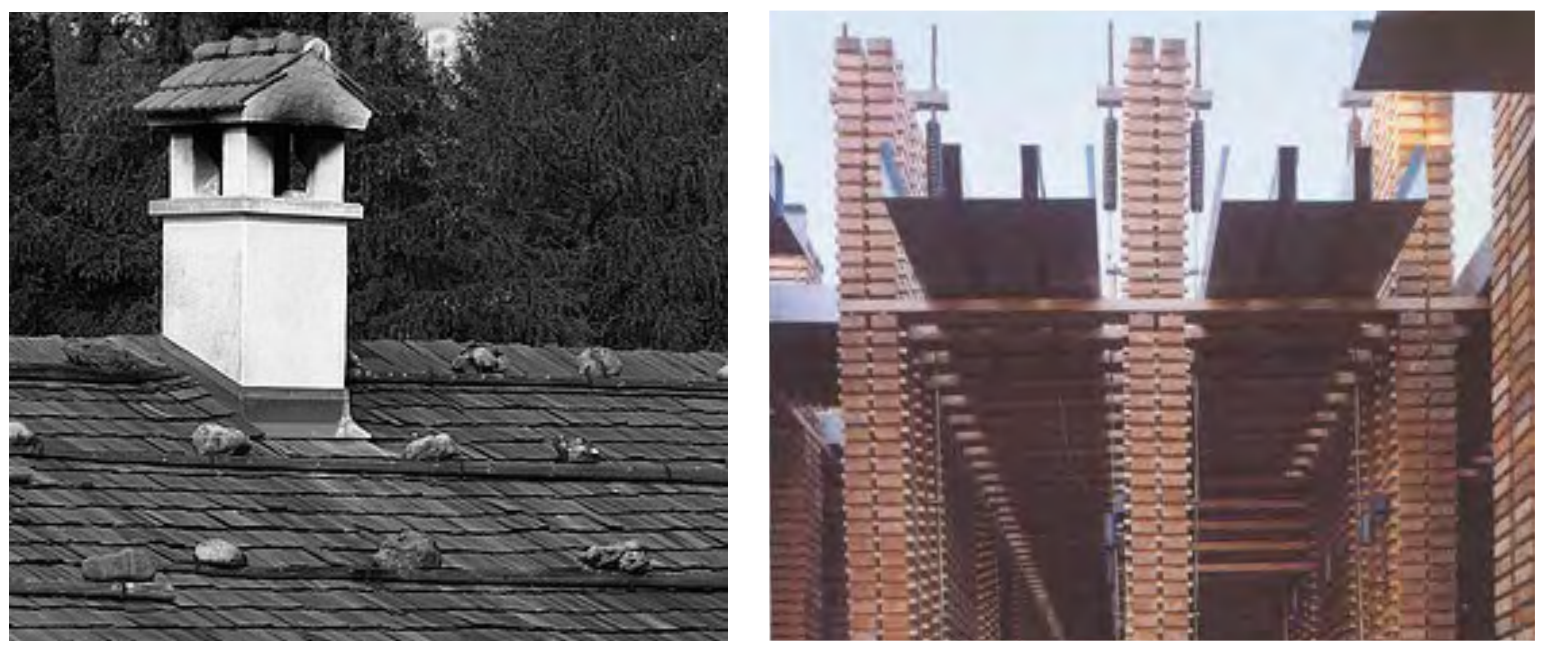

Figura 58 - 59.

Schwärdach - cubierta de ganeros en Suiza versus Pabellón helvético
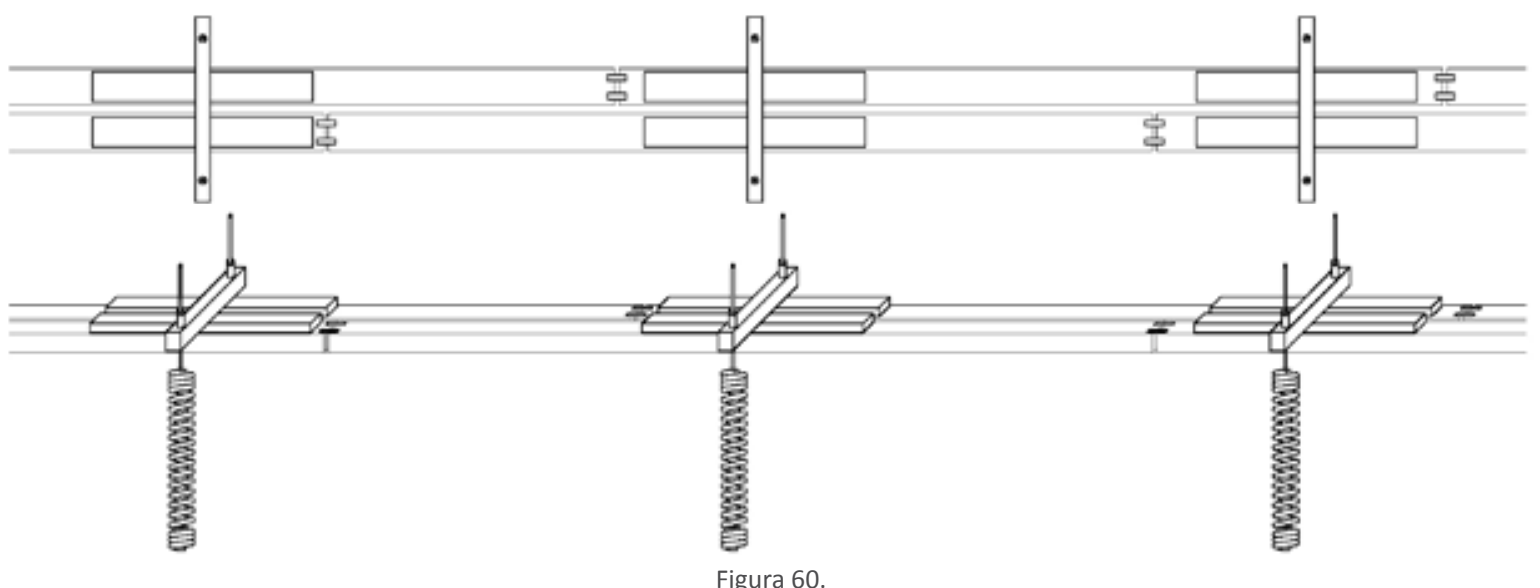

Pletinas guías de acero con una aleta perpendicular / Pabellón helvético / Hannover / 2000 Dibujo de la autora

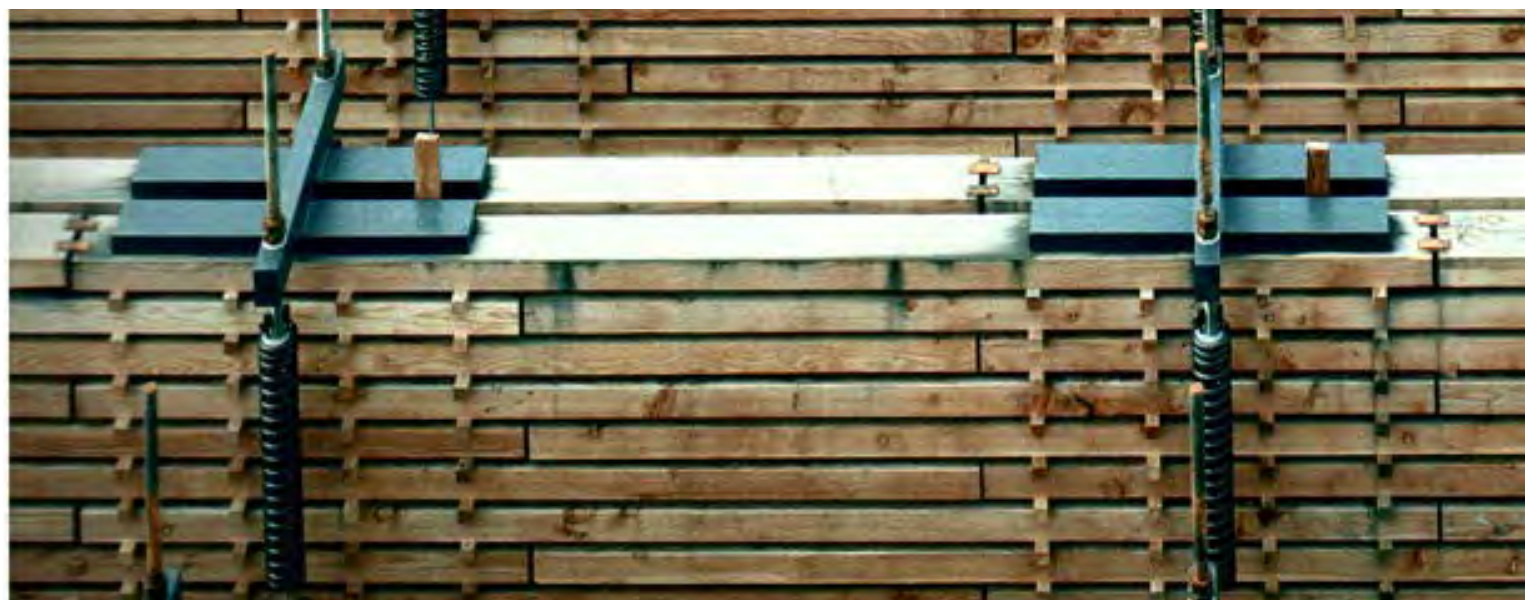

Figura 61.

Pletinas guías de acero con una aleta perpendicular / Pabellón helvético / Hannover / 2000 


\section{[Postensado]}

"Los arquitectos no inventan nada, transforman la realidad"49

Alvaro Siza

Algunos graneros suizos utilizan en sus cubiertas la tradicional técnica de estabilización mediante pesos. El Schwärdach ${ }^{50}$ es una de las formas más antiguas de tejar. Las tejas de madera sueltas se fijan con piedras como contrapeso frente al levantamiento provocado por la fuerza del viento. Un método de estabilización estructural mediante el incremento de peso.

Uno de los parámetros más críticos de la construcción del pabellón fue la gran esbeltez de las pilas. Los entramados de madera eran relativamente ligeros y no eran por sí mismos estables. Todas estas filigranas necesitaron de un apilamiento muy cuidadoso de los listones para no desencadenar el colapso.

Otra de las dificultades adicionales a solucionar fue resistir las acciones a viento; según la norma DIN la velocidad del viento podía llegar a $182 \mathrm{~km} / \mathrm{h}$ y una presión de $1,60 \mathrm{kN} / \mathrm{m} 2^{51}$ en este área. Todas las pilas debían evitar el vuelco por si mismas, además del posible efecto en cadena por flexión lateral. La necesidad de garantizar la estabilidad de los conjuntos durante su proceso de montaje llevó a estabilizar las pilas con andamios auxiliares de tubos de acero.

Para aumentar la capacidad de carga, y ganar altura en las pilas; se mejoró el comportamiento estructural del conjunto introduciendo el principio de postensado vertical. Este proceso que se remonta al ingeniero francés Eugéne Freyssinet, se realizó posteriormente a la ejecución de las pilas de madera. El mecanismo se diseñó basándose en el principio de "marco atirantado" - eingespannter Rahmen; donde todas las capas de listones se solidarizaron y estabilizaron a compresión mediante muelles de tensión conectados a tensores. Estos grandes "lazos" compactaron las pilas desde sus cumbres hasta las pletinas. Las piezas de todo este engranaje a compresión fueron diseñadas específicamente para las condiciones del pabellón. A diferencia de las pilas de madera; el montaje se ejecutó empezando desde arriba hacía abajo; para posteriormente atirantar desde la cumbre.

49 SIZA, Alvaro. Columbia Documents of Arquitecture and Theory I. 1992. Pág. 53 - 68.

50 CONZETT, Jürg. Stapellauf. Pavillon der Schweiz in Hannover. En: Deutsche Bauzeitung db. Vol. 134. Nr. 9. 2000. Pág. 90

51 Idem. Pág. 95. 


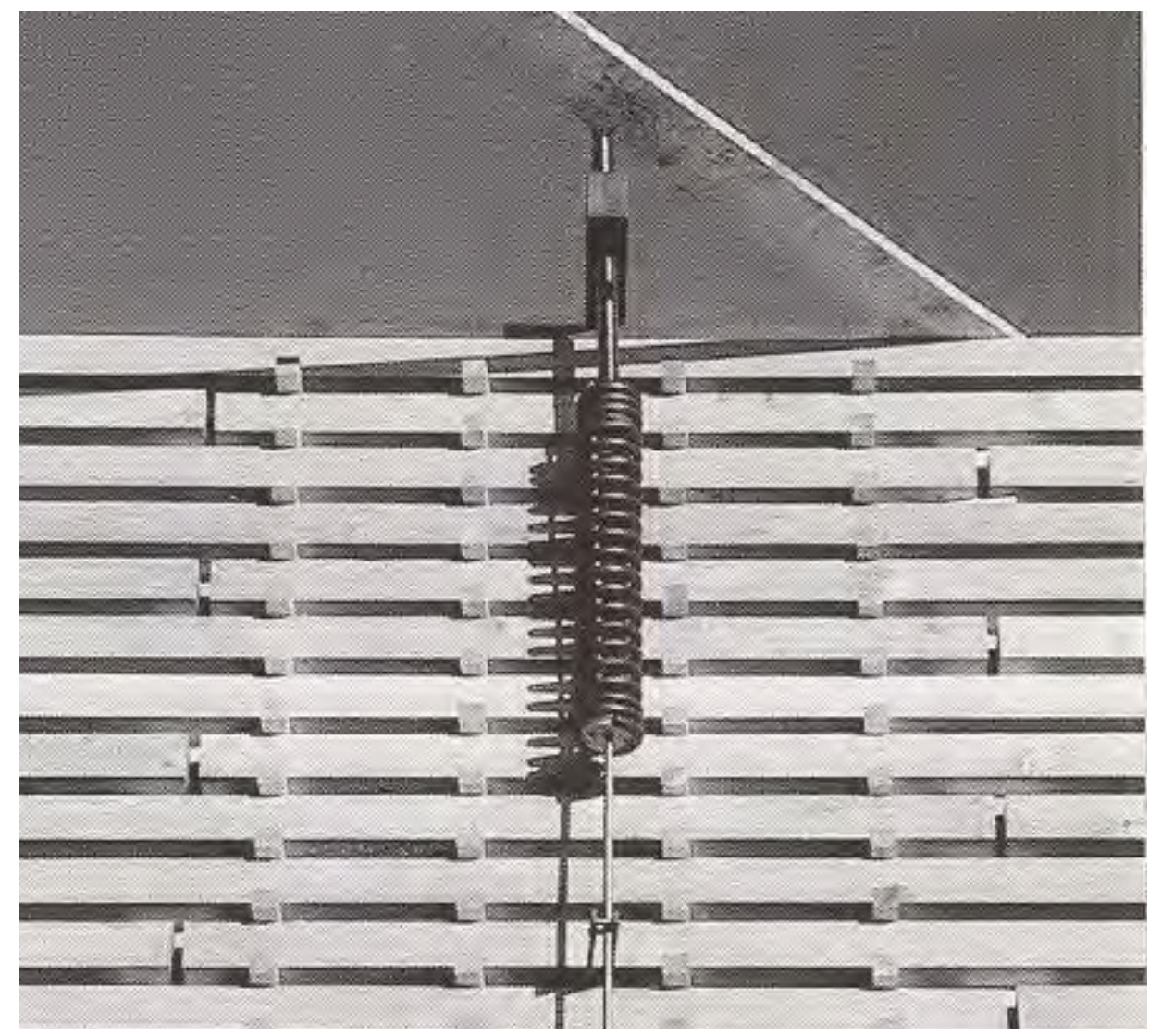

Figura 62.

Muelles de tirantes helicoidales / Pabellón helvético / Hannover / 2000
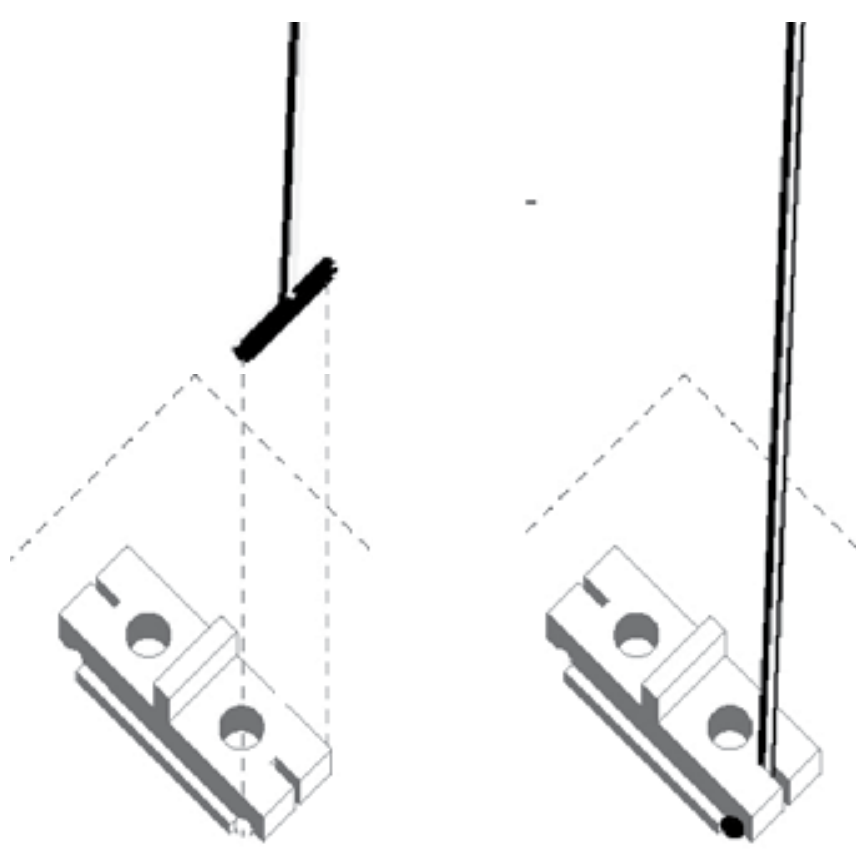

Figura 63

Sistema de anclaje inferior

Dibujo de la autora 
En la parte superior de las pilas, a intervalos equidistantes de 3,00 m coincidiendo con la cimentación, se colocaron unas pletinas de acero. Estas tapas en forma de $\mathrm{H}$ tenían dos pletinas metálicas que apoyaban directamente en los listones de la última capa y con un ancho equivalente a la zona de apoyo de los separadores de $1,17 \mathrm{~m}$. Estas pletinas permitían giros por lo que se usaron cuñas para evitarlo, Un conector perpendicular trasladaba las cargas a los dos muelles a ambos lados. La forma de los muelles fue decisiva para obtener el valor máximo de postensado. En una fase inicial se consideró el uso de muelles a presión, pero esta solución no convenció ni estética ni técnicamente, ya que tenían que soportar fuerzas de más de $50 \mathrm{kN}^{52}$. Alejado de soluciones industriales existentes; definitivamente se optó por un proceso de fabricación artesanal de Spannfedern - muelles de tirantes helicoidales termoformados blandos de un tamaño grande, de $870 \mathrm{~mm}^{53}$, que permitían regular la presión favoreciendo así la estabilidad de todo el conjunto en todo momento.

"Consisten en alambre redondo de $25 \mathrm{~mm}$ de espesor, tienen 20 bobinados, 15 de los cuales se estiran activamente. Su diámetro exterior es de $130 \mathrm{~mm}$, con una longitud no estirada de $600 \mathrm{~mm}$ y una longitud estirada de $870 \mathrm{~mm}$. Sólo la empresa Baumann de Rüti en Suiza, fabrica estos manantiales tan delgados mediante un proceso de conformado en caliente. Los muelles de tirantes helicoidales están fosfatados y aceitados para proteger el sensible acero de la oxidación."154

Durante el proceso de secado, las pilas trabajaron estructuralmente de forma solidaria por compresión. En el extremo inferior de cada uno de los dos muelles helicoidales se conectaron unos tensores de acero cromados de $16 \mathrm{~mm}^{55}$ de diámetro a cada lado como si se tratasen de péndulos. Enganchados con una hembrilla abierta, el tensor descendía las cargas trazando una trayectoria poligonal mediante una sucesión de pletinas solidarizando cada ocho listones a ambos lados hacía las pletinas del suelo. El extremo inferior del tensor en forma de T invertida se anclaba en las hendiduras de la pletina estabilizadora - Stahlschwerter.

52 CONZETT, Jürg. Stapellauf. Pavillon der Schweiz in Hannover. En: Deutsche Bauzeitung db. Vol. 134. Nr. 9. 2000. Pág. 95.

53 AAVV. Klangkörperbuch. Birkhäuser. Basel. 2000. ISBN: 3-7643-6324-X. Pág. 216.

54 Idem. Pág. 216. Traducción de la autora: "Sie bestehen aus 25 Millimeter starkem Runddraht, besitzen 20 Windungen, von denen 15 aktiv gedehnt werden. Ihr Aussendurchmesser beträgt $130 \mathrm{~mm}$, die ungedehnte Länge 600 Millimeter und die gespannte Länge $870 \mathrm{~mm}$. So schlanke Federn stellte in der Schweiz einzig die Firma Baumann in Rüti her, weil sie dazu ein Warmverformungsverfahren benutzt. Die Schraubenzugfedern sind phosphatiert und eingeölt, um den empfindlichen Federstahl vor Rost zu schützen."

55 Idem. Pág. 227. 


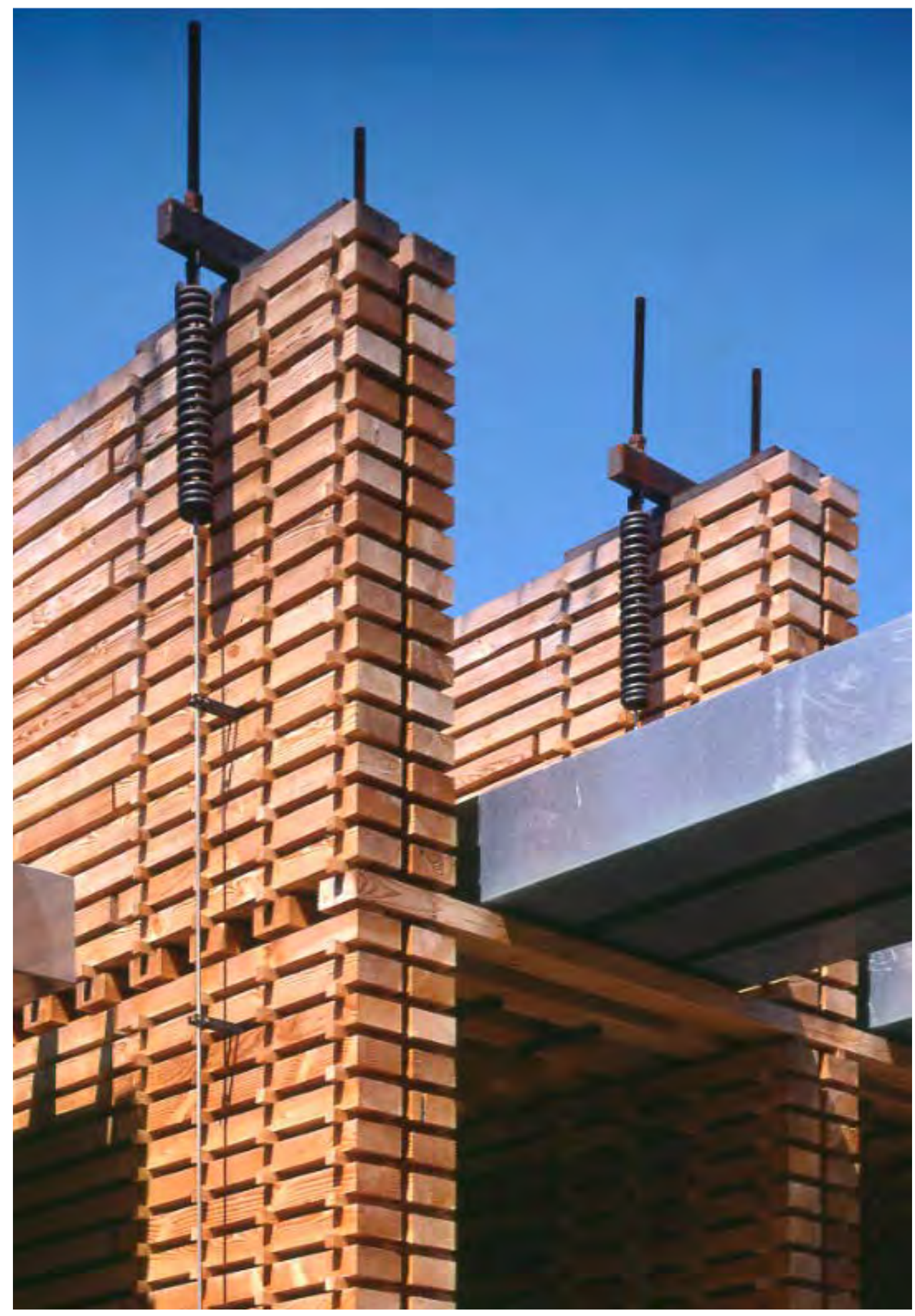

Figura 64.

Postensado / Pabellón helvético / Hannover / 2000 

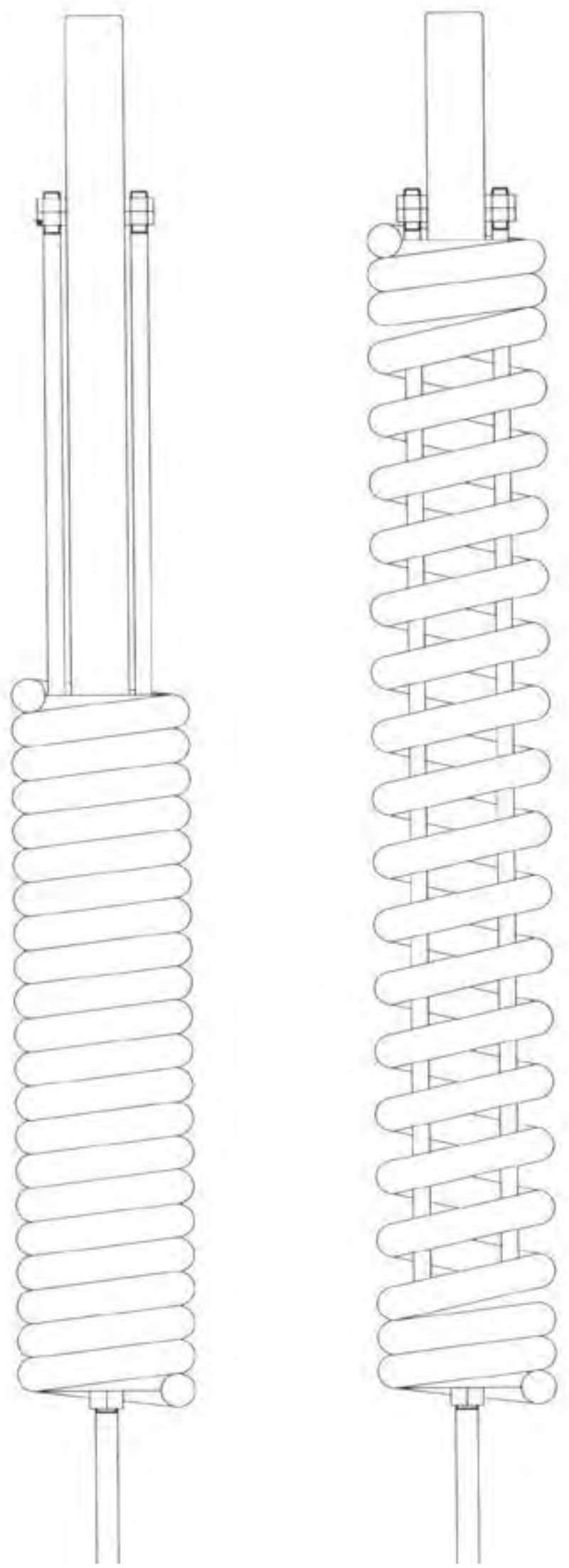

Figura 65.

Muelles de tirantes helicoidales 

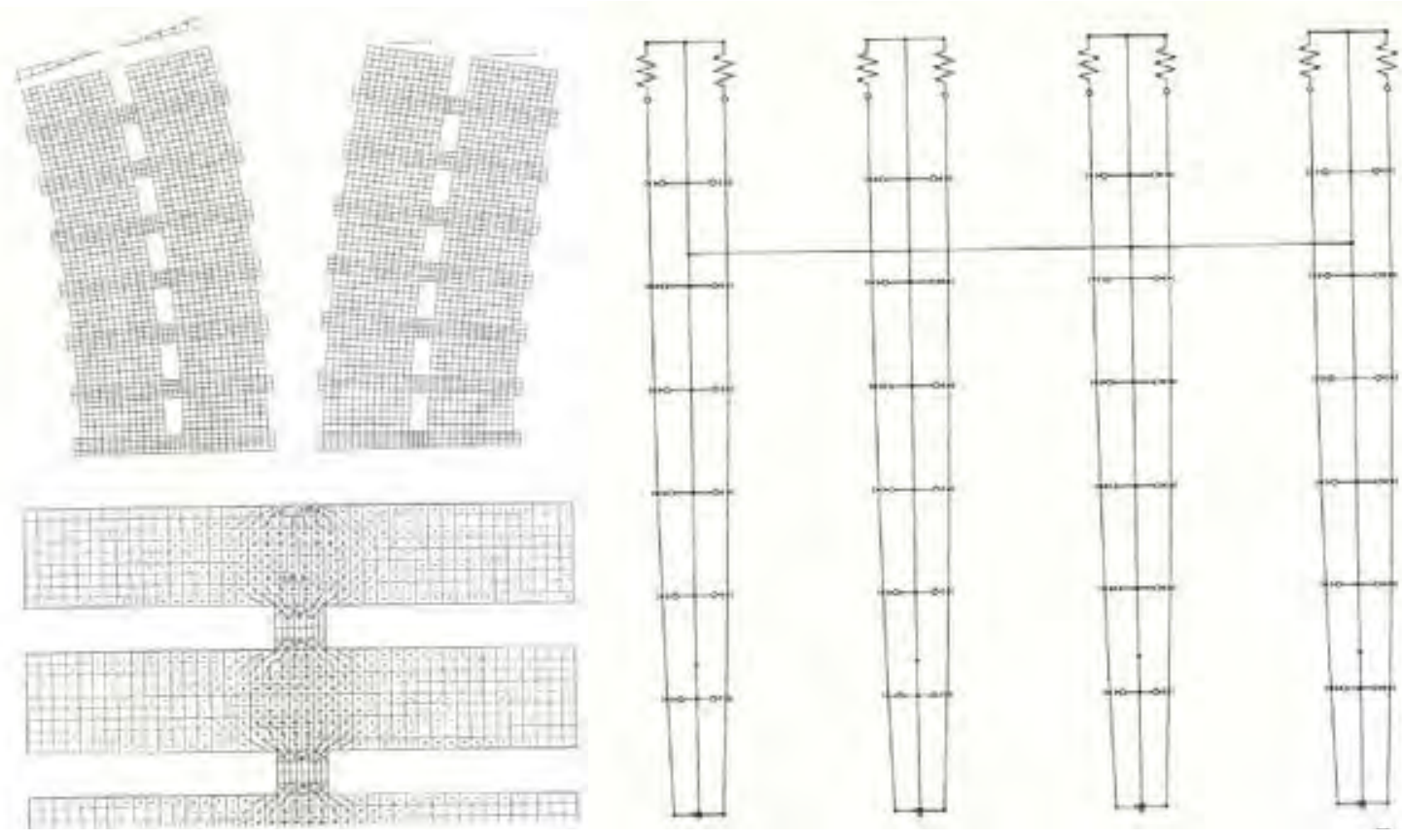

Figura 66.

Sistema de cálculo estructural / Pabellón helvético / Hannover / 2000

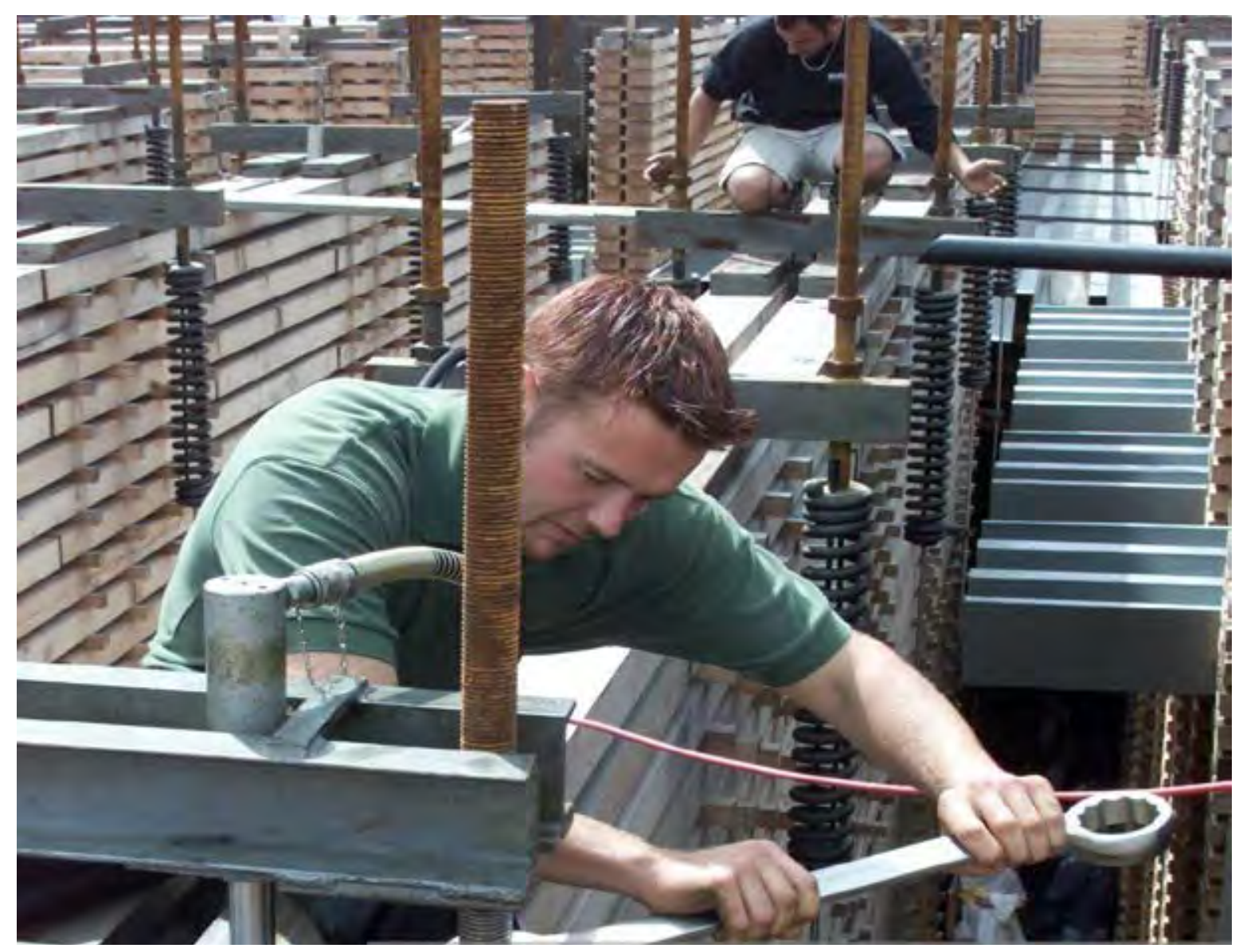

Figura 67.

Ajuste durante la Expo / Pabellón helvético / Hannover / 2000 
"Cuando el muelle se haya acortado en $90 \mathrm{~mm}$, deberá volver a apretarse. Para ello se utiliza el sistema de pretensado, que consiste en una bomba hidráulica accionada por motory dos cilindros de presión con yugo de acero. Para volver a apretar los muelles helicoidales, los cilindros de presión se colocan en las espadas de acero superiores. El yugo se coloca sobre las varillas roscadas superiores de los resortes de tensión en espiral y se fija a ellas con tuercas. Cuando los cilindros presionan el yugo hacia arriba, los dos resortes de tensión helicoidales se vuelven a apretar simultáneamente. El equipo de reajuste estaba formado por tres personas. Dos personas llevan el equipo pesado de $80 \mathrm{~kg}$ sobre los techos y durante el reapriete una tercera persona comprueba la estanqueidad del martillo de acero cromado en el extremo inferior de los tirantes." 56 Jürg Conzett

El sistema de cálculo estructural estaba diseñado para evitar curvaturas en forma de S, pandeo lateral y posibles apariciones de deformaciones. Debido a la utilización de un material como la madera a compresión con un comportamiento natural e imprevisible; cada pared tuvo que considerar diferentes cambios de volumen por contracción -Schwinden- e hinchamiento de aproximadamente $17 \mathrm{~cm}$, además de la deformación por fluencia lenta -Kriechen- de otros $6 \mathrm{~cm}$ bajo la carga constante ${ }^{57}$. Aunque hubo un cuidado en que la materia fuera semejante, incluso del mismo aserradero; sin embargo, fue complicado establecer una previsión exacta. La madera fue fresca, verde, con un contenido medio de humedad del $22 \%{ }^{58}$. Normalmente una vez por semana la estructura fue regulada, ajustando la perdida de tamaño de los listones a la tensión de los muelles.

A tres kilómetros del estudio de Zumthor, en Chur se construyó un mock-up a tamaño real a principios de 1999, antes de comenzar la construcción. Además de realizar pruebas sobre la capacidad acústica para la música programada; pudo testar se el sistema estructural propuesto con madera fresca durante meses.

56 CONZETT, Jürg. Stapellauf. Pavillon der Schweiz in Hannover. En: Deutsche Bauzeitung db. Vol. 134. Nr. 9. 2000. Pág. 102. Traducción de la autora: "Wenn sich die Feder um 90 mm verkürzt hat, muss nachgespannt werden. Dazu dient die Nachspannanlage, die aus einer motorbetriebenen Hydraulikpumpe und zwei Druckzylindern mit Stahljoch besteht. Zum Nachspannen der Schraubenzufedern werden die Druckzylinder auf die oberen Stahlschwerter abgestellt. Das Joch wird über die oberen Gewindestangen der Schraubenzugfedern gestülpt und daran mit Muttern befestigt. Wenn die Zylinder das Joch nach oben pressen, werden beide Schraubenzugfedern gleichzeitig nachgespannt. Das Nachspannteam bestand aus drei Personen. Zwei tragen die $80 \mathrm{~kg}$ schwere Apparatur über die Dächer und während de Nachspannens kontrolliert ein Dritter das Festsitzen des Chromstah/hammers am unteren Ende der Zugstangen."

57 AAVV. Klangkörperbuch. Birkhäuser. Basel. 2000. ISBN: 3-7643-6324-X. Pág. 221.

58 CONZETT, Jürg. Stapellauf. Pavillon der Schweiz in Hannover. En: Deutsche Bauzeitung db. Vol. 134. Nr. 9. 2000. Pág. 95. 
[Manual de instrucciones en 34 pasos]

I.

CIMENTACIÓN
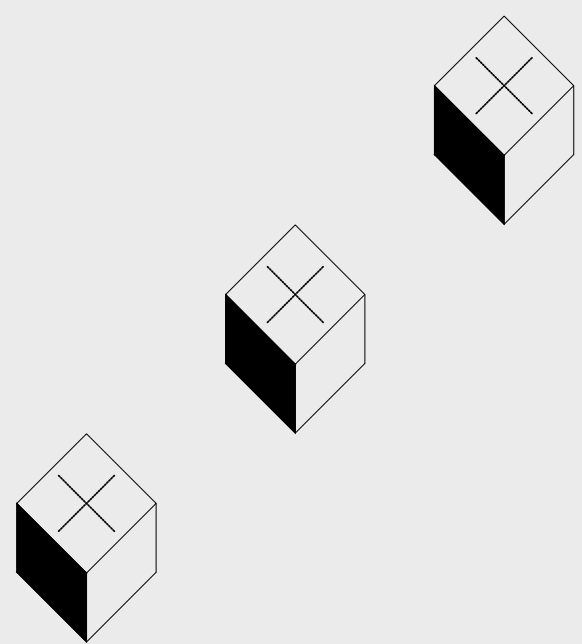

1

II.

PLACAS DE ANCLAJE METÁLICAS

$\$$

1.
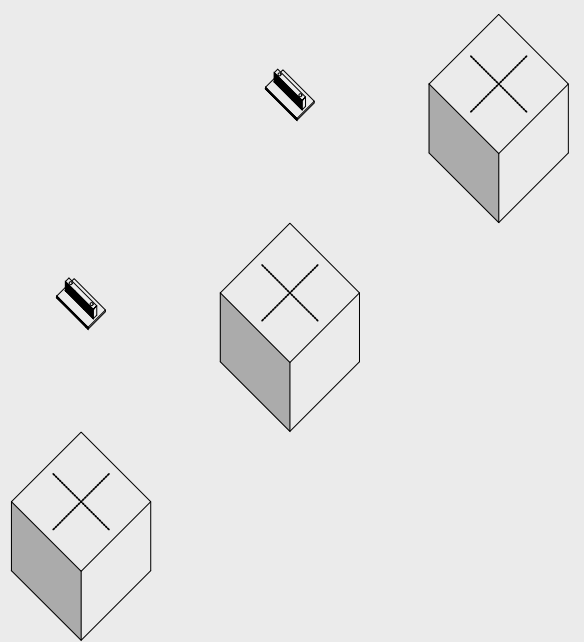
III.

PLETINAS DE ACERO

8

8

$\$$

8

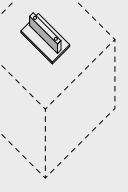

1

IV.

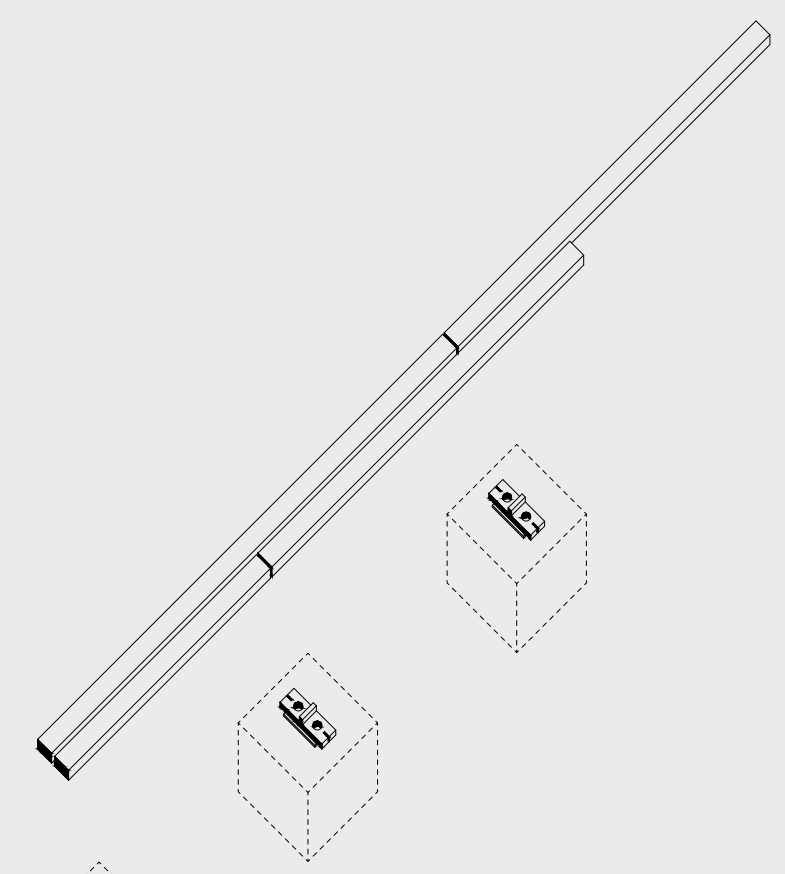

LISTONES DE MADERA: PRIMERA CAPA

_LONGITUDINAL 
V.

SEPARADORES: PRIMERA CAPA

_10 FILAS

- TRANSVERSAL

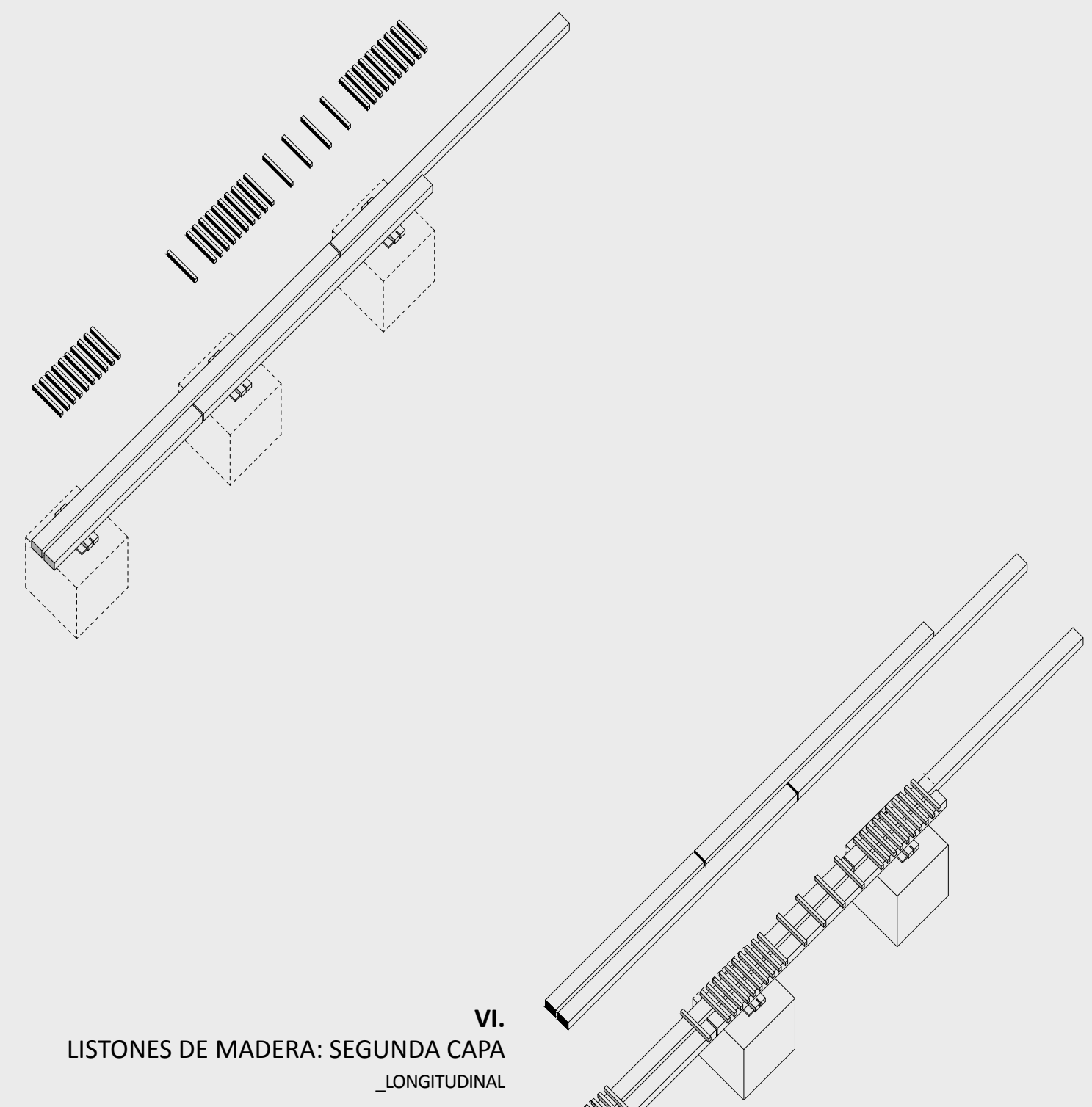


VII.

SEPARADORES:SEGUNDA CAPA _10 FILAS

_TRANSVERSAL

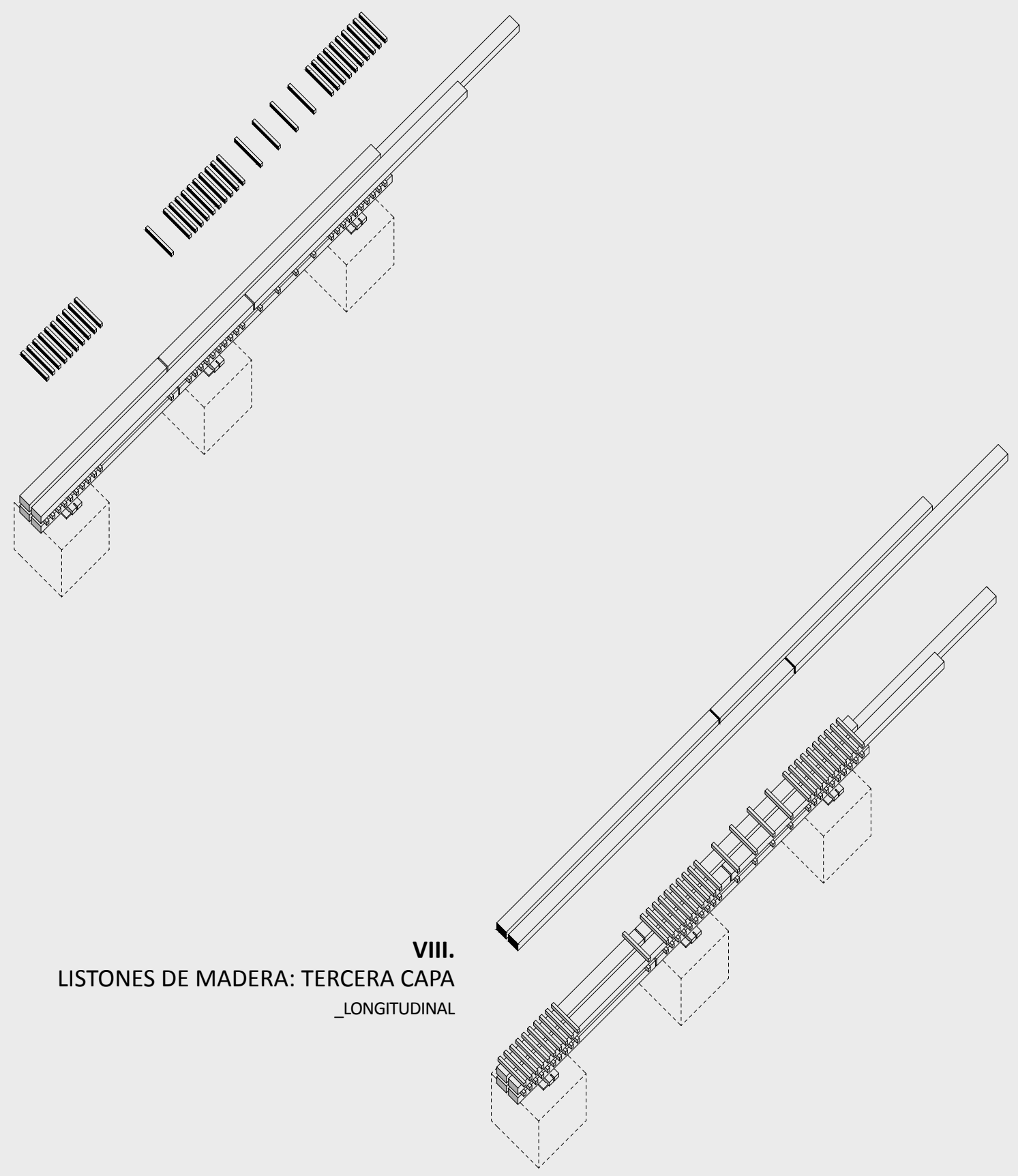


IX.

SEPARADORES: TERCERA CAPA

_10 FILAS

_TRANSVERSAL

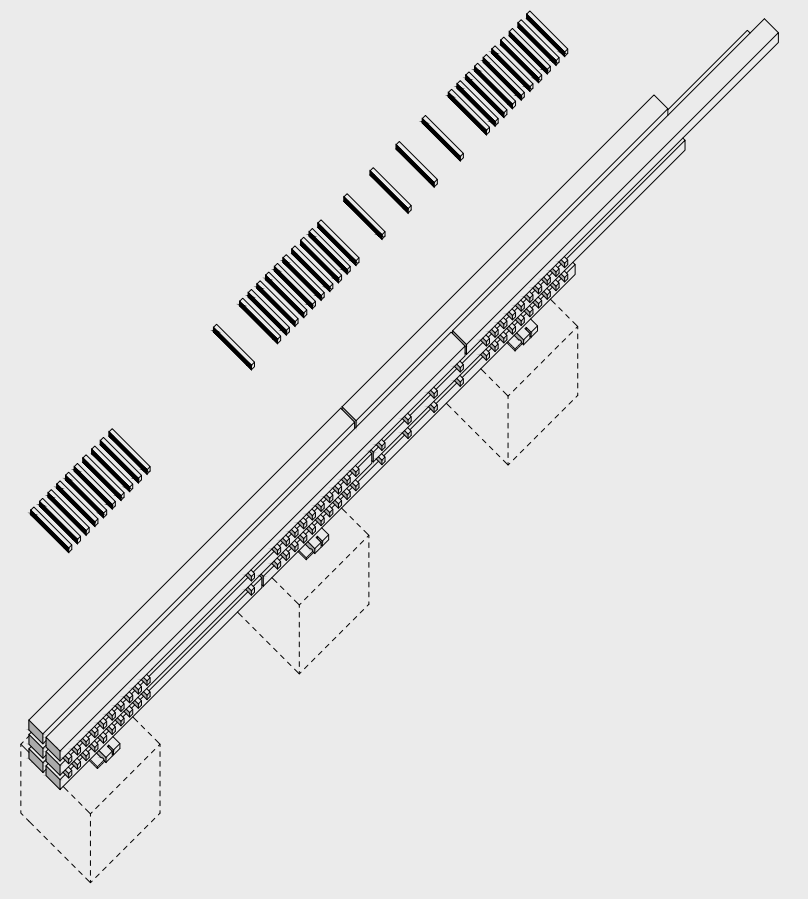

X.

LISTONES DE MADERA: CAPAS 4 - 12

SEPARADORES: CAPAS 4 - 11 
XI.

SEPARADORES: DUODÉCIMA CAPA

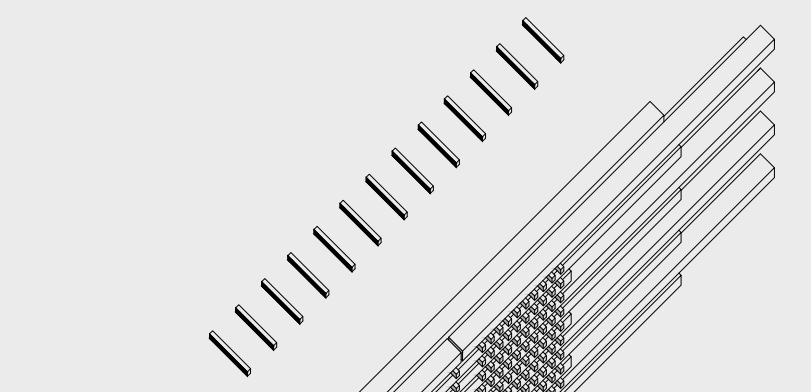
_ 4 FILAS

TRANSVERSAL

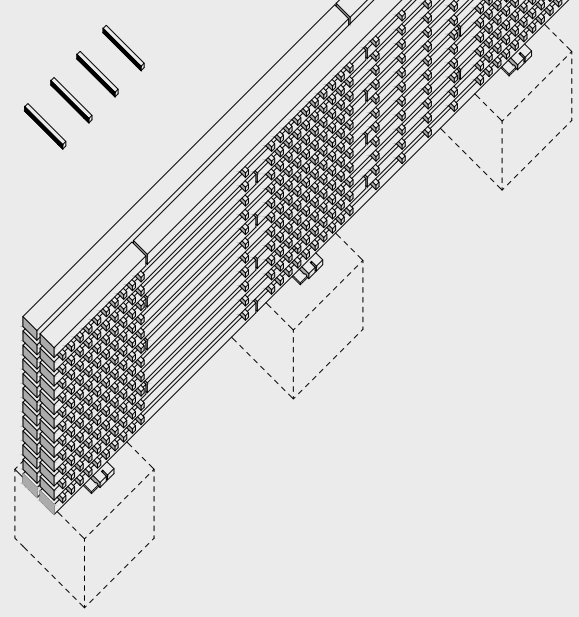

XII.

LISTONES DE MADERA: CAPAS $13-37$

SEPARADORES: CAPAS $13-36$

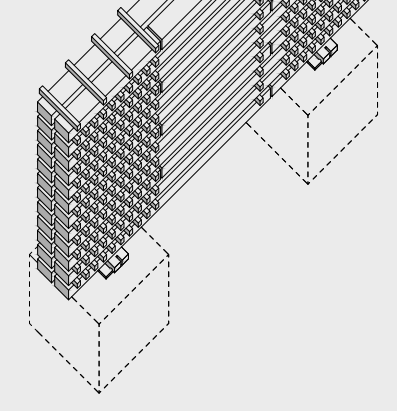




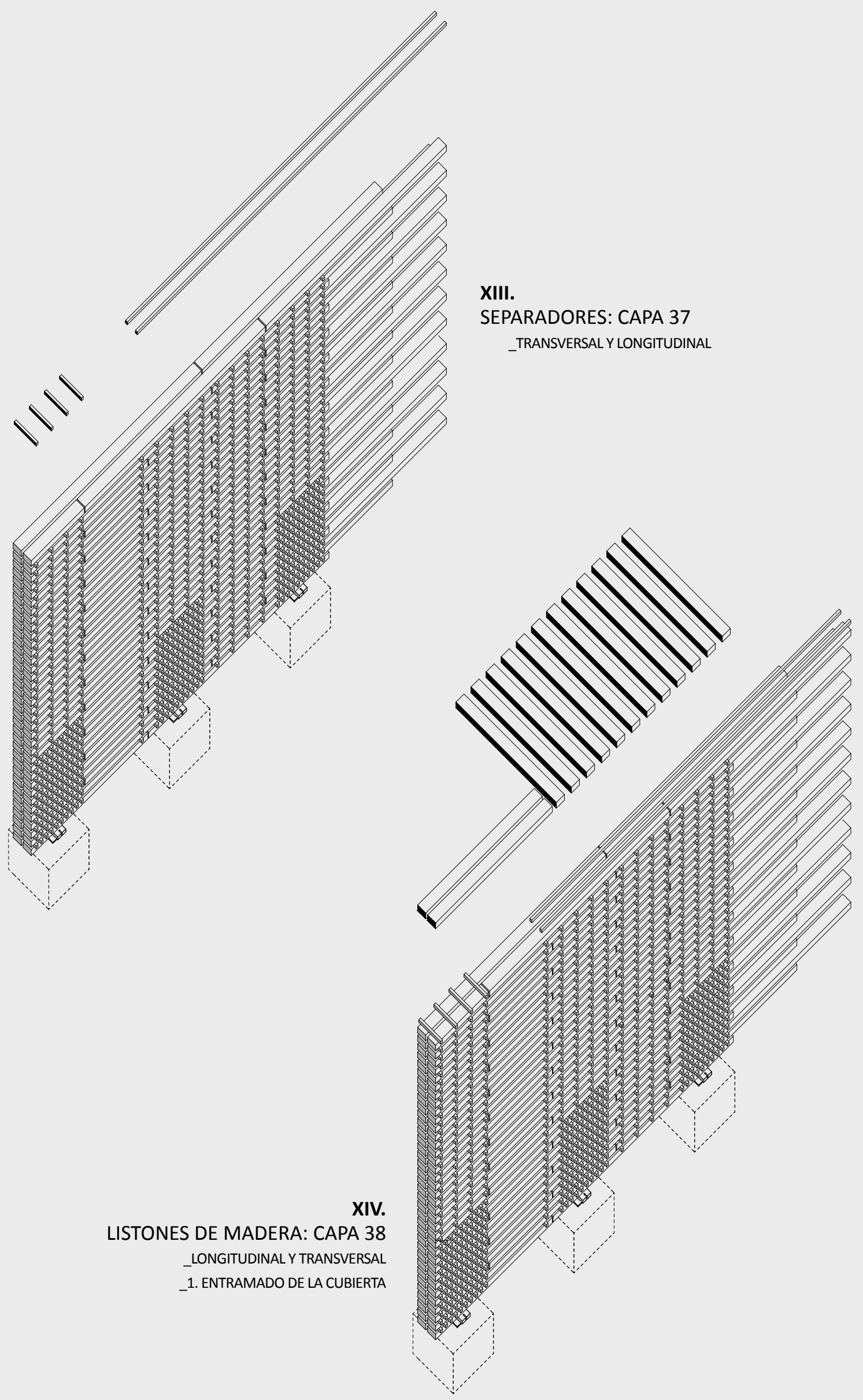




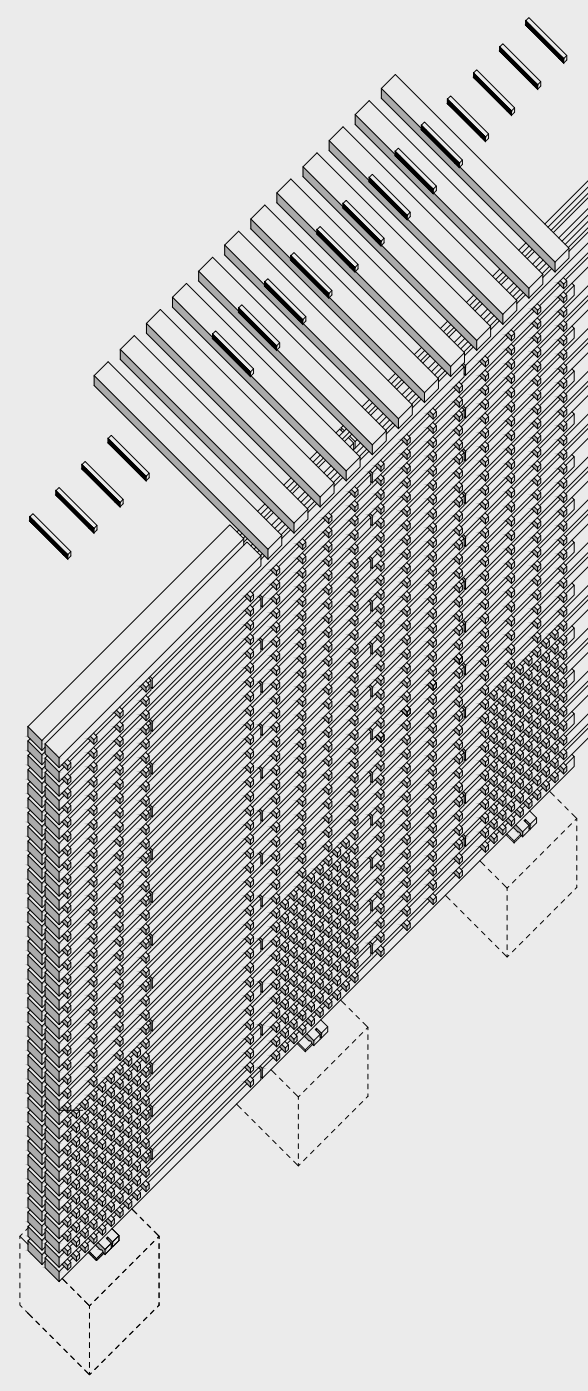

XV.

SEPARADORES: CAPA 38

_TRANSVERSAL

XVI.

LISTONES DE MADERA: CAPA 39

_LONGITUDINAL 


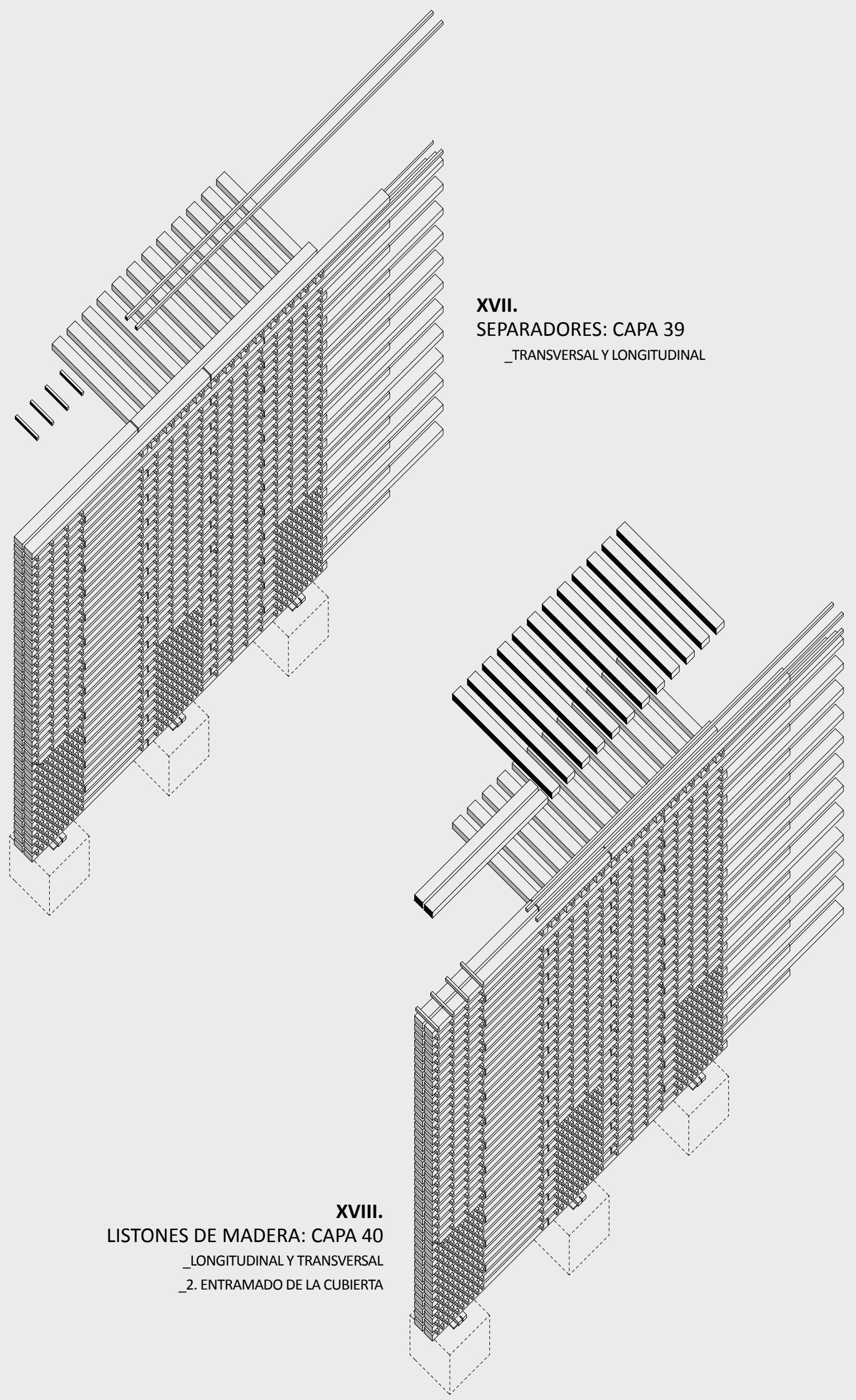




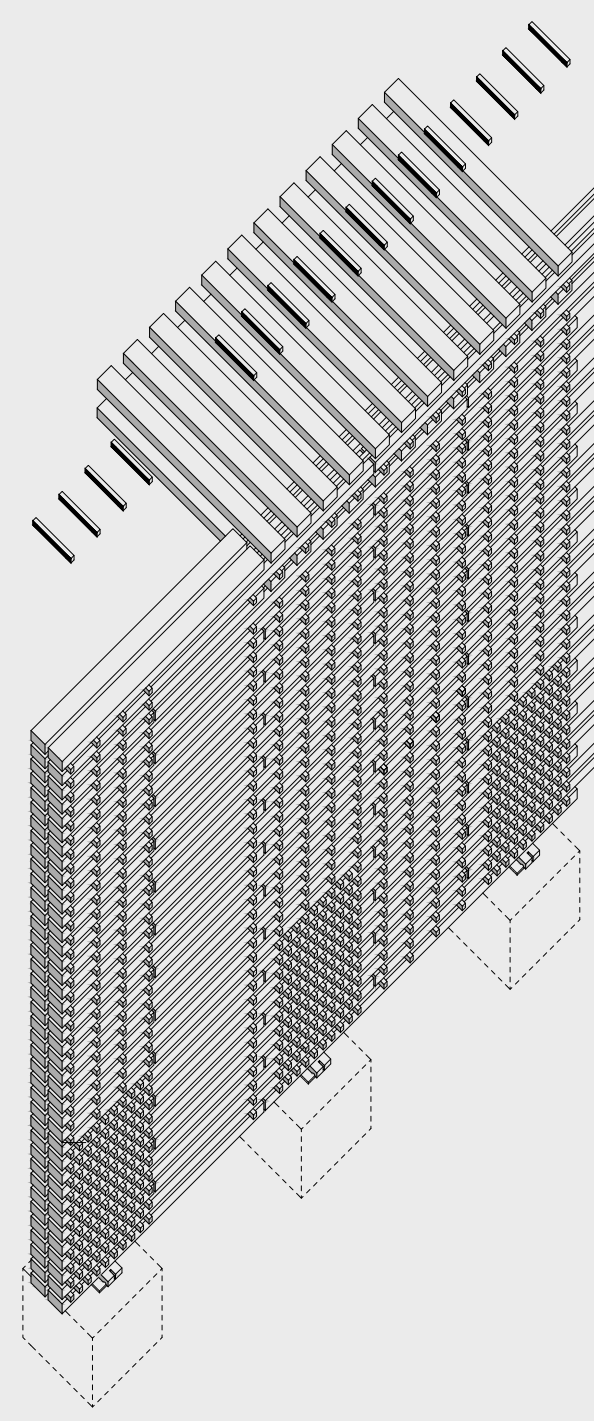

XIX.

SEPARADORES: CAPA 40

_TRANSVERSAL

$\mathbf{X X}$.

LISTONES DE MADERA: CAPA 41

_LONGITUDINAL 


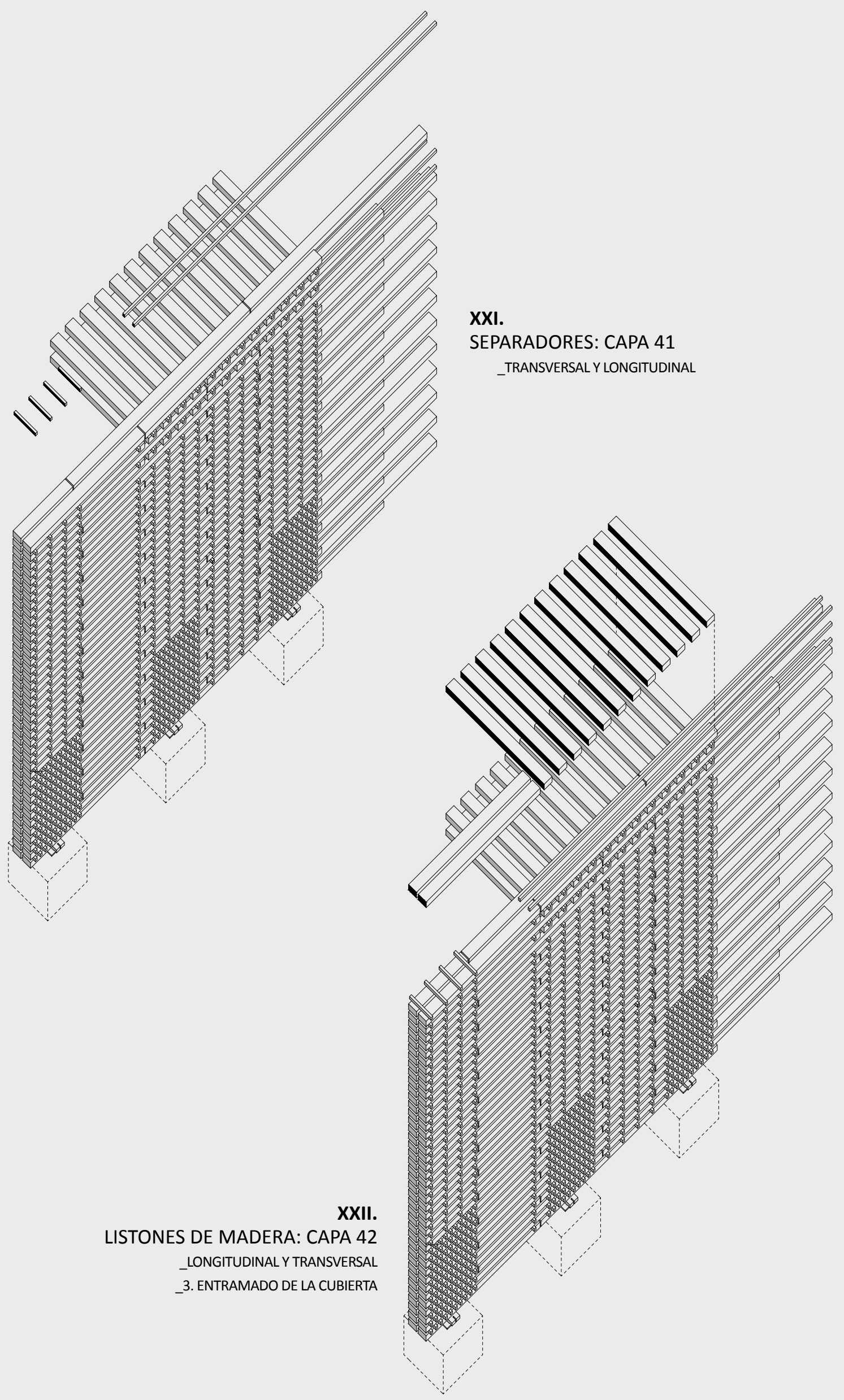




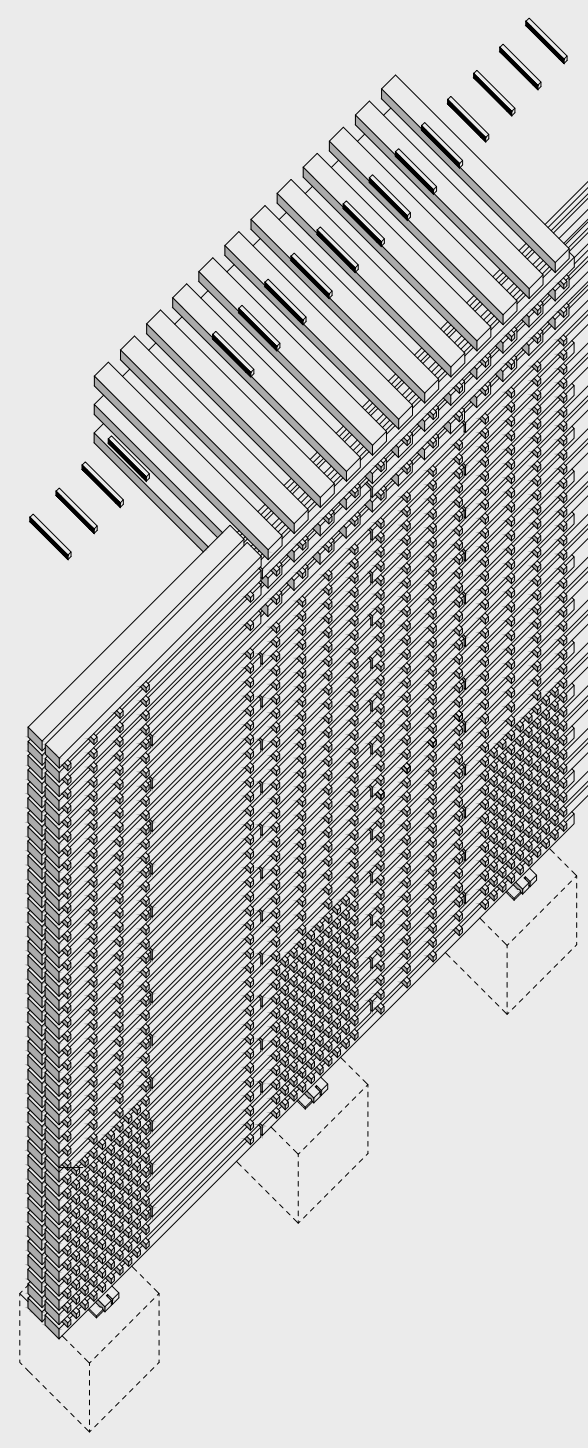

XXIII.

SEPARADORES: CAPA 42

_TRANSVERSAL

XXIV.

LISTONES DE MADERA: CAPA 43

_LONGITUDINAL

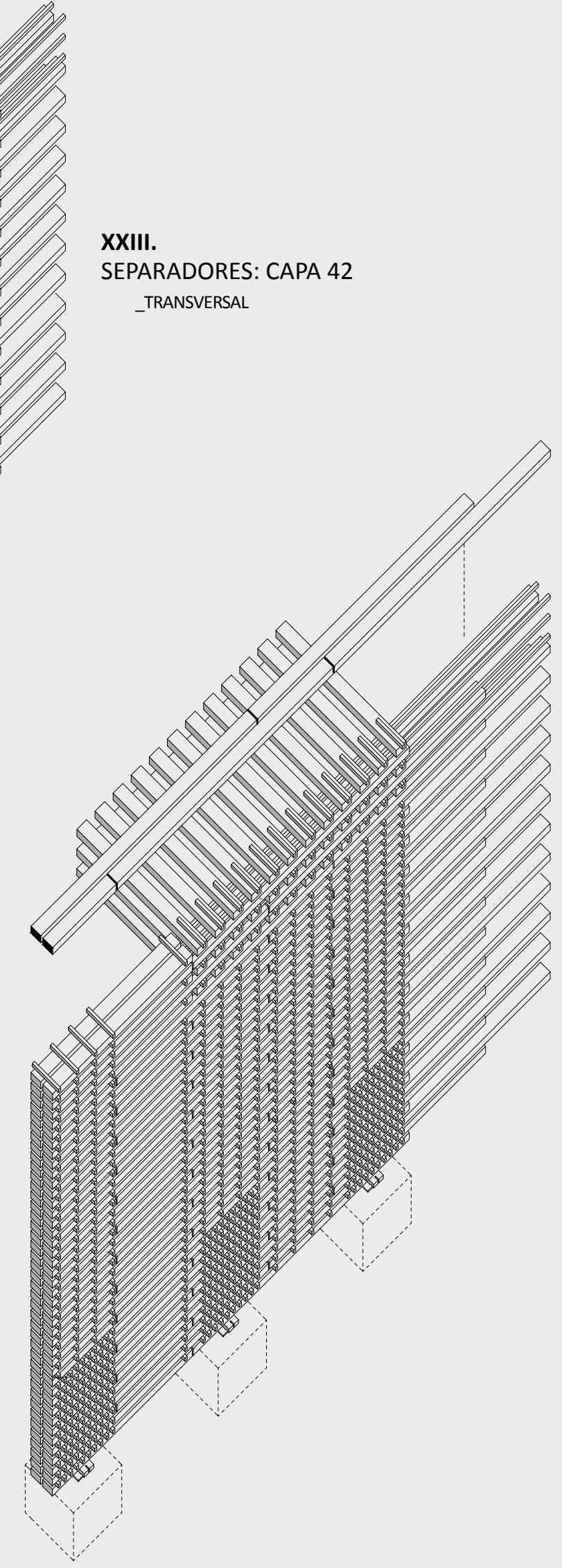




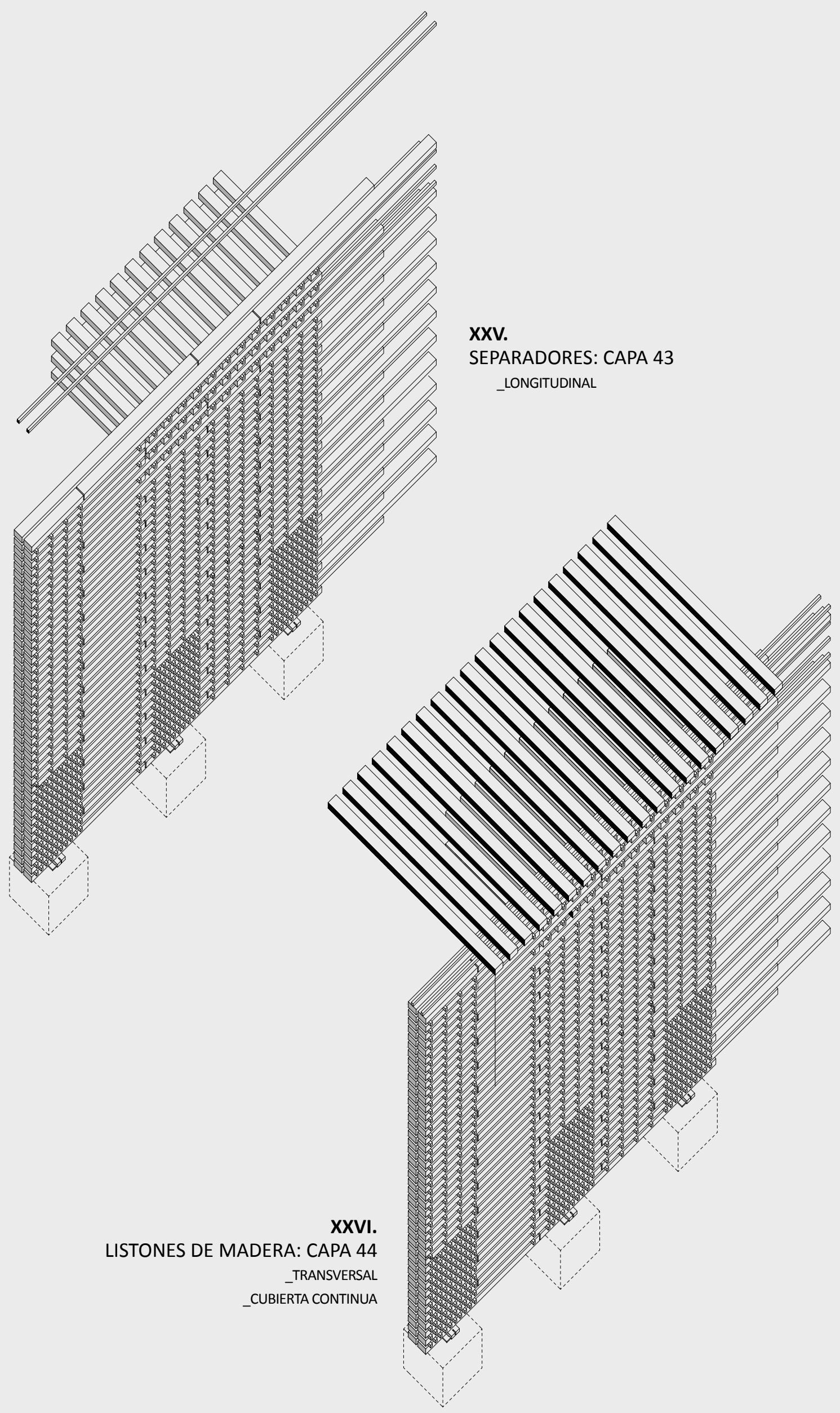




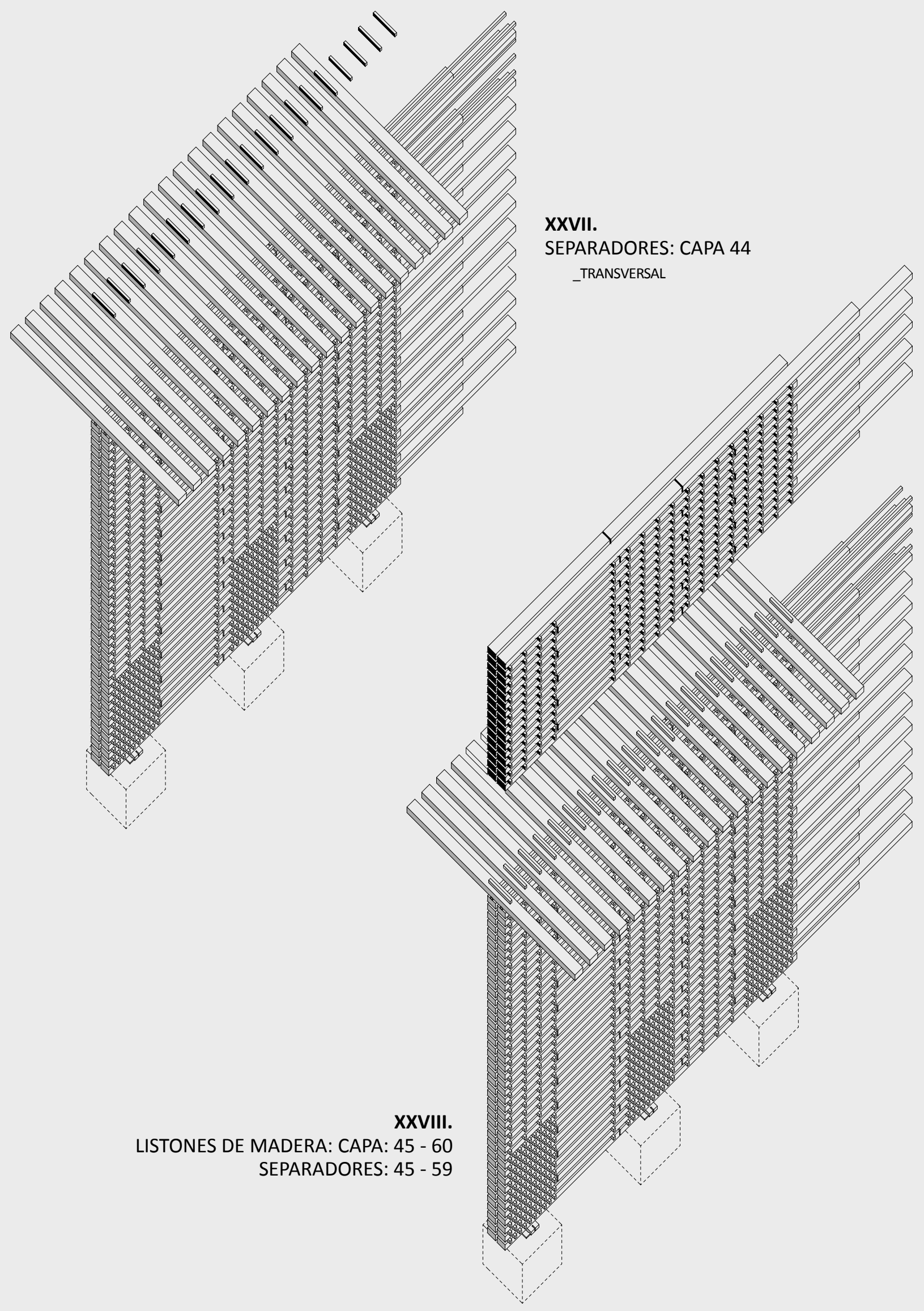




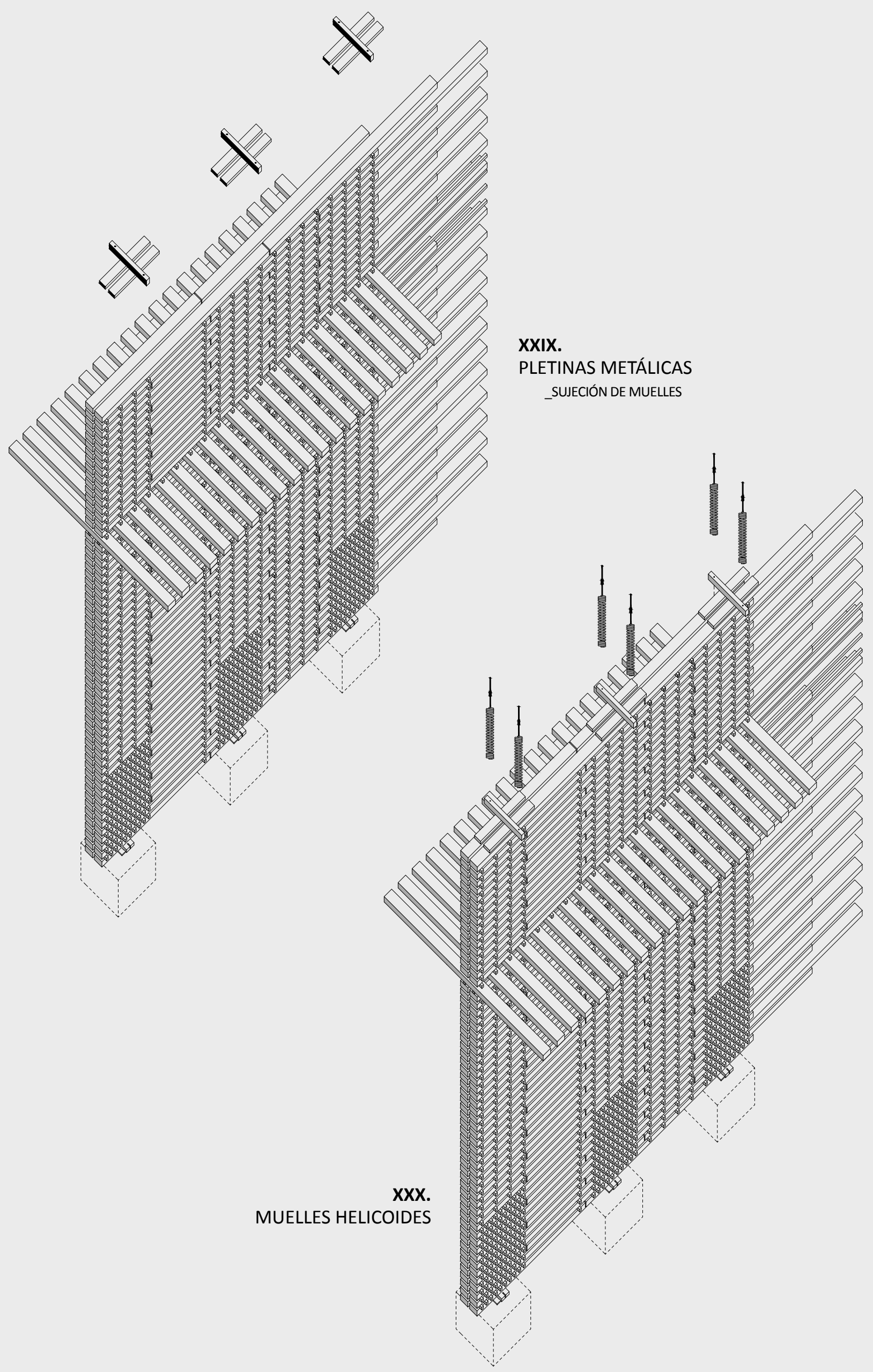




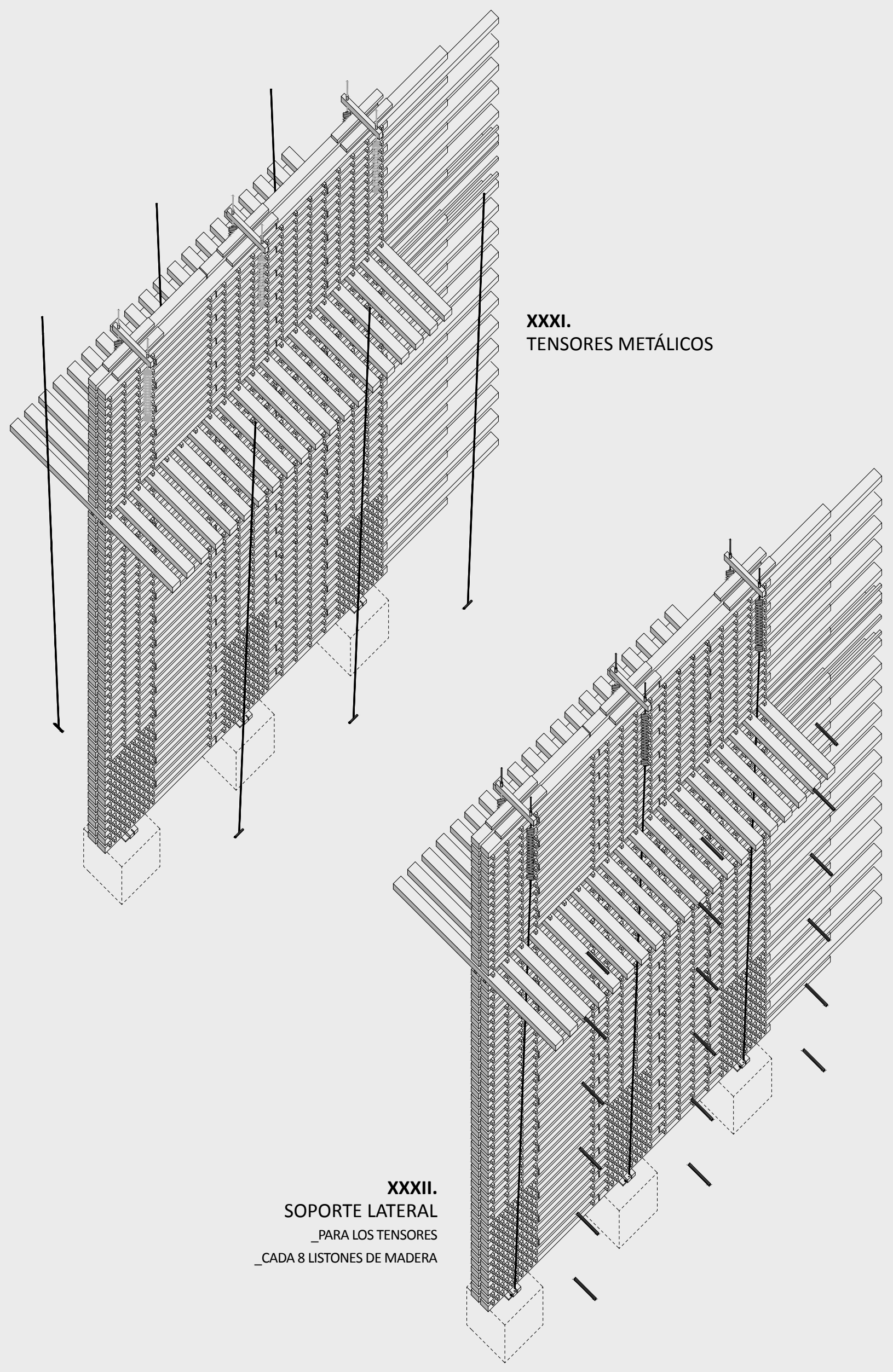




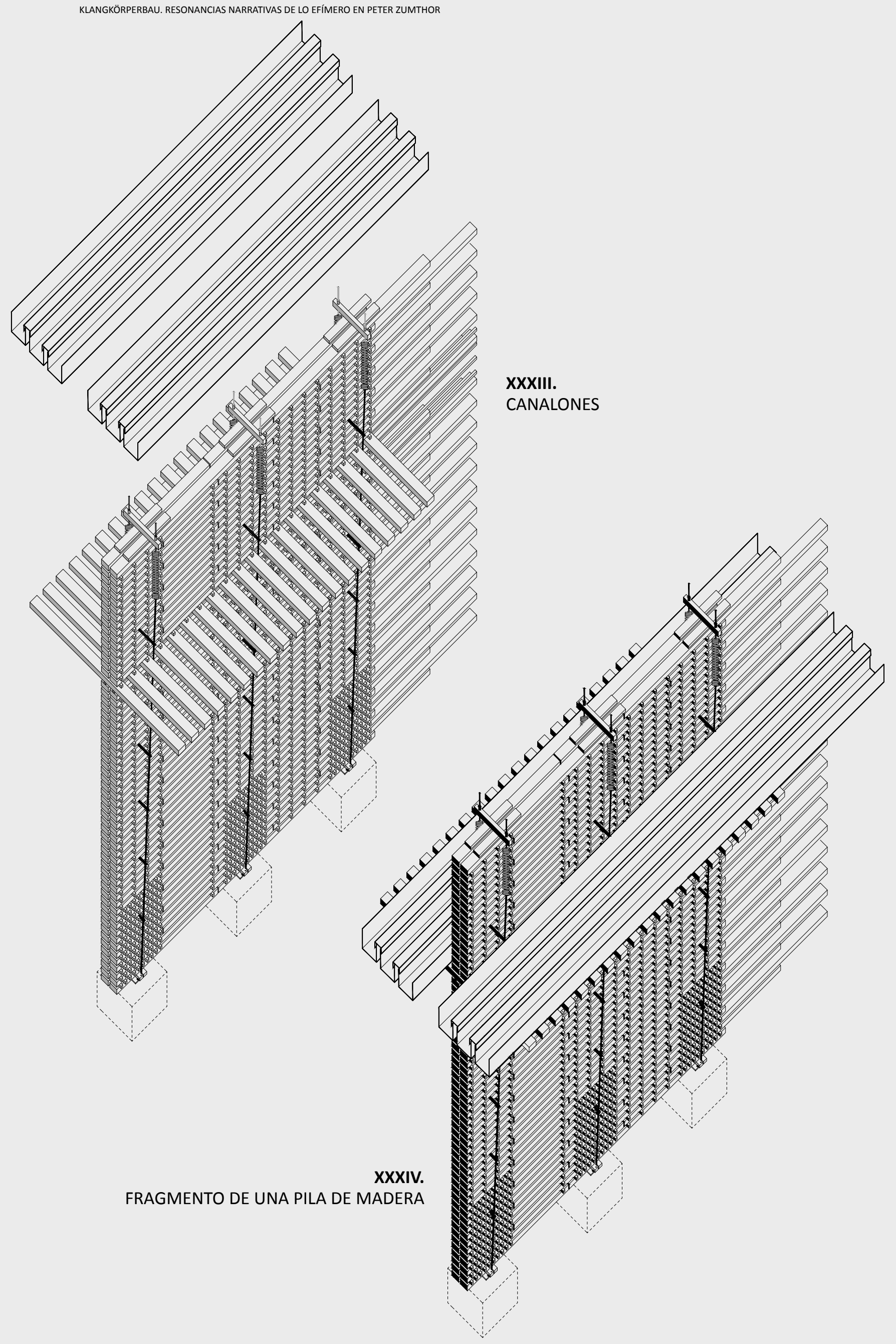




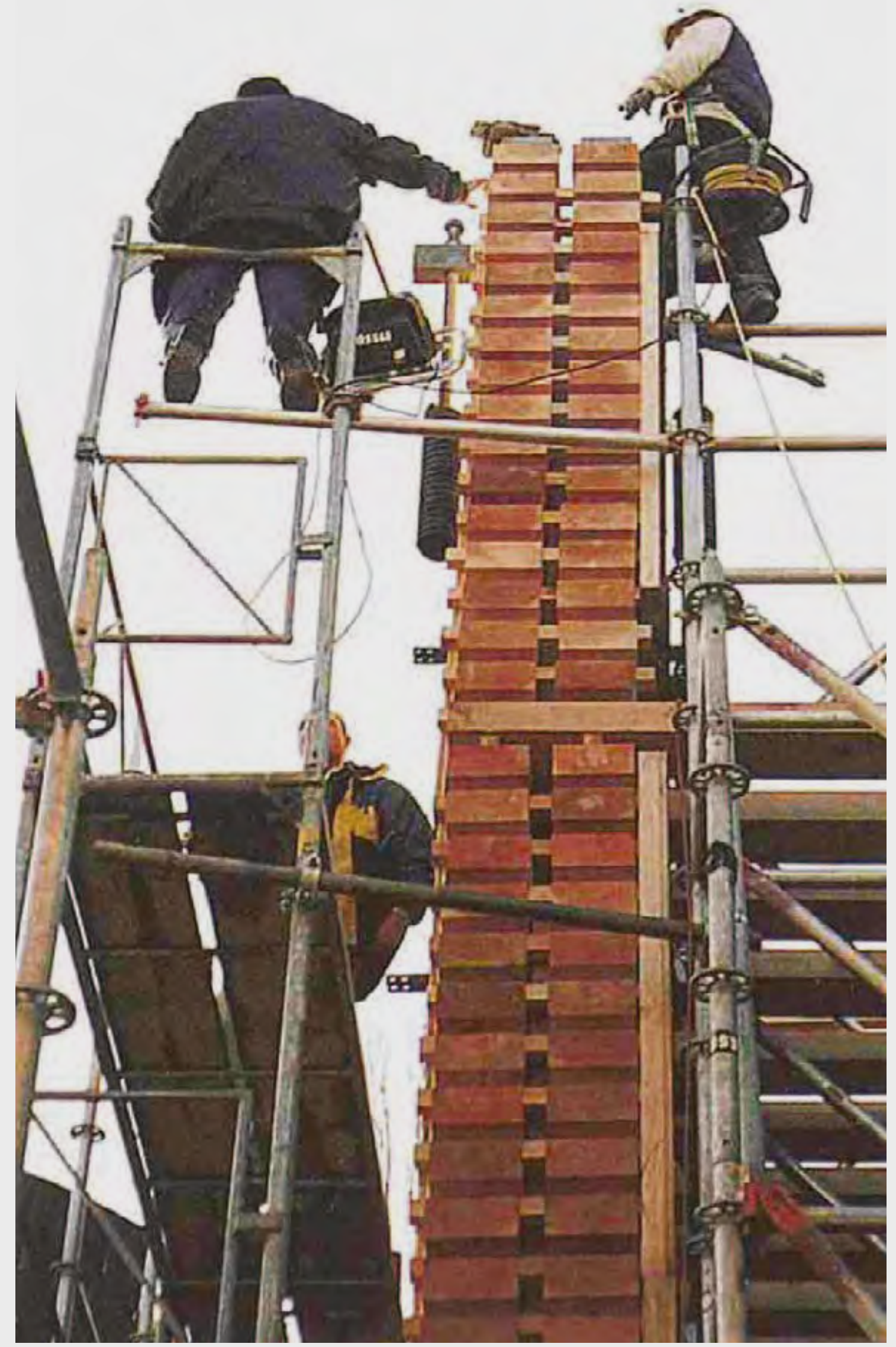

Figura 68 - 102.

Manual de instrucciones en 34 pasos / Pabellón helvético 


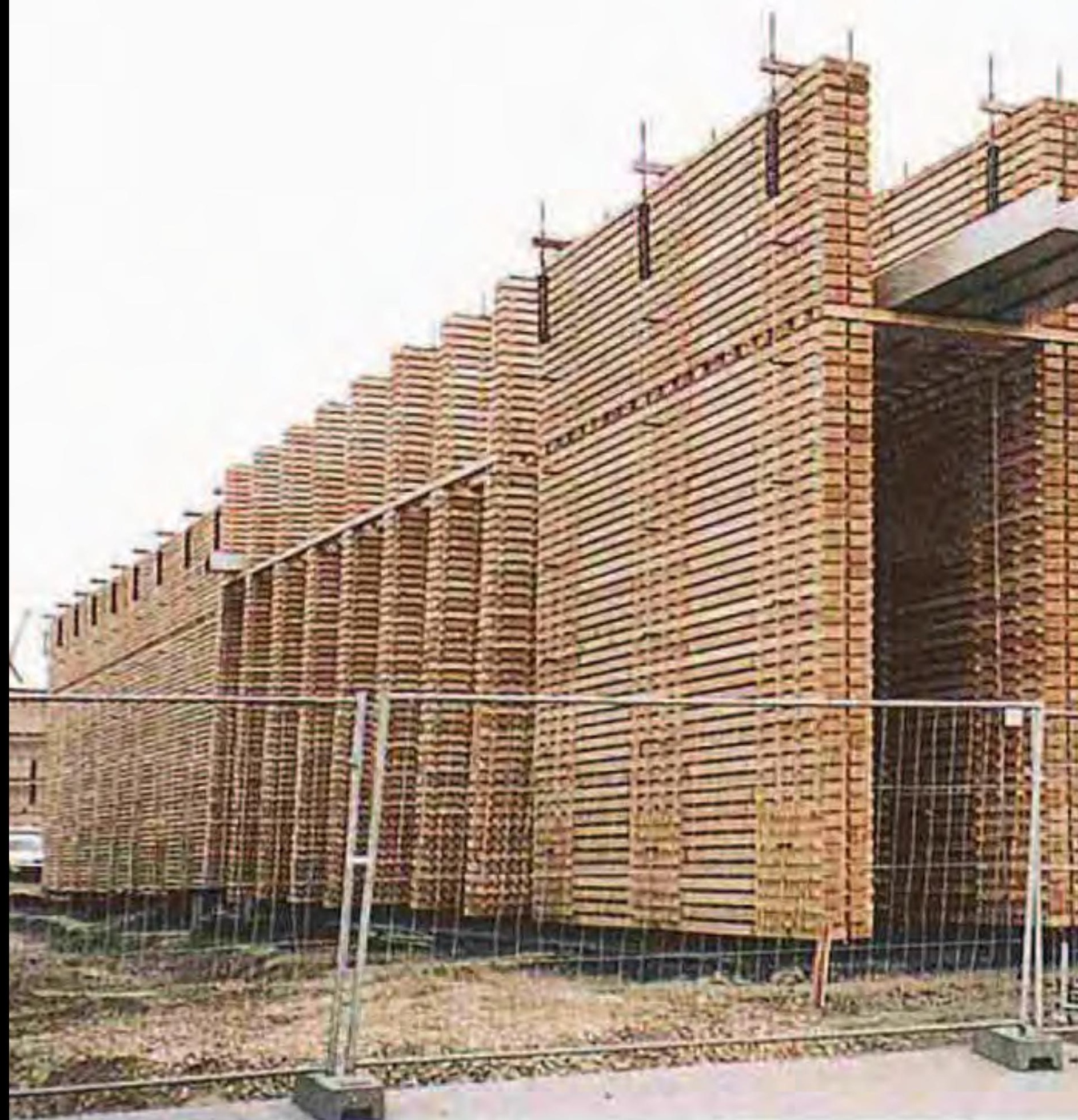



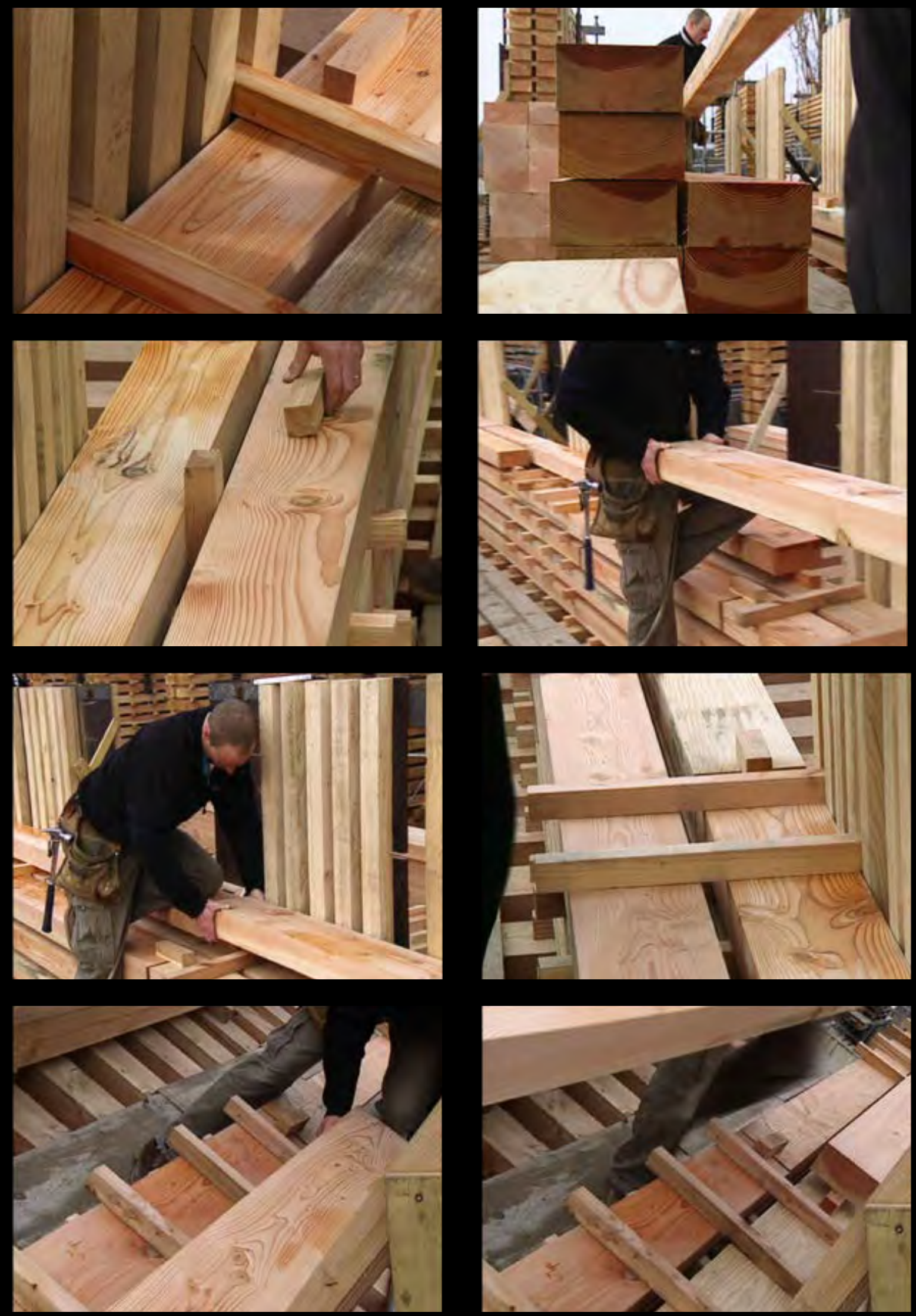

Figura 104 - 111.

Proceso de construcción / Pabellón helvético / Hannover / 2000 

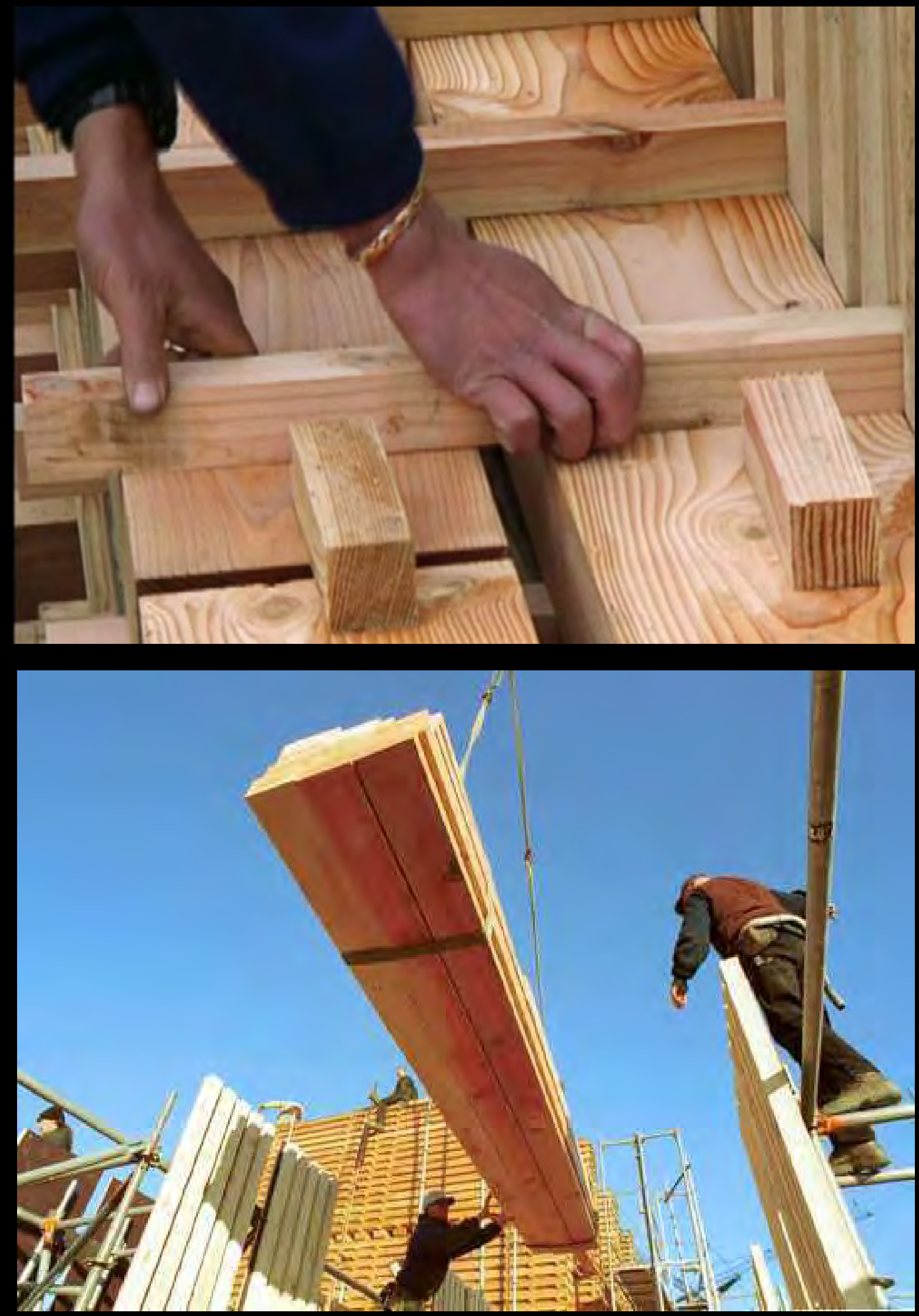

Figura 112 - 113

Proceso de construcción / Pabellón helvético / Hannover / 2000 

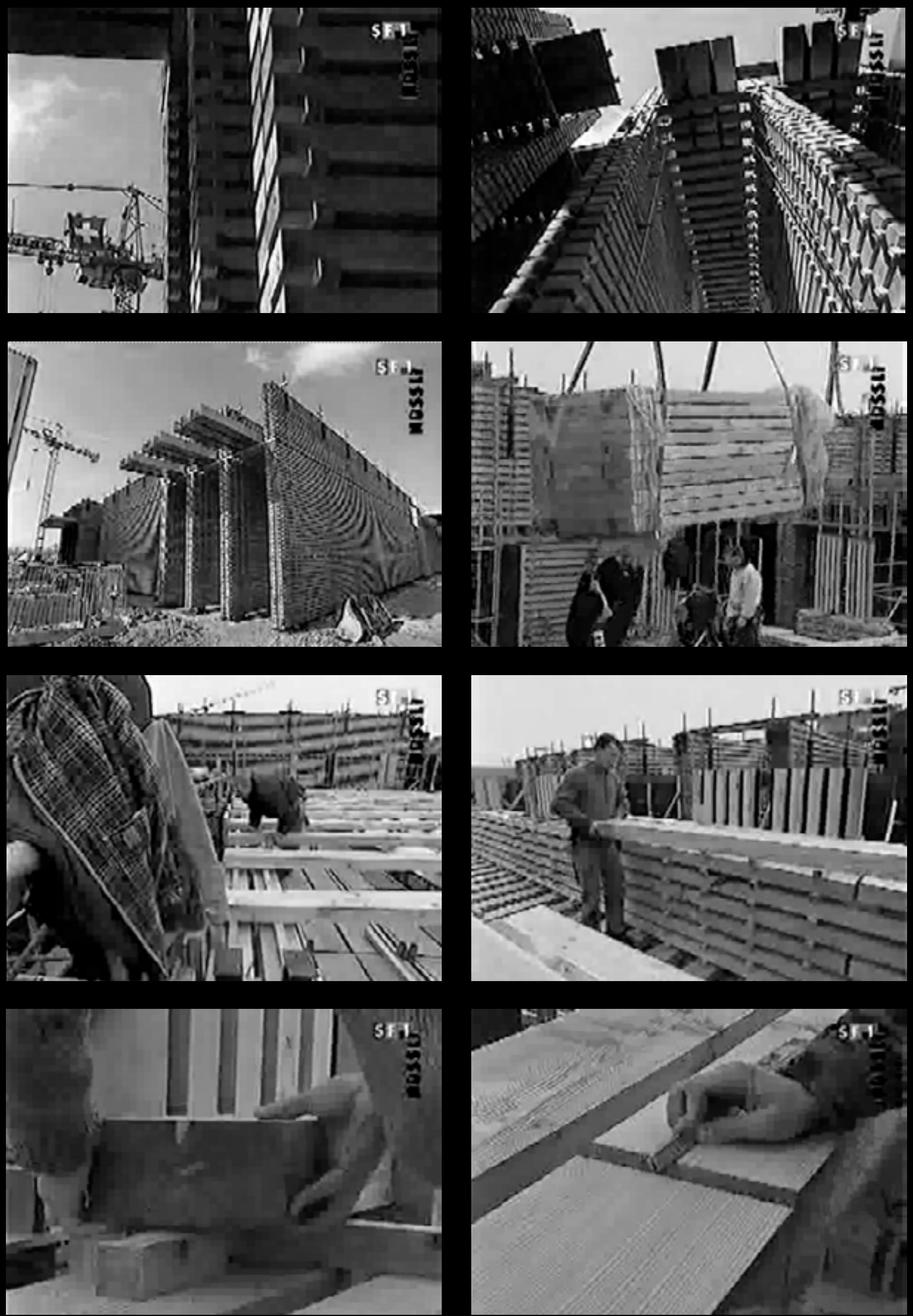

Figura 114 - 121.

Proceso de construcción / Pabellón helvético / Hannover / 2000 

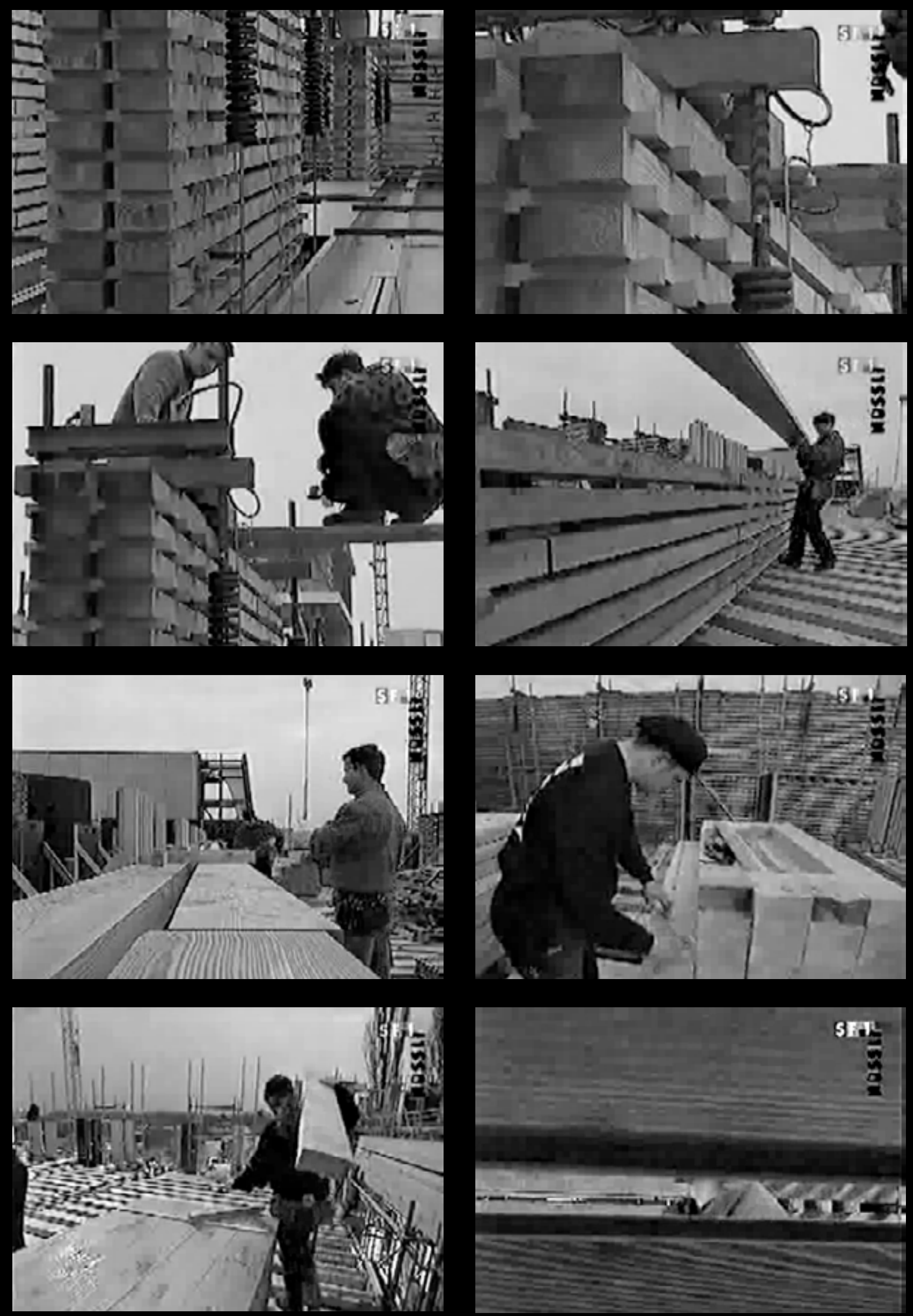

Figura 122 - 129

Proceso de construcción / Pabellón helvético / Hannover / 2000 

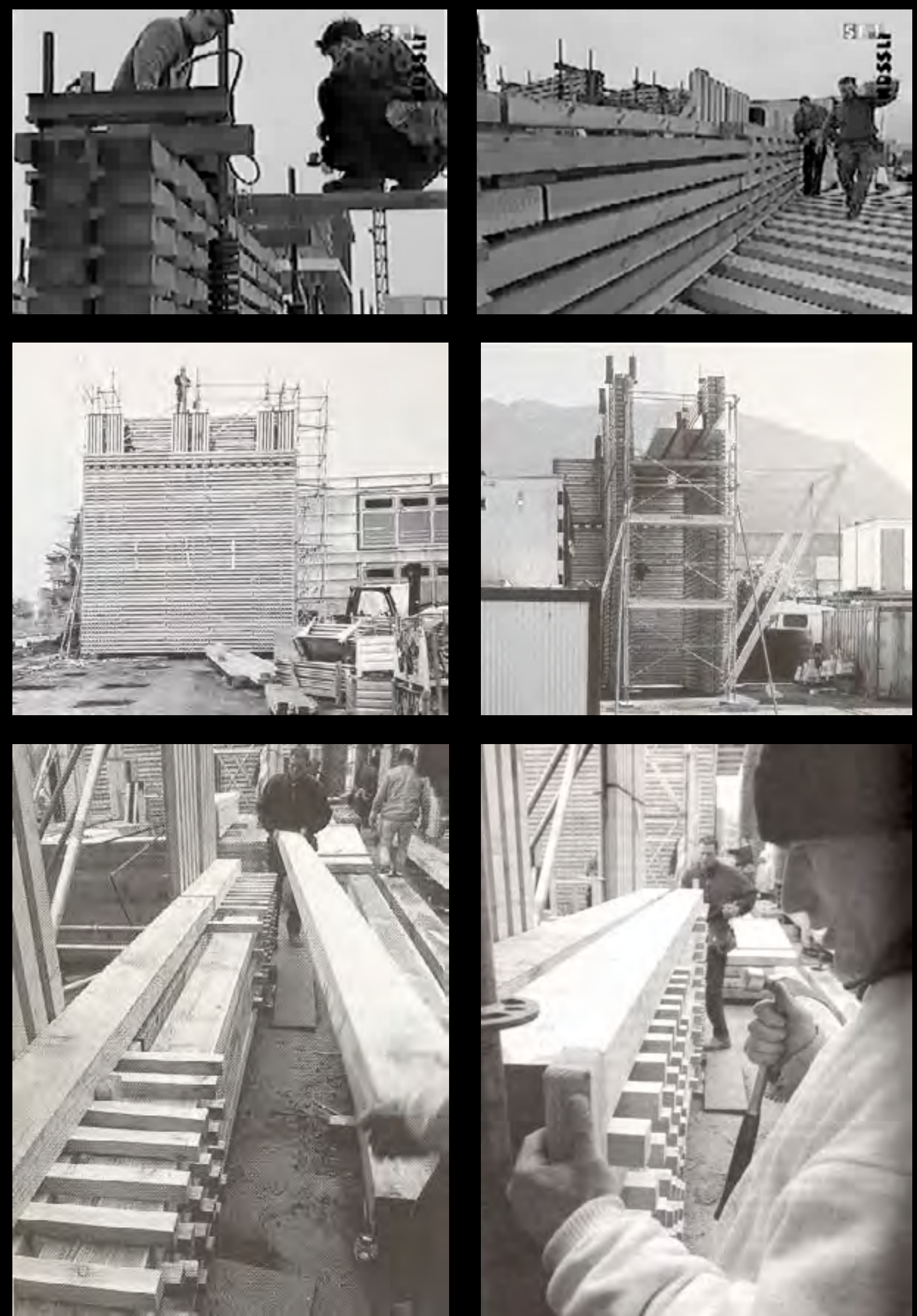

Figura 130 - 135.

Proceso de construcción / Pabellón helvético / Hannover / 2000 


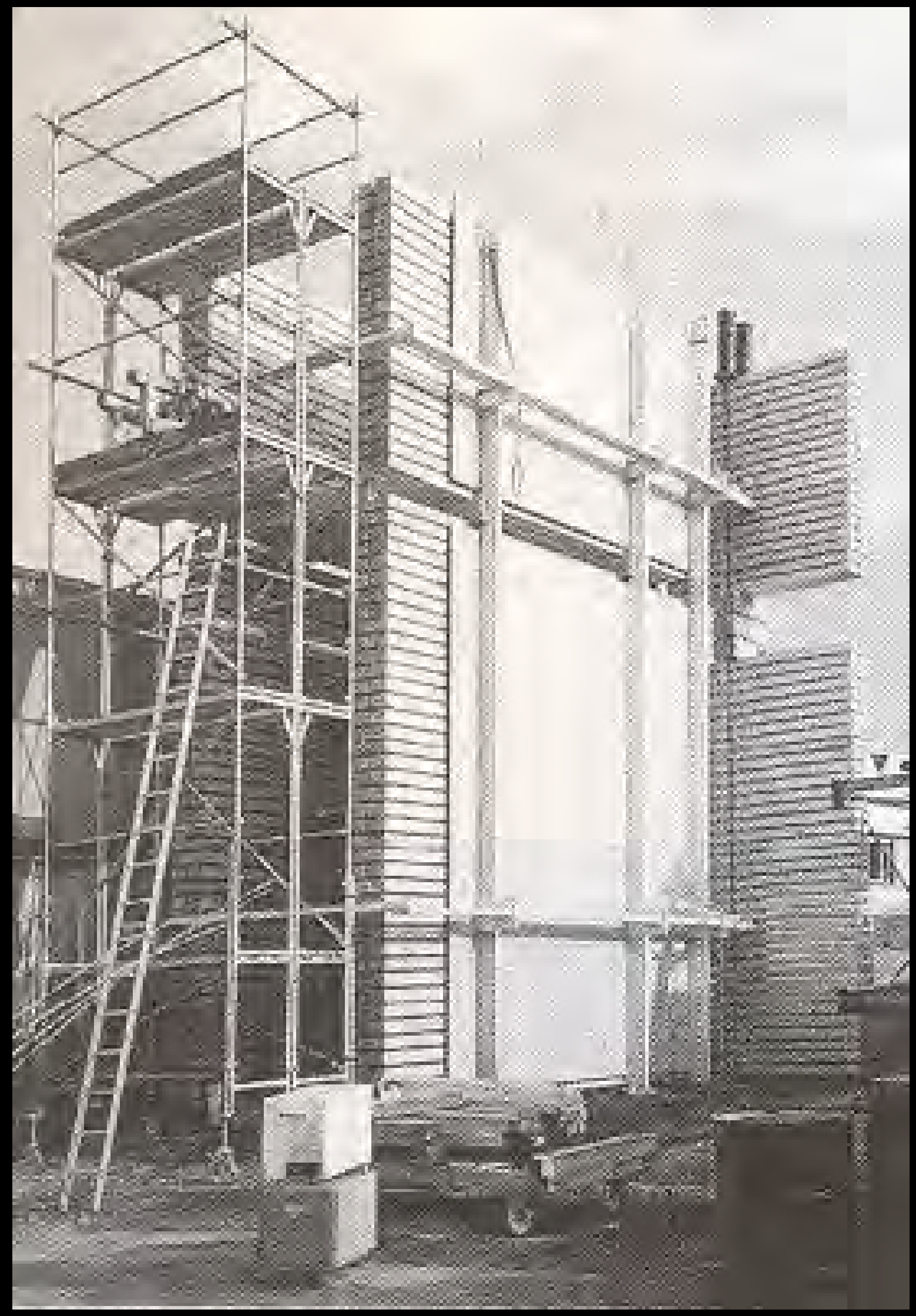




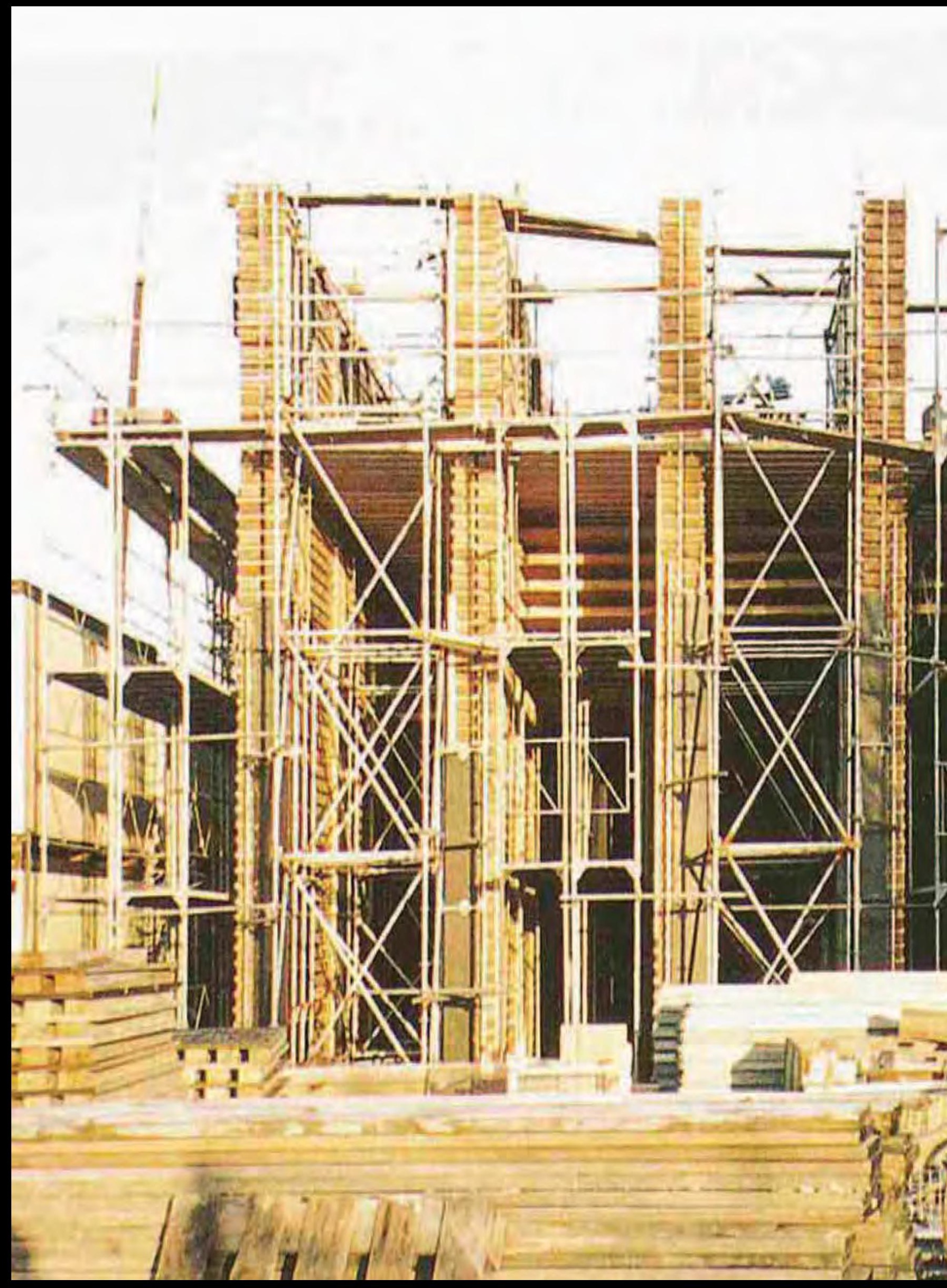




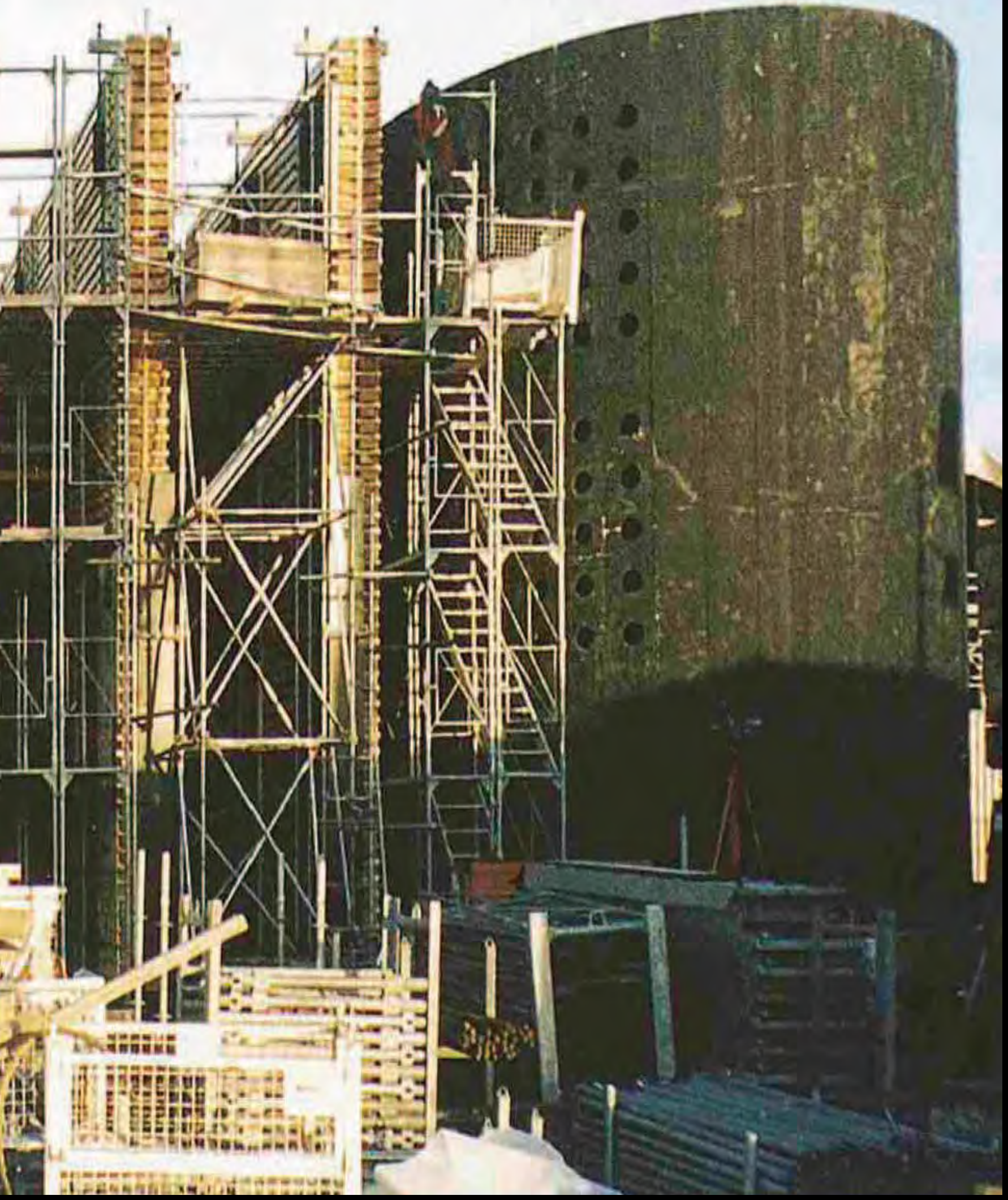




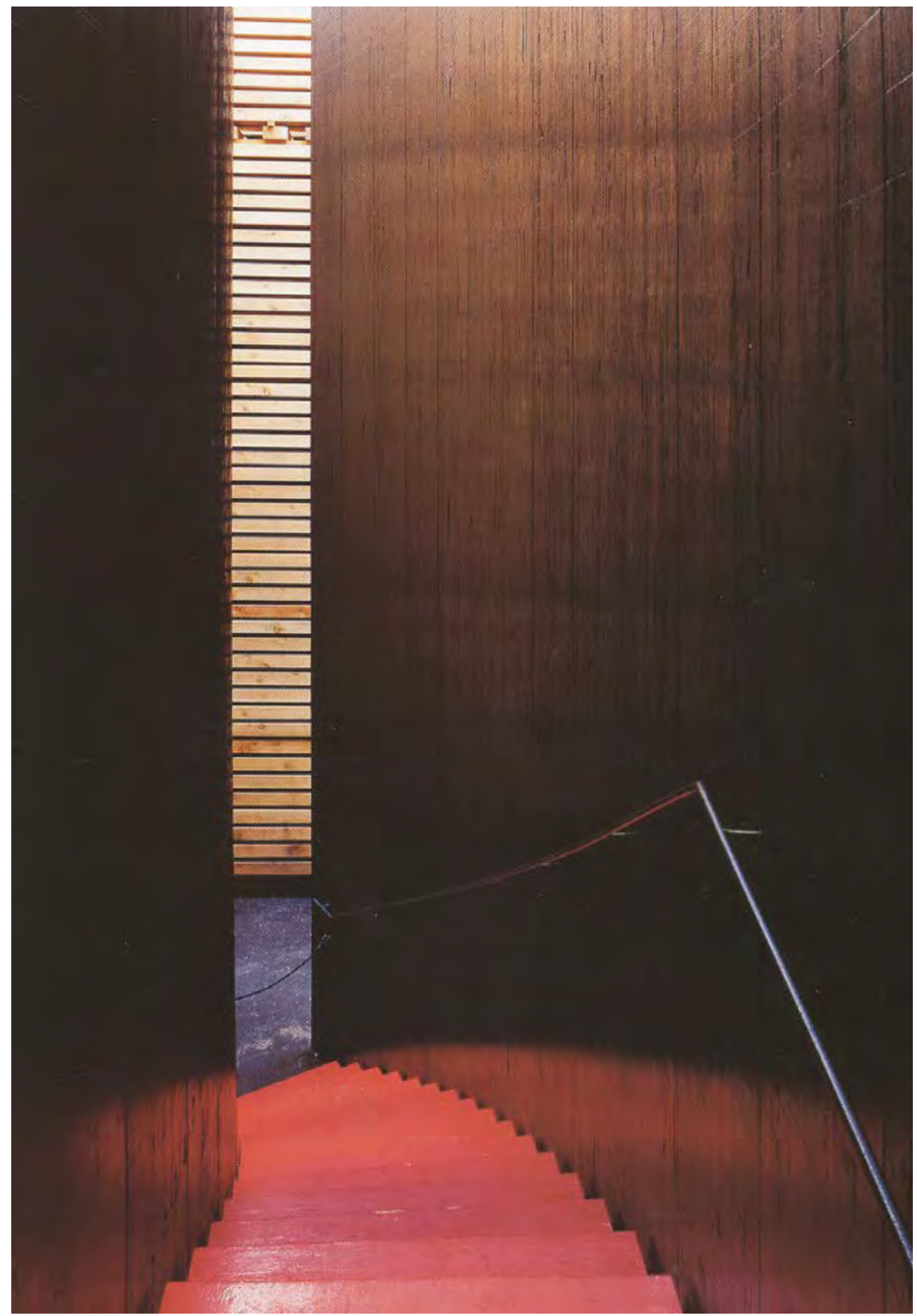

Figura 138.

Versorgungseinheit / Pabellón helvético / Hannover / 2000 


\section{[Versorgungseinheiten]}

En el patrón geométrico del Klangkörper se injertaron tres unidades de servicio en forma de espiral -Versorgungseinheiten. Construidas en madera maciza laminada estaban recubiertas con una emulsión acrílica negra Un recurso posteriormente utilizado en el Serpentine Gallery Pavilion en 2011. Unos intrusos, atípicos formal y constructivamente, compuestos de dos elipses con tangentes comunes ${ }^{59}$, ubicando las escaleras entre ellas.

Frente a la manual, artesanal y meticulosa construcción de las pilas de madera; las finas y curvadas piezas prefabricadas estructurales se realizaron mediante una máquina fresadora controlada por ordenador ${ }^{60}$. Un mecano compuesto por 225 elementos en total perfectamente enumerados; con dimensiones de $9 \mathrm{~m}$ de largo, 50 $\mathrm{cm}$ de ancho y $7,7 \mathrm{~cm}$ de grosor ${ }^{61}$; pero con radios interiores y exteriores específicos y diferentes. Piezas compuestas por tres capas de grosores $21+35+21 \mathrm{~mm}^{62}$. Cada una de las piezas del perímetro fueron montadas en obra encoladas entre sí y fijadas al suelo mediante ángulos de acero.

Estos polizones del sistema funcional, tenían accesos restringidos. En planta baja se situaron los espacios auxiliares, zonas húmedas y cuartos de servicio como una oficina de administración (Versorgungseinheiten A), la cocina (Versorgungseinheiten $B$ ) y un cuarto de basuras (Versorgungseinheiten C). Los aseos en la proyección de la escalera perimetral de acceso a los diferentes niveles superiores. Ovnis de tres niveles con espacios diáfanos contenedores de programas como un club o una sala vip.

Enfatizando su carácter escenográfico, el acabado del suelo de la planta baja fue el propio asfalto negro del pabellón. En cambio los techos se resolvieron suspendidos como cajas huecas - Hohlkasten ${ }^{63}$. Los portones de acceso de estas áreas se diseñaron como puertas correderas de aluminio delgadas de $6 \mathrm{~mm}$ que siguen la curvatura de la pared exterior. Toda esta pared continua contenía 800 perforaciones redondas de vidrio, ojos de buey - Bullaugen, con un diámetro de aprox. $20 \mathrm{~cm}$ y un grosor de 9 $\mathrm{cm}^{64}$. Mirillas voyeristas ajenas a las diversas melodías sonoras del pabellón.

59 AAVV. Klangkörperbuch. Birkhäuser. Basel. 2000. ISBN: 3-7643-6324-X. Pág. 229.

60 Idem. Pág. 267

61 Según la memoria descriptiva del pabellón facilitado por el Exposeeum Hannover.

62 Idem

63 Idem.

64 Idem 


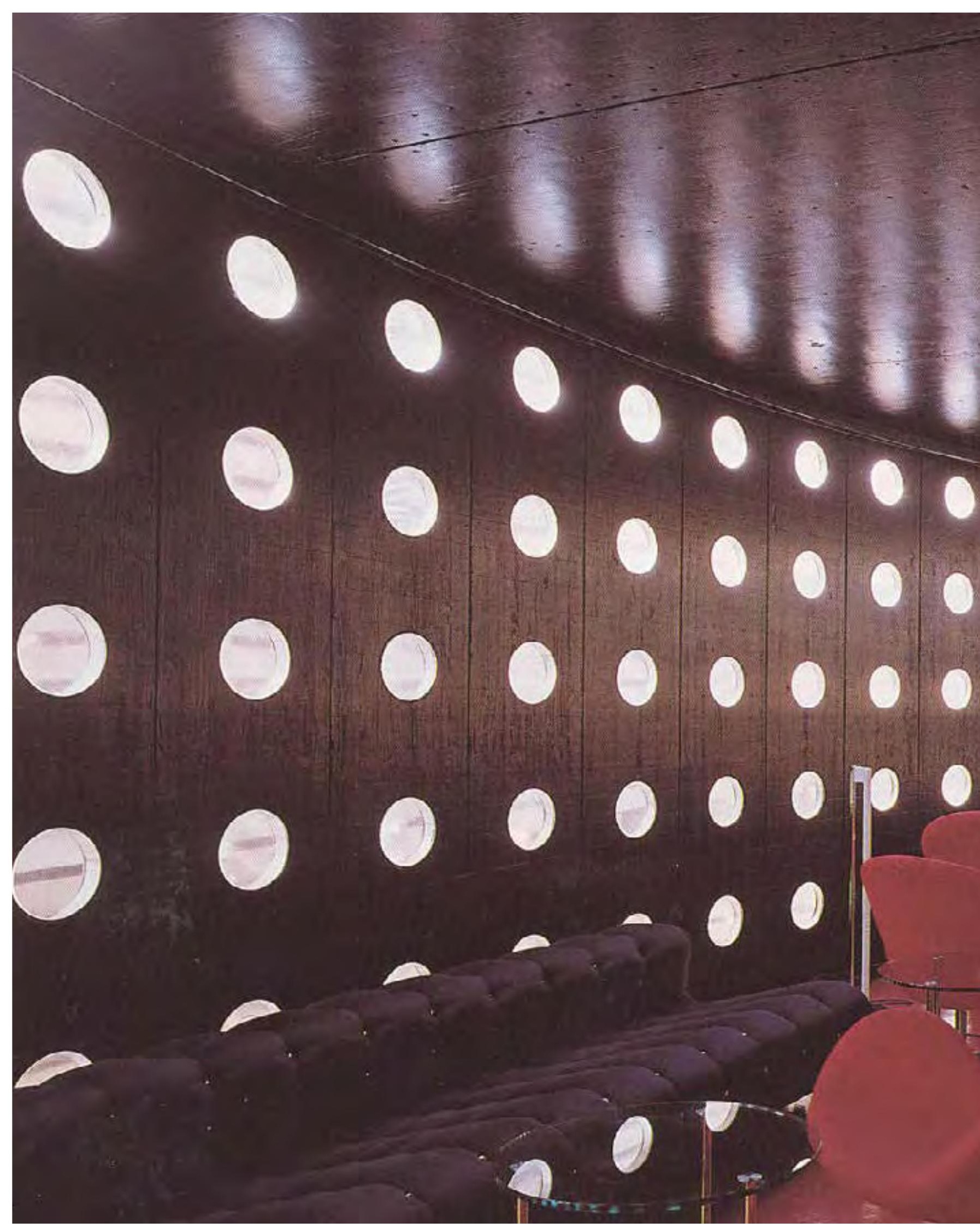



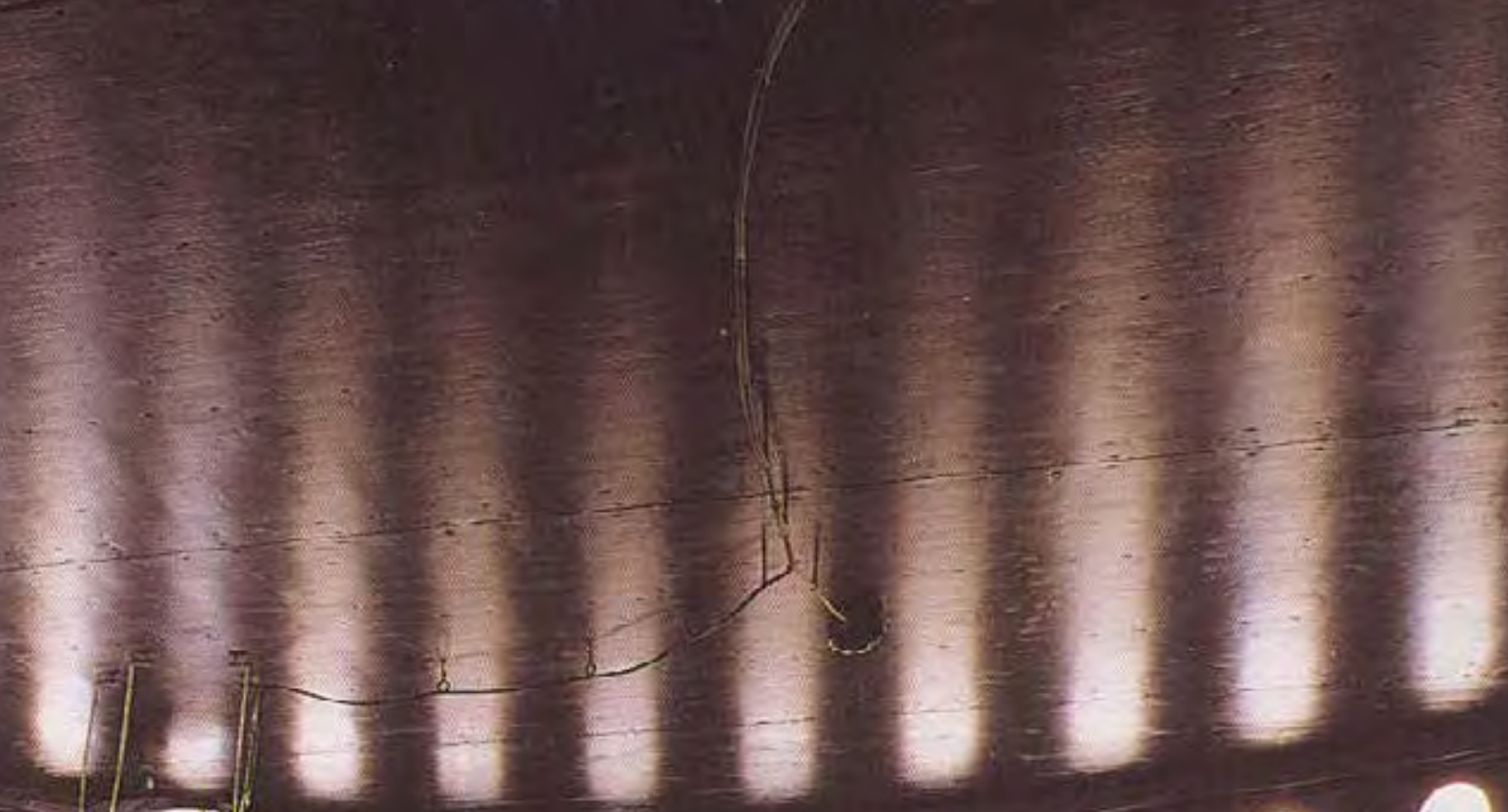

$0, \frac{1}{0}$
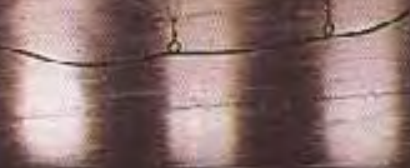

-

0

00000

0

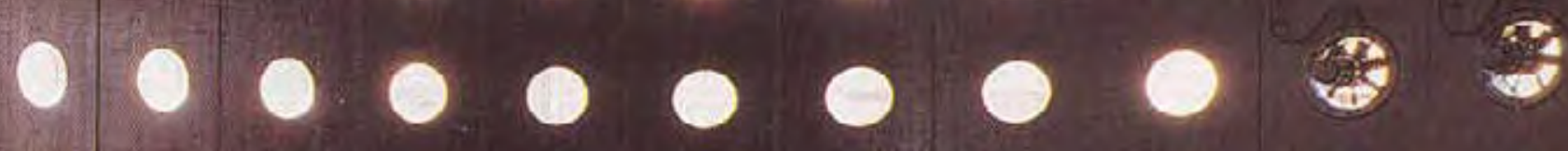

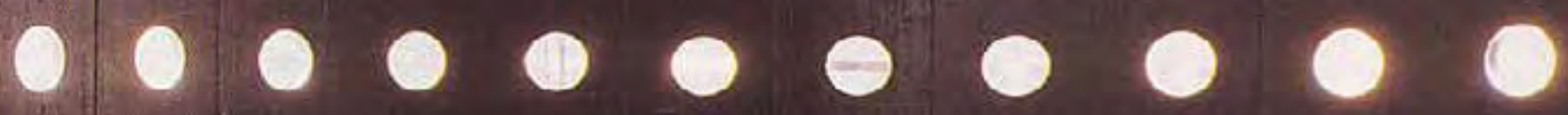

o o o o o o o

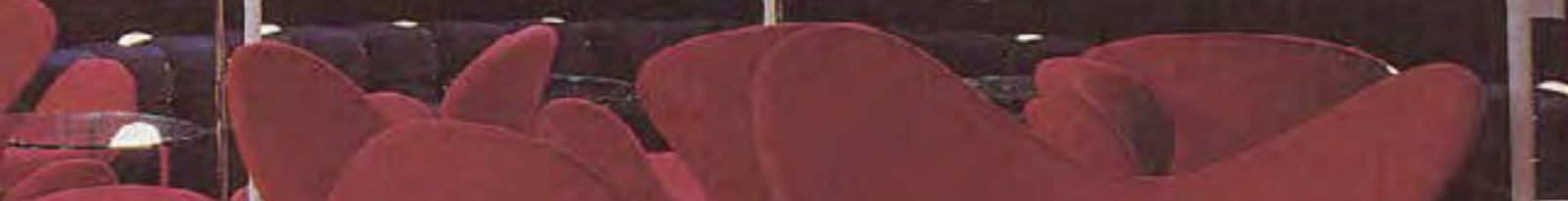

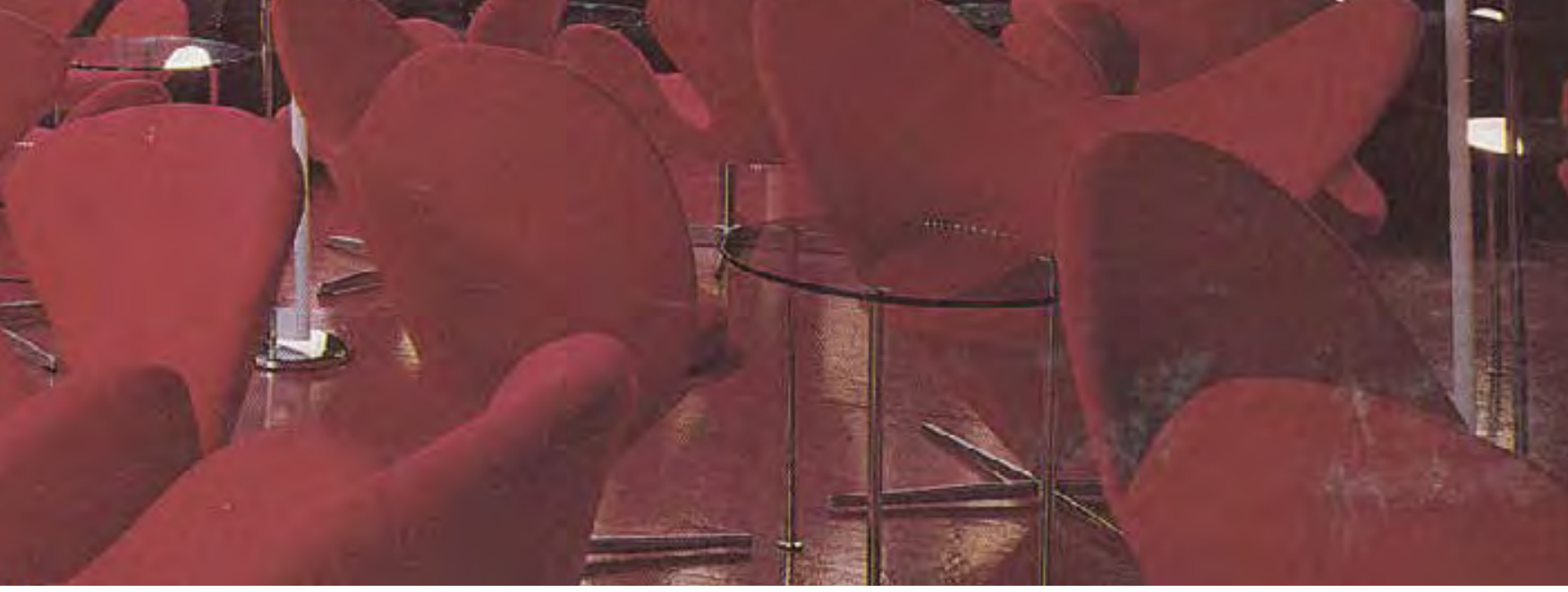




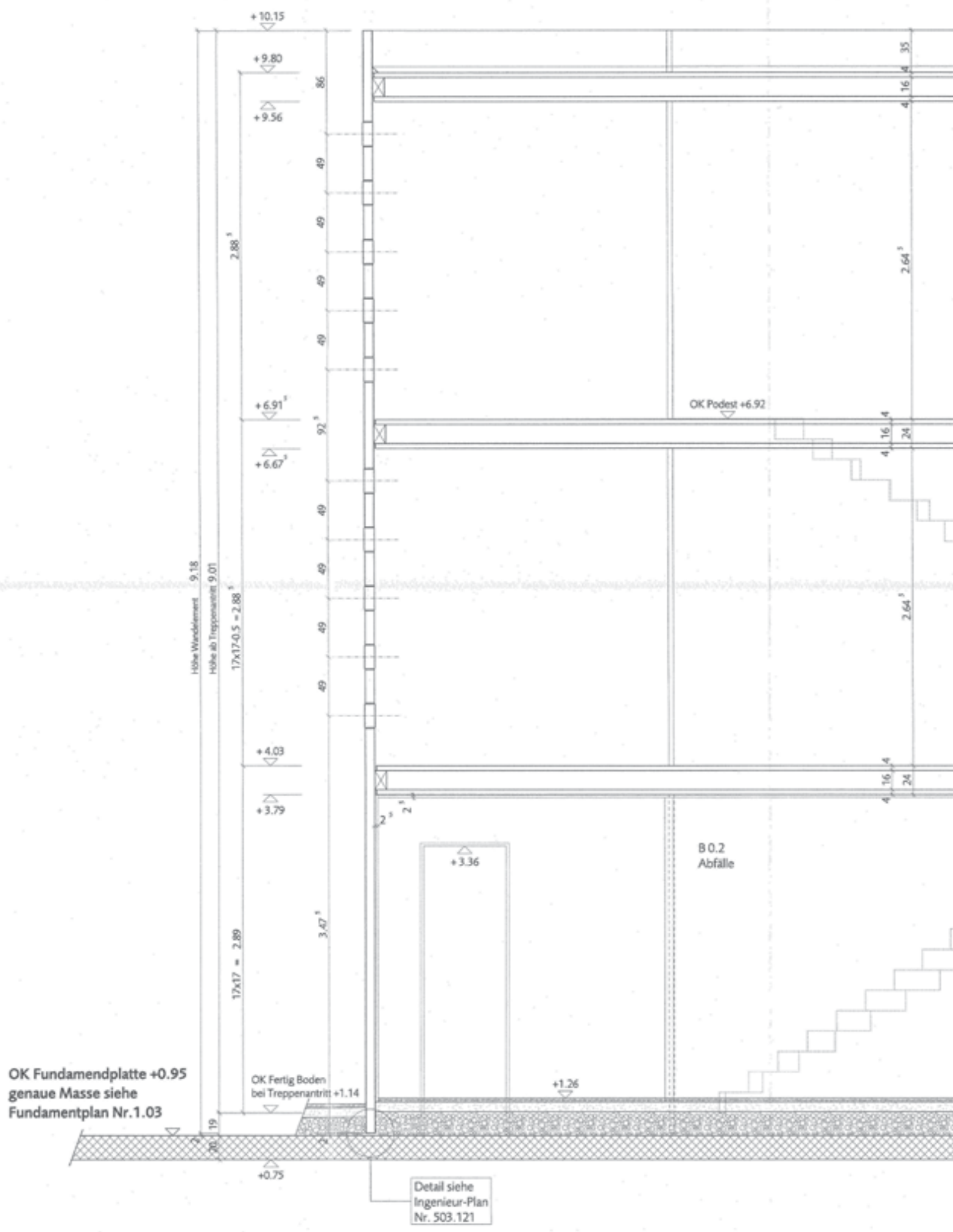

Figura 140

Plano original sección de la Versorgungseinheit B / Pabellón helvético / Hannover / 2000 6. Octubre 1999 


\section{Hinweis:}

-Material und Detailangaber

zur Holzkonstrultion

siehe Plan Nr. 503.121

Ing, Conzett, Bronzini, Gartmann AC

inkl, separatem Beschrieb

Sämtliche Aufrissmasse sind

massstablich gezeichnet und

kömen direkt von der Zeichnung

abgegriffen werden

-Sämtliche Abwicklungen sind

auf Crund der gekroimmten Projektionslinie

NICHT MASSSTABLCH. Die richtigen Masse

sind den Grundrissen zu entnehmen.

$\pm 0.00=77.55$ m.ü.N.N.

Klangkörper Schweiz

Schweizer Pavillon

Expo 2000 Hannover

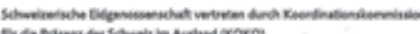

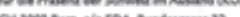

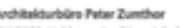

Versorgungseinheit B

Querschnitt B-B

Maßstab 1:20

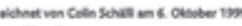

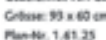




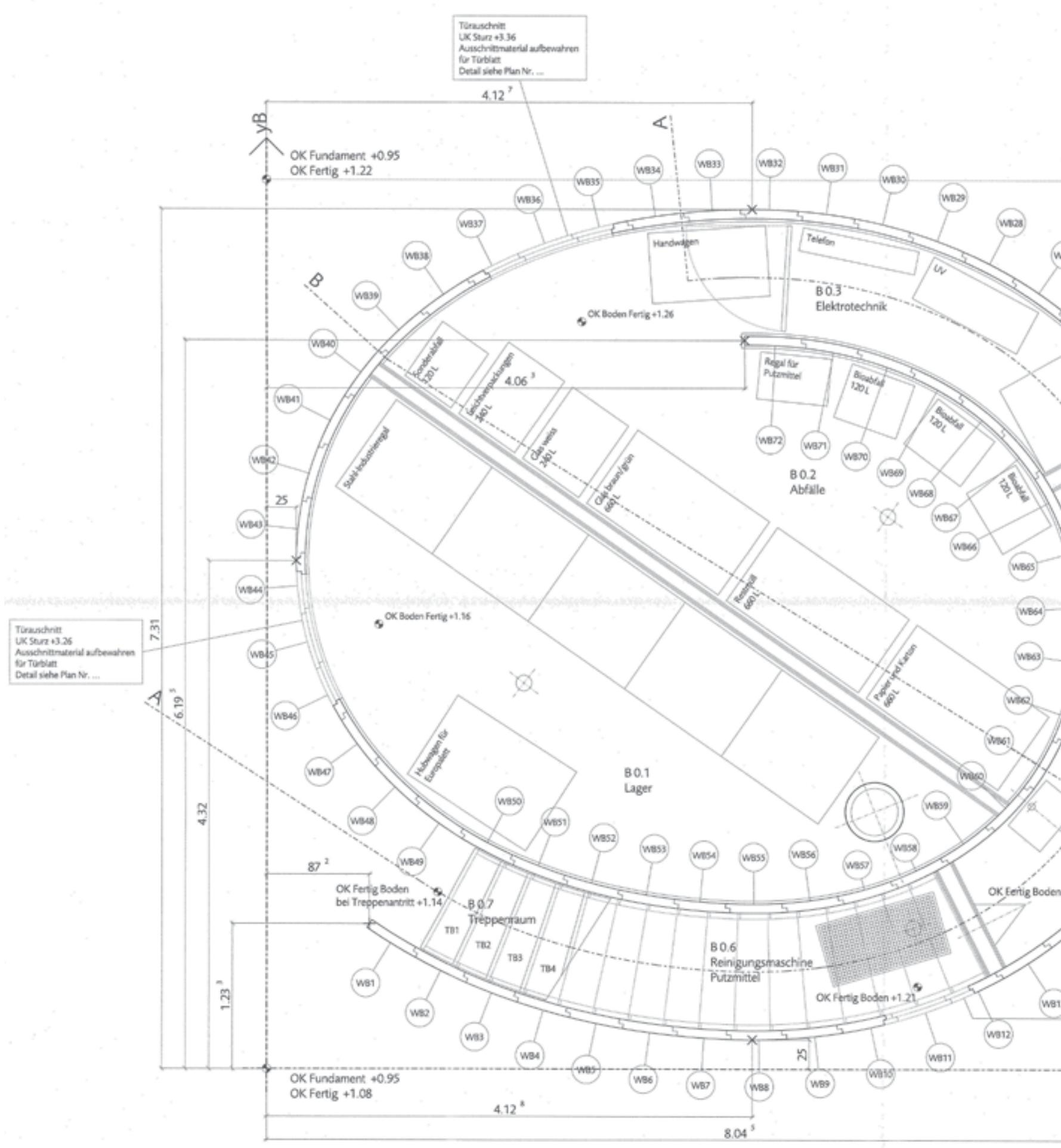

Figura 141.

Plano original planta baja de la Versorgungseinheit B / Pabellón helvético / Hannover / 2000 6. Octubre 1999 
Anmerkung:

- Das Koordinatenkreus

X6//3B wird gemiss

Plan Nr.1.03 eingemessen

-Simtliche Rohbaumasse (Holzbau)

sind direkt aus der Zeichnung

abzugreifen (CAD, Mst. 1:1)

-Kontrolimasse zur Festlegung

sich auf das Koordinatenkreuz $\times \mathrm{B} / \mathrm{y} \theta$

$\pm 0.00=77.55$ m.ü.N.N.

Klangkörper Schweiz

Schweizer Pavillon

Expo 2000 Hannover

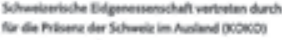

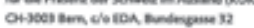

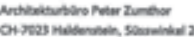

Versorgungseinheit B

Grundriss Erdgeschoss

Maßstab 1:20

Tinaschint
UKStan 43.34

UK Stan 63.34 .

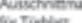

Der Tutiac

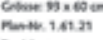

TOnuschis: 


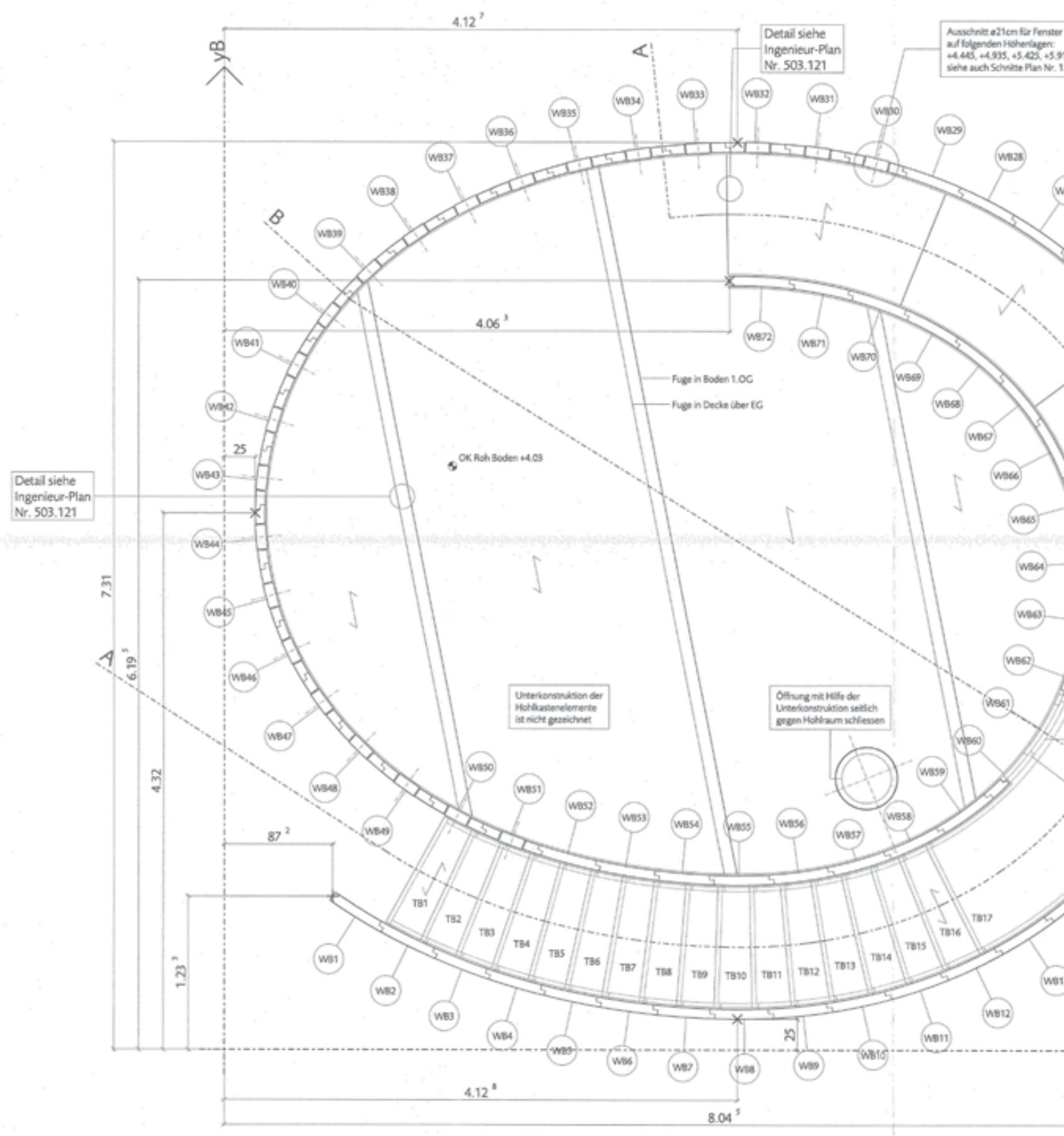

Figura 142.

Plano original primera planta de la Versorgungseinheit B / Pabellón helvético / Hannover / 2000 6. Octubre 1999 


\section{Anmerkung:}

\section{-Das Koordinatenkreuz}

XB/ $\mathrm{y}$ B wird gemäss

Plan Nr.1.03 eingemessen

-Säntliche Rohbaumasse (Holzbau)

sind direkt aus der Zeichnung

abzugreifen (CAD, Mst. 1:1)

-Kontrollmasse zur festiegung

der Lage in Grundriss beziehen

sich auf das Koordinatenkreuz xB/yB

$\pm 0.00=77.55$ m.ü.N.N.

Klangkörper Schweiz

Schweizer Pavillon

Expo 2000 Hannover

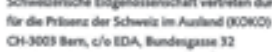

Toraschinit
UKStann +613

OK schmele 3.396

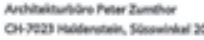

Nuschilinuterial adsemativen

Versorgungseinheit B

Grundriss 1.Obergeschoss

Maßstab 1:20

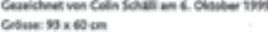

Cosuensen on

Menter.1.5. 


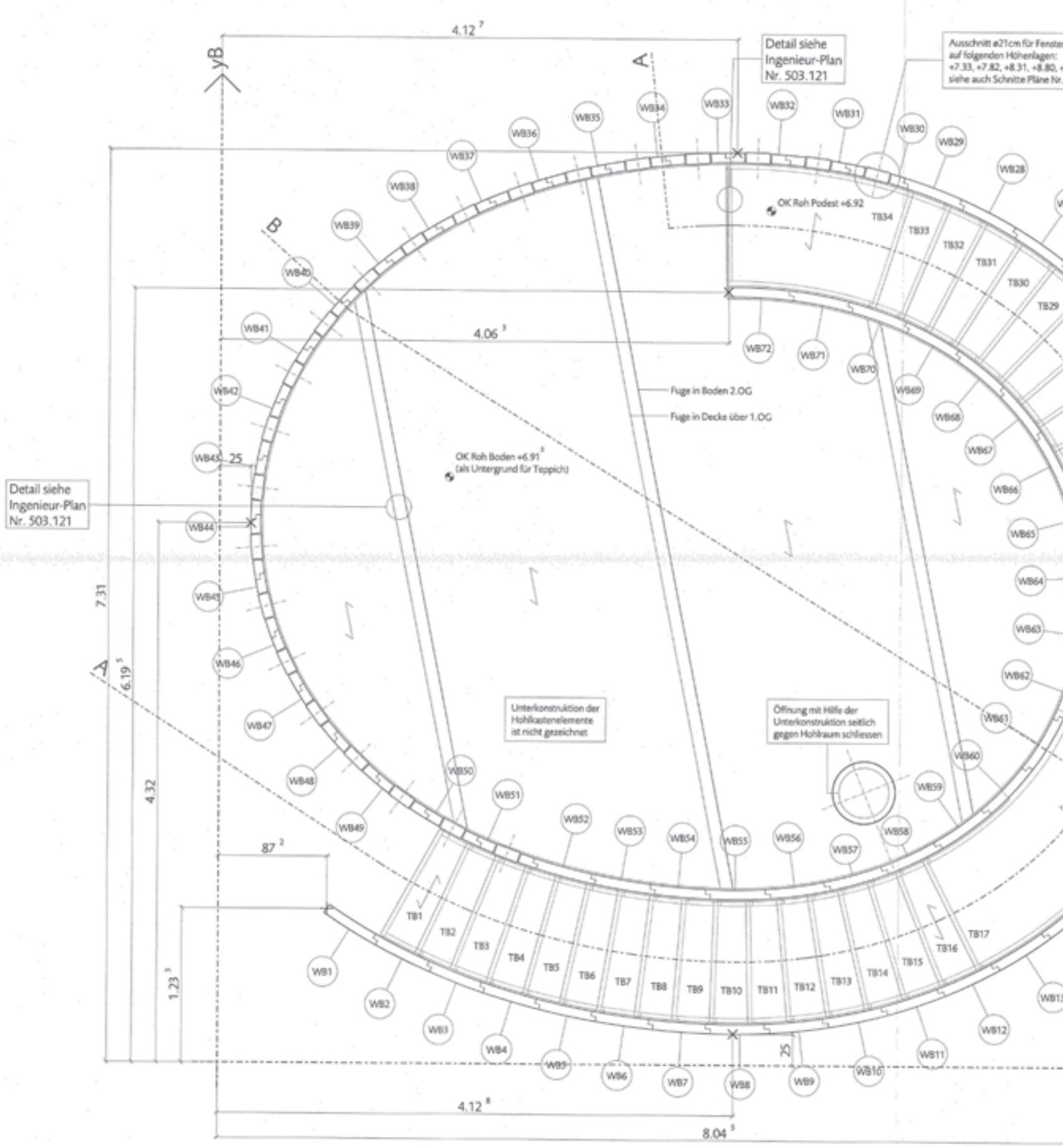

Figura 143.

Plano original segunda planta de la Versorgungseinheit B / Pabellón helvético / Hannover / 2000 6. Octubre 1999 


\section{Anmerkung:}

Das Koordinatenkreuz

XB/yB wird gemalss

Plan Nr.1.03 eingemessen

Samtliche Rohbaumasse (Holzbau)

sind direkt aus der Zeichnung

abzugreffen (CAD, Mst. 1:1)

Kontrollmasse zur Festlegung

der Lage im Crundriss beziehen

sich auf das Koordinatenkreuz $\times \mathrm{B} / \mathrm{yB}$

$\pm 0.00=77.55$ m.ü.N.N.

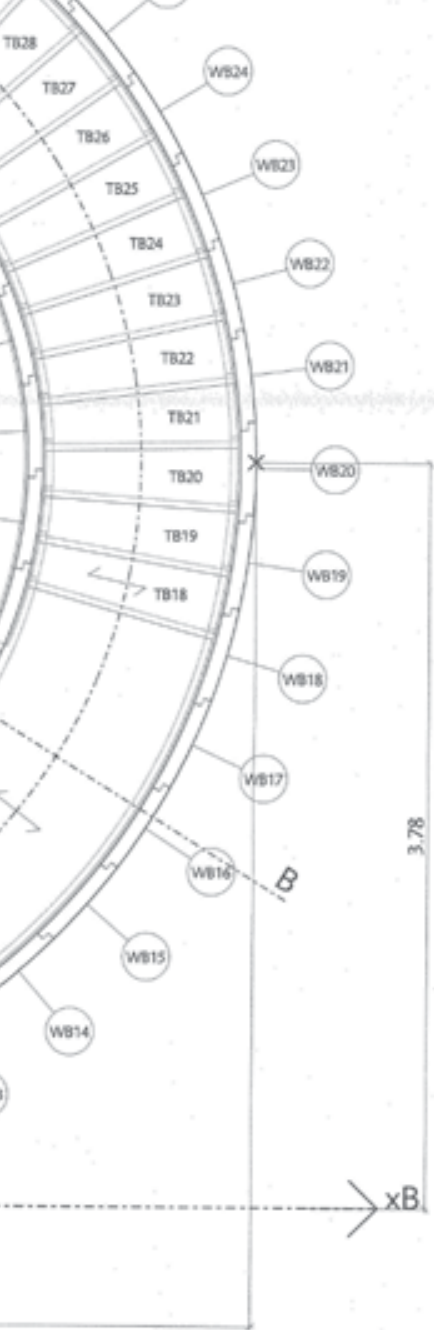

Klangkörper Schweiz

Schweizer Pavillon

Expo 2000 Hannover

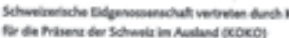

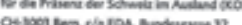

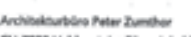

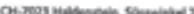

Versorgungseinheit B

Grundriss 2.Obergeschoss

Maßstab 1:20

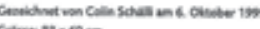

$\cos 2 \sin 28$ 


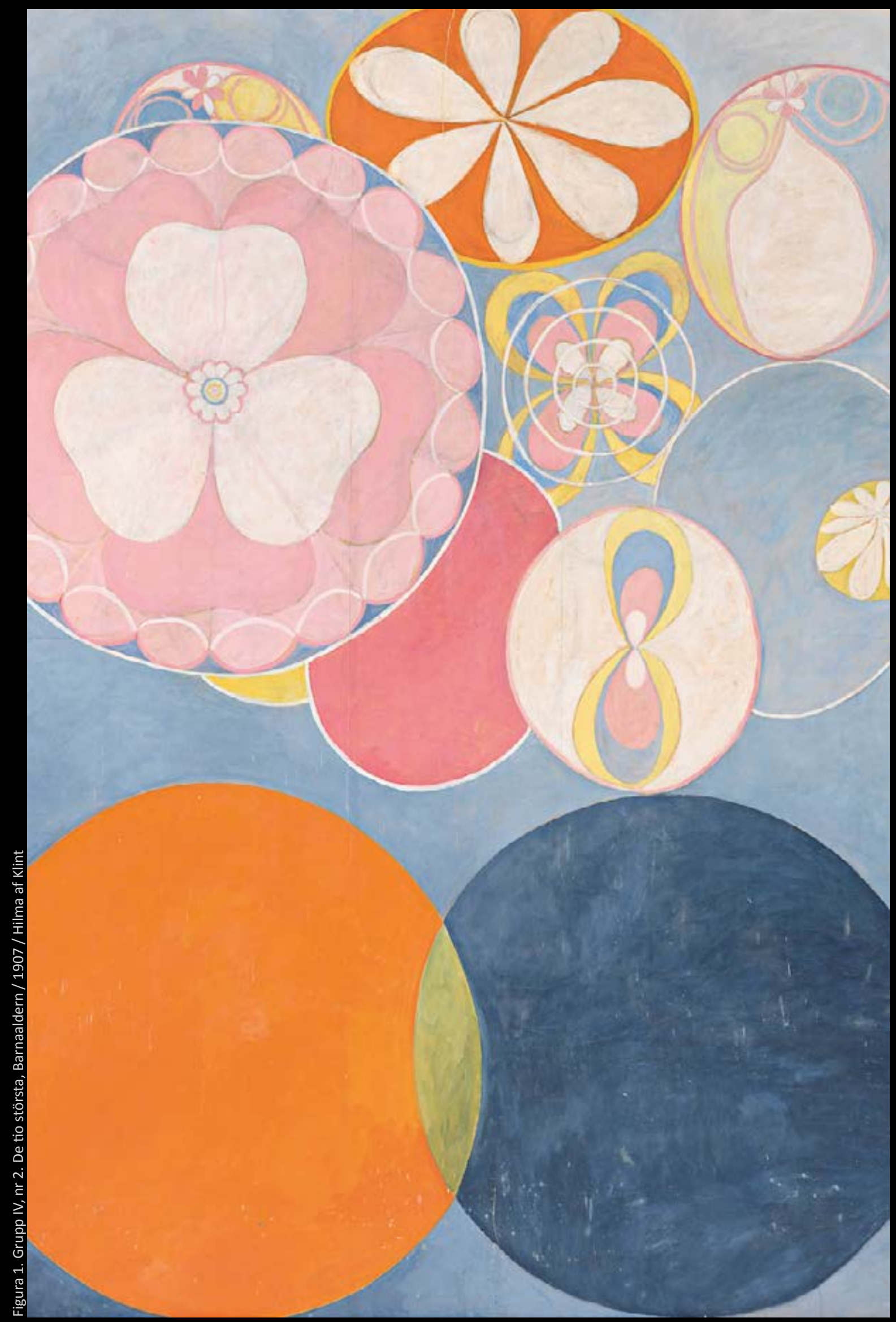




\section{ABSTRACCIÓN CONCRETA}

KONKRETE ABSTRAKTION

"La abstracción es un proceso de pensamiento que lleva a la eliminación de una determinada idea como concepto único de su contexto para poder verla y representarla por sí misma. La abstracción es una herramienta necesaria de pensamiento. Al eliminar todas las yuxtaposiciones perturbadoras de las cosas, lo insignificante y por lo tanto sólo lo confuso de la apariencia real, las conexiones esenciales se hacen más claras. Esta abstracción aislante pretende reconocer los fenómenos individuales y sus estructuras en procesos complicados. Abstracción significa: abstenerse de lo particular y azaroso en favor de lo general, esencial, por medio del pensamiento analítico." ${ }^{1}$

Max Bill

BILL, Max. Konkrete Kunst. 50 jahre entwicklung. zürcher kunstgesellschaft. verwaltungsabteilung des stadtpräsidenten. helmhaus zürich. 1960. Pág. 59. Traducción de la autora: "abstraktion ist ein denkvorgang, der dazu führt, eine bestimmte vorstellung als einzelnen begriff aus ihrem zusammenhang herauszulösen, um diese für sich allein betrachten und darstellen zu können. die abstraktion ist ein notwendiges hilfsmittel des denkens. indem alles störende nebeneinander der der dinge, das unwesentliche und deshalb nur verwirrende an der realen erscheinung weggedacht wird, werden die wesentlichen zusammenhänge klarer ersichtlich. diese isolierende abstraktion bezweckt, bei komplizierten vorgängen die einzelerscheinungen und ihre strukturen zu erkennen. das abstrahieren bedeutet: absehen vom besonderen und zufälligen zugunsten des allgemeinen, wesentlichen, vermittels des analytischen denkens" 

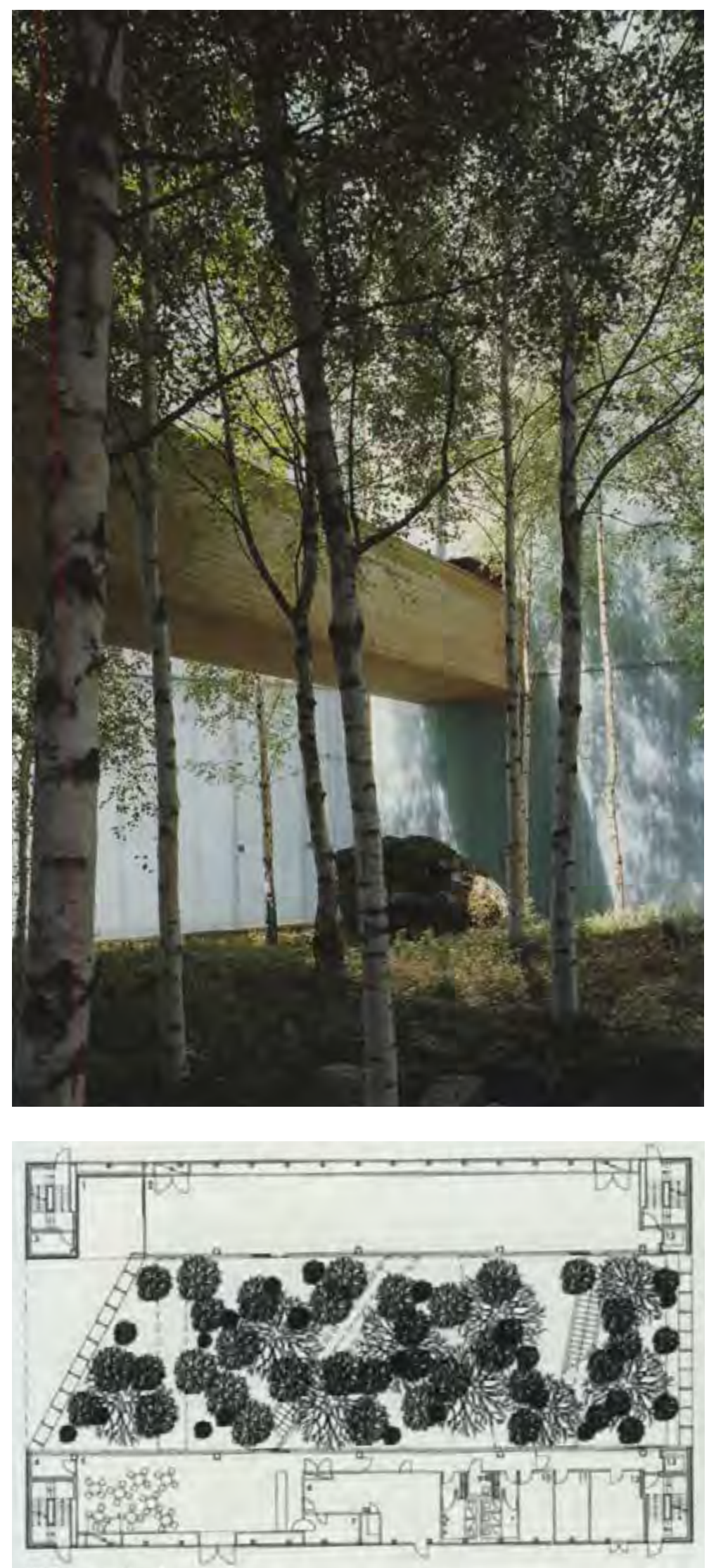

Figura 2 - 3

Pabellón finlandés / 2000 / SARC Architects 


\title{
[Natural y artificial]
}

\author{
"Vuestros edificios ... que llevarás al cielo para que puedan \\ ascender como un sublime y extendido árbol de Dios, con mil \\ ramas, millones de ramos y hojas, como la arena junto al mar..."2 \\ Johann Wolfgang von Goethe
}

En su obra Sobre el estilo y el arte alemán de 1772, Goethe describió la analogía entre un edificio gótico y un árbol. El paralelismo morfológico entre naturaleza y arquitectura, también fue recurrente en la Expo 2000, donde varias naciones recurrieron a la representación del concepto de bosque como referente simbólico de sostenibilidad y bio-diversidad. Un sistema vivo pero con recursos finitos. La naturaleza como modelo. Una nueva conciencia ecológica, y constructiva; traducida en diversas arquitecturas.

El pabellón finlandés, obra del estudio SARC Architects $^{3}$, contenía en su interior una mimesis secuestrada de la naturaleza finlandesa. Un bosque natural de abedules de 12 a $15 \mathrm{~m}$ de altura ${ }^{4}$. Los arboles trasplantados directamente desde Finlandia, colonizaban el espacio entre los dos volúmenes paralelos de cuatro plantas. Surge así una arboleda instantánea. Se podía transitar de una edificación a otra por medio de cinco puentes de madera a diferentes alturas que atravesaban este lugar. Una experiencia donde poder tocar la corteza de los troncos atravesando las copas de los frondosos árboles. El bosque natural, sin tratamiento arquitectónico, funciona como nexo. Un elemento de relación con una geometría estricta delimitada por los dos volúmenes. Una traslación parcial y natural de un bosque finlandés.

El poeta francés Charles Baudelaire, sostiene sin embargo que la belleza solamente emerge mediante "una deformación sublime de la naturaleza, o más bien ... un ensayo permanente y sucesivo de reforma de la naturaleza", ya que "Ia fantasmagoría se

2 GOETHE, Johann Wolfgang von. Goethes Werke: Schriften zur Kunst, Schriften zur Literatur, Maximen und Reflexionen. Volumen 12 de Goethe Werke: Hamburger Ausgabe in 14 Bänden. C.H.Beck. München. 1994. ISBN: 9783406084928 . Pág. 10. Traduccion de la autora: “Eure Gebäude...die du gen Himmel führen sollst, dass sie aufsteige gleich einem hocherhabnen, weitverbreiteten Baum Gottes, der mit tausend Ästen, Millionen Zweigen und Blättern wie der Sand am Meer ringsum der Gegend verkündet die Herrlichkeit des Herrn..."

3 Nota: El estudio SARC Architects está dirigido por Antti-Matti Siikala y Sarlotta Narjus.

4 SARC ARCHITECTS. Pabellón finlandés. Expo 2000 Hannover. En: Vía Arquitectura 08. Exterior e interior. Colegio Oficial de Arquitectos de la Comunidad Valenciana. Valencia. 2000. Pág. 74.

5 BAUDELAIRE, Charles. El artista, hombre de mundo, hombre de la multitud y niño. En: El pintor de la vida moderna. 1863. Pág. 27 http://www.ecfrasis.org/wp-content/uploads/2014/06/CharlesBaudelaire-El-pintor-de-la-vida-moderna.pdf 


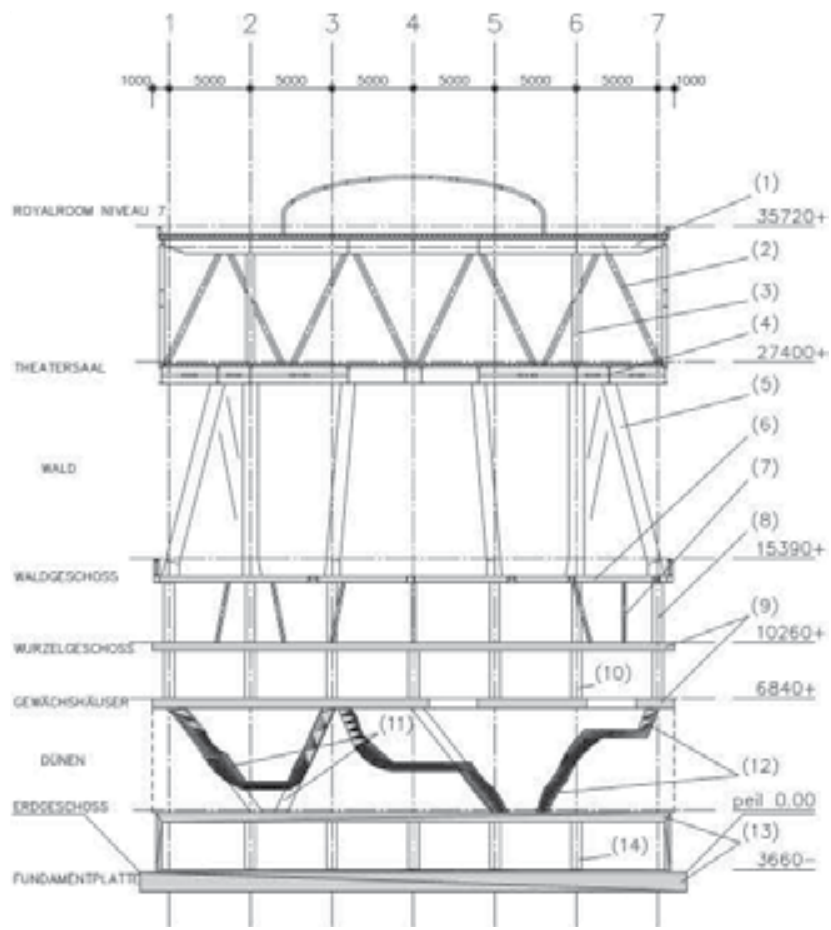

Figura 4.

Sección / Pabellón de los Países Bajos / 2000 / MVRDV

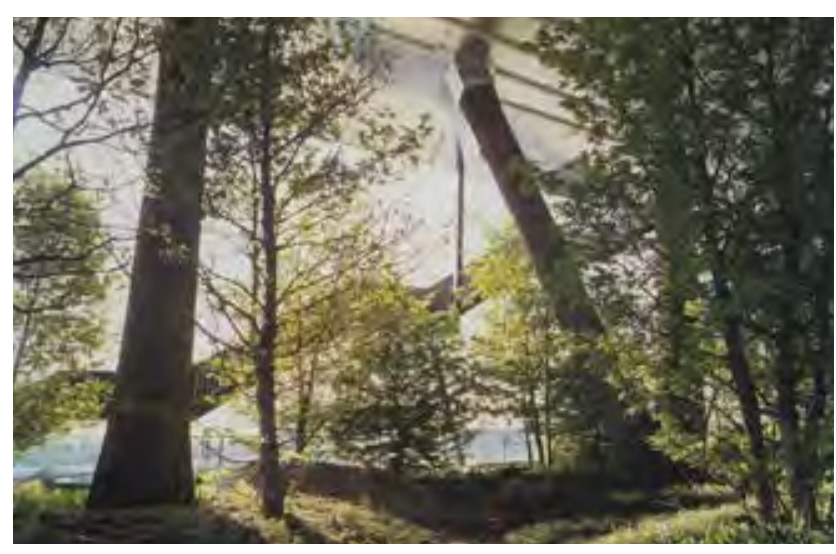

Figura 5.

Bosque / Pabellón de los Países Bajos / 2000 / MVRDV

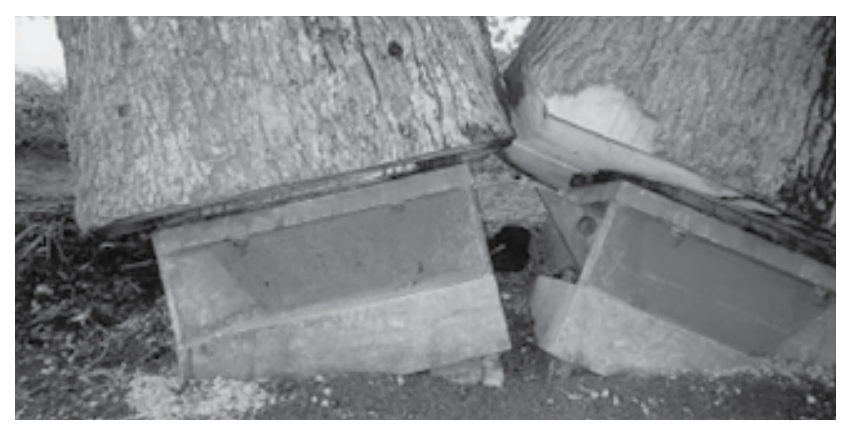

Figura 6.

Detalle de conexión / Pabellón de los Países Bajos / 2000 / MVRDV 
ha extraído de la naturaleza" ${ }^{\prime \prime}$. La fantasía solamente puede ser desarrollada en un mundo artificial, en el que el artista no imita, sino que se comunica a través de su imaginación para superar la naturaleza.

\section{"La naturaleza es fea, y yo prefiero los monstruos de mi fantasía a la trivialidad positiva."7 Charles Baudelaire}

La interpretación sobre la belleza de Baudelaire; podría ser aplicada a la propuesta construida de los Países Bajos de MVRDV. En uno de los estratos apilados se suspendió un bosque elevado, referencia de los Jardines Colgantes de Babilonia. Un espacio ambiguo de realidad y fantasía. Aparecen tres capas dentro del sándwich: el nivel de las raíces - Wurzelgeschoss; el suelo de la arboleda - Waldgeschoss, y un bosque natural de roble con una altura libre de $15 \mathrm{~m}$ - Wald. La arquitectura como soporte de la naturaleza. Una estructura, a modo de estantería; en hormigón armado en las dos primeras capas terrosas, mientras que en el espacio del bosque se resolvió a través de 14 troncos de árboles cortados con su corteza. Estos soportes inclinados, con longitudes entre 11 y $14 \mathrm{~m}^{8}$ y calibres de 0,80 m, garantizaban la estabilidad con las plantas superiores. Un soporte de apilamientos de paisajes. Parafraseando a Baudelaire, una fantasía creada a partir del paisaje artificial de los Países Bajos.

El lema de la Expo Hombre - naturaleza - técnica. Origen de un nuevo mundo invitaba a la reflexión sobre estos tres conceptos abstractos, sus posibles simbiosis. Todo ello en la experimentación de diferentes pócimas arquitectónicas compuestas a partir de estos ingredientes dados. Un laboratorio universal origen de un nuevo mundo. Lo natural como modelo. El bosque como motivo, como inspiración. El árbol como objeto. La vegetación como material de construcción. Un diálogo entre la naturaleza y la arquitectura, entre lo natural y lo artificial.

6 BAUDELAIRE, Charles. El artista, hombre de mundo, hombre de la multitud y niño. En: El pintor de la vida moderna. 1863. Pág. 9 http://www.ecfrasis.org/wp-content/uploads/2014/06/CharlesBaudelaire-El-pintor-de-la-vida-moderna.pdf

7 BAUDELAIRE, Charles. Aufsätze zur Literatur und Kunst 1857-1860. Carl Hauser Verlag. München, Wien. 1989. ISBN: 3-44613335-6. Pág.140. Traducción de la autora: "Die Natur ist hässlich und ich ziehe die Monster meiner Fantasie der positive Trivialitäten vor."

8 DETZEL, Annette. Der niederländische Pavillon für die EXPO 2000 in Hannover. En: Stahlbau Volumen 70. Heft 3. Marzo 2001. ISSN: 0038-9145. Pág. 204-205. 


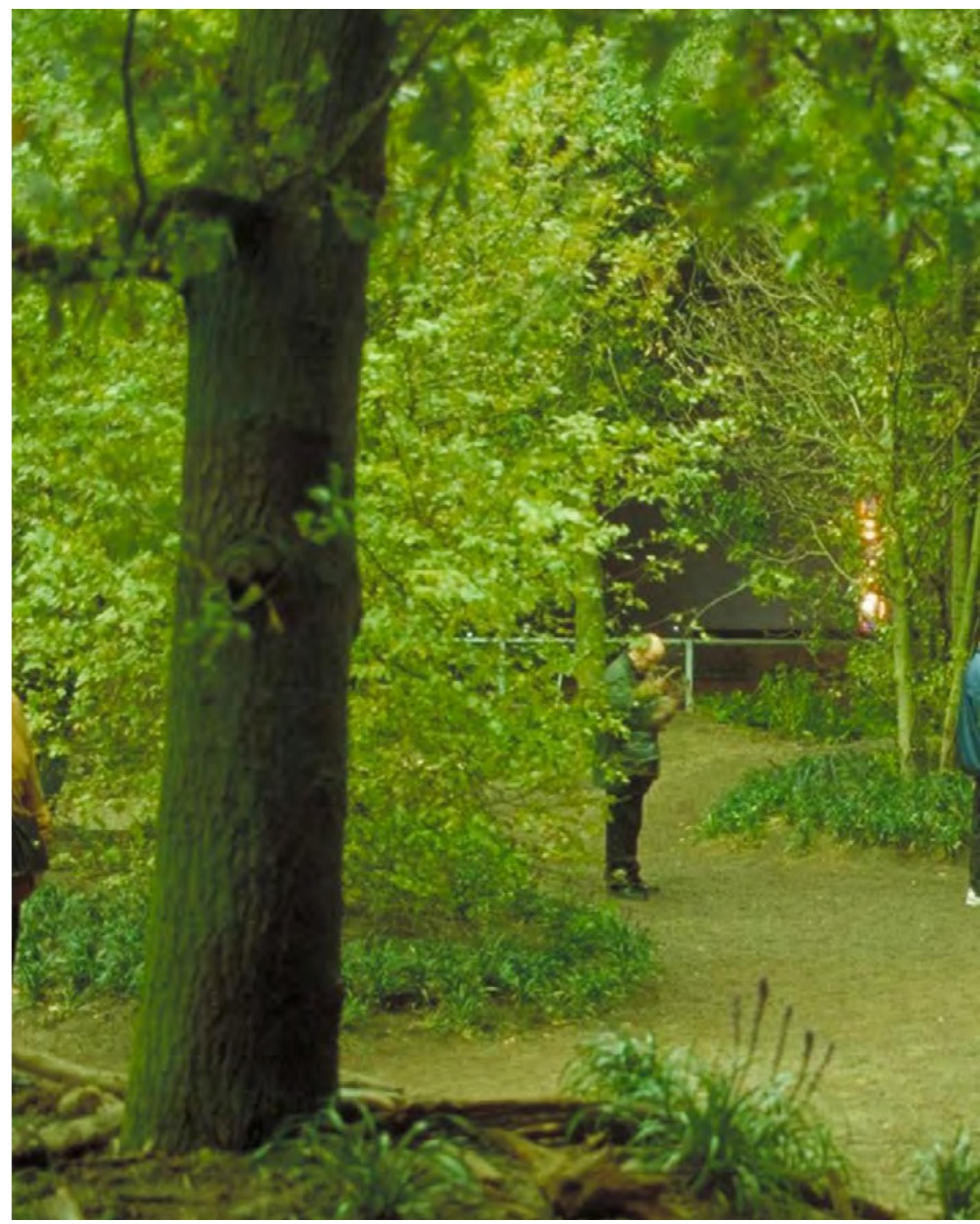

Figura 7.

Pabellón de los Países Bajos / 2000 / MVRDV 


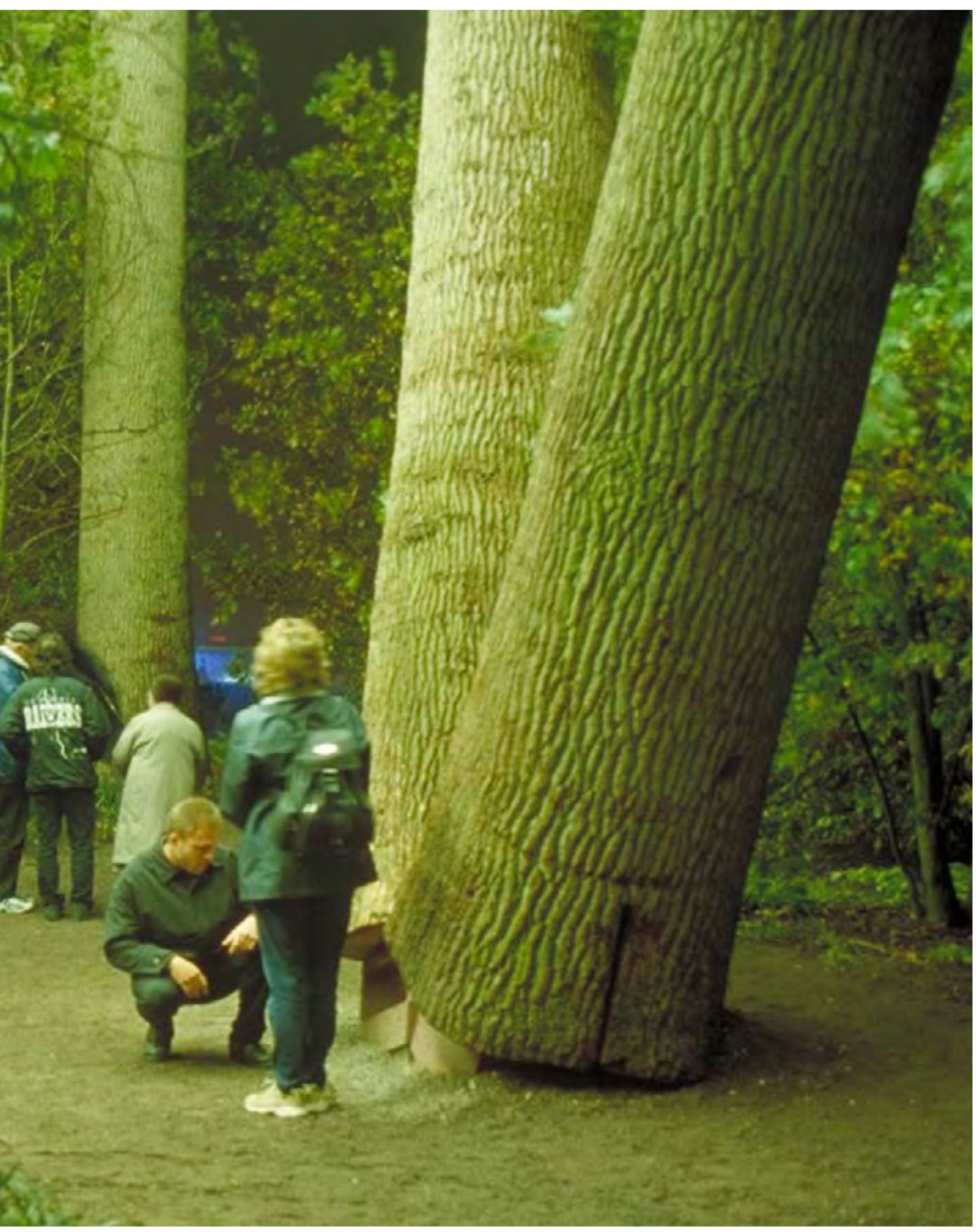




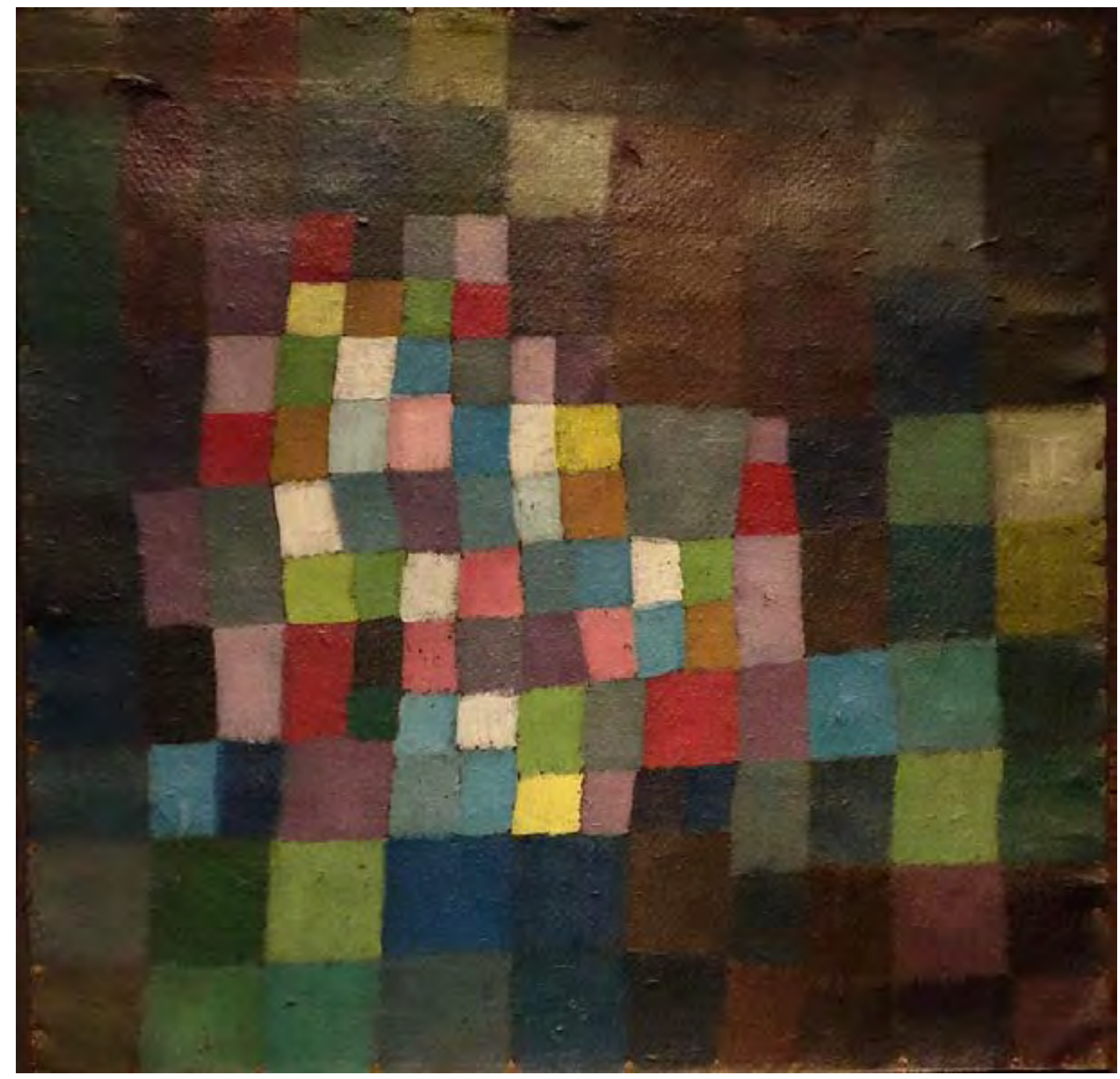

Figura 8.

Abstraction with Reference to a Flowering Tree / 1925 / Paul Klee 


\section{[Abstraktion und Einfühlung $\left.{ }^{9}\right]$}

"La naturaleza puede permitirse el lujo de desperdiciar todo, el artista debe ser económico hasta el final."10 Paul Klee

El término abstracto tiene varias acepciones. Según la Real Academia Española se deriva de la palabra latina abstractus que significa "alguna cualidad con exclusión del sujeto"11. Se refiere generalmente a la omisión de características consideradas insignificantes, preservando únicamente lo esencial. Esta arbitrariedad fue criticada por el filósofo alemán Georg Wilhelm Friedrich Hegel.

“¿Quién piensa abstractamente? El hombre inculto, no el culto. Por ello la buena sociedad no piensa abstractamente, porque eso es demasiado fácil, demasiado vulgar; vulgar no según un estatus externo o por una nobleza vacía que se pone por encima de lo que no es capaz, sino debido a la inferioridad intrínseca de la cosa."12 Georg Wilhelm Friedrich Hegel

Desde otro punto de vista filosófico, el término abstraer "se usaba comúnmente para designar el acto de sacar algo de alguna cosa, separar algo de algo"13. La abstracción como una "acción y efecto de 'sacar', 'arrancar', 'privar'”14. Por otro lado, en arte se entiende por abstracción "Ia supresión de elementos de la realidad en orden a lograr de una síntesis estética o de una interpretación subjetiva de los temas por el artista"15. En 1905, el pintor checo František Kupka consideró innecesario "...pintar árboles, porque la gente puede ver mejores en el camino a la exposición ${ }^{\prime 16}$. Una reacción

9 Nota: Titulo de la tesis doctoral de Wilhelm Worringer, publicada por primera vez en 1908. Traducida al castellano como "Abstracción y naturaleza".

10 KLEE, Paul. Zwiesprache mit der Natur. Tagebücher. 1909. Nr. 857. Pág. 292. Traduccion de la autora: "Die Natur kann sich Verschwendung in allem erlauben, der Künstler muss bis in letzte sparsam sein."

11 Real Academia Española

12 HEGEL, Georg Wilhelm Friedrich. Georg Wilhelm Friedrich Hegel's vermischte Schriften. Duncker und Humblot. Band 2. Berlin 1835. Pág. 402. Traducción de la autora: "Wer denkt abstrakt? Der ungebildete Mensch, nicht der gebildete. Die gute Gesellschaft denkt darum nicht abstrakt, weil es zu leicht ist, weil es zu niedrig ist, niedrig nicht dem äußeren Stande nach, nicht aus einem leeren Vornehmtun, das sich über das wegzusetzen stellt, was es nicht vermag, sondern wegen der inneren Geringheit der Sache."

13 FERRATER MORA, J. Diccionario de filosofia. Tomo 1. A-D. (1994). Ariel Referencia. Barcelona. 2004. ISBN: 84-344-0501-6. Pág. 26.

14 Idem. Pág. 26.

15 MONREAL Y TEJADA, Luis y HAGGAR, R.G. Diccionario de términos de arte. Editorial Juventud, S.A. Barcelona. 1992. ISBN: 84-261-2701-0. Pág. 8.

16 KUPKA, Frantisek. En: GALL, Bernd Erich. Playground. Katalog. Dada-schriftreihe. Bonn. 2005. http:// bernderichgall.de/Kat_playg_text.html. Traducción de la autora: “... Bäume zu malen, denn die Leute können auf dem Weg zur Ausstellung bessere sehen" 


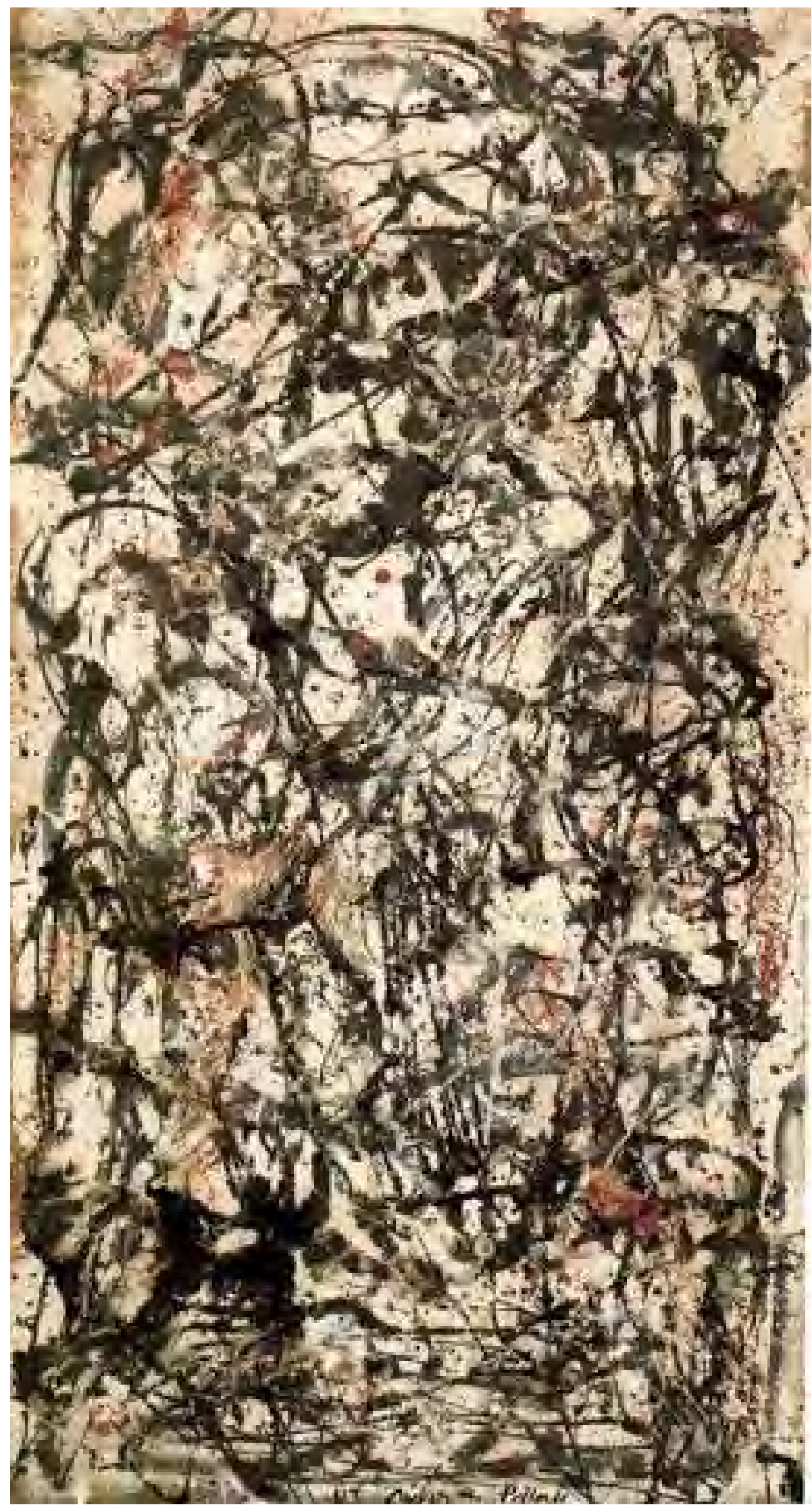

Figura 9.

Enchanted Forest / 1947 / Jackson Pollock 
ante la representación realista, objetiva, figurativa; ante el proceso de imitación fiel de la naturaleza. Una interpretación basada en un lenguaje visual de composiciones puramente geométricas, de formas lineales, colores puros y ángulos rectos.

\begin{abstract}
"la obra de arte se halla al lado de la naturaleza como un organismo autónomo equivalente y, en su más hondo ser, sin nexo con ella, si es que por 'naturaleza' se entiende la superficie visible de las cosas. De ningún modo debe considerarse lo bello natural como una condición de la obra de arte, ..."17 Wilhelm Worringer
\end{abstract}

La abstracción y la naturaleza forman conceptos dicotómicos: la concepción racional del arte y el arte comprometido con el sentimiento y la naturaleza. Según Worringer, la naturaleza está conectada con el espacio ${ }^{18}$, mientras que la abstracción se refiere a la representación dentro del plano ${ }^{19}$. La naturaleza es orgánica ${ }^{20}$, la abstracción inorgánica ${ }^{21}$. La naturaleza prefiere la línea curva ${ }^{22}$, la abstracción la línea recta ${ }^{23}$. La naturaleza es una inmediata reproducción del modelo natura ${ }^{24}$, la abstracción significa la desvinculación. La naturaleza hace referencia al espíritu ${ }^{25}$, la abstracción a la materia ${ }^{26}$. La naturaleza está conectada con el mundo terrestre ${ }^{27}$, la abstracción con el más allá28. La naturaleza está asociada al arte de la antigua Grecia, la abstracción con el arte del antiguo Egipto ${ }^{29}$. El arte egipcio-oriental contaba con elementos fundamentales como el retorno al plano, la supresión de lo orgánico, una composición cristalino-geométrica ${ }^{30}$. Lo bello en el arte se distingue claramente de la estética de lo bello natura ${ }^{31}$. Madrid. 1997. ISBN: 84-375-0431-7. Pág. 17.

18 Idem. Pág. 51. Nota: "El espacio es, pues, el mayor enemigo de todo esfuerzo abstrayente..."

19 Idem. Pág. 89.

20 Idem. 98.

21 Idem. 98.

22 Idem. 75.

23 Idem. 75.

24 Idem. 81.

25 Idem. 107.

26 Idem. 107.

27 Idem. 107.

28 Idem. 107.

29 Idem. Pág. 108. Nota: "Hay que considerer a la Hélade y al Egipto, a pesar de sus multiples nexus culturales, como representantes más extremos de conceptions del mundo antagónicas."

Idem. Pág. 108.

31 Idem. Pág. 17. 

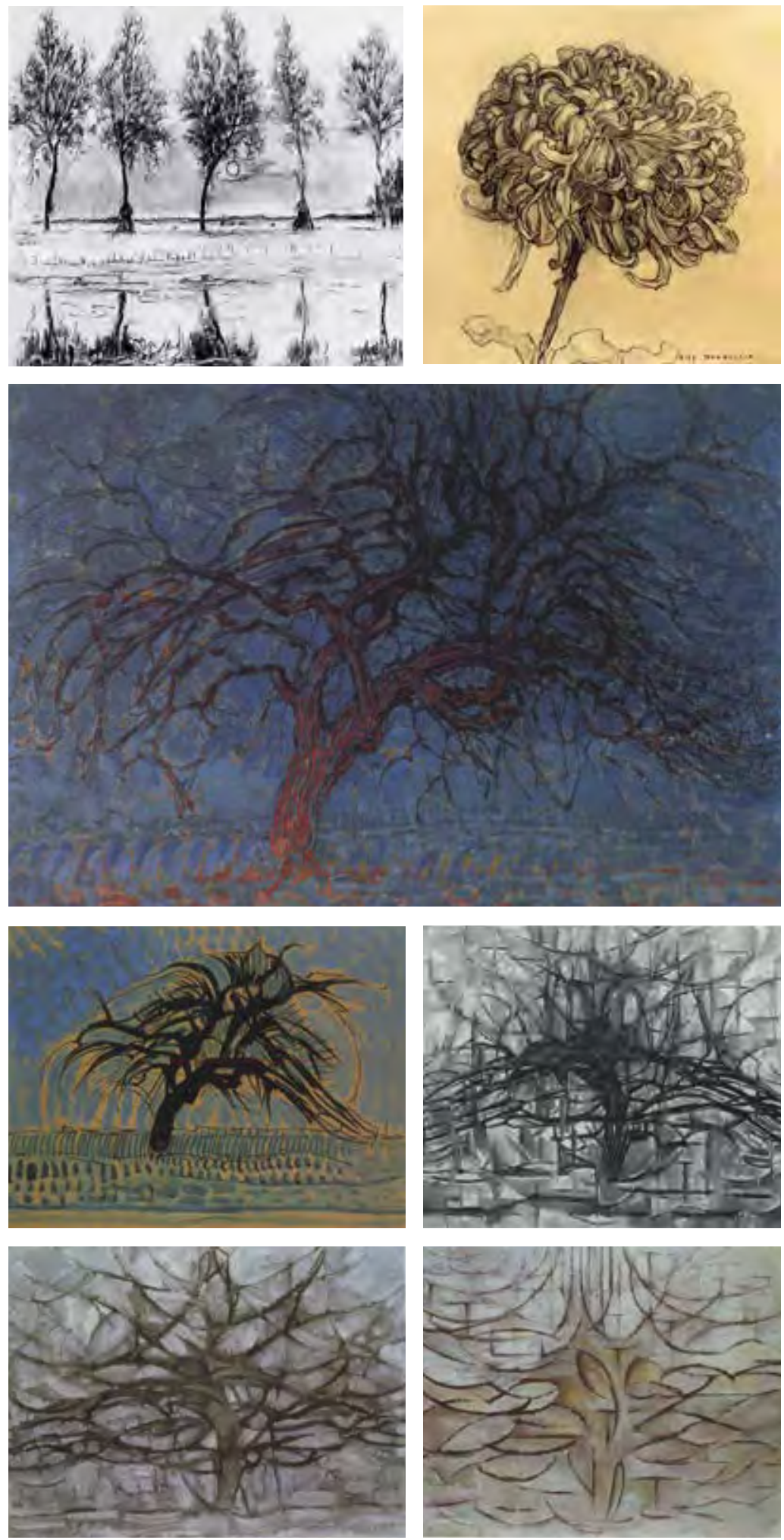

Figura 10 - 16.

Study for five trees along the Gein with moon / 1907-08 / Piet Mondrian

Chrysanthemum / 1908-09 / Piet Mondrian El árbol rojo / 1908 / Piet Mondrian

El árbol azul / 1908-09 / Piet Mondrian

El árbol horizontal / 1911 / Piet Mondrian

El árbol gris / 1911 / Piet Mondrian

Manzano en flor / 1912 / Piet Mondrian 


\title{
[Meta-morfosis]
}

"Me gustaba pintar flores, no ramos, sino flores individuales para poder expresar su estructura plástica."32 Piet Mondrian

Los inicios de la obra de Mondrian están enormemente influidos por la pintura realista. Entre los motivos elegidos destacaron flores, árboles y sobre todo paisajes holandeses. Sin embargo; entre 1911 - 14, durante su estancia en París, las nuevas representaciones cubistas de Paul Cézanne, Pablo Picasso, Georges Braque, Juan Gris o Fernand Léger, fueron el detonante de su paulatina transformación. Piet realizó durante este breve pasaje parisino, físico y conceptual, una serie de ilustraciones de árboles. No la representación de hileras de árboles, sino un único árbol. No la forma o el color natural del árbol, sino la estructura, la relación horizontal-vertical entre sí, la composición, las líneas con una limitada paleta de colores. El objetivo principal era encontrar "una nueva forma de expresar la belleza de la naturaleza ${ }^{\prime 33}$. Los árboles miméticos del Row of Eight Young Willows Reflected in the Water en 1905, se irán transformando paulatinamente. Cada paso será una renuncia al principio de mimesis; y por otro lado un avance hacía la abstracción.

\begin{abstract}
"Mientras la relación equilibrada se expresa en lo natural por medio de posición, tamaño y valor de forma y color naturales, lo 'abstracto' se expresa por medio de posición, tamaño y valor de la línea recta y el plano (de color) rectangular."134 Piet Mondrian
\end{abstract}

Sin referencias reconocibles del mundo real, tradujo la naturaleza en una composición pictórica mediante reglas geométricas, leyes internas, cambios de color, modificaciones de la estructura y del estilo incluso. Todo ello para "liberar el arte del lastre del mundo objetivo"135. El cuadro Árbol rojo de 1908 supone uno de los primeros alejamientos de representación de la naturaleza de manera fiel,

32 MONDRIAN, Piet. Piet Mondrian: durch drei Themenbereiche von seinem Frühwerk zu seinem Spätwerk: Lebenserinnerungen und Gedanken über die "Neue Gestaltung". En: Kulturelle Monatsschrift. Band 16. Heft 2. 1956. Traducción de la autora: "Ich malte gerne Blumen, aber nicht Buketts, sondern nur einzelne Blumen, damit ich ihre Gestalt besser ausdrücken konnte"

33 Idem. Traducción de la autora: "Das erste, was ich in meiner Malerei ändern musste, war die Farbe. Ich gab die natürliche Farbe auf zugunsten der reinen Farbe. Ich begann zu spüren, dass die Farben der Natur auf der Leinwand nicht reproduziert werden können. Instinktiv fühlte ich, dass die Malerei einen neuen Weg finden musste, um die Schönheit der Natur auszudrücken."

34 MONDRIAN, Piet. La nueva imagen en la pintura. La realización del neoplasticismo en la arquitectura del futuro lejano y de hoy. Colegio Oficial de Aparejadores y Arquitectos Tecnicos de Madrid. Madrid. 1983. ISBN: 84-500-9019-9. Pág. 19.

35 MALEVICH, Kasimir. En: ARNOLD, Heinz Ludwig, Visuelle Poesie. Sonderband. edition text + kritik GmbH. Universidad de California. 1997. Pág. 93. Traducción de la autora: "die Kunst vom Ballast der gegenständlichen Welt befreien" 

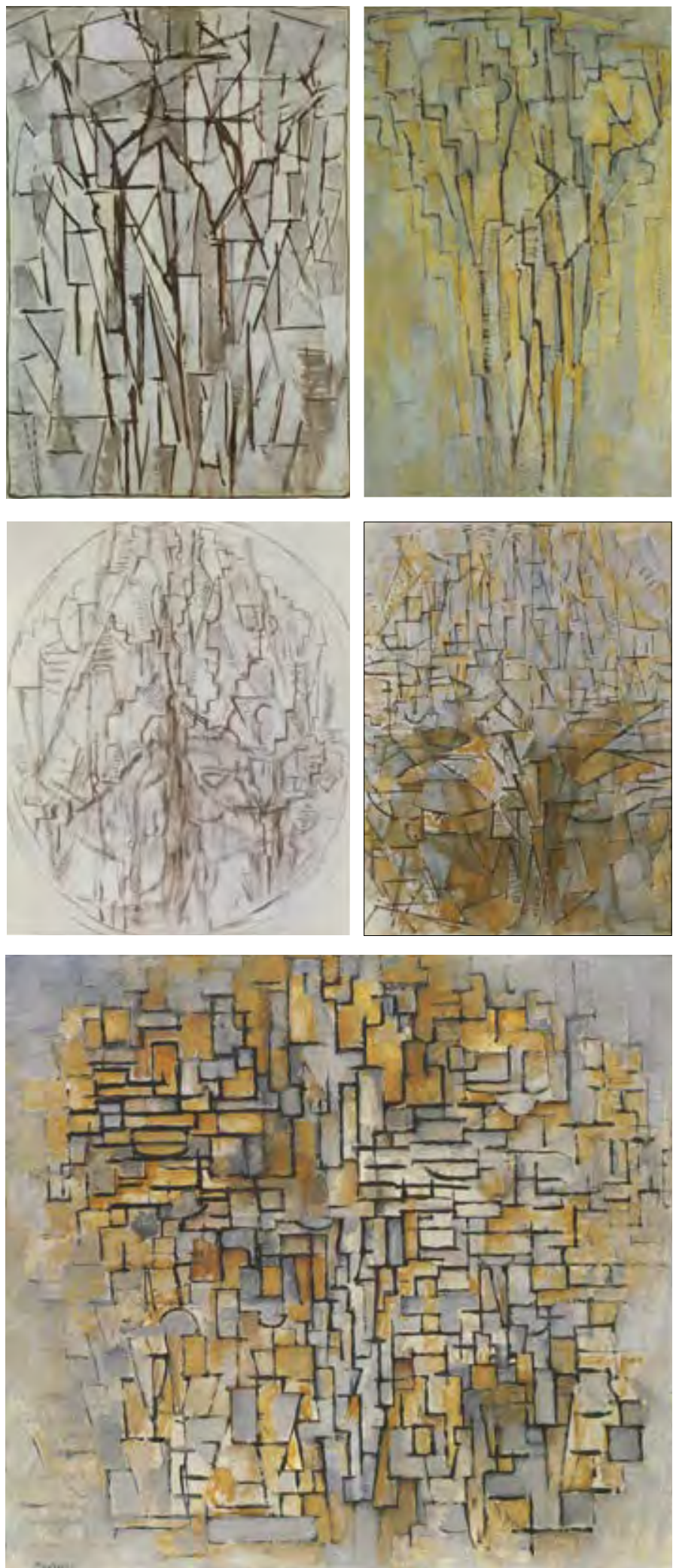

Figura 17 - 21.

Composition Trees II / Mondrian / 1912

The Tree A / Mondrian / 1913

Composition in Oval / Mondrian / 1913

Composition III in Colour / Mondrian / 1913

Composition № VII / Mondrian / 1913 
renunciando al color natural del objeto en favor de uno puro ${ }^{36}$. Un contraste entre la representación figurativa y el uso de colores primarios. Un árbol rojo invernal separado de su contexto paisajístico, trasplantado en un terreno amarillo y un fondo azul. Este afán de abstracción - Abstraktionsdrang ${ }^{37}$ hace alusión al arte en el antiguo Egipto. Representa las características principales de los motivos naturales; basándose en formas puras, abstractas, geométricas. Una técnica casi pictográfica.

Durante los años siguientes, Mondrian continuó experimentando sucesivamente la reducción de elementos representativos. Aunque el cuadro Árbol gris de 1911 permite intuir fácilmente el motivo naturalista por la verticalidad dominante del tronco y la horizontalidad de las ramas, suponía un gran paso hacia la disolución de formas reconocibles. La pérdida de referencias espaciales, la esquematización del árbol, la depuración de líneas así como la reducción del color a tonos grises y negros; encarnan un paisaje plano, una estructura geométrica.

El árbol trazado por Piet Mondrian en Composición № VII de 1913 es netamente abstracto ya que no hace referencia a la naturaleza, rechazando paulatinamente toda asociación figurativa; incluso el título niega su relación con el árbol. Se centra en las características de la estructura, la geometría y los colores. La naturaleza se reduce a un sistema ortogonal de líneas rectas horizontales y verticales. Una interacción de formas rectangulares de colores en tono pastel. Un árbol fragmentado, desmaterializado, generando una trama laberíntica. Una metamorfosis como margen de interpretación.

36 MONDRIAN, Piet. Piet Mondrian: durch drei Themenbereiche von seinem Frühwerk zu seinem Spätwerk: Lebenserinnerungen und Gedanken über die "Neue Gestaltung". En: Kulturelle Monatsschrift. Band 16. Heft 2. 1956. Traducción de la autora: "Das erste, was ich in meiner Malerei ändern musste, war die Farbe. Ich gab die natürliche Farbe auf zugunsten der reinen Farbe." En castellano: "Lo primero que tuve que cambiar en mi pintura fue el color. Renuncié al color natural en favor del color puro."

37 Nota: Según Worringer. En: WORRINGER, Wilhelm. Abstracción y naturaleza. (1908). Fondo de Cultura Económica de España. Madrid. 1997. ISBN: 84-375-0431-7. 

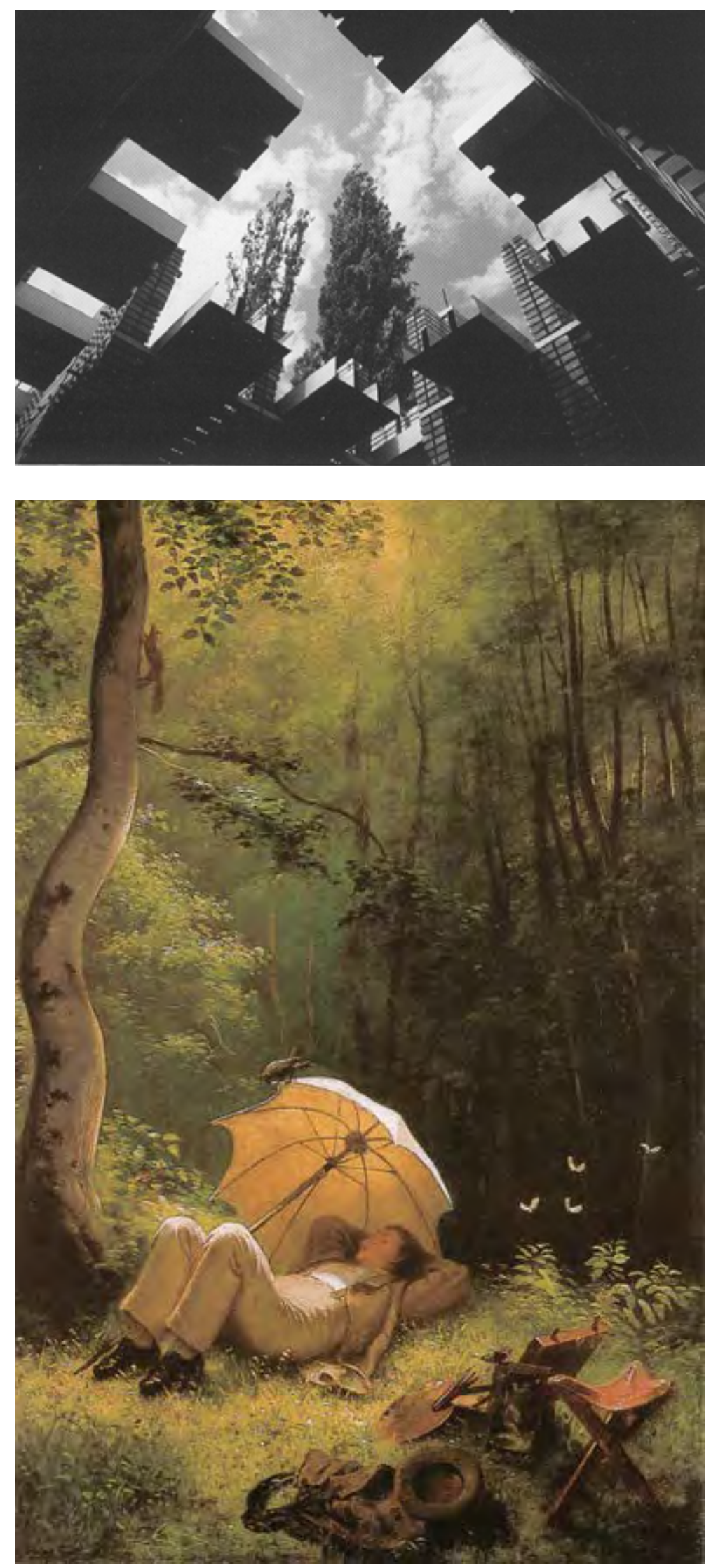

Figura 22 - 23.

Claro del bosque / Pabellón helvético / Hannover / 2000

El pintor en un claro del bosque / alrededor de 1850 / Carl Spitzweg 


\title{
[Arquitectura concreta]
}

\section{“(...) que en el arte abstracto el contenido pictórico sigue dependiendo} de las imágenes de la naturaleza, mientras que en el arte concreto el contenido pictórico surge independientemente de las imágenes naturales... (un caso límite en la pintura sirve de ejemplo): en un lienzo blanco se encuentra un punto rojo. este puede ser creado de dos maneras: en primer lugar, puede representar la salida del sol en la niebla y por lo tanto puede ser considerado como una abstracción, o en segundo lugar pude ser un punto rojo, que expresa una realidad artística por su relación con la superficie... es decir de un arte concreto." ${ }^{\prime 38}$ Max Bill

El termino concreto fue determinado por Theo van Doesburg en el Manifiesto de Arte Concreto $^{39}$ publicado en 1930. Posteriormente Max Bill lo tomó prestado para dos exposiciones, celebradas en Suiza en 1944 y 1960; tituladas Arte Concreto y Arte Concreto - 50 años de desarrollo respectivamente ${ }^{40}$. A diferencia del arte abstracto destinado al uso espiritual ${ }^{41}$; lo concreto es tangible, real y de uso práctico. "El término concreto evoca lo sólido, la corporeidad con tres dimensiones, en general el elemento completo, mientras que la pintura abstracta afirma habitualmente una exigencia de bidimensionalidad" ${ }^{42}$.

\author{
"Usted entra en el edifico y no se hace notar un orden clásico. Al \\ igual que en un bosque. En el bosque hay muchos árboles, todos \\ desordenados, se puede pasar entre estos árboles, esto es el \\ principio básico de nuestro pabellón." ${ }^{\prime 3}$ Peter Zumthor
}

38 BILL, Max. Konkrete Kunst. 50 jahre entwicklung. zürcher kunstgesellschaft. Verwaltungsabteilung des Stadtpräsidenten. Helmhaus Zürich. 1960. Pág. 59. Traducción de la autora: “...dass in der abstrakten kunst die bildinhalte noch von naturbildern abhängig sind, währenddem die bildinhalte in der konkreten kunst unabhängig von naturbildern entstehen... (als beispiel diene ein grenzfall in der malerei: auf einer weißen Leinwand befindet sich ein roter Punkt. dieser kann auf zwei arten entstanden sein: erstens kann es ein sonnenaufgang im nebel sein und ist somit als abstraktion anzusehen, oder es kann, zweitens, ein roter punkt sein, der einzig durch sein verhältnis zur fläche eine künstlerische realität ausdrückt. In diesem zweiten fall handelt es sich um die konkretion eines abstrakten gedankens, also um konkrete kunst."

39 VAN DOESBURG, Theo. Base de la Peinture concrète. En: Numéro d'Introduction du groupe et de la revue art concret. Paris. 1930. https://monoskop.org/images/2/2d/Art_concret_1_1930.pdf

40 Nota: En 1944 comisarió la exposición titulaba "konkrete kunst" en Basilea. En 1960 fue resposnable de la muestra "Konkrete Kunst - 50 Jahre Entwicklung" celebrada en Zurich.

41 BILL, Max. Konkrete Kunst. 50 jahre entwicklung. zürcher kunstgesellschaft. Verwaltungsabteilung des Stadtpräsidenten. Helmhaus Zürich. 1960. Pág. 60.

42 SOURIAU, Étienne. Diccionario Akal de Estética. Ediciones Akal, S.A. Madrid. 2010. ISBN: 978-84-4600832-3. Pág. 337.

43 ZUMTHOR, Peter. Der Architekt baut anders: ein Balken-Labyrinth für die Expo 2000, ein kostspieliges Filigranwerk für die Berliner Topographie des Terrors. Periodico: Der Tagesspiegel. 09. April 2000. Traducción de la autora: "Sie gehen in das Gebäude hinein, und es lässt keine klassische Ordnung erkennen. Wie ein Wald gibt es viele Blumen, die stehen alle ungeordnet, und man geht zwischen diesen Bäumen durch, das ist das Grundrissprinzip unseres Pavillons." 

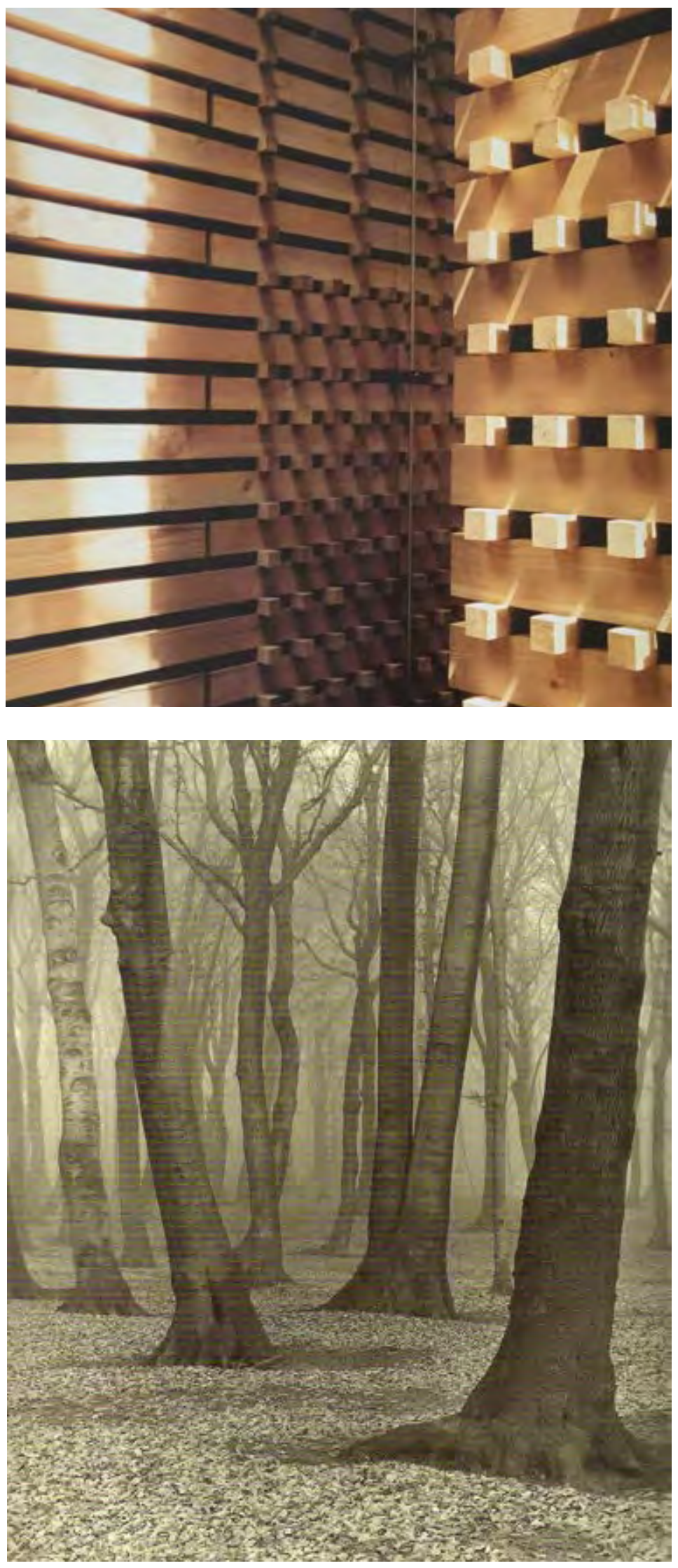

Figura $24-25$.

Pabellón helvético / Hannover / 2000

Beech wood / 1936 / Albert Renger Patzsch 
El pabellón de Suiza es considerado por Zumthor un bosque. Una transición desde lo concreto hacia lo abstracto en el proceso generador de la arquitectura. Concreto, ya que desde el principio se refiere a un cuerpo arquitectónico. Estudia la luz, la sombra, el material, el espacio, el uso, la construcción, las medidas, las proporciones, el lugar, la orientación, las aperturas; pero también incluye en el desarrollo la atmósfera, la temperatura, la escala humana, las direcciones de movimiento, las transiciones entre el interior y el exterior, entre otros. Zumthor traduce lo concreto en "lo convertido en forma, masa y espacio" ${ }^{\prime 4}$. No hay una voluntad de alcanzar la abstracción, la reducción, la simplificación, la esquematización, la eliminación o la derivación de los fenómenos naturales externos, sino la unión ${ }^{45}$ de diversos elementos, o partes, para "experimentar la arquitectura de una forma concreta, es decir tocar su cuerpo, ver oir, oler ${ }^{\prime \prime 4}$.

"Y también realizo el proceso de proyectar en forma de imágenes. No puedo empezar un proyecto con una idea abstracta." 47 "Mis imágenes virtuales son imágenes reales que veo en mi cabeza, no ideas abstractas. Al principio de un proyecto siempre hay un mundo de imágenes y sentimientos. El pensamiento abstracto sólo entra en juego cuando miramos el proyecto y nos preguntamos: ¿nos gusta lo que vemos? ¿Y por qué? O: Eso nos molesta, ¿por qué? Pero también es posible que una imagen sea provocada por una idea abstracta." 48 Peter Zumthor

Aunque la morfología del Klangkörper pueda tener semejanzas a un bosque geométrico, el pensamiento abstracto se produce a través de lo concreto. Para Zumthor, un bosque natural representa una estructura insólita. Consiste en un orden, que a primera vista parece caótico, pero al mismo tiempo armónico. Un

44 ZUMTHOR, Peter. Pensar la arquitectura. Editorial Gustavo Gili. SA. Bacelona. 2004. ISBN: 84-2521992-2. Pág. 34.

45 Nota: Etimológicamente concreto proviene de la palabra latína concretus que significa la unión o crecer unidos.

46 ZUMTHOR, Peter. Pensar la arquitectura. Editorial Gustavo Gili. SA. Bacelona. 2004. ISBN: 84-2521992-2. Pág. 56

47 ZUMTHOR, Peter. Peter Zumthor: Dear to me. En: https://www.dear-magazin.de/interviews/ Peter-Zumthor_-Dear-to-Me_18067117.html. Traducción de la autora: "Und auch das Entwerfen vollziehtsich bei mir in Form von Bildern. Mit einer abstrakten Idee kann ich keinen Entwurf beginnen."

48 ZUMTHOR, Peter. Projekte machen, die Moden überleben: in der neuen Architektur vermisst Peter Zumthor oft die durch Licht und Schatten erzeugte schöne Atmosphäre. En: DU. Die Zeitschrift der Kultur Band.69. Heft 796. 2009. Pág. 49. Traducción de la autora: "Meine virtuellen Bilder sind richtige Bilder, die ich in meinem Kopf sehe, keine abstrakten Ideen. Am Anfang eines Projekts steht bei mir immer eine Bilder- und Gefühlswelt. Das abstrakte Denken kommt erst dazu, wenn wir das Bild dann anschauen und uns fragen: Gefällt uns das, was wir sehen? Und warum? Oder: Das stört uns, weshalb? Aber es ist auch möglich, dass ein Bild durch eine abstrakte Idee ausgelöst wird." 


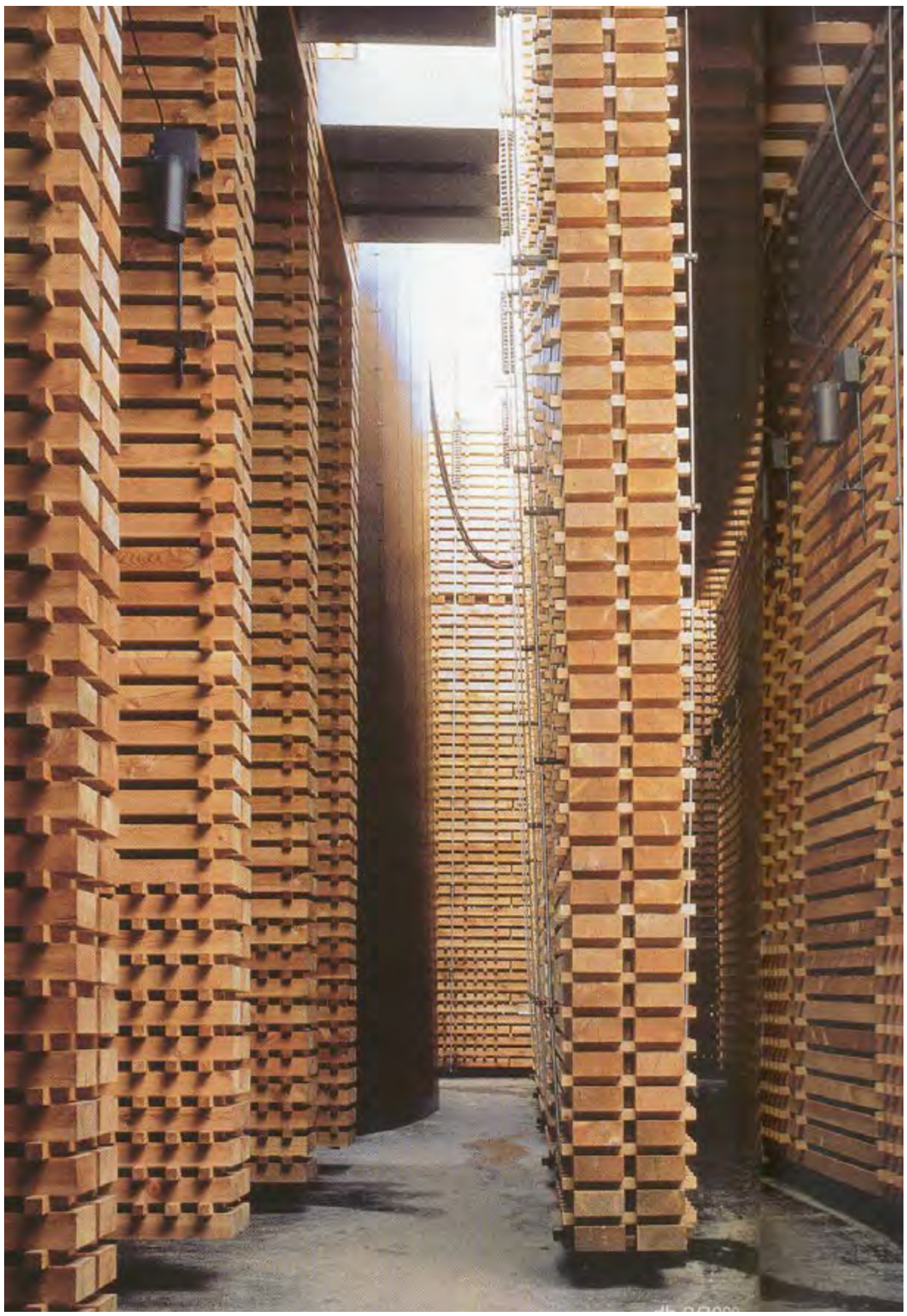

Figura 26.

Pabellón helvético / Hannover / 2000 
bosque no es un espacio estático, sino un organismo. Un espacio, que se descubre experimentándolo. En su interior hay un número infinito de formas y posibilidades de agrupamientos entre sí. Zumthor busca analogías operativas naturales: la nodireccionalidad, la incidencia de la luz, la formación de claros, los contrastes entre abierto y cerrado, entre los claros y los oscuros.

"Paseo a través de un bosque, los árboles se yerguen con densidad regular, aquí y allí un claro, un matorral, unos arbustos, sin largos caminos, sin espacios abiertos, quizá senderos serpenteantes..."49 Roderick Hönig

El espacio arquitectónico como condensador de sensaciones que uno puede encontrar en un bosque: el viento, el olor, el agua de lluvia, los muros evocando a los árboles. Sin embargo, el pabellón helvético no es un bosque, al igual que los Baños Termales de Vals no son una cantera o una cueva, sino un sistema geométrico, creando una composición, un organismo, un lugar proyectado, predeterminado, un microcosmos sensitivo desde lo concreto hacía lo abstracto. 


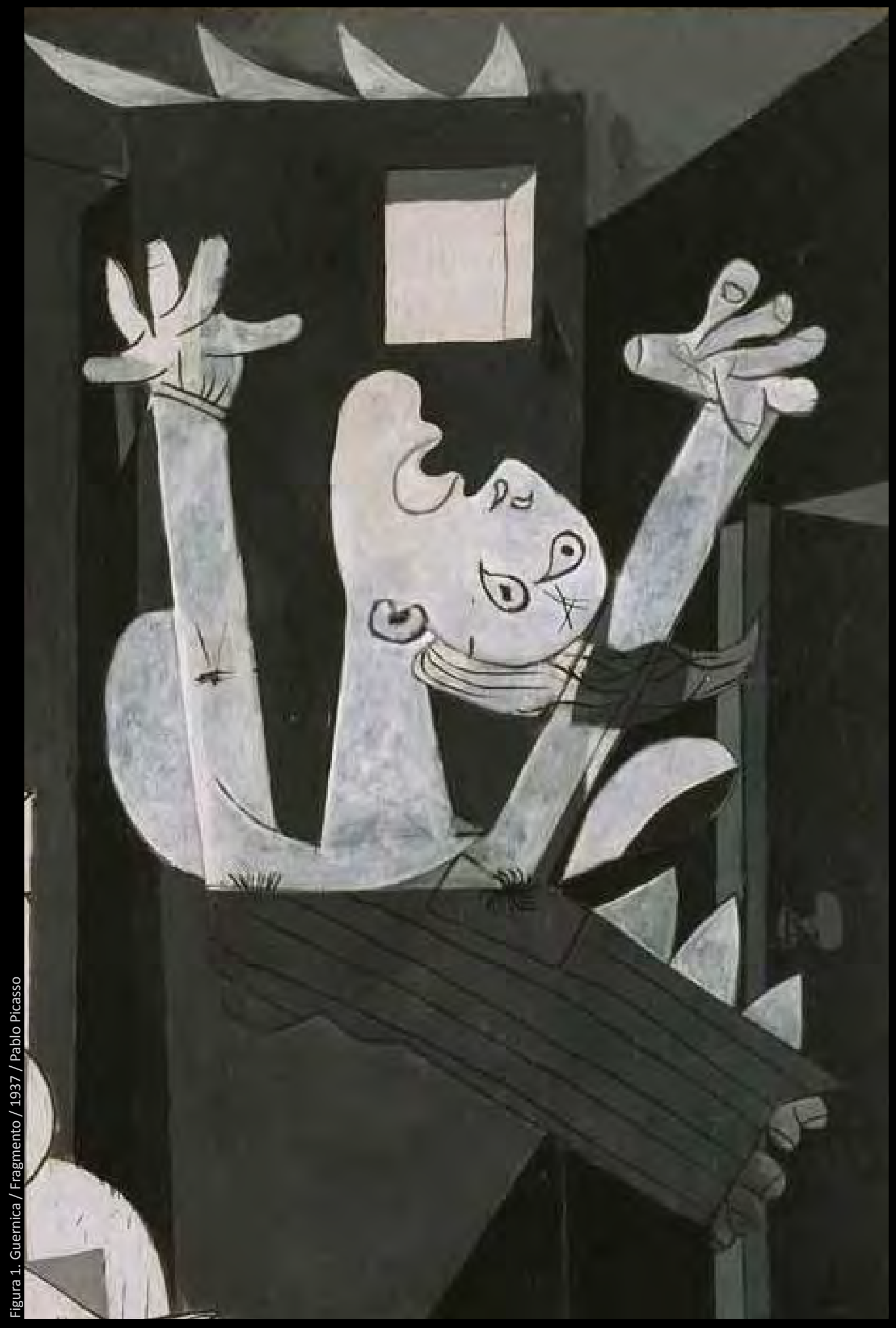




\section{GESAMTKUNSTWERK}

GESAMTKUNSTWERK

"Dar el todo, descubrir la conexión con el universo o querer realizar un universo concentrado, es sólo una tendencia, una confesión, una obsesión, un destilado de arte y el deseo de salvación. El Gesamtkunstwerk no existe."

Harald Szeemann Sauerländer. Frankfurt am Main. 1983. ISBN: 3-7941-2445-6. Traducción de la autora: "Das Ganze geben, den Zusammenhang mit dem Universum aufdecken oder ein geballtes Universum realisieren zu wollen, ist nur ein Hang, ein Bekenntnis, eine Obsession, ein Destillat aus Kunst und Erlösungswunsch. Das Gesamtkunstwerk gibt es nicht." 


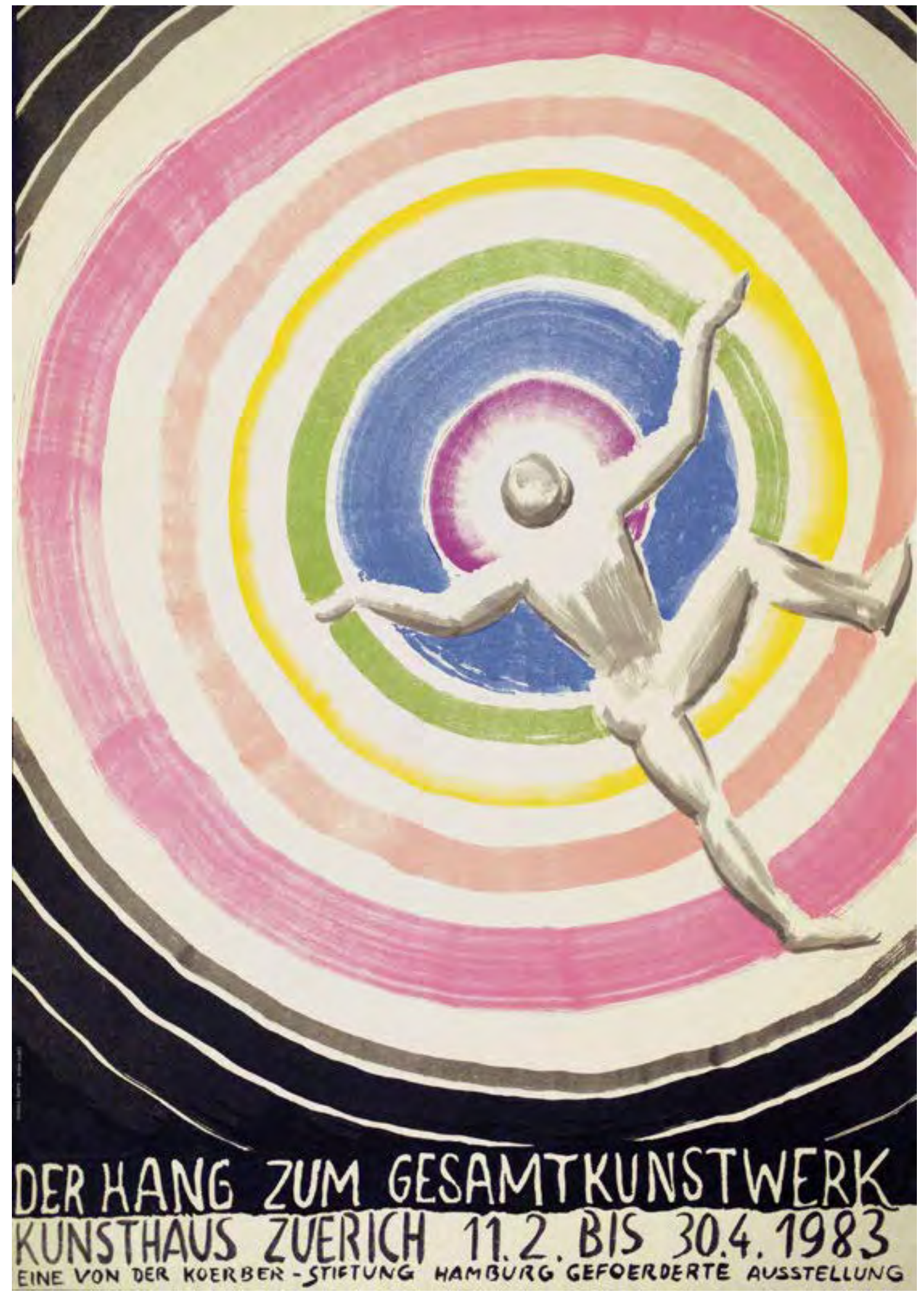

Figura 2.

Cartel de la exposición Der Hang zum Gesamtkunstwerk / 1983 / Harald, Szeemann 


\section{[Síntesis creativa]}

"La cosa es más antigua que el nombre. Desafortunadamente, no está muy claro de qué se trata, debido a esto, el concepto de "Gesamtkunstwerk' debería haber encontrado características tan diversas, entre las cuales los alemanes -especialmente en los últimos cien años - fueron capaces de despertar un interés particular..." Bazon Brock

"G, de Gesamtkunstwerk: El concepto de Gesamtkunstwerk (obra de arte total) surgió en el siglo XIX como un modo de reconciliar el arte y la vida...Por ejemplo: el modo en que hoy se juzgan las exposiciones de arte y arquitectura, atendiendo al concepto expositivo más que al contenido de las propias piezas. El valor de la exposición se impone frente al valor del arte y a cualquier otro valor; todas las exposiciones se piensan como instalaciones, todos los museos como Gesamtkunstwerk. ${ }^{\prime 3}$ Hal Foster

"Obra de arte total, unión de todas las artes: poesía, música, danza, pintura y arquitectura en un gran conjunto unitario en palabra, sonido e imagen, en el cual, sin embargo, debido a que la mera adición de los efectos no significa un aumento, un área de arte prevalece." ${ }^{\prime 4}$ Gero von Wilpert

"Gesamtkunstwerk se basa en el principio de la transgresión intermedia de los límites intermedia de los limites - que revoca la autonomía de las artes individuales - y pretende reintegrar los medios de representación como la poesía, la música, el teatro, la danza y las artes visuales en un todo complejo." Jürgen Söring

2 Brock, Bazon. Der Hang zum Gesamtkunstwerk. Pathosformeln und Energiesymbole zur Einheit von Denken, Wollen und Können. Katalog zur Ausstellung. Aarau, Frankfurt am Main. 1983. En: http://www.brock.uniwuppertal.de/Schrifte/AGEU/Totalkun.html. Traducción de la autora: "Die Sache, um die es dabei geht, ist älter als der Name. Leider ist nicht ganz klar, um welche Sache es geht nicht zuletzt deswegen dürfte das Konzept 'Gesamtkunstwerk' so vielfältige Ausprägungen gefunden haben, unter denen die deutschen - vor allem in den vergangenen hundert Jahren - besonderes Interesse zu wecken vermochten(...)"

3 FOSTER, Hal. Voces en vanguardia. Pequeño diccionario de ideas del diseño actural. Arquitectura Viva. $\mathrm{n}$ ㅇ 93. 2003.

4 VON WILPERT, Gero. Sachwörterbuch der Literatur. Kröner. Stuttgart. 1989. ISBN: 9783520231079. Pág. 338. Traducción de la autora: "Gesamtkunstwerk, Vereinigung aller Künste: Dichtung, Musik, Tanz, Malerei und Architektur zu einem einheitlichen, grossartigen rauschhaften Ganzen in Wort, Ton und Bild, bei dem allerdings, da die blosse Addition der Wirkung keine Steigerung bedeutet, ein Kunstbereich meist strukturell überwiegt(...)"

5 SÖRING, Jürgen. Gesamtkunstwerk. En: Reallexikon der deutschen Literaturwissenschaft. Band 1. Berlin. 1997. ISBN: 978-3-11-019355-8 Pág. 710. Traducción de la autora: "Das Gesamtkunstwerk beruht auf dem - die Autonomie der Einzelkünste widerrufenden - Prinzip der intermedialen Grenzüberschreitung und intendiert eine Reintegration der Darstellungsmittel von Dichtung, Musik, Schauspiel-, Tanz- und bildender Kunst zu einer komplexen Ganzheit." 


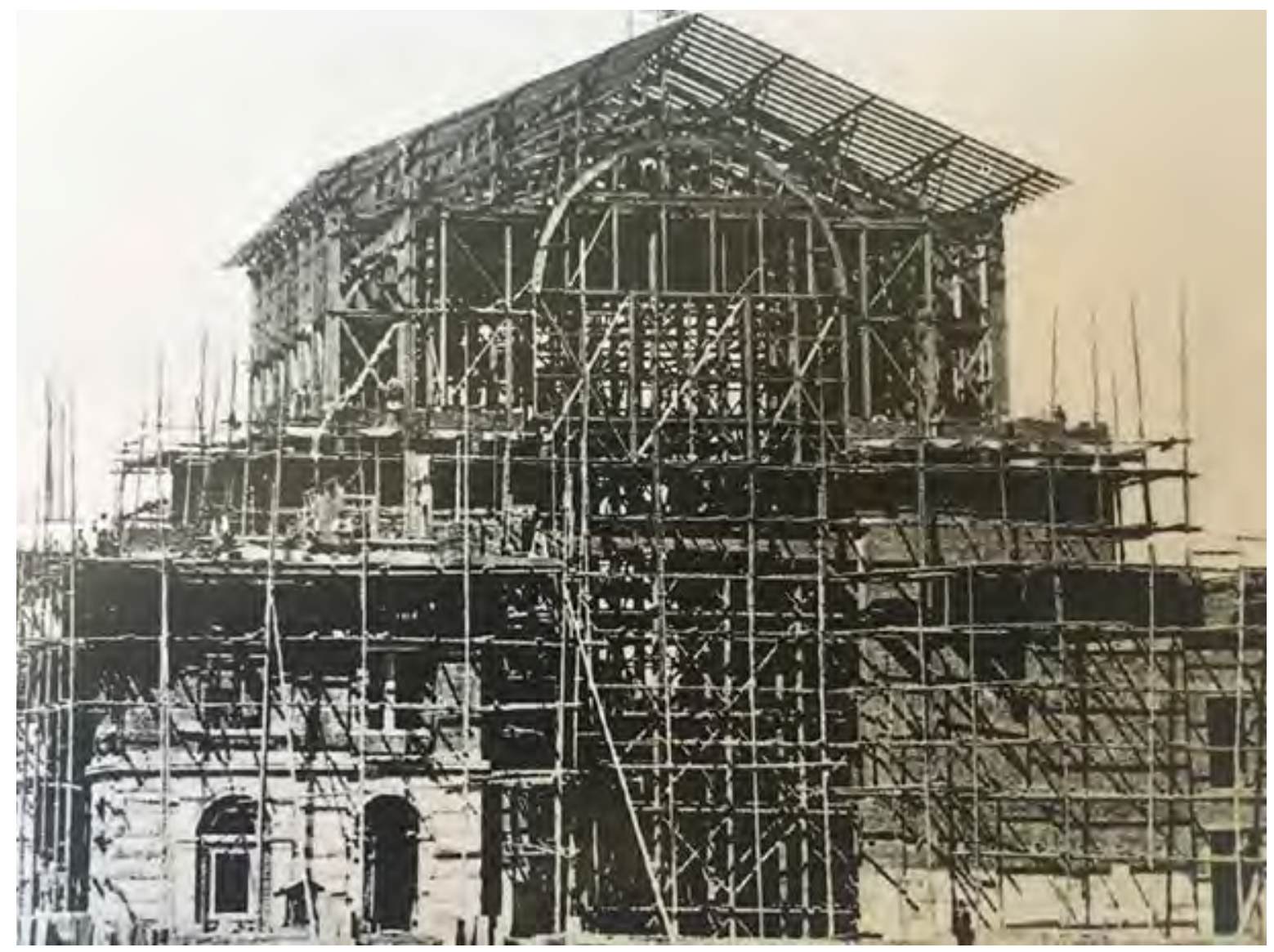

Figura 3.

Obra / Festspielhaus Bayreuth

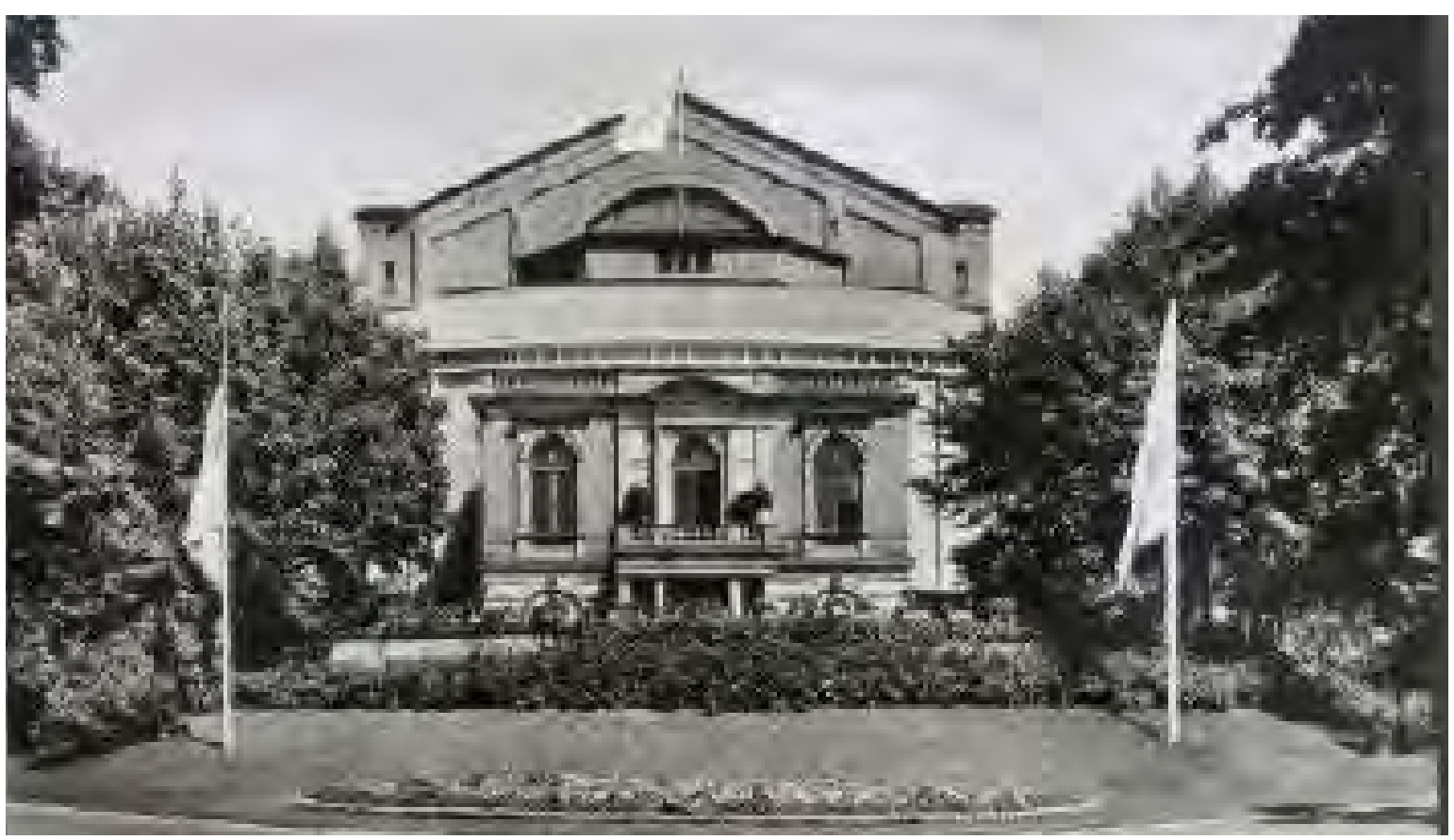

Figura 4.

Carta postal / Festspielhaus Bayreuth / 1958 


\title{
[Idea wagneriana]
}

\begin{abstract}
"Pero esta posibilidad se basa en un esfuerzo en todo el campo del arte a un Gesamt=Kunstwerk por parte de todas las artes, ... Así que se convierte en la aspiración de unir todas las artes en una obra de arte..." Karl Friedrich Eusebius Trahndorff
\end{abstract}

El término Gesamtkunstwerk fue acuñado en 1827 por el escritor y filósofo alemán Karl Friedrich Eusebius Trahndorff. En su ensayo Estética o teoría de la ideología y el arte se refirió a que las cuatro disciplinas, "el arte de la fonética, la música, la mímica y el arte de la danza" ${ }^{\prime \prime}$, eran equivalentes. Las cuatro fluyen juntas, formando una unidad.

Sin embargo, la idea romántica ${ }^{8}$ del Gesamtkunstwerk en relación con la síntesis de las artes está ligada estrechamente a Richard Wagner. En sus ensayos Kunst und Revolution Arte y revolución, Das Kunstwerk der Zukunft - La obra de arte del futuro, ambos de 1849, y Oper und Drama - Ópera y Drama de 1851; el compositor, poeta y dramaturgo describió la búsqueda de un nuevo drama musical alemán, exigiendo la reunificación de las "tres formas de arte puramente humano en su unión original", "danza, música y poesía" como "las tres hermanas primordiales ${ }^{\prime \prime 1}$. La pureza artística y la autonomía fueron las ideas centrales en la formulación original de Wagner. Retomando el texto Philosophie der Kunst ${ }^{12}$ - Filosofía del arte de Friedrich Wilhelm Joseph Schelling; Wagner señaló el arte de la antigua Grecia ${ }^{13}$ como $^{\circ}$ modelo para la concepción del Gesamtkunstwerk. Idealización de la síntesis de las diferentes artes “(...) como la expresión de una unidad del mundo perfectamente armoniosa, (...)”nt.

6 TRAHNDORFF, Karl Friedrich Eusebius. Ästhetik oder Lehre von der Weltanschauung und Kunst. 2. Band. Berlin. 1827. Pág. 312-313. Traducción por el autror: "Diese Möglichkeit gründet sich aber auf ein in dem gesamten Kunstgebiete liegendes Streben zu einem Gesamt=Kunstwerke von Seiten aller Künste, ein Streben das in dem ganzen Kunstgebiete ursprünglich ist, sobald wir die Einheit seines inneren Lebens erkennen...Es wird also das Streben, alle Künste zu einem Kunstwerke zu vereinigen..." Idem. Pág. 312. Traducción de la autora: "Kunst des Wortklanges, die Musik, Mimik und Tanzkunst"

8 BERMBACH, Udo. Der Wahn des Gesamtkunstwerks. Richard Wagners politisch-ästhetische Utopie. (1994) Verlag J.B. Metzler. Stuttgart. 2004. ISBN: 978-3-476-01868-7. Pág. 127

9 WAGNER, Richard. Das Kunstwerk der Zukunft. Verlag von Otto Wigand. Leipzig. 1850. Pág. 43. Traducción de la autora: "drei reinmenschlichen Kunstarten"

10 Idem. Pág. 43. Traducción de la autora: "Tanzkunst, Tonkunst und Dichtkunst"

11 Idem. Pág. 43. Traducción de la autora: "heissen die drei urgeborenen Schwestern"

12 SCHELLING, Friedrich Wilhelm Joseph. Philosophie der Kunst (1859). Darmstadt. 1990. Pág. 380. Nota: "Sólo noto que la composición más perfecta de todas las artes, la unión de la poesía y la música a través del canto, de la poesía y la pintura a través de la danza, incluso sintetizada de nuevo, es el fenómeno teatral más complejo, lo mismo que el drama de la antigüedad, del que sólo nos quedó una caricatura, la ópera...". Traducción de la autora: "Ich bemerke nur noch, dass die vollkommenste Zusammensetzung aller Künste, die Vereinigung von Poesie und Musik durch Gesang, von Poesie und Malerei durch Tanz, selbst wieder synthetisiert die componierteste Theatererscheinung ist, dergleichen das Drama des Altertums war, wovon uns nur eine Karrikatur, die Oper geblieben ist(...)"

13 WAGNER, Richard. Die Kunst und die Revolution. Verlag von Otto Wigand. Leipzig. 1850. Pág. 17.

14 Idem. Pág. 17. Traducción de la autora: “...als der Ausdruck einer vollkommen harmonisch gestimmten Einheit der Welt, wie es die Kunst der griechischen Welt war,..." 


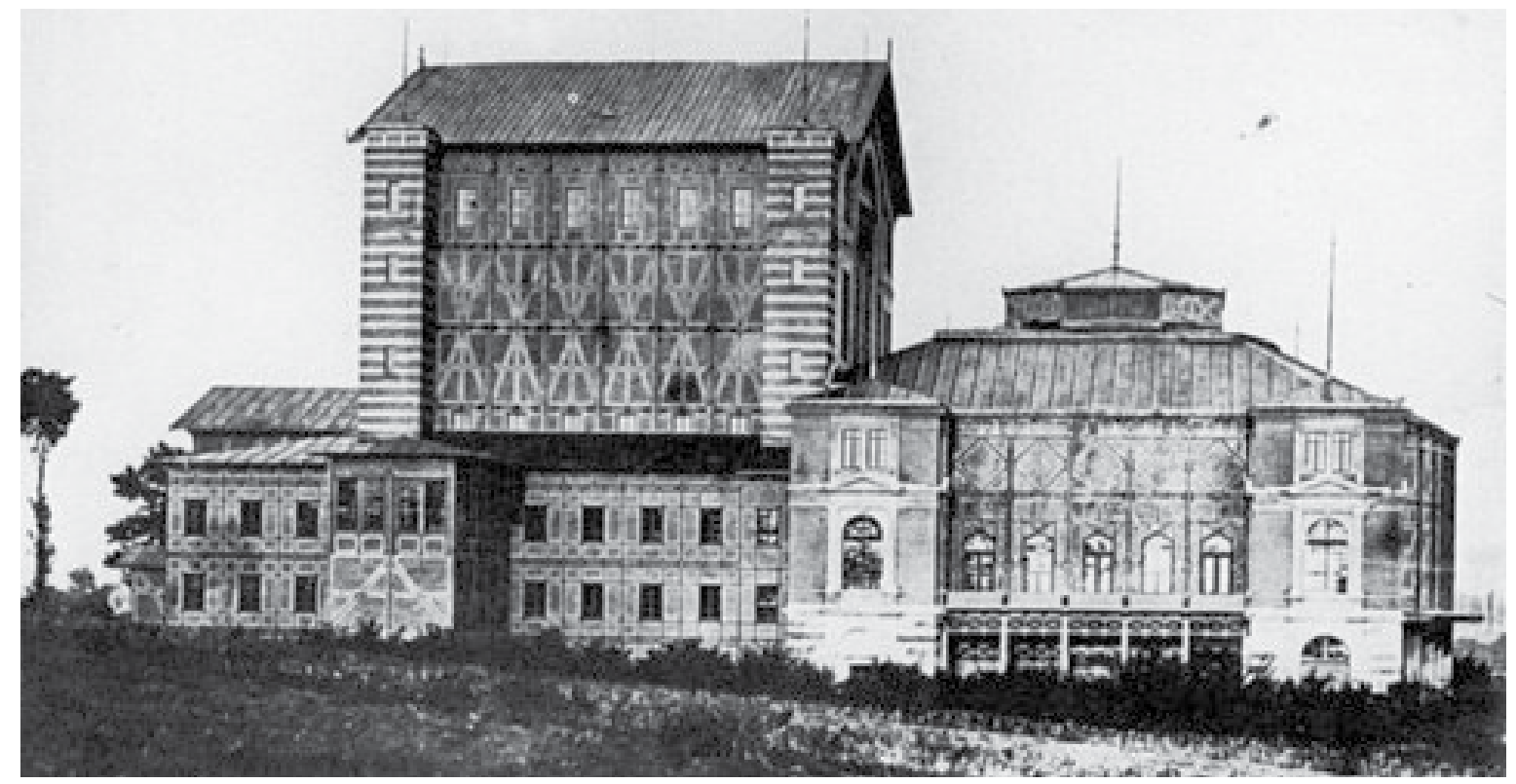

Figura 5.

Festspielhaus Bayreuth

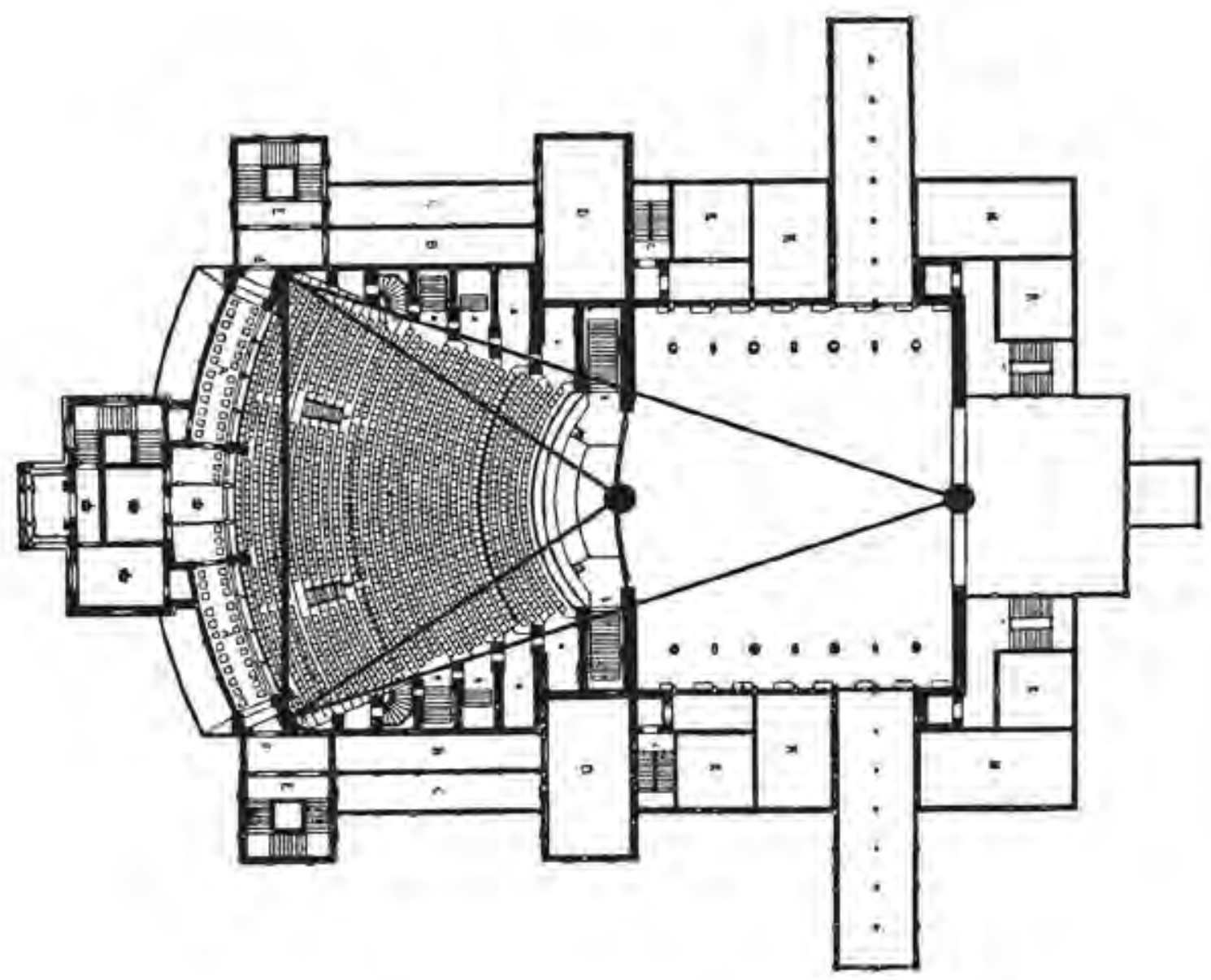

Figura 6.

Planta / Festspielhaus Bayreuth 
"Para los griegos, la obra de arte perfecta y dramática era el epítome de todo lo que se puede representar desde el ser griego; era, en íntima conexión con su historia, la nación misma, que se oponía a la realización de la obra de arte, se entendía a sí misma y, en el curso de unas pocas horas, se consumía como a sus propios y más nobles placeres. Cada división de este placer, cada fragmentación de las fuerzas unidas en un punto, cada divergencia de los elementos de acuerdo a diferentes direcciones especiales - una obra de arte, como el estado similarmente constituido en sí mismo, sólo tenía que ser perjudicial para este maravilloso..." ${ }^{\prime 15}$ "Es precisamente la disolución del Estado ateniense lo que ha llevada al colapso de la tragedia. Así como el espíritu común se fragmentó en mil direcciones egoístas, la gran Gesamtkunstwerk de la tragedia también se disolvió en sus componentes artísticos individuales. ${ }^{116}$ Richard Wagner

La definición wagneriana del Gesamtkunstwerk tiene su origen en el anabolismo de las diferentes artes de la antigüedad involucradas en una unidad armoniosa. Una interacción equitativa de la música, el canto, la danza, la iluminación, los efectos sonoros, el vestuario, la escenografía, el movimiento y los textos; logrando una completa inmersión del espectador en el drama. El ojo y el oído se funden de mutuo acuerdo ${ }^{17}$.

"La gran obra de arte total, que ha de abarcar todos los géneros del arte, con el fin de utilizar adecuadamente como medio cada una de sus maneras específicas, y aniquilar la propia individualidad de éstas en favor de la consecución de un objetivo común para todos. Es decir, la representación más incondicional y directa de la naturaleza completa del hombre. Él no reconoce esta gran obra de arte como una acción arbitraria, sino el trabajo necesario del hombre del futuro. ${ }^{\text {178 }}$ Richard Wagner

15 Idem. Pág. 22. Traducción de la autora: "Bei den Griechen war das vollendete, das dramatische Kunstwerk der Inbegriff alles aus dem griechischen Wesen Darstellbaren; es war, im innigen Zusammenhange mit ihrer Geschichte, die Nation selbst, die sich bei der Aufführung des Kunstwerkes gegenüberstand, sich begriff und im Verlaufe weniger Stunden zum eigenen, edelsten Genüsse sich gleichsam selbst verzehrte. Jede Zerteilung dieses Genusses, jede Zersplitterung der in einen Punkt vereinigten Kräfte, jedes Auseinandergehen der Elemente nach verschiedenen besonderen Richtungen - mußte diesem herrlich einen Kunstwerke, wie dem ähnlich beschaffenen Staate selbst, nur nachteilig sein,(...)"

16 Idem. Pág. 10. Traducción de la autora: "Genau mit der Auflösung des athenischen Staates hängt der Verfall der Tragödie zusammen. Wie sich der Gemeingeist in tausend egoistische Richtungen zersplitterte, löste sich auch das große Gesamtkunstwerk der Tragödie in die einzelnen, ihm inbegriffenen Kunstbestandteile auf."

17 WAGNER, Richard. Die Kunst und die Revolution. Verlag von Otto Wigand. Leipzig. 1850. Pág. 8. Nota: "(...)wo Aug und Ohr, wie Geist und Herz lebendig und wirklich alles erfassten und vernahmen."

18 WAGNER, Richard. Das Kunstwerk der Zukunft. Verlag von Otto Wigand. Leipzig. 1850. Pág. 32. Traducción de la autora: "Das große Gesammkunstwerk, das alle Gattungen der Kunst zu umfassen hat, um jede einzelne dieser Gattungen als Mittel gewissermaßen zu verbrauchen, zu vernichten zu Gunsten der Erreichung des Gesammtzwecks aller, nämlich der unbedingten, unmittelbaren Darstellung der vollendeten menschlichen Natur, - dieses große Gesamtkunstwerk erkennt er nicht als die willkürlich mögliche Tat des Einzelnen, sondern als das nothwendig denkbare gemeinsame Werk der Menschen der Zukunft." 


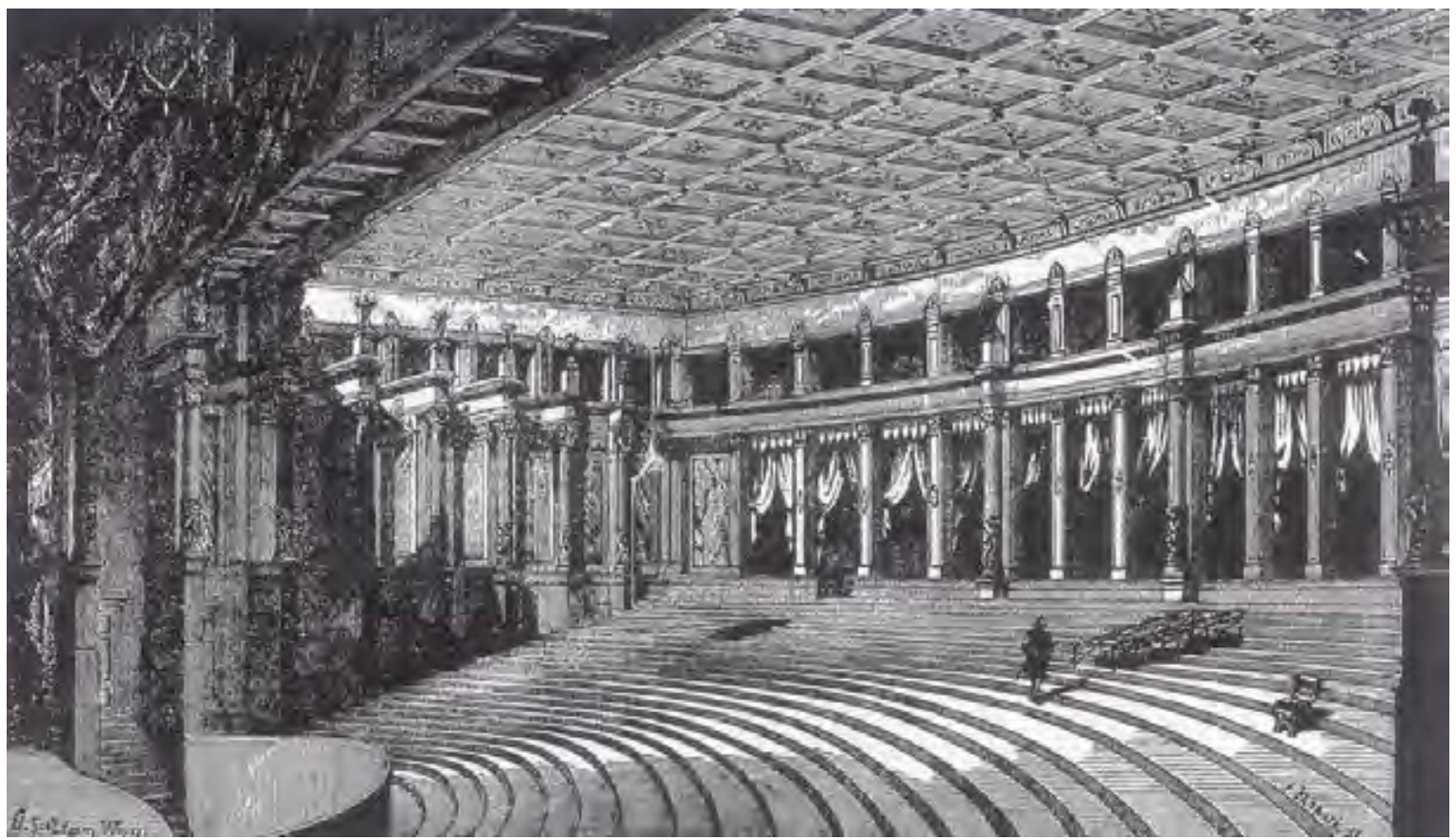

Figura 7.

Interior del Festspielhaus Bayreuth

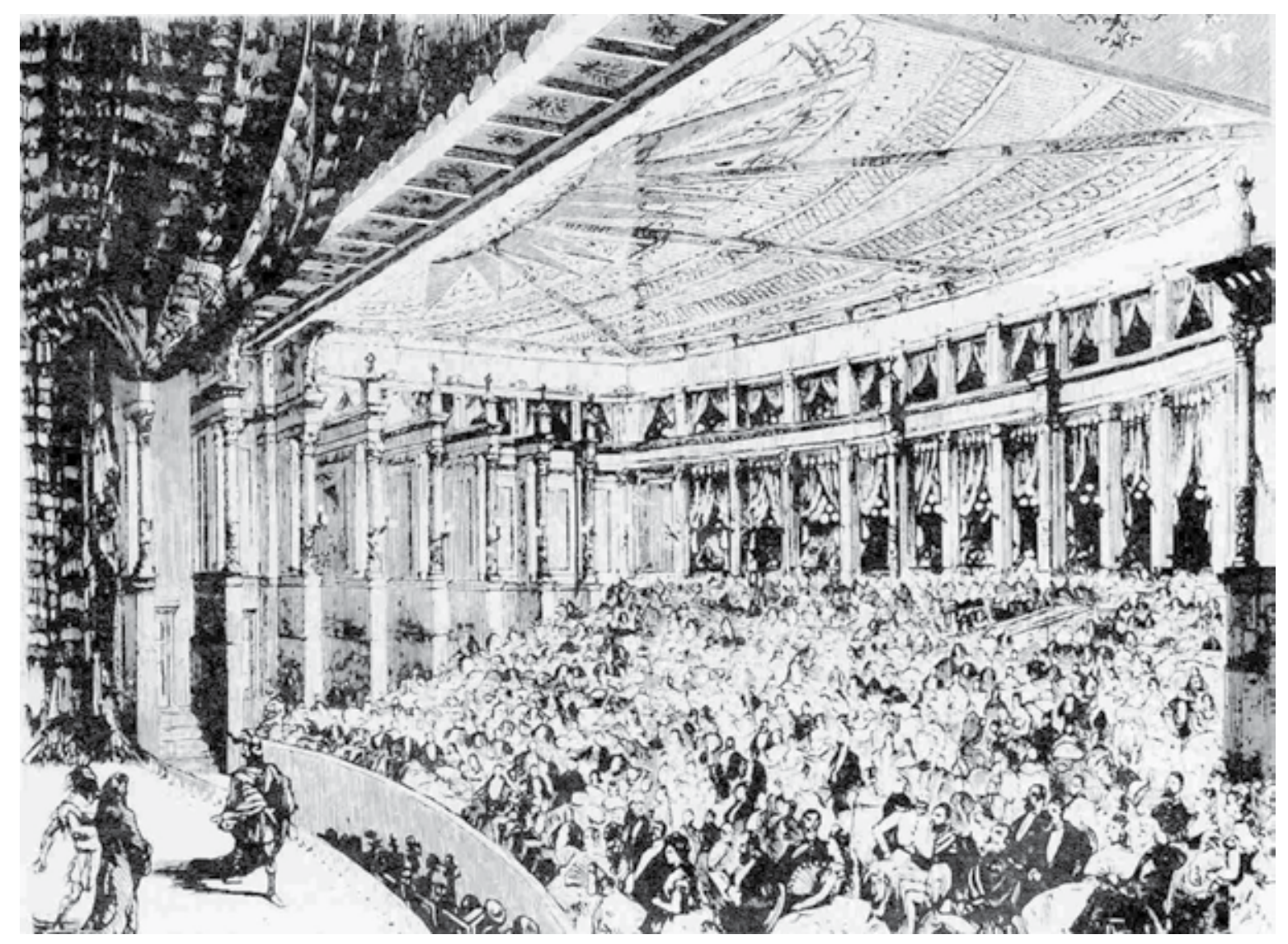

Figura 8.

El interior del Festspielhaus, durante la primera representación de El anillo del nibelungo / 1876 
En un mundo marcado por la industrialización, Wagner buscó la reunificación de los ideales artísticos, estéticos e incluso políticos; como mecanismo de transformación de la sociedad.

\begin{abstract}
"En su concepto estético, Wagner busca ponerse al día con lo que la fallida revolución de 1849 le había negado: el replanteamiento de todas las condiciones religiosas, políticas, sociales y culturales existentes, la renovación revolucionara de un mundo moral e institucionalmente considerado en bancarrota por la Gesamtkunstwerk concebida por él - una visión de salvación." ${ }^{19}$ Udo Bermbach
\end{abstract}

En la obra inaugurada en 1876, Der Ring des Nibelungen - El anillo del Nibelungo, plateó un drama en cuatro partes ${ }^{20}$. Con una duración de 16 horas aproximadamente, se construyó una edificación específicamente para su representación, el Festspielhaus de Bayreuth. Según las especificaciones concretas de Richard Wagner, fue proyectada en colaboración con el arquitecto Otto Brückwald tomando como referencia las representaciones dramáticas de la Antigua Grecia. Un teatro funcional, sin ornamentos con un auditorio anfiteatro, que contenía una orquesta completa en el foso para no perturbar la concentración y atención sobre el escenario. Una intervención artística total donde convergen la música, la poesía, la letra, la coreografía, el diseño escenográfico y el vestuario; porque "(...) lo que realmente es solo una sensación [temporal-musical] ... se transforma en una sensibilidad [espacialmente arquitectónica] (...) ${ }^{121}$. Síntesis de las diferentes artes - visuales, acústicas y atmosféricas; un conjunto sensorial simultáneo, y sobre todo total.

19 BERMBACH, Udo. Der Wahn des Gesamtkunstwerks. Richard Wagners politisch-ästhetische Utopie. (1994) Verlag J.B. Metzler. Stuttgart. 2004. ISBN: 978-3-476-01868-7. Pág. IX Traducción de la autora: "Wagner sucht hier in seinem ästhetischen Konzept einzuholen, was die gescheiterte Revolution von $1849 \mathrm{ihm}$ verweigert hatte: das Umdenken aller bestehenden religiösen, politischen, gesellschaftlichen und kulturellen Verhältnisse, die revolutionäre Erneuerung einer moralisch wie institutionell als bankrott erachteten Welt durch das von ihm konzipierte Gesamtkunstwerk - Vision einer Erlösung."

20 Nota: La obra consta de cuatro partes: Das Rheingold - El oro de Rin, Die Walküre - La valquiria, Siegfried - Sigfrido, Götterdämmerung - El ocaso de los dioses.

21 FLIEDNER, Hans-Jürgen. Architektur und Erlebnis - das Festspielhaus Bayreuth (Von der architektonischen Schematisierung des Ideenerlebnisses), 40 Schaubilder und Abbildungen. Synästhesie Verlag. Coburg. 1999. ISBN: 3-931248-05-4. Pág. 66. Traducción de la autora: “... das, was eigentlich nur [zeitlich-musikalische] Empfindung ist, ... in ein [räumlich architektonisch] Empfindbares verwandelt... " 

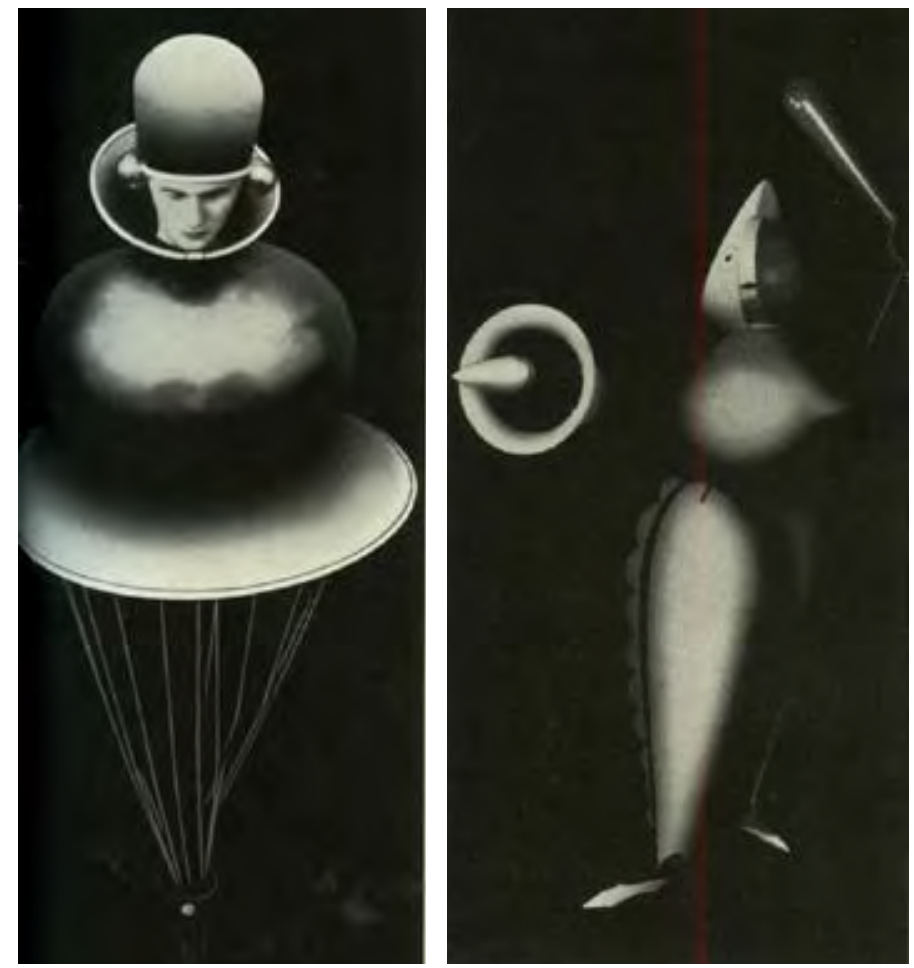

Figura 9 - 10 .

Modelo para el Ballet Triádico / 1922 / Oskar Schlemmer

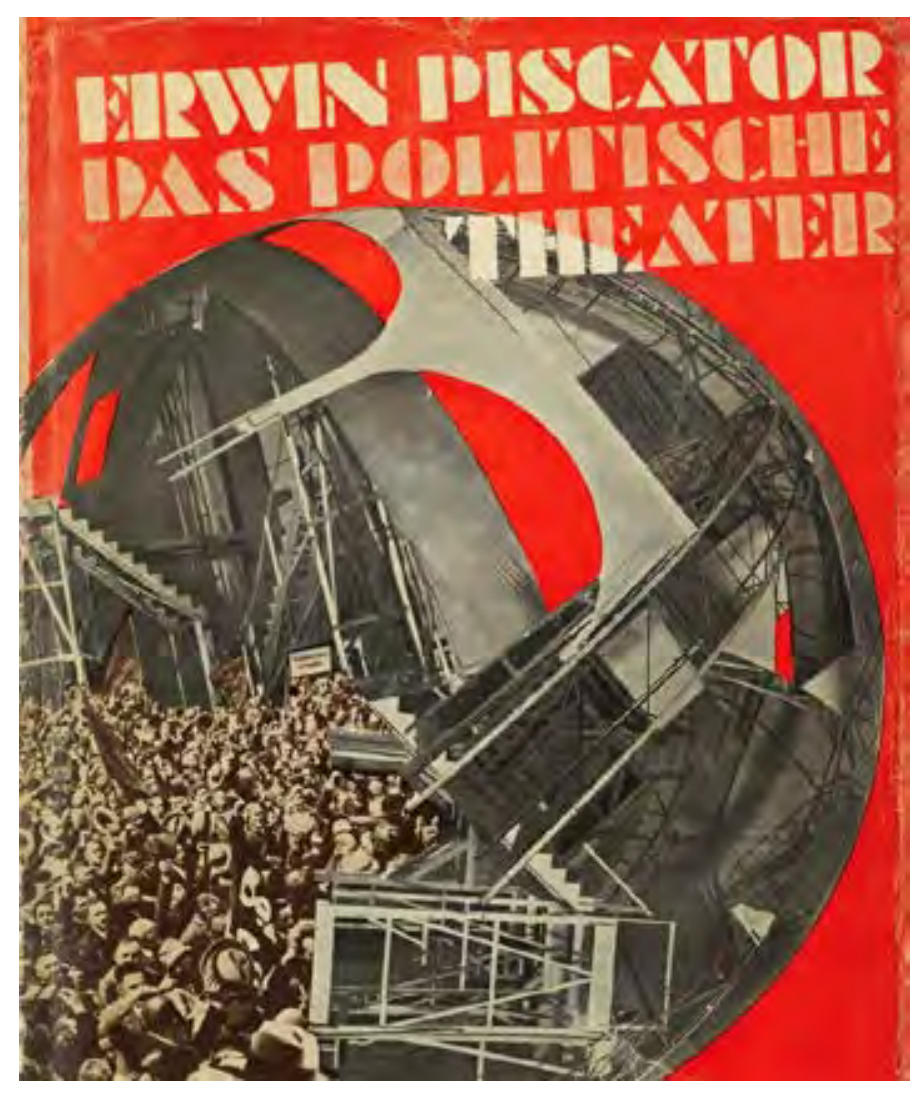

Figura 11.

Das politische Theater / 1929 / Erwin Piscator / Portada de Lázló Moholy-Nagy 


\title{
[Tentáculos]
}

\begin{abstract}
"La Bauhaus se propone reunir en una unidad todas las formas de creación artística, reunificar en una nueva arquitectura, como partes invisibles, todas las disciplinas de la práctica artística: escultura, pintura, artes aplicadas y artesanía. El fin último, aunque remoto, de la Bauhaus es la obra de arte unitaria..."22 Walter Gropius
\end{abstract}

La Bauhaus fue el resorte creativo durante más de una década, absorbiendo los ecos de la escuela rusa Vkhutemas. Un espíritu de la investigación y experimentación ${ }^{23}$ con simiente en el intercambio interdisciplinario de diferentes estilos artísticos. Sin embargo, dado que el término Gesamtkunstwerk se relacionó estrechamente con Richard Wagner, y su ideología nacionalista y antisemita ${ }^{24}$; en el Manifiesto de la Bauhaus ${ }^{25}$ de 1919 la palabra fue evitada y sustituida por una nueva, Einheitskunstwerk-obra de arte unitaria. Así se renovó, eliminando la paternidad de la idea de Gesamtkunstwerk wagnerianaa; y emergieron diferentes formas de arte y nuevos medios de expresión. Un nuevo conjunto entre arquitectura, danza, movimiento, material, luz, escenografía, espacio, vestuario, música, máscara, sonido, texto y la representación del cuerpo humano entre otros. Uno de los casos paradigmáticos fue el Ballet Tríadico de 1922 de Oskar Schlemmer.

\begin{abstract}
"Simplicidad de expresión y construcción, efecto claro e inequívoco sobre los sentimientos del público obrero, subordinación de toda intención artística a la meta revolucionaria: énfasis consciente y propagación de la idea de la lucha de clases. ${ }^{126}$ Erwin Piscator
\end{abstract}

El Teatro Proletario de Erwin Piscator también incorporará la integración de diferentes disciplinas artísticas en una sola entidad. Un teatro de masas donde el espectador se convierte en parte activa de los actos escénicos, "usando todas las posibilidades

22 WINGLER, Hans M. La Bauhaus Weimar Dessau Berlin 1919-1933. (1962) Editorial Gustavo Gili, S. A. Barcelona. 1980. ISBN: 84-252-0841-6. Pág. 42

23 En: https://www.bauhaus100.de/das-bauhaus/koepfe/direktoren/walter-gropius/. Traducción de la autora: "im Geiste des Forschens und Experimentierens erfunden"

24 Nota: En 1850, Wagner escribió el escrito antisemita contra los judíos bajo el seudónimo de K. Freigedank, titulado "El judaísmo en la música - Das Judenthum in der Musik". También se sabe que Hitler era un admirador de la música de Wagner e incluso conocía a la familia Wagner.

25 Nota: En consonancia con la idea wagneriana del arte total, el arquitecto Peter Behrens persiguió la idea de la unificación de las artes. Así ejerció una gran influencia en Walter Gropius, tras trabajar durante cuatro años, junto a Mies van der Rohe, en su estudio de arquitectura.

26 PISCATOR, Erwin. Das politische Theater. Volumen 1. Schriften. Henschelverlag Kunst und Gesellschaft. Berlin. 1968. Pág. 36. Traducción de la autora: "Einfachheit im Ausdruck und Aufbau, klare eindeutige Wirkung auf das Empfinden des Arbeiterpublikums, Unterordnung jeder künstlerischen Absicht dem revolutionären Ziel: bewußte Betonung und Propagierung des Klassenkampfgedankens." 

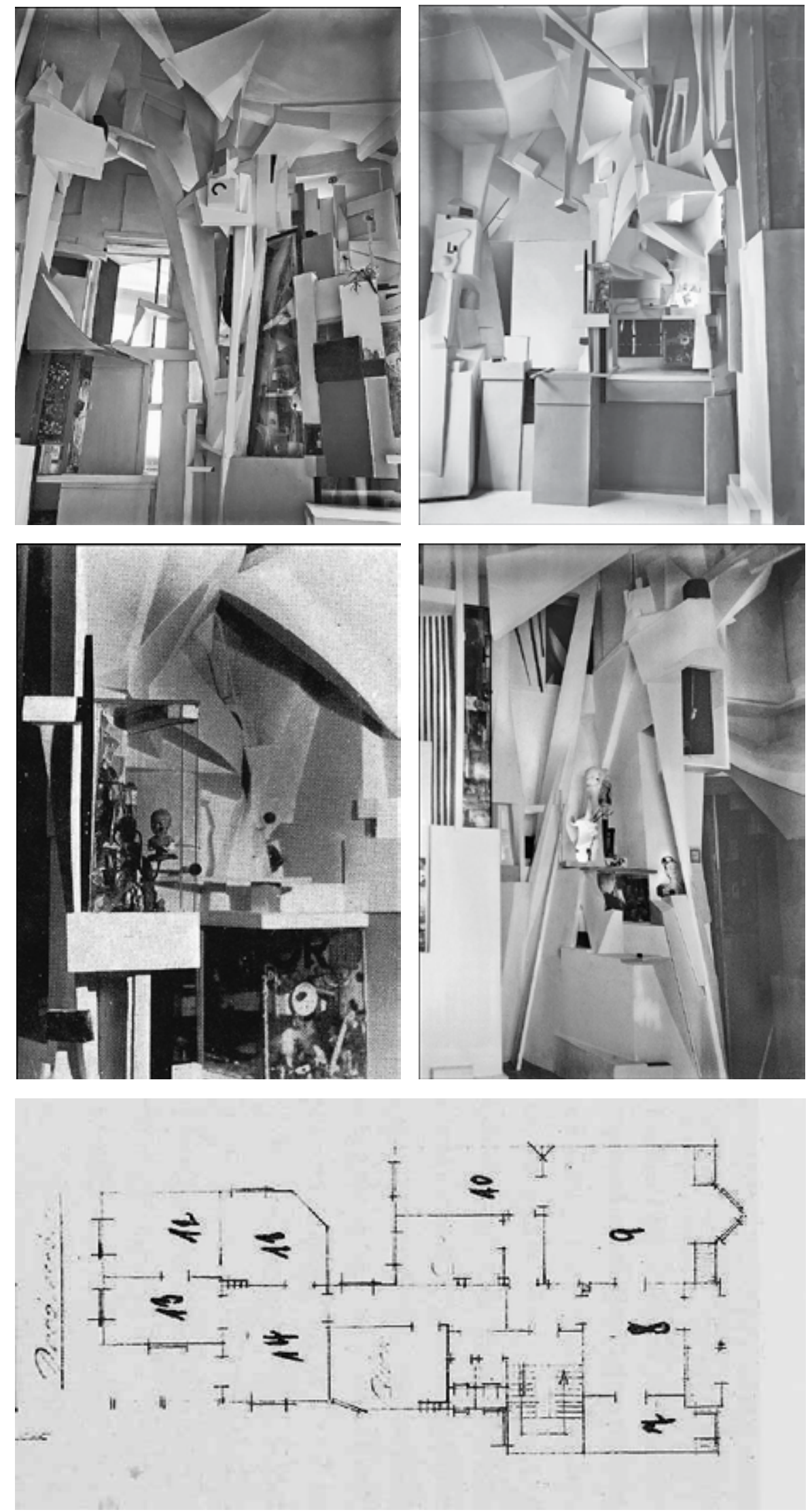

Figura 12 - 16

Merzbau / Kurt Schwitters 
sin escrúpulos: música, chanson, acrobacia, dibujo rápido, deportes, proyección, cine, estadísticas, actuación, discurso"27. La función como collage escénico ${ }^{28}$. Un sistema abierto mediante la abolición del limite entre escenario y audiencia. El lugar se transforma en un espacio participativo, una vida comunitaria. Gesamtkunstwerk como organización colectiva, Einheitskunstwerk.

Al igual que Piscator; la concepción del Gesamtkunstwerk del compositor John Cage es un conglomerado sin jerarquía: experimentación, interacción del público, azar, ruido ambiental, silencio, improvisación, disolución del espacio escénico tradicional o performance. Una colisión de sonidos, personas, imágenes y movimientos, donde ninguna acción es controlada por otra. Gracias al azar, así como a la participación activa de la audiencia, cada actuación es diferente. Una experiencia donde "Todo hombre es un artista"29. Para Joseph Beuys, la acción creativa de cada ser humano tiene que tener como objetivo crear arte. El trabajo artístico como transgresión, como fusión con la vida, como provocación, como una declaración socio-política. El arte como mecanismo de transformación de la sociedad.

"El empleo de diferentes tipos de arte fue una necesidad artística para mí. La razón no fue el impulso de ampliar mi campo de actividad, sino la aspiración de no ser un especialista en un tipo de arte sino ser un artista. Mi objetivo es el Merz-Gesamtkunstwerk, que resume todo tipo de arte en unidad artística. ${ }^{130}$ Kurt Schwitters

La obra de Kurt Schwitters es próxima a la definición wagneriana. Sin embargo, la diferencia principal radica en que este no concibe la música como el arte predominante. Entre 1918-37 transformó paulatinamente su casa de Hannover ${ }^{31}$ en un Merzbau. Una escultura espacial en forma de gruta. Una instalación llena de recuerdos, inicialmente de amigos y familiares, los cuales comenzó a almacenar ya que era un material que

27 AAVV. Reallexikon der deutschen Literaturwissenschaft: Neubearbeitung des Reallexikons der deutschen Literaturgeschichte. Band 1. Walter de Gruyter. Berlin. 2010. ISBN: 978-3-11-0193558. Pág. 711. Traducción de la autora: "unter skrupelloser Verwendung aller Möglichkeiten: Musik, Chanson, Akrobatik, Schnellzeichnung, Sport, Projektion, Film, Statistik, Schauspielszene, Ansprache"

28 SCHLICHER, Susanne. TanzTheater: Traditionen und Freiheiten: Pina Bausch, Gerhard Bohner, Reinhild Hoffmann, Hans Kresnik, Susanne Linke. Rowohlt. Reinbek bei Hamburg. 1987. ISBN: 3-499-55441-0. Pág. 17.

29 KRÜGER, Werner. Joseph Beuys: Jeder Mensch ist ein Künstler (Portrait). Edmund Schmidt-Produktion, WDR. 1980. Traducción de la autora: "Jeder Mensch ist ein Künstler"

30 SCHWITTERS, Kurt. Merz. En: Der Ararat. vol. 2. no1. 19. Dezember 1920. Pág. 6-7. http://sdrc.lib.uiowa.edu/ dada/articles/schwitters.htm. Traducción de la autora: "Die Beschäftigung mit verschiedenen Kunstarten war mire in künstlerisches Bedürfnis. Der Grund dafür war nicht etwa Trieb nach Erweiterung des Gebietes meiner Tätigkeit, sondern das Streben, nicht Spezialist einer Kunstart, sondern Künstler zu sein. Mein Ziel ist das Merzgesamtkunstwerk, das alle Kunstarten zusammenfasst zur küntlerischen Einheit."

31 Nota: Schwitters ideó tres Merzbauten: en Hannover, destruido en un bombardeo durante la segunda guerra mundial y reconstruido entre 1981 y 1983, y en Noruega y en el exilio inglés. 


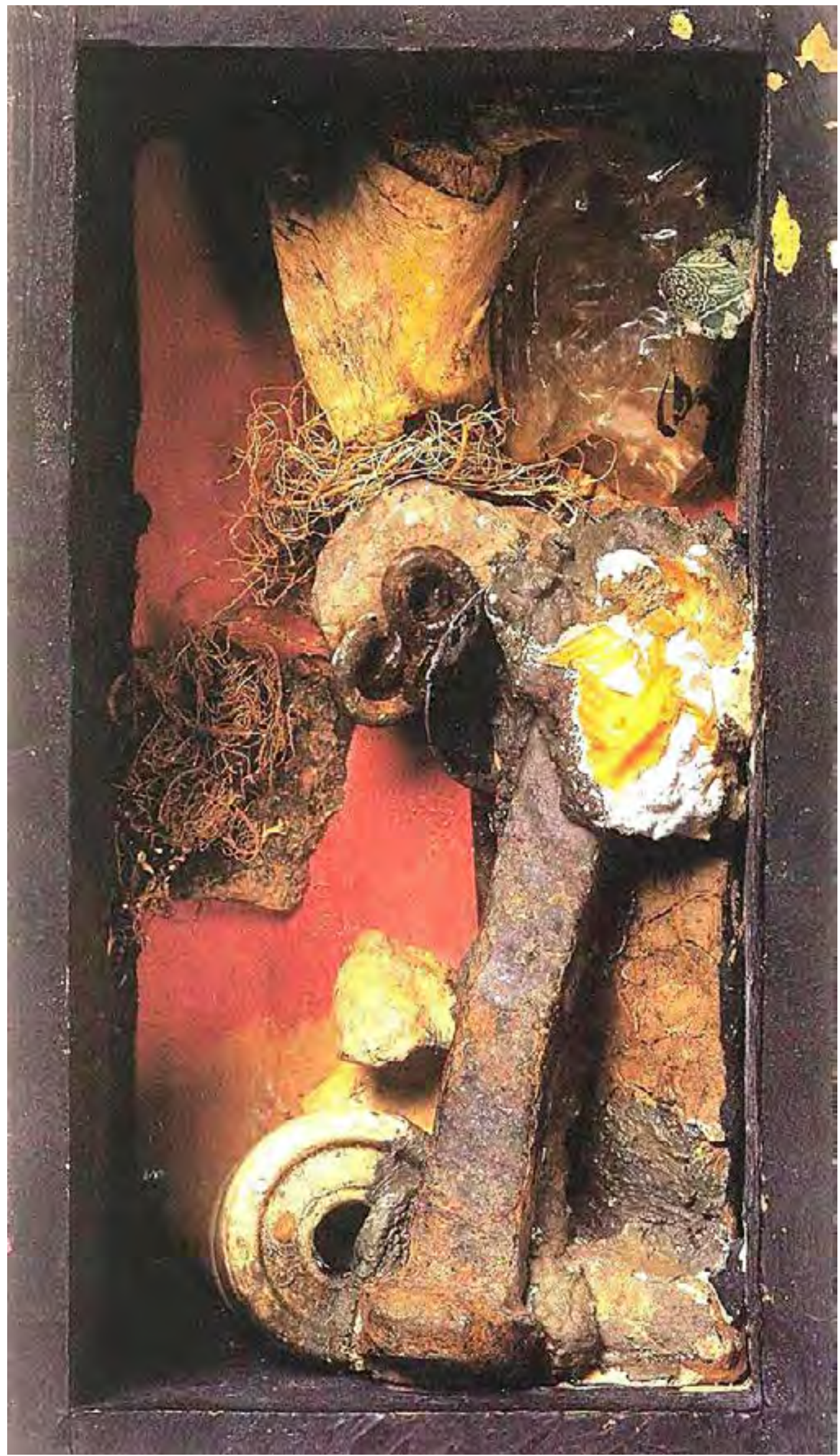

Figura 17.

Merzbau / Ensamblaje sin título / Kurt Schwitters 
tenía "cómodamente a mano"32. Más tarde añadió objetos como "billetes de tranvía, tickets de guardarropa, trozos de madera, alambre, cuerda, ruedas dobladas, papel tisú, latas, astillas de vidrio, etc ${ }^{\prime \prime 33}$, construyendo un collage arquitectónico. Un ensamblaje en constante transformación; "rompiendo los límites entre escultura y arquitectura"34. Una fusión creciente de diversos géneros artísticos como la arquitectura, la pintura, la escultura, la literatura, la representación, la escenografía, para "crear relaciones, preferiblemente entre todas las cosas del mundo ${ }^{135}$.

"Mi objetivo es la obra de arte total MERZ, que abarca todas las expresiones artísticas en su totalidad. Ante todo, he combinado modos artísticos independientes. He creado poemas pegando palabras y oraciones, unas junto a otras, de tal manera que la ordenación rítmica resulte un dibujo. $Y$, por el contrario, he pegado cuadros de tal manera que junto a la impresión pictórica se produjera una impresión plástica en relieve. Y esto lo hice con el fin de difuminar los límites de las diversas expresiones artísticas (...)" 36 "La forma más elevada del arte es la obra del arte total, en la cual los límites entre el arte y no-arte están suspendidos. ${ }^{137}$ Kurt Schwitters

Su nombre Merz, derivado de un fragmente impreso en papel de la palabra Kommerzund Privatbank ${ }^{38}$ - banco comercial y privado, era para Schwitters una expresión de construir algo nuevo de algo viejo. Con el espíritu de reconstruir lo que fue destruido después de la guerra. De una forma lúdica. A partir de un material heterogéneo creó un conjunto homogéneo "para desdibujar los límites de las formas de arte"39. Un collage teatral. Un Gesamtkunstwerk transitable.

32 SCHWITTERS, Kurt. Das literarische Werk. Manifeste und kritische Prosa. M.DuMont Buchverlag. Köln. 1981. ISBN: 3-7701-0841-8. Pág. 134. Traducción de la autora: "(...)bequem zur Hand hatte"

33 Idem. Pág. 134. Traducción de la autora: "(...)Straßenbahnfahrscheine, Garderobenmarken, Holzstückchen, Draht, Bindfaden, verbogene Räder, Seidenpapier, Blechdosen, Glassplitter usw."

34 DE MOLINA, Santiago, Collage y arquitectura. La forma intrusa en la construcción del proyecto moderno. Recolectores Urbanos Editorial. Sevilla. 2014. ISBN: 978-84-940196-5-4. Pág. 50.

35 SCHWITTERS, Kurt. Das literarische Werk. Manifeste und kritische Prosa. M.DuMont Buchverlag. Köln. 1981. ISBN: 3-7701-0841-8. Pág. 187 Traducción de la autora: "MERZ bedeutet, Beziehungen schaffen, am liebsten zwischen allen Dingen der Welt"

36 SZEEMANN, Harald. Der Hang zum Gesamtkunstwerk. Europäische Utopien seit 1800, AusstellungsKatalog. Verlag Sauerländer. Frankfurt am Main. 1983. Pág. 322.

37 DEISS, Richard. Leonardo des Nordens und Mini-Monet. Malerbeinamen und Künstlerfakten, welche Ihnen gerade noch gefehlt haben. BoD. Norderstedt. 2019. ISBN: 978-3-848-2513-46. Pág. 23. Traducción de la autora: "Die höchste Form der Kunst ist das Gesamtkunstwerk, in dem die Grenzen zwischen Kunst und Nichtkunst aufgehoben sind."

38 SCHWITTERS, Kurt. Kurt Schwitters. En: Merz. no20. 1927. Pág. 99. Traducción de la autora: "(...)das Wort MERZ, aufgeklebt und ausgeschnitten aus einer Anzeige der KOMMERZ UND PRIVATBANK, $(\ldots)^{\prime \prime}$

39 SCHWITTERS, Kurt. Das literarische Werk. Manifeste und kritische Prosa. M.DuMont Buchverlag. Köln. 1981. ISBN: 3-7701-0841-8. Pág. 79. Traducción de la autora: “um die Grenzen der Kunstarten zu verwischen” 


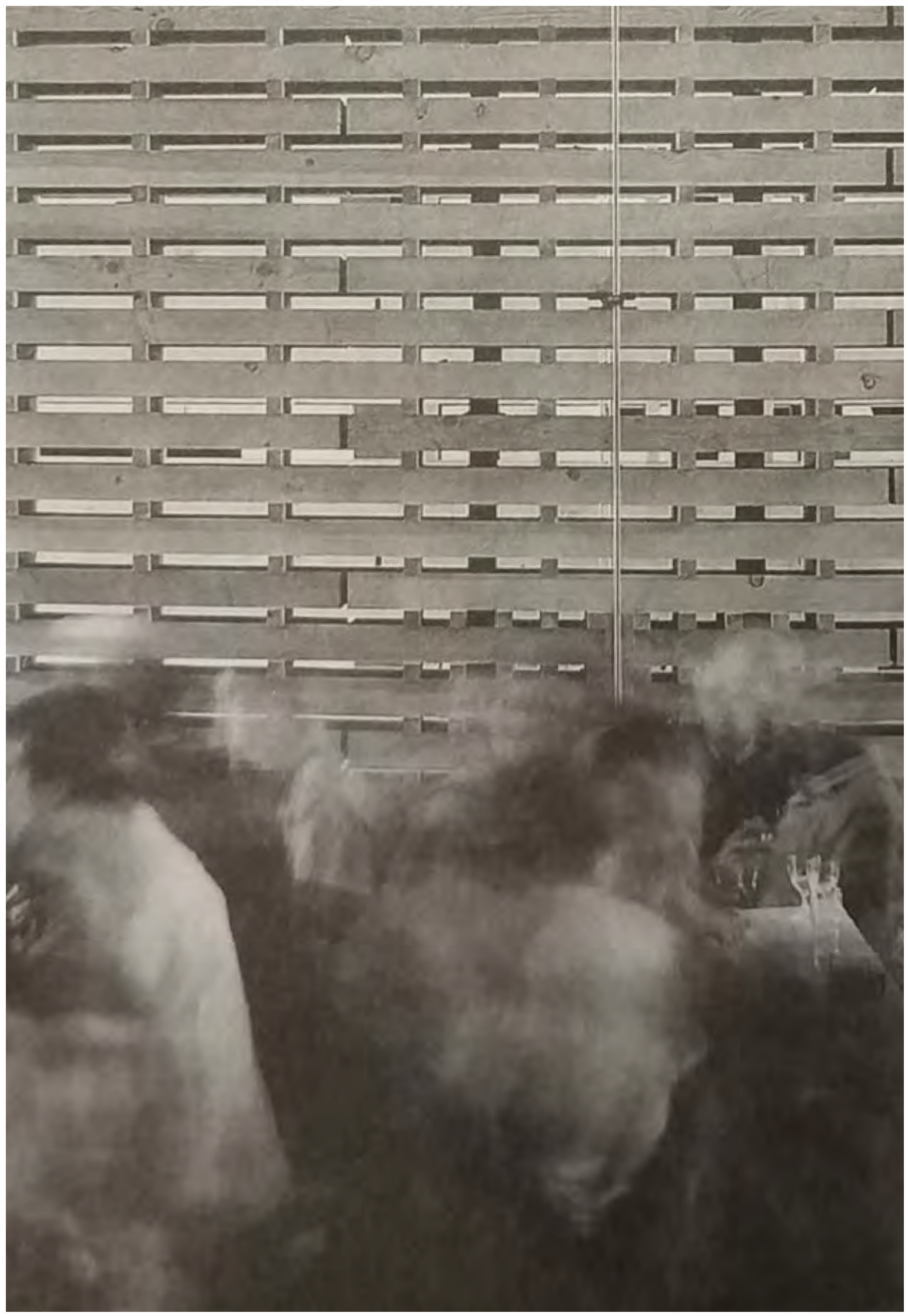

Figura 18.

Pabellón helvético / Hannover / 2000 


\title{
[Polifonía de los sentidos $\left.{ }^{40}\right]$
}

\begin{abstract}
"Me gusta la idea de la obra de arte total, la obra del autor. Mis proyectos van más allá de lo puramente estructural, comienzan mucho antes. Me gusta desarrollar mi arquitectura desde los contenidos. Como en el pabellón suizo de la Expo 2000 de Hannover. Alli podía hacer todo." ${ }^{\prime 11}$ Peter Zumthor
\end{abstract}

Aunque fue ideado como un Gesamtkunstwerk ${ }^{42}$, el Klangkörperbau no puede ser entendido únicamente como la adición de diferentes géneros para alcanzar la perfección en el sentido wagneriano; ni tampoco como una conglomeración de objetos en el sentido schwitteriano.

El pabellón helvético es la "interacción de todas las modalidades sensoriales"43. EI arquitecto como director de orquesta. Una "obra de autor artístico en los campos de la arquitectura, la música, la luz, la bebida y la comida, y la ropa"144, forman una unidad entre sí.

Seleccionados por el propio Zumthor, emerge una orquesta de colaboradores instrumentales: el espacio sonoro de Danil Ott, el espacio literario de Plinio Bachmann, el espacio gastronómico de Max Rigendinger, el espacio para la moda de Ida Gut y el espacio escenográfico de Karoline Gruber.

\footnotetext{
"Cada experiencia conmovedora de la arquitectura es multisensorial; las cualidades de espacio, de la materia y de la escala se miden a partes iguales por el ojo, el oído, la nariz, la piel, la lengua, el esqueleto y el
}

40 BACHELARD, Gaston. La poética de la ensoñación. Fondo de Cultura Económica. México D. F. 2013. ISBN: 978-607-16-1458-2. Introducción

41 HESS, Ewa y SPÖRRI. Entrevista a Peter Zumthor. Stararchitekt Zumthor: Wir Schweizer sind nicht so anfällig für Moden. Periódico: Spiegel online. 29 de Mayo 2009. https://www.spiegel.de/kultur/ gesellschaft/stararchitekt-zumthor-wir-schweizer-sind-nicht-so-anfaellig-fuer-moden-a-627167. html. Traducción de la autora: "Mir gefällt die Idee des Gesamtkunstwerks, der Autorenarbeit. Meine Projekte gehen über das rein Bauliche hinaus, sie beginnen viel früher. Ich entwickle meine Architektur gerne aus den Inhalten heraus. Wie beim Schweizer Pavillon für die Expo 2000 in Hannover. Da durfte ich alles machen."

42 Nota: Según Zumthor, la interacción de diferentes artes en una obra de arte unificada posea de una larga tradición en Alemania. Entre los representantes destacaron figuras como Richard Wagner, Max Reinhard, Erwin Piscator, Ivan Groll o la escuela de arquitectura, diseño, artesanía y arte fundada en 1919 por Walter Gropius, la Staatliche Bauhaus.

43 PALLASMAA, Juhani. Los ojos de la piel. Editorial Gustavo Gili SL. Barcelona.2006. ISBN: 978-84-2522135-4. Pág. 43.

44 AAVV. Klangkörperbuch. Birkhäuser. Basel. 2000. ISBN: 3-7643-6324-X. Pág. 82. Traducción de la autora: " Pag. 82. "Künstlerisch eigenständige Autorenarbeiten in den Bereichen Architektur, Musik, Lichtschriften, Trinken und Essen und Klangkörperbekleidung werden in einer besonderen Inszenierung zu einem Gesamtereignis, zu einer Art installativen Performance zusammengeführt." 


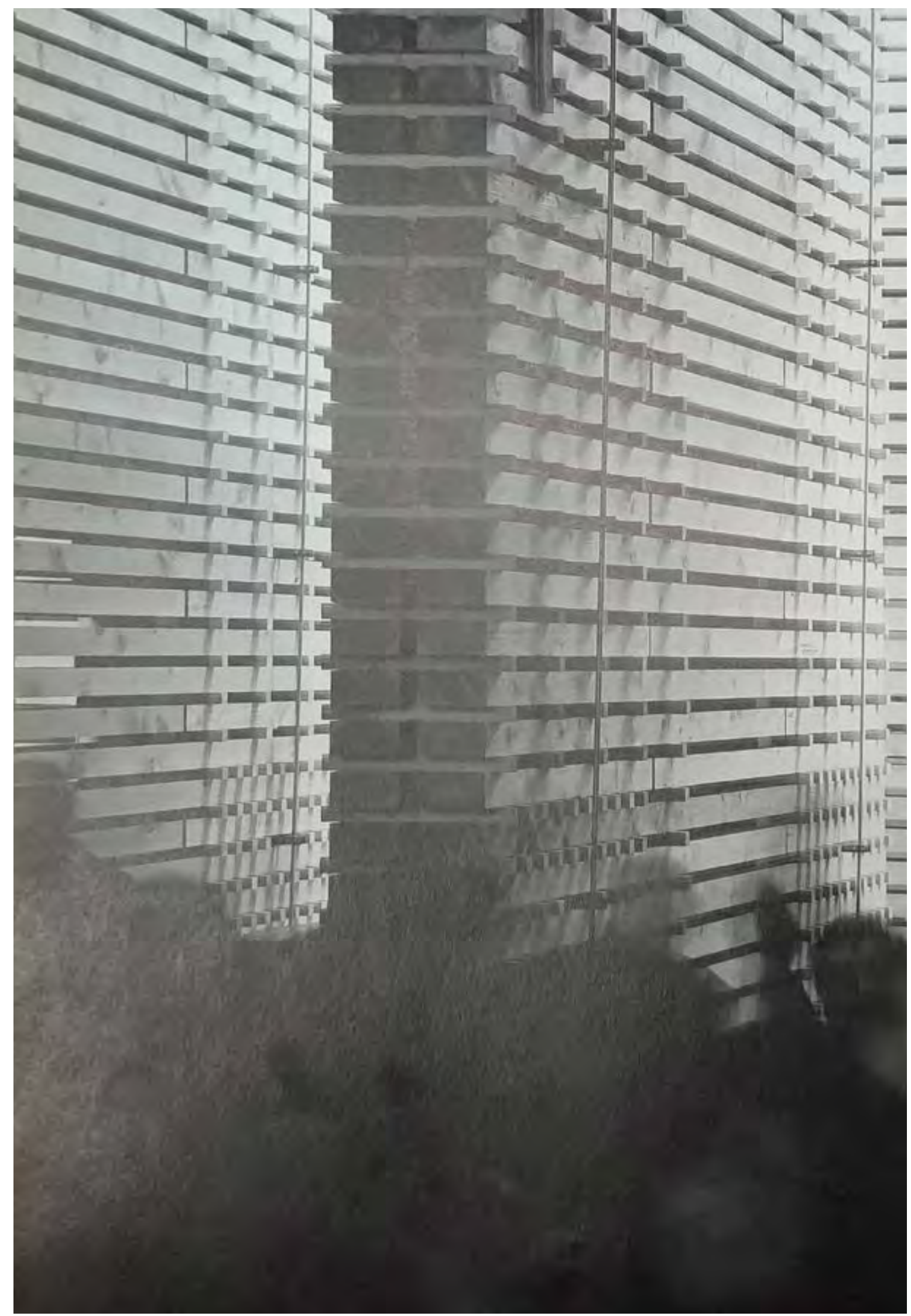

Figura 19.

Pabellón helvético / Hannover / 2000 
músculo. La arquitectura fortalece la experiencia existencial, el sentido de cada uno de ser-en-el-mundo, y esto constituye fundamentalmente una experiencia fortalecida del yo." ${ }^{\prime 45}$ Juhani Pallasmaa

El Klangkörper es una estructura laberíntica de madera con diversas tonalidades. Un gran instrumento musical transitable. Seduciendo al usuario mediante cualidades táctiles, sonoras, visuales, gustativas y olfativas. La interdependencia de las cinco percepciones sensoriales permite producir información cualitativa para crear una experiencia espacial holística. Un lugar dinámico de intercambio, cuyo contenido es sensorial. Una atmósfera multi-sensorial, un Gesamtkunstwerk sinestésico, ya que "incluso el ojo toca; la mirada implica un tacto inconsciente"46. Una polifonía de los sentidos. 


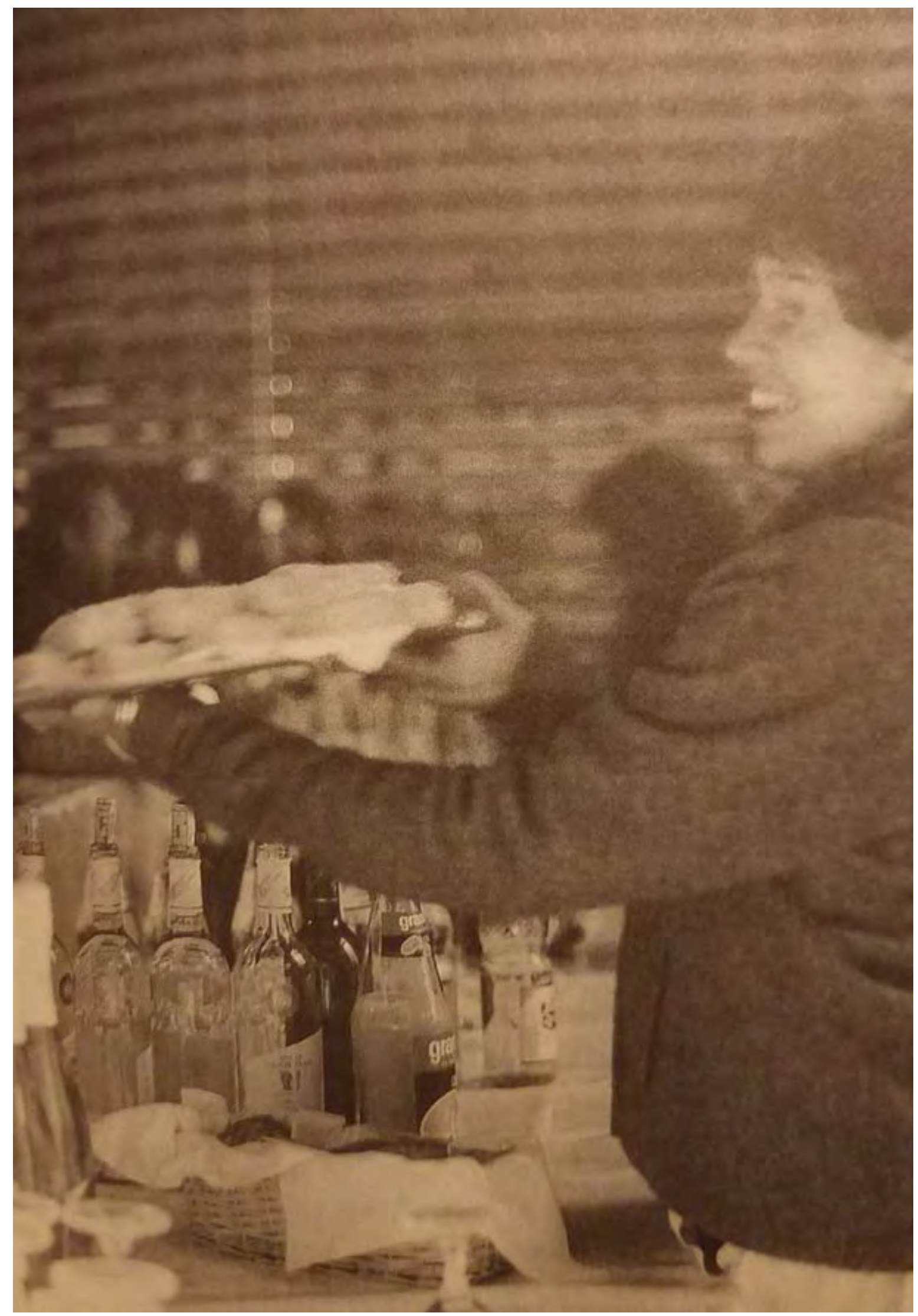

Figura 20.

Sector gastronómico / Pabellón helvético / Hannover / 2000 


\section{[Arquitectura comestible]}

"En la Expo 2000 de Hannover, Suiza presentará un pabellón del arquitecto Peter Zumthor. El pabellón está diseñado como un "cuerpo sonoro" hecho de madera. De junio a octubre combina la arquitectura, el sonido, las palabras, la bebida y la comida, así como la puesta en escena y la ropa: una obra de arte total. El huésped pasea por los pasillos y los espacios de diversas maneras. Experimenta la arquitectura, sigue los sonidos y observa los escritos de luz proyectados sobre los listones de madera. Pasa por bares en tres lugares seleccionados donde los suizos ofrecen comida y bebidas de Suiza. La oferta es sencilla, elegante, económica, fresca, de alta calidad, reducida a lo esencial y estéticamente presentada. Los productos acabados tradicionales, como la carne seca del Valais, el Emmentaler almacenado en cuevas, el salsiz de ciervo de Oberhalbstein, el Geissen-Formaggini de Val di Muggio, el Amaretti de Ticino y el Läckerli de Basilea, desempeñan un papel importante. Nos limitamos en gran medida a proporcionar estas conservas de alta calidad delante de los ojos del cliente. Esta es una experiencia estética y nos permite responder a los deseos individuales, tal y como le gusta hacer a un buen anfitrión. Pequeñas guarniciones hacen referencia a la temporada, como un apio marinado en un buen aceite de oliva y zumo de limón, que hemos preparado recientemente en la cocina del pabellón. Al lado se encuentra el queso, sin adornos. El huésped come con las manos o con un palillo de madera. Para beber, ofrecemos vinos regionales tradicionales como Cornalin y Humagne blanche, vinos suizos clásicos, pero también cerveza, mosto dulce y chocolate caliente. En los días más fríos, las sopas típicas, quizás acompañadas de un trozo de pan Puschlaver y seguidas de vino caliente o 'Kaffee Luz', proporcionarán el calor necesario. Dado que también los pequeños productores y las especialidades locales aparecen, una parte de la oferta cambiará ocasionalmente. Se trata de productos de primera calidad, con una clara identidad y referencia local. El huésped debe poder encontrarlos de nuevo o pedirlos más tarde en un viaje por Suiza. Como buenos 


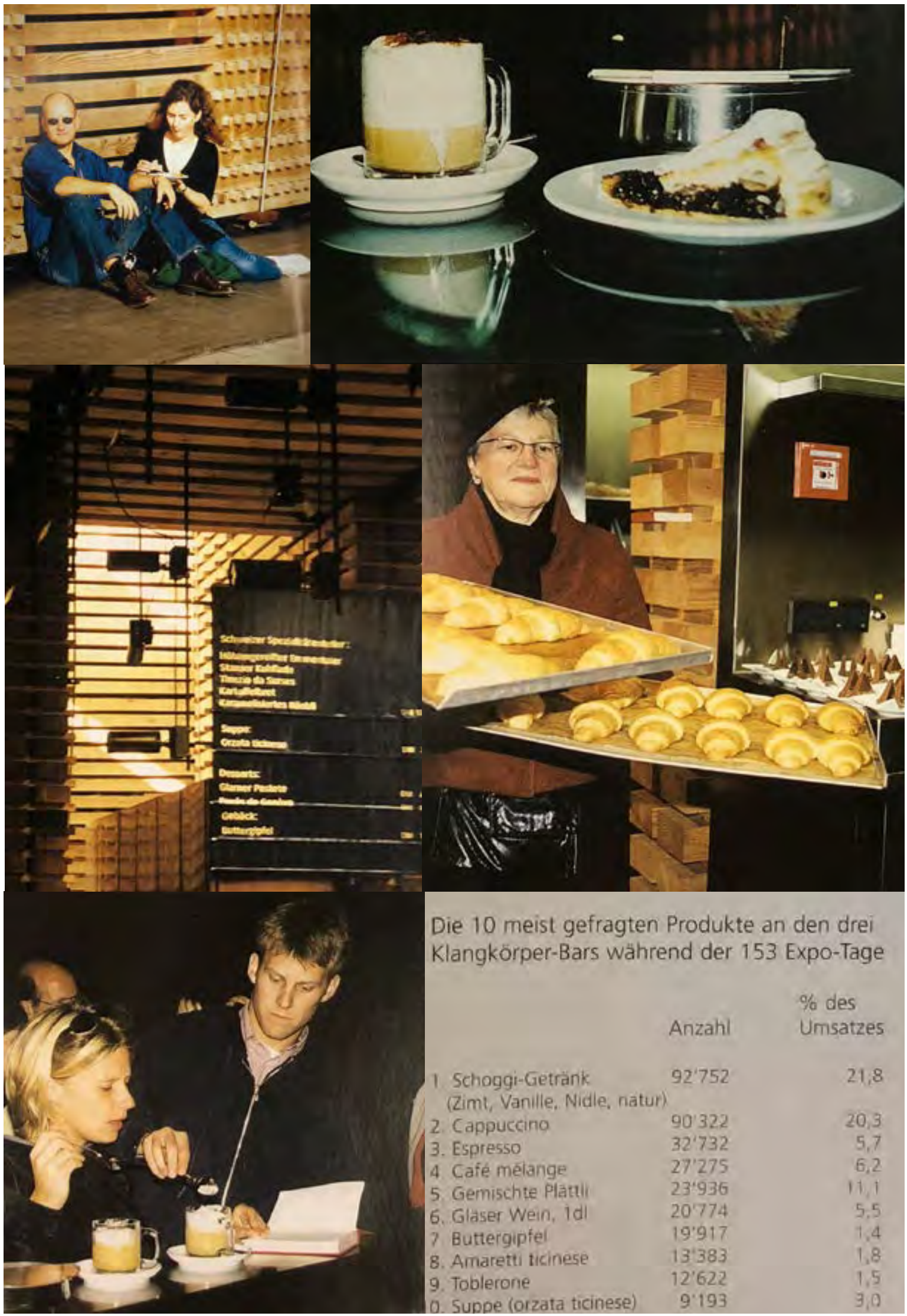

Figura 21 - 26.

Sector gastronómico / Pabellón helvético / Hannover / 2000 


\begin{abstract}
anfitriones, a veces cortamos un embutido especial y se lo ofrecemos a nuestros huéspedes para que lo prueben en el bar. Los Willisauerringli, que ofrecemos a los niños algunos días, también son gratuitos, al igual que un vaso de jarabe Waldmeister, como es tradicional en muchos negocios suizos. La comunicación, la conversación entre visitantes y anfitriones son parte de la experiencia gastronómica. Los productos, pero también la gente cuenta historias. Empleados entusiastas y lingüísticamente competentes de diferentes partes de Suiza esperan una conversación y, gracias a una formación intensiva, transmiten información de fondo sobre los productos que se ofrecen. Por último, que es a la vez inusual y fascinante para el sector gastronómico, cabe destacar que los anfitriones no son sólo camareras y camareros, sino que se integran en una obra de arte total. ${ }^{47}$ Max Rigendinger
\end{abstract}

47 GENERALKOMMISSARIAT. Schlussbericht des Generalkommissariates. Weltausstellung Expo 2000 Hannover 1.6.-31.10.2000. Die schweizerische Beteiligung mit "Klangkörper Schweiz". Bundesamt für Kultur. Bern. 2001. Pág. 111. Traducción de la autora: "An der Expo 2000 in Hannover tritt die Schweiz mit einem Pavillon des Architekten Peter Zumthor auf. Der Pavillon ist als 'klingender Körper' aus Holz konzipiert. Er verbindet von Juni bis Oktober Architektur, Klang, Wort, Trinken und Essen, sowie Inszenierung und Bekleidung: ein Gesamtkunstwerk. Auf verschiedenste Weise flaniert der Gast durch Gänge und Räume. Er erlebte Architektur, geht den Klängen nach und betrachtet die auf Holzbalken projizierten Lichtschriften. Dabei trifft er an drei ausgewählten Stellen auf Bars, wo Schweizerinnen und Schweizer Kleinigkeiten zum Trinken und Essen aus der Schweiz anbieten. Das Angebot ist einfach, elegant, preiswert, frisch, qualitativ hochstehend, reduziert aufs Wesentliche und ästhetische präsentiert. Eine wichtige Rolle spielen traditionelle Fertigprodukte, wie etwa Trockenfleisch aus dem Wallis, höhlengelagerter Emmentaler, Hirschsalsiz aus dem Oberhalbstein, Geissen-Formaggini aus dem Val di Muggio, Amaretti aus dem Tessin und Läckerli aus Basel. Wir beschränken uns weitgehend aus Portionieren dieser hochwertigen Konserven, vor den Augen des Gastes. Das ist ein ästhetisches Erlebnis und erlaubt uns auf individuelle Wünsche einzugehen, so wie es ein guter Gastgeber gerne macht. Kleine Beilagen nehmen den Bezug zur Jahreszeit auf, etwa ein knapp gegartes, hellgrün leuchtendes Stück Stangensellerie, mit gutem Olivenöl und Zitronensaft mariniert; das wir in der Küche des Pavillons frisch zubereitet haben. Das liegt neben dem Käse, ohne Firlefanz. Der Gast isst mit den Händen, oder hilft sich mit einem Holzspiesschen. Zum Trinken sind althergebrachte regionale Weine wie Cornalin und Humagne blanche, klassische Schweizer Weine, aber auch Bier, Süssmost und heisse Schokolade vorgesehen. An kühleren Tagen werden typische Suppen, vielleicht begleitet von einem Stück Puschlaver Ringbrot, und gefolgt von einem Glühwein oder 'Kaffee Luz', für die notwendige Wärme sorgen. Da auch Kleinproduzenten und lokale Spezialitäten zum Zug kommen, wird ein Teil des Angebots gelegentlich wechseln. Es handelt sich um erstklassige Produkte mit einer klaren Identität und mit einem lokalen Bezug. Der Gast soll sie später auf einer Reise durch die Schweiz wiederfinden oder bestellen können. Als gute Gastgeber scheiden wir manchmal eine spezielle Wurst auf und bieten sie den Gästen an der Bar zum Versuchen an. Auch die Willisauerringli sind gratis, die wir den Kindern an manchen Tagen anbieten, oder ein Glas Waldmeistersirup, so wie es in der Schweiz in vielen Betrieben Tradition ist. Die Kommunikation, das Gespräch zwischen Besuchern und Gastgebern gehören mit zum gastronomischen Erlebnis. Produkte, aber auch Menschen erzählen Geschichten. Begeisterungsfähige und sprachkundige Mitarbeiterinnen und Mitarbeiter aus verschiedenen Teilen der Schweiz freuen sich auf ein Gespräch und vermitteln dank intensiver Schulung Hintergründe zu den angebotenen Produkten. Schliesslich, für Gastronomen gleichsam ungewohnt und faszinierend, bleibt zu erwähnen, dass die Gastgeberinnen nicht einfach Kellnerinnen und Kellner sind, sondern dank der Regie in ein Gesamtkunstwerk eingebunden sind." 

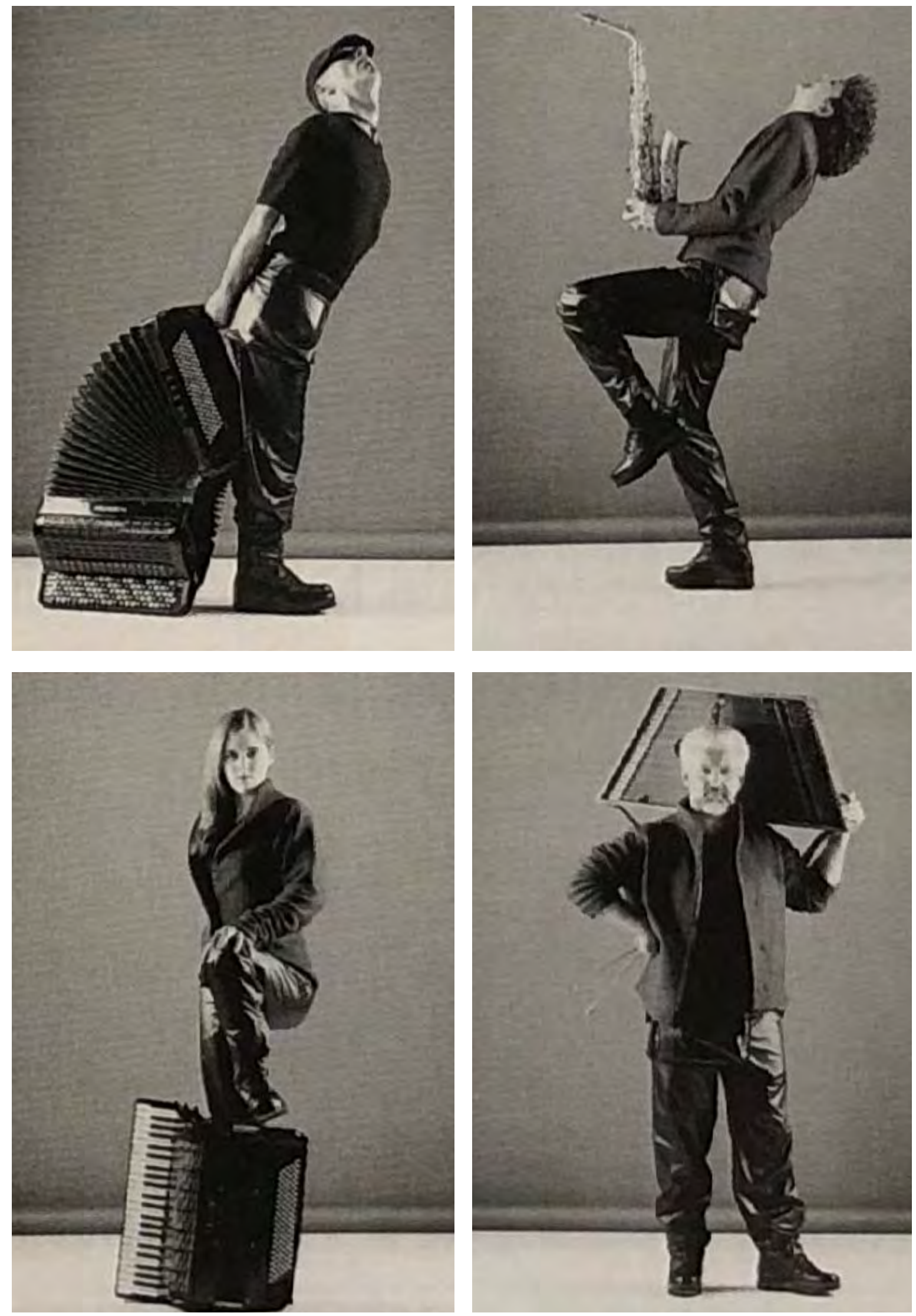

Figura 27.

Vestimenta / Pabellón helvético / Hannover / 2000 / Peter Zumthor 


\section{[Patrón de corte]}

"Músicos, propietarios gastronómicos y guías en el Pabellón Suizo de la Expo 2000 de Hannover visten trajes de Ida Gut. Especialmente diseñados para el 'Klangkörper Suiza' y en un tiempo récord de casi 10 semanas. ¿Cómo se ve la ropa que no es un uniforme ni un disfraz? ¿Protege contra el sol, el viento y la lluvia? ¿Y al mismo tiempo irradia confianza y apertura? El punto de partida para esto son las condiciones climáticas y estéticas del pabellón al aire libre. El diseño presenta una óptica que se mueve en el tiempo y una sensación que desencadena las emociones. El visitante encuentra siluetas claras y sólidas. Los cortes simples contrastan la arquitectura apilada. Y el toque sensual de los materiales seleccionados garantiza el bienestar de los participantes. Aquí se transmite una pieza textil Suiza: nueva moda suiza, hecha de innovadores tejidos suizos, producida en Suiza de una manera sofisticada. Típico del diseño de lda Gut son los insertos de brazo, que se desarrollan desde la espalda, por lo que también se pueden encontrar en las camisas y chaquetas de la ropa de Klangkörper. Ambas mangas están cortadas de una sola pieza continua de tela. Después de todo, nuestros brazos no están simplemente unidos al costado del cuerpo, sino que están unidos a la espalda a través del omóplato. En definitiva, la ropa del Klangkörper se parece a signos gráficos vivos que se mueven en la arquitectura. Los tejidos utilizados son materiales de alta tecnología de fabricantes suizos cuyas innovaciones causan sensación en todo el mundo. Por ejemplo, el vellón cálido de Eschler o el tejido deportivo altamente elástico de Schoeller, un tejido suizo que también utilizan marcas internacionales como Prada o Bogner. Con el apoyo de la Federación Suiza de Textiles, la colección completa de más de 2.500 partes individuales se procesó en Suiza y luego se adaptó individualmente a los más de 400 participantes. Se optó por los zapatos que pueden sorprender, pero que son absolutamente convincentes en vista de las condiciones locales: botas negras con cordones de media altura del ejército suizo. La vestimenta del Klangkörper está integrada en la coreografía general como elemento de diálogo. Diseñado para anfitriones con carácter. Mujeres y hombres llevan pantalones 

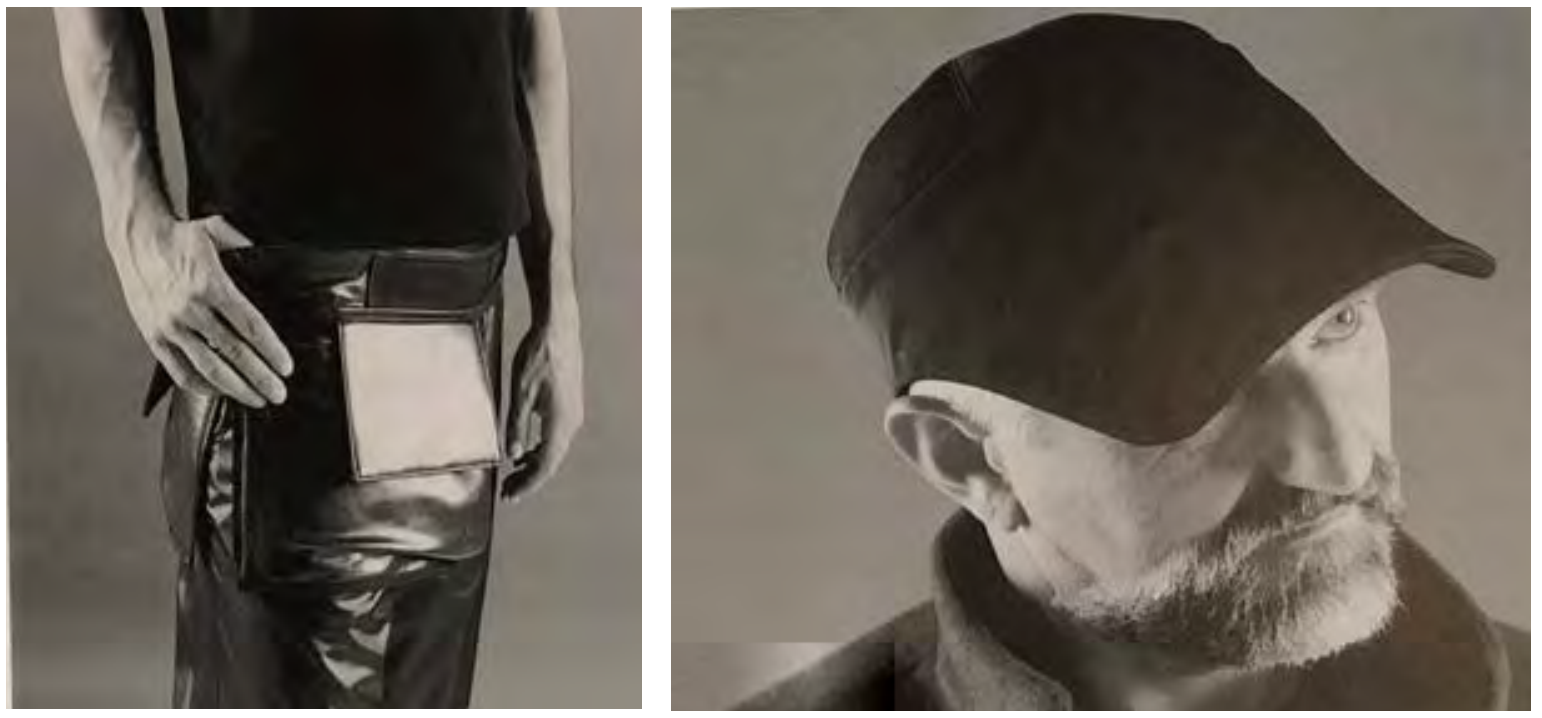

Figura 28 - 29

Detalles de la Vestimenta / Pabellón helvético / Hannover / 2000 / Peter Zumthor
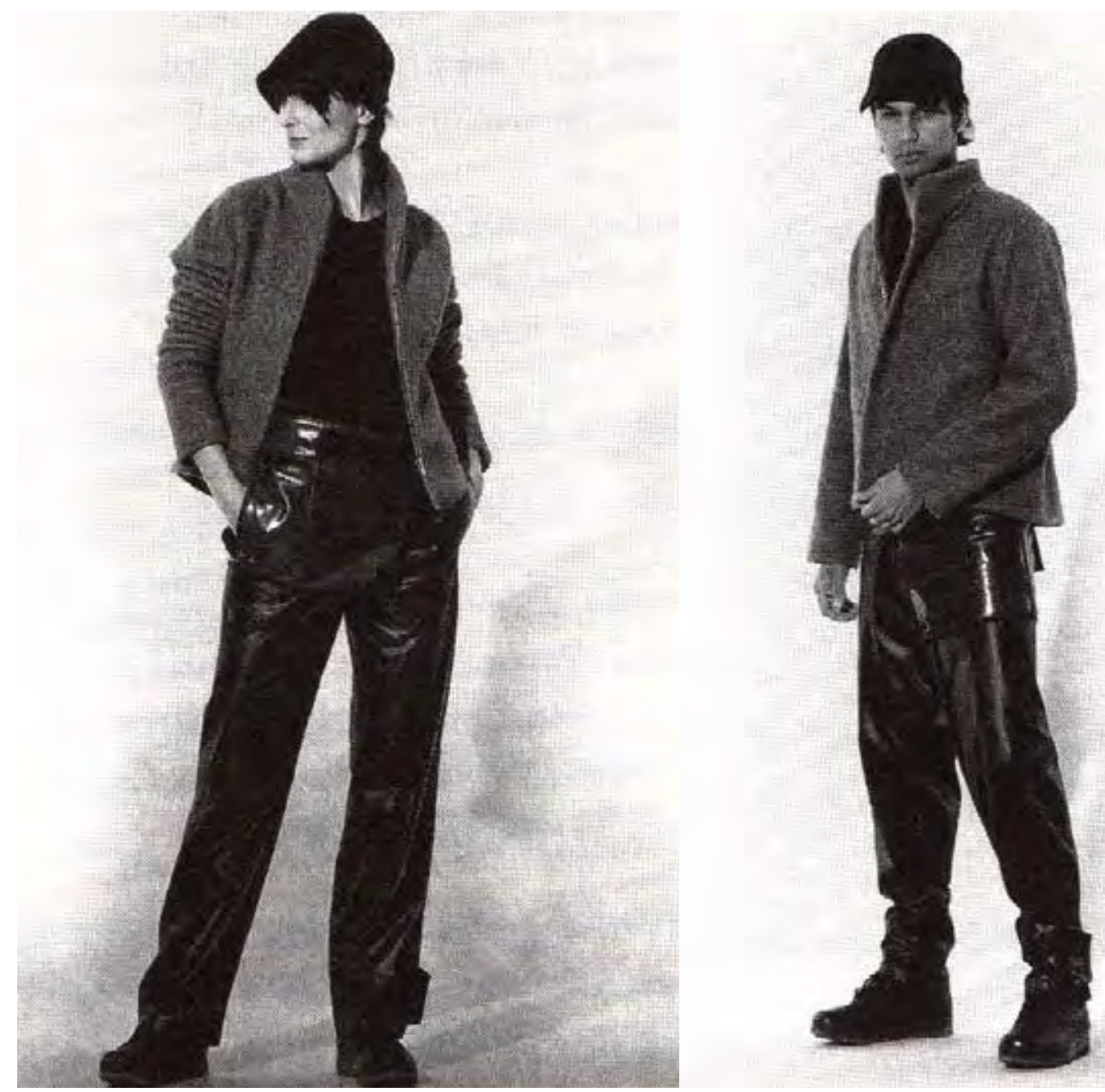

Figura 30 - 31.

Vestimenta mujer + vestimenta hombre / Pabellón helvético / Hannover / 2000 
de tejido resistente a la intemperie en un negro semimate. En la parte superior se encuentran camisas finamente estructuradas hechas de hilo de mélange negro-bronceado y chaquetas de lana roja. Además, se lleva una bolsa - Hig-Bag alrededor de la cadera, en la que todo lo que necesitas a lo largo del día tiene cabida: desde las notas musicales hasta el teléfono móvil, pasando por las necesidades personales. El contrapunto a la arquitectura al aire libre son las gorras negras con un elegante toldo contra la lluvia y el sol de Hannover. Los visitantes también pueden comprar los bolsos y gorras en el Klangkörper. A través del filtro de tiempo y de consideraciones estilísticas, las prendas absorben la información social en sí mismas y contra ellas de forma difusa. Es precisamente esta inexactitud la que, en su conjunto, dibuja una imagen muy precisa del medio ambiente -en Hannover y en Suiza. La anatomía es mi sistema de coordenadas, el tiempo fluido mi objetivo. ${ }^{148}$ Ida Gut Hannover 1.6.-31.10.2000. Die schweizerische Beteiligung mit "Klangkörper Schweiz". Bundesamt für Kultur. Bern. 2001. Pág. 112. Traducción de la autora: "Musiker, Gastronomen und Guides im Schweizer Pavillon an der Expo 2000 Hannover tragen Outfits von Ida Gut. Speziell für den 'Klangkörper Schweiz' entworfen und in der Rekordzeit von knapp10 Wochen. Wie sieht eine Bekleidung aus, die keine Uniform und kein Kostüm ist? Gegen Sonne, Wind und Regen schützt? Und gleichzeitig Selbstbewusstsein und Offenheit ausstrahlt? Ausgangspunkt dafür sind die klimatischen und ästhetischen Bedingungen des Freiluftpavillons. Das Design präsentiert eine Optik, die sich in der Zeit bewegt, und eine Haptik, die Emotionen auslöst. dem Besucher begegnen klare, unifarbene Silhouetten. Schlichte Schnitte kontrastieren die gestapelte Architektur. Und der sinnliche High-Touch der ausgewählten Materialen sorgt für das Wohlbefinden der Mitwirkenden. Vermittelt wird dabei ein Stück textile Schweiz: Neue Schweizer Mode, aus innovativen Schweizer Stoffen, anspruchsvoll in der Schweiz produziert Typisch für das Design von Ida Gut sind die Armeinsätze, die sich aus dem Rücken heraus entwickeln, so finden sich diese auch an den Shirts und Jacken der Klangkörperbekleidung. Beide Ärmel sind aus einem einzigen, durchgehenden Stück Stoff geschnitten. Schliesslich sind bei uns Menschen die Arme auch nicht einfach am Körper an der Seite angesetzt, sondern über das Schulterblatt mit dem Rücken verbunden. Insgesamt wirkt die Klangkörperkleidung wie lebendige grafische Zeichen, die sich in der Architektur bewegen. Als Stoffe kommen High Tech Materialien von Schweizer Herstellern zum Einsatz, deren Innovationen weltweit Furore machen. Zum Beispiel wärmendes Fleece von Eschler oder hochelastisches Sportsgewebe von Schoeller - ein Schweizer Gewebe, das auch von internationalen Marken wie Prada oder Bogner verwendet wird. Mit Unterstützung des Schweizer Textilverbands wurde die ganze Kollektion von über 2500 Einzelteilen in der Schweiz verarbeitet und dann individuell den mehr als 400 Mitwirkenden angepasst. Für die Schuhe wurde eine Wahl getroffen, die erstaunen mag, aber angesichts der Bedingungen vor Ort absolut überzeugt: halbhohe schwarze Schnürstiefel der Schweizer Armee. Die Klangkörperbekleidung ist als Dialogelement in die Gesamtchoreografie eingebettet. Entworfen für Gastgeber mit Charakter und Offenheit. Frauen und Männer tragen Hosen aus wetterfestem Stoff in selbstbewusst mattglänzendem Schwarz. Darüber fein strukturierte Shirts aus bronze-schwarzem Melangegarn und rote Fleece Jacken. Dazu wird ein Hig-Bag um die Hüfte getragen, in dem alles Platz hat, was man den Tag über braucht: von den Musiknoten über das Handy bis zu den persönlichen Unentbehrlichkeiten. Der Kontrapunkt zur Freiluftarchitektur sind die schwarzen Caps mit schnittigem Vordach gegen Hannover Regen und Sonne. Die Hip-Bags und Caps können die Besucher übrigens im Klangkörper auch kaufen. Die Kleidungsstücke nehmen durch den Zeitfilter und die stylistischen Überlegungen gesellschaftliche Informationen in sich auf und gegen sie diffus weiter. Gerade diese Ungenauigkeit zeichnet als Gesamtheit ein recht präzises Bild der Umwelt - in Hannover und der Schweiz. Ida Gut: "Die Anatomie ist mein Koordinatensystem, die Zeitflüssigkeit mein Ziel." 


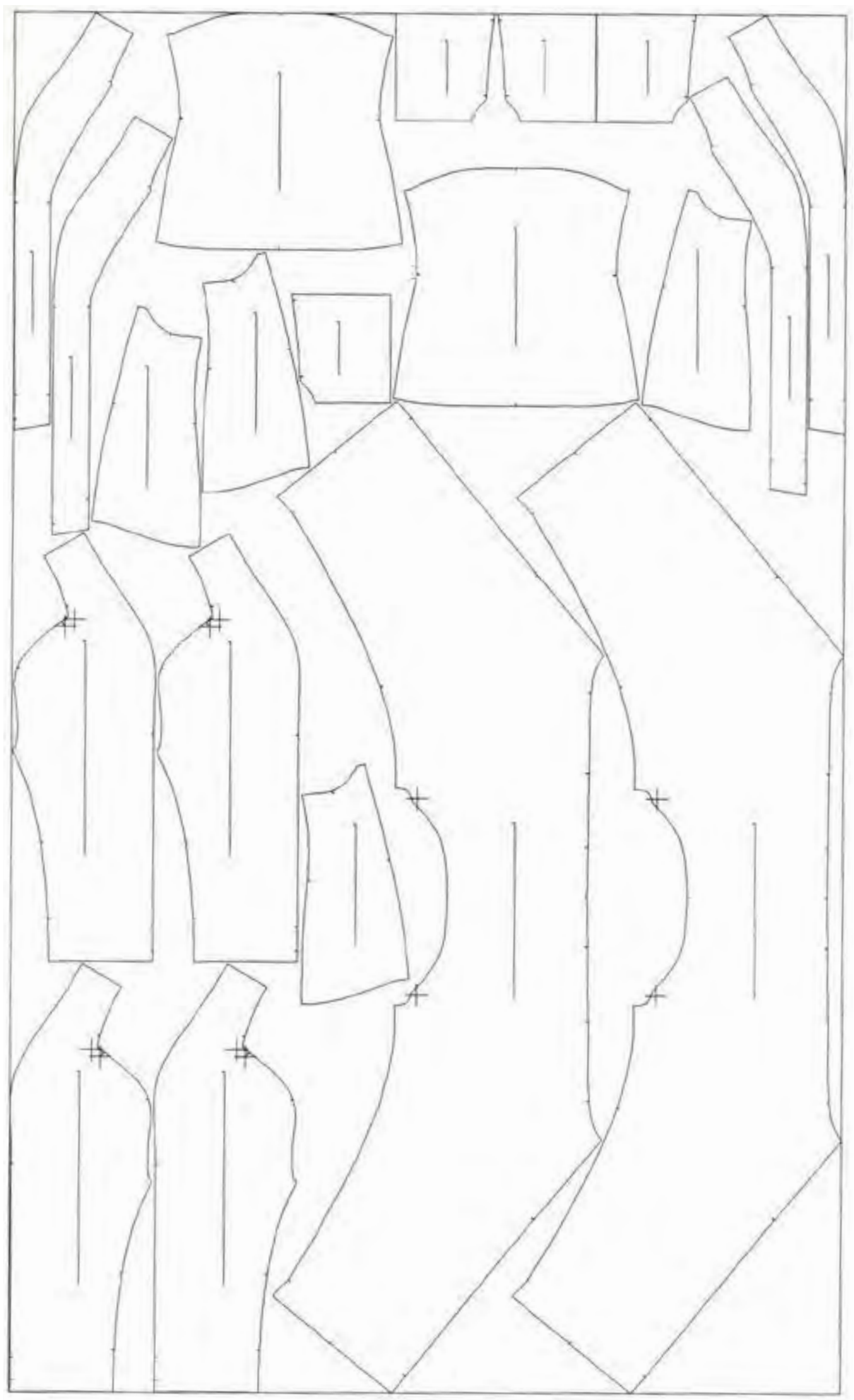

Figura 32

Patrón de corte chaqueta / Pabellón helvético / Hannover / 2000 


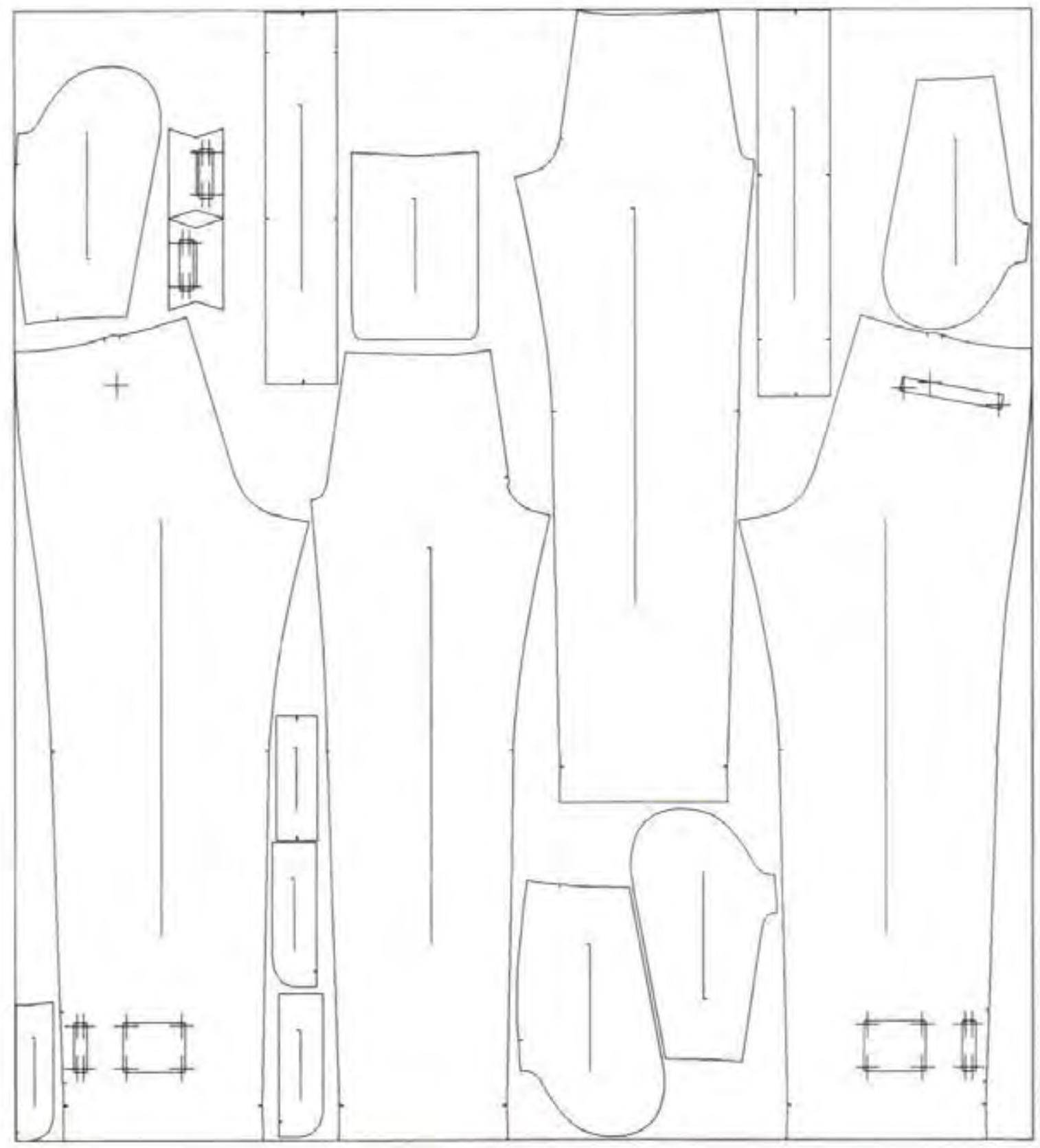

Figura 33.

Patrón de corte pantalón / Pabellón helvético / Hannover / 2000 


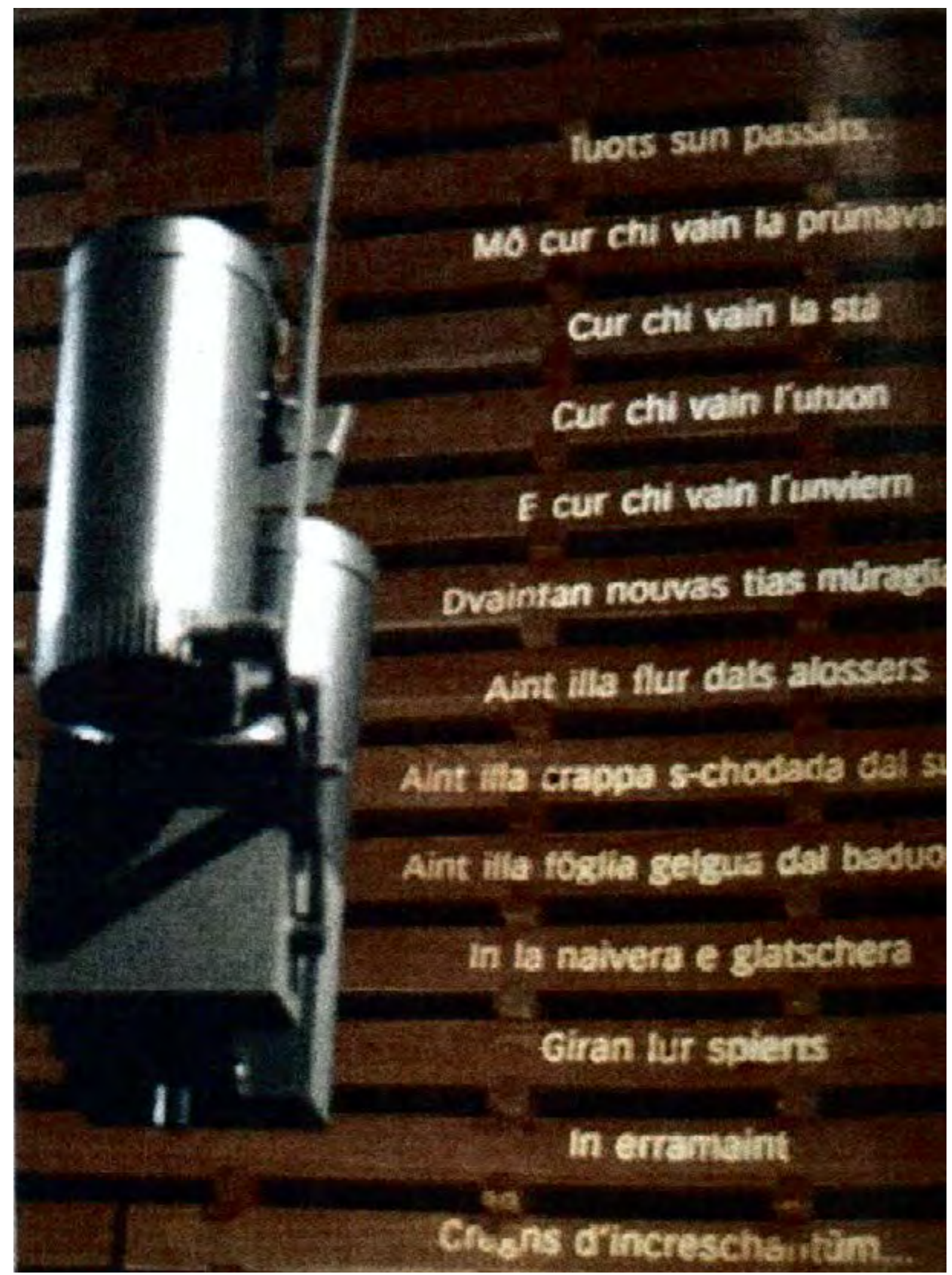

Figura 34.

Iluminación / Collage literario / Pabellón helvético / Hannover / 2000 


\title{
[La luz escrita]
}

\begin{abstract}
"Todo el Klangkörper, si nos lo imaginamos, fue fuertemente influenciado por los materiales, ya que está la madera, la comida, la bebida y los sonidos. Está muy presente en el nivel sensual y desde el principio hubo la necesidad de tener el lenguaje presente en él (...) el lenguaje puede ser irónico, el lenguaje puede ser humorístico y es mucho más flexible que la música. " ${ }^{\text {"P9 }}$ Plinio Bachmann
\end{abstract}

Zumthor desarrolló junto a Plinio Bachmann la idea de la proyección de textos que atraviesan el pabellón a modo de collage literario ${ }^{50}$. Escritos de luz sobre los "renglones" de madera, sin dañarla. Esta fuente de luz e instalación artística ${ }^{51}$, compuesta por frases, fragmentos y poemas ${ }^{52}$ distintos; exhibía la diversidad cultural del país representado. Uno podía asomarse a leer letras de canciones populares, modismos, artículos de periódico, eslóganes publicitarios y cómics relacionados con Suiza ${ }^{53}$. Mensajes en los tres idiomas oficiales del país: alemán, francés e italiano; y en ingles. Un país construido a base de conocimiento, de palabras ${ }^{54}$, de luz. "Lo oído, lo experimentado, lo pensado"55; todo ello proyectado, sin comentarios. Una acción similar a las instalaciones de Jenny Holzer, a base de mensajes proyectados en paredes y fachadas. Un nuevo medio de comunicación.

"En los pasillos con poca incidencia de luz y especialmente al atardecer y por la noche, los textos destacaban especialmente."156 Peter Zumthor

49 MOLL, Bruno. Klangkörper = Corps sonoré = Corpo sonoro. T\&C Film. Zürich. 2000. Traducción de la autora: "Der ganze Klangkörper, wenn wir ihn uns vorstellen, war stark geprägt von einer Eigentlichkeit der Materiale, als es gibt dieses Holz, es gibt das Essen, das Trinken und die Klänge. Es ist sehr stark auf der sinnlichen Ebene präsent und es gab von Anfang an ein Bedürfnis, Sprache darin präsent zu haben... Spache kann ironisch sien, Sprache kann humorvoll sein und ist dabei sehr viel gelenkiger als die Musik."

50 GENERALKOMMISSARIAT. Schlussbericht des Generalkommissariates. Weltausstellung Expo 2000 Hannover 1.6.-31.10.2000. Die schweizerische Beteiligung mit "Klangkörper Schweiz". Bundesamt für Kultur. Bern. 2001. Pág. 56. Traducción de la autora: "Literarische Collage"

51 AAVV. Klangkörperbuch. Birkhäuser. Basel. 2000. ISBN: 3-7643-6324-X. Pág. 24. Traducción de la autora: "Ein grosser Teil der Beleuchtung ist Lichtquelle und künstlerische Installation in einem."

52 GENERALKOMMISSARIAT. Schlussbericht des Generalkommissariates. Weltausstellung Expo 2000 Hannover 1.6.-31.10.2000. Die schweizerische Beteiligung mit "Klangkörper Schweiz". Bundesamt für Kultur. Bern. 2001. Pág. 106. Traducción de la autora: "Sätzen, Fragmenten und Gedichten"

53 AAVV. Klangkörperbuch. Birkhäuser. Basel. 2000. ISBN: 3-7643-6324-X. Pág. 155. Traducción de la autora: "(...)Sätze der Weltliteratur, die mit der Schweiz und den Schweizern zu tun haben. Dazu kommen Hausinschriften, Volkslieder, Redewendungen, Zeitungsartikel, Werbesprüche und Comics."

54 GENERALKOMMISSARIAT. Schlussbericht des Generalkommissariates. Weltausstellung Expo 2000 Hannover 1.6.-31.10.2000. Die schweizerische Beteiligung mit "Klangkörper Schweiz". Bundesamt für Kultur. Bern. 2001. Pág. 107. Traducción de la autora: "Bau ein Land aus Worten"

55 Idem. Pág. 106. Traducción de la autora: "Das Gehörte, Erlebte, Gedachte..."

56 Idem. Pág. 56. Traducción de la autora: "In den Korridoren mit wenig Lichteinfall und vor allem in der Dämmerung und nachts kamen die Texte sehr gut zur Geltung" 


\section{"Gelb"}

Tubelle der Konekturverte in \% gegervibar der Gmindeinie (Basis Butken 14, 2030 mm hoch) bei Aufhouging des Projektors in 3500 ment Höhe Grind drieck

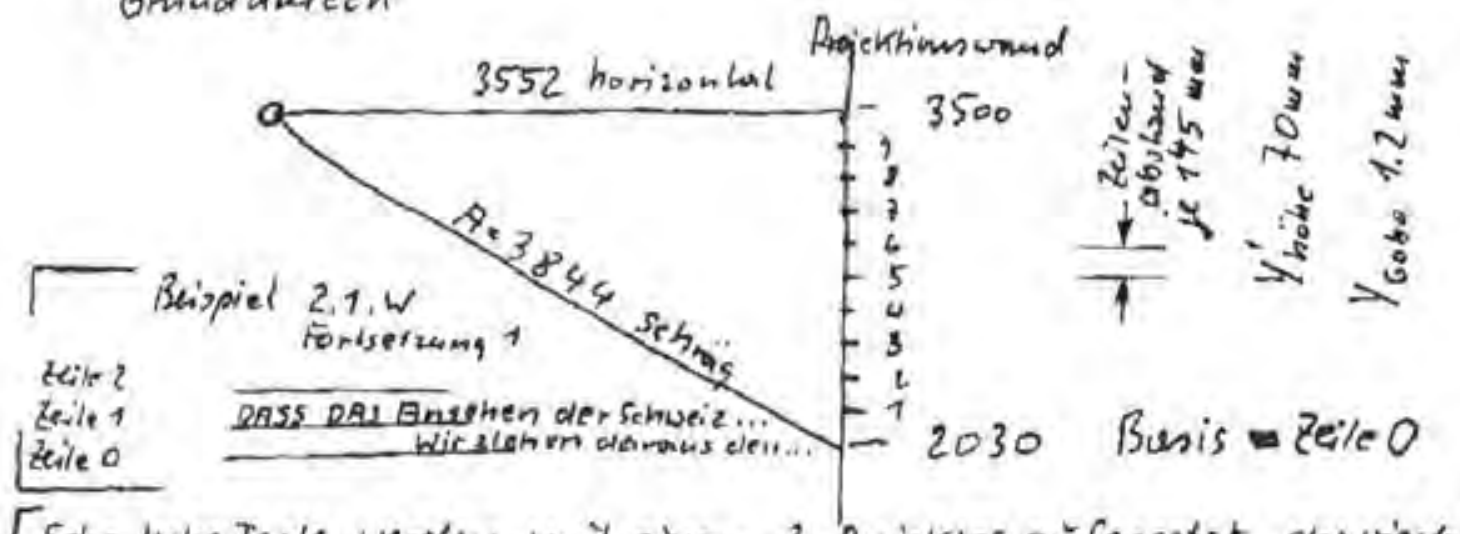

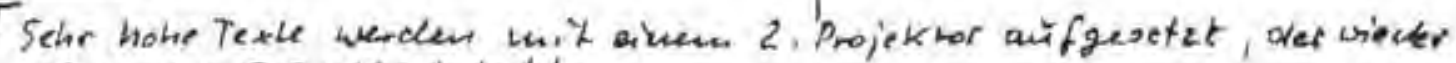
seine newe Grand conin hat!

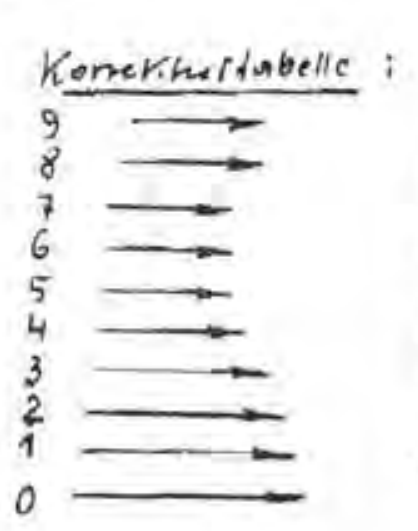

of ohen

$\%$ der Basintivite

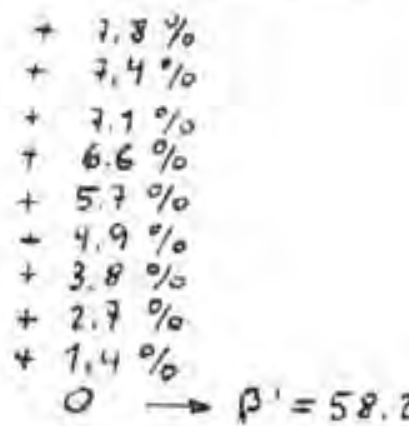

$0 \longrightarrow \beta^{\prime}=58.2$

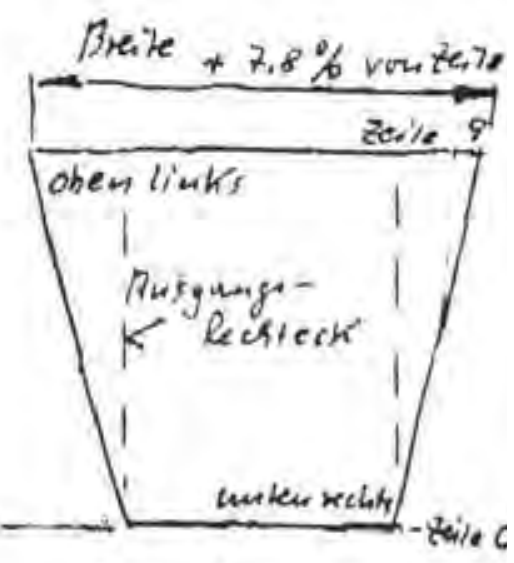

Spiequereskent bei hranficht ant die sialehtreite alen Gobos

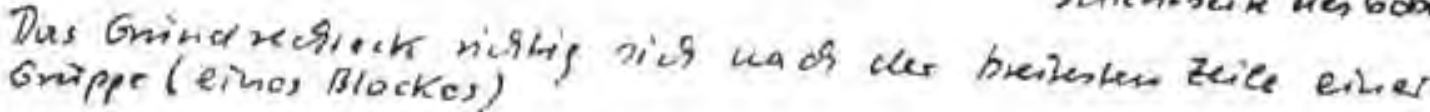
filet, wie bei 2.1.w Fortsetweing 4 wark ein text ant die Hïlets einen Gabos, tho z.B. und links rom

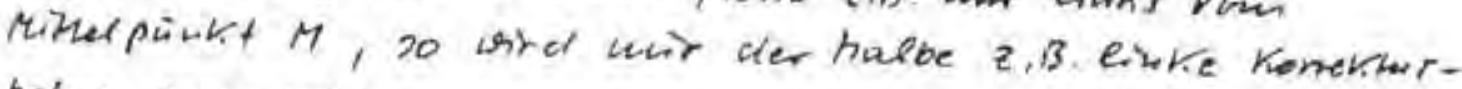
betrug cungesctit. 


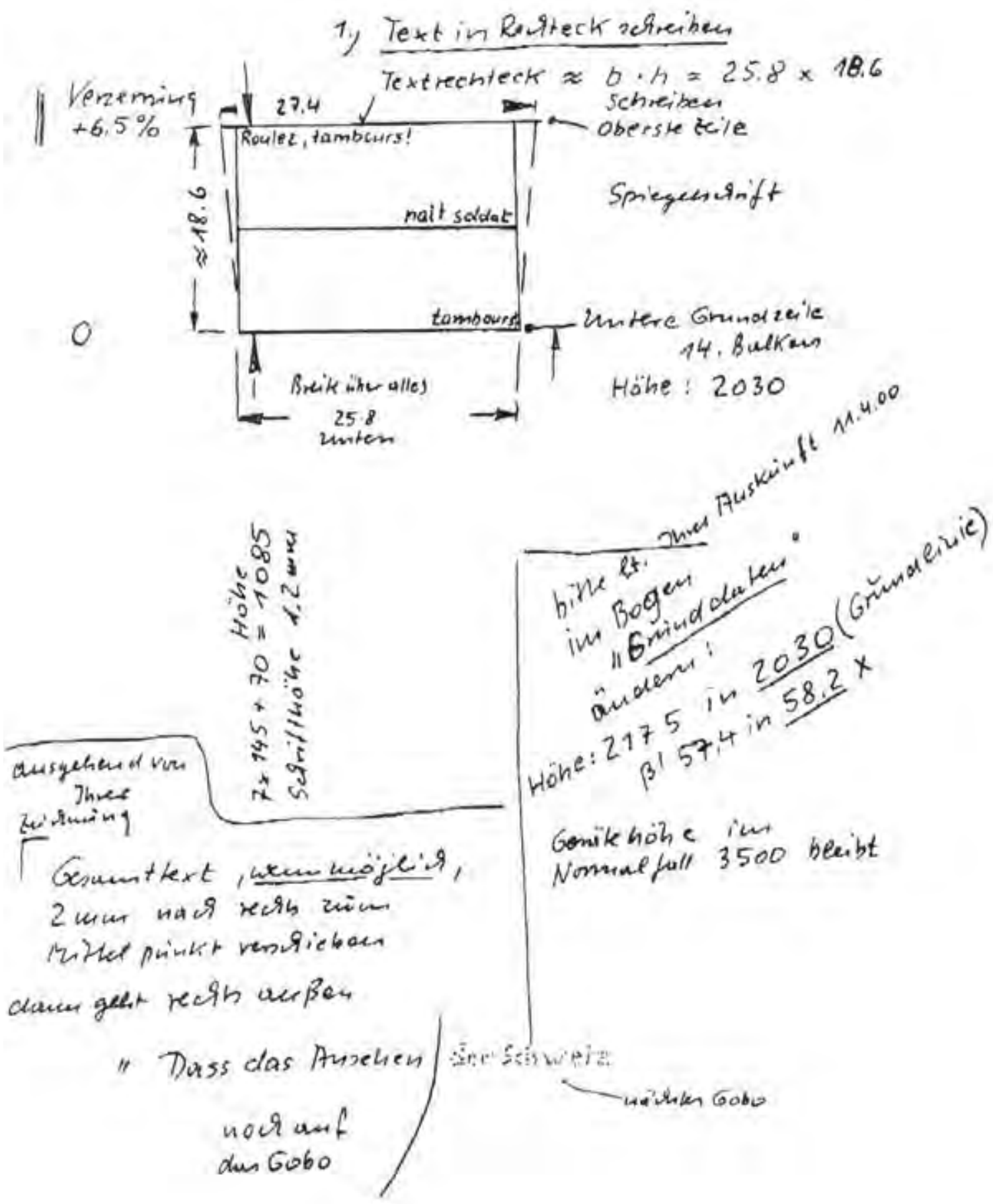



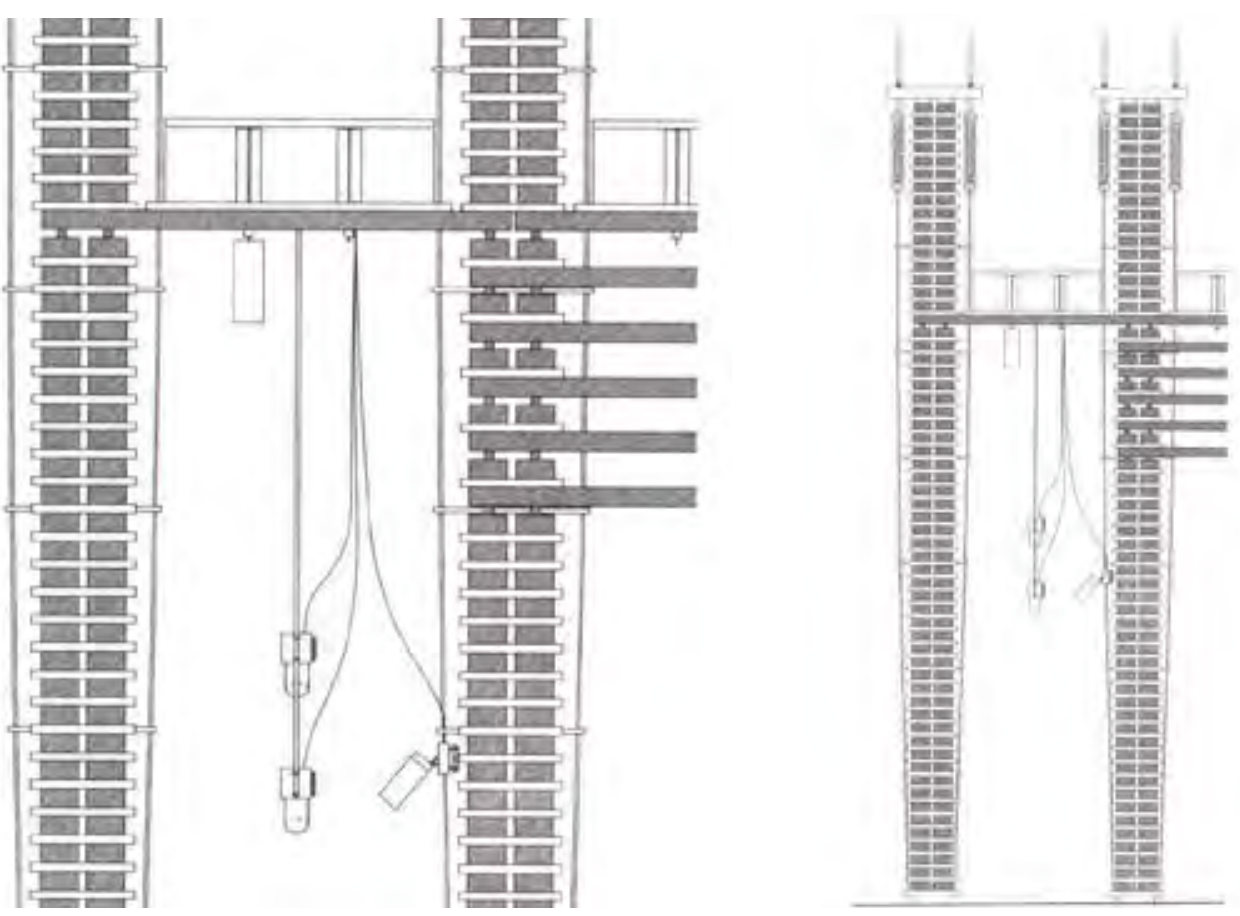

Figura 37.

Proyectores de luz / Pabellón helvético / Hannover / 2000

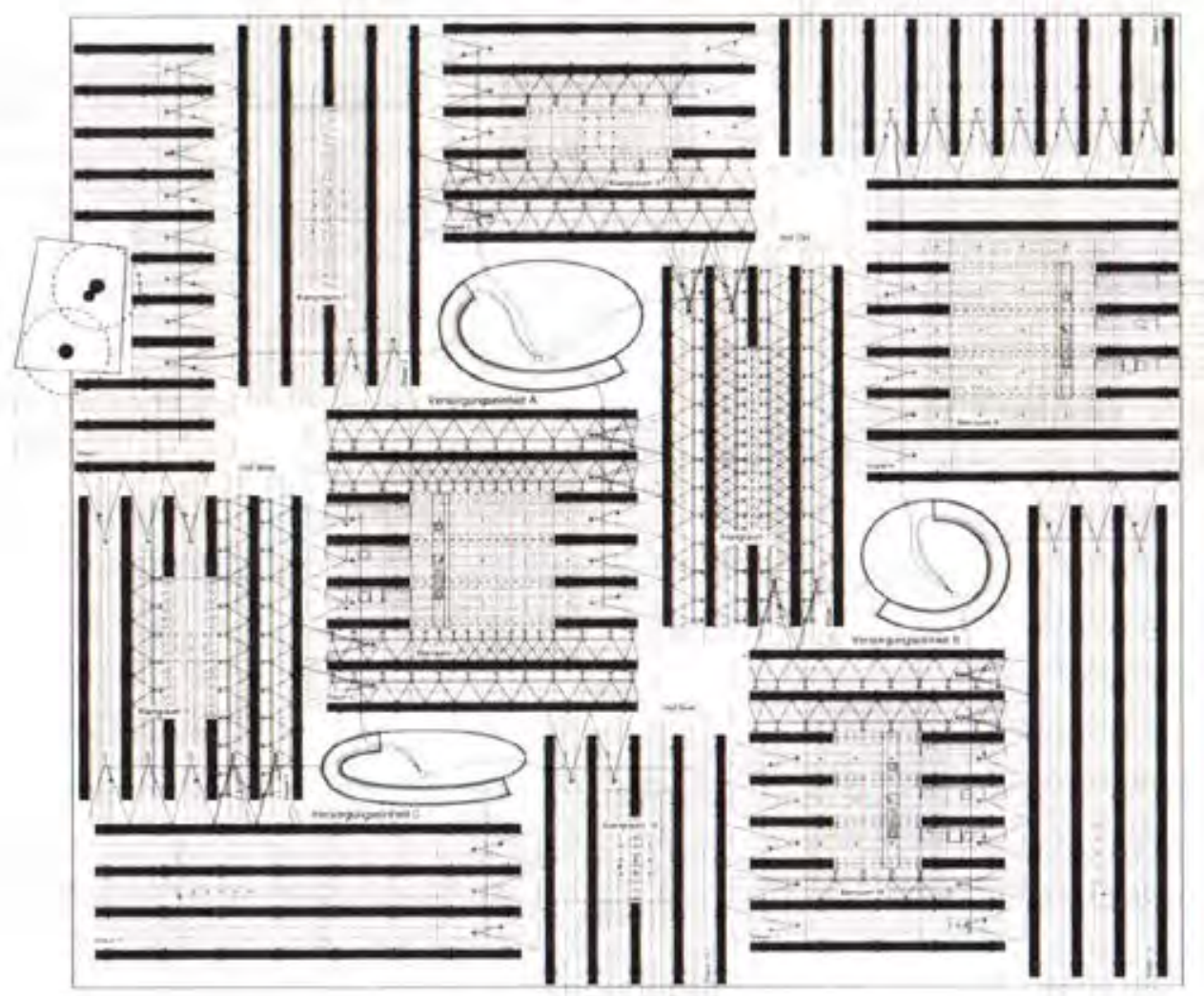

Figura 38.

Plan de instalación de los proyectores de luz / Pabellón helvético / Hannover / 2000 
Los escritos luminosos se realizaron mediante proyectores para textos de la línea $X{ }^{2} o^{57}$ de Zumtobel Staff. Para evitar que los textos tuviesen distorsiones, se usaron unas plantillas finas de corte láser, $G o b o^{58}$. Los proyectores estaban suspendidos de los techos en los pasillos conectados unos a otros. El control, así como las fuentes de alimentación, se ubicaban en el espacio elíptico más cercano dependiendo de su posición.

\begin{abstract}
"Aproximadamente 250 proyectores irradiaban luz fuertemente concentrada a través de gobos. Los gobos son plantillas en las que se graban minúsculas fuentes. Los proyectores cuelgan en los pasillos y son claramente visibles. A veces muchos, a menudo sólo uno. Cuando la luz se proyecta a una viga de madera a través de los gobos, aparece en ella una fuente brillante y bien cortada. Los gobos se rectifican para que el tipo de letra aparezca recto. "59 Plinio Bachmann
\end{abstract}

En el pabellón helvético se dictaminaron una serie de normas estrictas sobre la colocación y tamaño de las letras; así como del tipo de letra, la elegida fue Vectora ${ }^{60}$ proyectadas. No eran arbitrarias, sino se basaron en la arquitectura ${ }^{61}$. Diferentes situaciones espaciales, distintos tamaños de letra. Todo ello en un sistema integral que colonizó numerosos lugares del pabellón.

57 AAVV. Klangkörperbuch. Birkhäuser. Basel. 2000. ISBN: 3-7643-6324-X. Pág. 25

58 Idem. Pág. 84. Nota: "Bedampfte Glasschablone, durch die das gebündelte Licht der Projektoren im Klangkörper fällt. Diese so genannten Konturenstrahler arbeiten mit einem speziellen Linsensystem. So können Zitate ohne Verzerrung an die Stapelwände des Klangkörpers projiziert werden."

59 GENERALKOMMISSARIAT. Schlussbericht des Generalkommissariates. Weltausstellung Expo 2000 Hannover 1.6.-31.10.2000. Die schweizerische Beteiligung mit "Klangkörper Schweiz". Bundesamt für Kultur. Bern. 2001. Pág. 107. Traducción de la autora: "Ca. 250 Projektoren strahlten stark gebündeltes Licht durch Gobos. Gobos sind Schablonen, in die winzige Schriften eingeäzt sind. Die Projektoren hängen gut sichtbar in den Gängen. Manchmal viele, oft nur einer. Wenn das Licht durch die Gobos auf einen Holzbalken trifft, zeichnet sicht darauf eine helle, scharf geschnittene Schrift ab. Damit das Schriftbild gerade erscheint, werden die Gobos entzerrt."

60 AAVV. Klangkörperbuch. Birkhäuser. Basel. 2000. ISBN: 3-7643-6324-X. Pág. 218.

61 Idem. Pág. 216. Traducción de la autora: "Regeln gehen von der Architektur aus" 
Regla 1_Frases cortas y letra grande, de $50 \mathrm{~cm}$, donde la vista se dirige desde uno de los tres claustros a una pared de listones apilados ${ }^{62}$.

Regla 2_En dos pasillos que conducen desde los claustros a la pared donde se proyectaba la letra grande de la Regla 1 se empleó un pequeño tipo de letra de 2,5 cm a lo largo de toda la longitud de la pared. Esta situación se produjo catorce veces ${ }^{63}$.

\footnotetext{
62 AAVV. Klangkörperbuch. Birkhäuser. Basel. 2000. ISBN: 3-7643-6324-X. Pág. 216.

63 Idem. Pág. 216.
}
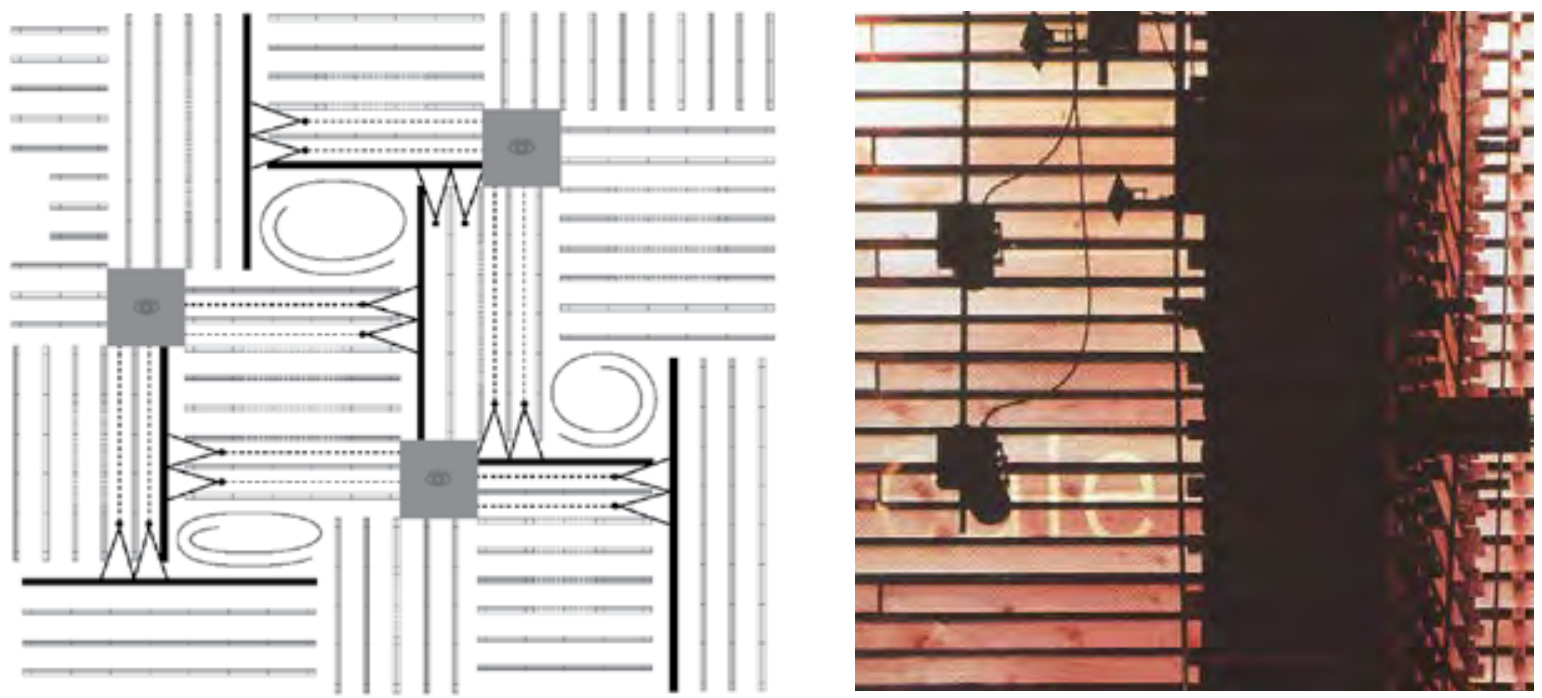

Figura 39 - 40

Regla 1

Esquema / Luz informativa / $50 \mathrm{~cm}$
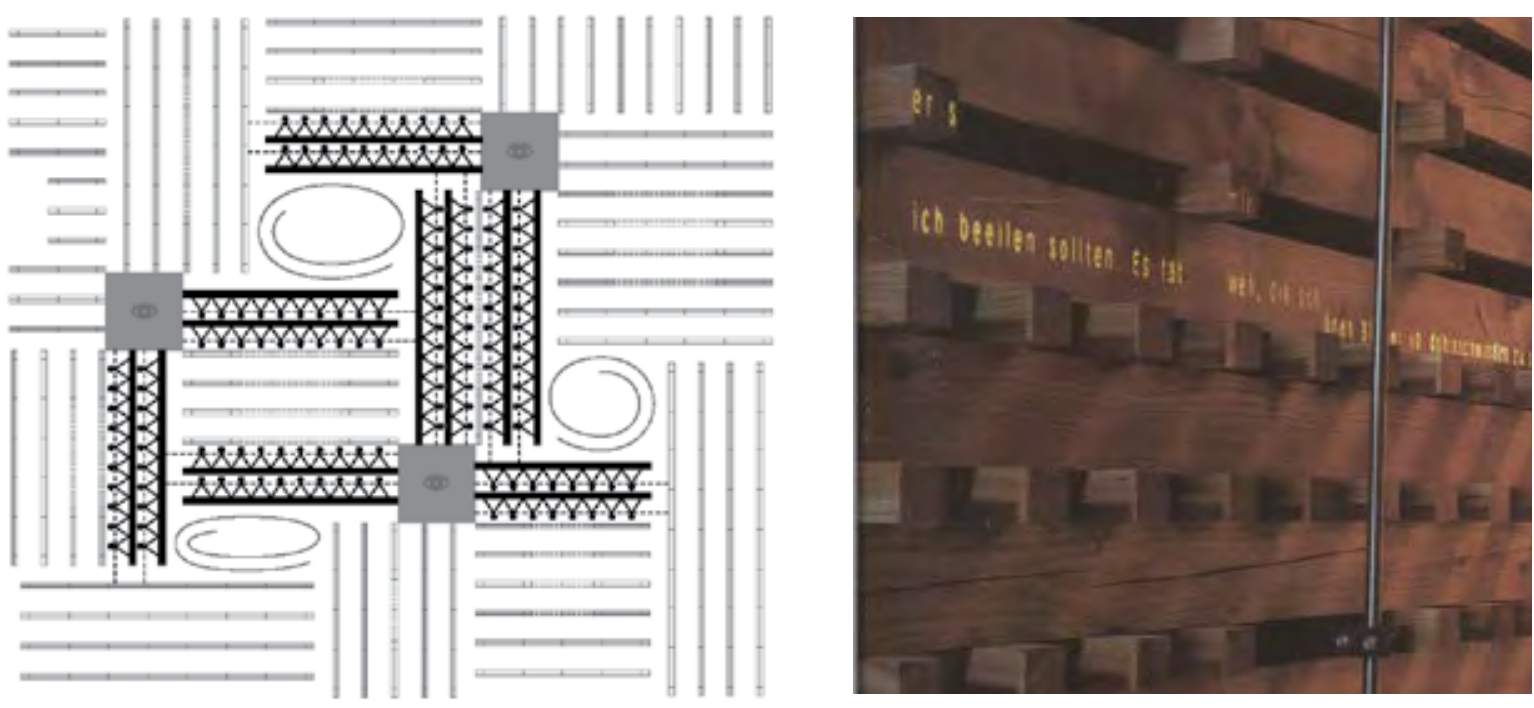

Figura $41-42$.

Regla 2

Esquema / Luz informativa / 2,5 cm 
Regla 3_Si la pared de la Regla 2 cruzaba un espacio gastronómico o de un espacio sonoro, partiendo de los claustros, se proyectaba un texto de tamaño medio de 5,0 $\mathrm{cm}$ en la pared. Esta situación se produjo siete veces ${ }^{64}$.

Regla 4_Cada mirada, desde el pasillo a una pared, se encuentra con una letra de tamaño mediano, de $7 \mathrm{~cm}^{65}$.

64 Idem. Pág. 216.

65 Idem. Pág. 218.
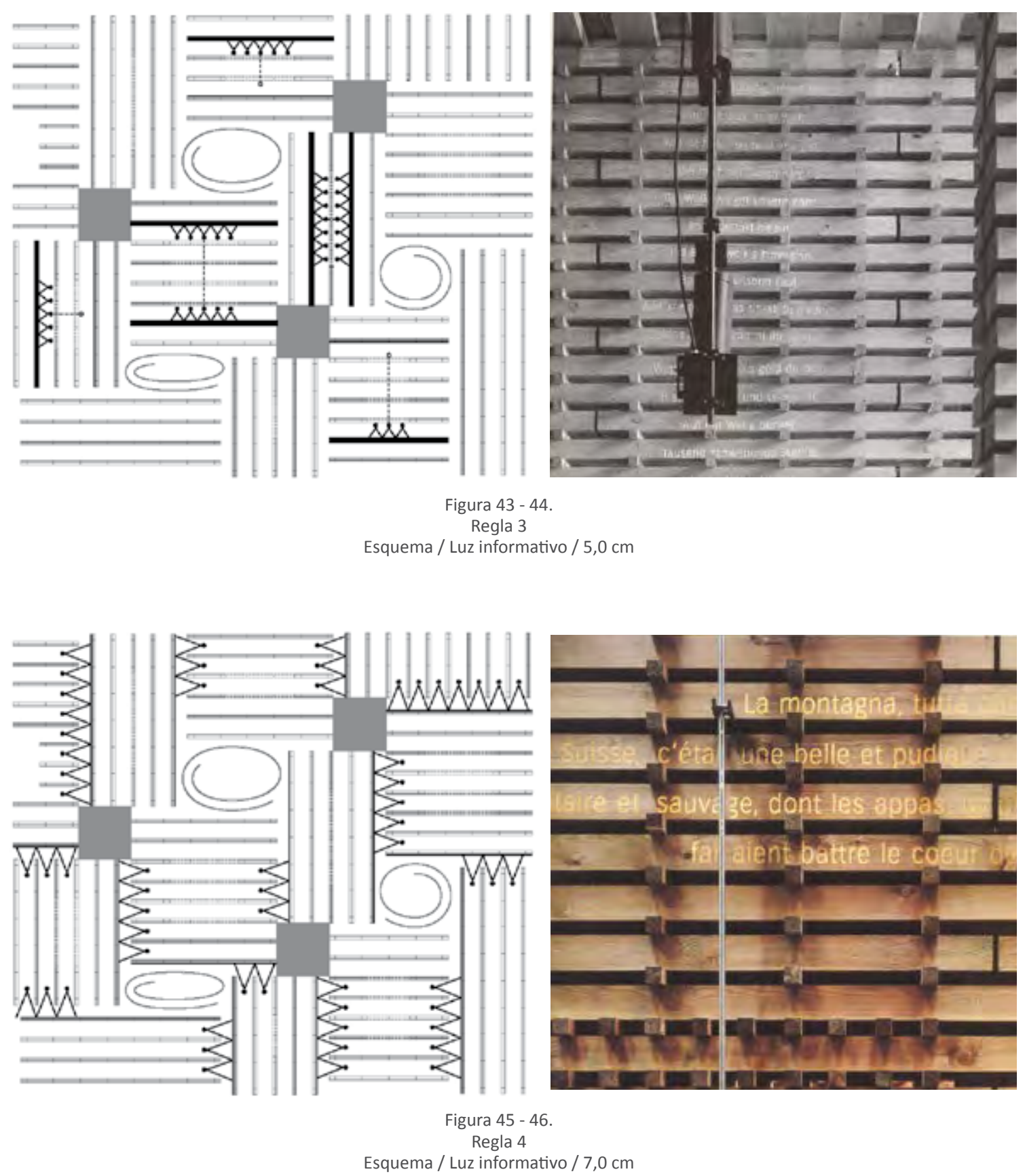


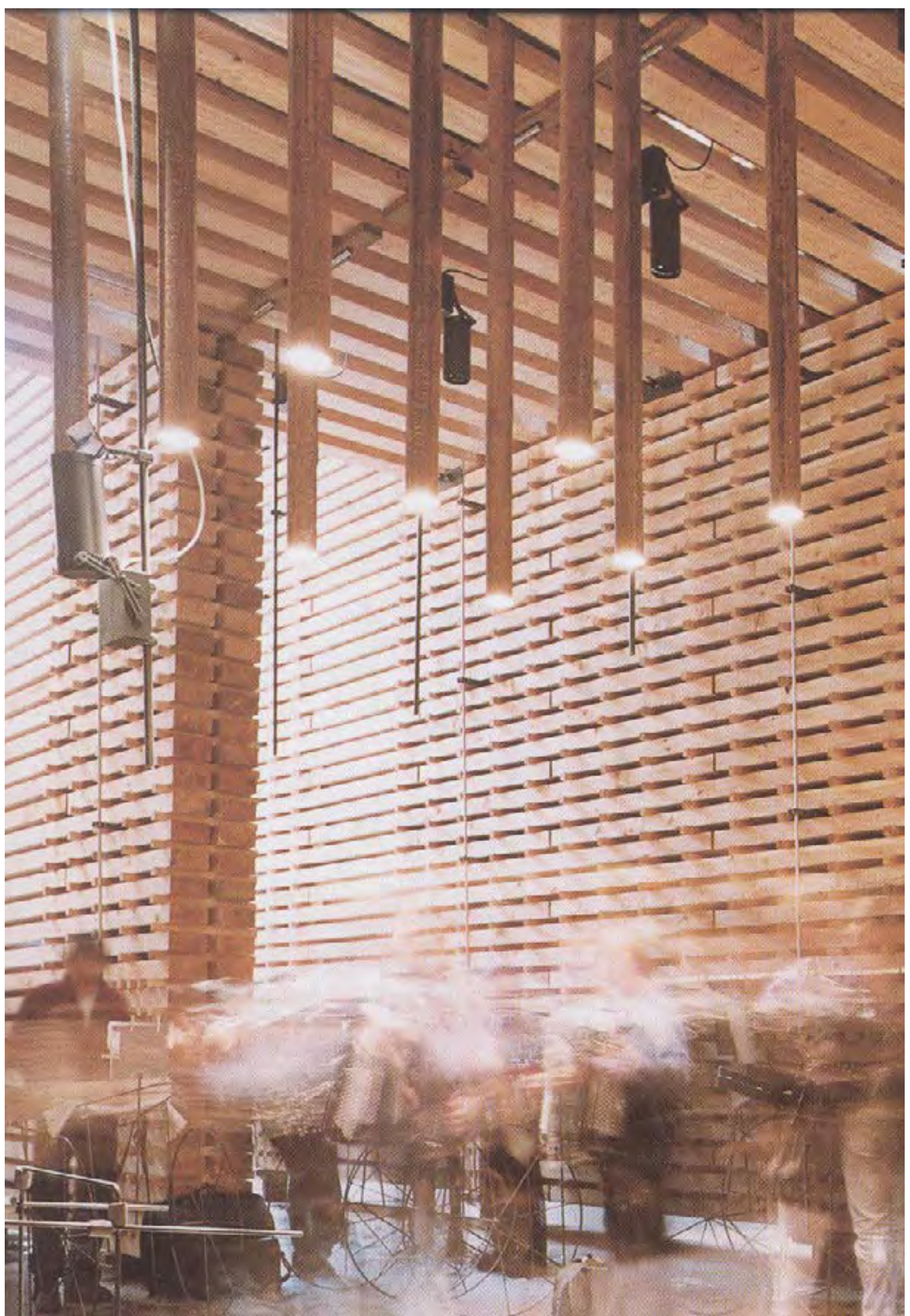

Figura 47.

Iluminación espacio sonoro / Pabellón helvético / Hannover / 2000 


\title{
[Ocaso]
}

\begin{abstract}
"Entre la puesta de sol y el amanecer nos orientamos con las luces que nosotros mismos producimos y encendemos. Estas luces no son comparables con la luz del día...Pero si no pienso en esas luces (...) como en un esfuerzo por suprimir la noche, sino que intento pensarlas en el seno mismo de la noche, como una acentuación de la misma (...) entonces se vuelven hermosas y pueden desarrollar su propio encanto."66 Peter Zumthor
\end{abstract}

El interior del Klangkörperbau albergaba una serie de elementos de apoyo de luz de baja intensidad. Este sistema auxiliar permitía la continuidad ininterrumpida de las actividades. Los espacios se orquestaron al ritmo cambiante del día y la noche, de la luminosidad y la oscuridad.

A diferencia del proyecto ganador, que contaba con cintas de luz de neón coloreadas y una serie de pantallas insertadas en el suelo que retransmitían diversos eventos diarios en directo desde Suiza; la iluminación del Klangkörper se llevó a cabo en gran medida gracias a los proyectores de textos suspendidos de la cubierta. En las zonas gastronómicas, los espacios sonoros y en los espacios elípticos se utilizaron "lámparas convencionales"67. Mientras que los espacios gastronómicos estaban iluminados por unos proyectores, de la misma empresa, así como por la luz inherente de los elementos del bar; los espacios sonoros lo hicieron gracias a nueve elegantes luminarias suspendidas en tres filas entre los listones del techo, y fabricadas con tubos largos y estrechos de acero corten. La intensidad de la luz era ínfima, "porque sólo en la oscuridad relativa nuestros ojos están realmente abiertos y sienten el espacio"168; ya que la plena luz es enemiga de la perspectiva ${ }^{69}$.

La experiencia visual como espacio de intimidad e imaginación. Una atmósfera relajante que fortalece el poder de la palabra hablada ${ }^{70}$, el poder de los sonidos tocados.

66 ZUMTHOR, Peter. Pensar la arquitectura. Editorial Gustavo Gili, SL. Barcelona. 2014. ISBN: 978-84252-2730-1. Pág. 93.

67 AAVV. Klangkörperbuch. Birkhäuser. Basel. 2000. ISBN: 3-7643-6324-X. Pág. 155. Traducción de la autora: "herkömmliche Leuchten"

68 BELLMANN, Beate. Mit den Augen fühlen. En: James Turrell Lighting a Planet. ....Pág. 32. Traducción de la autora: "Das Lichtiniveau seiner Installationen ist immer niedrig den nur in relativer Dunkelheit sind unsere Augen wirklich geöffnet und fühlen den Raum."

69 LEVI-STRAUSS, Claude. Tristes trópicos. (1955). Ediciones Paidós Ibérica. S.A. Barcelona. 1988. ISBN: 978-84-750-9465-6. Pág. 69.

70 PALLASMAA, Juhani. Los ojos de la piel. La arquitectura de los sentios: Editorial Gustavo Gili SL. Barcelona. 2014. ISBN : 978-84-252-2626-7. Pág. 59. 


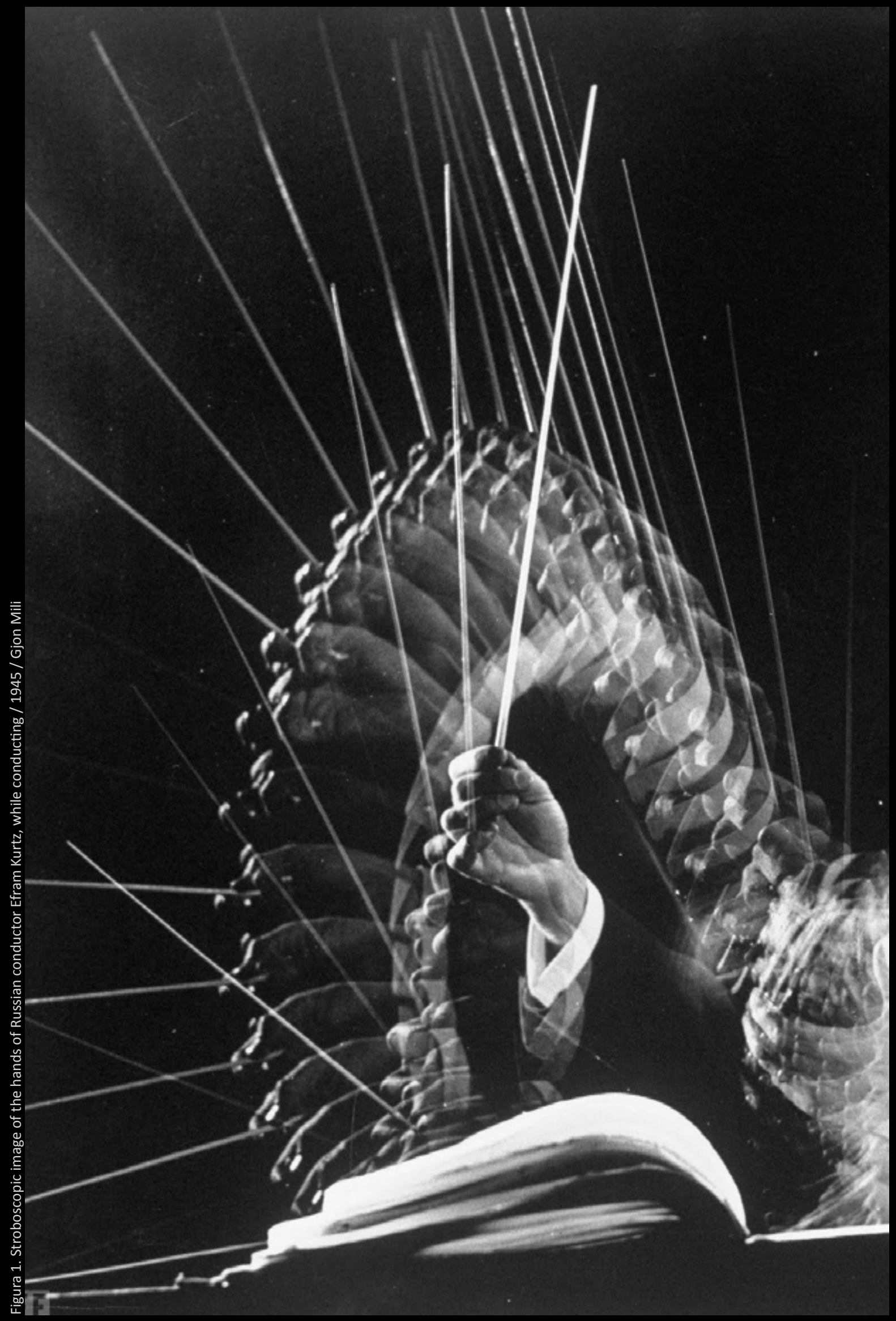




\section{CAPTURAS DE VERDAD}

WAHRNEHMUNGEN

"Las percepciones no son experiencias, sino tan solo el registro de estímulos sin contexto, juicio o significado. Las percepciones sensoriales interactúan con la memoria y la imaginación para conformar una experiencia completa e integrada con distintas conexiones y significados. Al proyectar obras de arquitectura, la capacidad más valiosa y más exigente consiste en ser capaz de intuir o simular la experiencia de una entidad fisicamente inexistente. ${ }^{\prime 1}$

Juhani Pallasma 


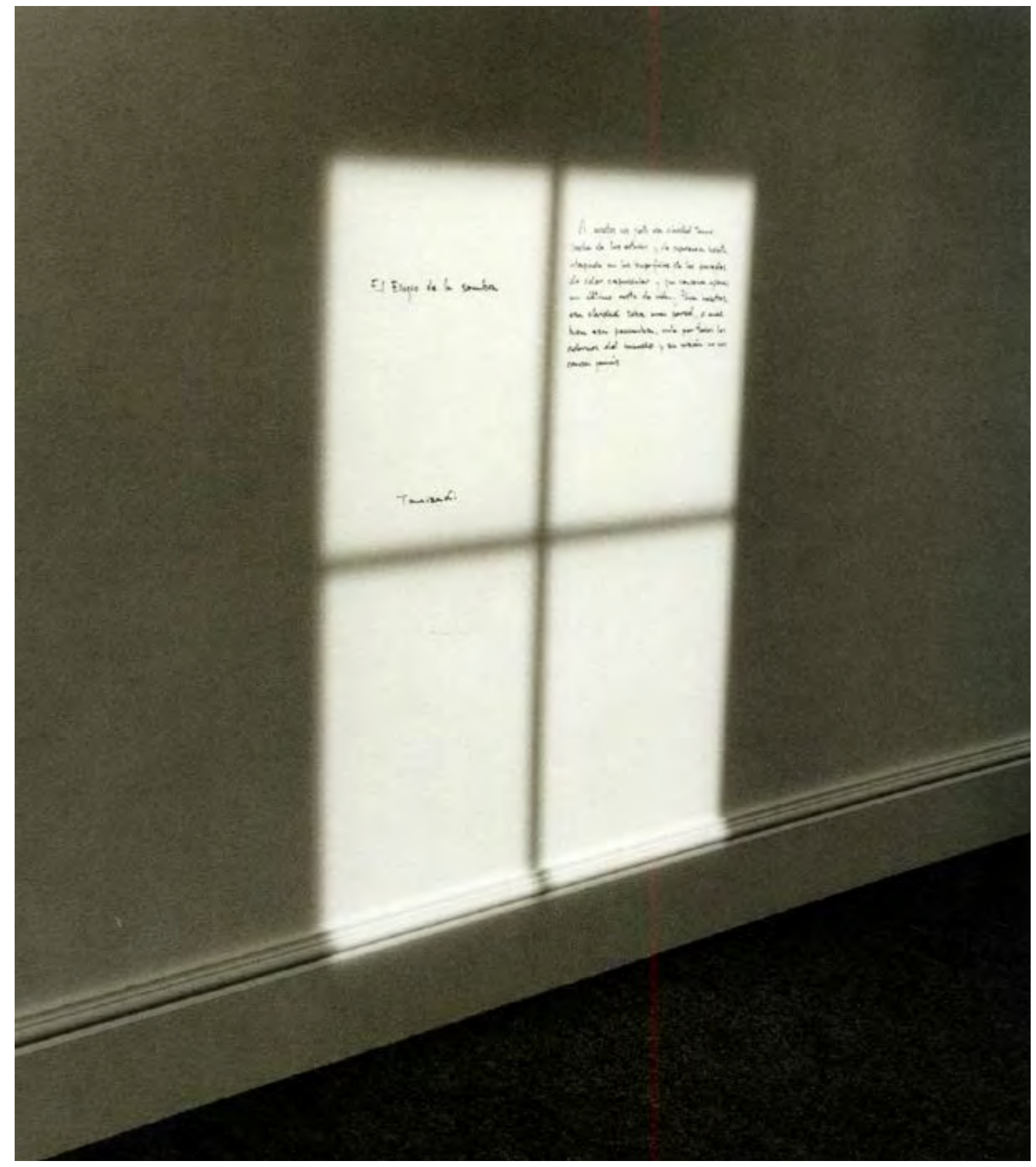

Figura 2.

El elogio a la sombra / Chema Madoz 


\section{[Chiaroscuro]}

"En el principio creó Dios los cielos y la tierra...Y dijo Dios: Sea la luz; y fue la luz. Y vio Dios que la luz era buena; y separó Dios la luz de las tinieblas. $Y$ Ilamó Dios a la luz Día, y a las tinieblas las Ilamó Noche."2 Genesis 1. Moises

La luz es un fenómeno de ondas electromagnéticas. Inmaterial, invisible, impalpable; pero también es volátil, variante, cambiante. Un mediador intangible entre la realidad y la percepción espacial. La luz se hace visible cuando se refleja en la materia. Y la materia solamente es comprensible por el impacto de esta. Ambos están inextricablemente unidos. Cuando se convergen, provocan una metamorfosis.

"Cada persona cree que sabe lo que es la luz. He pasado toda mi vida intentando averiguar que es la luz, y todavía no lo sé."3

Albert Einstein

La luz es un elemento constructivo. Cumple varias funciones. "Sin luz los ojos no pueden apreciar ninguna forma, ningún color, ningún espacio o movimiento...la luz... es requisito previo de casi toda actividad"'4. Una herramienta sutil atmosférica.

\footnotetext{
"Por su naturaleza, la sombra pertenece a las tinieblas, la luz (sobre los cuerpos) es de naturaleza de la claridad (primordial). Uno se esconde, el otro se revela. ${ }^{15}$ Leonardo Da Vinci
}

Para Leonardo da Vinci la pintura "surge de la luz y la sombra"6 porque "la sombra es el medio por el cual los cuerpos muestran su forma. Las formas de los cuerpos sólo pueden ser captadas en detalle por la sombra"7, consiguiendo así una conexión entre la iluminación y la perspectiva en la representación pictórica. Su máximo

2 Biblia. El antiguo testamento. Génesis. Primer libro de Moises. Capítulo 1.

3 EINSTEIN, Albert. Eröffnungsrede zur Ausstellung Luminale 08 von Andreas Beitin. Mainz. 6 de abril 2008. Nota: La Teoría de la Relatividad especial de Einstein de 1905 Traducción de la autora: "Jeder Mensch denkt, er wüsste, was Licht ist. Ich habe mein ganzes Leben damit verbracht, herauszufinden, was Licht ist, und weiss es immer noch nicht."

4 HALLER, Bert. Licht und Schatten. En: Detail Zeitschrift für Architektur. München. 4/2006. Licht und Innenraum. ISSN: 0011-9571. Pág.378. Traducción de la autora: "Schatten ist der Tanzpartner des Lichts in einem Duett der sinnlichen Wahrnehmung"

5 DA VINCl, Leonardo. Das Buch von der Malerei. Nach dem Codex Vaticanus 1270. Band 2. Wilhelm Braumüller. Wien 1882. Pág. 5. Traducción de la autora: "der Schatten ist das Mittel, durch den die Körper ihre Form zeigen. Die Formen von Körpern können nur durch den Schatten in allen Einzelheiten begriffen werden."

6 ISAACSON, Walter. Leonardo da Vinci: Die Biographie. Ullstein Buchverlag. GmbH. Berlin. 2018. ISBN: 978-3-8437-1884-4. Traducción de la autora: "entsteht aus Licht und Schatten"

7 Idem. Traducción de la autora: "der Schatten ist das Mittel, durch das Körper ihre Form zeigen. Die Formen von Körpern können nur durch den Schatten in allen Einzelheiten begriffen werden" 


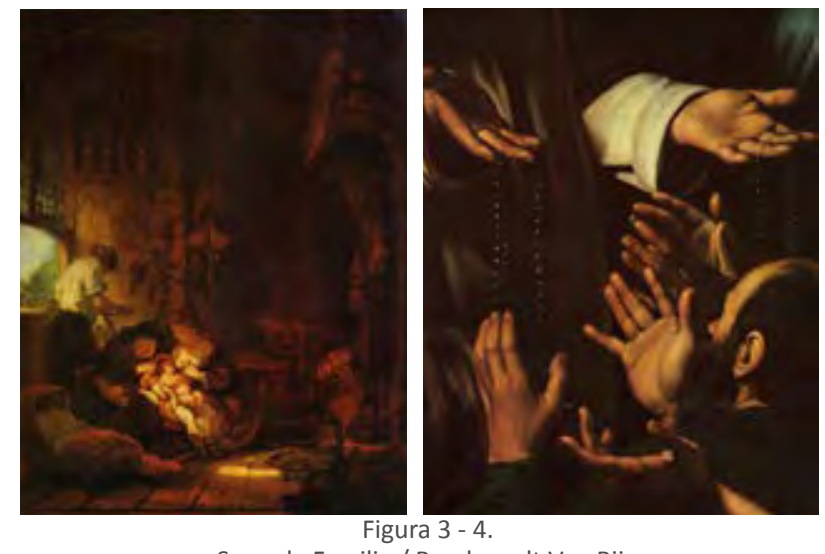

Sagrada Familia / Rembrandt Van Rijn

La Virgen del Rosario / Caravaggio

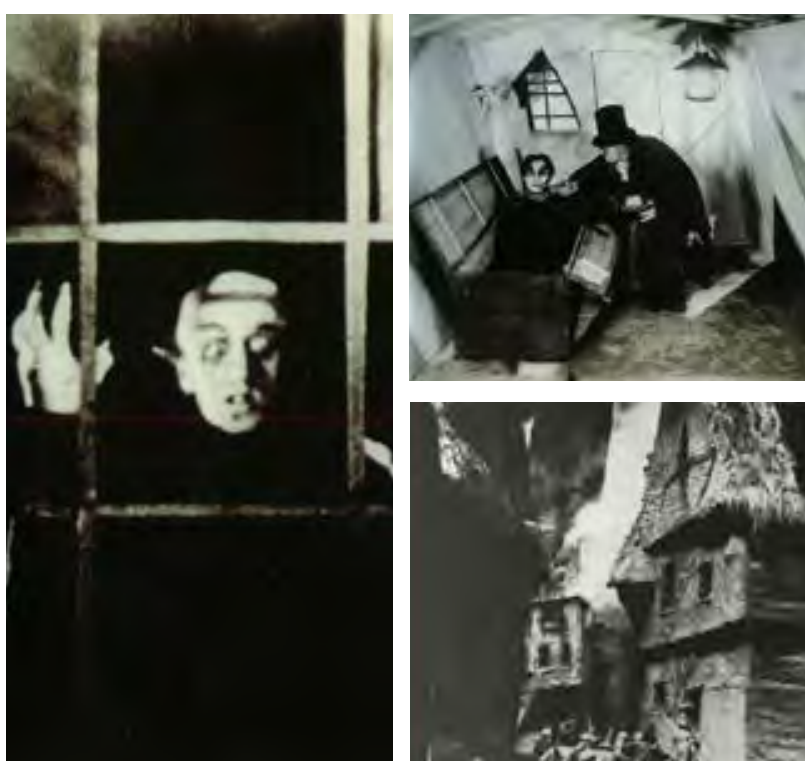

Figura 5 - 7.

Nosferatu, eine Symphonie des Grauens / 1922 / Friedrich Wilhelm Murnau Das Cabinet des Dr. Caligari / 1920 / Robert Wiene Der Golem, wie er in die Welt kam / 1920 / Paul Wegener
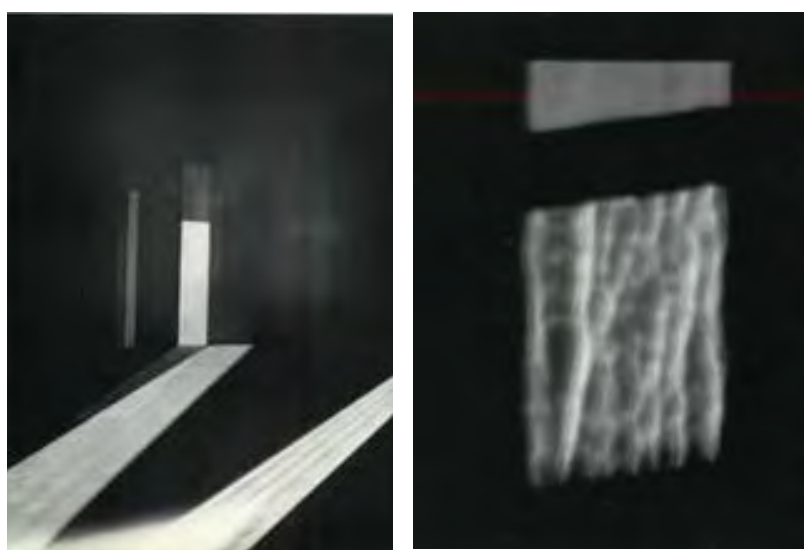

Figura 8 - 9.

Mendota Stoppage /1969-1974 / James Turrell 
exponente es la técnica del claroscuro - chiaroscuro. Un medio de expresión, recurrente en Miguel Ángel Merisi da Caravaggio o Rembrandt Harmenszoon van Rijn, para ensalzar efectos dramáticos, y aumentar la profundidad. Enfatizar los motivos pictóricos en un primer plano, mientras que los contornos en el fondo se disuelven gradualmente. Otro exponente de esta técnica fue el pintor romántico William Turner creador de atmósferas impregnadas de luz, niebla, bruma, movimiento y naturaleza salvaje. No en los detalles, sino en los colores y en la luz difusa.

Sin embargo, esta técnica dramática no fue aplicada solamente sobre lienzo, mudando hacia otras disciplinas como el teatro, la fotografía y posteriormente al cine. El uso de fuertes contrastes en la iluminación fue particularmente habitual en la cinematografía del expresionismo alemán: Nosferatu: Una sinfonía del horror de 1922 y Fausto de 1926, ambas de Friedrich Wilhelm Murnau, El gabinete del doctor Caligari de 1920 de Robert Wiene o El Golem de 1920 de Paul Wegener.

Los contrastes tambien fueron un recurso frecuente en algunas obras de arte experimental. En 1966, James Turrell ${ }^{9}$ alquiló el abandonado Hotel Mendota en Santa Mónica como estudio. Allí llevó a cabo el proyecto Mendota Stoppage entre 1969 - 1974; donde experimentó con la luz por contraste, natural y artificial. Algunas de las ventanas de sus habitaciones se oscurecieron completamente, sin ningún tipo de luz desde el exterior. Una especie de cámara oscura ${ }^{10}$. Posteriormente realizó una serie de "aberturas pequeñas y grandes, a través de las cuales la luz nocturna de las farolas, de los anuncios luminosos y de los coches pasantes, creaban proyecciones de luz y sombra más o menos abstractas"11. Estos rotos, semejantes a las propuestas de Gordon Matta-Clark, actuaban como claro-oscuros cambiantes para una audiencia seleccionada.

8 Nota: Títulos en alemán; Nosferatu, eine Symphonie des Grauens; Faust; Das Cabinet des Dr. Caligari, Der Golem, wie er in die Welt kam, respectivamente.

9 Nota: De estos experimentos nacen más tarde a otros proyectos de Turrell como Skyspaces, Dark Pieces o Roden Crater. El artista estadounidense también fue responsable de la exposición inaugural de Kunsthaus en Bregenz. Para la simbiosis del arte y la arquitectura, instaló luces de neón de diferentes colores y focos de luz de escape en la fachada intermedia. Convertido en una luminaria, el edificio de $30 \mathrm{~m}$ de altura brilló en tonos rojos y azules en un intervalo de tiempo determinado. Por lo tanto, la luz determina la atmósfera de los espacios, de los cuadros y de los objetos.

10 Nota: Este proyecto se puede comparar con las obras de Eliasson "360 Camera obscura" de 2000 o "Camera obsucra for the sky" de 2003.

11 HERRMANN, Hans-Christian von. Sensing Spaces, James Turrells helle Kammern. En: Bühnen des Wissens. Interferenzen zwischen Wissenschaft und Kunst. University Pres. Berlin. 2003. En: https:// www.literaturwissen.tu-berlin.de/fileadmin/f30/Texte_HCvH/Sensing-Spaces.pdf. Pág. 346. Traducción de la autora: "Öffnungen, durch die nachts das Licht von Straßenlaternen, Leuchtreklamen und vorbeifahrenden Autos fällt, so daß mehr oder weniger abstrakte Licht- und Schattenprojektionen" 


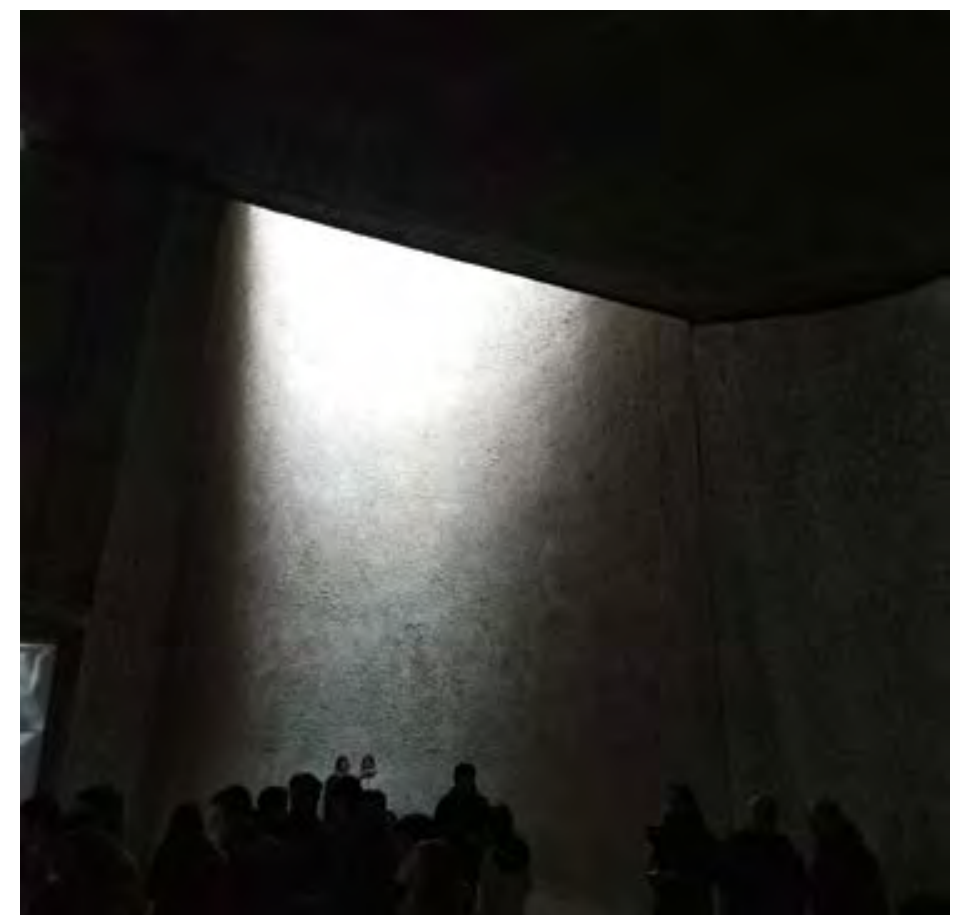

Figura 10

Capilla Notre Dame du Haut / Le Corbusier Foto de la autora

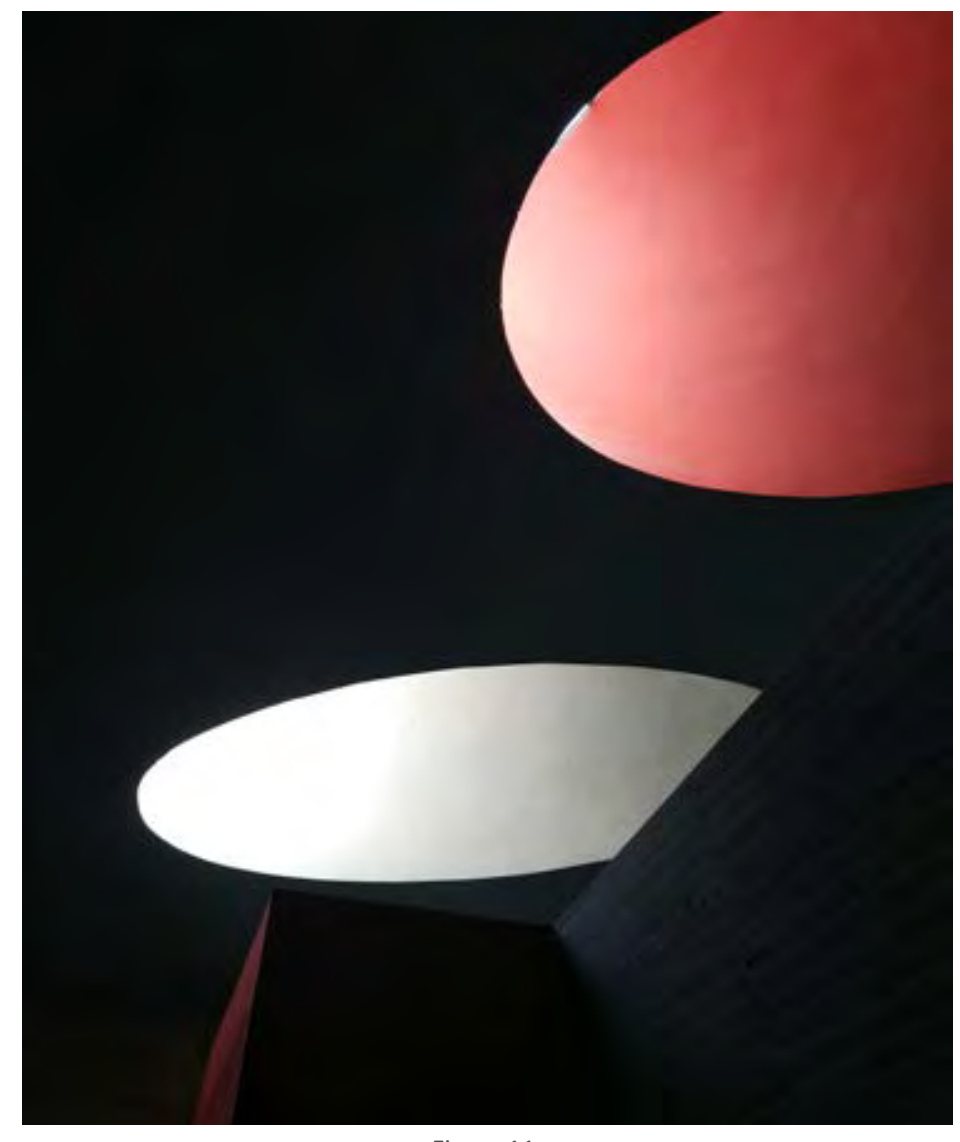

Figura 11.

Convento de La Tourette / Le Corbusier Foto de la autora 
La sombra se materializa en su antítesis simultánea, la luz. Ya que "donde hay mucha luz, hay mucha sombra"12. La simbiosis de esta pareja de baile ${ }^{13}$ desigual permite comprender la determinación mutua del espacio y del tiempo, así como la geometría del volumen y su modulación, otorgando a los objetos profundidad, cuerpo, textura o dimensiones espaciales. En El elogio de la sombra ${ }^{14}$, Tanizaki Jun'ichiro interpretaba los interiores tradicionales japoneses como resultado de la distribución de las sombras. Para él, la belleza reside en el juego de luces y sombras; así como en su gradación. "Tanizaki Jun ichiro alaba la sombra...Y la sombra alaba la luz"15.

En un viaje al Monasterio de Le Thoronet ${ }^{16}$ en 1953, Le Corbusier quedó impresionado por las condiciones de iluminación de la abadía cisterciense. Según él, "la luz y la sombra son los altavoces de esta arquitectura de la verdad, la tranquilidad y la fuerza. Nada podría añadírsele ${ }^{117}$. Los únicos elementos arquitectónicos para construir "son la luz y la sombra, el muro y el espacio"18. Los espacios de las capillas de la peregrinación de Ronchamp (1950-55) y del monasterio dominicano de La Tourette (1953-59) poseen una condición de protección frente al exterior y por contraste un sutil juego de luces y sombras en el interior. Mediante la penumbra, Le Corbusier creó una atmósfera sacra, mística. A través de una serie de perforaciones ${ }^{19}$, a modo de pozos, la luz cenital aparece. Las pesadas cubiertas se convierten en una escenografía espacial en la que la luz confiere al espacio una dimensión espiritual. Una sinfonía de luces y sombras, un chiaroscuro arquitectónico.

12 GOETHE, Johann Wolfgang von. Götz von Berlichingen. Cotta'scher Verlag. Stuttgart, Augsburg. 1859. Pág. 25. Traducción de la autora: "Wo viel Licht ist, ist starker Schatten."

13 HALLER, Bert. Licht und Schatten. En: Detail Zeitschrift für Architektur. München. 4/2006. Licht und Innenraum. ISSN: 0011-9571. Pág.378. Traducción de la autora: "Schatten ist der Tanzpartner des Lichts in einem Duett der sinnlichen Wahrnehmung"

14 TANIZAKI, Jun'ichiro. El elogio de la sombra. Ediciones Siruela. Madrid. 28010. ISBN: 978-84-7844258-4.

15 ZUMTHOR, Peter. Pensar la arquitectura. Editorial Gustavo Gili, SL. Barcelona. 2014. ISBN: 978-84252-2730-1. Pág. 92.

16 http://www.le-thoronet.fr/es/

17 GIEDION, Siegfried. Espacio, tiempo y arquitectura. Origen y desarrollo de una nueva tradición. Editorial Reverté. Barcelona. 2009. ISBN. 978-84-291-2117-9. Pág. 554.

18 LE CORBUSIER. Hacia una arquitectura. Ediciones Apóstrofe. Barcelona. 1998. ISBN: 978-84-4550277-8. Pág. 143.

19 Nota: En 1931 Le Corbusier visitó la mezquita Sidi-Brahim de El Atteuf, cuya fachada sirvió de inspiración para Ronchamp. 


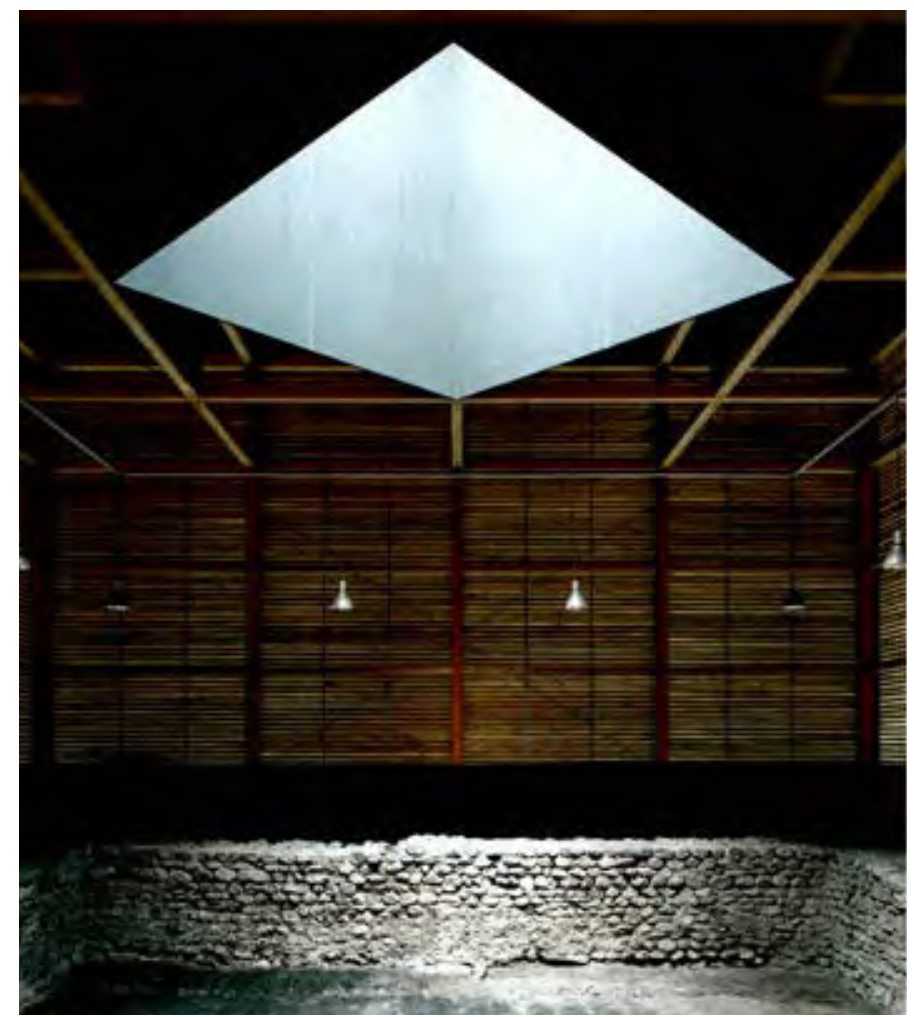

Figura 12.

Restos arqueológicos romanos / Chur / 1985 - 1986 / Peter Zumthor

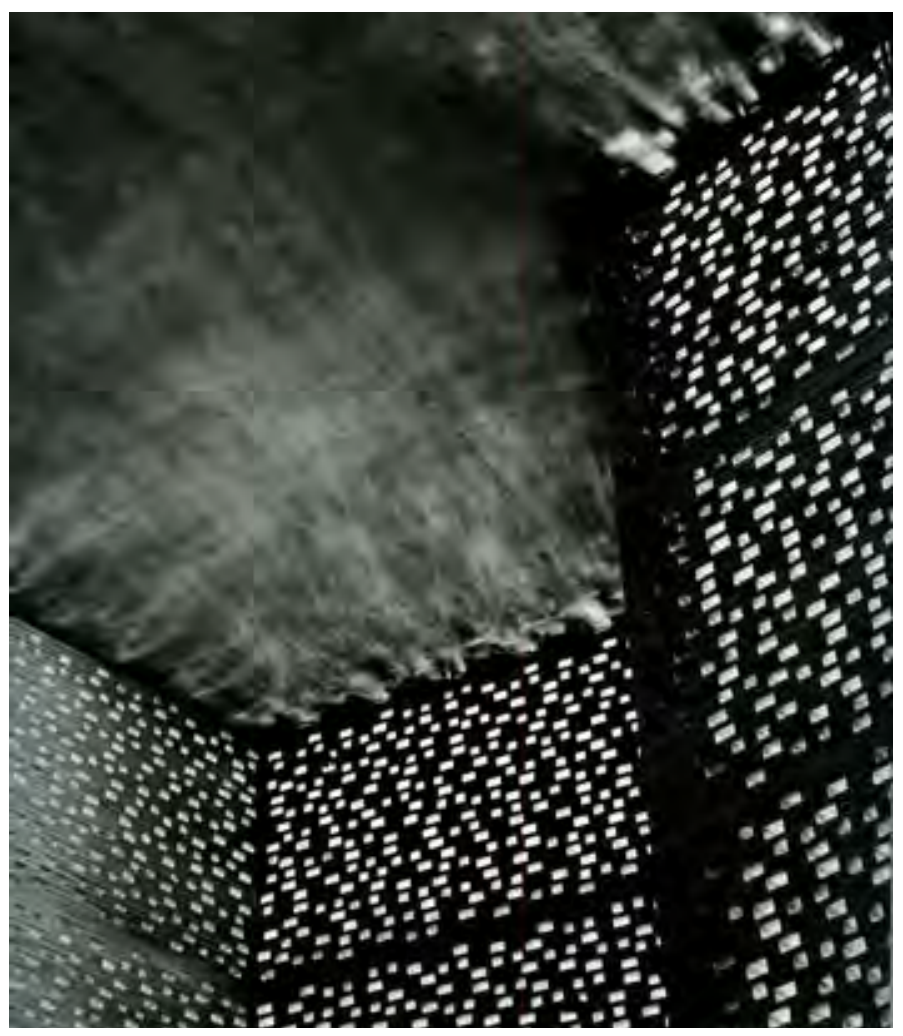

Figura 13.

Museo Kolumba / Colonia / 1997 - 2007 / Peter Zumthor 


\section{[Elogio de la penumbra]}

“...Una de mis ideas preferidas es primero pensar el conjunto del edificio como una masa de sombras, para, a continuación - como en un proceso de vaciado -, hacer reservas para la instalación que permita las luces que queremos. Mi segunda idea favorita (...) consiste en poner los materiales y las superficies bajo el efecto de la luz, para ver como la reflejan. Es decir, elegir los materiales con la plena conciencia de cómo reflejan la luz y hacer que todo concuerde." ${ }^{\prime 20}$ Peter Zumthor

La luz como material de construcción será recurrente en la obra de Zumthor. Pensar la arquitectura desde el dialogo entre los espacios, la luz y los materiales. Conseguir una atmósfera específica.

"La luz entra tímida entre los listones de madera que abrigan las ruinas y el tiempo parece detenerse en una penumbra de restos que se muestran y se esconden. Hasta que el sol se mueve y con su entrada cenital nos recuerda que el tiempo avanza, la historia sigue, la luz entra y desvela pasados escondidos." ${ }^{21}$ Peter Zumthor

Los cerramientos que albergan los Restos Arqueológicos Romanos en Chur de 1985 - 1986, tienen una condición ambigua. Hacía el exterior son dos volúmenes conectados, opacos, sin embargo, desde su interior la luz se filtra a través de los intersticios de las láminas de madera. Una interacción entre luz y material, creando una iluminación difusa en el interior. Cajones oscuros tatuados por la luz. En la propuesta ganadora del Museo Kolumba de Colonia de 1997 - 2007; el mecanismo es parecido, pero por medio de otro material. La fachada de ladrillo grisáceo está articulada a base de ausencia de piezas. En la zona de las ruinas se crea un filtro de luz y aire, sumergiendo el espacio interior en una penumbra. Un juego contemplativo de la luz, que se desarrolla en alternancia entre el periodo diario y estacional. "Un museo de luces y sombras, que se ajusta a la hora del día y las estaciones del año y conoces también la luz crepuscular"22.

20 ZUMTHOR, Peter. Atmósferas. Editorial Gustavo Gili, SL. Barcelona. 2006. ISBN: 987-84-252-2117-0. Pág. 59-61.

21 ZUMTHOR, Peter. Zumthor. Arquitectura para un lugar. Departamento de Proyectos Arquitectónicos ETSAB-UPC. Barcelona. 2013. ISBN: 978-84-616-3455-2. Pág. 24.

22 ZUMTHOR, Peter. Filter aus Stein. En: Velux. Daylight \& Architecture. Architektur-Magazin. Winter 2008. Pág.7. Traducción de la autora: "Nicht das lichtdurchflutete Museum war Ziel des Neubaus, vielmehr ist Kolumba ein Licht- und Schattenmuseum, das sich im Wechsel der Tages- und Jah- 


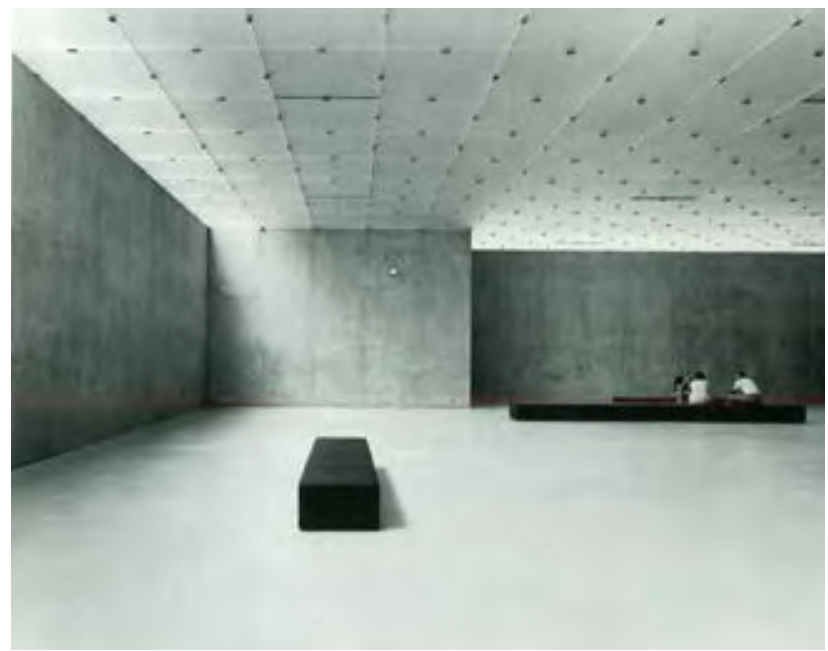

Figura 14

Kunsthaus Bregenz / Austria / 1989 - 1997 / Peter Zumthor

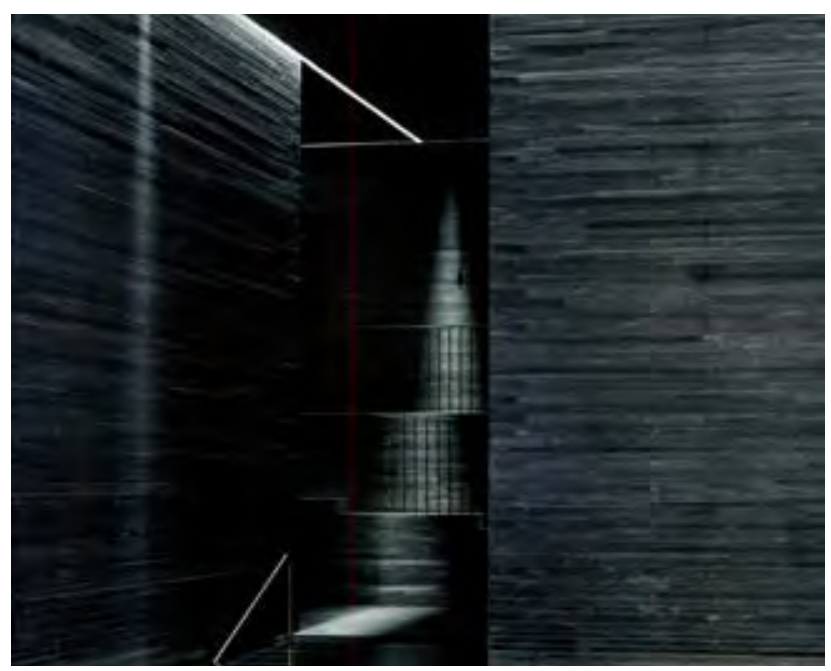

Figura 15.

Termas Vals / Suiza / 1990 - 1996 / Peter Zumthor

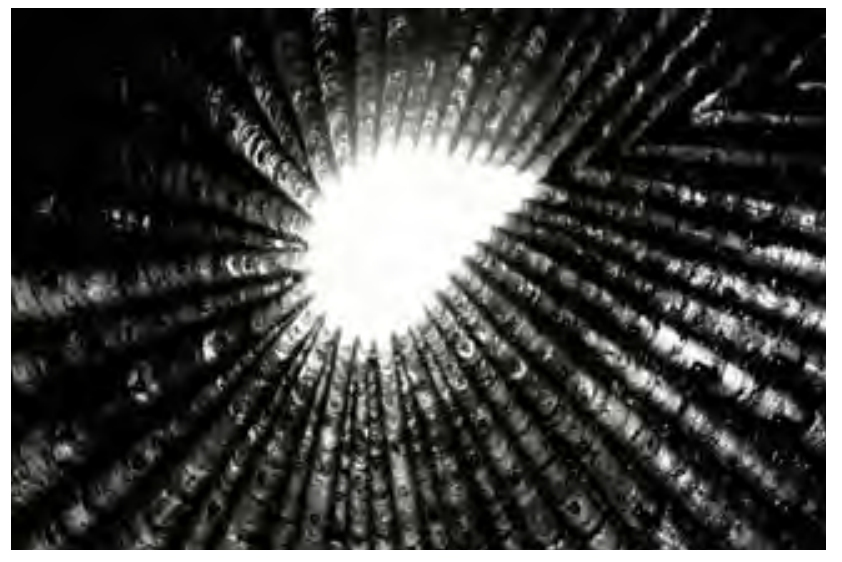

Figura 16.

Capilla de Campo Bruder Klaus / 2001 - 2007 / Peter Zumthor 
"El Kunsthaus se encuentra a la luz del lago Constanza. Su cuerpo está hecho de placas de vidrio, acero y una masa de hormigón vertido, que forma la estructura y el espacio interior. Visto desde fuera el edificio parece un cuerpo luminoso. Absorbe la luz cambiante del cielo, la bruma del lago, irradia la luz y el color y permite adivinar algo de su vida interior en función del ángulo visual, la hora del día y las condiciones climáticas."23 Peter Zumthor

La casa del arte, Kunsthaus ${ }^{24}$, es un contenedor igualmente introvertido de hormigón envuelto por un reflector, una piel de 712 paneles rectangulares de vidrio traslucido ${ }^{25}$. A diferencia de la planta baja, las tres plantas superiores reciben luz natural o artificial $^{26}$ a través de una serie de ausentes entre-plantas. Por contraste, la luz indirecta penetra sobre las austeras superficies grises de hormigón visto. Una atmósfera cambiante, según el momento del día y de las condiciones climáticas predominantes.

"Es una buena idea que, al principio, las casas, los espacios son oscuros y luego penetra la luz. Algunos materiales son hermosos bajo una luz muy específica,..."27 Peter Zumthor

Poner luz $z^{28}$ en la penumbra será una obsesión. La Capilla de Campo Bruder Klau se ilumina mediante un óculo en el umbral de los maderos carbonizados. Metáfora del mito de la caverna platónica. En Vals, se proponen diferentes gradaciones de iluminación solar según su proximidad a la montaña. En la zona más profunda, la penumbra total como gruta; en lo intermedio la luz penetra a través de las estrechas grietas entre los conjuntos; y hacia el valle, las imágenes del paisaje inundan el espacio. Una paleta de claro-oscuros, según el momento del día y su estación, enfatizan la experiencia sensorial.

reszeiten entfaltet und auch das Zwielicht kennt."

23 ZUMTHOR, Peter. Peter Zumthor: Kunsthaus Bregenz. Hatje Cantz Verlag. Ostfildern. 2007. ISBN: 9783775721592. Pág. 7. Traducción de la autora: "Das Kunsthaus steht im Licht des Bodensees. Sein Körper ist aus Glasplatten, Stahl und einer Steinmasse aus gegossenem Beton gebaut, die im Innern des Hauses Struktur und Raum bildet. Von außen betrachtet wirkt das Gebäude wie ein Leuchtkörper. Es nimmt das wechselnde Licht des Himmels, das Dunstlicht des Sees in sich auf, strahlt Licht und Farbe zurück und lässt, je nach Blickwinkel, Tageszeit und Witterung etwas von seinem Innenleben erahnen."

24 Nota: Edificio de exposición de $30 \mathrm{~m}$ de altura, de planta cuadrada de 26,57 m. Un edificio de administración situado ortogonalmente de 11 ×21,57 x 8,35 m.

25 Nota: Piel exterior de vidrio transparente de 712 placas de vidrio de tamaño idéntico, finamente grabadas al aguafuerte, que se solapan entre sí. Los paneles de vidrio de 293 x $172 \mathrm{~cm}$ de ancho y 20 $\mathrm{mm}$ de espesor no están perforados, sino sostenidos por ménsulas metálicas.

26 Nota: Si no entra suficiente luz al espacio expositivo desde el exterior, se activa la iluminación artificial.

27 APPELT, Siegrun. Entrevista con Peter Zumthor. En: http://www.langsameslicht.com/html/dt/ gespraeche_3.html. 07. Febrero de 2012. Traducción de la autora: "Es ist eine schöne Vorstellung, dass die Häuser, die Räume erst dunkel sind und dann kann man Licht hineinlassen. Manche Materialien sind schön in einem ganz bestimmten Licht, 

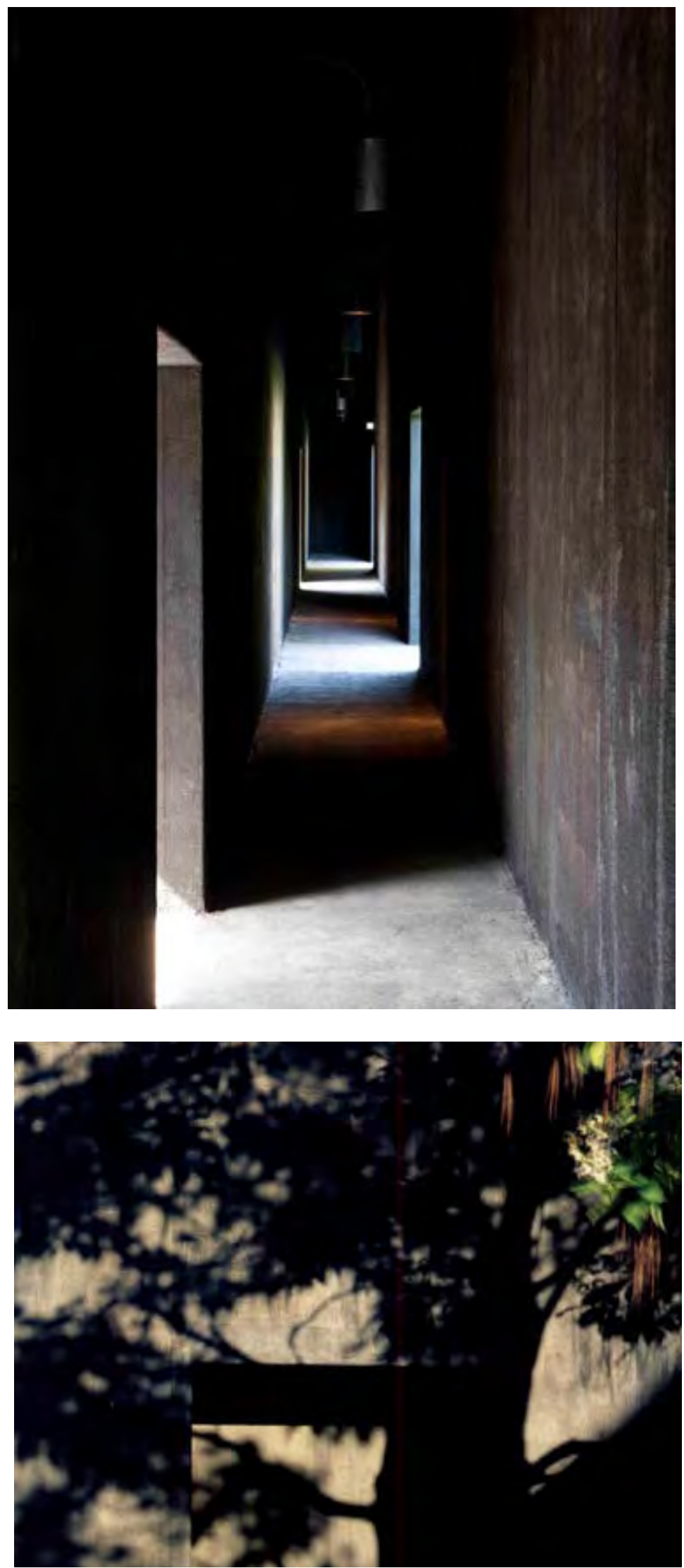

Figura 17 - 18.

Serpentine Gallery / Londres / 2011 / Peter Zumthor 
Zumthor es un metódico escenógrafo que domina a la perfección los escenarios de luces y sombras.

"Él controla la luz y la oscuridad de una manera maravillosa y crea una gran obra que ya puede considerarse un clásico hoy en día. Para el jurado, Peter Zumthor es un artista que se ocupa de la luz natural "29 Informe del jurado

La propuesta construida para el Serpentine Gallery Pavillon en 2011, también puede ser entendida como un juego de luces y sombras. Un gran contenedor de madera, compuesto por dos anillos paralelos rectangulares. Secuencias de pórticos de madera. Estos delimitan un espacio cubierto perimetral convertido en sombra, con paramentos negros enfoscados con gasas. Una especie de filtro oscuro y estrecho que conduce al interior del pabellón. Al atravesar la segunda capa del muro, en el interior se encuentra un patio rodeado de paredes negras que enmarcan el cielo. El centro del patio está cubierto con una alfombra vegetal, el hortus conclusus. Un jardín lleno de matices donde la naturaleza florece día a día. Un florero arquitectónico. Las condiciones de luz cambiantes, la forma sencilla de la construcción y el contraste entre el negro y los colores agudizan la experiencia sensual en este refugio íntimo, introvertido.

Para Zumthor la luz es algo más que un simple mecanismo para ver. Es una herramienta para horadar la penumbra. Un medio de composición, un medio narrativo. No sólo visual, sino sensorial de las percepciones hápticas, acústicas y olfativas. Mediadora directa e indirectamente del espacio. A la pregunta de cuanta cantidad de luz necesita una persona para poder vivir; Zumthor respondió comparándolo con la velocidad $^{30}$. La gente vive la velocidad, hasta que de repente tiene la sensación de necesitar tranquilidad y lentitud. Lo mismo pasa con la luz, es cuestión de matices y transiciones; atmósferas. Elogios, al fin al cabo, de la penumbra.

29 JURYBERICHT. Tageslicht-Award. Velux Stiftung. En: https://www.presseportal.ch/de/ pm/100018937/100596579 Traducción de la autora: "Er kontrolliert Licht und Dunkelheit auf wunderbare Weise und schafft daraus ein großartiges Werk, das schon heute als Klassiker gelten darf. Für die Jury ist Peter Zumthor ein Künstler im Umgang mit natürlichem Licht."

30 RAU, Cordula. Entrevista a Peter Zumthor: Peter Zumthor - Die schöne Langsamkeit. Arwela. 2006. Traducción de la autora: "Wir leben an sich die Geschwindigkeit. Und mit einem Mal müssen wir wieder ein Gefühl bekommen für die Langsamkeit und die Ruhe und das ist das gleiche beim Licht und der Dunkelheit. Im Moment wird alles immer mehr beleuchtet und beleuchtet und beleuchtet. Aber eigentlich, wenn wir unser Leben anschauen, gab es da wunderbare Schatten, Dunkelheiten und Übergänge, die uns nicht Angst machten, sondern die wir gern hatten." 


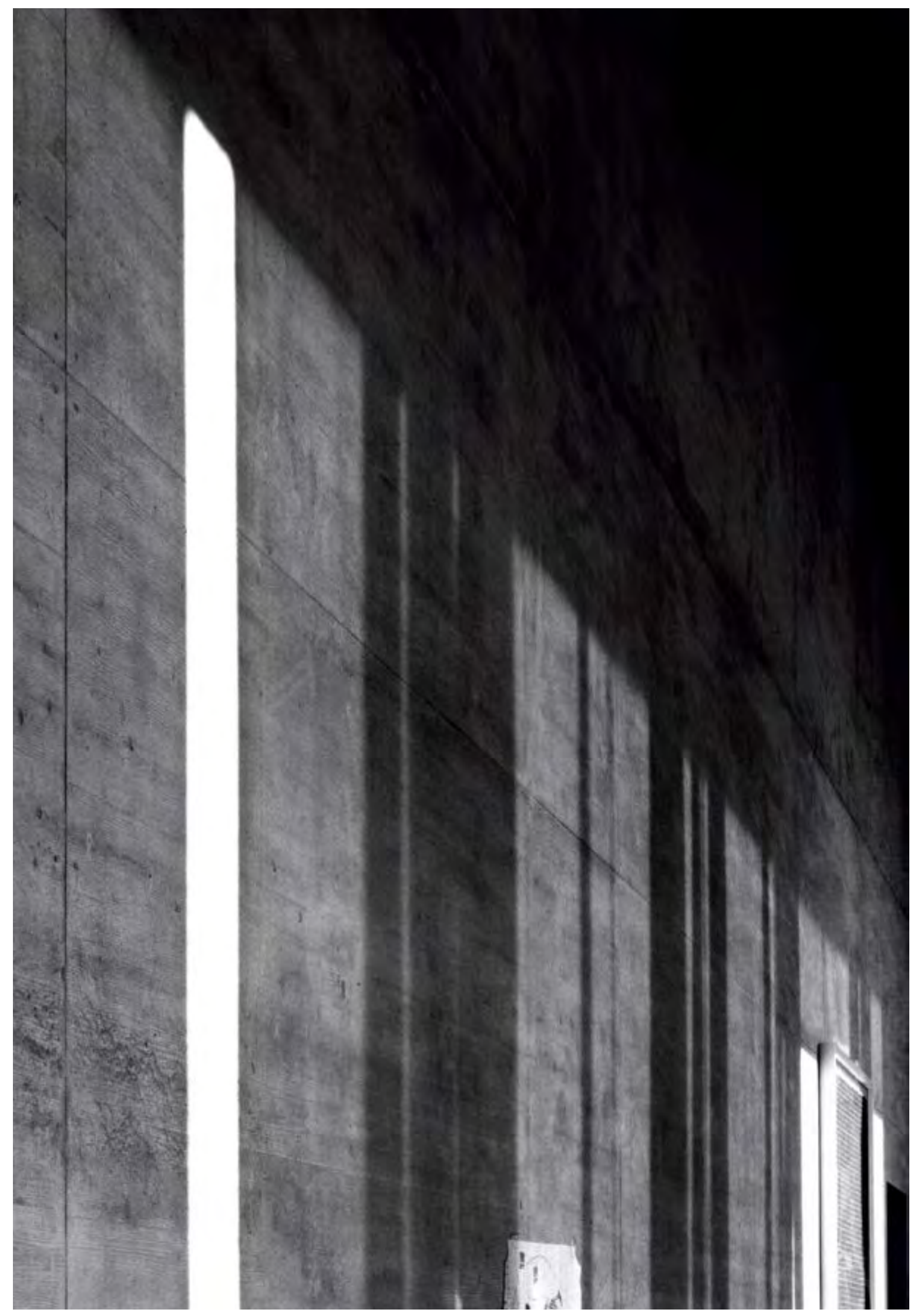

Figura 19.

Zumthor House / Haldenstein / 1998 - 2005 / Peter Zumthor 


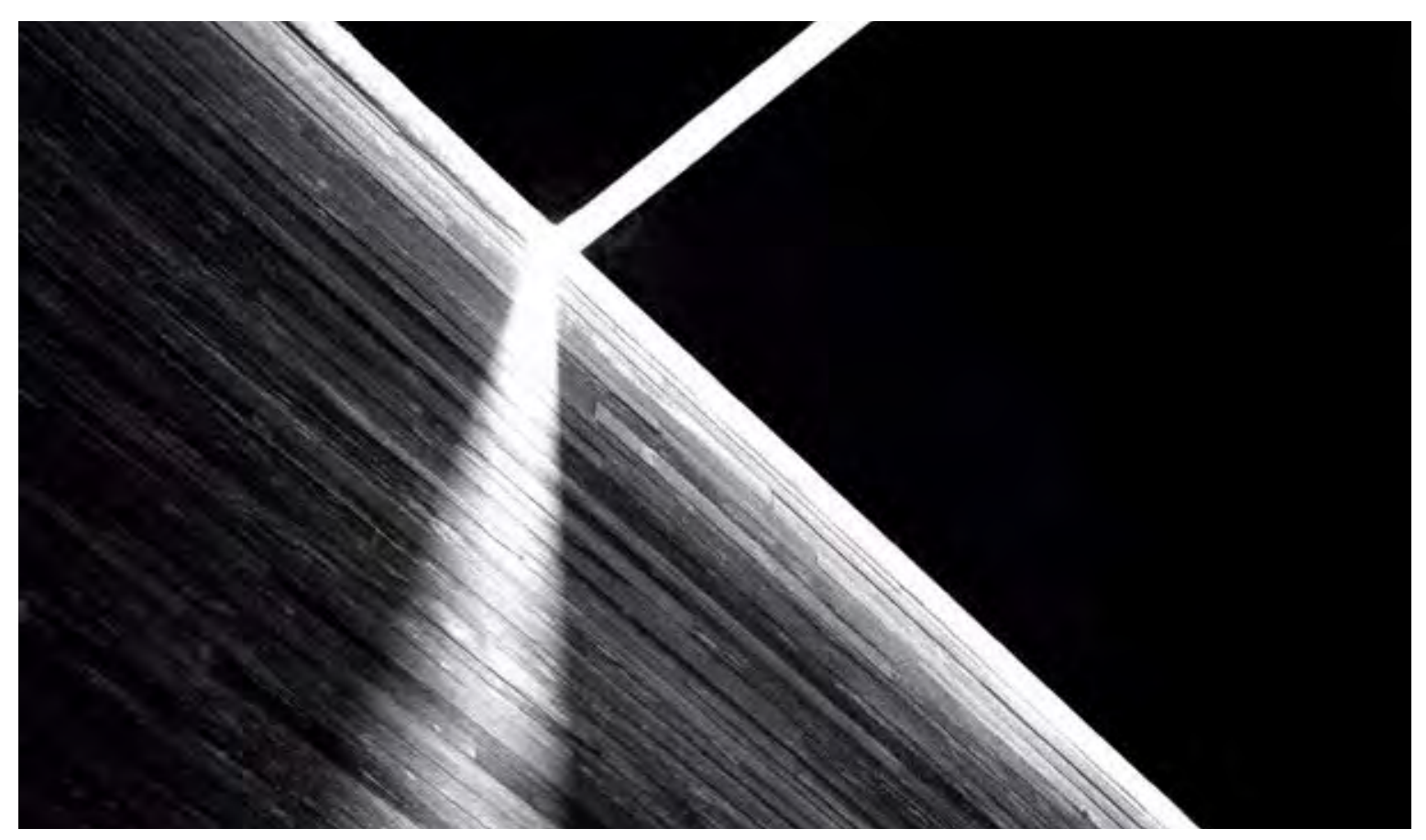

Figura 20

Termas Vals / Suiza / 1990 - 1996 / Peter Zumthor

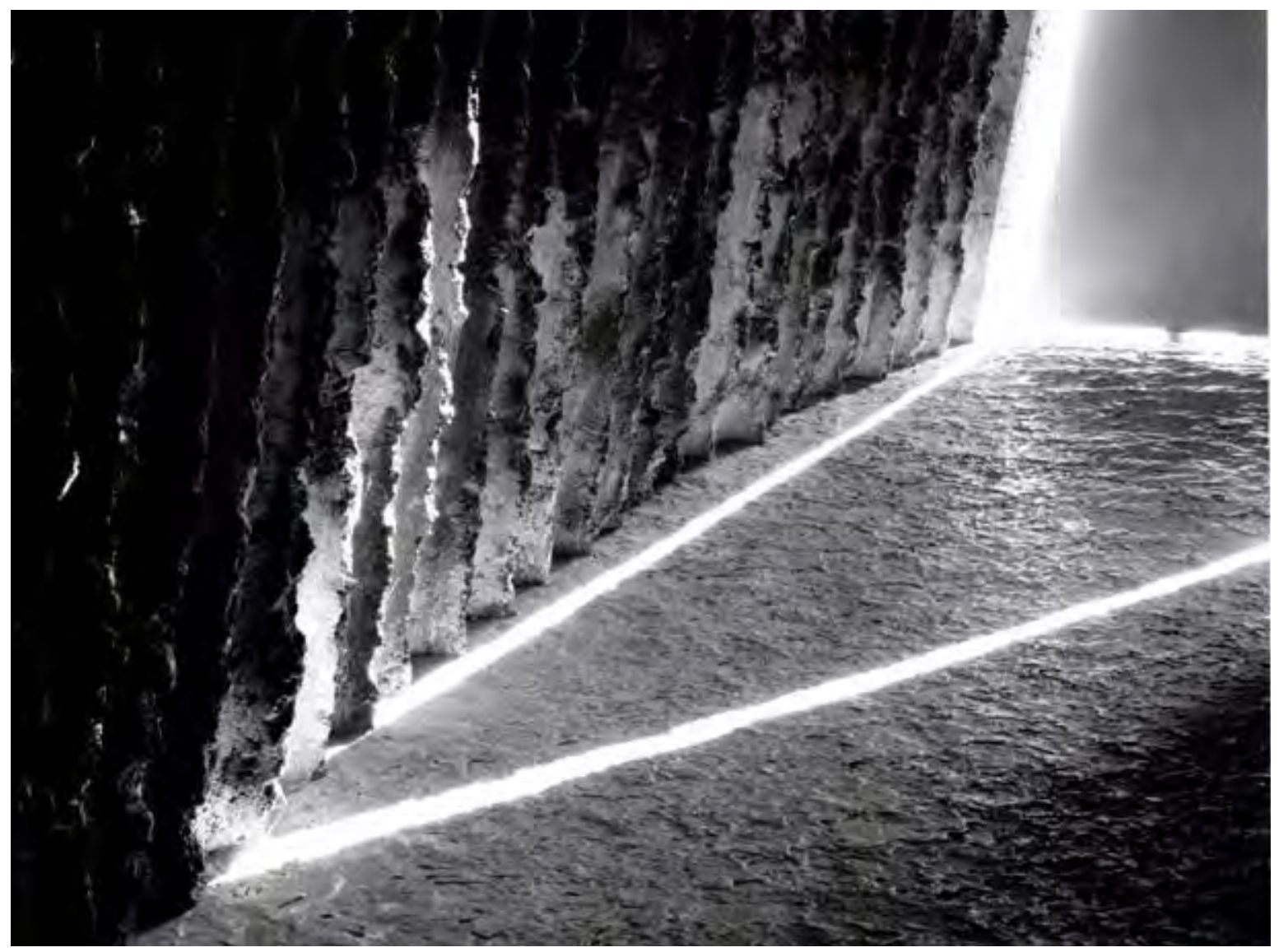

Figura 21

Capilla de Campo Bruder Klaus / 2001 - 2007 / Peter Zumthor 


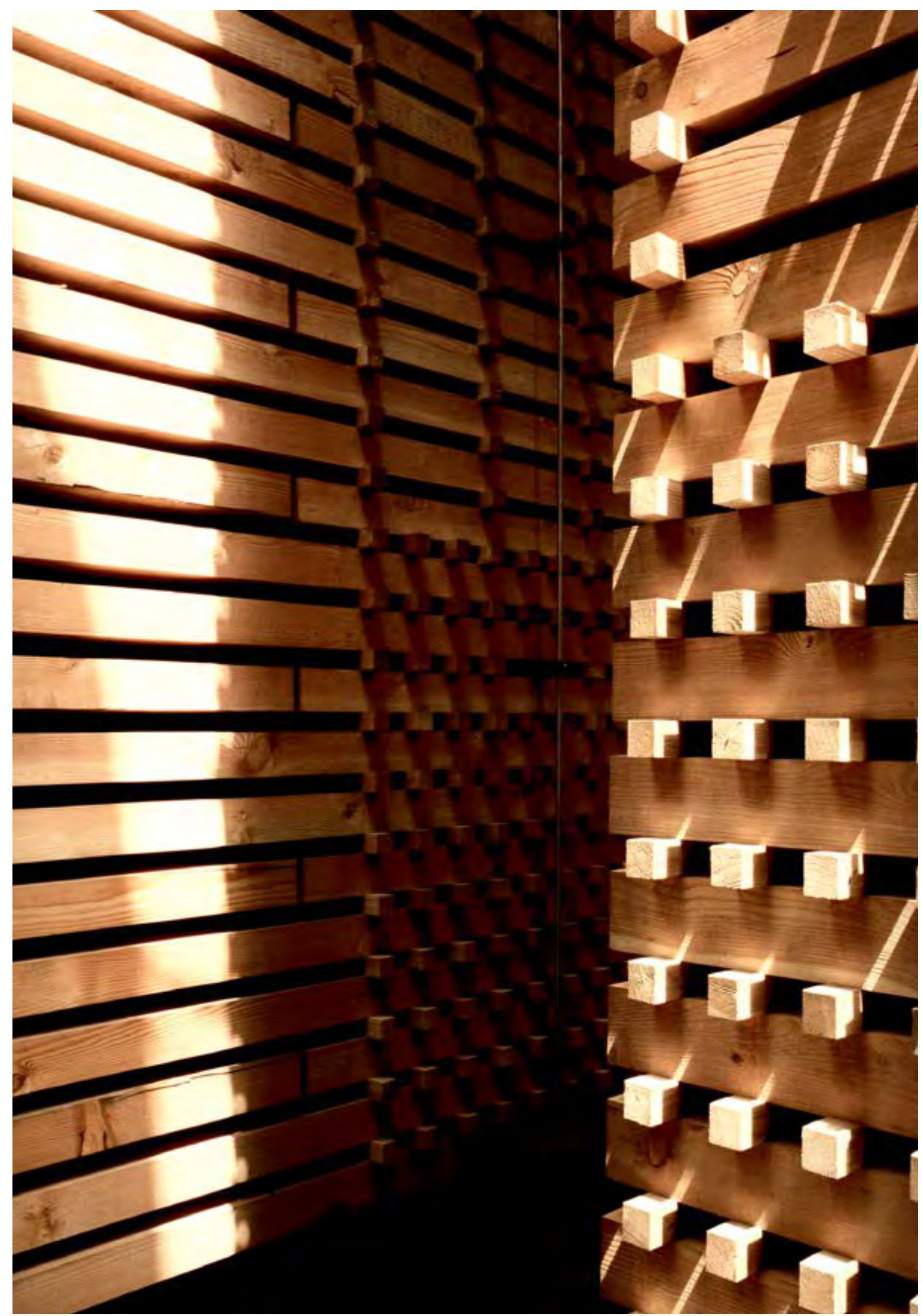

Figura 22.

Pabellón helvético / Hannover / 2000 


\section{[Amanecer]}

"Creo que se necesitan tres elementos para la cristalización de la arquitectura. En primer lugar, materiales auténticos, es decir materiales de substancia tales como el hormigón visto o la madera sin pintar. Segundo, una geometría pura, como en el Panteón. Esta es la base o marco que otorga presencia a la arquitectura. Puede ser un volumen del tipo de un sólido platónico, pero a menudo es un marco tridimensional, ya que en mi opinión eso va más de acuerdo con la geometría pura. El último elemento es la naturaleza. No quiero decir la naturaleza salvaje, sino la naturaleza domesticada, a la que el hombre ha dotado de un orden y que contrasta con la naturaleza caótica. ${ }^{131}$ Tadao Ando

El pabellón helvético es un cobijo del entorno caótico de la Expo, un refugio para el alma. Un espacio aparentemente aséptico, sin propaganda, limitado a un material homogéneo, desnudo, pesado, denso, con un bajo grado de reflectancia. Un dispensador de sombras, donde la luz se canaliza mediante el intercambio de elementos opacos y abiertos que funcionan como celosías ${ }^{32}$. Aparecen aberturas con vistas discontinuas, juegos de luces y sombras, atmósferas.

La luz incidente se desliza sobre el suelo y las pilas, transformando los espacios, desdibujando los contornos, modificando las geometrías, creando un espacio en movimiento constante, acentuando tonalidades.

"(...) soy plenamente consciente de que es la luz del Sol la que ilumina los edificios que concibo. Sumerjo en la luz solar los espacios, los materiales, las texturas, los colores, las superficies, las formas, atrapo esa luz, la reflejo, la filtro, la atenúo y la rebajo para que luzca en el lugar justo."33 Peter Zumthor

El Klangkörperbau, metáfora de un bosque real, es una sinfonía lúdica de sombras, semi-sombra y semi-luz. Un bosque arquitectónico. Dos mundos enfrentados. El bosque y el pabellón, la naturaleza y la arquitectura, lo natural y lo creado. La luz solar

31 ANDO, Tadao. Materiales, geometría y naturaleza. En: Tadao Ando. Editorial Gustavo Gili, S.A. Barcelona. 1990. ISBN: 84-252-1452-1. Pág. 13.

32 Nota: Similar a la Protección para las ruinas romanas en Chur o al Museo Kolumba en Colonia.

33 ZUMTHOR, Peter. Pensar la arquitectura. Editorial Gustavo Gili, SL. Barcelona. 2014. ISBN: 978-84252-2730-1. Pág. 91. 


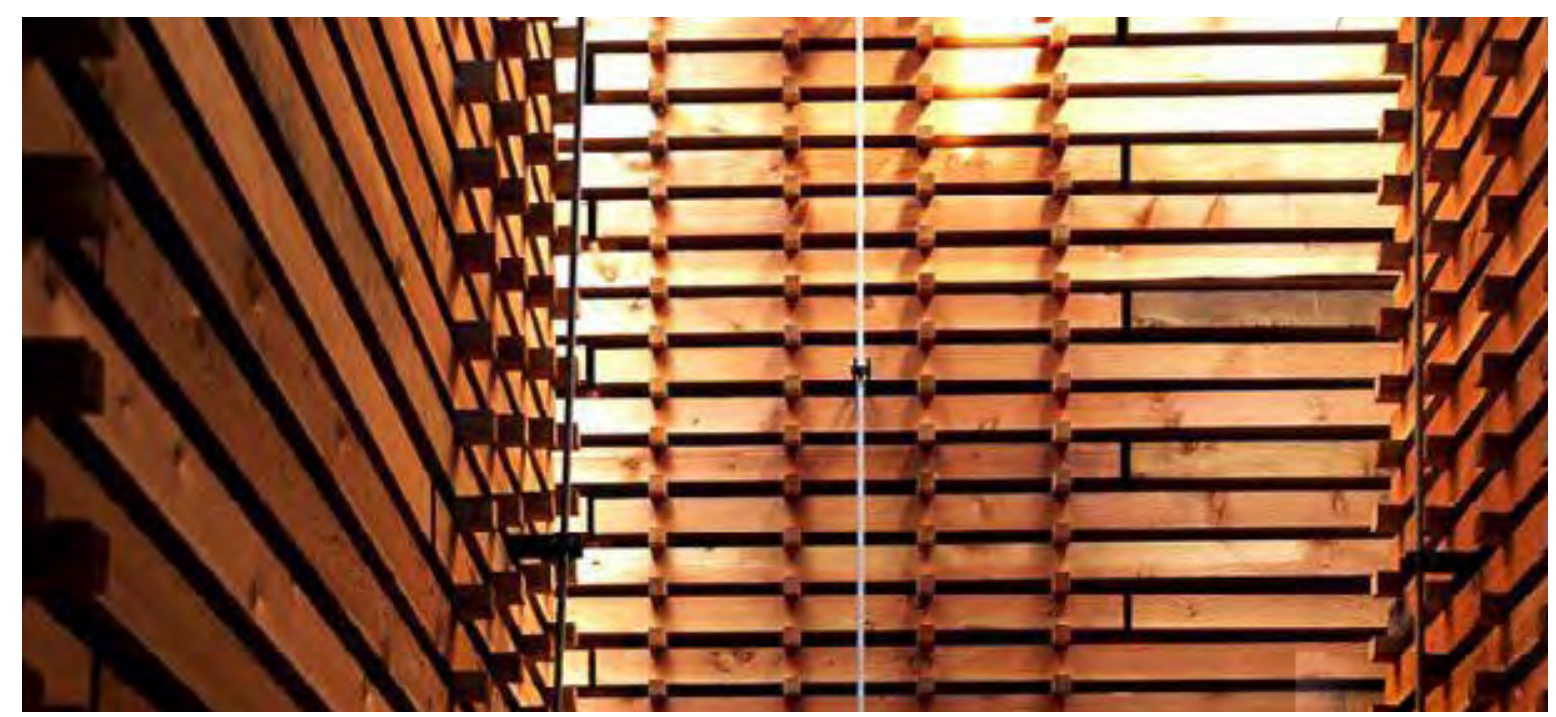

Figura 23.

Pabellón helvético / Hannover / 2000

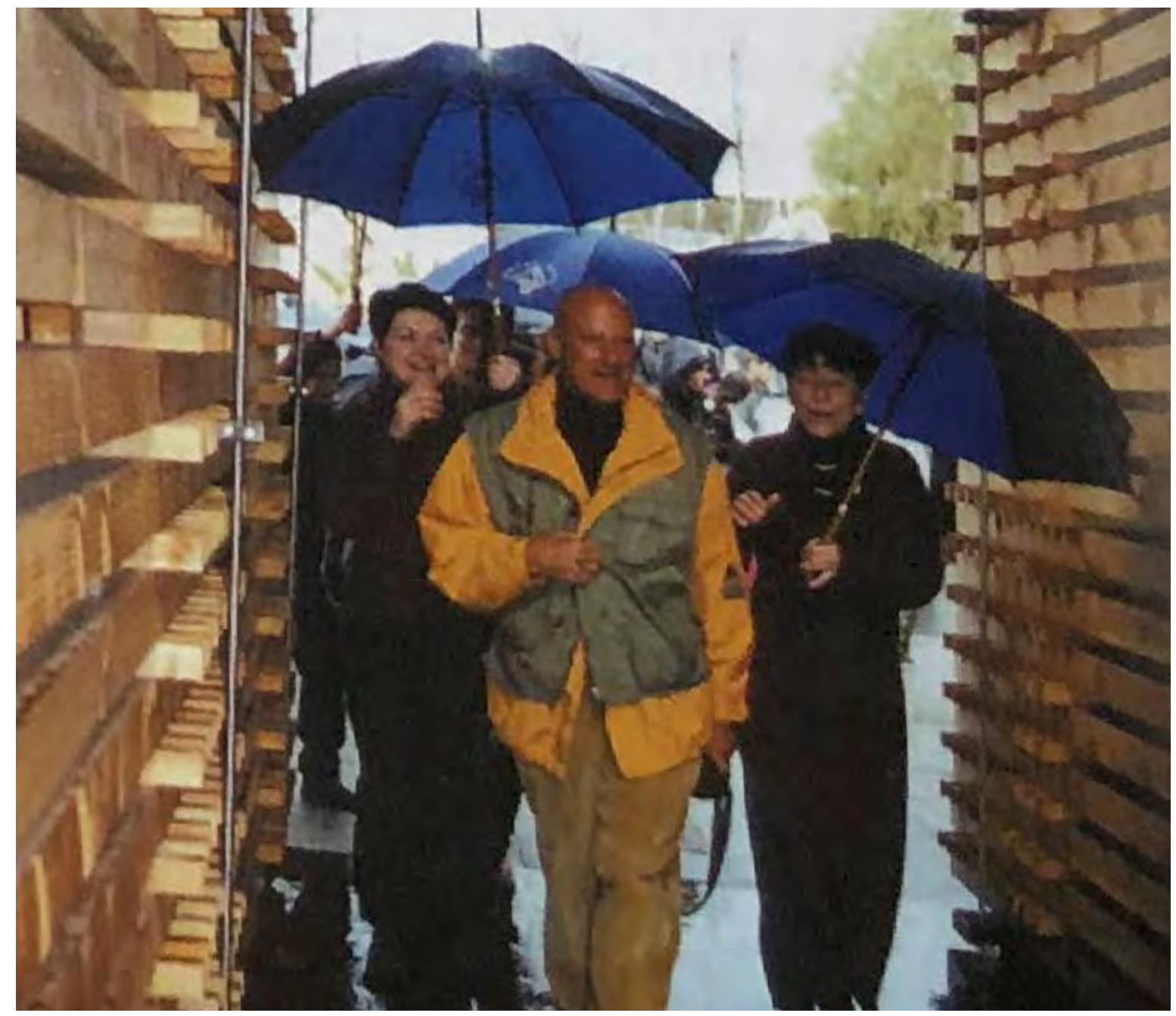

Figura 24.

Sir Norman Foster visita el pabellón helvético 
que atraviesa los espacios libres de los árboles filtrándose por las hojas, las ramas, los troncos. Una luz tamizada, tenue, heterogénea. Pero a diferencia de un bosque natural, donde existe una configuración arbitraria, el pabellón cuenta con un orden geométrico. Zumthor reduce la naturaleza a sus elementos esenciales, transformándolos en elementos arquitectónicos. No imita la naturaleza, sino trabaja con ella ${ }^{34}$. Incorpora al espacio arquitectónico otros elementos que se pueden encontrar en el bosque: el viento, el olor, el agua, el frío, el calor o fragmentos del cielo.

\begin{abstract}
"A las nueve de la mañana, comienza su recorrido. Al mediodía, sólo había conquistado un cuarto de la superficie de la pared. Dos horas y media después, sin embargo, el muro está completamente inundado. Un instante volátil, ya que los rayos de luz ya no se adhieren a la superficie de la pared. La luz sigue dejando sus huellas, pero...de forma más reducida."35 Pascual Bertran
\end{abstract}

A lo largo del día, la atmósfera cambia. Los rayos de luz penetran en el espacio, tocan la superficie. La luz deriva, palpita, cambia su intensidad, su difusión, crea sombras que van y vienen. Un juego de luces y sombras. Un juego visual, donde la luz se mueve en el transcurso de las horas, un reloj solar. La luz no es constante; depende del día, de la noche, del clima, de los cambios estacionales, de las condiciones climáticas, de la puesta y caída del sol.

Junto al ritmo poético del tiempo, la luz ambulante y errante evoca en las pilas seriadas este espectáculo natural. Tiene un efecto estimulante para el visitante. El espacio arquitectónico se convierte en un escenario teatral compuesto de diferentes secuencias, "el ojo en un órgano táctil de una persona que intenta orientarse"36.

34 Nota: "Nicht nach der Natur arbeite ich, sondern vor der Natur, mit ihr" Cita de Picasso. En: KRAUSS, Sebastian. Die Genese der autonomen Kunst: Eine historische Soziologie der Ausdifferenzierung des Kunstsystems Transcript Verlag. Bielefeld. 2012. ISBN: 978-3-8376-2147-1. Pág. 184.

35 BERTRAN, Pascal. Tadao Ando. Et La Maision Koshino. Pierre Mardaga, éditeur. Liège. 1990. ISBN: 2-87009431-0. Pág. 62. Traducción de la autora: "En fait, son rythme de progression est accéléré. A neuf heures du matin, elle commence son incursion. A midi, elle n'a envahi que le quart de la hauteur du mur. Par contre à deux heures et demi, ce dernier est totalement inondé de lumière. Instant éphémère, car les rayons lumineux s'inclinent alors advantage et cessent d'adhére à la surface du mur. La lumière continue tout de même à laisser les traces de sa course, mais sur le mur lateral du salon et de faÇon plus réduite."

36 BELLMANN, Beate. Mit den Augen fühlen. En: James Turrell Lighting a Planet. ....Pág. 31.Traducción de la autora: "Der Raum wird zum Geheimnis, das Auge zum Tastorgan eines Menschen, der sich zu orientieren sucht" 


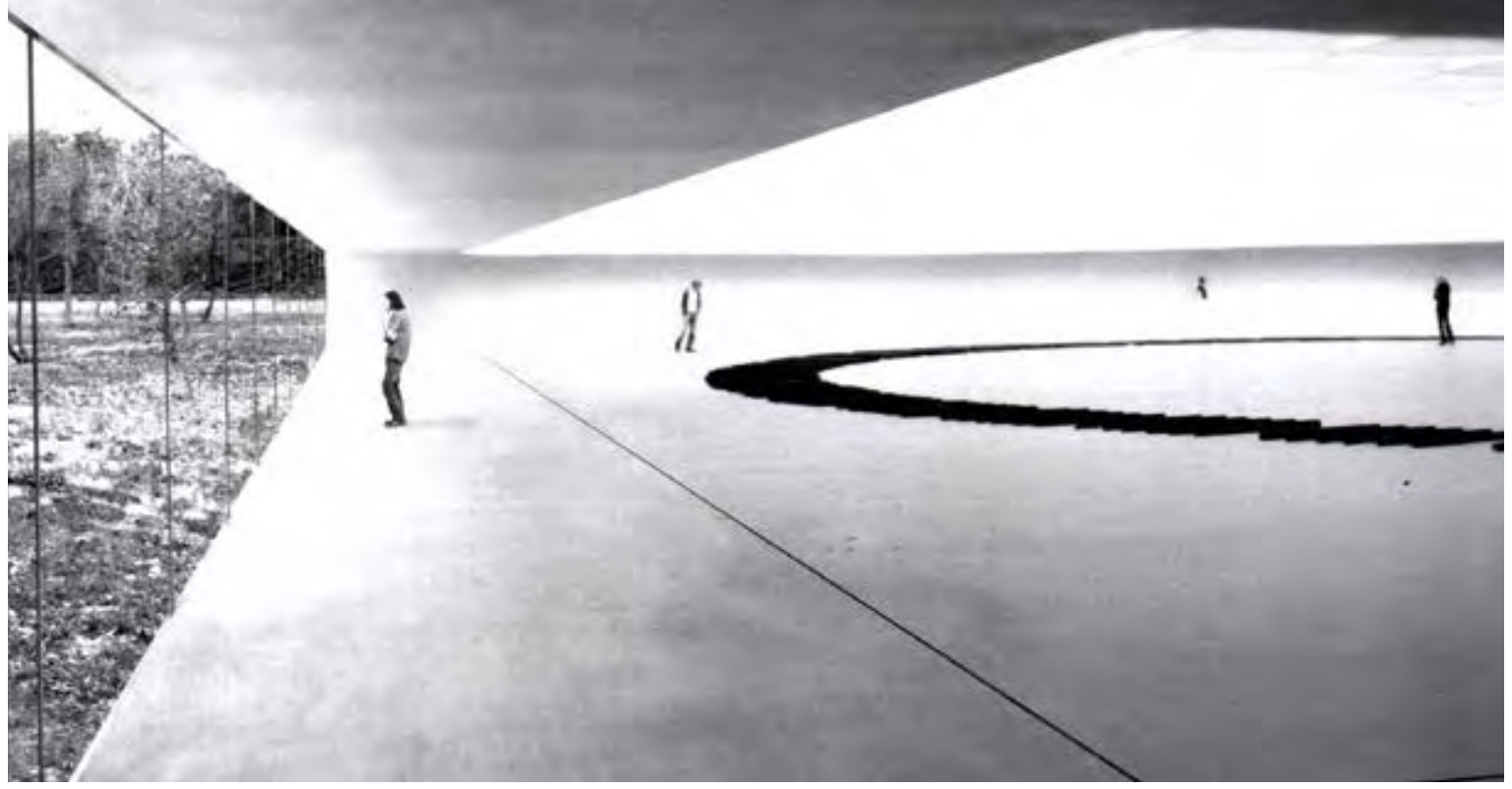

Figura 25.

I Ching Gallery, Dia Center for the Arts / Beacon, Nueva York / desde 2000 / Peter Zumthor.

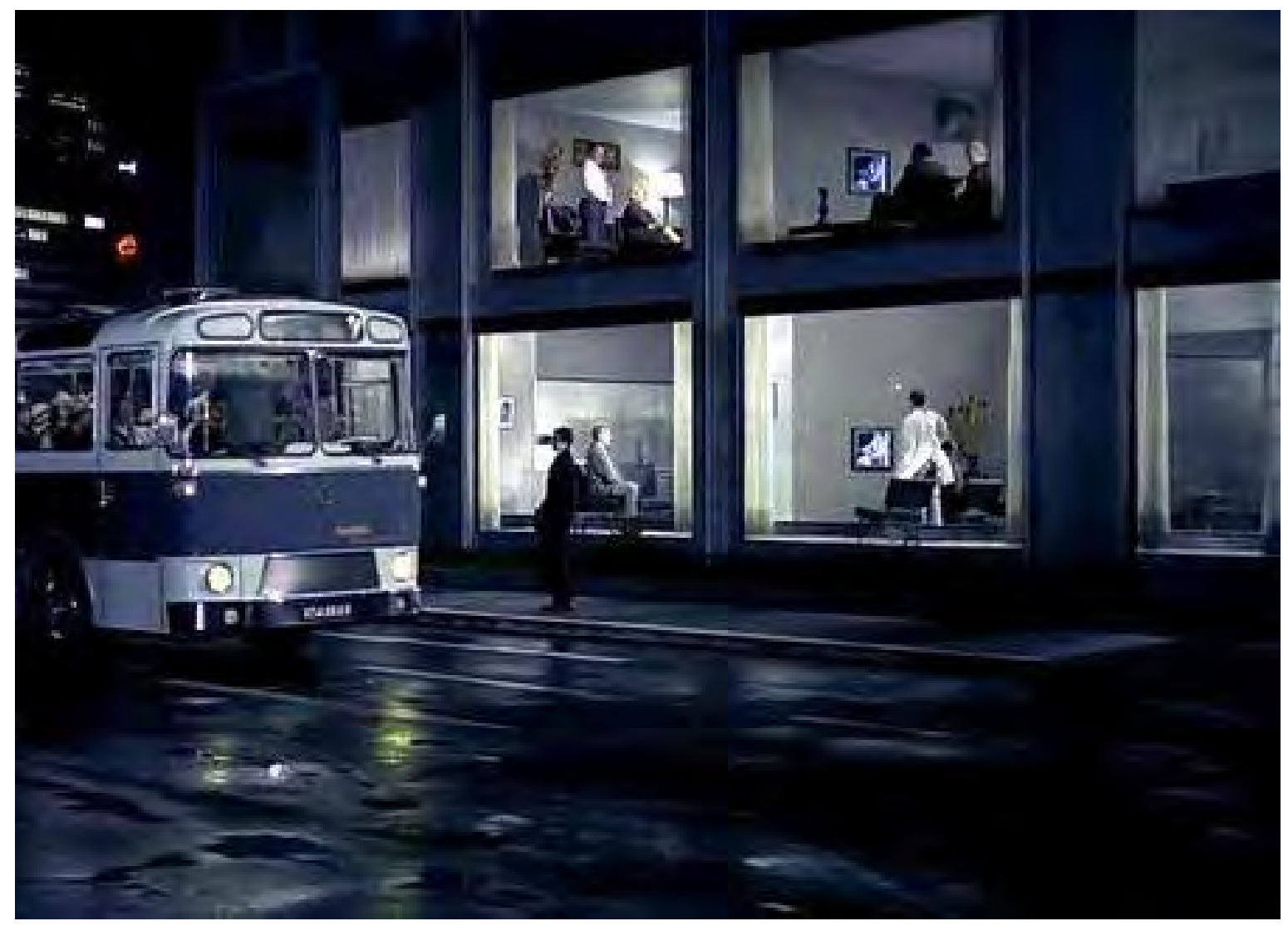

Figura 26.

Playtime / 1967 / J Jacques Tati 


\section{[El límite de la transparencia]}

"Las paredes son transparentes gracias a la madera apilable."37

Peter Zumthor

Liberación, honestidad, veracidad, pureza, orden, visibilidad, permeabilidad, reflejos, claridad y transmisión de luz; al igual que control, inseguridad, perdida de intimidad, voyeurismo son conceptos asociados a la transparencia. Habitualmente esta propiedad de los materiales se asocia a la capacidad de regular la comunicación entre dos ámbitos; reduciéndose a una experiencia únicamente visual.

"Ser capaz de ver lo que uno no puede oír, tocar, sentir, refuerza la sensación de que lo que está dentro es inaccesible."138

Richard Sennett

En la película Playtime de 1967 de Jacques Tati, la ciudad moderna de Paris se representa como un gran laberinto de vidrio, en la cual casi nadie es capaz de orientarse. Una sátira exhibicionista con escasa intimidad. En una escena nocturna, el protagonista es invitado a "entrar visualmente" desde el exterior del edificio a la casa de un amigo, a la vida interior de unos apartamentos iluminados. Unos escaparates habitados, espacios amueblados iguales. Acompañado únicamente por el ruido de la calle, la cámara sigue a los sucesos interiores, convirtiendo al espectador en un voyeur. Cada acción es visible. Cada personaje esta expuesto y es observado. Como en "una enorme prisión con frentes de vidrio"39. El vidrio como un límite invisible; transparencia como pérdida de todos los $\operatorname{secretos}^{40}$.

Colin Rowe y Robert Slutzky establecieron en los años 60 una distinción entre la transparencia literal y fenomenal. Dos interpretaciones diferentes entre "una cualidad inherente de la sustancia, como en un muro cortina de vidrio; o ... una

37 GENERALKOMMISSARIAT. Schlussbericht des Generalkommissariates. Weltausstellung Expo 2000 Hannover 1.6.-31.10.2000. Die schweizerische Beteiligung mit "Klangkörper Schweiz". Bundesamt für Kultur. Bern. 2001. Pág. 31. Traducción de la autora: "Die Wände sind dank der Stapelhölzchen transparent."

38 SENNETT, Richard. Civitas. Die Großstadt und die Kultur des Unterschieds. Fischer Verlag. Frankfurt/M. 1991. ISBN: 978-3100725042. Pág. 147. Traducción de la autora: "Sehen zu können, was man nicht hören, berühren, spüren kann, verstärkt das Gefühl, das, was sich im Inneren befindet, sei unzugänglich."

39 WRIGHT, Frank Lloyd. Begehrlicher Blick und die List des Schleiers. En: Daidalos. Architektur. Kunst. Kultur. 33. 15. September 1989. Transparenz und Verhüllung. Bertelsmann Fachzeitschriften GmbH. Güterloh ISSN 07214235. Pág. 41 Traducción de la autora: "die seelenlose Wohnstätte des Regals...verglaste Schachtelungen, die in andere Glasschachteln blickt. Schwarze Schatten fallen auf Glasfronten mit künstlichen Lichtern, die den ganzen Tag hinter ihnen brennen...Ein ungeheures Gefängnis mit Glasfronten."

40 BAUDRILLARD, Jean. Transparenz des Bösen. Merve Verlag. Berlin. 1992. ISBN: 978-3883960982. 


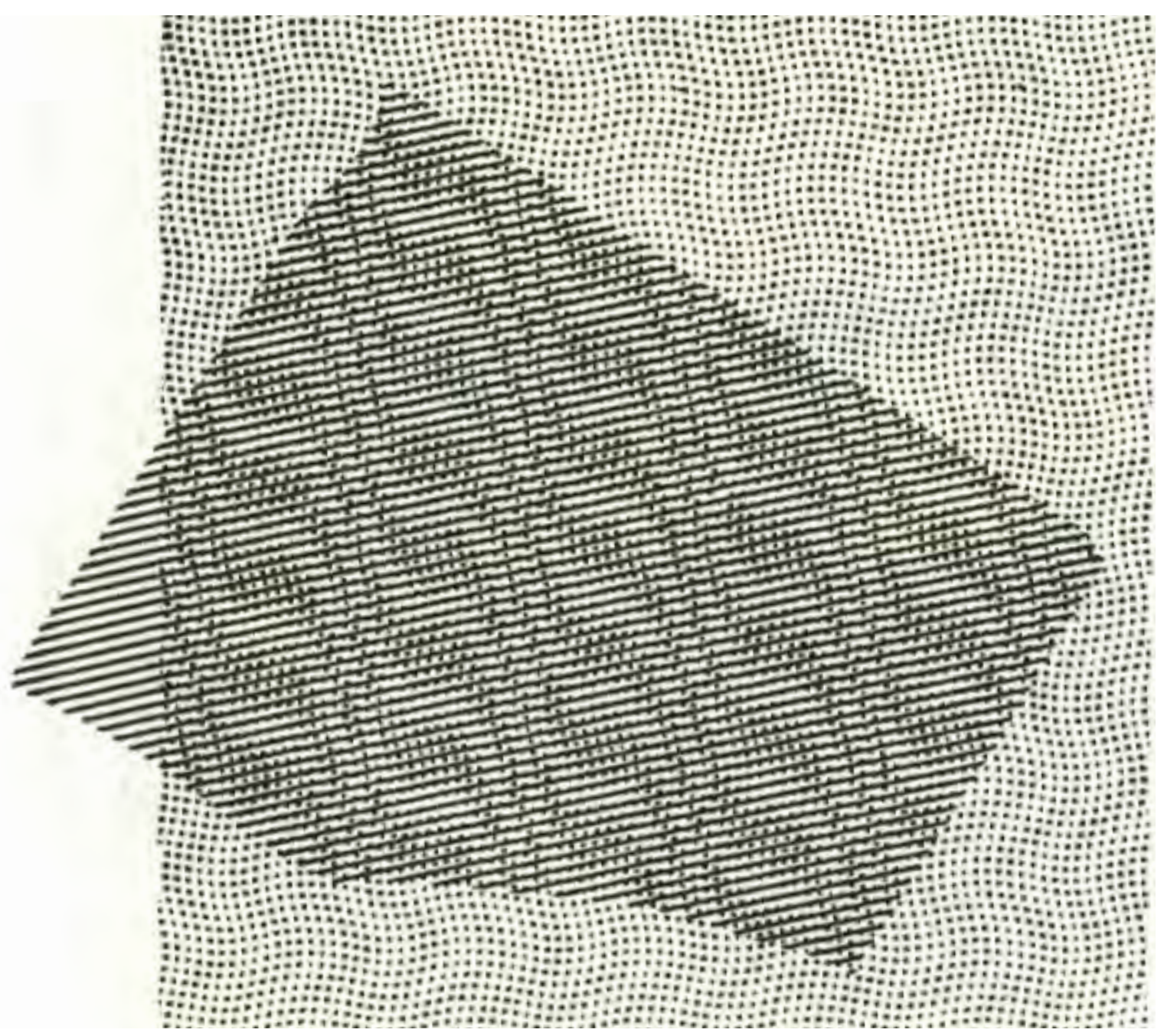

Figura 27.

Interferencias / Le Corbusier
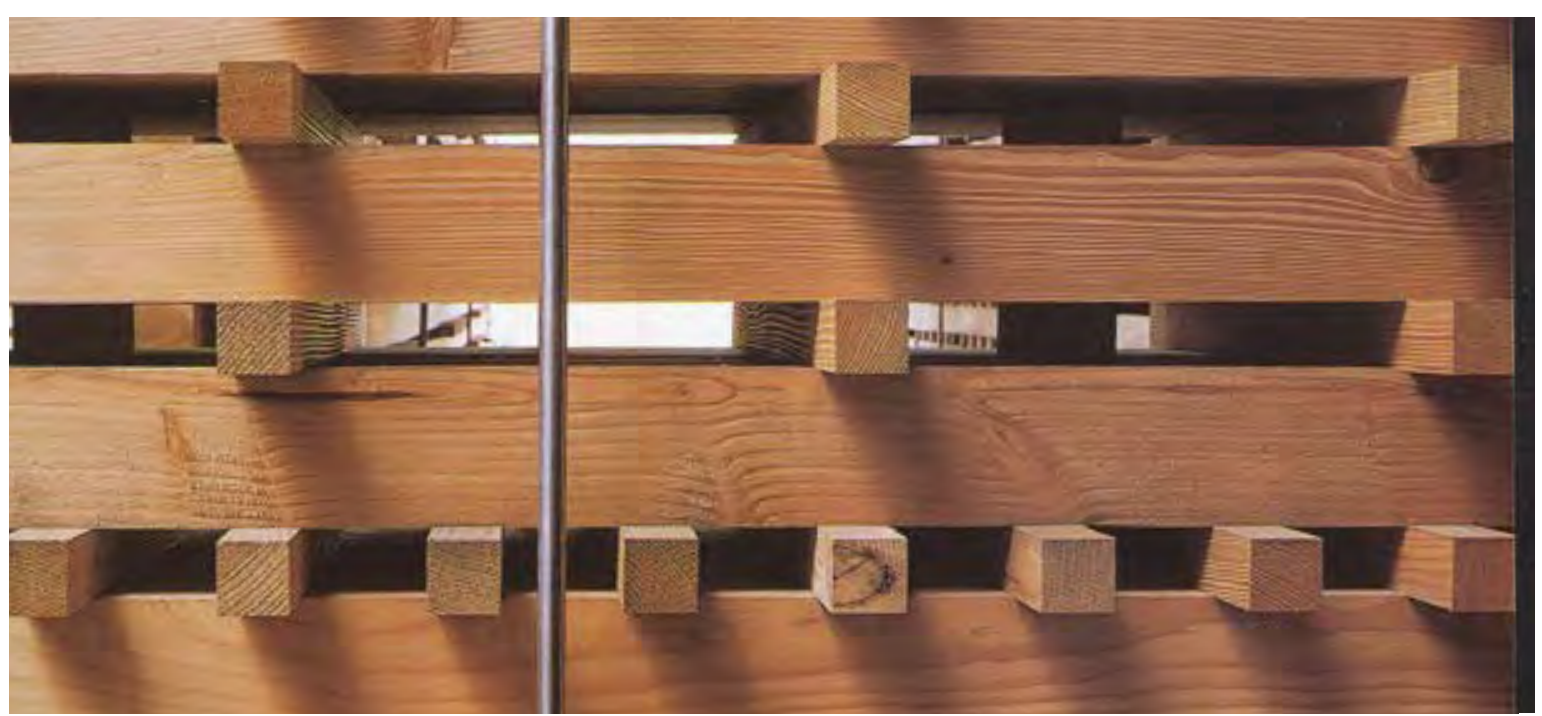

Figura 28.

Pabellón helvético / Hannover / 2000 
cualidad inherente de la organización ${ }^{\prime \prime 41}$. La transparencia literal o rea ${ }^{42}$, asociada a la materialidad versus la transparencia fenomenal o aparente ${ }^{43}$, relacionada con la ambigüedad entre el espacio y la profundidad. Una percepción simultánea de diferentes capas y formas superpuestas sin destruirse visualmente entre sí.

"El término transparencia "operativa" surge de la convicción de que el desplazamiento de superficies y patrones no transparentes da lugar a diferentes apariencias, que se acercan mucho a la idea real de "transparencia" y por lo tanto le hacen justicia. ${ }^{144}$ Matthias Loebermann

El Klangkörperfue un sistema complejo y natural, opaco y macizo. Una estratificación espacial cuyo ritmo compositivo permite transiciones, perspectivas y vistas sorprendentes. La "percepción simultánea de diferentes ubicaciones espaciales" ${ }^{45}$. Un juego de aperturas y opacidad. La transparencia se produce a través de la interacción, la interconexión, el ritmo, la superposición y la interferencia ${ }^{46}$ de los muros por medio de aperturas de diferentes densidades de separadores. Graduación entre lo opaco y lo permeable, entre lo oculto y lo visible, entre lo escondido y lo revelado.

41 ROWE, Colin; SLUTZKY, Robert. Transparency. Birkhäuser Verlag. Basel, Boston, Berlin. 1997. ISBN: 3-7643-5615-4. Pág. 23. Traducción de la autora: "may be an inherent quality of substance, as in a glass curtain Wall; or it may be an inherent quality of organization."

42 IDEM. Pág. 21.

43 IDEM. Pág. 21.

44 LOEBERMANN, Matthias. Operative Transparenz. Arch+. 144/45. Pág. 103. Traducción de la autora: "Der Begriff "operative" Transparenz entsteht aus der Überzeugung, dass durch das Verschieben an sich nicht transparenter Flächen und Muster unterschiedliche Erscheinungsbilder entstehen, die dem eigentlichen Gedanken des "Durchscheinens" sehr nahe kommen und damit auch gerecht werden."

45 GIEDEON, Sigfried. Nachlass. Archiv des Instituts für Geschichte und Theorie der Architektur. Eidgenössische Technische Hochschule Zürich. Besitz. 43 - T13. Traducción de la autora: "...sie bedeutet die simultane Wahrnehmung verschiedener räumlicher Orte."

46 Nota: El termino interferencia fue descrito por Le Corbusier en su libro El Modulor en 1949. "Para entrar en el juego (inesperado) que propongo, basta con tomar el primer fragmento de "trama de sombreado" que tengáis a mano, colocarlo sobre su semejante y, haciéndolo girar ligeramente de izquierda a derecha o viceversa, se podrá apreciar que se han producido, en menos de un cuarto de rotación, siete dibujos distintos de hexágono. Esto sucede ante los ojos: en un segundo, habéis visto nacer y desarrollarse un fenómeno geométrico impresionante." En: Le Corbusier. Modulor 2. Ediciones Apóstrofe. Madrid. ISBN. 84-455-0264-6. Pág. 159 


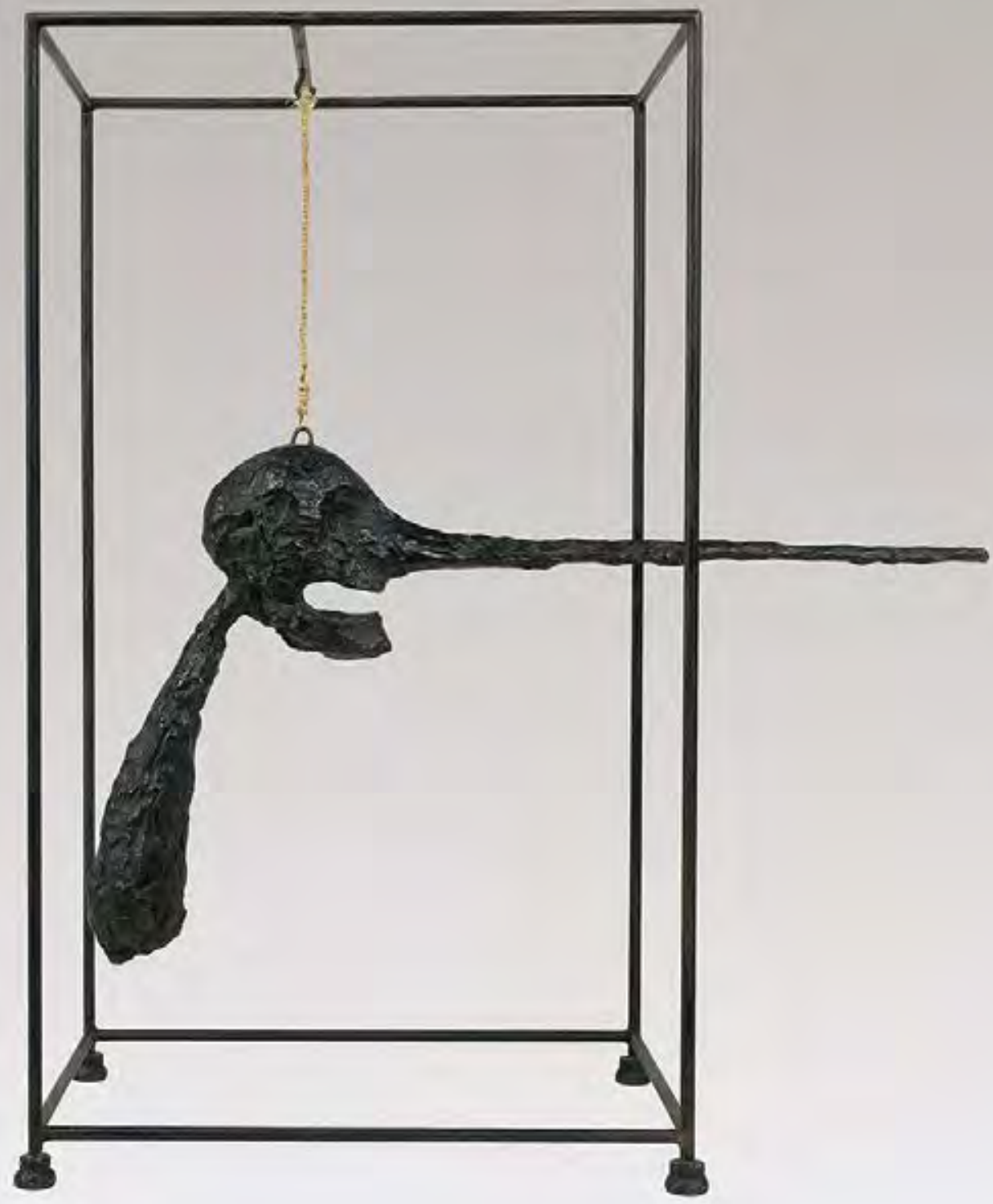




\section{[Selva olfativa]}

"Pero en el mismo instante en que aquel trago, con las migas del bollo, tocó mi paladar, me estremecí, fija mi atención en algo extraordinario que ocurría en mi interior... Y de pronto el recuerdo surge... Ver la magdalena no me había recordado nada, antes de que la probara... y Combray entero y sus alrededores, todo eso, pueblo y jardín...sale de mi taza de té."47 Marcel Proust

Un olor aparentemente banal y cotidiano, lleva al protagonista ${ }^{48}$ a un viaje de vuelta a su infancia. "A menudo, el recuerdo más persistente de cualquier espacio es su olor."49 Muchos recuerdos están estrechamente relacionados con fragancias. De repente, lo que nuestra nariz percibe, nos remonta a tiempos pasados, reactivando imágenes casi olvidadas, experiencias positivas o negativas. Como dijo Aristóteles: "El hombre, en efecto, capta torpemente los olores y no percibe objeto alguno oloroso a no ser con dolor o placer" ${ }^{\prime \prime 50}$.

El sentido del olfato es uno de los sistemas más antiguos de los seres vivos para poder comunicarse entre sí. Los seres humanos carecen de un sentido olfativo tan agudo como los animales, pero este desempeña un papel importante en la percepción. El sentido olfativo es una experiencia personal, subjetiva, cuya descripción resulta difícil por falta de vocabulario odorífero especifico. Conectado con el subconsciente, el olfato generalmente es no-verbal, difuso, invisible, intangible, fugaz y emocional. Mensajero de recuerdos del pasado, evocando emociones, memorias, sentimientos, impresiones intensas. "La nariz hace que los ojos recuerden" ${ }^{\prime \prime 1}$.

47 PROUST, Marcel. En busca del tiempo perdido. Greenbooks editore. Edición digital. 2019. ISBN: 97888-3295-399-2. https://books.google.es/books?id=QgSuDwAAQBAJ\&printsec=frontcover\&hl=es\&s ource=gbs_ge_summary_r\&cad=0\#v=onepage \&q\&f=false

48 Nota: Zumthor alude a la novela de Proust con el título del primer capítulo de su libro Pensar la arquitectura. En lugar de En busca del tiempo perdido, lo cambia a En buscar de la arquitectura perdida.

49 PALLASMAA, Juhani. Los ojos de la piel. Editorial Gustavo Gili, SL. Barcelona. 2010. ISBN: 978-84-2522135-4. Pág. 55.

50 ARISTOTELES. Acerca del alma. Biblioteca Básica Gredos Pág. 74 http://eltalondeaquiles.pucp.edu. pe/wp-content/uploads/2015/09/Aristoteles-Acerca-del-alma.-Gredos.-Trad-Tomas-Calvo.pdf

51 PALLASMAA, Juhani. Los ojos de la piel. Editorial Gustavo Gili, SL. Barcelona. 2010. ISBN: 978-84-2522135-4. Pág. 55. 


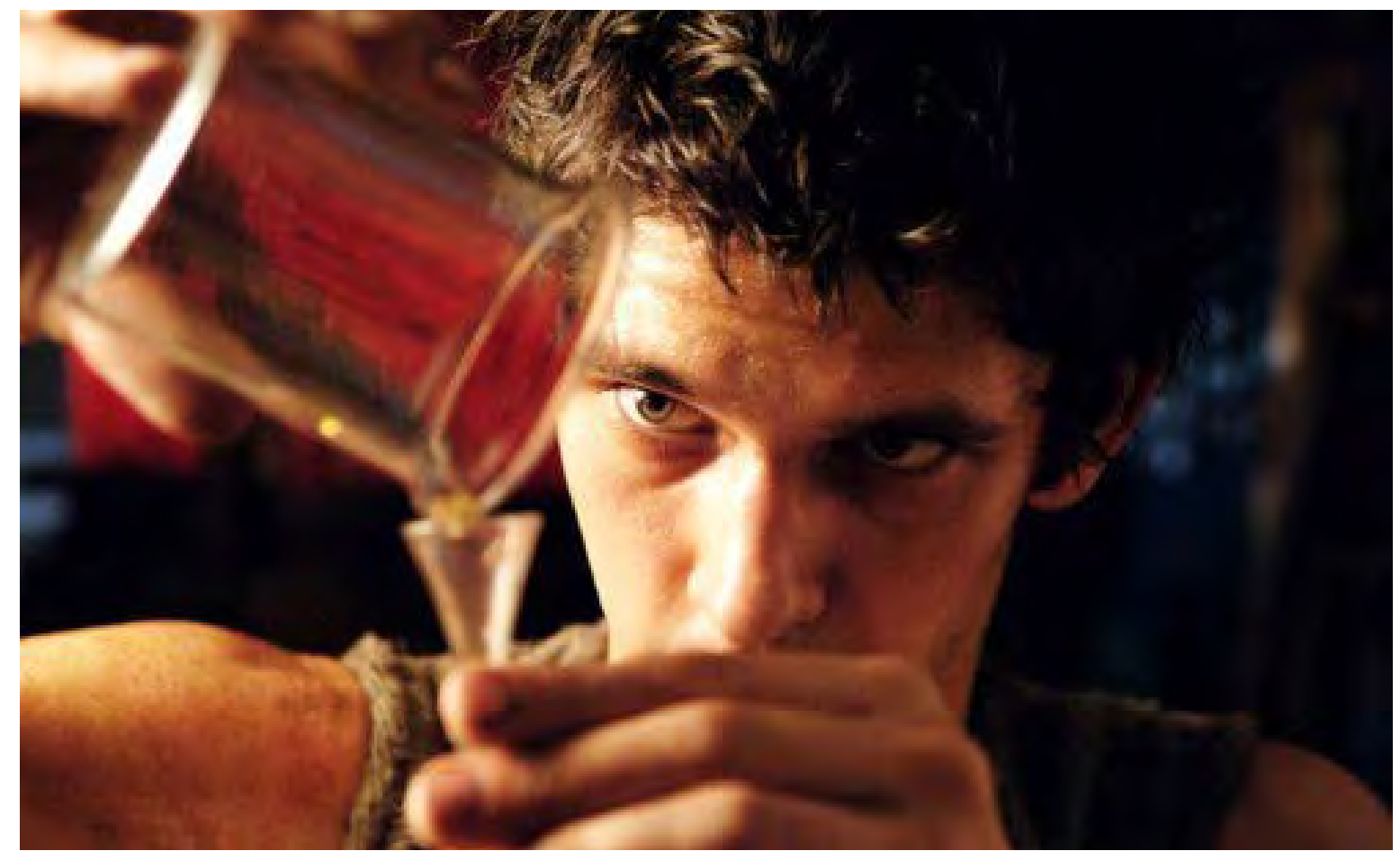

Figura 30.

Fragmento de la película "El perfume: historia de un asesino" de Tom Tykwer / 2006
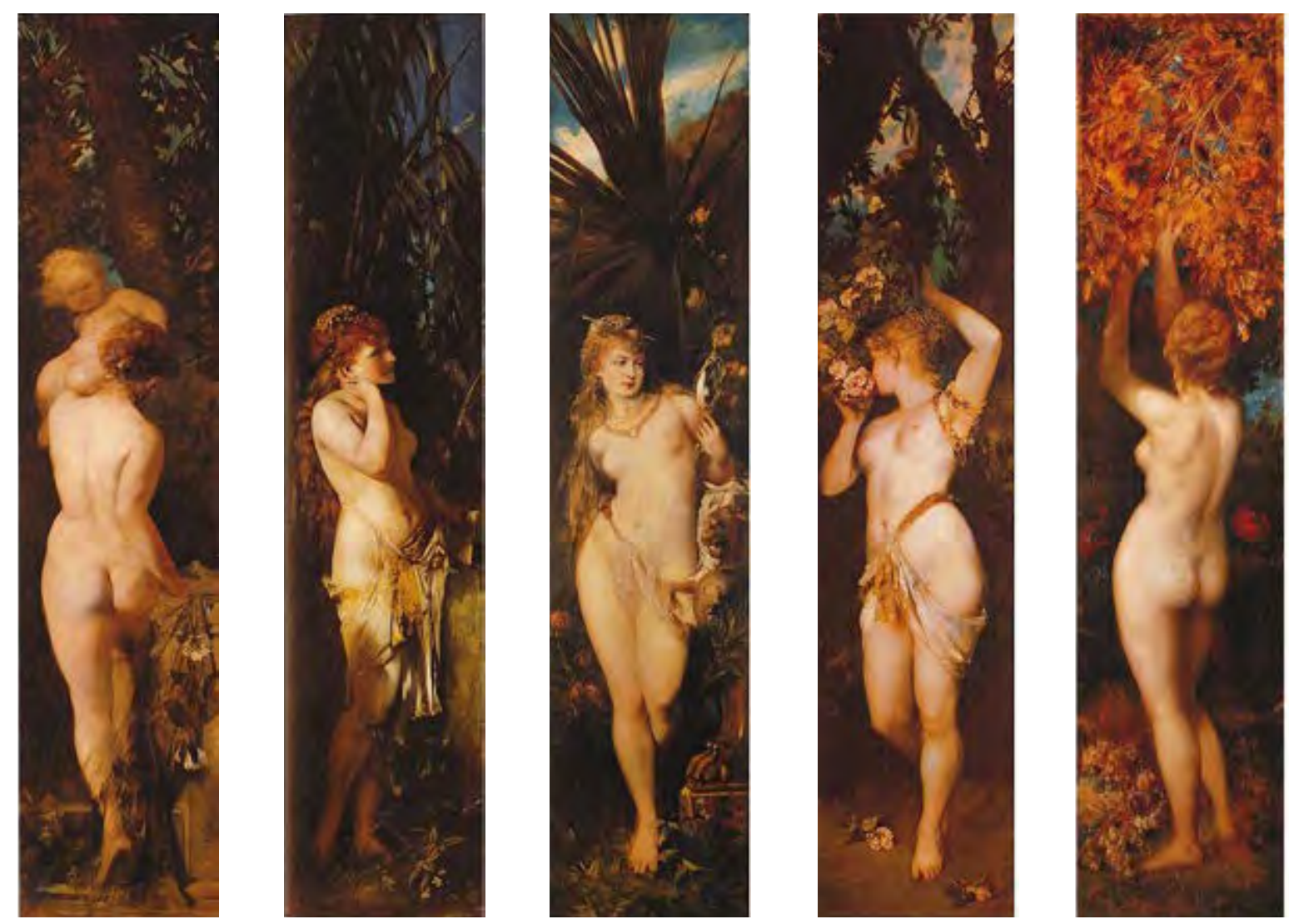

Figura 31.

Los cinco sentidos / 1872-1879 / Hans Makart 
"Hay en el perfume una fuerza de persuasión más fuerte que las palabras, el destello de las miradas, los sentimientos y la voluntad. La fuerza de persuasión del perfume no se puede contrarrestar, nos invade como el aire invade nuestros pulmones, nos llena, nos satura, no existe ningún remedio contra ella. ${ }^{152}$ Patrick Süskind

La pintura, la literatura, la poesía, o incluso las instalaciones artísticas, han tratado las experiencias sensoriales. Sin embargo, el olfato ha sido frecuentemente ignorado, habiendo escasos ejemplos. Charles Pierre Baudelaire fue uno de los primeros en utilizar conscientemente los olores en sus poemas ${ }^{53}$, usando especialmente los olores corporales femeninos y los olores sexuales para sus versos eróticos ${ }^{54}$. Escribió algunas de sus obras con tinta perfumada ${ }^{55}$ incluyendo la colección de poemas Les fleurs du Mal56.

En la novela El perfume: historia de un asesino de Patrick Süskind, los olores constituyen el tema principal. De una manera clara y contundente el autor describe la historia de Jean-Baptist Grenouille y su universo olfativo en París durante el siglo XIIX. Las fragancias, los olores, los perfumes y el hedor son omnipresentes. El personaje principal dispone de un olfato sobrenatural. Olores y aromas que otras personas nunca reconocerían, dominan su vida. Sin embargo, él mismo no tiene olor propio por lo que se mueve en un entorno de desconfianza. Decide crear un perfume, convirtiéndose en un asesino en serie en busca del olor perfecto. Se trata de una representación narrativa de la riqueza olfativa de la seducción, la transitoriedad, la pureza, la salud; pero también del hedor, el pecado y la enfermedad. Entre el olor agradable y el olor desagradable ${ }^{57}$.

"De entre los cinco sentidos, el olfato es el que incuestionablemente da la idea de inmortalidad"158 Salvador Dali ISBN. 978-3-257-22800-7. Pág. 107-108.

53 Nota: Por ejemplo: El perfume, Perfume exótico, La cabellera, El frasco.

54 OHLOFF, Günther. Düfte. Signale der Gefühlswelt. Helvetica chimica Acta. Zürich. 2004. ISBN: 3-906390-30-6. Pág. 229.

55 AAVV. Gesichter Europas. En: Deutschlandfunk. Septiembre 2013. https://www.deutschlandfunk.de/immerder-nase-nach-frankreich-und-seine-parfumeure-text.media.03feeb549d58715a01a8782efcb59745.txt

56 BAUDELAIRE, Charles. Las flores del mal. Cátedra. Madrid. 2008. ISBN: 978-84-376-2487-7.

57 PLATON. Timaios. Felix Meiner Verlag. Hamburg. 2017. ISBN: 978-3-7873-2867-3. Pág. 71. Traducción de la autora: "Es gibt nun dabei zwei Besonderheiten, ... es werden hier nur das Angenehme und das Abstossende klar getrennt."

58 DESCHARNES, Robert. NÉRET, Gilles. DALI, Salvador. Dali Jumbo T25 2007 Edition. Taschen. Köln. 2007. ISBN 978-3-8228-3822-8. Pág. 8. Traducción de la autora: "Of all the five senses, only smell can horrify us. Smell is the locomotive that pulls the train to immortality." 


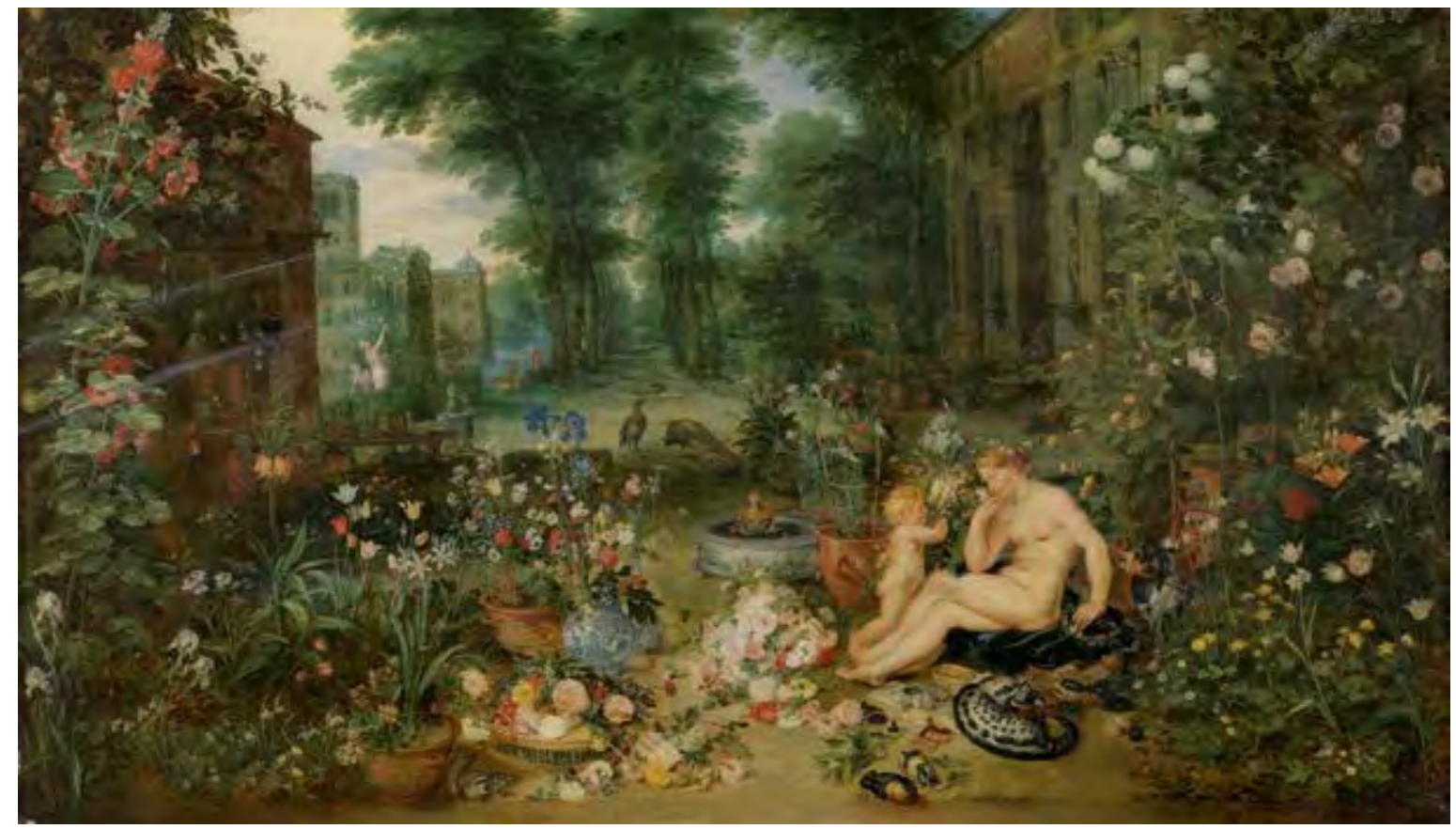

Figura 32.

El olfato / 1617 -1618 / Jan Brueghel el Viejo y Pedro Pablo Rubens

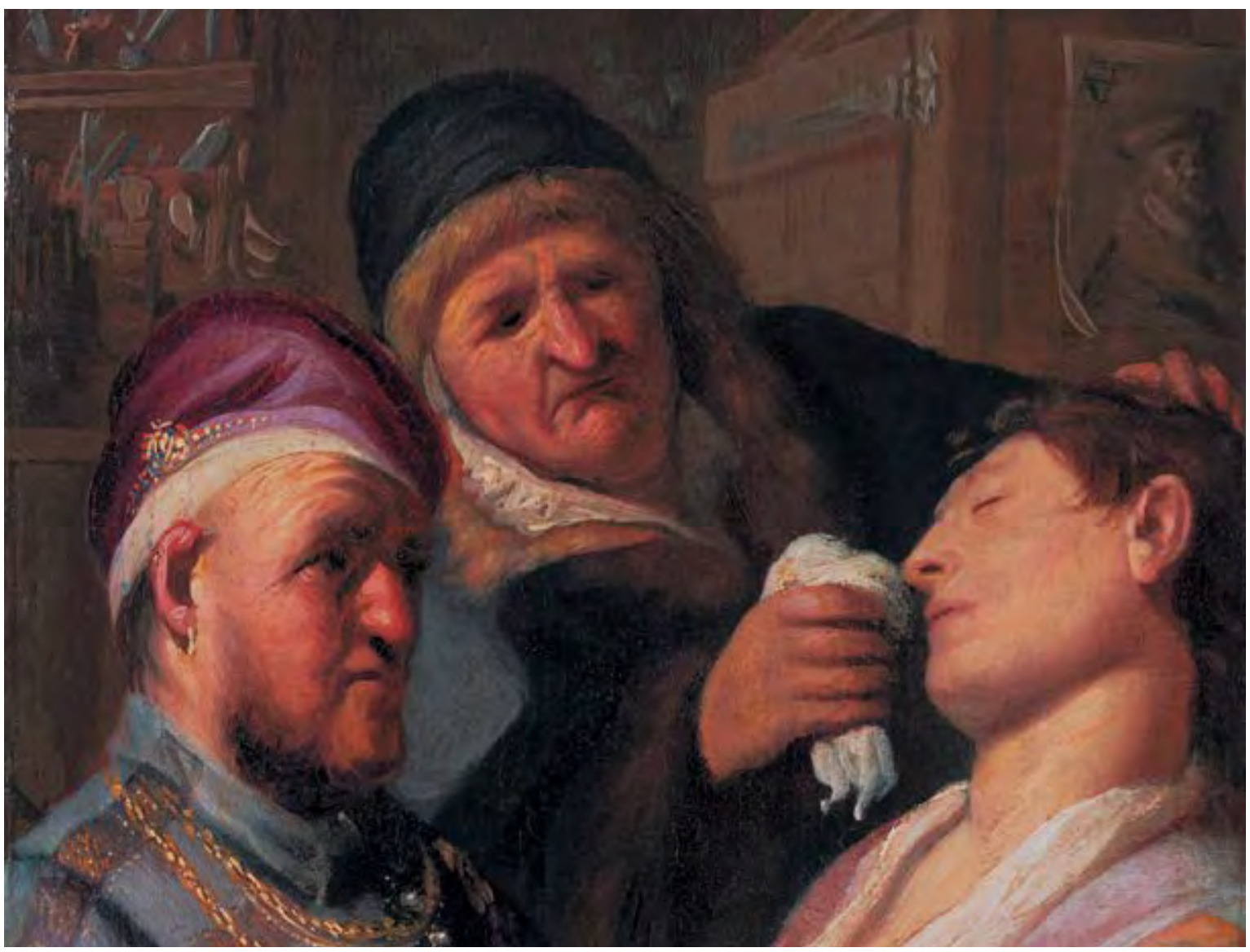

Figura 33.

El paciente inconsciente / Fragemento / 1624 -1625 / Rembrandt Harmenszoon van Rijn 
La serie Los cinco sentidos de Jan Brueghel el viejo en colaboración con Peter Paul Rubens, realizados entre 1617 - 1618; Los cinco sentidos entre 1872 - 1879 del pintor austriaco Hans Makart de 1872 - 1879 o el cuadro titulado Les cinq sens de nature de Jean Baudoin de 1636 son representaciones pictóricas de la vista, el oído, el gusto, el tacto; y además el olfato. Junto a mujeres semidesnudas, jardines con flores, sobre todo con rosas; así como la representación de perros olfateadores eran motivos pictóricos recurrentes, alegorías representativas del olfato.

Con el tiempo, las escenas idealizadas se conviertes en escenas más cotidianas. El cuadro El paciente inconsciente de Rembrandt van Rijn de 1624 - 1625 muestra tres personas. Uno de ellos parece haberse desmayado, razón por la cual un anciano sostiene un paño blanco empapado con una solución de olor fuerte bajo su nariz. Un cambio en la representación de la metáfora olfativa.

A finales de la primera mitad del siglo pasado; tras una supuesta primacía del sentido de la vista, el arte usará un nuevo lenguaje para crear composiciones que rompen con la representación solamente figurativa. Se plasma en otros modos de expresión artística, exigiendo una nueva actitud al espectador ante las obras de arte. Un arte multisensorial que se experimenta con todos los sentidos; donde las impresiones olfativas ya no figuran solamente como una representación bidimensional y pictórica sino el espectador puede percibir el propósito que el artista ha querido transmitir a través de la obra.

"Podemos ver mirar. ¿Podemos oír, escuchar, oler, olfatear, etc?"59

Marcel Duchamp

La Exposition Internationale du Surréalisme de 1938 fue una de las primeras instalaciones de arte en el espacio. Artistas surrealistas, entre ellos Marcel Duchamp, participaron en dicha muestra.

"El pasillo desembocaba en la sala principal de la exposición, que Duchamp había transformado en una fantástica cueva subterránea. Mil doscientos sacos de carbón colgaban del techo. A pesar de estar rellenos de papel de periódico, soltaban un ligero polvillo negro, acre, (Duchamp tenía pensado colocar paraguas del 


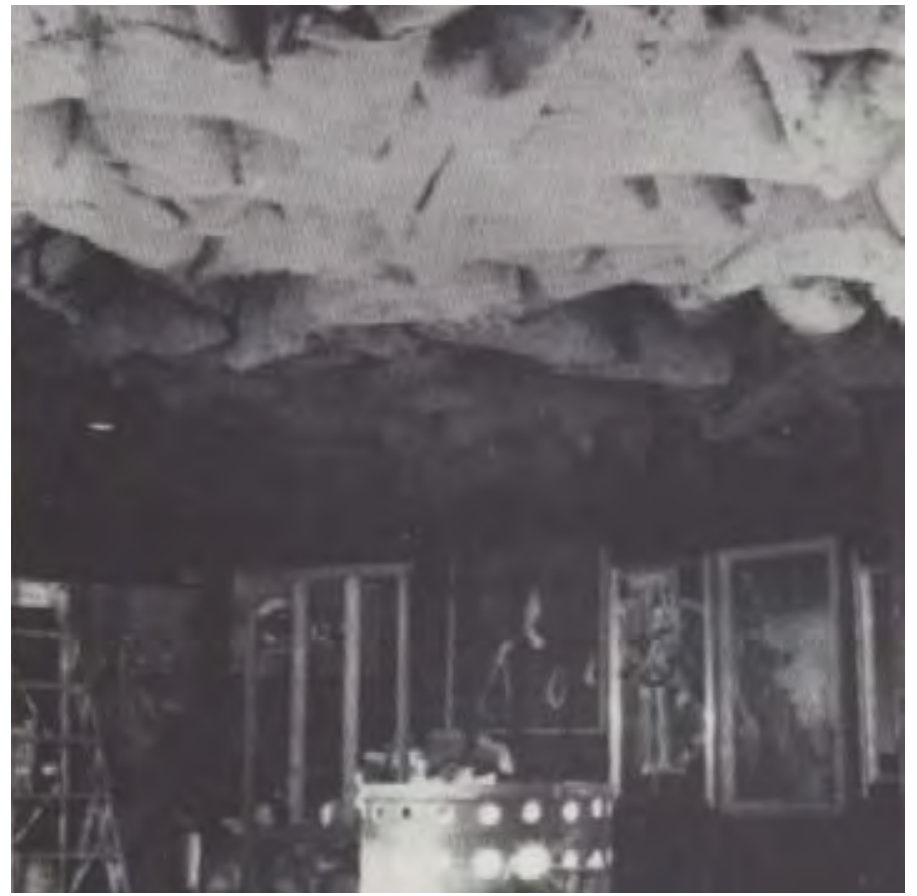

Figura 34.

Mil doscientos sacos de carbon suspendidos del techo sobre un brasero / Paris / 1938/ Marcel Duchamp

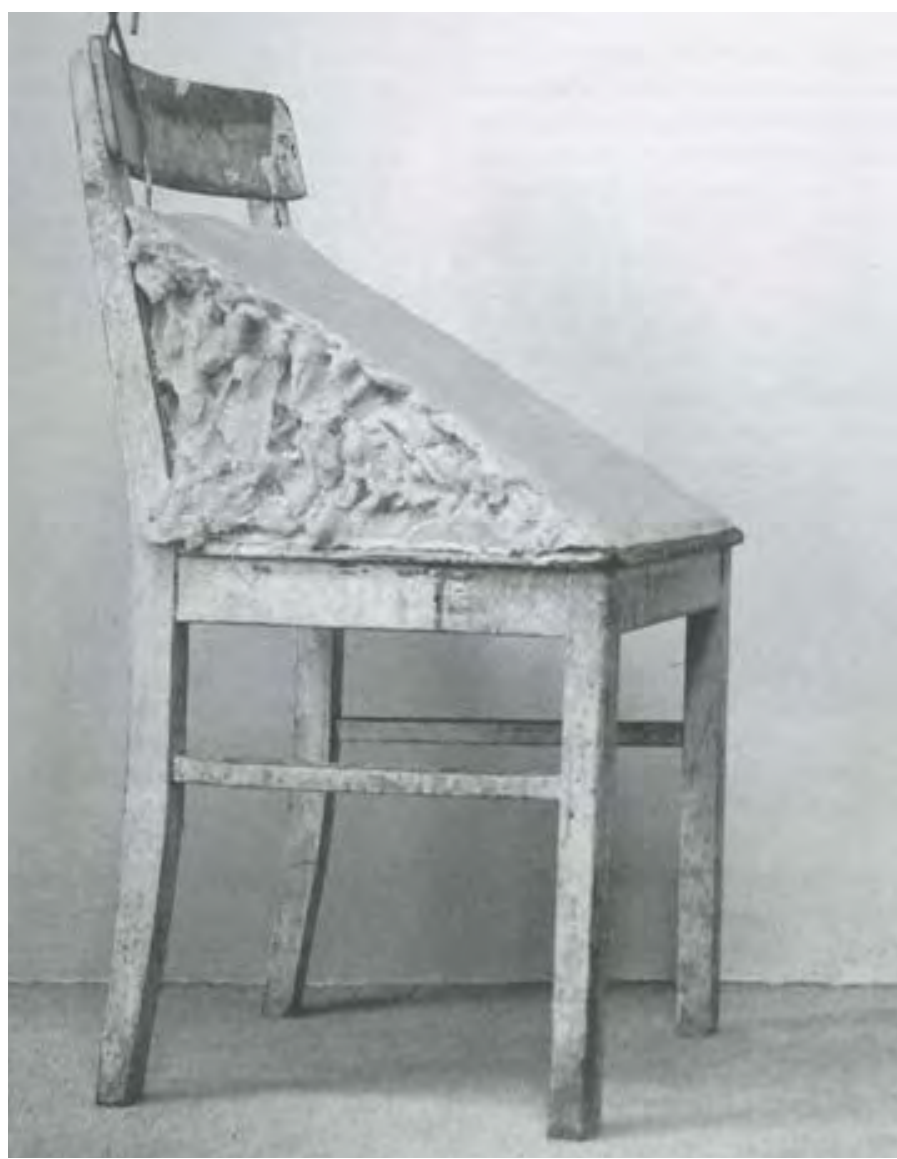

Figura 35.

Stuhl mit Fett / 1963 / Joseph Beuys 